\title{
Internationale bescherming van het recht op onderwijs
}

Citation for published version (APA):

Coomans, A. P. M. (1992). Internationale bescherming van het recht op onderwijs. [Doctoral Thesis, Maastricht University]. Stichting NJCM-Boekerij. https://doi.org/10.26481/dis.19920410ac

Document status and date:

Published: 01/01/1992

DOI:

10.26481/dis.19920410ac

Document Version:

Publisher's PDF, also known as Version of record

\section{Please check the document version of this publication:}

- A submitted manuscript is the version of the article upon submission and before peer-review. There can be important differences between the submitted version and the official published version of record.

People interested in the research are advised to contact the author for the final version of the publication, or visit the DOI to the publisher's website.

- The final author version and the galley proof are versions of the publication after peer review.

- The final published version features the final layout of the paper including the volume, issue and page numbers.

Link to publication

\footnotetext{
General rights rights.

- You may freely distribute the URL identifying the publication in the public portal. please follow below link for the End User Agreement:

www.umlib.nl/taverne-license

Take down policy

If you believe that this document breaches copyright please contact us at:

repository@maastrichtuniversity.nl

providing details and we will investigate your claim.
}

Copyright and moral rights for the publications made accessible in the public portal are retained by the authors and/or other copyright owners and it is a condition of accessing publications that users recognise and abide by the legal requirements associated with these

- Users may download and print one copy of any publication from the public portal for the purpose of private study or research.

- You may not further distribute the material or use it for any profit-making activity or commercial gain

If the publication is distributed under the terms of Article $25 \mathrm{fa}$ of the Dutch Copyright Act, indicated by the "Taverne" license above, 


\section{DE INTERNATIONALE BESCHERMING VAN HET RECHT OP ONDERWIJS}


CIP-GEGEVENS KONINKLIJKE BIBLIOTHEEK, DEN HAAG

Coomans, Alphonsus

De internationale bescherming van het recht op onderwijs / Alphonsus Coomans. - Leiden : Stichting NJCM-Boekerij. (Stichting NJCM-Boekerij ; 20)

Proefschrift Maastricht.

ISBN 90-6750-020-8

Trefw.: onderwijs en rechten van de mens

Ontwerp omslag: Stan Heijnen

Gedrukt door: Drukkerij Haveka B.V., Alblasserdam 


\section{DE INTERNATIONALE BESCHERMING VAN HET RECHT OP ONDERWIJS}

\section{PROEFSCHRIFT}

ter verkrijging van de graad van doctor aan de Rijksuniversiteit Limburg te Maastricht op gezag van de Rector Magnificus, Prof.mr. M.J. Cohen, volgens het besluit van het College van Dekanen, in het openbaar te verdedigen op vrijdag, 10 april 1992 om 16.00 uur

DOOR

Alphonsus Paulus Maria Coomans 


\section{Promotores:}

Prof.mr. C. Flinterman LL.M

Prof.dr. Th.C. van Boven

\section{Beoordelingscommissie:}

Prof.mr. M.J. Cohen (voorzitter)

Prof.dr. M.J. Bossuyt (Universitaire Instelling Antwerpen)

Prof.mr. G.J.H. van Hoof (Rijksuniversiteit Utrecht) 
Aan mijn ouders 



\section{VOORWOORD}

Dit proefschrift werd geschreven in het kader van het onderzoeksproject naar de universaliteit van de rechten van de mens dat in 1986 aan de Juridische Faculteit van de Rijksuniversiteit Limburg van start ging. Eén van de thema's van dit project was het onderzoek naar betekenis en reikwijdte van internationale economische, sociale en culturele mensenrechtennormen.

In die tijd besloot ik, als deelstudie van dit project, een onderzoek naar de internationale bescherming van het recht op onderwijs te beginnen. Eén van de redenen daarvoor was dat er weinig over de internationale dimensie van dit recht geschreven werd.

Gedurende de afgelopen jaren heb ik met mijn promotores, prof.mr. C. Flinterman en prof.dr. Th.C. van Boven vaak van gedachten gewisseld over het onderwerp van dit onderzoek. Ik wil hen op deze plaats bedanken voor hun suggesties en prikkelende opmerkingen. Hun commentaar betekende voor mij steeds een stimulans. In het bijzonder wil ik Cees Flinterman bedanken voor de steun die hij mij in de voorbije jaren heeft gegeven.

Het schrijven van een proefschrift doe je nooit helemaal alleen. Een aantal mensen is mij met hun ondersteunende werkzaamheden zeer behulpzaam geweest. Ik noem in dit verband de student-assistenten Jeroen Jansen, Lucia Geurts en Eva Rieter. Ik wil hier ook al die mensen bedanken die op de een of andere wijze hebben bijgedragen tot de tekstverwerking van dit proefschrift. Zonder de accuratesse en snelheid van Lisette Damen, Imme Titulaer, Jean-Pierre Raes, Argie Lankkamp en Joke Oud was dit onderzoek nooit tot een goed einde gebracht. Met name beidle laatstgenoemden hebben met veel toewijding de aangebrachte wijzigingen verwerkt in de tekst. Wies Rayar wil ik dankzeggen voor het vervaardigen van de Engelse samenvatting, en Stan Heijnen voor het omslag-ontwerp. Ook veel dank aan Hedy Braun voor de 'finishing touch'. Tot slot ben ik veel dank verschuldigd aan Lilian die er steeds weer begrip voor opbracht dat mijn onderzoekswerkzaamheden veel van mijn (privé)tijd in beslag namen.

De tekst van dit proefschrift is afgesloten op 1 december 1991. 


\section{INHOUDSOPGAVE}

Voorwoord

Inhoudsopgave

Lijst met afkortingen

viii

Hoofdstuk 1

Inleiding

1.1 Het onderwerp van onderzoek

1.2 De probleemstelling 3

1.3 Het behandelingsplan 5

Hoofdstuk 2 Economische, sociale en culturele rechten als mensenrechten

2.1 Inleidende opmerkingen 8

2.2 Historische ontwikkeling in VN-verband 9

2.3 Het traditionele onderscheid tussen burger- en politieke rechten en economische, sociale en culturele rechten

2.4 De eenheid en onderlinge afhankelijkheid van van mensenrechten

2.5 De verwezenlijking van economische, sociale en culturele rechten; een alternatieve benadering

2.5.1 Verplichtingen voor de staat 26

2.5.2 Een typologie van verplichtingen 29

2.6 Verplichtingen van staten op grond van artikel 2 lid 1 IVESCR

2.6.1 Algemeen 32

2.6.2 Interne verplichtingen 34

2.6.3 Externe verplichtingen 37

2.6.4 Artikel 4 IVESCR 38

2.6.5 De waarde van IVESCR-normen in tijden van economische teruggang 
Hoofdstuk 3 Het recht op onderwijs in internationale verdragen en verklaringen

3.1 Afbakening en definitie

3.2 Het recht op onderwijs in internationale verdragen en verklaringen in vogelvlucht

3.3 De Universele Verklaring van de Rechten van de Mens

3.3.1 De plaats van artikel 26 in de Universele Verklaring

3.3.2 De term 'recht op onderwijs'

3.3.3 Het sociale aspect van het recht op onderwijs 53

3.3.4 Het vrijheidsaspect van het recht op onderwijs 55

3.4 Het Europees Verdrag tot Bescherming van de Rechten van de Mens en de Fundamentele Vrijheden, Eerste Protocol

3.4.1 Inleidende opmerkingen

58

3.4.2 De eerste fase (1949-1950)

60

3.4.3 De tweede fase (1951-1952)

63

3.4.4 Het sociale aspect van het recht op onderwijs in de tweede fase van de ontstaansgeschiedenis van artikel 2

3.4.5 Het vrijheidsaspect van het recht op onderwijs in de tweede fase van de ontstaansgeschiedenis van artikel 2

3.5 Het UNESCO Verdrag tot Bestrijding van

3.5.1 Voorgeschiedenis

3.5.2 De totstandkoming en inhoud van de Conventie 80

3.5.3 Samenvattende opmerkingen

3.6 Het Internationaal Verdrag inzake Economische, Sociale en Culturele Rechten

3.6.1 Inleidende opmerkingen

3.6.2 Het sociale aspect van het recht op onderwijs tijdens de beraadslagingen in de Commissie voor de Rechten van de Mens (1951-1952)

3.6.3 Het vrijheidsaspect van het recht op onderwijs tijdens de beraadslagingen in de Commissie voor de Rechten van de Mens (1951-1952)

3.6.4 Het sociale aspect van het recht op onderwijs tijdens de beraadslagingen in de Derde Commissie van de Algemene Vergadering (1957) 114

3.6.5 Het vrijheidsaspect van het recht op onderwijs tijdens de beraadslagingen in de Derde Commissie van de Algemene Vergadering (1957) 
3.7 Het Internationaal Verdrag inzake Burger- en Politieke Rechten

3.7.1 Artikel 18(4)

3.7.2 Artikel 27

3.7.3 Internationale jurisprudentie over onderwijsrechten van minderheden: Minderhedenscholen in Albanië

3.8 Het Verdrag inzake de Uitbanning van alle Vormen van Discriminatie van Vrouwen

3.9 Het Protocol inzake Economische, Sociale en Culturele Rechten bij de Amerikaanse Conventie inzake de Rechten van de Mens (Protocol van San Salvador)

3.10 Documenten in het kader van de Conferentie over Veiligheid en Samenwerking in Europa (CVSE)

3.11 ILO Conventies betreffende Inheemse Volken 148

3.12 De Conventie inzake de Rechten van het Kind 152

3.13 Analyse van het recht op onderwijs in internationale verdragen en verklaringen

Hoofdstuk 4 De internationale implementatie van het recht op onderwijs

4.1 Internationale jurisprudentie over het recht op onderwijs: het Europees Verdrag tot Bescherming van de Rechten van de Mens

4.1.1 Inleidende opmerkingen

4.1.2 Definitie van termen

4.1.3 De reikwijdte van artikel 2: het sociale aspect van het recht op onderwijs

4.1.4 De tweede zin van artikel 2: het vrijheidsaspect van het recht op onderwijs

4.1.4.1 De plichten voor de staat ingevolge de tweede zin van artikel 2

4.1.4.2 De rechten van de ouders in het bijzonder het respect voor hun religieuze en filosof ische overtuigingen

4.1.4.3 De betekenis van artikel 2 voor het privéonderwijs

4.1.4.4 Is een leerplicht verenigbaar met artikel 2 ? 
4.2 Internationale jurisprudentie over het recht op onderwijs: het Internationaal Verdrag inzake Burger- en Politieke Rechten

4.3 De UNESCO klachtenprocedure

4.4 Het recht op onderwijs in statenrapporten: het Internationaal Verdrag inzake Economische, Sociale en Culturele Rechten

4.4.1 Algemeen

4.4.2 De internationale implementatie ingevolge het Internationaal Verdrag inzake Economische, Sociale en Culturele Rechten

4.4.3 Het recht op onderwijs in statenrapporten ingevolge het IVESCR

4.4.4 Evaluatie van de statenrapporten

4.5 De internationale implementatie van het recht op onderwijs: Het UNESCO Verdrag tot Bestrijding van Discriminatie in het Onderwijs 215

4.6 Het recht op onderwijs; norm en naleving

Hoofdstuk $5 \quad$ Naar de verwezenlijking van het recht op onderwijs

5.1 Inleidende opmerkingen

5.2 Verplichtingen van de staat en de verwezenlijking van het recht op onderwijs

5.2.2 De reikwijdte van artikel 13 IVESCR

5.3 Een typologie van verplichtingen met betrekking tot het recht op onderwijs

5.4 Schending van het recht op onderwijs

5.4.1 Criteria voor een schending

5.4.2 Voorbeelden van schendingen van het recht op onderwijs

5.5 Een Nederlands voorbeeld: De Les- en

5.5.1 Inleiding

5.5.2 Toetsingscriteria

5.5.3 Materiële interpretatie van artikel 13

5.5.4 Recente jurisprudentie

5.6 Het recht op onderwijs als universeel mensenrecht? 
5.6.1 Algemeen 258

5.6.2 Universele geldigheid en acceptatie van het recht op onderwijs

5.6.3 Formele en materiële aspecten van het

5.6.4 Recht op onderwijs versus leerplicht 269

5.6.5 Het recht op onderwijs als sleutelrecht 270

5.7 Conclusies 272

Hoofdstuk 6 Verbetering van het internationale toezicht op de verwezenlijking van het recht op onderwijs

6.1 Algemeen 276

6.2 Het opstellen van statenrapporten 276

6.3 De rol van de inter-gouvernementele organisaties, in het bijzonder de UNESCO en de ILO

6.4 De rol van niet-gouvernementele organisaties 290

6.5 Uitbouw van taken van het Comité inzake Economische, Sociale en Culturele Rechten; enkele aanbevelingen

6.5.1 De beoordeling van statenrapporten 293

6.5.2 Het gebruik van indicatoren 297

6.5.3 Een individueel klachtrecht bij het IVESCR? 302

6.6 Slotopmerkingen 304

Bijlage: Internationale teksten aangaande het recht op onderwijs als mensenrecht

Lijst van bronnen en aangehaalde literatuur

Aangehaalde jurisprudentie

Summary 
Lijst met afkortingen

\begin{tabular}{|c|c|}
\hline $\begin{array}{l}\text { ARRS } \\
A V(G A)\end{array}$ & $\begin{array}{l}\text { Afdeling Rechtspraak Raad van State } \\
\text { Algemene Vergadering van de Verenigde Naties } \\
\text { (General Assembly) }\end{array}$ \\
\hline CESCR & $\begin{array}{l}\text { Comite inzake Economische, Sociale en Culturele } \\
\text { Rechten }\end{array}$ \\
\hline CRvB & Centrale Raad van Beroep \\
\hline CVSE & Conferentie over Veiligheid en Samenwerking in Europa \\
\hline Doc. & Document \\
\hline $\begin{array}{l}\text { ECOSOC } \\
\text { ed(s) }\end{array}$ & $\begin{array}{l}\text { Economic and Social Council of the United Nations } \\
\text { editor(s) }\end{array}$ \\
\hline EG & Europese Gemeenschap \\
\hline ESH & Europees Sociaal Handvest \\
\hline EVRM & $\begin{array}{l}\text { Europees Verdrag voor de Rechten van de Mens en de } \\
\text { Fundamentele Vrijheden }\end{array}$ \\
\hline FAO & Food and Agriculture Organisation \\
\hline HR & Hoge Raad \\
\hline ICJ & International Commission of Jurists \\
\hline ILC & International Law Commission \\
\hline ILM & International Legal Materials \\
\hline ILO & International Labour Organization \\
\hline IMF & Internationaal Monetair Fonds \\
\hline IVBPR & $\begin{array}{l}\text { Internationaal Verdrag inzake Burger- en Politieke } \\
\text { Rechten }\end{array}$ \\
\hline IVESCR & $\begin{array}{l}\text { Internationaal Verdrag inzake Economische, Sociale en } \\
\text { Culturele Rechten }\end{array}$ \\
\hline MvA & Memorie van Antwoord \\
\hline MvT & Memorie van Toelichting \\
\hline NGO & Niet-gouvernementele organisatie \\
\hline NJCM & Nederlands Juristen Comité voor de Mensenrechten \\
\hline OAE & Organisatie voor Afrikaanse Eenheid \\
\hline OAS & Organisatie van Amerikaanse Staten \\
\hline PCIJ & Permanent Court of International Justice \\
\hline Res. & Resolution \\
\hline TK & Tweede Kamer der Staten-Generaal \\
\hline UNESCO & $\begin{array}{l}\text { United Nations Educational, Scientific and Cultural } \\
\text { Organization }\end{array}$ \\
\hline UNICEF & United Nations Children Fund \\
\hline VN (UN) & Verenigde Naties (United Nations) \\
\hline Vol. & Volume \\
\hline WHO & World Health Organization \\
\hline WUS & World University Service \\
\hline
\end{tabular}




\section{Verklaring symbolen $\mathrm{VN}$ documenten}

A/... document van de Algemene Vergadering van de

Verenigde Naties

A/C.3/... document van de Derde Commissie van de Algemene

E/.... Vergadering (Sociale en Humanitaire aangelegenheden) document van de Economische en Sociale Raad van de Verenigde Naties

E/CN.4/... document van de Commissie voor de Rechten van de Mens van de Verenigde Naties

E/CN.4/Sub.2/... document van de Sub-Commissie inzake het Voorkomen van Discriminatie en de Bescherming van Minderheden

E/CN.6/... document van de Commissie inzake de Status van de Vrouw

E/../WG.1/... document van de 'Sessional Working Group of Governmental Experts on the Implementation of the International Covenant on Economic, Social and Cultural Rights'

E/C.12/... document van het Comité inzake Economische, Sociale en Culturele Rechten

Add.

Addendum

L. Limited; document met een beperkte verspreiding

Rev. Revised; herziene versie van een document

SR. Summary Record; officiële verslag van een bijeenkomst

UN Doc. United Nations document 



\title{
HOOFDSTUK 1
}

\author{
Inleiding
}

\subsection{Het onderwerp van onderzoek}

In het algemeen wordt onderwijs als een waardevol goed beschouwd. Onderwijs vormt een bron van kennis en draagt bij tot ontplooiing en ontwikkeling van het individu. ${ }^{1}$ Het recht op onderwijs, en meer in het bijzonder de vrijheid van keuze van de onderwijsvorm en -instelling worden in het Westen tegenwoordig veelal ervaren als vanzelfsprekend. In veel westerse landen zijn het recht op onderwijs en de vrijheid van onderwijs verankerd in de constitutie. ${ }^{2}$ In deze landen zijn dan ook allerlei voorzieningen getroffen ten behoeve van het geven en genieten van onderwijs. In het bijzonder wettelijke maatregelen hebben bijgedragen aan vormgeving en inhoud van het onderwijs op verschillende niveaus.

In andere landen, veelal ontwikkelingslanden, is onderwijs nog lang niet voor allen beschikbaar, hoewel het ook daar vaak wel als recht in de grondwet is opgenomen. ${ }^{3}$ Het onderwijsstelsel verkeert in dergelijke landen nog in een fase van opbouw, en de overheid kan er slechts in gebrekkige of beperkte mate zorg dragen voor het functioneren van onderwijsinstellingen. Het gevolg hiervan is dat vele kinderen, maar ook volwassenen, verstoken blijven van elementair onderwijs, terwijl een gedegen beroepsopleiding vaak niet tot de mogelijkheden behoort. Juist in Derde Wereldlanden is het geven en ontvangen van onderwijs éên van de cruciale elementen van het ontwikkelingsproces.

1. De International Dictionary of Education geft de vollgende definities van het begrip "education": 1. 'The total process of developing human ability and behaviour. 2. Social process in which one achieves social competence and individual growth, carried on in a selected, controlled setting which can be institutional as school or college". De officiele UNESCO definitie luidt: 'organized and sustained instruction designed to communicate a combination of knowledge, skills and understanding valuable for all the activities of life'.

Zie G.T. Page and J.B. Thomas, The International Dictionary of Education, London 1978 (1977), pp. 112, 113.

2. In Nederland is het grondrecht onderwijs vastgelegd in artikel 23 van de Grondwet.

3. Indien in deze studie over ontwikkelingslanden of Derde Wereldlanden wordt gesproken is dat in het besef dat er tussen die landen grote verschillen bestaan, ook op het terrein van het onderwijs. De onderwijaproblematiek in sommige Afrikaanse landen, waar een samenhangend onderwijsbestel goeddeels ontbreek $t$, is bijvoorbeeld wezenlijk anders dan die in Latijnsamerikaanse landen. 
Het recht op onderwijs is niet alleen op het nationale niveau, in nationale wetgeving, vorm gegeven; ook op het internationale vlak zijn inspanningen geleverd om het recht op onderwijs van elke mens vast te leggen. Dit is met name gebeurd in het kader van internationale organisaties zoals de Raad van Europa, de Verenigde Naties en de UNESCO. Door internationale verdragen op dit terrein te bekrachtigen hebben staten de verplichting op zich genomen de vrijheid van onderwijs te respecteren en het recht op onderwijs te realiseren. Het zijn meestal verdragen waarin ook andere mensenrechten zijn opgenomen, in het bijzonder economische, sociale en culturele mensenrechten. Een groot aantal staten is inmiddels partij bij deze verdragen, waarbij voor dleze studie het Internationaal Verdrag inzake Economische, Sociale en Culturele Rechten (IVESCR) van bijzonder belang is. Voor een aantal verdragspartijen geldt evenwel dat de situatie van het onderwijs in die landen niet beantwoordt aan de internationale verdragsnormen. Er is, met andere woorden, een kloof tussen de norm en de feitelijke situatie.

De gebrekkige verwezenlijking van het recht op onderwijs in een groot deel van de wereld kan worden geilllustreerd aan de hand van enkele gegevens, ${ }^{4}$ In 1990 konden ongeveer 900 miljoen mensen lezen noch schrijven. Het grootste gedeelte van deze mensen leeft in Derde Wereldlanden. In alle regio's van de wereld zijn er meer ongeletterde vrouwen dan mannen. In de minst ontwikkelde landen is meer dan $70 \%$ van de vrouwen analfabeet, terwijl dat voor mannen meer dan $50 \%$ bedraagt. In ontwikkelingslanden makt nog geen tweederde deell van de kinderen tussen de zes en elf jaar de basisschool af. Het niveau dat zij bereiken is veelal laag en de kwaliteit van het onderwijs slecht. Vooral meisjes, plattelandskinderen en kinderen uit arme gezinnen blijven verstoken van onderwijs. Ontwikkelde landen besteden bijna 6\% van het Bruto Nationaal Produkt aan onderwijs, terwiji dat voor ontwikkelingslanden $3 \%$ bedraagt. In ontwikkelingslanden wordt aan een leerling van de basisschool 31 dollar uitgegeven, terwijl dat in ontwikkelde landen meer dan 1500 dollar is. Ook met de vrijheid van onderwijs is het lang niet overal goed gesteld. De vrije keuze van onderwijs is vaak een holle frase, omdat er niets te kiezen valt. Vormen van privé-onderwijs zijn in sommige landen niet toegestaan. En vaak is er in een stad of dorp slechts éen type of vorm van onderwijs beschikbaar.

In het kader van mijn onderzoek reken ik het recht op onderwijs tot de groep van economische, sociale en culturele rechten. Dit zijn rechten die de leef- en arbeidsomstandigheden van mensen betreffen. $\mathrm{Zij}$ geven een persoon recht op een behoorlijke levensstandaard; zij benadrukken, met andere woorden, de kwaliteit van het leven. Economische, sociale en culturele

4. Deze gegevens zijn afkomstig uit publikaties van UNESCO, namelijk Basic Education and Literacy, World Statistical Indicators, 1990 on UNESCO Sources, March 1989, alamede het rapport van de Wereldbank, Primary Education (1990), besproken in NRC Handelsblad van 30-10-1990. 
rechten geven een persoon een aanspraak op activiteiten door de staat gericht op de verwezenlijking van die rechten. ${ }^{5}$

In het verleden hebben economische, sociale en culturele rechten in de schaduw gestaan van burger- en politieke rechten. De laatste jaren is er evenwel meer aandacht voor de verwezenlijking van eerstgenoemde rechten. Dat is mede het gevolg van de verbeterde relatie tussen Oost en West waardoor discussies over mensenrechten hun scherpe ideologische kanten verloren. De normering en naleving van zowel burger- en politieke rechten als economische, sociale en culturele rechten werd in toenemende mate op constructieve wijze binnen allerlei internationale fora bespreekbaar. Voorts groeide eind jaren zeventig, begin jaren tachtig, op initiatief van de Derde Wereldlanden de relatie tussen mensenrechten en het ontwikkelingsvraagstuk uit tot een zwaartepunt binnen de VN. Deze aandacht voor ontwikkelingsvraagstukken resulteerde in de totstandkoming van de Verklaring inzake het Recht op Ontwikkeling die in december 1986 door de Algemene Vergadering van de VN werd aanvaard. ${ }^{6}$ In deze Verklaring werd onder meer bepaald dat voor de realisering van het recht op ontwikkeling de verwezenlijking van zowel burger- en politieke rechten als economische, sociale en culturele rechten onontbeerlijk is. De onderlinge af hankelijkheid van beide groepen rechten wordt in toenemende mate benadrukt.

\subsection{De probleemstelling}

De interpretatie en implementatie van economische, sociale en culturele rechten heeft in het verleden minder aandacht gekregen dan die van burger-en politieke rechten. De groeiende belangstelling voor economische, sociale en culturele rechten in aanmerking genomen, moet ook de interpretatie en implementatie van deze rechten nieuwe impulsen krijgen. In sommige gevallen zijn economische, sociale en culturele verdragsnormen in algemene termen geformuleerd waardoor niet altijd even duidelijk is wat hun precieze betekenis, reikwijdte en inhoud is. De interpretatie van elk recht afzonderlijk is daarom vereist ten einde de implementatie van deze rechten op het nationale niveau te bevorderen. Op deze wijze wordt het mogelijk staten meer concreet aan te spreken op hun verplichtingen. Naar de internationale bescherming van het recht op onderwijs is nog maar weinig onderzoek gedaan. Als mensenrecht is het in het verleden onderbelicht gebleven. Het is daarom van belang het juridisch karakter van dit recht vast te stellen en na te gaan welke verplichtingen een staat heeft aangaande de verwezenlijking van het recht op onderwijs.

Ten behoeve van deze studie dienen twee aspecten van het recht op onderwijs als onderzoekskader. Enerzijds heeft het recht op onderwijs een so-

5. Zie A.W. Heringa, Sociale Grondrechten, diss. "s-Gravenhage 1989, p. 2 en A. Glenn Mower Jr., International Cooperation for Social Justice, Westport 1985, p. 3.

6. Declaration on the Right to Development, G.A. Res: $41 / 128$ van 4 december 1986. 
ciaal aspect: een inspanning van de zijde van de overheid is vereist om het recht op onderwijs te verwezenlijken. Anderzijds is er het vrijheidsaspect: een ieder bezit een vrije keuze van onderwijs en heeft in beginsel de vrijheid onderwijsinstellingen te stichten en in te richten. Aan de hand van deze beide aspecten zal ik analyseren op welke wijze het recht op onderwijs in internationale teksten is vastgelegd. Twee vragen staan in dat verband centraal: Wat is de inhoud en betekenis van het recht op onderwijs in internationale verdragen? En voorts, welke verplichtingen voor staten vloeien voort uit de internationale teksten inzake het recht op onderwijs? Het gaat hier om de vraag op welke wijze de implementatie van economische, sociale en culturele rechten op grond van internationale normen het best vorm gegeven kan worden. Veelal hebben de formuleringen van economische, sociale en culturele rechten in internationale verdragen het karakter van programma's vervat in termen die voor verschillende uitleg vatbaar zijn. Mijn benadering is dat de implementatie van economische, sociale en culturele rechten op grond van internationale normen nader uitgewerkt kan worden in termen van verplichtingen van staten. Het betreft verplichtingen die een staat dient na te leven, omdat die staat partij is bij juridisch bindende verdragen. Het is dan zaak de verplichtingen van staten op een zodanige wijze uiteen te rafelen en te omschrijven dat een stat er op aangesproken kan worden indien hij faalt in de naleving van die verplichtingen. Juist deze uitwerking van verplichtingen biedt aanknopingspunten ten behoeve van de naleving door staten.

Nadat de normstellende werkzaamheden ten aanzien van de internationale bescherming van de rechten van de mens goeddeels waren voltooid kon de aandacht worden gericht op het toezicht op de naleving van mensenrechten. De meeste aandacht ging daarbij uit naar burger- en politieke rechten. De internationale implementatie ${ }^{7}$ van economische, sociale en culturele rechten verkeert daarentegen nog in een fase van ontwikkeling. Effectieve internationale toezichthoudende procedures zijn in dat verband noodzakelijk. Een belangrijke aanzet daartoe vormen de werkzaamheden van het Comité inzake Economische, Sociale en Culturele Rechten dat sedert 1987

7. De term 'implementatie' heeft in het mensenrechtenjargon een tweeledige betekenis. Enerrijds wordt ermee bedoeld de naleving van verdragsverplichtingen door staten in de vorm van nationale wetgeving, alsmede de feitelijke situatie met betrekking tot de verwesenlijking van de rechten van de mens. Het betreft de sociaal-economische en politieke context warin de verwezenlijking van die rechten plaats vindt. Dit aspect. wal ik verder aanduiden als de nationale implementatie of de implementatie. Anderwijds kent de naleving $v a n$ mensenrechtennormen ook een internationale kant. Op grond van het feit dat een staat partij is bij een mensenrechtenovereenkomst is die staat veelal verplicht regelmatig te rapporteren aan een internationaal orgaan van deskundigen over de voortgang die geboekt is bij de verwezenlijking van de rechten van de mens en de moeilijkheden die daarbij zijn ondervonden. Voorts bestaat er jurisprudentie van internationale rechtsprekende organen over de naleving van de rechten van de mens, alsmede uitspraken, van andere internationale organen over individuele zaken, die niet het karakter hebben van rechtspraak. Al deze internationale aspecten aangaande het toezicht op de naleving van de rechten van de mens betitel ik als de internationale implementatie. 
toezicht houdt op de naleving van het IVESCR door partijstaten. De internationale bescherming van het recht op onderwijs kan worden versterkt door het internationale toezicht op de verwezenlijking van dat recht te verbeteren. Een aantal mogelijkheden daartoe zal in deze studie aan de orde komen. Doel van het onderzoek is een bijdrage te leveren tot de theorievorming aangaande de implementatie van economische, sociale en culturele rechten, in het bijzonder het recht op onderwijs. Voorts beoogt deze studie het begrip van het in internationale teksten vastgelegde recht op onderwijs en de (internationale) implementatie ervan te bevorderen.

Een belangrijk aspect betreffende de internationale bescherming van de rechten van de mens is de vraag naar de universele gelding van deze rechten. In het verleden is de discussie over deze vraag vooral gevoerd ten aanzien van burger- en politieke rechten. Maar deze kwestie is ook van belang ten aanzien van de verwezenlijking van economische, sociale en culturele rechten. Gaat het bij deze rechten om waarden en aanspraken die in de verschillende politieke, sociale en culturele gemeenschappen en stelsels in de wereld aanvaard zijn? In deze studie zal deze vraag worden gesteld met betrekking tot het recht op onderwijs. In dat verband moet gekeken worden naar de aanvaarding van de waarde van onderwijs in de verschillende maatschappelijke en culturele stelsels alsmede naar de geldigheid van de aanspraak op en de vrijheid van onderwijs. Deze studie beoogt een bijdrage te leveren aan de discussie over deze veelzijdige problematiek.

\subsection{Het behandelingsplan}

Deze studie kan als volgt worden ingedeeld. Hoofdstuk 2 heeft een inleidend karakter, waarin een aantal lijnen voor deze studie wordt uitgezet, terwijl de hoofdstukken 3 en 4 in hoofdzaak beschrijvend van aard zijn. Het meer beschouwende en betogende gedeelte van deze studie komt aan de orde in de hoofdstukken 5 en 6.

In hoofdstuk 2 wordt een analyse gegeven van het juridisch karakter van economische, sociale en culturele rechten en hun verhouding tot burger- en politieke rechten. Dit hoofdstuk behandelt de internationale dimensie van deze kwestie. $\mathrm{Na}$ een bespreking van de traditionele theoretische inzichten aangaande deze problematiek wordt ingegaan op de huidige door de VN gehanteerde uitgangspunten inzake de internationale bescherming van de rechten van de mens. Voorts komt een alternatieve benadering betreffende de verwezenlijking van economische, sociale en culturele rechten aan bod. $\mathrm{Zij}$ benadrukt de verplichtingen van staten op grond van verdragen en legt minder nadruk op de afdwingbaarheid van rechten voor een rechterlijke instantie.

In hoofdstuk 3 wordt vervolgens aandacht besteed aan de internationale regeling van het recht op onderwijs in zowel mondiale als regionale verdragen en verklaringen. Daartoe wordt een analyse gemaakt van de ontstaansgeschiedenis van deze verschillende internationale teksten. Op deze 
wijze wordt inzicht verkregen in de betekenis en reikwijdte van het recht op onderwijs.

Hoofdstuk 4 behandelt een aantal aspecten van de nationale en internationale implementatie van het recht op onderwijs ingevolge verschillende verdragen. Dat gebeurt aan de hand van een analyse van de rapportage door staten over de verwezenlijking van het recht op onderwijs. Het betreft hier een onderzoek naar standpunten van regeringen vastgelegd in officiele documenten. Voorts wordt uitvoerig ingegaan op de jurisprudentie van de Europese Commissie en het Europese Hof voor de Rechten van de Mens over de onderwijsbepaling uit het EVRM. Statenrapportage en jurisprudentie dragen bij tot een beter begrip van de werking van het recht op onderwijs in verschillende landen.

Hoof dstuk 5 behandelt een aantal aspecten betreffende de verwezenlijking van het recht op onderwijs. In dit hoofdstuk staat de onderwijsbepaling uit het IVESCR centraal. Voortbouwend op de analyse van verplichtingen ingevolge artikel 2 lid 1 IVESCR zoals die in hoofdstuk 2 werd gegeven, wordt uiteen gezet welke concrete verplichtingen een staat heeft aangaande de realisering van het recht op onderwijs. Aan de hand van een typologie kunnen deze verplichtingen van staten verder uitgewerkt worden. In dit hoofdstuk worden voorts enkele criteria gesuggereerd aan de hand waarvan een schending van het recht op onderwijs kan worden vastgesteld. Hoofdstuk 5 bevat verder een uitstapje naar de Nederlandse situatie. De vraag wordt gesteld hoe bepaalde Nederlandse onderwijswetgeving zich verhoudt tot de internationale normen inzake het recht op onderwijs. Tot slot van dit hoofdstuk wordt een aantal kwesties besproken die alle te maken hebben met de vraag of het recht op onderwijs een universeel karakter toekomt. In hoofdstuk 6 tenslotte wordt vanuit verschillende invalshoeken bekeken op welke wijze de internationale implementatie van het recht op onderwijs (meer in het bijzonder artikel 13 IVESCR) kan worden verbeterd en bevat met het oog daarop een aantal aanbevelingen.

Een centrale plaats in het onderzoek wordt ingenomen door artikel 13 van het Internationaal Verdrag inzake Economische, Sociale en Culturele Rechten. Dit is de belangrijkste internationale bepaling inzake het recht op onderwijs en heeft een universele reikwijdte. Voorts is het een uitvoerige, omvattende bepaling die zich ertoe leent verplichtingen van staten nader uit te werken.

De groeiende bemoeienis van de Europese Gemeenschappen met onderwijskwesties valt buiten het bestek van dit onderzoek. Deze bemoeienis kan mijns inziens niet worden gezien vanuit mensenrechtenperspectief, maar geschiedt voornamelijk vanuit overwegingen van economische ordening. ${ }^{8}$ Goeddeels buiten beschouwing blijven ook de doeleinden van het onderwijs zoals die onder meer in artikel 26 lid 2 van de Universele Ver-

8. Zie hierover het owerachtsartikel van M. de Blois, Europees Gemeenschapsrecht en Onderwijs, in: S.E.W. (Tijdschrift voor Europees en economisch recht), vol. 39 (1991), pp. 513-538. 
klaring van de Rechten van de Mens zijn vastgelegd, alsmede het zich sterk ontwikkelende mensenrechten-onderwijs. Beide onderwerpen hebben zeker raakpunten met de problematiek van deze studie, maar verdienen mijns inziens toch afzonderlijke behandeling en bestudering, omdat het gaat om specifieke onderwerpen met een eigen karakter. ${ }^{9}$ Ik onderken evenwel het belang van hun rol met betrekking tot de inhoud en de kwaliteit van het onderwijs, alsmede de functie van het onderwijs ten aanzien van de ontplooiing van het individu.

Tenslotte moet nog worden opgemerkt dat deze studie niet ingaat op het functioneren van de onderwijsstelsels in af zonderlijke staten, noch op de daarmee in verband staande administratieve en bestuurlijke strategieën. ${ }^{10}$ Deze kwesties hebben geen directe relatie met de internationale bescherming van het recht op onderwijs.

9. Zie bijv. N.J. Graves, O.J. Dunlop, J.V. Torney Purta, Teaching for International Understanding, Peace and Human Rights, UNESCO "Paris 1984.

10. Zie hierover D. Haag, The Right to Education: what kind of managernent?, UNESCO, Paris 1982. 


\section{HOOFDSTUK 2}

\section{Economische, sociale en culturele rechten als mensenrechten}

\subsection{Inleidende opmerkingen}

In de afgelopen decennia is er veel discussie geweest over het karakter van economische, sociale en culturele rechten. Deze discussie, die zich zowel binnen als buiten de VN afspeelde, spitste zich toe op de volgende, samenhangende vragen. Hebben economische, sociale en culturele mensenrechten wel het karakter van echte rechten? Wat is hun relatie tot burger- en politieke rechten? Welke verplichtingen voor staten vloeien voort uit verdragen waarin economische, sociale en culturele rechten zijn vastgelegd? Zijn economische, sociale en culturele rechten juridisch afdwingbaar? Het beantwoorden van deze vragen is van belang, omdat daardoor meer inzicht kan worden verkregen in de reikwijdte en betekenis van het internationale recht op onderwijs. In de internationaalrechtelijke literatuur bestond aanvankelijk een stroming die een strikt onderscheid tussen economische, sociale en culturele rechten enerzijds en burger- en politieke rechten anderzijds makkte. Mede als gevolg van de rechtsontwikkeling werd in de loop der jaren het strikte onderscheid tussen beide groepen rechten gerelativeerd. In de jaren zeventig won binnen de $\mathrm{VN}$ de benadering aan invloed die de eenheid en onderlinge afhankelijkheid van burger- en politieke rechten en economische, sociale en culturele rechten voorop stelde.

De juridische reikwijdte en betekenis van afzonderlijke economische, sociale en culturele rechten kunnen geanalyseerd worden door na te gaan welke concrete verplichtingen voor staten voortvloeien uit deze internationale normen. Daarbij wordt dan minder nadruk gelegd op de vraag of een bepaald recht voor een nationale rechterlijke instantie kan worden afgedwongen. Voortbouwend op eerdere theorievorming over dit onderwerp stel ik een typologie van verplichtingen voor die behulpzaam kan zijn bij de vraag welke verplichtingen voor staten voortvloeien uit het recht op onderwijs en bij de beoordeling of een staat zijn verplichtingen ook naleeft. De algemene verplichtingen van staten aangaande de realisering van economische, socialle en culturele rechten kunnen het best worden gedefinieerd aan de hand van artikel 2 lid 1 IVESCR. Dit Verdrag vormt de belangrijkste mondiale tekst aangaande economische, sociale en culturele rechten. Een analyse van artikel 2 lid 1 laat zien wat van staten mag worden verwacht indien zij partij zijn bij het IVESCR. 
De hierboven aangeduide aspecten en vragen komen in dit hoofdstuk aan bod. De bespreking daarvan vormt de basis voor de analyse van de inhoud en betekenis van het recht op onderwijs zoals dat in de verschillende internationale teksten is vastgelegd. Paragraaf 2 gaat in op de discussies binnen de VN ten aanzien van de formulering van mensenrechtennormen in verdragen. De traditionele benadering aangaande het karakter van economische, sociale en culturele rechten wordt behandeld in paragraaf 3 . Vervolgens komt in paragraaf 4 de moderne benadering aan de orde die de eenheid en onderlinge afhankelijkheid van beide groepen rechten benadrukt. Paragraaf 5 besteedt aandacht aan de alternatieve benadering die uitgaat van verplichtingen van staten. Tenslotte geeft paragraaf 6 een analyse van artikel 2 lid 1 IVESCR en van de uit deze bepaling voortvloeiende verplichtingen.

\subsection{Historische ontwikkeling in VN-verband}

De kwestie van eenheid of deelbaarheid van mensenrechtennormen heeft binnen de Verenigde Naties van begin af aan een belangrijke rol gespeeld. Aanleiding daarvoor was het opstellen van de 'International Bill of Human Rights' door de Commissie voor de Rechten van de Mens. De opzet was om de niet-bindende formulering van de individuele rechten uit de Universele Verklaring uit te werken in juridisch bindende vorm. De vraag die zich voordeed was of burger- en politieke rechten en economische, sociale en culturele rechten in eén juridisch instrument moesten worden ondergebracht of dat regeling zou moeten geschieden in twee af zonderlijke verdragen. Reden voor deze discussie was het beweerde eigen karakter van zowel de klassieke burger- en politieke rechten als van de recentere economische, sociale en culturele rechten. ${ }^{1}$ De opvattingen van de lidstaten van de VN over deze kwestie waren verdeeld. Het betrof in feite meer een verschil in benadering dan verdeeldheid over het na te streven doel. Het streven was gericht op de bescherming en bevordering van de rechten van de mens in het algemeen, maar hieraan werden kwesties verbonden als prioriteit en hiërarchie van de ene groep rechten ten opzichte van de andere. De problematiek omvatte tevens politieke en ideologische aspecten. Staten met een

1. Hier zal niet worden ingegaan op de geschiedenis van de totstandkoming van beide United Nations Covenants, zoals die zich heeft afgespeeld in de Commisaie voor de Rechten van de Mens en de Derde Commissie van de Algemene Vergadering in de periode 1948-1966. Hiervoor zij rerwezen naar de Official records, General Asiembly, Agenda item 28, UN Doc. A/2929 (1955), Annotations on the text of the draftinternational Covenanti on Human Rights, Prepared bij the Secretiary-General en F. Jhabvala, On Human Rights and the Socio-Economic Context, in: Netherlanda International Law Review, 1984, pp. 149-182, in het bijzonder pp. 163-161. Zie aok, M. Ganji: International Protection of Human Rights, Genewe, Paris 1962, en M. Boneuyt, Guide to the 'Travaux Préparatoires' of the International Covenant on Civill and Political Rights, Dordrecht 1987. Zie ook E. Schwelb, Notes on the Early Leglislative Hisitory of the meagures of implementation of the Human Rights Covenants, in: Melanges offerts à Polye Modinos, Paris 1968, pp. 270-290.

Zie ook Publikaties van het Miniaterie van Buitemlandse Zaken, Nr 29, "B-Gravemhage, pp. 131-136. 
communistisch stelsel bepleitten het ontwerpen van ến alomvattend instrument met een beperkt implementatie-mechanisme. Traditioneel legden communistische landen de nadruk op het belang en de implementatie van economische, sociale, culturele rechten, terwijl de feitelijke eerbiediging van burger- en politieke rechten in hun maatschappij-visie niet goed paste, en dus ook minder aandacht kreeg. Westerse landen hechtten daarentegen veel waarde aan de klassiek liberale opvatting van het bestaan van twee categorieën rechten waarbij burger- en politieke rechten internationale bescherming verdienden als garantie voor de vrije ontwikkeling van het individu. Bescherming van economische, sociale en culturele rechten vormde geen prioriteit in een kapitalistische inrichting van de economie en maatschappij; verwezenlijking ervan zou op geleidelijke wijze moeten geschieden. Deze westerse staten stelden daarom een tweetal af zonderlijke verdragen voor met elk een afzonderlijk implementatie-mechanisme. Van het relatief geringe aantal Derde Wereldlanden, dat eind jaren veertig en in de jaren vijftig lid was van de $\mathrm{VN}$ steunde een gedeelte het westerse standpunt, terwijl een ander gedeelte opteerde voor de positie van de communistische groep van staten. ${ }^{2}$ Uiteindelijk werd gekozen voor twee afzonderlijke instrumenten waaruit men kan concluderen dat de westerse benadering toentertijd de meeste invloed had in de Algemene Vergadering waar de definitieve beslissing werd genomen. ${ }^{3}$

Binnen de $\mathrm{VN}$-organen, waar vertegenwoordigers van regeringen zich bezig hielden met de uitwerking van de bepalingen van de Universele Verklaring van de Rechten van de Mens in juridisch bindende instrumenten, bestond de algemene indruk dat de sociaal-economische situatie in een staat van invloed was op de implementatie van economische, sociale en culturele mensenrechten, met name het beschikbaar zijn van financiële en technische middelen. De heersende opinie was echter ook dat de implementatie van burger- en politieke rechten niet afhankelijk was of mocht zijn van de sociaal-economische situatie. Kortom, maatregelen op het nationale vlak tot naleving en uitwerking van economische, sociale en culturele rechten werden als geheel verschillend beschouwd van maatregelen tot implementatie van burger-en politieke rechten. ${ }^{4}$

De voorstanders van éên juridisch instrument voor zowel economische, sociale en culturele rechten, als voor burger en politieke rechten, beweerden dat er geen sprake kon zijn van een hiërarchie van rechten:

2. Jhabvala, a.w. p. 159; zie voor de verschillende benaderingen van kapitalistische, communistische en Derde Wereldlanden, A. Cassese, International Law in a Divided World, Oxford 1988 (1986), pp. 297-315, en L. Henkin, International Law: Politics, Values and Functions, in Recueil des Cours, Tomé 216 (1989-IV), Pp. 236 239.

3. General Assembly Res. 543 (VI), (1951), 'Preparation of two Draft International Covenants on Human Rights".

4. Jhabvala, a.w. pp. 156-157. 
'All rights should be promoted and protected at the same time. Without economic, social and cultural rights, civil and political rights might be purely nominal in character; without civill and political rights, economic, social and cultural rights could not be long ensured. ${ }^{5}$

Bovendien moest de eenheid van alle mensenrechten zoals geformuleerd in de preambule en verschillende artikelen van het VN Handvest, alsmede in de Universele Verklaring bewaard blijven. Het opstellen van twee afzonderlijke documenten zou tevens betekenen dat staten de implementatie van economische, sociale en culturele rechten als een lagere prioriteit zouden zien, omdat de verwezenlijking ervan een grote hoeveelheid financiële middelen zou vergen. Hierdoor zou de implementatie van een verdrag aangaande enkel deze categorie rechten op de lange baan worden geschoven en van minder betekenis zijn. ${ }^{6}$

De voorstanders van twee afzonderlijke verdragen waren van mening dat burger- en politieke rechten "were rights of the individual "against" the State, that is against unlawful and unjust action of the State', terwijl economische, sociale en culturele rechten 'were rights which the State would have to take positive action to promote, ${ }^{, 7}$ Een andere reden voor een regeling van de twee categorieën rechten in aparte verdragen was het verschil in implementatieprocedure. Burger- en politieke rechten werden gekarakteriseerd als 'legal rights' waarvan de naleving het best gegarandeerd kon worden door een internationaal toezichthoudend orgaan. Economische, sociale en culturele rechten daarentegen waren eerder programmarechten. Het toezicht op naleving daarvan kon het best worden verwezenlijkt door een systeem van periodieke staten-rapportage. Een laatste argument was dat een verdrag dat alleen burger en politieke rechten zou bevatten universeel aanvaard zou worden ${ }^{8}$, terwijl economische, sociale en culturele rechten geen aanspraak konden maken op universaliteit. De Algemene Vergadering besloot tenslotte in 1951 met het aanvaarden van Resolutie 543 (VI) dat er twee ontwerp-verdragen voorbereid zouden worden. De twee verdragen zouden zoveel mogelijk gelijkluidende bepalingen moeten bevatten, en op het zelfde tijdstip aanvaard en opengesteld voor ondertekening moeten worden. Op deze wijze zou de 'unity of purpose' benadrukt worden. ${ }^{9}$ Zowel de voorstanders van één alomvattend verdrag, als die van twee aparte instrumenten waren het erover eens dat 'the enjoyment of civil and political freedom and of economic, social and cultural rights are interconnected and interdependent' en dat 'when deprived of economic, social and

5. UN Doc. A/2929, p. 7, par. 8.

6. Jhabvala, a.w. p. 159.

7. UN Doc. A/2929, p. 8 i par. 9.

8. Jhabvala, a.w. p. 158. Jhabvala voegt hier in een noot aan toe dat de verklaringen van communistische staten een dergelijk optimisme in die tijd (1950) niet rechtvaardigden.

9. UN Doc. A/2929, p. 7, par. 6. 
cultural rights, man does not represent the human person whom the Universal Declaration regards as the ideal of the free man. ${ }^{10}$ Dit idee van interdependentie tussen beide categorieën rechten is in de preambule van zowel het IVBPR als het IVESCR terug te vinden. ${ }^{11}$

\subsection{Het traditionele onderscheid tussen burger- en politieke rechten en economische, sociale en culturele rechten}

De regeling, in het kader van de $\mathrm{VN}$, van de beide categorieën rechten in afzonderlijke juridische teksten heeft het onderscheid tussen burger- en politieke rechten en sociale rechten versterkt. Niet alleen op mondiaal niveau werd een onderscheid gemaakt bij de formulering van mensenrechtennormen. Ook op regionaal niveau, met name het Europese, vond een dergelijke tweedeling plaats. Burger- en politieke rechten zijn in het Europese kader gecodificeerd in het Europees Verdrag tot Bescherming van de Rechten van de Mens en de Fundamentele Vrijheden (1950). Economische en sociale rechten zijn daarentegen neergelegd in het Europees Sociaal Handvest (1961). Het feit dat beide groepen rechten eigen kenmerken en eigenschappen bezitten, alsmede verschillende implementatie-mechanismen heeft geleid tot de bestendiging van deze tweedeling.

Burger- en politieke rechten kwamen voort uit de idealen van de Amerikaanse en Franse revoluties aan het einde van de $18 \mathrm{e}$ eeuw en zij worden dan ook vaak aangeduid als de klassieke vrijheidsrechten. Deze revoluties vormden ook de eerste aanzet tot de erkenning van economische en sociale rechten van de burger. Zo spreekt de Amerikaanse 'Declaration of Independence' (1776) van de 'pursuit of happiness' als éen van de onvervreemdbare rechten van de mens. De wel aangenomen, maar niet ingevoerde Franse grondwet van 1793 legde reeds de verantwoordelijkheid van de staat voor de zwakkeren in de maatschappij vast. ${ }^{12}$ Artikel 22 van deze grondwet bepaalde dat 'l'instruction est le besoin de tous. La société doit favoriser de tout son pouvoir le progrès de la raison publique et mettre l'instruction a portée de tous les citoyens'. De Staatsregeling voor het Bataafsche Volk van 1798 bepaalde in artikel 49 dat 'er gezorgd (zal) worden voor de opvoeding van verworpen kinders'. In de grondwet van 1815 voor het Koninkrijk der

10. Deze beide formuleringen werden zowel gehanteerd in Sectie E van G.A. Res. 421 (V) op gromd waarvan én verdrag zou worden voorbereid, als in de preambule van G.A. Resolutie 543 (VI), de basis voor twee verdragen.

11. Namelijk in de derde paragraaf die voor IVBPR en IVESCR vrijwel identiek is.

12. De Franse Grondwet van 1793 bepaalde in artikel 21 dat, 'Les secours publics sont une dette sacrée. La société doit la subsistance aux eitoyens malheureux soit en leur procurant du travail ${ }_{1}$ soit en assurant les moyens d'exister à ceux qui sont hors d'état de travailler', en in artike] 23, 'La garantie sociale consiste dans l'action de tous pour assurer à chacun la jouissance et la conservation de ses droits'.

Zie ook F.M. van Asbeck, (ed.), The Universal Declaration of Human Rights and its Predecessors (1679-1948), Leiden 1949. 
Nederlanden werd de (mede) verantwoordelijkheid van de staat voor het onderwijs duidelijk geformuleerd. Artikel 226 bepaalde: "Het openbaar onderwijs is een aanhoudend voorwerp van zorg der Regering'. Economische, sociale en culturele rechten vormden een belangrijk thema tijdens de Russische en Mexicaanse revoluties uit het begin van de 20e eeuw. Een belangrijke impuls aan de ontwikkeling van economische en sociale rechten werd verder gegeven door de Amerikaanse president Roosevelt. In zijn 'Four Freedoms' boodschap aan het Amerikaanse Congres in 1941 lanceerde hij naast de klassieke vrijheden onder andere ook de vrijwaring van gebrek ('freedom from want'). Voortbouwend op de ervaringen met de New Deal politiek in de Verenigde Staten meende hij dat totalitaire tendensen en economische recessies slechts in mondiaal verband door verstrekkende sociale en economische hervormingen konden worden tegengehouen. ${ }^{13}$

Pogingen daartoe waren reeds ondernomen in het Volkenbond Verdrag van 1919 dat in de artikelen 22-25 enige algemene richtlijnen op sociaal gebied gaf. De aan de Volkenbond gelieerde Internationale Arbeids Organisatie bevorderde in sterke mate de ontwikkelingen op dit terrein.

Door de jaren heen zijn er auteurs geweest die de eigen aard en het eigen karakter van zowel economische, sociale en culturele rechten, als van burger- en politieke rechten hebben bepleit met als consequentie dat ook de implementatie verschillend zou moeten zijn. Het achterliggende idee hierbij was steeds dat economische, sociale en culturele rechten een lagere prioriteit zouden bezitten. ${ }^{14}$

Een belangrijk argument van deze benadering dat het onderscheid in aard en karakter tussen de beide groepen rechten moest onderbouwen was de rol van de staat bij de verwezenlijking van de rechten. ${ }^{15}$ Voor de implementatie van burger- en politieke rechten is onthouding van overheids-

13. Zie hierover L.B. Sohn, The New International Law: Protection of the Rights of Individuals rather than States, in: The American University Review, vol. 32 (1982), pp. 1-64, op pp. 32-37. Zie voor de tekst van Roosevelt's Four Freedoms Message, F. Newman, D. Weissbrodt (eds), International Human Rights: Law Policy and Process, Cincinatti 1990, p. 362.

14. Een belangrijke vertegenwoordiger van deze auteurs was $M$. Cranston. Hij verkondigde de opvatting dat economische, sociale en culturele rechten niet eens het karakter hebben van mensenrechten:

'(...) the effect of a Universal Declaration which is overloaded with affirmations of socalled human rights which are not human rights at all is to push all talk of human rights out of the clear realm of the morally compelling into the twilight world of utopian aspiration." Zie M. Cranston, Human Rights, Real and Supposed, in: D.D. Raphael (ed.), Political Theory and the Rights of Man, London 1967, Pp. 43-53, op p. 52.

15. Jhabvala parafraseert de opinies aangaande de rol van de staat bij de verwezenlijking van de beide categorieën rechten, zoals die verwoord werden in VN-verband tijdens het opstellen van de beide verdragen:

'... the implementation of civil and political rights was aseen requiring the abstention by, or the non-intervention of, the state in the lives of individuals, whereas the implementation of economic, social and cultural rights was universally perceived as calling for active state direction and intervention in the life of the society and, in consequence, in the lives of the constituent individuals'. Jhabvala, a.w. p. 160. 
zijde vereist. De verwezenlijking van economische, sociale en culturele rechten daarentegen is afhankelijk van de betrokkenheid en interventie van de overheid. ${ }^{16}$ Dit betekent dat de verwezenlijking van burger- en politieke rechten negatieve verplichtingen aan de staat oplegt, terwijl de implementatie van economische, sociale en culturele rechten positieve maatregelen van de zijde van de overheid vereist. Bepalend voor het onderscheid tussen beide groepen rechten is volgens Bossuyt de aan- of afwezigheid van een financiële overheidsbijdrage aan de verwezenlijking van de rechten. Voor de verwezenlijking van sociale rechten is een grote financiële inspanning van staatswege vereist, terwijl voor de verwezenlijking van burger- en politieke rechten geen of slechts een geringe overheidsbijdrage noodzakelijk is. ${ }^{17}$ De relatie tussen de classificatie van een bepaald recht en een financiële inspanning van overheidszijde werd door Bossuyt als volgt aangeduid:

'Un droit ne saurait impliquer un effort financier parce qu'il est un droit social, mais ce droit est un droit social parce qu'il implique un effort financier!"18

Het verschil in overheidsverplichtingen doet volgens de traditionele theorie ook zijn invloed gelden op de implementatie van beide categorieën. Dit betekent dat het genot van burger-en politieke rechten onmiddeliijk gegarandeerd kan worden, terwijl de implementatie van economische, sociale en culturele rechten het karakter heeft van 'progressive realization', af hankelijk van de fase van economische ontwikkeling die een staat heeft bereikt en de beschikbaarheid van (financiële) middelen. Voor eerstgenoemde categorie rechten werd het tot stand brengen van nationale wetgeving voldoende geacht en zou dientengevolge de implementatie snel kunnen geschieden. Daarentegen zou voor de verwezenlijking van sociale rechten een breed opgezet actieprogramma noodzakelijk zijn hetgeen een stap voor stap benadering impliceert. Deze groep rechten wordt dan ook aangeduid als programmarechten, daarmee een geleidelijke implementatie aangevend. Geleidelijke verwezenlijking was noodzakelijk vanwege:

16. M. Bossuyt, La distinction juridique entre les droits divils et politiques et les droits economiques, sociaux et culturels, in: Revue des Droits de l'Homme/Human Rights Journal, Vol. VIII, (1975), pp, 783-821, op p. 790.

Bossuyt heeft het traditionele onderscheid tussen beide categorieèn rechten op een doorwrochte en uitvoerige manier onderzocht en in dit artikel beschreven. Zie ook $\mathrm{R}$. Brunet, La Garantie Internationale des Droits de l'homme, d'après la Charte de San Francisco, Geneve 1947, p. 226.

17. Het bezwar dat hiertegen ingebracht kan worden is dat ook de verwezenlijking wan bepaalde burger - en politieke rechten financielle overheidsinspanningen vereist. Hierbij valt te denken aan het recht op een eerlijk proces en het functioneren wan een onafhankelijke rechterlijke macht, alsmede het recht wan politieke participatie. Bossuyt is echter van mening dat deze overheidsinspanningen bescheiden van omvang gijn en 'ne dépasse( $n t)$, à aucun moment, la limite du minimum indispensable pour qu"un Etat puisse fonctionner'. Bossuyt, a.w. noot 16 , op p. 814 .

18. Bossuyt, a.w. p. 790 . 
'wide divergencies in natural wealth, scientific and technical advancement and in consequence, in the rapidity of economic development in different countries. ${ }^{19}$

Verder meent Bossuyt dat burger- en politieke rechten voor alle individuen gegarandeerd moeten worden en universeel moeten gelden. De verwezenlijking van sociale rechten dient echter selectief te geschieden, dat wil zeggen, slechts bepaalde individuen of groepen kunnen aanspraak maken op een aantal specifieke rechten. ${ }^{20} \mathrm{Zij}$ genieten aldus een zekere voorkeursbehandeling. Het betreft dan veelal personen met bijzondere behoeften, bijvoorbeeld mensen die een sociale uitkering genieten. Met name deze sociale rechten vereisen een bijzondere bescherming en inspanning van de zijde van de overheid. Men kan zich in dit verband afvragen of deze opvatting niet in strijd is met het non-discriminatiebeginsel, omdat mensenrechten per definitie voor alle mensen gelden.

Een ander onderscheid, volgens de traditionele benadering, tussen burgeren politieke rechten aan de ene kant en economische, sociale en culturele rechten aan de andere kant is een verschil naar inhoud en karakter. Bossuyt is van mening dat de inhoud van burger- en politieke rechten onveranderlijk is ('invariable'), omdat minimum rechten niet van land tot land kunnen verschillen. Economische, sociale en culturele rechten hebben daarentegen een veranderlijke inhoud ('variable") die mede wordt bepaald door het ontwikkelingsniveau van de economie van een staat en de mate van prioriteit van de verwezenlijking van die rechten. ${ }^{21}$ Hieruit kan worden afgeleid dat de inhoud van burger- en politieke rechten duidelijk en onomstreden is, terwijl de inhoud van economische, sociale en culturele rechten nog vaag en betwistbaar is. ${ }^{22}$ Het verschil in karakter manifesteert zich in het absolute karakter van burger- en politieke rechten:

'En reconnaissant des droits civils, le droit positif ne fait que protéger des matières que l'homme possède déjä. 23

Economische, sociale en culturele rechten zijn daarentegen relatief en gekwalificeerd van karakter hetgeen betekent dat:

19. M. Ganji, International Protection of Human Rights, Genève - Paris 1962, p. 205.

20. Bossuyt, a.w. p. 792 .

21. Bossuyt, a.w. p. 790 .

22. Zie in dezelfde zin, P. Sieghart, The International Law of Human Righta, Oxford 1983, pp. 57 en 62.

23. Bossuyt, a.w. p. 791 en p. 802 . 
'l'homme ne peut obtenir les matières qui sont couvertes par les droits sociaux, que dans la mesure où ces droits sont devenus les droits subjectifs. ${ }^{34}$

Er zijn ook andere auteurs die aan economische, sociale en culturele rechten een ander karakter toeschrijven dan aan burger- en politieke rechten. $\mathrm{Zo}$ is Kühnhardt van mening dat economische, sociale en culturele rechten de uitdrukking zijn van bepaalde maatschappelijke behoeften en aanspraken, maar niet als onvervreemdbare rechten geformuleerd kunnen worden. Zij zijn immers afhankelijk van nationale uitvoeringsmaatregelen die cultureel en maatschappelijk bepaald zijn. ${ }^{25}$

De traditionele literatuur kenmerkt zich verder door de stelling dat mensenrechtenbepalingen in internationale verdragen pas als 'echte' individuele rechten kunnen worden aangemerkt indien aan een tweetal vereisten is voldaan, namelijk:

- zij moeten op dusdanige wijze geformuleerd zijn dat het om een individueel recht gaat;

- zij moeten voor een rechter afgedwongen kunnen worden.

Algemeen wordt aanvaard dat burger- en politieke rechten, neergelegd in internationale mensenrechtenverdragen aan beide normen voldoen. ${ }^{26}$ Van economische, sociale en culturele rechten daarentegen, zoals onder meer opgenomen in het IVESCR, wordt beweerd dat zij geen aanspraak kunnen maken op de status van individuele rechten, omdat beide genoemde criteria niet op hen kunnen worden toegepast. Een van de meest uitgesproken vertegenwoordigers van deze richting in de volkenrechtelijke literatuur is Vierdag. ${ }^{27}$

Hij is van mening dat de materiële bepalingen in het IVESCR geen rechten van individuen zijn, maar 'broadly formulated programmes for governmental policies in the economic, social and cultural fields'. ${ }^{28} \mathrm{De}$ verwezenlijking van economische, sociale en culturele bepalingen uit mensenrechtenverdragen is volgens hem geen juridische kwestie, maar is veeleer een politiek vraagstuk. Hij voegt daar aan toe dat in het IVESCR 'the word "right" appears to be used as it of ten is in political programmes, viz., in a moral and hortatory sense. ${ }^{29}$ Slechts indien het genoemde beleid op eco-

24. Idem, p. 791 .

25. La Kahnhardt, Die Universalität der Menschenrechte; Studie zur ideengeschichtlichten Bestimmung eines politischen Schlisselbegriffs, München 1987, op pp. 337-339.

26. Zie onder meer Bossuyt, a.w. p. 793; TK 1975-1976, Kamerstuk 13932 ('R 1037), Nr. 3, p. 13. (Goedkeuring wan het IVBPR, Memorie van Toelichting); E.W. Vierdag, "The legal nature of the rights granted bij the International Covenant on Economic, Social and Cultural Rights', in: Netherlands Yearbook of International Law, vol.9 (1978), pp. 69-106, in het bijzonder pp. 76-79.

27. Zie Vierdag, a.w.

28. Vierdag, a.w. p. 103 (mijn cursivering, A.C.).

29. Idem. 
nomisch, sociaal en cultureel terrein is voltooid kan er sprake zijn van individuele rechten. ${ }^{30}$ Dezelfde gedachte vinden we terug bij Bossuyt die stelt dat:

'[D]ans certains Etats qui jouissent d'un niveau élevé de développement économique, la réalisation de certains droits socio-économiques peut atteindre un stade d'élaboration généralement accepté de manière qu'elle ne soulève plus de controverses politiques. ${ }^{31}$

Deze richting in de literatuur is de mening toegedaan dat het absoluut noodzakelijk is de precieze reikwijdte en inhoud van een sociale bepaling in een mensenrechteninstrument te definiëren in termen van 'legal rights'. Is dit in voldoende mate het geval, dan is er sprake van een 'recht'. In de woorden van Vierdag:

'In order to be a legal right, a right must be legally definable; only then can it be legally enforced, only then it can be said to be justiciable.. ${ }^{32}$

Dit brengt ons op het tweede punt, te weten, de voorwaarde dat economische, sociale en culturele rechten voor een rechterlijke instantie afdwingbaar moeten zijn. Kan een persoon die meent het slachtoffer te zijn van een schending van bijvoorbeeld een sociaal recht als het recht op arbeid dit recht geldend maken voor een nationale instantie, in het bijzonder een nationale rechterlijke instantie? Kan een persoon zich beroepen op een internationale norm die een bepaald sociaal recht garandeert voor de nationale rechter? Vierdag ${ }^{33}$ is van mening dat, indien het internationale recht rechten toekent aan een individuele persoon er ook rechtsmiddelen dienen te zijn, op nationaal en/of internationaal niveau. Zo bepaalt artikel 13 van het Europees Verdrag voor de Rechten van de Mens en de Fundamentele Vrijheden dat een ieder daadwerkelijke rechtshulp voor een nationale instantie gegarandeerd moet worden in geval van schending van rechten en vrijheden vermeld in dit Verdrag. Het betreft hier burger- en politieke rechten. Op het internationaal niveau heeft de klager vervolgens de mogelijkheid een procedure voor de Straatsburgse instantie, te weten de Europese Commissie, te beginnen. Het IVBPR kent een gelijkluidende bepaling in artikel 2(3). Bovendien bestaat op grond van het Facultatief Protocol bij het IVBPR de mogelijkheid dat een individu een klacht aanhangig kan maken bij het Mensenrechten Comité aangaande de beweerde schending van éen of meerdere rechten en vrijheden uit het IVBPR. ${ }^{34}$ Het IVESCR kent geen bepalingen, die aan burgers een rechtsmiddel voor een nationale

30. Vierdag, a.w. p. 104.

31. Bossuyt, a.w. p. 806 .

32. Vierdag, a.w. p. 93.

33. Vierdag, a.w. p. 74 .

34. Artikel 1, Facultatief Protocol bij het IVBPR. 
en/of internationale instantie toekennen in geval van een beweerde schending van êen van de materiële rechten door een verdragsstaat.

In de literatuur is een aantal auteurs het erover eens dat economische, sociale en culturele rechten in de meeste staten vooralsnog niet "justiciable" zijn, dat wil zeggen voor een nationale rechterlijke instantie afdwingbaar. Bossuyt merkt op dat sociale rechten, zelfs op het nationale niveau, slechts bij uitzondering juridisch afdwingbaar zijn. ${ }^{35}$ Dat betreft dan gevallen waarin sociale rechten gedetailleerd ziljn geregeld waarbij de nationale rechter binnen bepaalde grenzen kan toetsen. Op het internationale niveau bestaat echter geen enkele mogelijkheid tot het afdwingen van economische, sociale en culturele normen:

'Préconiser un contrôle judiciaire des droits sociaux au niveau international constituerait donc un manque de réalisme. ${ }^{36}$

Reeds in de jaren vijftig, tijdens de discussies over de vraag of er één of twee mensenrechtenverdragen opgesteld moesten worden, speelde de kwestie van de verwezenlijking van die rechten in de nationale rechtsorde. Het onderscheid tussen burger- en politieke rechten enerzijds en economische, sociale en culturele rechten anderzijds diende volgens een memorandum van Israël genuanceerd beschouwd te worden. ${ }^{37}$ Niet de vraag of een recht politiek, dan wel sociaal van aard is was relevant. Het ging veel meer om de vraag op welke wijze een bepaald recht verwezenlijkt kon worden in de nationalle rechtsorde. In dat verband konden twee groepen rechten onderscheiden worden. Enerzijds de rechten die verwezenlijkt konden worden door onmiddellijke wetgevende of bestuurlijke handelingen van de staat en die ook direct afgedwongen konden worden voor een nationale rechterlijke instantie. Deze groep omvatte ook die rechten die al verwezenlijkt waren voordat een staat partij werd bij éẻn van beide mensenrechtenverdragen. Anderzijds is er de groep rechten die pas in juridische zin verwezenlijkt zijn nadat bepaalde programma"s, waaronder sociaal-economische programma's, zijn uitgevoerd. De eerste groep werd aangeduid als 'legal rights', de tweede groep rechten als 'programme rights'. Een bepaald recht, bijvoorbeeld het recht op kosteloos en verplicht primair onderwijs, kan voor de ene staat een 'programme right' zijn, terwijl het in een andere staat reeds een verworvenheid is en dus een 'legal right'. Volgens deze Israëlische opvatting is het onderscheid tussen de verschillende rechten niet strikt, maar veeleer gradueel en af hankelijk van de implementatie in de nationale rechtsorde. Vierdag sluit aan bij deze Israëlische opvatting en stelt dat niet zonder meer kan worden gezegd dat sociale, economische en culturele rechten niet afdwingbaar zijn. Naar zijn mening is de afdwingbaarheid van econo-

35. Bossuyt, a.w. p. 794. Zie ook Brunet, a.w. p. 226.

30. Ibid. Zie ook A. Berenstein, Economic and Social Rights: Their Inclusion in the European Convention of Human Rights. Problems of Formulation and Interpretation, in: Human Rights Law Journal, Vol. 2 (1936), pp. 257-281, p. 271.

37. UN Dac. A/C $3 / 565,(9-1-1952)$ Memorandum van Israël. 
mische, sociale en culturele rechten afhankelijk van de maatschappelijkeconomische context waarin zij werken. ${ }^{38}$

Bovendien is de overheidsbemoeienis, met name een financièle inspanning, die noodzakelijk is voor de verwezenlijking van bepaalde economische, sociale en culturele rechten in bepaalde staten wel aanwezig. Het betreft in de meeste gevallen westerse, ontwikkelde landen waarin bijvoorbeeld het recht op sociale zekerheid, voedsel, kleding, gelijke beloning volgens ILO-normen of medische verzorging volgens Vierdag niet per definitie niet afdwingbaar zijn. ${ }^{39}$

Een aantal sociale rechten is zonder meer afdwingbaar, zoals de vrijheid van vakvereniging en het recht op werkstaking. Belangrijke artikelen uit het IVESCR die volgens Vierdag niet afdwingbaar zijn voor een nationale rechterlijke instantie zijn het recht op werk (artikel 6), huisvesting (artikel 11) en het recht op onderwijs (artikel 13). ${ }^{40}$ De verwezenlijking van deze rechten is eerder een kwestie van politieke, economische en sociale aard, die aanzienlijke overheidsuitgaven met zich meebrengt, en geen juridische kwestie die gedefinieerd kan worden in termen van juridische aanspraken.

Aan de andere kant zijn er ook auteurs die het standpunt innemen dat bepaalde sociale rechten, met behulp van het gelijkheidsbeginsel, well juridische afdwingbaar zijn, afhankelijk van de wijze van doorwerking van het internationale recht in de nationale rechtsorde. ${ }^{41}$ Dat kan bijvoorbeeld gebeuren door een beroep te doen op artikel 26 IVBPR dat een zelfstandig karakter heeft, en dat niet alleen betrekking heeft op de rechten uit het IVBPR, maar ook op sociale, economische en culturele rechten. ${ }^{42}$

38. Vierdag, a.w. p. 85 .

39. Vierdag, a.w. p. 103 . Zie ook gericht op de Nederlandse situatie, A.W. Heringa, Equal Remuneration as a self-executing social right, in: SIM Newsletter, No. 8 , October 1984, pp. 10-15 en L. Betten, P. van Dijk, Lentezwaluw of dode mus? Enige beschouwingen over de wijzen waarop de doorwerking van internationale normen angaande de economische en sociale grondrechten binmen de Nederlande rechtsorde wordt bevorderd, in: J.B.M.M. ten Berge e.a. (red.), Recht als norm en aspiratie, Nijmegen 1986, pp. 266-286.

Heringa heeft in zijn dissertatie aangetoond op welke verschillende wijzen sociale rechten uit verdragen kunnen doorwerken in de Nederlandse rechtsorde; zie hoofdstuk $V$ van zijn dissertatie, A.W. Heringa, Sociale grondrechten, hun plaats in de gereedschapsikist van de rechter, 'B-Gravenhage 1989.

40. Vierdag, a.w. p. 103. Zie ook "Goedkeuring van het Internationaal Verdrag ingake Economische, Sociale en Culturele Rechten, TK, xitting 1975-1976, Kamerstuk 13932 (R 1037), Memorie van Toelichting, nr. 3, pp. 12, 13.

41. Zie Heringa (1989), a.w. pp. 297-305, en E.A. Alkema, Het internationale gelijkheidsbeginsel en de Nederlandse staatsrechtelijke verhoudingen, in: Staatsrecht, Buitenlandse Betrekkingen en de internationale rechtsorde (Staatsrechtconferentie 1986), Nijmegen 1987, pp. 64-105, op p. 95 e.v.

42. Deze opvatting werd ook door het Mensenrechtencomité onderschreven; zie de zaak B. tegen Nederland, 9-4-1987, in: NJCM-Bulletin 12-5 (1987), pp. 378-391 (met noot $\operatorname{van}$ T. Zwart). 
Een en ander samenvattend zijn er een aantall auteurs die zowel aan burger- en politieke rechten alls aan economische, sociale en culturele rechten een eigen karakter toekennen. Eén van de implicaties daarvan is dat ook hun wijze van implementatie verschillend zou zijn. Zo zouden economische, sociale en culturele rechten niet afdwingbaar zijn voor een nationale rechterlijke instantie, terwijl burger-en politieke rechten zich wel daartoe lenen. Dit strikte onderscheid kan gerelativeerd worden door te wijzen op het feit dat voor beide groepen rechten geldt dat hun verwezenlijking af hankelijk is van de maatschappelijke context en de nationale rechtsorde waarin deze rechten doorwerken.

\subsection{De eenheid en onderlinge afhankelijkheid van mensenrechten}

Zoals gezegd werd de traditionele mensenrechtenbenadering binnen de VN vooral gepropageerd door de westerse landen die binnen deze organisatie tot het einde van de jaren vijftig een numeriek overwicht hadden. Nadat in de jaren zestig steeds meer nieuwe, onafhankelijke staten lid waren geworden van de VN, begonnen ook de accenten ten aanzien van de mensenrechtenbenadering te verschuiven. Onder invloed van Derde Wereldlanden en communistische staten werd de hiërarchie van de rechten van de mensen omgekeerd. Dat betekende dat de verwezenlijking van economische, sociale en culturele rechten volgens de meerderheid van de lidstaten prioriteit verdiende boven de verwezenlijking van burger- en politieke rechten. Deze stroming kwam vooral tot bloei in de jaren zeventig, mede onder invloed van belangrijke resoluties over een Nieuwe Internationale Economische Orde. ${ }^{43}$ De aanzet tot deze verlegging van accenten werd gegeven in de Proclamatie van Teheran van 1968. Paragraaf 13 van dit document bepaalde:

'Since human rights and fundamental freedoms are indivisible, the full realization of civil and political rights without the enjoyment of economic, social and cultural rights, is impossible. The achievement of lasting progress in the implementation of human rights is dependent upon sound and effective national and international policies of economic and social development.'

In feite werd hier de volledige verwezenlijking van burger- en politieke rechten afhankelijk gesteld van nationale en internationale sociaal-economische vooruitgang. Deze gedachte werd verder uitgewerkt in een belangrijke resolutie van de Algemene Vergadering van de VN, te weten Resolutie $32 / 130$ van 16 december 1977. Deze tekst legt de ondeelbaarheid en onderlinge afhankelijkheid van beide categorieën rechten vast, en bepaalt daarnaast dat:

43. Zie over de mensenrechtenbenadering van Derde Wereldlanden, Cassese, a.w. pp. 307-309. 
'The full realization of civil and political rights without the enjoyment of economic, social and cultural rights is impossible; the achievement of lasting progress in the implementation of human rights is dependent upon sound and effective national and international policies of economic and social development, as recognized by the Proclamation of Teheran (1968).'

Deze Resolutie benadrukt vooral het belang van de verwezenlijking van economische, sociale en culturele rechten. ${ }^{44}$ Resolutie $32 / 130$ werd aangenomen met 123 stemmen vóor, geen tegen bij 15 onthoudingen. De negen lidstaten van de EG, met uitzondering van Denemarken, en voorts onder meer de Verenigde Staten en Oostenrijk onthielden zich van stemming. De EG-lidstaten verklaarden onder meer dat zij een gelijk gewicht toekenden aan de politieke- en burgerrechten enerzijds en de economische, sociale en culturele rechten anderzijds. $\mathrm{Zij}$ konden niet instemmen met prioriteit van de ene groep rechten ten koste van de andere. ${ }^{45}$

Begin jaren tachtig begon zich in de VN een ontwikkeling af te tekenen die op een meer genuanceerde manier aandacht vroeg voor de verwezenlijking van de rechten van de mens. Dat is de benadering die primair de eenheid en ondeelbaarheid van beide categorieën rechten benadrukt. Daarbij wordt in eerste instantie gewezen op de universele notie van de rechten van de mens zoals die in thet Handvest van de $\mathrm{VN}$ is vastgelegd. De bevordering en de naleving van de rechten van de mens wordt in artikel 55 van het Handvest in verband gebracht met internationale economische en sociale samenwerking. Tevens bestaat er een verband tussen het bevorderen van de rechten van de mens en één van de hoofddoeleinden van de VN, namelijk 'to achieve international co-operation in solving international problems of an economic, social, cultural and humanitarian character. ${ }^{46}$ Dezelfde gedachte is te vinden in de preambule van de Universele Verklaring van de Rechten van de Mens, waarin wordt bepaald dat de volkeren van de VN 'have determined to promote social progress and better standards of life in larger freedom'. 47

Resoluties die sedert de jaren tachtig tot stand zijn gekomen spreken zich niet langer uit voor de prioriteit van de ene categorie rechten boven de

44. Zie Ph. Alston, Prevention versus Cure as a Human Rights Strategy, in: Development, Human Rights and the Rule of Law, Report of a Conference held in The Hague on 27 April - 1 May 1981, convened by the International Commission of Jurists, 1981, pp. 31-109, met name pp. 34-47. Zie ook, Cassese, a.w. pp. 309, 310.

45. Zie Uitgaven van het Ministerie van Buitenlandse Zaken, no. 120 deel $I_{n} p p .169-171$ en de Verklaring wan de Nederlandse afgevaardigde in Commiesie III (22-11-1977), deel II bijlage 170 .

46. Artikel 1(3) Handveat VN.

47. Zie ün dit verband ook artikel 22 van de Universele Verklaring. 
andere categorie. ${ }^{48}$ In het bijzonder de belangrijke 'Declaration on the Right to Development' geeft dit idee duidelijk weer. Artikel 6 lid 2 van deze Declaratie bepaalt:

'All human rights and fundamental freedoms are indivisible and interdependent; equal attention and urgent consideration should be given to the implementation, promotion and protection of civil, political, economic, social and cultural rights. ${ }^{, 49}$

Het eerste gedeelte van deze zin is afkomstig uit Resolutie $32 / 130$.

De gedachte achter deze benadering is dat het belang van economische, sociale en culturele rechten moet worden aangevuld met de noodzaak om burger- en politieke rechten te verwezenlijken die immers het individu in staat stellen de staat te controleren.

Recente politieke veranderingen in Oosteuropese en Latijnsamerikaanse landen geven uiting aan de wens tot pluralistische structuren en de noodzaak van naleving van burger- en politieke rechten. Eén van de vragen die zich in dit verband voordoen is welke invloed deze politieke veranderingen (kunnen) hebben op de verwezenlijking van economische, sociale en culturele rechten. Men kan zich bijvoorbeeld afvragen welke invloed de opkomst van het politiek pluralisme in Oosteuropese landen heeft op de ontwikkeling van een pluralistische organisatie van het onderwijs. Betekent dat dat de vrijheid van onderwijs werkelijk inhoud krijgt en dat de indoctrinatie verdwijnt?

Als gevolg van de ideologische ontspanning tussen Oost en West krijgt de verwezenlijking van economische, sociale en culturele rechten sedert een aantal jaren binnen de $\mathrm{VN}$ hernieuwde aandacht. In een recente studie van Türk, rapporteur van de Subcommissie inzake de Voorkoming van Discriminatie en de Bescherming van Minderheden, wordt gesteld dat zich binnen de $\mathrm{VN}$ een meer evenwichtige, minder hiërarchische benadering begint te ontwikkelen aangaande de verwezenlijking van beide groepen mensenrechten. Volgens Türk kan in de huidige tijd gesproken worden van een 'unified approach' in de relatie tussen burger- en politieke rechten en eco-

48. Ook in resoluties van jongere datum wordt de ondeelbaarheid en interdependentie van economische, sociale en culturele rechten en burger- en politieke rechten benadrukt, qie bijvoorbeeld General Assembly Res. 40/114 van 13 december 1985. Vóór deze Resolutie stemden 134 ataten (waaronder Nederland), slechts 1 staat stemde tegen (de V.S.) bij 19 onthoudingen (waaronder een achttal leden van de Europese Gemeenschap).

Zie ook, in regionalal verband, Declaration on Human Rights, adopted by the Foreign Ministers of the European Community, Brussels 21 July 1986, 0.a. afgedrukt in Sim Newsletter, No. 16, November 1986, pp. 69, 70.

49. G.A. Res. 41/128 van 4 december 1986, anvaard met 146 tegen 1 stem (de Verenigde Staten), bij 8 onthoudingen (Denemarken, Finland, de BRD, IJsland, Israël, Japan, Zweden en het Verenigd Koninkrijk). Vergelijk ook de tiende Preambulaire paragraaf van deze Declaratie. 
nomische, sociale en culturele rechten. ${ }^{50}$ Deze benadering is gebaseerd op de gedlachte van de menselijke waardigheid ('human dignity') die inherent is aan de verwezenlijking van alle rechten van de mens. Dit idee van menselijke waardigheid is onder meer vastgelegd in artikel 1 van de Universele Verklaring van de Rechten van de Mens, alsmede in de preambules van beide mensenrechtenverdragen van 1966.

Het besef dat niet alleen de verwezenlijking van economische, sociale en culturele rechten een overheidsinspanning of bemoeienis vereist, maar ook de implementatie van burger- en politieke rechten heeft bijgedragen tot de relativering van de benadering die een inherent onderscheid in aard en karakter tussen beide groepen rechten propageert. Een ander aspect dat het onderscheid tussen beide groepen rechten doet vervagen is dat een aantal rechten dat opgenomen is in het IVESCR toch voor onmiddellijke implementatie in aanmerking kan komen. Voorbeelden hiervan zijn de vrijheid van vakvereniging en het recht van staking (artikel 8(1)), als ook de vrijheid van ouders bij de keuze van het onderwijs voor hun kinderen (artikel 13(3)). Aan de andere kant zijn er ook bepalingen in het IVBPR die niet onmiddellijk verwezenlijkt kunnen worden en dus meer het karakter hebben van programmarechten. Voorbeeld hiervan is artikel 24(1) IVBPR, dat bepaalt dat elk kind recht heeft op bescherming door gezin, maatschappij en de staat. Bovendien kan worden gesteld dat de eenheid en onderlinge afhankelijkheid van beide groepen rechten versterkt wordt doordat sommige rechten 'double' of 'mixed" van karakter zijn. Dit betekent dat zij zowel kenmerken bezitten van sociale rechten als van vrijheidsrechten. De implementatie van deze bijzondere categorie rechten impliceert zowel ne-

50. Zie Realization of Economic, Social and Cultural Rights, Preliminary Report by D. Türk, Special Rapporteur, UN Doc. E/CN.4/Sub.2/1989/19. Toch zijn er nog steeds staten die hardnekkig vast houden an het strikte onderscheid en de hiërarchie tussen

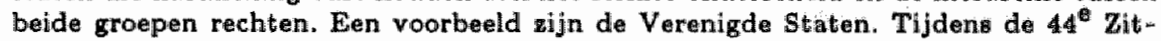
ting van de Commissie voor de Rechten van de Mens in 1988, merkte de Amerikanse afgevaardigde ander meer op:

'What was needed was international introspection on the meaning of human rights. Such introspection, would return one to the "core" understanding of human rights as political and civil rights, including, but not limited to, rights of political participation, religious freedom, free speech, private property and protection from arbitrary government interference - in short, to many of the protections encompassed the American 'Bill of Rights'. The so-called social and economic 'rights' were, in reality, proper goals of governnemt. The endless enumeration of 'rights:" such as the undefined 'right to development' - demeaned the core notion of rights as protecting individuals from official abuse. Indeed, social and economic 'rights' were only calls to increase the State's power over the lives of its people. Rights were grounded in individual persons and individual preferences and he rejected the notion that individual rights could be subordinated to the social good."

Zie UN Press Release HR/2125 (Geneva), 15-2-1988, p. 8.

Zulke opvattingen blijven gelnspireerd door ideologische motieven. Zie hierover, P.J.I.M. de Waart, Veertig jaar economische, sociale en culturele mensenrechten, in: Rechtskundig Weekblad 1988-1989, nr. 32 - 8 april 1989, pp. 1073-1078. Zie voorts Ph. Alston, U.S. Ratification of the Covenant on Economic, Social and Cultural Rights: The need for an entirely new strategy, in: American Jourmal of International Law, rol. 84 (1990), pp. $365-393$. 
gatieve als positieve overheidsverplichtingen. Tot deze groep rechten behoren met name de culturele rechten. ${ }^{51}$ Verschillende auteurs rekenen het recht op onderwijs tot de categorie van de culturele rechten. ${ }^{52}$

Gesteld kan worden dat er volgens recente opvattingen geen strikt onderscheid bestaat tussen burger- en politieke rechten en economische, sociale en culturele rechten. Het gaat eerder om een verschil in gradatie. Zowel de implementatie van burgerrechten als van sociale rechten wordt mede bepaald door de beschikbaarheid van economische en financiële hulpbronnen als ook door het tot stand brengen van maatschappelijke structuren en instituties, met name in ontwikkelingslanden. ${ }^{53}$ Dit doel kan slechts verwezenlijkt worden, indien rekening wordt gehouden met de specifieke economische, maatschappelijke en politieke structuur van elke afzonderlijke staat. De relatie tussen beide categorieên rechten werd ook onderkend door de Inter-Amerikaanse Commissie voor de Rechten van de Mens. Ten aanzien van de Latijnsamerikaanse regio merkte de Commissie op:

Neglect of the economic and social rights is another cause, though more diffuse and problematic, of the violence and social conflicts. The general and apparently well-founded belief is that in some countries, the extreme poverty of the masses - the result in part of an inequitable distribution of the resources of production - has been the fundamental cause of the terror that afflicted and continues to afflict those countries.'

Bovendien was de Commissie van oordeel dat:

"the essence of the legal obligation incurred by any government in this area is to strive to achieve the economic and social aspirations of its people, by following an order that assigns priority to the basic needs of health, nutrition and education. The priority of the "rights of survival" and "basic needs" is a natural consequence of the right to personal security. ${ }^{54}$

De Commissie betoogt hier dat verwezenlijking van de sociale en economische rechten van de bevolking een gunstige invloed zal hebben op het respect voor burger- en politieke rechten, in bijzonder het recht op leven.

51. Bossuyt, a.w. p. 809 .

62. Zie bijvoorbeeld I. Szab $\delta_{,}$Cultural Rights, Leiden/Budapest, 1974.

53. Th.C. van Boven, Distinguishing Criteria of Human Rights, in: K. Vasak/Ph. Alston (eds). The International Dimensions of Human Rights, UNESCO/Greenwood Press, 1982, vol. 1, pp. 43-60, p. 53.

54. Zie Annual Report of the Inter-American Commission on Human Rights, 1982-1983, Washington D.C. 1983 , pp. 36,37 . 
Het Europese Hof voor de Rechten van de Mens heeft eveneens de verwantschap tussen economische, sociale en culturele rechten en burger- en politieke rechten benadrukt. In de Airey-Case stelde het Hof:

'Whilst the (European) Convention sets forth what are essentially civil and political rights, many of them have implications of a social or economic nature. The Court therefore considers ..., that the mere fact that an interpretation of the Convention may extend into the sphere of social and economic rights should not be a decisive factor against such an interpretation; there is no watertight division separating that sphere from the field covered by the Convention. ${ }^{.55}$

Ook recentere literatuur betreffende klassieke en sociale rechten wordt niet gekenmerkt door de veronderstelling van een strikt onderscheid. $\mathrm{Er}$ is eerder sprake van een dynamische ontwikkeling, waarbij toepassing en handhaving van beide categorieën rechten naar elkaar toegroeien. ${ }^{56}$ Een van oorsprong klassieke vrijheid zoals de vrijheid van onderwijs vereist een actief overheidsbeleid dat het kader moet scheppen waarin die vrijheid kan worden genoten. Hier doet zich het sociale aspect gelden. Andlerzijds wordt het recht op werkstaking van oudsher gerekend tot de sociale grondrechten, maar het heeft ook onmiskenbare vrijheidsaspecten, in die zin dat de overheid zich in principe dient te onthouden van interventie in de arbeidsverhoudingen tussen werkgevers en werknemers. Daarnaast is er een nieuwe categorie bepalingen ontstaan waarbij het gaat om aanspraken op een

55. Judgement of 9 October 1979, Publications of the European Court of Human Rights, Series A., Vol. 32, p. 15, par. 26.

56. Zie E.A. Alkema, Schakelbepalingen: Enige beschouwingen over samenhang en werking van de rechten van de mens, Oratie, Universiteit van Amsterdam, Deventer 1981 .

Alkema is van mening dat de afstand tussen klassieke en sociale rechten is verminderd dankrij de werking van ischakeilbepalingen. Als schakelbepalingen onderscheid: hij:

- De zogenaamde 'modaliteiten", de regel die aangeven hoe met mensenrachten moet worden omgegaan (discriminatieverbod, misbruikverbod, en algemene regels over de beperkingen wan mensenrechten).

- implementatie- en nalevingsregels aangaande verdragsbepalingen.

Gemeenschappelijk hebben deze schakelbepalingen dat ze 'accessoir' zijn, d.w.z. zij vervullen hun functie in samenhang met de klasaieke en sociale mensenrechten. In de loop der jaren is het aantal mensenrechtenverdragen toegenomen; dit heeft gelleid tot een explosieve groei van mensenrechtennormen.

Dankzij de schakelbepalingen is er een net van materiele normen ontgtaan waardoor de garanties voor hun naleving onderling worden versterkt.

Zie ook Jhabvala, a.w. pp. 160-162 en Henkin, a.w. p. 239. Ook volgens Vierdag is er geen sprake van een strikt onderscheid tussen beïde categorieën rechten, maar earder van een relatief of gradueel verschil, zie $\mathbf{E}$.W. Vierdag, The concept of discrimination in international Law (with special reference to human rights), The Hague 1973, pp. 76, 77. Zie verder P. Sieghart, The Lawful Rights of Mankind, Oxford 1986, pp. 81 84, en R.J. Vincent, Human Rights and Intermational Relations, Cambridge 1986, pp. 89-90. 
prestatie van de zijde van de overheid ('Leistungsansprüche'). ${ }^{57}$ Het betreft van oorsprong sociale rechten waarbij de staat een zekere verzorgingsverplichting heeft die zich manifesteert in de vorm van een financiële prestatie van overheidszijde, zoals de bijstand. Het gaat hier om aanspraken die verder gaan dan het voeren van een bepaald overheidsbeleid; het zijn individuele aanspraken die voor de rechter afged wongen kunnen worden. Op deze wijze heeft de praktijk van de rechtsontwikkeling bijgedragen aan de vervaging van het onderscheid tussen klassieke rechten enerzijds en sociale rechten anderzijds.

Samengevat kan worden gezegd dat de huidige benadering binnen de VN aangaande de verwezenlijking van de rechten van de mens gebaseerd is op de eenheid en onderlinge afhankelijkheid van burger- en politieke rechten en economische sociale en culturele rechten. Dit uitgangspunt vindt mede onderbouwing in het feit dat voor de verwezenlijking van beide groepen rechten overheidsbemoeienis noodzakelijk is. Bovendien bezitten sommige rechten een gemengd karakter, en heeft de rechtsontwikkeling het onderscheid tussen beide groepen rechten doen vervagen.

\subsection{De verwezenlijking van economische, sociale en culturele rechten; een alternatieve benadering}

\subsubsection{Verplichtingen voor de staat}

De benaderingen die een, al dan niet strikt, onderscheid aanbrengen en voorstaan tussen burger- en politieke rechten enerzijds en economische, sociale en culturele rechten anderzijds zijn naar mijn mening inmiddels achterhaald en in de praktijk van weinig nut.

Een benadering die de eenheid tussen beide categorieën rechten bepleit draagt meer bij aan een wetenschappelijke theorie van de rechten van de mens, als ook aan de daadwerkelijke verwezenlijking en bevordering van die rechten. Het concept van economische, sociale en culturele rechten behoeft nadere uitwerking opdat de juridische implicaties van deze categorie mensenrechten duidelijk worden. Op deze wijze kan de verhouding tot burger- en politieke rechten worden vastgesteld. Om karakter, betekenis en reikwijdte van economische, sociale en culturele rechten te analyseren moet niet uitsluitend aandacht worden geschonken aan het 'individuele' aspect van deze rechten, zoals dat in de traditionele literatuur veelal het geval is. De benadering die benadrukt dat verwezenlijking van economische, sociale en culturele mensenrechten verplichtingen voor staten impliceert, biedt hiertoe een beter perspectief.

57. Zie T. Koopmans, Vrijheden in beweging, Rede, Zwolle 1977. Vergelijk ook D. Pieters, Sociale Grondrechten op prestaties in de grondwetten van de landen van de Europese Gemeenschap, Antwerpen 1985, alsmede de dissertatie van A.W. Heringa, pp. 109-113. Ook Vierdag onderscheidt deze categorie rechten, zie Vierdag (1978), a.w. pp. 102, 103. 
Een staat die partij is bij een internationaal verdrag is gebonden aan de bepalingen van het verdrag. Met andere woorden, een staat die de bepalingen van een verdrag heeft aanvaard heeft bepaalde verplichtingen op zich genomen. ${ }^{58}$ Zoals hiervoor al is gesteld wordt de formulering van de bepalingen in internationale mensenrechtenverdragen aangaande economische, sociale en culturele rechten soms gekenmerkt door vaagheid en algemeenheid. Dat wil zeggen dat het niet altijd duidelijk is welke concrete verplichtingen daar voor een staat uit voortvloeien. Het is zaak inhoud en betekenis te geven aan de verdragsbepalingen, deze te verfijnen en concrete ijkpunten te ontwikkelen waaraan de nationale implementatie van economische, sociale en culturele rechten kan worden getoetst ${ }^{59} \mathrm{Bij}$ dit onderzoek dient een onderscheid gemaakt te worden tussen interne en externe verplichtingen. Interne verplichtingen heeft de staat ten opzichte van de eigen bevolking, het betreft de nationale implementatie van verdragsbepalingen; externe verplichtingen, de internationale implementatie, gaat een staat aan ten opzichte van andere landen. Ten tijde van het opstellen van beide VN mensenrechtenverdragen werd door een belangrijke groep landen reeds gepleit voor het opnemen van gedetailleerde bepalingen en specifieke verplichtingen voor staten in de ontwerpverdragen:

'what was the purpose of drafting covenants on human rights if not define the scope and substance of each right, its limitations, and the obligations of the State in respect thereof, as precisely as possible, and thereby to set up international legal standards and rules whereby a State would abide. ${ }^{60}$

Een staat die partij is bij een of meer verdragen die economische, sociale en culturele mensenrechten vastleggen, heeft de verplichting aan zijn onderdanen een bepaald minimum niveau van economisch, sociaal en cultureel welzijn te garanderen en dit minimum verder uit te bouwen en te versterken. Om dit doel te bereiken dient een staat bepaalde programma's op economisch, sociaal en cultureel gebied op te stellen en uit te voeren. Het vergt mijns inziens nader onderzoek om aan te kunnen geven hoe de algemene verdragsformuleringen van sociale mensenrechten kunnen worden vertaald in concrete programma's tot wetgeving of andere overheidsmaatregelen die moeten leiden tot de daadwerkelijke verwezenlijking van die sociale mensenrechten.

Trubek heeft aangegeven waarom het van belang is deze programmatische verplichtingen van de staat vorm te geven in internationale verdragen:

58. Zie de 'Vienna Convention on the Law of Treaties', artikel 26: 'Every treaty in force is binding upon the parties and must be performed by them in good faith".

59. Zie G.J.H. van Hoof, The Legal Nature of Economic, Social and Cultural Rights: A Rebuttal of some Traditional Views, in: $\mathrm{Ph}$. Alston/K. Tomasevski (edis), The Right to Food, The Hague, 1984, p. 102. Zie ook, Report on the Right to Adequate Food as a Human Right, by Mr. Asbjørn Eide, Special Rapporteur, UN Doc. E/CN.4/Sub.2/ $1987 / 23$, hoofdstuk II.

60. UN Doc. A/2929 (1955), p. 9, par. 22. 
'The idea that welfare is a social construct, and the conditions of welfare in part a governmental responsibility, lies behind the separate "rights" articulated by numerous international instruments. It also expresses what is universal in this area. It is an idea held, at least at the most general level, by all nations, (...) It is because proponents of the liberal welfare state, and the socialist state, as well as variations and permutations of these structures, agree on the importance of state action for the promotion of individual welfare that these rights have been accepted in international law: ${ }^{, 61}$

De nationale implementatie van economische, sociale en culturele rechten is gegoten in de vorm van individuele rechten, maar impliceert bemoeienis en interventie van de zijde van de overheid die kan worden gedefinieerd in termen van verplichtingen voor de staat.

Indien een staat verdragsverplichtingen is aangegaan dient hij te garanderen dat de nationale wetgeving in overeenstemming is met die internationale verplichtingen. ${ }^{62}$ Een staat die nalaat zijn internationale verplichtingen intern na te leven is daarvoor internationaal aansprakelijk. Er bestaat een tweetal vormen aangaande de manier waarop een internationale bepaling verplichtingen oplegt aan een staat, namelijk 'obligations of conduct' en 'obligations of result'. ${ }^{63}$ In het kader van mensenrechtenverdragen zijn 'obligations of result' een veel voorkomende vorm. ${ }^{64}$

81. David M. Trubek Economic, Social and Cultural Rights in the Third World: Human Rights Law and Human Rights Needs Programs. In: Th. Meron (ed.), Human Rights in International Law: Legal and Pollicy Issues, Oxford 1984, Vol. I, pp. 205, 206.

62. Zie artikel 27, Vienna Convention on the Law of Treaties; 'A party may not invoke the provisions of its internal law as justification for its failure to perform a treaty (....)" Zie ook, Permanent Court of International Justice, Advisory Opinion on Exchange of Greek and Turkish Populations, Series B, No. 10, p. 20.

Het nilet nakomen van internationale werdragsverplichtingen door een staat $\mathrm{kan}$ miet gerechtivardigd worden door het inroepen van bepalingen van nationale wetgeving, zelfe niet grondwetsbepalingen. Zie, Advisory Opinion on the Treatment of Polish Nationals and Other Persons of Polish Origin or Speech in the Danzig Territory. PCIJ "Series A/B, No. 44 , p. 24 .

63. Zie, Sixth Report on State Reaponsibility, by Mr. Roberto Ago, Special Rapporteur. UN Doc. A/CN.4/302 and Add. 1-3. In: Yearbook of the International Law Commission, 1977, Vol. II, Part one, pp. 3-20, en Report of the International Law Commission on its twentyninth session. In: Yearbook of the International Law Commission, 1977, Vol. II, part two, pp. 11-30.

64. G.S. Goodwin-Gill, Obligations of Conduct and Result, in: Alston/Tomasevski, The Right to Food, a.w. pp. 111-119.

De ILC definieert een schending van een 'obligation of result" aldus:

'1. There is a breach by a State of an international obligation requiring it to achieve, by means of its own choice, a specified result if, by the conduct adopted, the State does not achieve the result required of it by that obligation.

2. When the conduct of the State has created a gituation not in conformity with the result required of it by an international obligation, but the obligation allows that this or an equivalent result may nevertheless be achieved by subsequent conduct of the State, there is a breach of the obligation only if the State also fails by its subsequent conduct to achieve the result required of it by that obligation'. 
Bij een 'obligation of result' hebben staten een vrije keus van middelen aangaande de verwezenlijking van het door de verplichting vereiste resultaat. Dit is veelal het geval indien staten een bepaalde situatie moeten verwezenlijken in hun eigen rechtssysteem. De 'obligation of result' laat daartoe alle middelen en methoden open, indien uiteindelijk maar het resultaat in overeenstemming is met het vereiste van de internationale verplichting. In het kader van mensenrechtenverdragen bezitten staten soms een aanzienlijke mate van keuzevrijheid, of een verdragsbepaling spreekt een voorkeur uit voor wetgevende maatregelen. Dit is zeker het geval bij economische, sociale en culturele mensenrechten. ${ }^{65}$

Er zijn evenwel ook bepalingen in mensenrechtenverdragen die het karakter hebben van 'obligations of conduct'. Dat wil zeggen dat de bepaling een specifieke handelswijze of gedragslijn vereist die in de tekst duidelijk wordt beschreven. Dan bestaat er geen beleidsvrijheid voor de staat. ${ }^{66}$ Deze is verplicht precies zo te handelen zoals de verdragsbepaling gebiedt te doen.

Het valt niet altijd even eenduidig vast te stellen of een verdragsbepaling een 'obligation of result', dan wel een 'obligation of conduct' inhoudt. Soms bevat een verdragsbepaling elementen van beide en is er sprake van een mengvorm. Zo kan het ene lid van een bepaling de staat de nodige beleidsvrijheid geven om een bepaald resultaat te verwezenlijken. Een ander lid van dat verdragsartikel kan daarentegen de staat een specifieke gedragslijn voorschrijven. We zullen in hoofdstuk 5 zien dat sommige internationale teksten die het recht op onderwijs vastleggen inderdaad beide vormen van verplichtingen behelzen. Dit onderscheid kan behulpzaam zijn bij de beantwoording van de vraag welke concrete verplichtingen een staat heeft aangaande de verwezenlijking van het recht op onderwijs.

\subsubsection{Een typologie van verplichtingen}

De ontwikkeling van het internationale recht gaat, zoals gezegd, in een richting waarbij verpllichtingen ontstaan die staten binden programma's op te zetten en uit te voeren gericht op het waarborgen van minimumniveaus van sociaal-economisch welzijn en deze niveaus geleidelijk te verhogen. ${ }^{67} \mathrm{De}$ grondslag voor deze benadering werd gelegd door $\mathrm{H}$. Shue in zijn boek 'Basic Rights'.8 $\mathrm{Hij}$ analyseerde de verplichtingen die verbonden zijn met de erkenning van een recht op een bestaansminimum ('right to subsistence').

65. Goodwin-Gill, a.w. p. 115. Vergelijk bijvoorbeeld artikel 2(1) en 11 IVESCR.

66. Vergelijk bijwoorbeeld de artikelen 2(1) en 7 IVBPR. In haar 'Draft Articles on State Responsibility' geeft de ILC een definitie van een achending van een 'obligation of conduct':

'There is a breach by a state of an international obligation requiring it to adopt a particular course of conduct when the conduct of that State is not in conformity with that required of it by that obligation" (Draft Article 20).

67. Trubek, a.w. pp. 206, 207.

68. H. Shue, Basic Rights, Subsistence, Affluence and U.S. Foreign Policy, Princeton, New Jersey 1980, in het bijzonder hoofdstuk 2. 
Shue onderscheidde:

1. Verplichtingen de bestaande mogelijkheden op een bestaansminimum van een individu niet te vernietigen, dat wil zeggen 'duties to avoid depriving'. Het betreft hier een negatieve verplichting.

2. Verplichtingen om mensen te beschermen tegen beroving van hun mogelijkheden op een bestaansminimum door anderen, dat wil zeggen, 'duties to protect from depriving'. Het betreft hier een positieve verplichting.

3. Verplichtingen om te voorzien in het bestaansminimum van die personen die daar zelf niet toe in staat zijn, dat wil zeggen 'duties to aid the deprived'. Het gaat hier eveneens om een positieve verplichting. ${ }^{69}$

Deze typologie van verplichtingen is verder ontwikkeld en verfijnd met betrekking tot het recht op voedsel (artikel 11 IVESCR). Met name in het kader van de VN werd de studie van het recht op voedsel geëntameerd. De Economische en Sociale Raad machtigde de Subcommissie inzake de Voorkoming van Discriminatie en de Bescherming van Minderheden een onderzoek te beginnen naar het recht op voedsel. ${ }^{70}$ De Sub-commissie benoemde éên van haar leden, Asbjørn Eide, tot bijzonder rapporteur inzake dit onderwerp. De rapporteur diende onder meer aandacht te besteden aan de normatieve inhoud van het recht op voedsel. Daarnaast werd cok in andere fora aandacht besteed aan het recht op voedsel. De International Law Association nam het onderwerp in studie en het Studie- en Informatiecentrum Mensenrechten (SIM) organiseerde in Utrecht in juni 1984 een conferentie over 'the right to food; from soft to hard law. ${ }^{, 71}$ Rapporteur Eide bracht twee interim-rapporten uit en voltooide in 1987 zijn eindrap-port. ${ }^{72}$

De discussie over verplichtingen van staten voortvloeiend uit economische, sociale en culturele rechten is vooral toegespitst op de bepalingen uit het

69. Shue, a.w. p. 53.

70. ECOSOC Res. $1988 / 140$ van 27 meil 1983.

71. Zhe Ph. Alaton, K. Tomasevski (eds), The Right to Food, Utrecht, 1984. Zie met name de bijdragen van Alston, Shue, Van Hoof, Tomasevski.

72. De twee interim-rapporten zijn gepubliceerd als UN Doc. E/Sub.2/1983/25 en E/CN.4/ Sub.2/1984/22. Het eindrapport is gepubliceerd als UN Doc. E/CN.4/Sub.2/1987/23. Daarnaast zij hier verwezen naar $\mathrm{Ph}$. Alston en A. Eide, Advancing the Right to food in international law, in: A. Eide, W.B. Eide (eds), Food as a Human Right, United Nations University, Tokyo 1984, pp. 249-260. Zie ook A. Eide, Realization of Social and Economic Rights; The Minimum Threshold Approach, in: The Review of the International Commission of Jurists, No. 43-1989, pp. 40-53, ook gepubliceerd in Human Rights Law Journal, Vol, 10 (1989), pp. 35-51.

Nadere uitwerking en toepassing met betrekking tot het recht op voedsel wordt gegeven door van Hoof, a.w. pp. 106-108, wie ook G.J.H. van Hoof, Een doorbraak voor het recht op voedsel? in: NJCM-Bulletin 13-2 (1988), pp. 78-90. Dit analytisch kader wordt eveneens gehanteerd door Van den Berg en Guldenmund met betrekking tot hat recht op werk, zie G.P. van den Berg en R.M.A. Guldenmund, The Right to Work in East and West, in: A. Bloed en P. van Dijk (eds), Essays in Human Rights in the Helsinki Process, The Hague 1985, pp. 103-127. 
IVESCR. In dit verband kunnen een drietal dragers van verplichtingen onderscheiden worden, te weten:

a. staten ten aanzien van hun interne verplichtingen;

b. staten ten aanzien van hun externe verplichtingen;

c. individuen. ${ }^{73}$

Interne verplichtingen heeft een staat ten opzichte van personen die zich onder zijn rechtsmacht bevinden. Externe verplichtingen gaat een staat bilateraal met een andere staat aan, bijvoorbeeld een samenwerkingsovereenkomst (vgll. artikel 2(1) IVESCR). We zullen hierna ingaan op de interne verplichtingen van een staat. We gaan uit van een staat die partij is bij het IVESCR, als voornaamste universele regeling van economische, sociale en culturele rechten. Bij het analyseren van de verschillende verplichtingen van de staat moet steeds bedacht worden dat het daarbij primair gaat om een relatie tussen staat en individu. De staat heeft verplichtingen ten opzichte van het individu aangaande de verwezenlijking van de materiële rechten. Maar ook het individu heeft plichten jegens anderen en de gemeenschap. Op het individu rust een verantwoordelijkheid te streven naar bevordering van de rechten van de mens. ${ }^{74}$

Ten aanzien van de interne verplichtingen van staten kan een typologie van een drietal niveaus onderscheiden worden. ${ }^{75}$ Het eerste niveau betreft een 'obligation to respect'. Deze verplichting verbiedt de staat zelf te handelen in strijd met erkende en verleende rechten en vrijheden. Dit betekent dat de staat zich dient te onthouden van inmenging of dwang met de uitoefening van erkende rechten en vrijheden. Het tweede niveau handelt over de 'obligation to protect'. Deze verplichting gebiedt de staat stappen te ondernemen - door wetgeving of andere maatregelen - die er op gericht zijn te voorkomen en te verbieden dat de staat zelf of derden erkende rechten en vrijheden zullen schenden. Dit kan onder meer gebeuren door rechten en vrijheden in de grondwet of wet te verankeren. Het gaat hier met name om de garantie van het non-discrimatiebeginsel in wetgeving en beleid en het beschikbaar stellen van rechtsmiddelen. Op grond van deze verplichting is de staat gehouden bepaalde beschermende maatregelen te nemen. Het derde niveau van verplichtingen betreft de 'obligation to fulfil'. Deze verplichting vereist van de staat verdergaande positieve maatregelen, met het oog op een effectieve verwezenlijking van rechten. Deze verplichting kan worden aangeduid als een programmaverplichting. Veelal zal deze verplichting een

73. Zie P. Alston, International Law and the Human Right to Food, in: Alston/Tomaseviki (eds), a.w. pp. 9-68, op p. 37 .

Alstion onderscheidt nog een vierde drager van werplichtingen namelijk de internationale gemeenschap, bijvoorbeeld in het kader van multilaterale amenwerking. Ik laat deze verder buiten beschouwing, omdat het mijns inziens niet gat om een zelfstandige drager van volkenrechtelijke rechten en plichten.

74. Vgl artikel 29 Universele Verklaring van de Rechten van de Mens en de preambule van IVESCR en IVBPR.

75. Zie A. Eide, Report on the right to adequate food human right, UN Doc. E/CN.4/ Sub.2/1987/23, par. 66-71, en par. 169-181 ten anzien van het recht op voedsel. 
(financiele) inspanning vereisen die niet door individuen alleen kan worden opgebracht. De typologie biedt de mogelijkheid staatsaansprakelijkheid voor de verwezenlijking van de rechten van de mens te analyseren. Het voordeel van deze benadering is dat zij toepasbaar is op elk specifiek mensenrecht, of dit nu behoort tot de sociale rechten of tot de burger- en politieke rechten. Bovendien draagt de typologie bij tot de eenheid van beide categorieen rechten. Deze benadering impliceert ook dat de verwezenlijking van een bepaald recht zowel overheidsonthouding als bemoeienis door de overheid met zich mee kan brengen of het nu gaat om een sociaal recht of een vrijheidsrecht. Daarmee draagt zij bij aan de vervaging van de grenzen tussen beide categorieën rechten als ook aan de devaluatie van de traditionele benadering die een scherp onderscheid tussen klassieke en sociale rechten propageerde. De typologie van Eide sluit aan bij die van Shue. Het voorstel van Shue heeft betrekking op het recht op een bestaansminimum, terwijl dat van Eide een meer algemene betekenis heeft, dat wil zeggen voor zowell burger- en politieke rechten als voor economische, sociale en culturele rechten. Van Hoof heeft geprobeerd de typologie van verplichtingen te verfijnen. Naast de verplichtingen 'to respect' en 'to protect' onderscheidt hij een verplichting 'to ensure'. Deze komt overeen met de verplichting 'to fulfil' van Eide. Zijn typologie kent bovendien een vierde verplichting, te weten de 'obligation to promote'. Deze gebiedt de staat tot het geleidelijk verwezenlijken van lange termijn doeleinden. ${ }^{76}$ Ten aanzien van het recht op onderwijs zal ik in hoofdstuk 5 de typologie van Eide toepassen. De verplichting 'to promote' bij van Hoof voegt naar mijn mening geen extra dimensie toe aan de verplichting 'to ensure'. In de verplichting 'to fulfil' ligt al het idee besloten dat de verwezenlijking van sommige (elementen van) rechten een lange termijn beleid vereist en dus slechts op geleidelijke wijze kan geschieden.

\subsection{Verplichtingen van staten op grond van artikel 2 lid 1 IVESCR}

\subsubsection{Algemeen}

De specifieke verplichtingen van staten aangaande de materiële rechten van het IVESCR kunnen slechts geanalyseerd worden in samenhang met artikel 2 lid 1 van dit Verdrag. Dit is de centrale bepaling van het Verdrag die de aard en de reikwijdte van de verplichtingen van staten nader definieert. De traditionele benadering die het juridisch karakter van economische, sociale en culturele rechten relativeert, betwijfelt dan ook of de reik-

76. Zie G.J.H. van Hoof, The Legal Nature of Economic, Social and Cultural Rights: a Rebuttal of Some Traditional Views, in Alston/Tomasevski (eds), a.w. pp. 97-110, op p. 106. De typologie van Van Hoof heb ik toegepast met betrekking tot de onderwijsrechten van leden van minderheden, ie $\mathbb{F}$. Coomans, Volkenrechtelijke aspecten van onderwijsrechten van minderheden, in: Nederlands Tijdschrift voor Onderwijsrecht 1990, pp. 5-21, in het bijzonder pp. 15-17. 
wijdte en inhoud van artikel 2 lid 1 IVESCR in voldoende mate kunnen worden vastgesteld. ${ }^{77}$ Anderzijds zijn er ook schrijvers voor wie het juridisch karakter van artikel 2 lid 1 duidelijk is: het IVESCR 'uses language of obligation, not merely of aspiration or hope." ${ }^{78}$ Als gevolg van hernieuwde aandacht in de VN voor de verwezenlijking van economische, sociale en culturele rechten werd in 1986 in Maastricht een symposium gehouden over de implementatie van het IVESCR. Daaraan werd deelgenomen door deskundigen op het gebied van het internationale recht afkomstig uit verschillende landen en vertegenwoordigers van internationale organisaties zoals de ILO en de UNESCO. Concreet resultaat van deze bijeenkomst was de unanieme aanvaarding van de 'Limburg Principles on the Implementation of the International Covenant on Economic, Social and Cultural Rights'. ${ }^{79}$ $\mathrm{Zij}$ geven een belangrijke interpretatie van de algemene bepalingen van het IVESCR. Zij hebben echter geen juridisch bindend karakter. De deelnemers waren van mening dat de Limburg Principles 'reflect the present state of international law, with the exception of certain recommendations indicated by the use of the verb "should" instead of "shall"' 80 Aan de hand van deze 'Limburg Principles' zal ik proberen inzicht te krijgen in de verplichtingen van verdragsstaten ingevolge artikel 2 lid 1 IVESCR. Bovendien maak ik gebruik van een gezaghebbende interpretatie van artikel 2 lid 1 IVESCR door het Comité inzake Economische, Sociale en Culturele Rechten die eind 1990 werd afgerond. Dit 'general comment' gaat in op het (juridisch) karakter van de verplichtingen van staten ingevolge artikel 2 lid 1 . Inhoud en stijl van dit 'general comment' vertonen sterke overeenkomst met de Limburg Principles. ${ }^{81}$

77. Zie E.W. Vierdag, The Legal Nature of the Rights granted by the International Cow venant on Economic, Social and Cultural. Rights, in: Netherlands Yearbook of International Law, 1978, pp. 69-105, op pp. 95 en 101.

78. Henkin, a.w. p. 266. Vergelijk ook de opvatting van Glenn Mower: 'Economic/social rights are indeed rights, not more privileges or goals, and create a legally binding obligation on governments to take appropriate measures to give effect to them'. Zie A. Glenn Mower Jr. International Cooperation for Social Justice, Westport 1985, p. 5 .

79. De 'Limburg Principles' zijn gepubliceerd als VN-document $E / C N .4 / 1987 / 17$ en in de Human Rights Quarterly, Vol. 9 (1987) "pp. 122-135.

Het symposium vondt plaats van 2-6 juni 1986 en werd georganiseerd door de Internationale Commissie van Juristen, de Juridische Faculteit van de Rijksuniversiteit Limburg en het Urban Morgan Institute for Human Rights, University of Cincinatti, Ohio, Verenigde Staten.

80. UN Doc. E/CN.4/1987/17, p. iv introdiuction.

81. CESCR, Gemeral Comment no. 3 (1990), The nature of States Parties obligationa (Article 2, paragraph 1). UN Doc. E/1991/23, Annex III (Report on the Fifth session).

Het 'general comment' werd opgesteld door de rapporteur van het CESCR, Phillip Alston, die ook deelnam aan de conferentie over de Limburg Principles. 


\subsubsection{Interne verplichtingen}

\section{Artikel 2 lid 1 IVESCR luidt als volgt:}

'Each State Party to the present Covenant undertakes to take steps, individually and through international assistance and cooperation, especially economic and technical, to the maximum of its available resources, with a view to achieving progressively the full realization of the rights recognized in the present Covenant by all appropriate means, including in particular the adoption of legislative measures'.

Deze bepaling impliceert voor de staat een plicht zorg te dragen voor de verwezenlijking van de in het Verdrag erkende rechten. Deze verplichting is niet absoluut, maar veeleer geconditioneerd door een aantal clausules die de algemene verplichting beogen te kwalificeren. Het is van belang de betekenis van deze clausules te analyseren, omdat zij een nadere invulling kunnen geven aan de verwezenlijking van het recht op onderwijs. Bij een bespreking van artikel 2 lid 1 moeten twee niveaus van verplichtingen onderscheiden worden. Enerzijds zijn er de interne verplichtingen jegens de personen die onder de rechtsmacht van de verdragspartij vallen. Anderzijds bestaan er externe verplichtingen, dat wil zeggen verplichtingen ten opzichte van andere staten. We beginnen met een bespreking van de interne verplichtingen. In de eerste plaats verbindt iedere verdragspartij zich maatregelen te nemen. Deze verwijzing naar de verschillende maatregelen ('steps') beantwoordt aan een gedachte die speelde ten tijde van het opstellen van het Verdrag. Men was toen van mening dat ten aanzien van elk materieel recht de precieze maatregelen aangeduid moesten worden die vereist waren om dat recht te verwezenlijjken. Met andere woorden, de specifieke maatregelen genoemd in een aantal rechten kunnen worden opgevat als onderdelen van een programma om die rechten te verwezenlijken. ${ }^{82}$ Bovendien kunnen die maatregelen worden beschouwd als een uitwerking van de betekenis van een materieel recht. ${ }^{83}$ Het Comité inzake Economische, Sociale en Culturele Rechten heeft in een 'general comment' over artikel 2 lid 1 duidelijk gemaakt dat de verplichting maatregelen te nemen een onmiddellijk karakter heeft. Het Comité was voorts van mening dat 'such steps should be deliberate, concrete and targeted as clearly as possible towards meeting the obligations recognized in the Covenant'.84

82. Zie voor een uitvoerige analyse van artikel 2 lid 1, Ph. Alston, G. Quinn, The Nature and Scope of States Parties" Obligations under the International Covenant on Economic, Social and Cultural Rights, in: Human Rights Quarterly, vol. 9 (1987), pp. 156-229, op p. 165. Dit artikel werd geschreven als 'working paper' voor het symposium over economische, sociale en culturele rechten in Maastricht, juni 1986.

In mijn uiteenzetting maak ik gebruik van dit uitstekende artikel. Zij hanteren een teleologische methode bij de interpretatie van het IVESCR. Verder baseren zij zich mede op de 'travaux préparatoires'.

83. Trubek, a.w. P. 214.

84. Zie General Comment no. 3 (1990), a.w. par. 2. 
Vervolgens is een staat verplicht met alle passende middelen, in het bijzonder wetgevende maatregelen, de materiële rechten uit het Verdrag te verwezenlijken. Passende middelen zijn die middelen die in overeenstemming zijn met de aard van het recht. Vele soorten middelen zijn in beginsel mogelijk. Vaak zullen wetgevende maatregelen noodzakelijk zijn om een kader te scheppen waarbinnen een bepaald recht verwezenlijkt kan worden. Wetgeving wordt door het Verdrag niet verplicht gesteld, maar wel van groot belang geacht. Wetgeving is wel vereist ter vervanging van bestaande wetgeving die in strijd is met de bepalingen van het Verdrag. ${ }^{85} \mathrm{Sta}-$ ten hebben de vrijheid dié maatregelen te kiezen die zij geschikt achten met het oog op de verwezenlijking van de materiële rechten. Het Comité beoordeelt uiteindelijk of een staat alle passende maatregelen heeft genomen gericht op de verwezenlijking van die rechten. ${ }^{86}$

De kern van artikel 2 lid 1 is de verplichting steeds nader tot een algehele verwezenlijking van de materiële rechten uit het Verdrag te komen. Deze verplichting tot geleidelijke verwezenlijking is nauw verbonden met en afhankelijk van de beschikbaarheid van financiële middelen. Met andere woorden, de financieel-economische situatie van een land bepaalt mede de mate waarin een land in staat is de rechten uit het Verdrag ook daadwerkelijk te verwezenlijken. De essentie van de verplichting tot geleidelijke verwezenlijking is kernachtig geformuleerd in de Limburg Principles:

'The obligation "to achieve progressively the full realization of the rights" requires States Parties to move as expeditiously as possible towards the realization of the rights. Under no circumstances shall this be interpreted as implying for States the right to defer indefinitely efforts to ensure full realization. On the contrary all States Parties have the obligation to begin immediately to take steps to fulfil their obligations under the Covenant. ${ }^{87}$

Volgens het Comite inzake Economische, Sociale en Culturele Rechten is het idee van geleidelijke verwezenlijking 'a necessary flexibility device, reflecting the realities of the real world and the difficulties involved for any country in ensuring full realization of economic, social and cultural rights' ${ }^{88}$ Maar dit doet niet af aan het feit dat het IVESCR verplichtingen voor staten vastlegt.

Het feit dat een staat partij is bij dit Verdrag alsmede het beginsel van goede trouw betekenen dat die staat zich dient in te spannen om de rechten te verwezenlijken. Daartoe dient hij meteen na ratificatie maatregelen te ne-

85. Limburg Principles, nr. 18.

86. Zie General Comment no. 3 van het CESCR, par. 4 en de Limburg Principles, nr. 20.

87. Limburg Principles, nr. 21.

88. General Comment no. 3 (1990), par. 9. 
men. De staat is verplicht zonder dralen het proces van implementatie op gang te brengen. Impliciet in deze verplichting liggen de bedoeling en de verwachting besloten dat steeds hogere niveaus van voorzieningen behoren te worden bereikt. Dit proces moet uitmonden in de volledige verwezenlijking van de rechten. Daarnaast hebben staten een onmiddellijke verplichting op grond van artikel 2(2) discriminatie de jure bij de uitoefening van de rechten uit te bannen. Het idee van geleidelijke verwezenlijking is hier niet van toepassing. Vormen van passieve discriminatie bijvoorbeeld als gevolg van een gebrek aan middelen daarentegen dienen zo spoedig mogelijk uitgebannen te worden. De facto discriminatie is immers hardnekkig van aard en kan niet alleen worden beëindigd door wettelijke maatregelen. Uitbanning vereist de inzet van positieve maatregelen die in aanzienlijke mate een beslag kunnen leggen op schaarse middelen. De garantie van nondiscriminatie op grond van artikel 2 lid 2 IVESCR impliceert dan ook een sterke juridische verplichting, is van onmiddellijke toepassing en afdwingbaar voor een nationale rechter. ${ }^{89}$ Dit beginsel speelt een essentiële rol bij de verwezenlijking van economische, sociale en culturele rechten. Indien een staat bijvoorbeeld onderwijsfaciliteiten financiert voor de leden van een bepaalde godsdienstige, etnische of linguistische minderheid, dan is hij op grond van het non-discriminatiebeginsel verplicht ook financiële maatregelen te nemen ten gunste van leden van andere minderheden op godsdienstige, etnische of linguïstische grondslag. ${ }^{90}$

De verplichting steeds nader tot de volledige verwezenlijking van de materiële rechten te komen wordt, zoals gezegd, voor een groot deel bepaald door de beschikbaarheid van financiële middelen. De hoeveelheid en de beschikbaarheid zijn afhankelijk van de financieel-economische situatie van het land. Artikel 2 lid 1 bepaalt nu dat een staat gehouden is volledig gebruik te maken van de hem ter beschikking staande middelen. Dit betekent dat staten geen absolute vrijheid hebben bij de toewijzing van middelen, maar wel een aanzienlijke vrijheid om te bepalen welke middelen beschikbaar zijn voor de verwezenlijking van economische, sociale en culturele rechten. De ratio van dit punt is dat staten 'without exceeding the possibilities open to them ... do their utmost in implementing the rights', ${ }^{91}$ Graadmeter voor de toetsing van deze inspanningsverplichting is 'equitable and effective use of and access to the available resources' ${ }^{92}$ Bij de toewijzing van de beschikbare middelen moet de staat prioriteit geven aan de verwezenlijking van economische, sociale en culturele rechten, in het bijzonder aan rechten die betrekking hebben op de garantie van het bestaans-

89. Limburg Principles, nr. 35-39. Vgl. ook beginsel 8.

90. Zie hierover mijn bijdrage Volkenrechtelijke aspecten wan onderwijsrechten van minderheden, in: Nederlands Tijdschrift voor Onderwijsrecht, 1990, pp. 5-21, op pp. 13, 14.

91. Mr. Cassin tijdens de totstandkoming van deze bepaling in de jaren 50 . Zie UN Doc. E/CN.4/SR.271, p.6, geciteerd bij Alston/Quinn, a.w. p. 179.

92. Limburg Principles, nr. 27. 
minimum. ${ }^{93}$ De term 'resources' moet worden opgevat als al die nationale middelen, waaronder financieel-budgettaire, alsmede buitenlandse hulp, technische dan wel financiële, waarover de staat de beschikking heeft. ${ }^{94}$

\subsubsection{Externe verplichtingen}

Externe verplichtingen gaan staten aan ten opzichte van elkaar. $\mathrm{Zij}$ geven uiting aan de gedachte van internationale samenwerking en solidariteit. ${ }^{95}$ Het belang van internationale samenwerking voor de bevordering van vrede, welzijn en eerbied voor de rechten van de mens wordt benadrukt in het Handvest van de Verenigde Naties. ${ }^{96}$ In het bijzonder artikel 55 sub b handelt over de bevordering van internationale samenwerking inzake cultuur en onderwijs. Volgens artikel 56 Handvest verbinden de lidstaten van de VN zich gezamenlijk en afzonderlijk op te treden in samenwerking met de VN ter verwezenlijking van de doeleinden van internationale economische en sociale samenwerking. Artikel 22 van de Universele Verklaring van de Rechten van de Mens erkent eveneens de waarde van internationale samenwerking voor de verwezenlijking van economische, sociale en culturele rechten.

De plicht tot samenwerking tussen staten werd uitgewerkt in de belangrijke Verklaring inzake Beginselen van Internationaal Recht betreffende Vriendschappelijke Betrekkingen en Samenwerking tussen Staten. ${ }^{97}$ Volgens deze Verklaring dienen staten onder meer samen te werken voor de bevordering van vooruitgang op het gebied van onderwijs en cultuur. Het IVESCR kent eveneens de verplichting tot internationale samenwerking gericht op de verwezenlijking van economische, sociale en culturele rechten. Volgens artikel 2 lid 1 heeft elke staat de verplichting maatregelen te nemen 'zowel zelfstandig als binnen het kader van de internationale hulp en samenwerking, met name op economisch en technisch gebied' ten einde de rechten van het Verdrag te verwezenlijken. Op grond van de ontstaansgeschiedenis van deze clausule concludeerden Alston en Quinn dat deze bepaling geen juridisch bindende verplichting voor een bepaalde staat impliceert om een specifieke vorm van hulp te verlenen. De clausule is evenwel niet zonder betekenis:

'[I]n the context of a given right it may, according to the circumstances, be possible to identify obligations to cooperate internationally that would

93. Limburg Principlea, nr. 28, zie ook Trubek, a.w. p. 215.

94. Limburg Principles, nr. 26.

95. Zie Ph. Alston, A. Eide, Advancing the right to food in international law, in: A. Bide, W.B. Eide c.B. (eds), Food as a human right, United Nations University, Tokyo 1984, pp. 249-260, op p. 251.

96. Zie artikel 1 lid 3 Handvest VN.

97. A.V. Res. 2625 (XXV) van 24 oktober 1970. 
appear to be mandatory on the basis of the undertaking contained in Article 2(1) of the Covenant. ${ }^{98}$

Mijns inziens bevat artikel 2 lid 1 een belangrijke stimulans voor staten de verwezenlijking van economische, sociale en culturele rechten ook in mondial perspectief te zien en concrete steun te verlenen aan internationale samenwerking op dat terrein, in bilateraal dan wel multilateraal verband.

\subsubsection{Artikel 4 IVESCR}

Het IVESCR biedt partijstaten de mogelijkheid beperkingen op te leggen aan het genot van de materiële rechten. Die mogelijkheid is evenwel niet absoluut, maar veeleer geconditioneerd. Artikel 4 luidt:

'The States Parties to the present Covenant recognize that, in the enjoyment of those rights provided by the State in conformity with the present Covenant, the State may subject such rights only to such limitations as are determined by law only in so far as this may be compatible with the nature of these rights and solely for the purpose of promoting the general welfare in a democratic society'.

Deze bepaling heeft als ratio de bescherming van de rechten van individuen en niet het verlenen van een vrijbrief aan de staat om materiële rechten te beperken. Artikel 4 is beschermend ten aanzien van de doeleinden waarvoor beperkingen mogen worden opgelegd en de wijze waarop dat behoort te gebeuren. ${ }^{99}$ Artikel 4 suggereert dat deze bepaling niet van toepassing is indien de verdragsrechten in een staat nog niet geïmplementeerd zijn en geldt dus voor de materiële rechten 'indien en voor zover deze zijn gerealiseerd: ${ }^{100}$ Deze interpretatie kan worden afgeleid uit de tekst van artikel 4. Deze spreekt immers van het genot van de door de Staat verleende rechten. Dit betekent dat de staat een duidelijke taak heeft ten aanzien van de implementatie van de rechten. Een en ander valt ook af te leiden uit het beginsel van geleidelijke verwezenlijking dat ten grondslag ligt aan het Verdrag.

Beperkingen van rechten in de zin van artikel 4 mogen nooit zover gaan dat ze de rechten zonder waarde en inhoud maken. Dat is in feite de strekking van de clausule dat beperkingen zijn toegestaan alleen voor zover deze niet in strijd zijn met de aard van deze rechten. De aard van een recht moet wor-

98. Alston/Quinn a.w. p. 191 .

99. Limburg Principles, a.w. nr. 46. Alston/Quinn, a.w. p. 193 spreken van een "permissive function' en van een "protective function".

100. Zie de goedkeuring van het IVESCR in het Nederlandse parlement, Memorie van Toelichting, Tweede Kamer, 1975-1976, 13932, nr. 3, p. 46. Zie ook A.W. Heringa, Sociale grondrechten, disss., 's-Gravenhage 1989 , p. 89 . 
den begrepen als de kern of het wezenlijke van een recht. ${ }^{101}$ De staat die een beperking op een bepaald recht wil doorvoeren moet kunnen aantonen dat de voorgestelde beperking verenigbaar is met de aard van dat recht, Beperkingen op grond van het bevorderen van het algemeen welzijn kunnen niet lichtvaardig opgelegd worden. Het moet immers gaan om 'furthering the wellbeing of the people as a whole ${ }^{4}{ }^{102}$ Het gaat hier om het beschermende aspect van artikel 4 . Uit de 'travaux préparatoires' valt op te maken dat artikel 4 betrekking heeft op andere beperkingen van de rechten dan die welke het gevolg zijn van beperkte beschikbare middelen in de zin van artikel 2 lid 1.103 Volgens Alston en Quinn kan de beperkingsclausule van artikel 4 toch in verband gebracht worden met de algemene verplichtingen van staten op grond van artikel 2 lid 1 en dus met de aard van economische, sociale en culturele rechten. ${ }^{104}$ In beginsel kan gezegd worden dat een teruggang of vermindering van genot of verwezenlijking van een bepaald recht als gevolg van een afname van beschikbare (financiële) middelen geen beperking is in de zin van artikel 4 . Indien evenwel een staat een dergelijke teruggang aanduidt als een beperking van een recht, dan moet die teruggang gerechtvaardigd worden in de zin van artikel 4. Dat betekent dat de teruggang in voorzieningen moet voldoen aan de eisen gesteld in die bepaling. ${ }^{105}$

Beperkingen van het sociale aspect van recht op onderwijs die mijns inziens in strijd komen met de vereisten van artikel 4, zijn bijvoorbeeld het op willekeurige wijze sluiten van bestaande (openbare) onderwijsinstellingen en het op discriminerende wijze beperken van de toegang tot het onderwijs van bepaalde groepen uit de bevolking. Daarmee wordt immers de kern van het recht op onderwijs geraakt, te weten de garantie van beschikbaar en toegankelijk onderwijs op een non-discriminatoire grondslag. Een beperking van het vrijheidsaspect van het recht op onderwijs die niet door de beugel kan in het licht van artikel 4 , is bijvoorbeeld het verbieden van de bestaande vrijheid van onderwijs in de zin van de oprichting en instandhouding van particuliere onderwijsinstellingen. Een ander voorbeeld betreft het stellen van beperkingen aan de vrije keuze van (levensbeschouwelijk) onderwijs.

\subsubsection{De waarde van IVESCR normen in tijden van economische teruggang}

Men kan zich af vragen of de internationale normen op het gebied van economische, sociale en culturele rechten in een tijd van economische terug-

101. Limburg Principles, a.w. nr. 56.

102. Idem, nr. 52.

103. Alaton/Quinn, a.w. p. 194.

104. Alston/Quinn, a.w. p. 193.

105. Idem, pp. 205, 206. 
gang en financiële beperkingen nog wel realistisch genoemd kunnen worden. Met andere woorden is de verwezenlijking van de materiële rechten uit het IVESCR voor regeringen nog wel haalbaar? Betekenen de normen geen te grote belasting voor regeringen? Geven zij niet uiting aan idealen die in de huidige tijd eerder bijstelling verdienen ${ }^{106}$ Het is waar dat het IVESCR is opgesteld in een tijd - de jaren vijftig en zestig - waarin er wereldwijd optimisme bestond over de groei van de economie en over de vooruitzichten op de ontwikkeling van de Derde Wereldlanden. Het IVESCR geeft uiting aan deze rooskleurige verwachtingen en spreekt niet voor niets in artikel 2 lid 1 over de geleidelijke verwezenlijking van de rechten uit het Verdrag. De ratio van het Verdrag was immers te komen tot steeds hogere niveaus van voorzieningen. De huidige tijd beantwoordt volgens Tomuschat niet langer aan dit idee:

'With the collapse of the underlying economic assumptions in a world progressively marked by serious crisis symptoms, the CSECR itself now seems to have lost some of its cornerstones'. ${ }^{107}$

Tegen deze opvatting kan worden ingebracht dat de naleving van de rechten van de mens in beginsel niet afhankelijk mag worden gesteld van veranderende sociaal-economische omstandigheden. Juist in tijden van financieel-economische moeilijkheden moet een staat zich inspanningen getroosten om het niveau van de economische, sociale en culturele rechten te kunnen blijven waarborgen. ${ }^{108}$ Juist dan hebben bepaalde groepen uit de bevolking basisvoorzieningen nodig zonder welke de menselijke waardigheid in het geding komt. Het IVESCR biedt een garantie tegen aantasting van bestaande niveaus van voorzieningen ten kosten van de sociaal zwakkeren in de samenleving. ${ }^{109}$ Er zijn natuurlijke bepaalde sociaal-economische ontwikkelingen die een negatieve invloed hebben op de verwezenlijking van economische, sociale en culturele rechten. Die ontwikkelingen doen zich wereldwijd voor. In rijke landen manifesteren zij zich in inflatoire tendensen, recessies en begrotingstekorten als gevolg van te hoge overheidsuitgaven. Deze leiden tot de noodzaak te bezuinigen en de collectieve uitgaven te herverdelen. Arme landen daarentegen hebben te kampen met zeer hoge buitenlandse schulden en een sterk onevenwichtige betalingsbalans. Vaak zijn deze landen genoodzaakt overeenkomsten te sluiten met het Internationale Monetaire Fonds om de sanering van de staatshuishouding

106. Chr. Tomuschat, International Standards and Cultural Diversity in: Bulletin of Human Rights - Special Issue 1985 , pp. 24-35, op p. 34.

107. Chr. Tomuschat, Human Rights in a World-Wide Framework - Some Current Issues, in: Zeitschrift fur Ausländisches öffentliches Recht und Völkerrecht, vol. 45, (1985), pp. 547-584, op p. 567 .

108. Alston/Quin, a.w. p. 164.

109. Zie B. Simma, Der Ausschuss für wirtschaftliche, soziale und kulturelle Recht (CESCR): Ein neues Menschenrechtsgremium der Vereinten Nationen, in: Vereinte Nationen, Dezember 1989, pp. 191-197, op p. 193. 
door te voeren. Het structureel aanpassingsbelleid dat landen, als uitvloeisel van overeenkomsten met het IMF, in de samenleving moeten uitvoeren heeft vaak ernstige gevolgen voor het niveau van sociaal-economische voorzieningen, zoals voedsel, arbeid, gezondheidszorg en onderwijs. ${ }^{110}$ Het is mijns inziens evident dat dit beleid vaak op gespannen voet zal staan met voorwerp en doel van het IVESCR.

Het Comité inzake Economische, Sociale en Culturele Rechten dat toezicht houdt op de naleving van het IVESCR onderkende de problemen van ontwikkelingslanden in dit opzicht. Het Comité was van mening dat de internationale economische situatie evenals de nationale situatie en het niveau van ontwikkeling van een land in ogenschouw genomen moet worden bij de internationale implementatie van de bepalingen uit het IVESCR. ${ }^{111}$ In dit verband rijst de vraag of het Comite niet wat soepeler moet zijn ten opzichte van bepaalde Derde Wereldlanden met grote financieel economische problemen en wat strikter ten opzichte van rijke landen. Ik ben van mening dat het Comité met staten in discussie moet gaan vanuit de gedachte dat rekening wordt gehouden met de specifieke sociaal-economische situatie waarin een staat verkeert. Het Comité kan strikter zijn ten opzichte van rijke landen, omdat in dergelijke landen veelal de realisering van sociale rechten reeds een bepaald niveau heeft bereikt. Bovendien zijn rijke landen in het algemeen beter in staat het hoofd te bieden aan sociaal-economische tegenslag. Sommige Derde Wereldlanden kampen daarentegen met veel grotere problemen bij de verwezenlijking van de materiële rechten uit het Verdrag. Er zijn evenwel bepaalde minimumnormen die mijns inziens niet overschreden mogen worden. Een voorbeeld hiervan is artikel 13 lid 2 sub a: de verplichting tot het verwezenlijken van kosteloos en verplicht primair onderwijs. Ten aanzien van arme landen zou het Comité vooral moeten toezien op de naleving van dergelijke minimumnormen. Deze moeten garanderen dat bepaalde basisvoorzieningen beschikbaar blijven voor met name de achtergestelde en kwetsbare groepen in de samenleving. Veelal zullen regeringen die geconfronteerd worden met financiële beperkingen prioriteiten moeten stellen bij de toewijzing van middelen ten behoeve van bijvoorbeeld de verwezenlijking van het recht op onderwijs. Dat betekent dat vaak voorrang wordt gegeven aan de verwezenlijking van primair onderwijs ten koste van bijvoorbeeld het (technisch) beroepsonderwijs, terwijl dit laatste nu juist belangrijk is voor de vorming van een kader voor de ontwikkeling van het land. Het draagt immers bij aan de opleiding van onderwijsgevenden en de ontwikkeling van bedrijf en beroep. Een regering heeft dus voortdurend te maken met dilemma's binnen de beperkte financieel-economische beschikbare ruimte. In een dergelijke situatie dienen de internationaal aangegane verplichtingen als richtsnoer voor beleid te gelden. Dat betekent onder meer dat de kwetsbare sociale

110. Zie D. Turk, Special Rapporteur of the Sub-Commission on Prevention of Discrimination and Protection of Minorities "UN Doc. E/CN.4/Sub.2/1989/19, par. 52-64.

111. Zie Committee on Economic, Social and Cultural Rights. Report on the First Beseion, UN Doc. E/ $/ 1987 / 28$, par. 301-304. 
groepen in een dergelijk beleid ontzien moeten worden. Ten behoeve van hen dienen programma"s te worden opgezet die, tegen relatief lage kosten, bepaalde basis behoeften garanderen. ${ }^{112}$

Volgens de Limburg Principles hebben staten een verplichting onverwijld de verwezenlijking van de materielle rechten uit het IVESCR ter hand te nemen. De verplichting tot geleidelijke verwezenlijking volgens artikel 2 lid 1 bestaat ongeacht de toename van financiële middelen: 'it requires effective use of resources available'. ${ }^{113}$ Deze interpretatie van artikel 2 lid 1 geeft, naar het mij voorkomt, blijk van te hoge verwachtingen. Zij getuigt van het beeld van een ideaalsituatie die bepaald niet voor alle partijstaten bij het IVESCR realistisch en haalbaar is. Maar er zijn natuurlijk ook landen die wel de (financiële) middelen bezitten en op wie de genoemde interpretatie van artikel 2 lid 1 als maatstaf heel wel toepasbaar is. Voor andere staten kan deze interpretatie dienen als richtsnoer voor toekomstig overheidsoptreden.

De vraag rijst nu hoe een verminderde bescherming van sociale rechten, als gevolg van de af name van beschikbare middelen, zich verhoudt tot het beginsel van geleidelijke verwezenlijking vervat in artikel 2 lid 1 IVESCR. Uitgangspunt voor wetgeving en beleid dient steeds te zijn dat de staat ondanks financieel-economische tegenslag blijft streven naar een toenemende verwezenlijking van sociale, economische en culturele rechten. Indien de regering van een staat een teruggang in het niveau van verwezenlijking van sociale rechten wil doorvoeren dan dienen de verdragsverplichtingen daarbij expliciet in de overwegingen te worden betrokken. De staat dient gemotiveerd de noodzaak van de achteruitgang in de realisering van sociale rechten aan te geven. ${ }^{114}$ Dat wil zeggen dat de gevolgen van de voorgestelde beperkingen op de verwezenlijking van sociale rechten moeten worden aangegeven, met name voor kwetsbare maatschappelijke groepen. Daarbij dient de staat te garanderen dat een vermindering van bescherming van rechten een niet-discriminerende uitwerking heeft. De teruggang mag niet ten koste gaan van een bepaalde maatschappelijke groep. Het Comité is in dit verband van opvatting dat een opzettelijk regressieve maatregel 'would require the most careful consideration and would need to be fully justified by reference to the totality of the rights provided for in the Co-

112. Zie General Comment no. $3(1990)$ a.w. par. 12. Het Comite heeft er in een eerder 'general comment' voor gepleit de bescherming $v$ an de meest basale economische, sociale en culturele rechten ten behoeve van de armen op te nemen in de zogenaamde "aanpassingsprogramma's" die landen onder IMF - en Wereldbankvoorwaarden (moeten) doorvoeren. Zie CESCR, General Comment no. 2 (1990), International technical assistance measures (Article 22 of the Covenant), in: UN Doc. E/1990/23, Annex III.

113. Limburg Principles, a.w. nr. 21 en 23.

114. Zie A.W. Heringa, Sociale grondrechten, "g-Gravenhage 1989, pp. 138-141 en het redactionele commentaar in het NJCM-Bulletin 16-2 (1991), pp. 103-104. 
venant and in the context of the full use of the maximum available resources. ${ }^{115}$

Indien een staat een achteruitgang in de bestaande voorzieningen definieert als een beperking van rechten dan dient de rechtvaardiging daarvan te voldoen aan de criteria die artikel 4 stelt. Een beperking van minimumnormen, ingegeven door een afname van financiële middelen, is mijns inziens niet toelaatbaar, omdat dan de werkelijke inhoud en betekenis van een recht een lege huls wordt.

Geconcludeerd kan worden dat juist in tijden van financieel-economische beperkingen de rechten vervat in het IVESCR hun waarde dienen te bewijzen als (minimum) normen ter bescherming van, met name maar niet uitsluitend, de zwakkere groepen in de samenleving. Deze normen, die uitdrukking geven aan een bepaald niveau van welzijn, dienen voor beleid en wetgeving als ijkpunten te fungeren. 


\section{HOOFDSTUK 3}

\section{Het recht op onderwijs in internationale verdragen en verklaringen}

\subsection{Afbakening en definitie}

Ten behoeve van de onderhavige studie dient het onderzoek naar het recht op onderwijs te worden afgebakend. ${ }^{1}$ Het onderzoek richt zich in hoofdzaak op het recht en de daarmee verbonden vrijheid van elke mens tot het volgen van primair, secundair en hoger onderwijs. Ook het beroepsonderwijs, verdeeld over verschillende leeftijdsgroepen valt binnen het kader van dit onderzoek. Soms zal ook worden ingegaan op het vervolgonderwijs voor volwassenen en de permanente educatie. Het is moeilijk aan te geven welke de leeftijdsgrenzen zijn voor de verschillende geledingen van het onderwijs. Deze worden veelal bepaald door de nationale omstandigheden. Wel bestaan er enige richtlijnen op dit gebied. Zo wordt onder meer aanbevolen dat de verplichte fase van het onderwijs tenminste zeven à acht jaren moet duren. ${ }^{2}$ Het is niet altijd mogelijk vergelijkingen te maken tussen onderwijsgeledingen en onderwijsniveaus van verschillende landen. $\mathrm{Te}$ denken valt in dit opzicht bijvoorbeeld aan de grote verscheidenheid in het beroepsonderwijs in verschillende landen en culturen. Ook de rol, aard, opzet en inrichting van het primair, secundair en hoger onderwijs verschillen aanmerkelijk tussen landen. Wel is het zo dat landen binnen een bepaalde regio overeenkomsten vertonen in de organisatie en de inrichting van het onderwijs. Dit is vooral in Europa het geval. Deze regio kent een zekere homogeniteit in de inrichting en de organisatie van het onderwijs. Tussen de onderwijsstelsels van Derde Wereldlanden bestaan daarentegen aanzienlijke verschillen, gebaseerd, als ze zijn, op lokale behoef ten en culturele tradities. Deze landen kennen wel een globale indeling van het stelsel in primair, secundair en hoger onderwijs. Veelal is dit stelsel een erfenis uit de koloniale periode. Westerse landen hebben immers geprobeerd het eigen onderwijsstelsel over te plaatsen naar hun koloniën.

In dit onderzoek zal de universele gelding van het recht op onderwijs centraal staan. Met name in Derde Wereldlanden waar nog een aanzienlijk deel

1. De betekenis en de reikwijdte van de term 'onderwijs", en dan in het bijzonder de Engelse en Franse termen komt in hoof datuk 3.3.2. aan de orde.

2. Zie de Aanbevelingen van de International Conference on Education, No. 1 Compulsory Schooling and the Raising of the School Leaving Age (1934) en no. 32, Compulsory Education and its Prolongation (1951). 
van de bevolking analfabeet is, is de garantie van primair-en secundair onderwijs van bijzonder belang. Dit onderzoek richt zich dan ook op de verwezenlijking van het recht op onderwijs in staten met verschillende economische, maatschappelijke en culturele achtergronden. Het recht op onderwijs vormt naar mijn mening één van de middelen om daadwerkelijke ontwikkeling van Derde Wereldlanden en hun bevolkingen te bevorderen. Het primaire- en het direct daarop volgende secundaire onderwijs staan in dit ontwikkelingsproces centraal.

Volgens UNESCO-normen dient het onderwijs globaal verdeeld te worden in het zogenaamde reguliere onderwijs enerzijds en het volwassenen onderwijs anderzijds. Verder moet een onderscheid worden gemaakt naar openbaar onderwijs en niet- openbaar of privé-onderwijs. Een openbare onderwijsinstelling wordt beheerd en bestuurd door een plaatselijk, regionaal of nationaal overheidsorgaan, ongeacht de herkomst van de financiële middelen die de instelling ter beschikking heeft. Een privé-onderwijsinstelling wordt niet beheerd en bestuurd door een overheidsorgaan. $\mathrm{Zij}$ kan wel of geen financiële steun van de overheid ontvangen. ${ }^{3}$

Aan het recht op onderwijs als mensenrecht zijn, zoals gezegd, een tweetal aspecten te onderscheiden. Aan de ene kant vereist de verwezenlijking van het recht op onderwijs een bepaalde overheidsinspanning tot het verzorgen van bepaalde vormen van onderwijs van overheidswege. Zo zal bijvoorbeeld in de meeste landen het recht van elke mens om onderwijs te volgen zonder betekenis blijven, indien niet de overheid op financiële en technische wijze bijdraagt aan het opzetten en in stand houden van een onderwijsstelsel. Het gaat hier om een positieve verplichting voor de overheid. Ik duid dit aan als het sociale aspect van het recht op onderwijs.

Aan de andere kant houdt het recht op onderwijs de vrijheid in van elke persoon de onderwijsvorm van de eigen keuze te volgen. Dit wil ik aanduiden als het vrijheidsaspect van het recht op onderwijs. In de praktijk houdt dit in dat naast het bestaan van openbaar onderwijs het stichten van privé-vormen van onderwijs mogelijk moet zijn. De staat is verplicht zich te onthouden van bemoeienis met de inrichting en/of het functioneren van deze vormen van privé-onderwijs, behoudens de in de wet voorziene regelingen en voorwaarden. Verder zijn staten verplicht de vrijheid van ouders te respecteren ten aanzien van de keuze van de specifieke onderwijsvorm voor hun kinderen. In het bijzonder betreft dit de vrijheid van ouders een keuze te maken aangaande het levensbeschouwelijke onderwijs en de zedelijke en morele opvoeding van hun kinderen die in schoolverband en het gezin plaats vinden. Tevens dient de overheid zich te onthouden van activiteiten die een schending vormen van het recht op onderwijs van elke burger, bijvoorbeeld het weigeren van de toegang van een leerling tot bepaalde openbare scholen. Hier ligt een verband met het non-discriminatie-

3. Zie voor indeling en definities de UNESCO Revised Recommendation concerning the International Standardization of Educational Statisties (1978). 
beginsel. Bij het vrijheidsaspect van het recht op onderwijs gaat het om een negatieve overheidsverplichting. Kortom het recht op onderwijs heeft zowel raakvlakken met de categorie van burger- en politieke rechten, als met die van economische, sociale en culturele rechten.

Hieronder zal eerst in het kort aangegeven worden in welke internationale juridische teksten het recht op onderwijs is vastgelegd. Op deze wijze krijgen we een inzicht in de diversiteit van regionale en mondiale regelingen waarin het recht op onderwijs geclausuleerd is. Vervolgens zal ik uiteen zetten op welke teksten ik in mijn onderzoek nader zal ingaan.

\subsection{Het recht op onderwijs in internationale verdragen en verklaringen in vogelvlucht}

Het recht op onderwijs is vastgelegd in zowel universele als regionale internationale juridische teksten. Eên van de eerste codificaties is artikel 26 van de Universele Verklaring van de Rechten van de Mens uit 1948. Zoals de titel van de Verklaring al aangeeft beoogt zij universeel van karakter te zijn. Artikel 26 regelt op uitvoerige wijze het recht van elk individu op onderwijs. De uitwerking van de bepalingen uit de Universele Verklaring in juridisch bindende verdragsbepalingen voor staten vond plaats in 1966 in het Internationaal Verdrag inzake Burgerrechten en Politieke Rechten (IVBPR), alsmede in het Internationaal Verdrag inzake Economische, Sociale en Culturele Rechten (IVESCR). Tezamen met de Universele Verklaring vormen zij het Internationaal Statuut van de Rechten van de Mens.

Het IVESCR bepaalt in artikel 13(1) dat de verdragsstaten het recht van een ieder op onderwijs erkennen. In deze verdragsbepaling is het recht op onderwijs uitvoerig omschreven, waarbij zowel het sociale aspect als het vrijheidsaspect van het recht op onderwijs uitgewerkt zijn. Bovendien is in artikel 18(4) IVBPR, in samenhang met de vrijheid van denken, geweten en godsdienst, de vrijheid van de ouders vastgelegd aangaande de godsdienstige en morele opvoeding van hun kinderen. Bovengenoemde bepalingen geven op algemene en fundamentele wijze de universele regeling van het recht op onderwijs weer. Daarnaast dient melding te worden gemaakt van artikel 27 IVBPR dat aan leden van minderheden bepaalde rechten toekent, zoals bijvoorbeeld het gebruik van hun eigen taal. Uitbanning van discriminatie in het onderwijs wordt genoemd in het Internationaal Verdrag inzake de Uitbanning van alle vormen van rassendiscriminatie.

Artikel 5 van dit Verdrag verplicht partijstaten onder meer discriminatie op grond van ras op het gebied van onderwijs en opleiding te verbieden en uit te bannen, en de gelijkheid van een ieder voor de wet op dit terrein te verzekeren." 
Een internationale overeenkomst geheel gewijd aan de uitbanning van discriminatie in het onderwijs is de op 14 december 1960 gesloten 'Convention against Discrimination in Education'. Dit Verdrag kwam tot stand binnen het kader en op initiatief van de UNESCO, de Organisatie voor Onderwijs, Wetenschappen en Cultuur van de Verenigde Naties, een gespecialiseerde organisatie.

Een ander belangrijk verdrag heeft de uitbanning van discriminatie van de vrouw tot onderwerp. Artikel 10 van de 'Convention on the Elimination of All Forms of Discrimination against Women' beoogt de uitbanning van discriminatie van vrouwen in het onderwijs. Deze doelstelling wordt in artikel 10 op uitvoerige wijze uitgewerkt.

Op 20 november 1989 aanvaardde de Algemene Vergadering van de Verenigde Naties de Conventie inzake de Rechten van het Kind. In dit Verdrag is een tweetal bepalingen gewijd aan het recht op onderwijs. ${ }^{5}$

Wat betreft de universele documenten moet ook genoemd worden de 'Proclamatie van Teheran' van 13 mei $1968 .^{6}$ Deze Proclamatie vormt geen bindend instrument, maar propageert op plechtige wijze het belang van de bevordering en naleving van de rechten van de mens. Zo bepaalt paragraaf 14:

'The existence of over seven hundred million illiterates throughout the world is an enormous obstacle to all efforts at realizing the aims and purposes of the Charter of the United Nations, and the provisions of the Universal Declaration of Human Rights. International action aimed at eradicating illiteracy from the face of the earth and promoting education at all levels requires urgent attention."

De Verklaring inzake de Uitbanning van Godsdienstige Onverdraagzaamheid waarborgt in artikel 5 de rechten van de ouders aangaande opvoeding van en het onderwijs aan hun kinderen ${ }^{7}$ Ook moet hier melding worden gemaakt van het Vluchtelingenverdrag van 1951, dat in artikel 22 lid 1 bepaalt dat "the contracting states shall accord to refugees the same treatment as is accorded to nationals with respect to elementary education'. Lid 2 van deze bepaling omvat regelingen over het vervolgonderwijs aan vluchtelingen, die evenwel minder garanties bieden. ${ }^{8}$

Binnen de Internationale Arbeidsorganisatie is een aantal teksten aanvaard die weliswaar in hoof dzaak betrekking hebben op arbeidsomstandigheden, maar die ook raakvlakken hebben met het recht op onderwijs, in het bijzonder de beroepsopleiding. In dit verband kunnen genoemd de Convention on Paid Educational Leave, 1974 (Conventie no. 140) en de Con-

5. Teket in Trb. 1990, 46.

6. Afgekondigd door de Internationale Conferentie over de Rechten van de Mens, welke van 22 april tot 13 mei 1968 in Teheran plaats vond. Deze conferentie werd gehouden bij gelegenheid wan het Internationale Jaar voor de Rechten van de Mens.

7. AV Res. $36 / 55$ van 21 nov. 1981; zie artikel 5 lid 1 en 2.

8. Verdrag van 28 juli 1951, Trb. 1954, 88. 
vention concerning Vocational Guidance and Vocational Training in the Development of Human Resources, 1975 (Conventie no. 142). Ook bestaan er aanbevelingen ten gunste van specifieke groepen zoals de Recommendation concerning Vocational Training of Seafarers, 1970 (Recommendation no. 137). Daarnaast werd in 1957 in ILO-verband een belangrijke conventie aanvaard betreffende de status en situatie van inheemse volken in staten, te weten de 'Indigenous and Tribal Populations Convention (Conventie no. 107$).{ }^{2}$ Dit Verdrag bevat een aantal bepalingen over onderwijs aan leden van inheemse bevolkingsgroepen. Mede op aandringen van organisaties van inheemse volken werd deze Conventie in 1989 herzien, en draagt nu de naam Convention concerning Indigenous and Tribal Peoples in Independent Countries, 1989 (Conventie no, 169). ${ }^{10}$

Op regionaal niveau is een aantal instrumenten tot stand gekomen waarin het recht op onderwijs is vastgelegd. In Europees verband is dat in de eerste plaats het Europees Verdrag tot Bescherming van de Rechten van de Mens en de Fundamentele Vrijheden van 4 november 1950. Het recht op onderwijs is vastgelegd in artikel 2 van het Eerste Protocol bij dit Verdrag van 20 maart 1952. In de tweede plaats is er het Europees Sociaal Handvest van 18 oktober 1961, dat in de artikelen 9 en 10 het recht op beroepskeuzevoorlichting alsmede het recht op vakopleiding regelt.

Zowel op het Amerikaanse, als op het Afrikaanse continent zijn regionale overeenkomsten gesloten en een verklaring afgekondigd ter bescherming van de rechten van de mens, tot stand gekomen in het kader van de OAS respectievelijk de OAE. De Amerikaanse Verklaring van de rechten en plichten van de mens (1948) bepaalt in artikel XII het recht op onderwijs voor elk individu. De Amerikaanse Conventie van de Rechten van de Mens van 22 november 1969 bepaalt niet af zonderlijk het recht op onderwijs. Wel garandeert artikel 12(4) de vrijheid van ouders en voogden de religieuze en morele opvoeding van hun kinderen te verzorgen welke in overeenstemming is met hun eigen overtuigingen. Artikel 26 uit deze Conventie, heeft als aanhef "progressive development". De partijstaten bij deze Conventie verplichten zich tot het nemen van maatregelen met het oog op het geleidelijk bereiken van de volledige verwezenlijking van onder meer de onderwijsnormen zoals die zijn neergelegd in het Handvest van de Organisatie van Amerikaanse Staten. Deze normen op het gebied van het onderwijs worden in de artikelen 45,47 en 48 van dit Handvest uitgewerkt. ${ }^{11}$

In 1988 kwam een Protocol bij de Amerikaanse Mensenrechtenconventie tot stand waarin economische, sociale en culturele rechten werden vastgelegd, waaronder het recht op onderwijs. ${ }^{12}$

9. Alle tot dusver genoemde ILO tekaten zijn te vinden in ILO, International Labour Conventions and Recommendations 1919-1981, Geneva 1982.

10. Trb. $1990,39$.

11. Deze Amerikanse teksten züjn te vinden in de losbladige editie Human Rights, The Inter American System, edited by Th. Buergenthal en R.E. Norris, Dobba Ferry, New York.

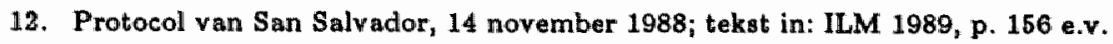


Het Afrikaanse Handvest voor de rechten van mensen en volken (27 juni 1981) bepaalt in artikel 17(1): "Every individual shall have the right to education'. Het Verdrag bevat geen nadere uitwerking van deze bepaling. ${ }^{13}$

In Europees verband verdient tenslotte nog vermelding de documenten tot stand gekomen in het kader van de Conferentie over Veiligheid en Samenwerking in Europa (CVSE). In het bijzonder het Slotdocument van Wenen (jan. 1989) bevat enkele belangrijke aspecten betreffende de vrijheid van onderwijs. Het document van Kopenhagen (juni 1990)voegt daar enige bepalingen over onderwijsrechten van minderheden aan toe.

In de volgende paragrafen zal nader worden ingegaan op de totstandkoming, de inhoud en de betekenis van het recht op onderwijs als mensenrecht. Dit zal geschieden aan de hand van een analyse van de onderwijsbepalingen uit de belangrijkste internationale verdragen en verklaringen. Daarbij wordt uitgegaan van de teksten zoals die in deze instrumenten zijn vastgelegd, waarbij de 'travaux préparatoires' een onmisbaar hulpmiddel vormen bij de interpretatie.

Omdat ons onderzoek zich richt op de universele gelding van het recht op onderwijs zullen de belangrijkste universele teksten bij de analyse centraal staan. Het betreft hier de Universele Verklaring van de Rechten van de Mens, het IVESCR, aangevuld met artikel 18(4) en 27 uit het IVBPR. Een aparte plaats in ons onderzoek is ingeruimd voor de UNESCO Conventie tot Bestrijding van Discriminatie in het Onderwijs, vanwege het belang van het onderwerp. In het kort zall verder aandacht worden besteed aan de onderwijsbepaling uit het Verdrag tot Uitbanning van alle Vormen van Discriminatie van Vrouwen en aan de Conventie inzake de Rechten van het $\mathrm{Kind}$. Nadere bestudering verdienen eveneens de beide ILO-conventies uit 1957 en 1989 over inheemse volken.

Wat de regionale teksten betreft zal ingegaan worden op het Europees Verdrag voor de Rechten van de Mens. De implementatie van de bepalingen van dit Verdrag in de lidstaten van de Raad van Europa is in de meeste gevallen ver doorgevoerd, terwijl ook de toezichthoudende procedures op de naleving van de verdragsbepalingen gedetailleerd en specifiek van karakter zijn. Tevens heeft de implementatie van de bepaling aangaande het recht op onderwijs uit dit Verdrag aanleiding gegeven tot jurisprudentie van het Europese Hof voor de Rechten van de Mens. Ook zal in het kort worden ingegaan op de relevante gedeeltes uit de documenten tot stand gekomen in het kader van het CVSE-Proces. Bovendien zal aandacht worden besteed aan het Protocol uit 1988 bij de Amerikaanse Mensenrechtenconventie. De andere hiergenoemdle internationale teksten waarin het recht op onderwijs is neergelegd blijven in het verdere onderzoek goeddeels buiten beschouwing. Zoals gezegd zal bij de analyse van de relevante onderwijsbepalingen uit de verschillende internationale teksten steeds gepoogd wor-

13. Zie voor de tekst wan dit Verdrag, ILM 1982 , p. 59 e.v. en 'The Review', I.C.J. No. 27 , december 1981 , pp. 76-86. Deze overeenkomst is in werking getreden op 21 oktober 1986. 
den dit te doen aan de hand van het sociale- en het vrijheidsaspect van het recht op onderwijs zoals hierboven aangegeven.

\subsection{De Universele Verklaring van de Rechten van de Mens}

\subsubsection{De plaats van artikel 26 in de Universele Verklaring}

Artikel 26 Universele Verklaring van de Rechten van de Mens formuleert het recht op onderwijs. Deze bepaling vormt éen van de sociale, economische en culturele mensenrechten in de Verklaring. Andere rechten behorende tot deze groep zijn het recht op arbeid, het recht op rust en op vrije tijd, het recht op gezondheid, huisvesting, alsmede culturele rechten. $\mathrm{Zij}$ zijn vastgelegd in de artikelen 22-27. Hun codificatie in een internationaal document kan worden aangemerkt als een novum. ${ }^{14}$ De algemene introductie tot de economische, sociale en culturele rechten in de Universele Verklaring vormt artikel 22 , dat als volgt luidt:

'Everyone, as a member of society, has the right to social security and is entitled to realization, through national effort and international cooperation and in accordance with the organization and resources of each State, of the economic, social and cultural rights indispensable for his dignity and the free development of his personality.'

Deze bepaling geeft de kern van de economische, sociale en culturele rechten aan, namelijk de menselijke waardigheid en de ontplooiing van het individu. Dit artikel kan worden beschouwd als een paraplu-bepaling. ${ }^{15}$ De implementatie ervan vergt van de overheid een zekere bemoeienis en inspanning. In de woorden van René Cassin,

'les droits à la vie et à la liberté sont inconditionnels. La satisfaction des droits économiques et sociaux nécessite, au contraire, des prestations matérielles de part de l'Etat, et, par conséquent, exige une garantie. ${ }^{16}$

Het recht op onderwijs heeft de meeste rakpunten met de notie van culturele rechten. ${ }^{17}$ Tot de culturele rechten worden verder nog gerekend: het recht om deel te nemen aan het culturele leven, de vrijheid van wetenschappelijk onderzoek en creatieve activiteit en het recht op intellectuele eigen-

14. Zie I. Saabs, Cultural Rights, Leiden/Budapest 1974, p. 35

15. Zie United Nations, These Rights and Freedoms, 1950, p. 60 .

16. R. Cassin bij de discussie aangaande het opstellen van de Uniwersele Verklaring in de Commissie vaor de Rechten van de Mens van de Verenigde Naties, zoals geciteerd door A. Verdoodt, Naissance et Signification de lla Declaration Universelle des Droits de l'Homme, Louvain/Paris 1964 , p. 213. 17. Y. Dinstein, Cultural Rights, in: Israel Yearbook on Human Rights, vol. 9 (1979), pp.
58-81, op p. 58 . 
dom. ${ }^{18}$ Binnen de groep van culturele rechten neemt het recht op onderwijs een bijzondere plaats in. Het heeft als het ware een algemene functionele rol ten behoeve van de verwezenlijking van andere mensenrechten. ${ }^{19}$ Deze functionele rol versterkt de onderlinge afhankelijkheid van en verband tussen burger- en politieke rechten aan de ene kant en sociale, economische en culturele rechten aan de andere kant. In de woorden van Szabó:

'by interpreting the right to education as a human right, the fundamental functions of which comprise education for preserving and enforcing human rights, we reach a correlation where human rights, so to say, revert to themselves through the medium of the right to education'. ${ }^{20}$

Het recht op onderwijs kan in deze zin bijvoorbeeld een functionele betekenis hebben bij de verwezenlijking van het recht op arbeid of het uitoefenen van de vrijheid van meningsuiting. Onderwijs maakt immers mogelijk dat genoemde rechten inhoud krijgen en daadwerkelijk binnen het bereik van het individu komen. Hiermee zij ook aangegeven dat het recht op onderwijs een essentiële rol vervult in het ontwikkelingsproces van Derde Wereldlanden. Indien mensen kunnen lezen en schrijven en een vervolgopleiding hebben genoten worden andere rechten voor hen bereikbaar en kunnen zij een zinvolle bijdrage leveren aan de ontwikkeling van de gemeenschap.

Bij beschouwing van artikel 26 vallen drie aspecten op. Lid 1 gaat in op het sociale aspect van het recht op onderwijs; lid 3 betreft het vrijheidsaspect, terwijl lid 2 de doeleinden van onderwijs vastlegt. Het sociale aspect van lid 1, alsmede het vrijheidsaspect van lid 3 zullen hieronder geanalyseerd worden aan de hand van de 'travaux préparatoires'. Lid 2 blijft hier verder buiten beschouwing.

\subsubsection{De term 'recht op onderwijs'}

De term "recht op onderwijs" omdat een drietal elementen, namelijk:

a) het recht om te onderwijzen ("la liberté d'enseigner"),

b) het recht om onderwijs te ontvangen ('la liberté d'être enseigné'),

c) de vrijheid van keuze van onderwijs ('la liberté de choix de l'enseignement'). ${ }^{21}$

18. Ibid.

19. Szabo, a.w. p. 36 .

20. Ibid.

21. Szabo, a.w. p. 11 hanteert in eerste instantie de term 'right to instruction' als vertaling voor dle oorspronkelijke term "droit d"enseignement" of "droit a l'enseignement". Als elementen van dit recht noemt hij de drie betekenissen zoals aangegeven (Szabo, a.w. p. 18). Zie ook G. Burdeau, Les libertés publiques, 4e druk 1972, Paris, p. 315 . Burdeau hanteert een vergelijkbare definitie. Hij onderscheidt 'le droit d'engeigner, le droit d'apprendre." en 'le droit de choisir con maitre'. 
Het eerste ontwerp voor de Universele Verklaring, opgesteld door het Secretariaat van de Commissie voor de Rechten van de Mens, bevatte een tweetall bepalingen ${ }^{22}$ dat de formulering van het recht op onderwijs beoogde. De eerste bepaling betrof het recht om onderwijs te ontvangen ('la liberté d'être enseignê') en luidde als volgt:

'Tout individu a droit à l'instruction. [...].'

De tweede formulering betrof de vrijheid van onderwijs (het recht om te onderwijzen):

'Tout individu peut fonder des établissements d'enseignement, conformément aux conditions établis par la loi."

Tijdens de derde zitting van de Commissie voor de Rechten van de Mens stelde René Cassin voor het woord 'instruction' te vervangen door 'éducation", omdat deze laatste term veel ruimer was en de eerste mede omvatte. ${ }^{23}$ Deze ruime betekenis blijkt ook uit het feit dat de term 'éducation' in lid 3 van artikel 26 in het Nederlands is vertaald met de woorden 'opvoeding en onderwijs'. Hieruit blijkt dat er een verband bestaat tussen onderwijs en opvoeding dat wel door middel van de term 'education' of 'éducation' kan worden aangeduid, maar dat de Nederlandse term 'onderwijs' alleen in dit opzicht onvoldoende is. ${ }^{24}$

In de internationale juridische praktijk, wordt de term "right to education' ('droit à l'éducation') beschouwd als het algemene overkoepelende begrip. ${ }^{25}$ Tevens is de term 'education" in de meeste internationale instrumenten vastgelegd. ${ }^{26}$ Gesteld kan worden dat de term 'right to education" algemeen aanvaard is.

22. Verdoodt, a.w. pp. $242,243$.

23. Verdoodt, a.w. p. 246.

24. Zie P.W.C. Akkermans. Onderwijs als constitutioneel probleem, Alphen aan de Rijn/ Brusgel 1980, p. 163.

25. Zie A.C. Kiss, 'La protection internationale du Droit de l'enfant a l'éducation', in: Revue des Droits de L'Homme/Human Righte Journal, vol. 6 (1973), p. 469.

Naar de mening van Szabó wordt op het internationale niveau de term 'right to instruction" aangeduid als 'right to education". Hierover bestaat eenstemmigheid, Srabó, a.w. p. 19.

26. In de Franse tekst van het EVRM wordt in artikel 2 van het Eerste Protocol gesproken van 'le droit a l'instruction'. Naar de mening van Kise, a.w. p. 469 gaat het hier om een schijnbare tegenstelling. De term "education' komt namelijk in de tweede volxin van de Franse tekst wel voor, en uit niets blijkt dat er een verschil in betekenis zou zijn. De interpretatie van artikel 2, Eerate Protocol EVRM komt later in deze studie nog aan de orde. 


\subsubsection{Het sociale aspect van het recht op onderwijs}

Lid 1 van artikel 26 omvat het sociale aspect van het recht op onderwijs. Lid 2 regelt expliciet de doelstellingen waarop het onderwijs gericht dient te zijn. Lid $\mathbb{1}$ geeft gedetailleerd aan wat de overheidstaak inhoudt aangaande de verwezenlijking van de verschillende onderwijsvormen. Dat artikel 26(1) de overheid een bepaalde taak opdraagt valt niet uitdrukkelijk uit de tekst af te leiden. Uit lid 1, alsmede uit de preambule ${ }^{27}$ van de Verklaring is echter impliciet op te maken dat de overheid een zekere zorgverplichting heeft, anders gezegd dat een bepaalde mate van overheidsbemoeienis vereist is, wil het recht op onderwijs gerealiseerd kunnen worden. Dit betekent niet dat uitsluitend de staat belast zou zijn met de uitvoering van de richtlijnen van artikel 26(1). Lid 1 staat niet aan de instelling van privê-onderwijs in de weg, mits het uiteindelijke resultaat maar in overeenstemming is met de bepalingen van lid $1 .^{28}$ De overheid kan bepaalde normen stellen teneinde het vereiste resultaat van lid 1 te waarborgen.

Artikel 26 lid 1 valt uiteen in een aantal elementen:

- het recht van elke mens op onderwijs.

Dit wordt als volgt uitgewerkt:

- het lager- en beginonderwijs dient kosteloos te zijn. Met de term beginonderwijs ('l'enseignement fondamental') wordt onderwijs voor volwassenen bedoeld die niet de kans hebben gehad eerder in hun leven enig lager onderwijs te volgen. Bij het opstellen van de Verklaring dacht men in dit verband aan volwassen analfabeten in met name ontwikkelingslanden. ${ }^{29}$ De term lager onderwijs kan gelijkgesteld worden met ons huidige basisonderwijs.

- het lager onderwijs is verplicht.

- technisch ('ambachts') onderwijs en beroepsonderwijs zullen algemeen beschikbaar worden gesteld.

- het hoger onderwijs dient voor een ieder op gelijke wijze toegankelijk te zijn op basis van studieprestaties.

Het recht op onderwijs, alsmede de verschillende onderwijsgeledingen dienen zonder enige vorm van discriminatie voor elk mens open te staan overeenkomstig artikel 2 van de Verklaring.

Wat betreft de verwezenlijking van de verschillende onderwijsgeledingen door de staat genoemd in artikel 26(1) zijn hier enige opmerkingen op

27. De preambule van de Verklaring bepaalt in dit verband dat:

'ieder individu en elk orgaan van de gemeenschap, met deze Verklaring voortdurend voor ogen, er naar zall streven door onderwijs en opvoeding de eerbied voor deze rechten en vrijheden te bevorderen, en door voomitstrevende maatregelen, op national en intemationaal terrein, deze rechten algemeen en daadwerkelijk te doen erkennen en toepassen ...' (Mijn cursivering A.C.)

28. Zie Akkermans, a.w. pp. 163, 164.

29. Verdoodt, a.w. p. 246. 
hun plaats. De verwezenlijking van de genoemde onderwijsgeledingen is in de meeste westerse, geindustrialiseerde landen veelal een feit. In het overgrote deel van de Derde Wereldstaten daarentegen is de fase van volledige verwezenlijking nog geenszins bereikt. Het opzetten van een onderwijsstelsel vereist het beschikbaar stellen van aanzienlijke financiële en technische middelen, die echter in de meeste ontwikkelingslanden niet voorhanden zijn. Bij de totstandkoming van artikel 26 onderkenden de opstellers dit probleem. In artikel 22 wordt dan ook bepaald dat elk mens aanspraak kan maken op de verwezenlijking van economische, sociale en culturele rechten, overeenkomstig de organisatie en de hulpbronnen van de betreffende staat' ${ }^{30}$ Deze interpretatie van artikel 26 juncto artikel 22 werd op de volgende wijze verwoord door een lid van de Commissie voor de Rechten van de Mens:

'(il) estime que l'on ne devrait imposer à aucun Etat l'obligation de fournir un enseignement d'un genre ou d'un degré particulier. Cela doit dépendre des ressources du pays ou de la communauté. ${ }^{31}$

Wat betreft de verwezenlijking van een onderwijsstelsel kunnen door de staat prioriteiten worden gesteld. In dit verband is de volgorde van de verschillende typen onderwijs in de formulering van artikel 26 relevant. De eerste zorg van de staat dient de verwezenlijking van het lager- en beginonderwijs te zijn. Dit onderwijs dient verplicht te worden gesteld en zal kosteloos aangeboden moeten worden. Dit betekent een aanzienlijk beslag op het organisatie-potentieel alsmede op de financiële middelen van de staat. Dat deze uitdaging zowel in 1948 als heden ten dage voor diverse staten tot problemen kan leiden werd bij het opstellen van de Verklaring door diverse leden van de Commissie erkend. Vandaar dat artikel 26(1) bepaalt: 'Het onderwijs zal kosteloos zijn, althans wat het lager- en beginonderwijs betreft'. Andere onderwijswormen dienen, overeenkomstig de beschikbare middelen, algemeen beschikbaar te worden gesteld, zoveel mogelijk kosteloos. ${ }^{32}$ Men zou kunnen stellen dat andere onderwijsvormen dan lager- en beginonderwijs een minder hoge prioriteit hebben ten aanzien van het kosteloze karakter daarvan. ${ }^{33}$

30. Zie ook Verdoodt, a.w. p. 251.

31. Harry (Australie); is Verdoodt, a.w. p. 244.

32. Kural (Turkije) sprak zijn voorkeur uit voor het opnemen in de Verklaring van de bepaling dat het secundaire en hoger onderwijg zoveel mogelijk kosteloos dient te zijn. Maar hij zag in dat een dergelijk stelsel niet overal direct gerealiseerd zou kunnen worden. Daarom stelde hij als compromis voor: "Toute personne a droit à l'éducation gratuite, au moins en ce qui concerne l'enseignement êlémentaire."

Voorstel gedaan tijdens de zitting van de Derde Commissie van de Algemene Vergadering, najaar 1948 ; zie Verdoodt, a.w. p. 248.

39. Akkermans, a.w. p. 164 . 


\subsubsection{Het vrijheidsaspect van het recht op onderwijs}

Lid 3 van artikel 26 geeft uiting aan het vrijheidsaspect van het recht op onderwijs. Met andere woorden het definieert het klassieke grondrecht. De staat, alsmede andere organisaties en personen dienen zich te onthouden van enigerlei dwang bij de keuze van de soort van opvoeding en onderwijs door ouders voor hun kinderen. De ouders bezitten in de eerste plaats, dat wil zeggen meer dan wie dan ook, dat recht. Het ligt voor de hand dat dit recht van de ouders vooral van toepassing en relevant is als het gaat om de keuze van onderwijs en opvoeding voor kinderen van de basisschoolleeftijd. $^{34}$

Het huidige lid 3 maakte geen deel uit van het ontwerp voor de Universele Verklaring zoals dat door de Commissie voor de Rechten van de Mens was opgesteld. Het idee werd in de Derde Commissie van de Algemene Vergadering van de VN in het najaar van 1948 gelanceerd door de Nederlandse afgevaardigde Prof. L.J.C. Beaufort O.F.M. Zijn amendement luidde als volgt:

'The primary responsibility for the education of the child rests with the family. Parents have the primary right to determine the kind of education their children should have. ${ }^{35}$

Samengevat motiveerde hij zijn amendement aldus:

'It was logical that the family should be given primary responsibility for education, because it was in the family that the child first learned to live as a member of the community. The family could not be replaced by any public or private institution which contributed to education. At the same time, the rights of the children were sacred, $[. .$.$] because a$ child could not demand implementation of its rights; parents were the most natural persons to do so, and parents would be unable to bear that primary responsibility unless they were able to choose the kind of educa-

34. Ibid.

35. Zie UN Doc. A/C.3/263. Tevens aangehaald door J.H. Burgers. De Rechten van de Mens en het Nederlandse Buitenlands. Beleid, in Ph.P. Everts, J.C. Heldring, Neder land en de rechten van de mens, Baarn 1981, p. 61. Zie ook Verdoodt, a.w. p. 249 en Akkermans, a.w. p. 162.

Burgera (a.w. p. 61) tekent hierbij aan dat Beaufort dit amendement op eigen initiathef had ingediend. Het $\mathrm{kwam}$ namelijk niet voor in een rapport van een door de regering ingestelde adviescommissie dat in maart 1948 werd uitgebracht. Tevens ontbrak een dergelijk amendement in het schriftelijk commentaar van de Nederlandae regering op de ontwerpverklaring ten behoeve van de zitting van de AV van dat jaar. Burgers wijst in dit verband op de grote mate van bandelingsvrijheid van de Nederlandse vertegenwoordiger op het gebied van het formulleren van mensenrechtennor-

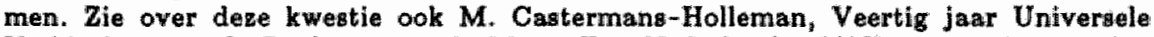
Verklaring van de Rechten van de Mens. Een Nederlandie bijdrage aan internationale normering in: International Spectator, november 1988, pp $696-702$. Zij wijst op het streven wan Nederland eigen waarden veilig te stellen (p.700). 
tion their children should have. Nazi-Germany, where the Hitler Youth Movement deprived parents of control over their children, had provided an experience which should never be permitted again., ${ }^{36}$

Dit voorstel was geinspireerd door de verregaande indoctrinatie-praktijken ten tijde van het Hitler-regime. ${ }^{37}$ Ook de overtuiging van Beaufort dat het gezin de hoeksteen vormde van de samenleving speelde waarschijnlijk een rol. Tegen het voorstel van Beaufort werden bezwaren ingebracht door o.a. Frankrijk en de Verenigde Staten. De vertegenwoordigers van deze staten achtten het Nederlandse voorstel niet passen in de moderne tijd, waarin naast de ouders en het gezin ook de staat een belangrijke rol speelde bij onderwijs en opvoeding. ${ }^{38}$ Het Nederlandse amendement werd uiteindelijk ingetrokken ten gunste van een voorstel van de Libanees Azkoul dat als volgt luidde:

'Les parents ont en priorité le droit de choisir le genre d'éducation et d'enseignement à donner à leurs enfants. ${ }^{39}$

Azkoul lichtte dit amendement toe met de opmerking dat de instelling van verplicht lager onderwijs de staat het recht gaf de ouders te verplichten hun kinderen naar school te sturen. Dit zou als tegenwicht moeten hebben dat ouders zelf kunnen bepalen naar welke school zij hun kinderen wensten te sturen. ${ }^{40}$ Vergeleken met het amendement van Beaufort is de vooraanstaande rol van het gezin bij de opvoeding en het onderwijs van kinderen in het voorstel van Azkoul weggelaten. In dit laatste voorstel wordt op meer genuanceerde wijze de speciale rol van de ouders vastgelegd, en is ook impliciet rekening gehouden met de taak van de staat op onderwijsgebied. ${ }^{41}$ Het amendement-Azkoul werd uiteindelijk met 17 tegen 13 stemmen bij 7 onthoudingen aangenomen. Na enkele tekstuele wijzigingen werd het als artikel $26(3)$ opgenomen.

Een punt dat nauw verbonden is met het vrijheidsaspect van het recht op onderwijs is het verplichte karakter van het lager (basis-)onderwijs. Relevant is hier de vraag of iets dat als een plicht wordt geformuleerd tevens kan worden opgevat als een recht. In de beraadslagingen van de Commissie voor de Rechten van de Mens kwam deze kwestie ook ter sprake:

36. These Rights and Freedoms, a.w. p. 69. Zie uitvoeriger, Uitgaven van het Ministerie van Buitenlandse Zaken No. 16 (juli 1949), pp. 66-68, 107-109.

37. Zie N. Robinson. The Universal Declaration of Human Rights. Its Origin, Significance, Application and Interpretation. World Jewish Congress, Institute of Jewish Affairi, New York 1958, p. 138.

38. Verdoodt, a.w. 249; Burgers, a.w. p. 61.

39. UN Doc. A/C.3/600 en Verdoodt, a.w. pp. 249-250.

40. Verdoodt, a.w. p. 250.

41. De interpretatie door Verdoodt van artikel $26(3)$ lijkt echter weer meer in de richting te gaan wan het amendement Beaufort. Zie Verdoodt, a.w. p. 252. 
'Madame Mehta (Inde) faisant objection à l'emploi du mot "obligatoire" dans une Déclaration de Droits, M. Cassin (France) répond qu'il signifie ici que personne, ni l'Etat, ni la famille, ne peut empecher l'enfant de recevoir une éducation élémentaire. Il n'y voit aucune idée de contrainte. ${ }^{, 42}$

In deze zin wordt het verplichte karakter van het lager onderwijs opgevat als een recht van een kind waarvan niemand het kan weerhouden. Het verplichte karakter van het basisonderwijs kan echter ook in een andere betekenis worden gezien. Zo achtte de Sovjet-vertegenwoordiger in de Commissie voor de Rechten van de Mens het de plicht van de staat om voor iedereen de mogelijkheid te bieden onderwijs te volgen. ${ }^{43}$ En Verdoodt concludeert dat:

'l'enseignement est obligatoire, non au sens que la famille ne pourrait pas choisir l'école que ses enfants fréquenteront, mais au sens que l'Etat, les communautés, et la famille sont obligés de mettre tout en oeuvre pour que l'enfant puisse fréquenter un enseignement élémentaire. ${ }^{44}$

Verdoodt ziet meer in de verantwoordelijkheid van de omgeving van het kind, waaronder de staat, om alles in het werk te stellen opdat het kind basisonderwijs kan genieten. Overigens waren de leden van de Commissie het er wel over eens dat het verplichte karakter van het basisonderwijs de vrijheid van de ouders aangaande de keuze van de school voor hun kinderen onverlet liet. ${ }^{45}$ Het verplichte karakter van het lager onderwijs kan aldus op verschillende wijzen geïnterpreteerd worden. Afsluitend kan men het eens zijn met Robinson die stelt dat artikel 26:

'contains an obligation of every person to possess elementary education. It is obvious that compulsory elementary education presupposes attendance at schools, but the Declaration does not impose an obligation to attend state or municipal schools, i.e. it does not exclude private schools of the elementary type or, in other words, the right of the parents to choose the school to which their children shall go. The compulsory nature of elementary education is preserved by the wording of par. 3, which grants parents the right to choose the kind of education of their children, but not to withhold it from them. ${ }^{46}$

Een ander element van het vrijheidsaspect van het recht op onderwijs betreft het recht van een ieder privè-vormen van onderwijs in te richten mits

42. Verdoodt i. a.w. p. 246.

43. Ibia.

44. Idem, p. 251.

45. Verdoodt, a.w. p. 246.

46. Robinson, a.w. p. 138. 
aan bepaalde door de overheid te stellen minimum-eisen is voldaan. Dit volgt uit artikel $26(3)$. Tevens vloeit hier uit voort dat het geven van godsdienstonderwijs is toegestaan, waarbij weer dient te worden uitgegaan van de vrije keuze van de ouders. ${ }^{47}$

Na beraadslagingen in de Derde Commissie van de AV van de Verenigde Naties werd artikel 26 daar aanvaard met 34 stemmen vóór, geen tegen bij twee onthoudingen. In de plenaire vergadering van de AV werd artikel 26 aangenomen met 53 tegen 0 bij 3 onthoudingen. ${ }^{48}$ Op grond van deze stemverhoudingen kan men concluderen dat artikel 26 de gemeenschappelijke opinie van de toenmalige lidstaten aangaande de inhoud en de verwezenlijking van het recht op onderwijs weergaf.

\subsection{Het Europees Verdrag tot Bescherming van de Rechten van de Mens en de Fundamentele Vrijheden, Eerste Protocol}

\subsubsection{Inleidende opmerkingen}

Het Europees Verdrag tot Bescherming van de Rechten van de Mens en de Fundamentele Vrijheden (EVRM) is een regionaal verdrag, gesloten door de lidstaten van de Raad van Europa op 4 november 1950.49 Het trad in werking op 3 september 1953. Dit Verdrag bevat geen bepaling die het recht op onderwijs vastlegt. Dit is later opgenomen in het Eerste Protocol bij het Verdrag dat op 20 maart 1952 tot stand kwam en wel in artikel 2.50 De reden voor het opstellen van een apart protocol was dat het formuleren van een aantal materiële rechten ${ }^{51}$ bijzonder veel tijd in beslag nam zodat zij niet meer opgenomen konden worden in het oorspronkelijk Verdrag. De oorzaak van deze vertraging was dat de organen van de Raad van Europa die betrokken waren bij het opstellen van het Verdrag het langdurig onderling oneens waren over de precieze formulering van met name de onderwijsbepaling. Bovendien was het aantal betrokken organen relatief

47. Mevr. Roosevelt (V.S.) bewerkstelligde in de Commissie voor de Rechten van de Mens, dat het volgende commentaar bij artikel 26 mou worden opgenomen:

"Dans les pays qui le voudront, le droit a une education privée sera respecté et l'education religieuse sera autorisé dans les écoles.'

Verdoodt, a.w. p. 245 . Zie ook p. 246.

48. Zie: These Rights and Freedoms, a.w. pp. 69, 70.

49. Trb. 1951, 154, laststelijk Trb. 1985, 68 .

50. Trb. 1952, 80 laatstelijk Trb. 1990, 167 .

51. Het Eerste Protocol bevat de volgende materielle bepalingen: het recht op eigendom, het recht op onderwijs (artikel 2), de verplichting voor de Staat tot het houden van vrije verkiezingen; artikel 5 van het Protocol bepaalt dat de materiéle bepalingen uit dit Protocol beschouwd diemen te worden als additionele artikelen bij de Conventie, en dat alle bepalingen uit de Conventie overeenkomstig van toepassing zijn. 
groot. $^{52}$ De belangrijkste fora in dit verband waren de Raadgevende Vergadering en het Comité van Ministers.

De 'travaux préparatoires' van het Verdrag en Protocol vormen een bijzonder complexe verzameling van documenten, verslagen van vergaderingen, voorstellen en amendementen. Dit heeft in het bijzonder betrekking op de onderwijsbepaling. Zo liep de periode waarin door verschillende organen gesleuteld werd aan de formulering van het onderwijsartikel van september 1949 tot maart 1952. In dit tijdsbestek werd met wisselende intensiteit gewerkt aan wat later artikel 2 van het Protocol werd. Er kunnen in dit verband een tweetal fases onderscheiden worden: ${ }^{53}$

1. de periode september 1949 - november 1950. In deze periode werd getracht het onderwijsartikel te incorporeren in het Verdrag zèlf. Toen door meningsverschillen tussen de betrokken organen dit voornemen mislukte, werd besloten de onderwijsbepaling en enige andere rechten op te nemen in een protocol;

2. de periode van januari 1951 - maart 1952 waarin op intensieve wijze de formulering van een afzonderlijk protocol ter hand werd genomen.

De langdurige ontstaansgeschiedenis van zowel Verdrag als Protocol werd mede veroorzaakt door het feit dat partijen de bedoeling hadden dat de bepallingen uit beide instrumenten bindend zouden moeten zijn voor de lidstaten en tevens onderworpen konden worden aan rechterlijke controle. Vandaar dat een grote mate van nauwkeurigheid bij het opstellen vereist was. ${ }^{54}$ IK zal hierna een analyse geven van de ontstaansgeschiedenis van artikel 2 uit het Eerste Protocol EVRM. Daarbij zal ik gebruik maken van

52. De volgende organen waren betrokken bij het opstellen van het Verdrag en het Protocal.

- Het Comite van Ministers, het uitvoerend orgaan van de Faad van Europa. Het Comite heeft intergouvernementele bevoegdheden.

- Het Comite van Regeringadeskundigen (Committee of Experts on Human Rights) dat de voorbereidende werkzaamheden verrïchtte voor het Comite van Ministers.

- Een groep van 'senior officials', de zogenaamde 'Ministers' Advisers", cen adviesorgaan van het Comite van Ministers.

- De Raadgevende Vergadering ('Consultative Assembly"), het orgaan bestaande uit vertegenwoordigers uit de parlementen van de lidstaten. De Vergadering formuleert aanbevelingen ten behoeve van het Comité van Ministers.

- Het Comité inzake Juridische en Administratieve Aangelegenheden (Committee on Legal and Administrative Questions), een functionele commissie van de Raadgevende Vergadering die belangrijk woorbereidend werk heeft verricht ten behoeve van het opatellen wan Verdrag en Protocol.

- Het Secretariaat van de Raad van Europa met aan het hoofd de Secretaris-Generaal.

53. Zie L. Wildhaber, To what extent has the right to education evolved?, in: Proceedings of the Fourth International Colloquy about the European Convention on Human Rights, Rome 5-8 november 1975. Council of Europe, Stragbourg 1976, pp. 141-183, op pp. 145-148. Zie ook in let andere zin, R. Errera, La Convention les problème de la laĩcitế et de l'enseignement, in: Revue des Droits de ل'Homme/Human Rights Journal, vol. 3 (1970), pp. 679-585.

54. Zie A.H. Robertson, The European Convention on Human Rights: Recent Developments, in: British Yearbook of International Law, vol. 28 (1951), pp. 359-365, op p. 361 . 
de 'travaux préparatoires", waarvan in de periode 1975-1985 een collectieve uitgave ${ }^{55}$ is verschenen.

Bij de analyse van de 'travaux préparatoires' valt op hoe zeer het sociale aspect en het vrijheidsaspect van het recht op onderwijs in de discussies met ellkaar verstrengeld waren. Dat maakt het bijzonder gecompliceerd de analyse van het tot stand komen van artikel 2 te scheiden in een sociaal aspect en een vrijheidsaspect. Vandaar dat in de hierna volgende uiteenzetting geregeld raakpunten van het socialle aspect aan het vrijheidsaspect en orngekeerd aan de orde zullen komen. Een strikt onderscheid tussen beide dimensies is dan ook in dit verband niet goed mogelijk.

Artikel 2 van het Eerste Protocol bij de EVRM luidt als volgt:

'No person shall be denied the right to education. In the exercise of any functions which it assumes in relation to education and to teaching, the State shall respect the right of parents to ensure such education and teaching in conformity with their own religious and philosophical convictions."

In de Franse versie:

'Nul ne peut se voir refuser le droit à l'instruction. l'Etat, dans l'exercice des fonctions qu'il assumera dans le domaine de l'éducation et de l'enseignement, respectera le droit des parents d'assurer cette éducation et cet enseignement conformément à leurs convictions religieuses et philosophiques.'

De Engelse en Franse versie van artikel 2 zijn hier weergegeven, omdat de beraadslagingen over de formulering van deze tekst in beide talen plaats vonden.

\subsubsection{De eerste fase (1949-1950)}

Eén van de eerste voorstellen ten behoeve van het opnemen van een bepaling aangaande de relatie ouders-kinderen-onderwijs in een toekomstig verdrag was afkomstig van de afgevaardigde Teitgen, tevens rapporteur van het 'Committee on Legal and Administrative Questions'. Hij verwees in een van zijn voorstellen naar de:

'rights of parents in regard to the education of their children, in accordance with Article 26(3) of the United Nations Declaration. 56

55. Council of Europe, Collected Edition of the "Travaux Préparatoires" of the European Convention on Human Rights 8 volumes, 1975-1985. Martinus Nijhoff Publishers, Dordrecht. Hierna te noemen Travaux Prép.

56. Travaux Prép., vol. 1, p. 168 (29 aug. 1949). 
Dit voorstel riep in de voltallige Assemble nogal heftige reacties op. Er waren gedelegeerden die van mening waren dat "family rights" niet thuis hoorden in een verdrag dat als eerst doel zou moeten hebben het waarborgen van politieke grondrechten ten behoeve van het functioneren van een democratisch stelsel. ${ }^{57}$ Voorts waren deze afgevaardigden van mening dat een onderwijsbepaling en bepalingen betreffende de plaats van het gezin zo gecompliceerd van karakter waren, alsmede dat de betekenis van deze termen in West-Europa zo verschillend was dat zulke bepalingen niet goed toegepast konden worden door een Europees Hof. ${ }^{58}$ Aan de andere kant waren er stemmen die een onderwijsbepaling propageerden waarin uitgegaan werd van de rechten van het kind, die op positieve wijze werden geformuleerd. ${ }^{59}$

Het Comité van Regeringsdeskundigen had in zijn voorstel voor een Mensenrechtenconventie de discussies zoals die gevaerd waren in de Assemblée nauwelijks laten meespelen. Het Comité deed dan ook geen voorstel aangaande een onderwijsbepaling in een toekomstig verdrag met het argument dat deze kwestie politiek van aard was en zich aan zijn bevoegdheden onttrok. ${ }^{60}$ Het 'Committee on Legal and Administrative Questions' boog zich opnieuw over de materie en kwam tot de volgende formulering:

'All persons are entitled to education. The responsibilities assumed by the State with regard to education may not encroach on the right of parents to ensure the spiritual and moral instruction of their children in accordance with their own religious and philosophical beliefs. ${ }^{, 11}$

Deze tekst bevatte zowel het vrijheidsaspect van het recht op onderwijs, omdat geen inbreuk mocht worden gemaakt op de rechten van ouders, als het sociale aspect, omdat voorzichtig verwezen werd naar de rol van de staat op het gebied van het onderwijs. Voorts formuleerde het ontwerp in de eerste volzin op positieve wijze het recht van een ieder op onderwijs.

Ook dit voorstel gaf aanleiding tot veel discussie in de Assemblêe. De algemene opinie was dat de rechten van ouders aangaande het onderwijs voor hun kinderen moesten dienen als waarborg tegen de mogelijke invloed

57. De Britge afgevaardigde Lord Layton was ến van de verkondigers van deze mening. (7 sept. 1949).

Zie Wildhaber, a.w. p. 145.

58. Wildhaber, a.w. p. 145.

59. Deze geluiden waren in het bijzonder afkomstig van de Frange afgevaardigden Philip en Mollet ( 7 iept. 1949).

Zie Wildhaber, a.w. p. 145.

60. Rapport van het Comité van Experts aan het Comité van Ministers, d.d. 13 maart 1950, zoals aangehaald door Errera, a.w. p. 581 .

61. Zie Wildhaber, a.w. p. 146. Op de eerste volzin na is deze bepaling ontworpen door de Belg Rodin. Zie ook Akkermans, a.w. p. 166. De eerste volkin werd toegevoegd door het Drafting - Subcommittee. Zle Travaux Prép., vol. V, pp. 204-206 (7 en 8 aug. 1950). 
van totalitaire ideologieèn, zoals fascisme en communisme. Daarbij werd verwezen naar de praktijken in Nazi-Duitsland waar scholen een belangrijk medium vormden in de verspreiding van de fascistische leer en kinderen stelselmatig werden geïndoctrineerd. Hetzelf de gold min of meer voor het onderwijs in de communistische landen. ${ }^{62}$ Iedereen in de Assemblee was het erover eens dat opvoeding en onderwijs cruciale elementen waren in de verwezenlijking van een vrije, pluralistische en democratische samenleving en de grondslag vormden voor andere persoonlijke en politieke vrijheden. Illustratief voor de stemming in de Assemblëe was de volgende vraag van de Franse afgevaardigde Mollet:

'Un père de famille, étant ou se croyant communiste, serait-il en droit d'exiger que l'Etat assure aux frais de la nation une instruction conforme au matérialisme dialectique? ${ }^{63}$

Het antwoord van de voorzitter van het "Committee on Legal and Administrative Questions' was ondubbelzinnig ontkennend. ${ }^{64}$

De rechten van de ouders aangaande het onderwijs voor hun kinderen werden door de afgevaardigden beschouwd als inherent aan het ouderschap, als natuurlijke rechten. Deze mening werd als volgt verwoord door de Fransman Pernot:

'Je considère que c'est pour moi le droit le plus naturel, celui qui me tient le plus au coeur, que d'être maître de l'éducation de mes enfants, de leur inculquer dans leur jeune âge mes propres convictions religieuses et philosophiques, sauf à eux à choisir librement plus tard selon leurs préférences personnelles. [...] Quand on a mis des enfants au monde, on a le devoir de les élever et ce que nous revendiquons pour les parents, c'est simplement la liberté, le droit d'accomplir ce devoir sacré., 65

Een aantal afgevaardigden verzekerde gedurende de discussies dat het voorliggende ontwerpartikel zich beperkte tot het recht van de ouders tot het oprichten van confessionele of anderszins niet-openbare scholen volgens hun eigen filosofische of religieuze overtuigingen. Het voorstel had geenszins de bedoeling de staat te verplichten bijzondere scholen in te richten waarbij de kosten voor de rekening van de staat zouden komen. ${ }^{66}$

62. Zie Mr. Maxwell-Fyfe, Chairman of the Committee on Legal and Administrative Questions, Travaux Prép., vol. VI, p. 162 (25 aug. 1950).

63. Travaux Prép., vol. VI, p. 159 (25 aug. 1950).

64. Travaux Prép., vol. VI, p. 162 (25 aug. 1950).

65. Travaux Prép., vol. VI, p. 109, 111 (25 aug. 1950).

66. Zie met name de interventies van Mr. Sichmid en Mr. Rolin, Travaux Prếp pp. 159, 161 (25 aug. 1950). Zie ook Wi]dhaber, a.w. p. 146 en Errera, a.w. p. 581. 
Uiteindelijk werd het ontwerpartikel, zoals voorgesteld door het $\mathrm{Com}-$ mittee on Legal and Administrative Questions' door de voltallige Raadgevende Vergadering aangenomen met 97 stemmen vóór bij 15 onthoudingen. ${ }^{67}$ De tekst van de Assemblée luidde als volgt:

'Every person has the right to education. The functions assumed by the State in respect of education and of teaching may not encroach upon the right of parents to ensure the religious and moral education of their children in conformity with their own religious and philosophical convictions. ${ }^{68}$

Het Comité van Ministers, tijdens zijn bijeenkomst van 4 en 5 november 1950 , besprak het ontwerp-Verdrag zoals voorgesteld door de Raadgevende Vergadering. De Ministers konden zich met een aantal bepalingen daaruit niet verenigen, waaronder de onderwijsbepaling. Besloten werd deze kwesties voor verdere studie door te verwijzen naar het Comité van Regeringsdeskundigen. $\mathrm{Zij}$ konden dan later in de vorm van een protocol aan het Verdrag toegevoegd worden. Tijdens deze zitting uitte een aantal Ministers ${ }^{69}$ zijn teleurstelling over het feit dat het aanvaarde Verdrag onvolledig was. De Nederlandse Minister van Buitenlandse Zaken Stikker ${ }^{70}$ verklaarde bij deze gelegenheid dat de Nederlandse regering en het parlement voorstander waren van een onderwijsbepaling in het Verdrag, en dat hij hoopte op een bevredigende regeling van deze kwestie.

Met deze beslissing tot regeling van een aantal bepalingen in een protocol bij het EVRM eindigt de eerste fase van de ontstaansgeschiedenis van het recht op onderwijs.

\subsubsection{De tweede fase (1951-1952)}

Het Comité van Regeringsdeskundigen dat in november 1950 van de Raad van Ministers de opdracht had meegekregen een tekst voor een protocol bij het Verdrag op te stellen had als mandaat ontwerpteksten te formuleren 'acceptable to all the Governments'. ${ }^{71}$ Dit beloofde een bijzonder moeilijke opgave te worden, omdat de ontwerptekst van de Assemblée een

67. Travaux Prếp., vol. VI, p. 164 (25 aug. 1950),

68. Travaux Prép., vol. VI, p. 52 en p. 53 voor de Franse tekst. Zie ook 'Text of the Draft amended by the Consultative Assembly including notes on the articles not yet approved by the Committee of Ministers and the adoption of which is urged by the Consultative Assembly" (doc. A 2838).

Zie Travaux Prép., vol. VI, pp. 248, 249 en 250.

69. Met name de Ministers Schuman, MacBride en Stikker. Zie Trawaux Prép., vol. VII, p. 46 ( 4 nov. 1950).

70. Travaux Prếp., vol. VII, p. 30 (3 nov. 1950).

71. Travaux Prêp., vol. VIII, p. 6 (18 sept. 1951). 
aantal problemen opriep bij de regeringsdeskundigen. We zullen hier in het kort deze problemen aanstippen.

1. Het eerste punt betrof de eerste volzin van het Assemblée-ontwerp: 'Every person has the right to education'. Bij de regeringsdeskundigen heerste de opvatting dat deze positieve formulering van het recht op onderwijs zo uitgelegd kon worden dat een staat de plicht zou hebben voor iedereen in zijn territoir onderwijs te verzorgen. Dit vond men duidelijk te ver gaan. ${ }^{72}$

2. Het tweede probleem had betrekking op de passage in de ontwerptekst op grond waarvan ouders het recht bezitten onderwijs voor hun kinderen te verzekeren in overeenstemming met hun godsdienstige overtuigingen. De toevoeging evenwel van 'philosophical convictions" veroorzaakte in het Comitê ernstige problemen.

Eên van de vragen die in dit verband aan de orde kwam was of de term 'filosofische overtuigingen' ook betrekking had op zulke ideologieën als het communisme of het marxisme. ${ }^{73}$ Indien op deze vraag een bevestigend antwoord zou worden gegeven betekende zulks dat politieke groeperingen die de vernietiging van de rechten en vrijheden van de Conventie beoogden, eveneens het recht zouden hebben hun kinderen te (laten) onderwijzen in overeenstemming met hun denkbeelden. In dit opzicht speelt artikel 17 EVRM een rol. Deze bepaling behelsde een verbod op activiteiten welke de vernietiging van de rechten en vrijheden uit het Verdrag ten doel hebben. Bovendien was het onduidelijk wanneer er sprake was van een overtuiging en welke overtuigingen 'filosofisch' van aard waren. Vandaar dat er in het Comité ook verzet bestond tegen de term 'moral education'.

Tussen februari en augustus 1951 kwam het Comité van Regeringsdeskundigen een aantal malen bijeen en probeerde een ontwerpartikel ten behoeve van het protocol op te stellen waarbij de kritiek op de ontwerptekst van de Assemblée werd verwerkt. De bepaling aangaande het recht op onderwijs vormde uiteindelijk de grootste gemeenschappelijke deler van de wetgeving van de versehillende lidstaten van de Raad van Europa. ${ }^{74}$ De tekst weerspiegelde de grootste mate van overeenstemming die in het Comité bereikt kon worden, en had dus zonder twijfel het karakter van een compromis. ${ }^{75}$ Over eventuele latere wijzigingen zou naar het oordeel van het Comité waarschijnlijk geen overeenstemming meer bereikt kunnen worden. Het Comité voegde daaraan toe:

72. Travaux Prép.y vol. VII, p. 128 (14 nov. 1950).

Zie ook A.H. Robertson, a.w. p. 362.

73. Robertson, a.w. p. 362 en Travaux Prép., vol. VII, p. 128 (14 nov. 1950).

74. Travaux Prép, vol. VIII, p. 6 (18 gept. 1951).

75. Idem. 
'while these texts do not go so far as some Governments would wish, it is possible for the domestic legislation of individual countries to furnish more extensive guarantees than are found in the draft Protocol. ${ }^{76}$

Het ontwerp-Protocol zoals opgesteld door het Comite van Deskundigen werd door het Comité van Ministers in augustus 1951 aanvaard. De tekst van de onderwijs-bepaling luidde als volgt:

'No person shall be denied the right to education. In the exercise of any functions which it may assume in relation to education and to teaching, the State shall have regard to the right of parents to ensure the religious education of their children in conformity with their own creeds.'

In oktober 1951 boog het 'Committee on Legal and Administrative Questions' van de Assemblée zich over het ontwerp-Protocol. Het Comité had kritiek op een drietal punten. ${ }^{77}$ In de eerste plaats achtte het Comité de term 'to have regard to the rights of parents' te onduidelijk. In de tweede plaats was de formulering van de onderwijsbepaling onbevredigend, omdat er slechts gesproken werd van 'education' en niet van 'education and teaching'. In de derde plaats tenslotte maakte het Comité ernstig bezwaar tegen het weglaten van de verwijzing naar filosof ische overtuigingen. $\mathrm{Na}$ bestudering van het ontwerp van het Comite van Deskundigen en na behandeling in het 'Committee on Legal and Administrative Questions', stelde dit laatste gremium het volgende amendement voor:

'No person shall be denied the right to education. In the exercise of any functions which it assumes in relation to education and to teaching, the State shall respect the right of parents to ensure such education and teaching in conformity with their own religious and philosophical convictions. ${ }^{78}$

Als voorlopige conclusie kan gesteld worden dat er in oktober 1951 op een drietal punten verschil van mening en inzicht bestond tussen het Comité van Ministers en het Comité van Regeringsdeskundigen aan de ene kant en de Raadgevende Vergadering aan de andere kant aangaande de formulering van het vrijheidsaspect van een onderwijsbepaling in een toekomstig ontwerp-Protocol. Het eerste punt betrof het recht van de ouders onderwijs voor hun kinderen te kiezen in overeenstemming met hun geloofsovertuiging (zoals het Comité van Deskundigen voorstelde) of hun religieuze en filosof ische overtuigingen (zoals benadrukt door de Assemblée). In deze kwestie ging het om de betekenis en reikwijdte van de term 'philosophical convictions', mede in relatie tot artikel 17 EVRM. In de tweede plaats bestond er verschil van inzicht over de aard, of het karakter van de

76. Idem.

77. Robertson, a.w. p. 363.

78. Travaux Prép., vol. VIII, p. 16 (1 okt. 1951). 
overheidsverplichting bij het eerbiedigen van de rechten van de ouders. In het bijzonder gaat het hier om de juridische betekenis van de termen 'to have regard to' versus 'to respect'. Ten derde heerste er verschil van mening aangaande de reikwijdte van de overheidsverplichting. Strekt deze zich slechts uit tot het gebied van de opvoeding ('education'), of omvat zij ook het onderwijs ('teaching')?

Wat betreft het sociale aspect van het recht op onderwijs, dat wil zeggen de bemoeienis van de staat met het opzetten en inrichten van openbaar onderwijs al dan niet met financiële middelen, is de eerste volzin van het Assemblêe-ontwerp relevant: 'No person shall be denied the right to education: Het gaat hier om de vraag welke concrete verplichtingen voor de overheid aangaande het voorzien in bepaalde onderwijsvormen uit deze negatieve formulering voortvloeien.

In de volgende paragrafen zullen we onderzoeken welke rol deze verschillen van inzicht tussen Comité van Ministers en Raadgevende Vergadering hebben gespeeld in de verdere ontstaansgeschiedenis van artikel 2 . We behandelen eerst het punt dat gerelateerd is aan het sociale aspect van het recht op onderwijs, te weten de negatieve formulering van de eerste volzin. Vervolgens gaan we in op het vrijheidsaspect van de onderwijsbepaling aan de hand van de drie hierboven genoemde punten.

In het algemeen kan gesteld worden dat de grondgedachte van de discussie omtrent de formulering van de onderwijsbepaling in het Comité van Ministers en Assemblée gevormd werd door het groeiend besef dat het niet ging om een declaratoire aspiratie, maar om een subjectief recht, dat voor een rechter afgedwongen zou kunnen worden. ${ }^{79}$

\subsubsection{Het sociale aspect van het recht op onderwijs in de tweede fase van de ontstaansgeschiedenis van artikel 2}

Opvallend in de ontstaansgeschiedenis van de onderwijsbepaling in het Protocol is dat de meeste deelnemers aan de discussies in het Comité van Ministers en met name in het 'Committee on Legal and Administrative Questions' het onderwijs-artikel beschouwden als de bepaling die de rechten van de ouders moest regelen, als uiting van het vrijheidsaspect van het recht op onderwijs. Mede ook daarom kwam de uiteindelijke negatieve formulering tot stand. Er werd vrijwel niet gerefereerd aan het sociale aspect van het recht op onderwijs, dat wil zeggen aan de zorgverplichting van de staat, noch aan het verplichte karakter van het basis-onderwijs. In de woorden van Opsahl: 
'There was never any strong sentiment in favour of positive obligations. ${ }^{.80}$

Als er al over mogelijk positieve verplichtingen voor de overheid werd gesproken beperkte de discussie zich tot de vraag in hoeverre de onderwijsbepaling aan staten de verplichting zou opleggen bepaalde onderwijsvormen in te richten of te subsidiëren overeenkomstig de versehillende filosof ische en religieuze stromingen in het land. ${ }^{81}$

Het probleem betrof in eerste instantie de formulering van de eerste volzin van de onderwijsbepaling. De door de Raadgevende Vergadering in augustus 1950 voorgestelde formulering 'Every person has the right to education' werd door het Comité van Deskundigen onmogelijk geacht, omdat het voor staten niet haalbaar zou zijn om alle mensen op hun grondgebied onderwijs aan te bieden. ${ }^{82}$ Daarbij werd onder meer verwezen naar kinderen woonachtig in afgelegen gebieden, schipperskinderen en volwassen analfabeten. ${ }^{83}$ Vanwege deze reden werd door het Comité van Regeringsdeskundigen gekozen voor de later niet meer gewijzigde negatief geformuleerde bepaling 'No person shall be denied the right to education'. Een meerderheid van de Regeringsdeskundigen was van mening dat "the right to education referred only to the right of parents to make their own choice of the type of education which they wished their children to receive ${ }^{84}$. Het recht op onderwijs wordt in feite hier beperkt tot het vrijheidsaspect, te weten de rechten van de ouders inzake het maken van een keuze aangaande het onderwijs voor hun kinderen. Genoemde uitleg van de negatieve formulering van de onderwijsbepaling werd nog eens bevestigd in een commentaar van het Secretariaat-Generaal waarin werd gesteld dat:

'while education is provided by the State for children, as a matter of course, in all member States, it is not possible for them to give an unlimited guarantee to provide education ..... ${ }^{85}$

Nog sterker werd het ontbreken van de verplichting voor staten tot het nemen van positieve maatregelen verwoord in het commentaar van het

80. T. Opsahl, The Convention and the right to respect for family life, particularly as regards the unity of the family and the protection of the rights of parents and guardians in the education of children, in: A.H. Robertson (ed.), Privacy and Human Rights, Manchester 1973, pp. 182-255, op p. 222.

81. Errera, a.w. p. 583. Zie ook Travaux Prép., vol. VII, p. 128 (14 nov. 1950).

82. De Britse, Noorse, Deense en Duitse regeringsdeskundigen uitten hun angat dat een positieve formulering van de onderwijsbepaling uitgelegd zou kunnen worden als een plicht voor staten tot het nemen van doeltreffende maatregelen zodat elk individu het onderwijs zou kunnen volgen dat hij wenste. Zie Travaux Prép, voll. VII, p. 202 (22 febr. 1951). Zie ook Wildhaber, a.w. p. 147.

83. Robertsion, a.w. p. 362.

84. Travaux Prép., vol. VII, p. 202 ( 22 febr. 1951). Zie ook Wildhaber, a.w. p. 147.

85. Commentary by the Secretariat-General on the Draft Protocol (18 sept. 1951). Travaux Prép., vol. VIII, p. 10. Zie ook Wildhaber, a.w. p. 147 en Opsahl, a.w. p. 228. 
'Committee on Legal and Administrative Questions' op de door hem voorgestelde onderwijsbepaling:

'If it is feared that any other formula would imply the duty of the State to establish or to support out of public funds, in whole or in part, schools corresponding to the various trends of opinion in the population, the Committee can only repeat, as has already been stated in the Consultative Assembly, that this question should be considered as being entirely outside the scope of the Convention or the Protocol. ${ }^{86}$

Deze woorden verwijzen naar het instellen dan wel het subsidiëren door de staat van allerlei vormen van privé-onderwijs gebaseerd op godsdienstige dan wel filosofische levensbeschouwingen. In beginsel blijft natuurlijk de vrijheid van het stichten en inrichten van niet-openbaar onderwijs door privé-groeperingen bestaan.

Partsch heeft erop gewezen dat de ontwerpers van de onderwijsbepaling geen overeenstemming hebben kunnen bereiken over de vraag welke verplichtingen een staat heeft ten opzichte van het privé-onderwijs bij de verwezenlijking van de rechten van de ouders. ${ }^{87}$ Dit gebrek aan eenstemmigheid bleek uit een drietal verklaringen van staten bij de ondertekening van het Protocol, die alle drie betrekking hadden op het sociale aspect van het recht op onderwijs.

Ondanks de voorgeschiedenis en de negatieve formulering legden het Verenigd Koninkrijk en de Bondsrepubliek Duitsland in hun verklaring vast dat het onderschrijven van artikel 2 van het Protocol niet impliceerde dat de staat een verplichting zou hebben tot het financieren van privé-onderwijsvormen. ${ }^{88}$ De Nederlandse regering daarentegen verklaarde dat.

80. Travaux Prep, vol. VIII, p. 24 (2 oktober 1951). Zie ook Errera, a.w. p. 585 en Opsaht, a.w. p. 231 .

87. KJ. Partich, Die Rechte und Feiheiten der europatischen Menschenrechtikonventhon, Berlin 1966, p. 240.

88. De Engelse Minister van Buitenlandae Zaken verklaarde bij ondertekening dat:

In view of certain provisions of the Education Acts in force in the United Kingdom, the principle affirmed in the second sentence of Article 2 is accepted by the United Kingdom only so far as it compatible with the provision of efficient instruction and training, and the avoidance of unreasonable public expenditure.'

Travaux Prepp, vol: VIII, p. 200 (20 maart 1952).

De Duitise verklaring luidde als volgt:

'La 2 eme phrase de l'article 2 du Protocole additionnel ne crée pour l'Etat aucune obligation de financer des tcoles de caractère religieux ou philosophique, ou de particlper a leur financement, cette question n'entrant pas selon la déclaration unanime de la commission des questions juridiques de l'Assemble Consultative et du Siecretaire Genéral du Conseil de l'Europe, dans le cadre de la Convention sur les Droits de I'Homme et les libertés fondamentales ainsi que du Protocole additionnel."

Teksten in. $\mathbb{H}$. G. Schermers, Het Europese Vercirag tot Bescherming ran de Rechten van de Mens en de Fundamentele Vrijheden, Zwolle 1964, p. 98.

(Wordt vervolgd...) 
'The State should not only respect the rights of parents in the matter of education but, if need be, ensure the possibility of exercising those rights by appropriate measures. ${ }^{89}$

Nederland beoogde op deze wijze op het nationale vlak een bescherming te garanderen die op een hoger niveau lag dan de normen die artikel 2 vastlegde. Dit impliceerde het subsidiëren van vormen van privé-onderwijs, met name, maar niet uitsluitend, het confessionele onderwijs.

Geconcludeerd kan worden dat het sociale aspect van de onderwijsbepaling tijdens het opstellen van het Protocol een ondergeschikte rol heeft gespeeld. Men kan zelfs stellen dat dit aspect buiten de discussie is gebleven c.q. gehouden om latere claims tegenover de overheid te voorkomen. Vandaar de negatieve formulering, waarvan een interpretatie alleen op grond van de 'travaux préparatoires', bijzonder weinig zal opleveren om een aanspraak op onderwijs volgens artikel 2 hard te maken. Het is het Europese Hof voor de Rechten van de Mens geweest dat later in zijn jurisprudentie het sociale element van artikel 2, aan de hand van artikell 14 EVRM heeft versterkt. ${ }^{90}$ Deze kwestie zal in het volgende hoofdstuk besproken worden.

88. (...vervolg)

Volgens Partsch, a.w. p. 240 valt aan te nemen dat de Duitse Verklaring de inhoud van artikel 2 op juiste wijze omschrijft. Hij geeft daarvoor echter geen bron of motivering.

89. Zie de Memorie van Toelichting bij de ontwerpwet tot goedkeuring van the EVRM en het Eerste Protocol, Tweede Kamer, zitting 1952-1953, Kamerstuk 3043, no. 3, p. 3.

Volgene de Travaux Prép., vol. VIII, p. 204 (20 mart 1952) luidde bij ondertekening van het Protocol daarentegen de formulering: "appropriate financial measures". De achtergrond wan dit versehil in formulering is mij niet duidelijk. De Nederlandae verklaring ontbreekt in de Nederlandse officiêle publikatie van het Protocol, Tractatenblad 1952, nr. 80, alsook in het officiele Yearbook on the European Convention.

Alkema vraagt zich af of de Nederlandse rechter rekening mag houden met deze verklaring, met andere woorden, kan zij 'self-executing' zijn? (E.A. Alkems, Studies over Europese Grondrechten, Deventer 1978, p. 89). Bij de goedkeuringsbehandeling merkte de Nederlandse regering op dat het om een unilaterale verklaring ging die geen der partijen bond, Mernorie van Toelichting, p. 4 .

Naar mijn mening betreft het een verklaring die de opvatting van de Nederlandse regering weergaf, zonder dat daaruit juridische consequentieg voortvloeien. De verklaring is nogal vrijblijvend van aard, zoals blijkt uit de woorden 'if need be'.

Zie over het besluitvormingsproces binnen de Nederlandse regering met betrekking tot de totstandkoming van het EVRM, Y.S. Klerk en L. van Poelgeest, Ratificatie a contre coeur: de reserves van de Nederlandse regering jegens het Europees Verdrag voor de Rechten van de Mens en het individueel klachtrecht, in: R.M. Themis no. 5 (1991), pp. 220-247; over het recht op onderwijis, pp. 227, 228. Dit artikel is gebaseerd op onderzoek van de archieven van verschillende Nederlandae Ministeries.

90. Zie Alkema, a.w. p. 89. 
3.4.5 Het vrijheidsaspect van het recht op onderwijs in de tweede fase van de ontstaansgeschiedenis van artikel 2

Eến van de grootste strijdpunten tussen Comité van Ministers (Comité van Regeringsdeskundigen) en de Raadgevende Vergadering (Committee on Legal and Administrative Questions) in de ontstaansgeschiedenis van artikel 2 betrof de verwijzing naar 'the right of parents to ensure the religious and moral education and teaching of their children in conformity with their own, religious and philosophical convictions", zoals geformuleerd in het ontwerpartikel van de Assemblée uit augustus 1950. Vooraf merk ik nog op dat de afgevaardigden in de Raadgevende Vergadering het erover eens waren dat de reikwijdte van de rechten van ouders niet beperkt is tot de godsdienstige of filosofische opvoeding van hun kinderen, maar zich ook uitstrekt tot de opvoeding in het algemeen. ${ }^{91}$ Het recht van de ouders om het soort onderwijs te kiezen voor hun kinderen overeenkomstig hun geloofsovertuiging vormde een onomstreden punt. De kwestie die verschil van mening veroorzaakte was veeleer de verwijzing naar 'philosophical convictions'. Volgens Opsahl kunnen aan dit begrip een drietal dimensies onderscheiden worden:

a. de aard van de overtuigingen ('filosofisch', of van een andere, mietfillosof ische aard);

b. de ernst van de denkbeelden in de zin van de vraag of het werkelijk om een overtuiging gaat;

c. de kwestie van de kwaliteit van de overtuigingen in verhouding tot de basis-gedachte van de Conventie zelf, in de zin van de vraag of de desbetreffende overtuigingen kunnen worden beperkt indien zij afbreuk doen aan het respect voor de democratische beginselen van het Verdrag. ${ }^{92}$ In dit verband speelt artikel 17 EVRM een rol.

De bezwaren van het Comité van Regeringsdeskundigen tegen de verwijzing naar 'philosophical convictions" in de tekst van de Assemblée concentreerden zich op twee punten. ${ }^{93}$ De verwijzing naar 'philosophical convictions' zou kunnen impliceren dat ouders wier overtuigingen in tegenspraak zouden zijn met de gedachten van democratie en mensenrechten het recht zouden hebben hun kinderen te onderwijzen volgens die overtuigingen. Het Comite van Deskundigen, beoogde met het schrappen van de term 'filosof ische overtuigingen' de verspreiding van doctrines die tegengesteld waren aan de beginselen waarop het Verdrag was gebaseerd te voorkomen. ${ }^{94}$ Het tweede bezwaar betrof de feitelijke omstandigheid van het bestaan van een staatsgodsdienst in tenminste één lidstaat ( $Z$ weden) die de vrijheid van

91. Opsahl a.w. p. 232.

92. Opsahl, a.w. p. 233.

93. Travaux Prép., vol. VIII, p. 12 (Commentary by the Secretariat-General on the Draft Protocol, 18 sept. 1951).

94. Travaux Prép., vol. VIII, p. 24 (2 oktober 1951). Zie ook Errera, a.w. p. 584. 
onderwijs in overeenstemming met fillosofische overtuigingen van de ouders niet kon toestaan.

Tijdens de derde reguliere zitting van de Raadgevende Vergadering in december 1951 kwam de kwestie van het al dan niet opnemen van de term 'filosofische overtuigingen' nog eens uitvoerig aar de orde. De onderwijsbepaling in het Protocol beoogde de rechten van de ouders te garanderen. Naar de mening van Rapporteur Teitgen schoot de voorgestelde formulering van het Comité van Deskundigen echter te kort om een volledige garantie te verwezenlijken:

'Mais si les parents invoquent d'autres convictions que des convictions religieuses et s'il s'agit d'une autre éducation que l'éducation religieuse, il n'y a plus de garantie. ${ }^{95}$

Teitgen waarschuwde dat het ouderrecht inzake het onderwijs geen voorrecht mocht worden voor alleen maar ouders met religieuze overtuigingen. Naar zijn mening beoogde de onderwijsbepaling de garantie van:

'le droit fondamental qui appartient à tout père de famille (sic, A.C.) de faire élever et instruire ses enfants selon sa conscience, quels que soient les impératifs de sa conscience, et ce n'est pas à l'Etat d'en juger. ${ }^{96}$

De beperkte formulering van het Comité van Deskundigen werd volgens Teitgen ingegeven door de angst voor de verspreiding van communistische en andere totalitaire ideeën in het onderwijs met een beroep op de bepalingen van het Verdrag. ${ }^{97}$ Als gevolg van het opnemen van de verwijzing naar filosofische overtuigingen zouden communistische organisaties en andere verwante groeperingen hun leer kunnen verkondigen door middel van propaganda en de inrichting van scholen gebaseerd op de communistische of anarchistische ideologie. Teitgen stelde hier tegenover dat de angst van het Comitê van Deskundigen niet reëel was, omdat artikel 17 EVRM een garantie vormde tegen de ondermijning van de Europese rechten en vrijheden. De tekst van artikel 17 luidt als volgt:

'Nothing in this Convention may be interpreted as implying for any State, group or person any right to engage in any activity or perform any act aimed at the destruction of any of the rights and freedoms set forth herein or at their limitation to a greater extent than is provided for in the Convention.'

95. Travaux Prép., vol. VIII, p. 93. Troisième Sessìon de l'Assemblée Consultative, 7-8 december 1951 . Veralag door Mr. Teitgen, Rapporteur.

96. Ibud.

97. Ibid. 
Op grond van die bepaling achtte Teitgen het vermijdbaar dat communistische of andere totalitair georiënteerde groeperingen een aanspraak konden maken op eerbiediging van ouderrechten. De reden hiervoor was dat genoemde overtuigingen als oogmerk hadden de ondermijning en de afschaffing van het Europese democratische bestel en de fundamentele rechten en vrijheden van de mens. ${ }^{98}$

Teitgen wist de grote meerderheid van de Raadgevende Vergadering te overtuigen met de uiteenzetting dat het van groot belang was de rechten van ouders op het gebied van opvoeding en onderwijs te beschermen:

'contre la menace de nationalisation, d'étatisation, d'accaparement, de réquisition de la jeunesse par l'Etat. ${ }^{, 99}$

In dat verband maakte het geen verschil of ouders zich beriepen op religieuze overtuigingen of op een humanistische levensbeschouwing.

Ook in de Vergadering bestond er discussie over de term 'philosophical convictions'. Met name was het voor een aantal afgevaardigden onduidelijk of de aard van een bepaalde overtuiging wel 'filosofisch' en van voldoende kwaliteit was. Er werd onder meer verwezen naar het humanisme, het atheïsme, nudisme, polygamie, het agnosticisme en het vegetarisme als voorbeelden van filosofische overtuigingen. Zo meende Mr. Renton ${ }^{100}$ dat de term 'philosophical convictions' in de praktijk 'unworkable' zou blijken te zijn. Mr. Boegholm ${ }^{101}$ wees er bovendien op dat de term 'religious and philosophical education' van Franse oorsprong was. Naar zijn mening was de betekenis van de Engelse versie onnauwkeurig en onduidelijk in deze context. ${ }^{102}$ Daarbij doelde hij in het bijzonder op de aard en de ernst van de overtuiging om als 'filosof isch' aangemerkt te worden. Rapporteur Teitgen omschreef de term als 'all those philosophical values of which humanism is made up' ${ }^{103}$ De meeste auteurs zijn het erover eens dat de term 'filosofische overtuigingen' vrij ruim opgevat dient te worden en onder meer betrekking heeft op sociale, ethische, culturele en politieke filosofieën ${ }^{104}$, alsmede anti-religieuze, quasi-religieuze en a-religieuze overtuigingen zo-

98. Ibid.

99. Travaux Prép., vol. VIII, P. 156 (8 dec. 1951).

100. Travaux Prep., vol. VIII, P. 110 (8 dec. 1951).

101. Travaux Prếp., vol. VIII, p. 144 (8 dec. 1951).

102. Meer in het algemeen merkte Mr. Boegholm (Denemarken) ten aanxien van het onderwerp van artikel 2 op:

'Nous admirons la clarté de l'esprit françaìs, mais il faut bien dire que la langue française s'y prête. Le texte de l'article 2 s'inspire des traditions politiques françaises. Dans les pays où s'est déroulée une lutte apre entre l'église et l'Etat, on conçoit fort bien ce que signifie le texte en question. Mais, dans les pays qui n'ont pas connu cette lutte, on ne le comprend pas."

Travaux Prép., vol. VIII, pp. 163, 165 (8 dec. 1951).

103. Travaux Prép., vol. VIII, p. 156 (8 dec, 1951 ).

104. Opsahl, a.w. p. 234. 
als agnosticisme en atheïsme, overtuigingen kortom betrekking hebbend op zulke waarden als leven, dood en het hiernamaals. ${ }^{105}$

Hoewel de Raadgevende Vergadering eensgezind vast hield aan de verwijzing naar filosofische overtuigingen in het ontwerp voor artikel 2 , bleef dit voor sommige regeringen die moesten beslissen over ondertekening van het Protocol een groot bezwaar. Het gebrek aan overeenstemming op dit punt tussen de regeringen van de lidstaten van de Raad van Europa bleek uit een drietal voorbehouden. Griekenland formuleerde bij ondertekening en ratificatie van het Protocol het volgende voorbehoud:

'Le mot "philosophique" par lequel se termine le second paragraphe de l'article 2, recevra en Grèce une application conforme aux dispositions y relatives de la législation intérieure. ${ }^{, 106}$

Dit betekende dat de Griekse staat de filosofische overtuigingen slechts in die mate zou/kon respecteren voor zover die in overeenstemming waren met de vereisten van de Griekse wet. ${ }^{107}$ Ook Turkije makkte door een voorbehoud bij artikel 2 duidelijk dat de eenheid van het onderwijs in Turkije gewaarborgd moest blijven. ${ }^{108}$ In het $Z$ weedse geval ging het om een land met een staatsgodsdienst. In dit land vormde onderwijs in de staatsgodsdienst een verplicht onderdeel van de lesprogramma's. Dispensatie werd slechts verleend aan kinderen met een andere religieuze overtuiging en niet op grond van zogenaamde filosofische overtuigingen. Op deze wijze werd in Zweden gegarandeerd dat alle kinderen een of andere vorm van godsdienstonderwijs zouden ontvangen. ${ }^{109}$

Een tweede fundamenteel verschil van opvatting tussen het Comité van Ministers enerzijds en de Raadgevende Vergadering anderzijds betrof een juridisch-technische kwestie. In de ontwerptekst voor een onderwijsbepa-

105. Wildhaber, a.w. P. 162.

106. Travaux Prép., vol. VIII, p. 219 (20 maart 1952).

107. De Griekse grondwet vereiste dat het basis - en middelbaar onderwijs "die sittliche und geistige Erziehung sowie die Entfaltung des nationalen Bewusstaeins der Jugend gemaiss den ideologischen Richtungen der griechisch christlichen Kultur" tot doel hebben. Geciteerd bij Partach, a.w. p. 239 noot 812.

108. De tekst van het Turkse voorbehoud luidde als volgt:

'L'article 2 du Protocole additionnel ne porte pas atteinte aux dispositions de La Loi No. 430 du 3 mars. 1924, relative l'unification de l'engeignement.'

Tekst bij Schermers, a.w. p. 97.

109. Zie Errera, a.w. p. 584 en Partsch, a.w. p. 240. De tekst van het Zweedse voorbehoud was aldus:

'... Sweden could not grant to parents the right to obtain, by reason of their philosophical convictions, dispensation for their children from the obligation of taking part in certain parts of the education in the public schools, and also to the effect that the dispensation from the obligation of taking part in the teaching of Christianity in these schools could only be granted for ehildren of another faith than the $S$ wedlish Church in respect of whom a satisfactory religious instruction had been arranged." 
ling van het Comite van Ministers uit augustus 1951 werd gesteld dat de staat 'shall have regard to' de rechten van ouders. Naar de mening van de Raadgevende Vergadering, in het bijzonder het 'Committee on Legal and Administrative Questions", was deze formulering vaag; deze zou niet misstaan in een aanbeveling aan staten als richtsnoer voor nationale wetgeving en overheidsbeleid. ${ }^{110}$ Hier ging het echter om een conventie met bindende werking waarvan naleving kon worden afgedwongen door rechterlijke sancties. Volgens Teitgen hadden de woorden 'have regard to' of in het Frans 'tenir compte' geen juridische betekenis, zij waren te rekbaar en hadden geen positieve bedoeling. Teitgen illustreerde zijn stellingname met de volgende uitspraak:

'Les régimes totalitaires qui pendent leur adversaires, tiennent compte au bout d"une corde, de leur droit à la vie."111

In plaats van de term 'to have regard to' of 'tenir compte' stelde Teitgen dan ook voor de uitdrukking 'to respect' te gebruiken die naar zijn mening een duidelijke verplichting voor de staat inhield ${ }^{112}$. Ook in de Raadgevende Vergadering bleef deze kwestie evenwel een discussiepunt vormen. Het was in het bijzonder de Britse afgevaardigde Renton die in deze zaak van zich deed spreken. Hij was het eens met Teitgen dat de term 'to have regard to' feitelijk geen verplichting aan de staat oplegde. ${ }^{113}$

Ten aanzien van de voorgestelde uitdrukking 'to respect' gaf hij toe dat deze voor de staat een sterkere verplichting betekende dan de woorden 'to have regard to'. Toch was hij van mening dat de verplichting 'to respect" niet meer inhield dan het aannemen van een welwillende houding. Hij voegde hieraan toe:

'It certainly does not compel the State to do anything positive. At the most it seems to me, it creates an obligation upon the State -which in circumstances is likely to turn out to be a moral one- not to do anything which might conflict with the parent's right to ensure that their children's education and teaching conform with their own religious and philosophical convictions."

Zijn conclusie was dat de door de Raadgevende Vergadering voorgestelde term 'to respect' weliswaar niet zonder betekenis was, maar wel 'unworkable' en tot grote verwarring aanleiding zou geven. ${ }^{115}$ In de Raadgeven-

110. Travaux Prép., vol. VIII, p. 87, Rapporteur Teitigen ( 8 dec. 1951). Zie ook Robertson, a.w. p. 363 .

111. Idem. p. 89.

112. Ibid.

113. Mr. Renton, 8 dec. 1951, Travaux Prép., vol. VIII, p. 106.

114. Idem, p. 108.

115. Idem, p. 110. 
de Vergadering bestond bij de grote meerderheid van de afgevaardigden echter de overtuiging dat in het kader van het EVRM met werkelijk afdwingbare rechten het de voorkeur verdiende de term 'to respect' te gebruiken. Deze opvatting werd in de Raadgevende Vergadering als volgt verwoord:

'Le mot "respecter", notamment dans le langage du droit international, a un sens très précis. Il y a là une obligation positive qui est mise à la charge de l'Etat, obligation qui par conséquent serait éventuellement sanctionnée par la cour européenne de justice si elle venait à être méconnue., ${ }^{116}$

Uiteindelijk hield de Raadgevende Vergadering vast aan de term 'to respect'; het werd duidelijk gemaakt aan het Comité van Ministers dat dit voor de Raadgevende Vergadering een essentieel punt vormde. In het definitieve Protocol werd deze wens inderdaad gehonoreerd.

Een andere kwestie waarin sprake was van verschil van inzicht tussen de Raadgevende Vergadering enerzijds en het Comité van Ministers anderzijds betrof de beperking van het ontwerp van het Comité tot de 'education' van kinderen. Het 'Committee on Legal and Administrative Questions' bepleitte daarentegen de verwijzing naar 'education and teaching'117 (in het Nederlands 'opvoeding en onderwijs').

Naar de mening van rapporteur Teitgen was het onvoldoende om in een belangrijke onderwijsbepaling de rechten van ouders te beperken tot de opvoeding. ${ }^{118}$ Dit punt wordt vooral duidelijk in de Franse versie van de bepaling. De beperking tot 'éducation' in de Franse tekst en het schrappen van de term 'enseignement' zou betekenen dat de rechten van ouders slechts betrekking zouden hebben op de morele en spirituele opvoeding van de kinderen. De rechten van de ouders zouden niet van toepassing zijn op de intellectuele opvoeding of het onderwijs in de school. ${ }^{119}$ Uiteindelijk besloot het Comité van Ministers zich bij het standpunt van de Raadgevende Vergadering neer te leggen. De rechten van de ouders dienen dus door de staat gerespecteerd te worden aangaande opvoeding en onderwijs van hun kinderen, zowel binnen als buiten schoolverband.

In een poging tegemoet te komen aan de verschillende vormen van kritiek op de ontwerp-onderwijsbepaling van het Comité van Ministers formu-

116. Mr. Pernot (Frankrijk), 8 dec. 1951, Travaux Prép, vol. VIII, p. 135. Zie in dezelfde zin de Italiaanse afgewaardigde Boggiano Pico, pp. 139, 141.

Zie ook Errera, a.w. p. 584,

117. Travaux Prép., vol. VIII, p. 70, 72 (4 dec. 1951).

118. Trawaux Prép., vol. VIII, p. 89 (8 dec. 1951).

119. Robertion, a.w. p. 363. 
leerde dit orgaan in november 1951 een herziene versie. ${ }^{120}$ Deze luidde als volgt:

"No person shall be denied the right to education. In the exercise of any functions which it may assume in relation to education and to teaching, the State shall have regard to the right of parents to ensure the religious education of their children in conformity with their own creeds and, where schools have been established by the State, to send their children to any other school of their choice, provided that such school conforms with the requirements of the law.'

Deze formulering behelsde de mogelijkheid van privé-onderwijs, dat wil zeggen onderwijs in andere dan overheidsscholen ('independent schools', 'enseignement libre'). Deze wijziging in de onderwijsbepaling erkende expliciet het recht op onderwijs in niet-openbare, met name confessionele, scholen. Het betekende evenwel geen verplichting voor de staat deze scholen ook financieel of anderszins te ondersteunen. ${ }^{121}$ Deze tekst werd in de Raadgevende Vergadering met scepsis ontvangen. Volgens Rapporteur Teitgen werd het voorstel van het Comité van Ministers gekenmerkt door vaagheidl en riep het allerlei vragen en twijfels op. ${ }^{122}$ Zo vroeg Teitgen zich onder meer af of de rechten van ouders slechts dan gewaarborgd waren indien een staat naast openbare scholen ook privé-onderwijs kende. Onduidelijk was ook of ouders konden verzoeken om de oprichting van niet-openbare scholen indien er geen bestonden. ${ }^{123}$ Teitgen adviseerde dan ook tot verwerping van het amendement van het Comité van Ministers, en vast te houden aan de oorspronkelijke ontwerpbepaling van de Raadgevende Vergadering. ${ }^{124}$ Het Comité van Ministers besloot uiteindelijk gehoor te geven aan de wensen van de Raadgevende Vergadering. ${ }^{125}$ Zoals gezegd betekende dit wel dat een aantal staten een voorbehoud maakte bij artikel 2. Met betrekking tot de kwestie van vormen van privé-onderwijs legde de Ierse Minister van Buitenlandse Zaken een verklaring af bij ondertekening van het Protocol. Deze verklaring luidde als volgt:

'In the view of the Irish Government, Article 2 of the Protocol is not sufficiently explicit in ensuring to parents the right to provide education for their children in their homes or in schools of the parents' own

120. Travaux Prép., vol. VIII, p. 50 (28 nov. 1951).

Zie ook Robertion, a.w. p. 363.

121. Zle Travaux Prép., vol. VII, pp. 190-194, Memorandum (not dated) by Mr. Robertson, member of the Secretariat; on Article 2 of the draft Protocol (unreferenced document), 'The right to education and the question of denominational schools.'

122. Travaux Prép., vol. VIII, p. 91 (8 dec. 1951). Zie ook Errera, a.w. p. 584.

123. Travaux Prép., vol. VIII, p. 91 (8 dec. 1951). Zie ook Errera, a.w. p. 584.

124. Idem, $p_{*} 95$.

125. Zie Robertion, a.w. p. 364 . 
choice, whether or not such schools are private schools or are schools recognised or established by the State. ${ }^{126}$

Uit deze verklaring blijkt dat de tekst van artikel 2 de Ierse regering niet ver genoeg ging aangaande de rechten van de ouders eigen onderwijsvormen in te richten. De Ieren wilden de ouders hierbij een grote mate van vrijheid laten, mits de leerplicht gegarandeerd bleef. Zelfs thuisonderwijs behoorde volgens de Ierse regering tot de mogelijkheden.

Op 8 december 1951 aanvaardde de Raadgevende Vergadering met 75 stemmen vóor, nul tegen, bij 23 onthoudingen ${ }^{127}$ een aanbeveling aan het $\mathrm{Co}-$ mitê van Ministers met de volgende ontwerptekst voor de onderwijsbepaling van artikel 2 ten behoeve van het Protocol:

'No person shall be denied the right to education. In the exercise of any functions which it assumes in relation to education and to teaching the State shall respect the right of parents to ensure such education and teaching in conformity with their own religious, and philosophical convictions.'

Op 19 maart 1952 stemde het Comité van Ministers in met de door de Raadgevende Vergadering voorgestelde tekst voor artikel 2, zij het met de aantekening van een aantal voorbehouden en verklaringen van staten. ${ }^{128}$

Samenvattend kan men zeggen dat de verschillen van opvatting binnen en tussen de organen die betrokken waren bij de totstandkoming van artikel 2 van invloed zijn geweest op de uiteindelijke formulering van de bepaling. Ten opzichte van de Raadgevende Vergadlering namen de vertegenwoordigers van regeringen een terughoudend standpunt in. Tijdens de totstandkoming stonden de rechten van de ouders als waarborg tegen indoctrinaire invloeden van de staat centraal. De discussie spitste zich vooral toe op de reikwijdte van de rechten van de ouders en de daaruit voortvloeiende verplichtingen van de staat. Dat bleek onder meer uit de verschillen van opvatting over een verwijzing naar de termen 'to respect' en naar 'filosofische overtuigingen' in de ontwerptekst, alsmede de kwestie van de privéonderwijsinstellingen. Met betrekking tot het sociale aspect kan worden gezegd dat de opstellers van artikel 2 geen positieve verplichtingen voor staten beoogden om door middel van financiële maatregelen onderwijs aan

126. Travaux Prép

127. Travaux Prép., wol. VIII, p. 168 (8 dec. 1951).

128. De volgende staten hebben een voorbehoud gemaakt of een verklaring afgelegd met betrekking tot artikel 2: Bondsrepubliek Duitsland, Griekenland, lerland, Malta, Nederland, Zweden, Turkije, Verenigd Koninkrijk, Portugal. Zie voor een overzicht, Council of Europe, European Convention on Human Rights, Collected Texts, Dordrecht 1987 , pp. 85-90. Portugal trok in mei 1987 een gedeelte van het voorbehoud bij artikel 2 in. Zie hierover Council of Europe, Information Sheet no. 21 (nov. 1986-okt. 1987), Strasbourg 1988 , pp. 12, 13. 
te bieden of onderwijsinstellingen te ondersteunen. De negatief geformuleerde eerste zin van artikel 2 geeft uiting aan deze opvatting.

De lange ontstaansgeschiedenis van artikel 2, de complexiteit van dat proces en het relatief grote aantal voorbehouden en verklaringen bij deze bepaling hebben bijgedragen aan de onduidelijkheid betreffende de reikwijdte en het juridisch karakter en betekenis van het onderwijs-artikel ${ }^{129}$. Pas eind jaren zestig zou het Europese Hof voor de Rechten van de Mens in zijn jurisprudentie enig licht werpen op een aantal van de problemen. ${ }^{130}$

Tenslotte moet hier worden verwezen naar de vertaling van artikel 2 in het Nederlands. De oorspronkelijke vertaling luidde als volgt: ${ }^{131}$

Niemand zall het recht op onderwijs worden ontzegd. Bij de uitoefening van alle functies welke de Staat in verband met de opvoeding en het onderwijs op zich neemt, zal de staat het recht eerbiedigen van de oudlers om (voor hun kinderen) zich van die opvoeding en van dat onderwijs te verzekeren, welke overeenstemmen met hun eigen godsdienstige en philisophische overtuigingen.

In 1990 werd de vertaling van het gehele EVRM en de bijbehorende protocollen herzien door de Ministeries van Buitenlandse Zaken en van Justitie. De herziene tekst van artikel 2 luidt nu aldus: ${ }^{132}$

Niemand mag het recht op onderwijs worden ontzegd. Bij de uitoefening van alle functies die de Staat in verband met de opvoeding en het onderwijs op zich neemt, eerbiedigt de Staat het recht van ouders om zich van die opvoeding en van dat onderwijs te verzekeren, die overeenstemmen met hun eigen godsdienstige en filosofische overtuigingen.

De belangrijkste wijziging is naar mijn mening dat het woordje 'zal' dat tweemaal in de oorspronkelijke vertaling voorkomt is vervangen. De eerste volzin van artikel 2 in de herziene tekst bepaalt nu dat niemand het recht op onderwijs mag worden ontzegd. De tweede volzin bepaalt voorts dat de staat het recht van de ouders eerbiedigt (in plaats van zal eerbiedigen). De nieuwe vertaling is op beide punten gebiedender dan de aude, en volgt meer de Engelse dan de Franse authentieke tekst.

129. Zie Wildhaber, a.w. p. 148, Opsahl, a.w. p. 221, Partsch, a.w. p. 237.

130. Zie de behandeling van de jurisprudentie in hoofdstuk 4 .

131. Trb 1952, 80.

132. Trb. $1990,157$. 


\subsection{Het UNESCO Verdrag tot Bestrijding van Discriminatie in het Onderwijs}

\subsubsection{Voorgeschiedenis}

Het Verdrag tot Bestrijding van Discriminatie in het Onderwijs werd gesloten op 15 december 1960 door de vertegenwoordigers van de deelnemende staten aan de elfde zitting van de Algemene Conferentie van de UNESCO.$^{133}$ De eerste aanzet tot deze internationale overeenkomst vormde een studie ondernomen in opdracht van de Sub-Commissie inzake Voorkoming van Discriminatie en Bescherming van Minderheden van de Verenigde Naties. Deze studie had de discriminatie in het onderwijs tot onderwerp. Als Speciale Rapporteur voor dit onderzoek werd de Libanees Charles D. Ammoun benoemd. Het onderzoek diende verricht te worden

"on a global basis and with respect to all the grounds of discrimination condemned by the Universal Declaration of Human Rights, but special attention should be given to instances of discrimination that are typical of general tendencies and instances where discrimination has been successfully overcome. ${ }^{134}$

In 1957 verscheen het resultaat van het onderzoek van Ammoun, getiteld 'Study of Discrimination in Education'. ${ }^{135}$ In zijn rapport formuleerde Ammoun een aantal basisbeginselen welke ten grondslag zouden moeten liggen aan de uitbanning van discriminatie in het onderwijs. Deze beginselen vormen de basis voor de door de staten te nemen maatregelen. Ze luiden als volgt: discriminatie op grond van ras, huidskleur, geslacht, taal, godsdienst, politieke overtuiging of andere status ten aanzien van de toegang tot het onderwijs en het feitelijk volgen van het onderwijs is verboden. Dit geldt zowel voor de wetgeving, het beleid als de praktijk. Voorts dient de vrije keuze van onderwijs, ook wat betreft het godsdienstonderwijs gewaarborgd te zijn. ${ }^{136}$ Ammoun stelde voor een internationale conventie op te stellen waarin bovengenoemde beginselen opgenomen zouden moeten worden. Een aparte overeenkomst aangaande de uitbanning van discriminatie in het onderwijs zou gedetailleerd geformuleerd kunnen worden en de verplichtingen van staten op nauwkeurige wijze kunnen vastleggen. Dit zou een voordeel zijn ten opzichte van de in algemene bewoordin-

133. De Engelse en Franse tekst en de Nederlandse vertaling zijn te vinden in Trb. 1964, nr. 69.

134. Sub-Commission on the Prevention of Discrimination and the Protection of Minorities, Resolution B (VI), 1954 (Resolution on a Study of Discrimination in Education).

135. UN Doc. E/CN.4/Sub.2/181/Rev.1, UN Sales no. 1957 XIV.3.

Dit rapport was het eerste uit en serie studies over discriminatie op verschillende terreinen, welke studies werden geäntameerd door de Sub-Commisise.

136. Ammoun (1957, XIV.3). Pp. 158, 159, 
gen gestelde bepalingen uit de VN ontwerp-mensenrechtenverdragen, die op het einde van de jaren vijftig hun voltooiing naderden. Met name zou een afzonderlijke conventie regeringen de mogelijkheid bieden hun vastberadenheid te tonen aangaande de uitbanning van discriminatie in het onderwijs, terwijl zij wellicht nog niet in staat waren de algemene mensenrechtenverdragen te aanvaarden met hun grote verscheidenheid aan bepalingen. ${ }^{137}$

Tijdens haar negende zitting in 1957 verzocht de Sub-Commissie aan UNESCO de mogelijkheid te bestuderen een internationaal instrument op te stellen met als onderwerp de bestrijding van discriminatie in het onderwijs. Daarbij zouden de beginselen zoals die door Ammoun waren geformuleerd de leidraad moeten vormen. ${ }^{138}$ De Algemene Conferentie van UNESCO besloot tijdens haar tiende zitting in 1958 het ontwerpen van een internationale overeenkomst en van aanbevelingen aangaande de uitbanning van discriminatie in het onderwijs ter hand te nemen. ${ }^{139}$ Aan de hand van een 'questionnaire' verzamelde de Directeur-Generaal van UNESCO opinies van regeringen en niet-gouvernementele organisaties betreffende de normen die ten grondslag zouden moeten liggen aan een ontwerp-conventie. Deze commentaren werden door de Directeur-Generaal verwerkt tot een ontwerptekst die de basis vormde voor de beraadslagingen van een 'Bijzonder Comité van Regeringsdeskundigen' dat in juni 1960 verder sleutelde aan een ontwerpverdrag. De ontwerptekst zoals die was opgesteld door het Comité van Regeringsdeskundigen werd tijdens de elfde zitting van de Algemene Conferentie van UNESCO op een aantal punten geamendeerd door een werkgroep bestaande uit de vertegenwoordigers van een aantal lidstaten. De Conventie werd tenslotte op 14 december 1960 door de Algemene Conferentie van UNESCO aanvaard. ${ }^{140}$

\subsubsection{De totstandkoming en inhoud van de Conventie}

De Conventie beoogt een bijdrage te leveren aan de bestrijding en het voorkomen van discriminatie en het verwezenlijken van gelijke kansen in het onderwijs. De preambule van het Verdrag spreekt van:

137. Idem, pp. $154_{1} 155$.

138. Resolution B (IX), 1957.

199. Zie H. Saba, La Convention et la Recommendation concernant la lutte contre la discrimination dans le domaine de l'enseignement, in: Annuaire Français de Droit International, 1960, pp. 646-652, p. 647; en P. Mertens, L'application de la convention t de la Recommendation de I"UNESCO concernant la lutte contre la discrimination dani le domaine de l'enseignement: un bilan provisoire, in: Revue des Droits de l'Homme, Tome 1 (1968), pp. 91-108, pp. 92, 93.

Een analyse van de Conventie wordt ook gegeven door W. McKean, Equality and Diecrimination under International Law, Oxford 1983, pp. 128-135.

140. Zie $P$. Juwigny, The fight against discrimination, towards equality in education, UNESCO, Paris 1963, pp. 13, 14. 
"to proscribe any form of discrimination in education (but) also to promote equality of opportunity and treatment for all in education."

De ratio van het Verdrag is door Juvigny, destijds Rapporteur bij de totstandkoming, als volgt omschreven:

'In the first place, the Convention and the Recommendation translate into legal criteria conceptions shared by the members of the international community; for some these conceptions represent a minimum, long since acknowledged, and embodied in law and in practice in their national life; for others, they represent an ideal to be attained, or one to which they subscribe with varying degrees of enthusiasm or conviction. Then, once they have been adopted, these instruments become factors in a forward movement. They open up a new era in which ideals may become realities. They also set an international barrier against attempts at - or temptations to - backsliding. ${ }^{141}$

Een juridisch instrument dat in het kader van UNESCO is gesloten beoogt een universele reikwijdte te hebben. Toch is de Conventie natuurlijk van toepassing op een van staat tot staat verschillende onderwijssituatie. Volgens Juvigny is deze verscheidenheid 'the token and the condition of (its) universality'.142

Deze nationale verscheidenheid op onderwijsgebied is ook erkend in de preambule van de Conventie. De preambule spreekt van 'respecting the diversity of national educational systems'. Deze passage werd op initiatief van Mexico opgenomen om recht te doen aan 'the essential characteristics of educational systems adopted by States, taking into consideration the great diversity of guiding principles accepted by UNESCO' ${ }^{143}$ Deze verscheidenheid van nationale onderwijsstelsels mocht niet worden geïnterpreteerd als het bestaan van een discriminatoire situatie. Bovendien werd de diversiteit van cultuur en opvoedingssystemen van de afzonderlijke staten erkend in de Constitutie van de UNESCO. ${ }^{144}$ Hieronder zal worden ingegaan op de totstandkoming, de betekenis en de reikwijdte van de belangrijkste bepalingen uit de Conventie.

Zoals hierboven reeds is aangegeven beoogt de Conventie enerzijds iedere vorm van discriminatie in het onderwijs te bestrijden en anderzijds gelijke kansen en een gelijke behandeling voor een ieder te bevorderen. Dit tweeledige doel vindt zijn oorsprong in de opdracht van de Sub-Commissie aan

141. Juvigny, a.w. 10. Gelijktijdig met de Conventie kwam een Aanbevelling van gelijke inhoud tot stand. Zie hierover de opmerkingen verderop in deze paragraaf.

142. Idem, p. 15 .

143. UN Doc. E/CN.4/Sub.2/210 Annex III, par. 8 (5 januari 1961), Report of the Working Party on the Draft Convention and Recommendation against Discrimination in Education.

144. Artikel I (3). 
Rapporteur Ammoun bij de aanvang van zijn studie naar discriminatie in het onderwijs. De studie zou moeten aangeven welke factoren 'in each instance have led to the discriminatory practices, pointing out those which are economic, social, political or historic in character and those resulting from a policy evidently intended to originate, maintain or aggravate such practices', ${ }^{145}$ Ammoun spreekt in dit verband respectievelijk van 'static discrimination' en van 'active discrimination' ${ }^{146}$ Het verschil tussen beide vormen is dat er bij 'active discrimination' sprake is van een opzettelijke intentie en handelen van de overheid, terwijl dit bij 'static discrimination' niet het geval is. ${ }^{147}$ Naar de mening van Ammoun komt 'static discrimination" in de huidige tijd veel meer voor dan 'active discrimination'. "Static discrimination' is veelal het gevolg van het onvermogen van de staat om op te treden of van een gebrek aan financiêle en andere middelen, dan wel te wijten aan maatschappelijke of geografische factoren. ${ }^{148}$ Dit onderscheid heeft ten grondslag gelegen aan de formulering van de verschillende bepalingen uit de Conventie en is van invloed geweest op de aard en de reikwijdte van de verdragsverplichtingen.

Artikel 1 van de Conventie luidt als volgt:

1. For the purpose of this Convention, the term 'discrimination' includes any distinction, exclusion, limitation or preference which, being based on race, colour, sex, language, religion, political or other opinion, national or social origin, economic condition or birth, has the purpose or effect of nullifying or impairing equality of treatment in education and in particular:

a. of depriving any person or group of persons of access to education of any type or at any level;

b. of limiting any person or group of persons to education of an inferior standard;

c. subject to the provisions of Article 2 of this Convention, of establishing or maintaining separate educational systems or institutions for persons or groups of persons; or

d. of inflicting on any person or group of persons conditions which are incompatible with the dignity of man.

2. For the purpose of this Convention, the term 'education' refers to all types and levels of education, and includes access to education, the standard and quality of education, and the conditions under which it is given.

145. Sub-Commission on the Prevention of Discrimination and the Protection of Minorities, Resolution B (VI), 1954 (Resolution on a Study of Discrimination in Education).

146. Ammoun, a. p.4.

147. Idem, p. 5.

Zie ook Juvigny, a.w. p. 18 en 20 ; en Saba, a.w. p. 648.

148. Ammoun, a.w. p. 5. 
Deze bepaling geeft een ruime definitie van discriminatie, meer in het bijzonder van de 'active discrimination'. Volgens deze bepaling is er sprake van discriminatie indien het een onderscheid betreft, dat tot doel of tot gevolg heeft de gelijkheid van behandeling in het onderwijs teniet te doen of aan te tasten. De tekst van artikel 1 is gebaseerd op ILO Conventie no. 111 'Concerning Discrimination in respect of Employment and Occupation' (1958) die in artikel 1 vrijwel gelijkluidende termen bevat voor het discriminatie-begrip. Later hebben beide bepalingen model gestaan voor artikel 1 van het Verdrag inzake de Uitbanning van alle Vormen van Rassendiscriminatie (1965). De discriminatie-gronden genoemd in artikel 1 UNESCO Verdrag vinden hun oorsprong in artikel 2 van de Universele Verklaring. In vergelijking met deze laatste bepaling ontbreekt in artikel 1 UNESCO Verdrag de discriminatiefactor 'of andere status' ('or other status'). Sommige leden van het Comité van regeringsdeskundigen dat belast was met het opstellen van de Conventie meenden dat de term 'or other status' betrekking had op feitelijke ongelijkheden welke slechts geleidelijk uitgebannen konden worden. Bovendien was de meerderheid in het Comite van mening dat de bepaling te algemeen was en zou kunnen leiden tot interpretatieverschillen en daarom moeilijk opgenomen kon worden in een Conventie waarin ondubbelzinnige formuleringen vereist waren. ${ }^{149}$ Aan de algemene formulering van het eerste gedeelte van lid 1 werd een niet-uitputtende verwijzing toegevoegd naar vier vormen van discriminatie die in het bijzonder relevant zijn voor wat betreft het onderwijs. ${ }^{150}$ Artikel 1 lid 2 geeft een algemene en ruime definitie van de term 'onderwijs'.

Artikel 2 noemt een drietal situaties welke niet als discriminatie in de zin van artikel 1 worden beschouwd. De tekst van artikel 2 is als volgt:

When permitted in a State, the following situations shall not be deemed to constitute discrimination, within the meaning of Article 1 of this Convention:

a. The establishment or maintenance of separate educational systems or institutions for pupills of the two sexes, if these systems or institutions offer equivalent access to education, provide a teaching staff with qualifications of the same standard as well as school premises and equipment of the same quality, and afford the opportunity to take the same or equivalent courses of study;

b. The establishment or maintenance, for religious or linguistic reasons, of separate educational systems or institutions offering an education which is in keeping with the wishes of the pupil's parents or legal guardians, if participation in such systems or attendance at such institutions is optional and if the education provided conforms to

149. UN Doc. E/CN.4/Sub.2/210, Annex II, par. 27, Report of the Special Committee of Governmental Experts on the Preparation of a Draft International Convention and a Draft Recommendation on the Various Aspects of Discrimination in Education. Zie ook Saba, a.w. p. 649 .

150. Saba, a.w. p. 649 . 
such standards as may be laid down or approved by the competent authorities, in particular for education of the same level;

c. the establishment or maintenance of private educational institutions, if the object of the institutions is not to secure the exclusion of any group but to provide educational facilities in addition to those provided by the public authorities, if the institutions are conducted in accordance with that object, and if the education provided conforms with such standards as may be laid down or approved by the competent authorities, in particular for education of the same level.

De openingszin van deze bepaling werd pas in een laat stadium van de totstandkoming van het Verdrag toegevoegd. In het bijzonder betrof het de formulering 'when permitted in a State'. Dit is een beperkende clausule die tegemoet kwam aan de constitutionele situatie in bepaalde landen (bijvoorbeeld Mexico) waar sprake is van een scheiding van kerk en staat en het onderwijs neutraal van aard is. De formulering biedt ruimte aan staten de stichting van onderwijsinstellingen georganiseerd op grond van godsdienst of taal niet toe te staan. ${ }^{151}$ De juridische betekenis van de clausule 'when permitted in a State' kan evenwell worden betwist.

Volgens artikel 13 van het Internationaal Verdrag inzake Economische, Sociale en Culturele Rechten (in 1960 nog artikel 14 van het ontwerpverdrag), is het aan individuen en organisaties zonder meer toegestaan eigen onderwijsvormen te stichten en in te richten indien aan een aantal door de staat vastgestelde minimumnormen is voldaan. Het gaat hier om het algemeen aanvaarde beginsel van de vrijheid van onderwijs zoals dat voortvloeit uit artikel 26(3) Universele Verklaring. Voor wat betreft de punten $b$ en c van artikel 2 is er dan ook geen sprake van discriminatie, maar van een gerechtvaardigd onderscheid ('distinction'). Daarnaast kan gewezen worden op artikel 5 UNESCO Verdrag waarin de vrije keuze van onderwijs en het recht van nationale minderheden op eigen onderwijsinstellingen zijn vastgelegd.

Artikel $2 \mathrm{a}$ bepaalt dat het oprichten of in stand houden van afzonderlijke onderwijssystemen of -instellingen voor leerlingen van het vrouwelijk en mannelijk geslacht niet als discriminatie wordt beschouwd, indien aan een aantal strikte voorwaarden is voldaan. Deze voorwaarden werden mede op aandrang van de 'Commission on the Status of Women' geformuleerd. ${ }^{152}$

Voor een land als Nederland doet het wellicht wat vreemd aan dat in een internationale conventie uitdrukkelijk de scheiding van jongens en meis jes in aparte scholen is toegestaan. Uit de 'travaux préparatoires' blijkt dat vooral de werkgroep uit de Algemene Conferentie van UNESCO zich heeft ingespannen om voor vrouwen dezelfde of gelijkwaardige studieprogramma's te garanderen. ${ }^{153}$ Rapporteur Juvigny rechtvaardigde deze afzonderlijke onderwijssystemen en -instellingen met de opmerking dat:

151. UN Doc. E/CN.4/Sub.2/210, Annex III, par. 9.

152. UN Doc. E/CN.4/Sub.2/210, Annex II, par. 38, en MeKean, a.w. p. 134.

153. Idem, Annex III, par. 10. 
"the "separation" of schools for pupils of the two sexes is still too widespread in practice for the Convention to be able to affirm that, at the international level, it amounted to a proscribed form of discrimination. 154

Het gevaar bestaat evenwel dat deze bepaling een excuus zal vormen voor staten om geen actief beleid te voeren gericht op integratie van jongens en meisjes in schoolverband. Artikel 2a kan mijn inziens leiden tot instandhouding van gescheiden stelsels zonder dat een gelijke kwaliteit van het onderwijs verzekerd is. In een aantal landen, niet alleen ontwikkelingslanden, heeft het onderwijs aan jongens een hogere prioriteit dan dat aan meisjes. Een stelsel van gescheiden scholen kan betekenen dat de achterstelling van meisjes in het onderwijs op dit punt blijft bestaan.

Wat betreft de artikelen $2 \mathrm{~b}$ en $2 \mathrm{c}$ kan gesteld worden dat zij gedeeltelijk dezelfde materie regelen. Naast de oprichting van af zonderlijke onderwijsinstellingen vanwege godsdienstige of taalkundige redenen door particulieren, heeft artikel $2 \mathrm{~b}$ impliciet ook betrekking op onderwijs ingericht en verzorgd door de staat. ${ }^{155}$ Artikel $2 c$ bepaalt daarnaast de klassieke vrijheid van onderwijs en biedt de mogelijkheid van de oprichting van particuliere vormen van onderwijs, naast die door de overheid worden verzorgd.

De vraag of speciale overheidsmaatregelen genomen door de staat ten gunste van bepaalde groepen in de samenleving die in een achterstandsituatie verkeren een vorm van discriminatie vormen volgens de bepalingen van de Conventie moet ontkennend worden beantwoord. Dat blijkt uit de 'travaux préparatoires'. De Conventie bepaalt niets over dit soort positieve maatregelen. Volgens artikel 1 echter vormt ieder onderscheid of voorkeur die tot doel of tot gevolg hebben dat de gelijkheid van behandeling ten aanzien van het onderwijs te niet wordt gedaan of wordt aangetast een vorm van discriminatie. Dat is bij positieve maatregelen ten gunste van bijvoorbeeld gehandicapten, analfabeten, en immigranten geenszins het geval. $\mathrm{Zij}$ proberen juist het tegenovergestelde te bewerkstelligen. Er is geen sprake van een ongerechtvaardigde voorkeur. ${ }^{156}$ Deze bijzondere overheidsmaatregelen vinden evenwel geen uitdrukkelijke bescherming in de Conventie; artikel 2 sub $\mathrm{c}$ heeft immers betrekking op vormen van privé-onderwijs. Het is een tekortkoming dat de Conventie zélf op dit punt geen duidelijkheid verschaft. ${ }^{157}$

Eên van de sleutelbepalingen uit de Conventie is artikel 3. Deze bepaling legt aan partijstaten een aantal verplichtingen op met de bedoeling discriminatie in het onderwijs uit te bannen en te voorkomen. De tekst van het artikel is als volgt:

154. Juvigny, a.w. p. 18.

15.5. Zie in dit verband, Annex II, par. 40.

156. Annex III, par. 13.

157. MeKean, a.w. p. 135. 
In order to eliminate and prevent discrimination within the meaning of this Convention, the States Parties thereto undertake:

a. To abrogate any statutory provisions and any administrative instructions and to discontinue any administrative practices which involve discrimination in education;

b. To ensure, by legislation where necessary, that there is no discrimination in the admission of pupils to educational institutions;

c. Not to allow any differences of treatment by the public authorities between nationals, except on the basis of merit or need, in the matter of school fees and the grant of scholarships or other forms of assistance to pupils and necessary permits and facilities for the pursuit of studies in foreign countries;

d. Not to allow, in any form of assistance granted by the public authorities to educational institutions, any restrictions or preference based solely on the ground that pupils belong to a particular group;

e. To give foreign nationals resident within their territory the same access to education as that given to their own nationals.

Het betreft hier nauwkeurig geformuleerde verplichtingen die een onmiddellijke toepassing vereisen. ${ }^{158} \mathrm{Zij}$ kunnen aangemerkt worden als 'obligations of conduct'. Het doel van deze bepaling is staten te verplichten om ook daadwerkelijk, dat wil zeggen feitelijk, de vereiste maatregelen uit te voeren. Tot die maatregelen behoort het uitvaardigen van wettelijke voorschriften. Eén van de discussiepunten bij het opstellen van deze bepaling was de vraag of staten erop zouden moeten toezien dat particuliere onderwijsinstellingen zich aan de non-discriminatie bepalingen hielden. Een aantal staten was van mening dat dit niet van de overheid verlangd kon worden. Andere staten meenden evenwel dat bestrijding van discriminatie in het onderwijs alleen dan effectief zou kunnen zijn indien ook bijzondere onderwijsinstellingen onderworpen zouden worden aan de bepaling van het Verdrag. ${ }^{159}$ Dit impliceerde dan wel een zekere vorm van toezicht dan well bemoeienis van de zijde van de overheid. Artikel $3 \mathrm{~b}$ bepaalt dan ook dat staten ervoor dienen te zorgen, zonodig door wettelijke voorschriften, dat er geen discriminatie bestaat bij de toelating van leerlingen tot onderwijsinstellingen. Daarbij is het onduidelijk of het toezicht door de staat zich ook uitstrekt tot particuliere onderwijsinstellingen, of slechts beperkt is tot het openbaar onderwijs. De 'travaux préparatoires' geven hierover geen uitsluitsel.

Artikel 3e garandeert aan buitenlandse onderdanen die wonen in een van de partijstaten dezelfde toegang tot het onderwijs als de eigen onderdanen van die staat. Deze bepaling betreft alleen de toegang tot het onderwijs. Artikel $3 \mathrm{c}$ daarentegen heeft alleen betrekking op onderdanen van de partijstaat en biedt de mogelijkheid van overheidsfaciliteiten voor leerlingen met de nationaliteit van de desbetreffende staat. De achterliggende

158. Annex II, par. 41; Saba, a.w. p. 650.

159. Annex II, par. 44. 
gedachte hierbij was dat het niet realistisch zou zijn indien staten geen onderscheid zouden mogen maken tussen onderdanen en niet-onderdanen wat betreft het verlenen yan financiële en andere faciliteiten aan leerlingen. Deze aanspraken op overheidssteun in de een of andere vorm dienden voorbehouden te blijven aan de eigen onderdanen. ${ }^{160}$ Dit betekent dat het Nederlandse (in de wet neergelegde) beleid om kinderen van buitenlandse ouders (niet-EG-onderdanen), die in Nederland woonachtig zijn, pas na 3 jaren studiefinanciering toe te kennen volgens de bepalingen van dit Verdrag geoorloofd is. ${ }^{161}$

Artikell 3 sub d bepaalt dat het de staat verboden is ten aanzien van eventuele steun aan onderwijsinstellingen beperkingen of voorkeur toe te staan uitsluitend gebaseerd op het feit dat de leerlingen tot een bepaalde groep behoren. Volgens de ontstaansgeschiedenis staat artikel 3 sub d niet in de weg dat staten positieve maatregelen nemen ten behoeve van maatschappelijke groepen die in een achterstandpositie verkeren. Daarbij werd o.a. gedacht aan kinderen met een onderwijsachterstand en immigranten. De term 'particular group' in artikel 3 sub d moet worden geïnterpreteerd in het licht van de artikelen 1 en $2{ }^{162}$ Toch is naar mijn mening de betekenis van artikel 3 sub d niet duidelijk. De tekst van deze bepaling suggereert dat (financiële) positieve maatregelen ten gunste van bijvoorbeeld leden van etnische minderheden niet zijn toegestaan. De vraag is dan hoe deze bepaling zich verhoudt tot artikel 2 lid 2 van het Internationaal Verdrag inzake de Uitbanning van alle Vormen van Rassendiscriminatie waarin positieve maatregelen ten gunste van leden van bepaalde rasgemeenschap verplicht worden gesteld. Wellicht biedt artikel 10 van het UNESCO Verdrag hier een uitweg. Deze bepaling zegt dat het UNESCO Verdrag niet tot gevolg mag hebben dat de rechten die personen of groepen personen eventueel genieten krachtens andere internationale overeenkomsten worden aangetast, indien die rechten niet in strijd zijn met de letter of de geest van het UNESCO Verdrag.

De uitbanning van vormen van discriminatie op grond van ras in het onderwijs krachtens artikel 2 lid 2 jo. artikel 5 van het Verdrag inzake de Uitbanning van alle Vormen van Rassendiscriminatie is naar mijn oordeel niet in strijd met het UNESCO Verdrag. Sterker, de maatregelen dragen op positieve wijze bij an de verwezenlijking van de doelstellingen van het UNESCO Verdrag, te weten de bevordering van gelijke kansen en een gelijke behandeling in het onderwijs. Deze doelstellingen zijn uitgewerkt in artikel 4 waarvan de tekst als volgt luidt:

160. Deze verwijging naar eigen onderdanen in artikel ac werd op initiatief van Italid in

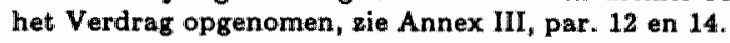

161. Vgl. artikel 7 Wet op de Studiefinanciering jo. artikel 3 Besluit Studiefinanciering (KB van 22 sept. 1986, Stb. 477). Met EG-onderdanen worden gelijk gesteld onderdanen van Joegoslavië, Marokko, Tunesië, Turkije en Zweden. Artikel 3 Besluit Studiefinanciering bevat enkele uitzonderingen.

162. Annex III, par. 13 . 
The States Parties to this Convention undertake furthermore to formulate, develop and apply a national policy which, by methods appropriate to the circumstances and to national usage, will tend to promote equality of opportunity and of treatment in the matter of education and in particular:

a. To make primary education free and compulsory; make secondary education in its different forms generally available and accessible to all; make higher education equally accessible to all on the basis of individual capacity; assure compliance by all with the obligation to attend school prescribed by law;

b. To ensure that the standards of education are equivalent in all public educational institutions of the same level, and that the conditions relating to the quality of the education provided are also equivalent;

c. To encourage and intensify by appropriate methods the education of persons who have not received any primary education or who have not completed the entire primary education course and the continuation of their education on the basis of individual capacity;

d. To provide training for the teaching profession without discrimination.

Deze bepaling draagt aan de staat de verplichting op een nationaal beleid te ontwikkelen. Het betreft een zorgplicht voor de overheid. Het gaat hierbij om de bestrijding van 'static discrimination'. In deze bepaling vindt men het sociale aspect van het recht op onderwijs terug; zij heeft het karakter van een geleidelijk te verwezenlijken verplichting. ${ }^{163}$ Dat wil zeggen dat de staat enige tijd wordt gegund de gestelde doeleinden te verwezenlijken. Dit is begrijpelijk omdat het realiseren van deze doeleinden het beschikbaar stellen van financiële, economische, technische en intellectuele middelen vereist. Bij het ontwikkelen en uitvoeren van dit beleid hebben staten de vrijheid die middelen en methoden te kiezen die afgestemd zijn op de specifieke nationale situatie. Men kan dan ook stellen dat artikel 4 'obligations of result' bevat.

Opvallend in dit artikel is dat de staten niet meteen verplicht worden de leerplicht in te voeren; de toegestane geleidelijke verwezenlijking van de leerplicht hebben de ontwerpers van het Verdrag bewust opgenomen in artikel 4. Oorspronkelijk was het de bedoeling deze verplichting een onmiddellijk karakter te geven en op te nemen in artikel 3, maar men vond het niet rechtvaardig staten die geen leerplicht hadden een ontsnappingsmogelijkheid te bieden. Indien een staat immers geen leerplicht kende kon er ook geen sprake zijn van de onmiddellijke verplichting de school te bezoeken 'prescribed by law". Vandaar de overheveling van deze clausule naar artikel 4 waarin het immers gaat om een verplichting tot geleidelijke verwezenlijking. ${ }^{164}$ 
Artikel 5 bevat een aantal beginselen welke gebaseerd werden op de relevante bepalingen uit de ontwerp-mensenrechtenverdragen van de Verenigde Naties die in 1960 hun voltooiing naderden. ${ }^{165}$ Artikel 5 luidt als volgt:

1. The States Parties to this Convention agree that:

a. Education shall be directed to the full development of the human personality and to the strengthening of respect for human rights and fundamental freedoms; it shall promote understanding, tolerance and friendship among all nations, racial or religious groups, and shall further the activities of the United Nations for the maintenance of peace;

b. It is essential to respect the liberty of parents and, where applicable, of legal guardians, firstly to choose for their children institutions other than those maintained by the public authorities but conforming to such minimum educational standards as may be laid down or approved by the competent authorities and, secondly, to ensure in a manner consistent with the procedures followed in the State for the application of its legislation, the religious and moral education of the children in conformity with their own convictions; and no person or group of persons should be compelled to receive religious instruction inconsistent with his or their convictions;

c. It is essential to recognize the right of members of national minorities to carry on their own educational activities, including the maintenance of schools and, depending on the educational policy of each State, the use or the teaching of their own language, provided however:

(i) That this right is not exercised in a manner which prevents the members of these minorities from understanding the culture and language of the community as a whole and from participating in its activities, or which prejudices national sovereignty;

(ii) That the standard of education is not lower than the general standard laid down or approved by the competent authorities; and

(iii) That attendance at such schools is optional.

2. The States Parties to this Convention undertake to take all necessary measures to ensure the application of the principles enunciated in paragraph 1 of this Article.

Lid 1 (a) omschrijft de doeleinden waarop het onderwijs gericht dient te zijn. Lid 1 (b) legt een aantal klassieke vrijheden vast, o.a. die van ouders welke door de staat geëerbiedigd moeten worden. Lid 1 (c) handelt over de rechten van minderheden. Lid 2 omschrijft de reikwijdte van de verplichting van de staat. Er is sprake van een sterkere verplichting dan de aanvankelijke tekst zoals die geformuleerd was in het ontwerp van de DirecteurGeneraal van UNESCO. Daarin was slechts sprake van het ten volle in aan- 
merking nemen van de beginselen van dit artikel bij de toepassing van de Conventie. . $^{166}$

Veel discussie bestond er over de uitdrukking 'religious and moral education' in lid 1 (b). Deze zinsnede werd mede op Nederlands initiatief in het Verdrag opgenomen. ${ }^{167}$ Het Comite van Regeringsdeskundigen dat in eerste instantie belast was met het opstellen van de verdragstekst was van mening dat de term 'religious and moral education does not relate to the education normally provided in schools, but merely to the religious and moral instruction which may be entirely or partly extra curricular'. ${ }^{168}$

Naar mijn mening is deze interpretatie niet juist. Het gaat hier mijns inziens om het veel bredere concept van godsdienstige en zedelijke opvoeding en onderwijs dat zich niet beperkt tot het gadsdienstonderwijs, maar ook betrekking heeft op godsdienstige en zedelijke aspecten die in andere vakken aan de orde komen. Artikel 5 lid 1 (b) spreekt van 'education' en dit omvat mede het onderwijs-aspect: ${ }^{169}$ Indien dit niet het geval zou zijn, zou de term niet thuis horen in een verdrag over onderwijskwesties.

De werkgroep uit de Algemene Conferentie van UNESCO die zich later met het ontwerpverdrag bezig hield was van mening dat 'religious and moral education' zowel binnen als buiten school kon plaatsvinden. Staten zouden echter op geen enkele wijze verplicht moeten worden godsdienstonderwijs in overheidsscholen aan te bieden. Daarvoor was de diversificatie tussen landen waarin godsdienstonderwijs in overheidsscholen wel werd gegeven en landen waarin dit niet gebeurde, te groot. ${ }^{170} \mathrm{Om}$ verschil van interpretatie van de betreffende formulering te voorkomen werd een Belgisch amendement toegevoegd aan de tekst van lid 1 (b). Dit bepaalde dat staten de vrijheid van ouders zouden eerbiedigen de godsdienstige en zedelijke opvoeding van hun kinderen te verzekeren op een wijze die verenigbaar is met de in die staat voor de toepassing van zijn wetgeving gevolgde procedures. ${ }^{171}$ Deze vage clausule bood alle staten een uitweg voor het in stand houden van het bestaande nationale systeem.

Artikel 5(1) (c) erkent het recht van leden van nationale minderheden hun eigen onderwijs te verzorgen, mits aan een aantal voorwaarden wordt voldaan. Dit recht komt slechts toe aan leden van nationale minderheden, daarmee immigranten en bijvoorbeeld leden van religieuze minderheden uit-

166. Idem, par. 48.

167. Zie de Memorie van Toelichting bij de goedkeuring van dit Verdrag, TK, 1964-1965, Kamerstuk 8052 (R 478), Nr. 3, p. 3.

168. Annex II, par. 51.

169. Zie ook de bespreking van artikel 18 (4) IVBPR in hoofdstuk 3.7 .1 infra.

170. Annex III, par. 19.

171. Ibid. 
sluitend. ${ }^{172}$ Omdat er nog geen algemeen aanvaarde definitie bestond van het begrip minderheid waren het primair de afzonderlijke staten die dit begrip interpreteerden. Op grond van deze interpretatie werden slechts rechten toegekend aan leden van minderheden die reeds lange tijd in een bepaalde staat gevestigd waren. ${ }^{173}$

Het voorstel dat staten zou verplichten openbare scholen voor leden van minderheden in te richten vond geen weerklank. Aanvankelijk werd aan leden van minderheden toegestaan het gebruik van of het onderwijs in hun eigen taal indien het nationale beleid van de desbetreffende staat dat toestond. ${ }^{174}$ Naar de mening van de leden van de Werkgroep van de Algemene Conferentie van UNESCO gaf deze formulering de staten teveel vrijheid de rechten van de leden van minderheden te beperken. Men koos uiteindelijk voor een meer strikte tekst, namelijk leden van minderheden kunnen vrij het onderwijs in hun eigen taal vorm geven indien het onderwijsbeleid van de desbetreffende staat dat toestaat. ${ }^{175}$ Met andere woorden, beperkingen van die vrijheid mochten dan alleen maar gebaseerd zijn op het onderwijsbeleid van de staat en niet meer op het veel ruimere nationale beleid. Tabory heeft gewezen op het vage karakter van deze formulering. Hij merkte op dat:

'[O]nce the entire right to "the use or the teaching of their own language" is made contingent upon a State's educational policy, it seems to be stripped of any objective criteria or contents. ${ }^{176}$

Naar mijn mening biedt de gekozen formulering door haar bewust onduidelijk gehouden betekenis inderdaad vele ontsnappingsmogelijkheden voor een staat om de rechten van minderheden op dit terrein te beperken of zelfs te ontkennen. In feite kan gesteld worden dat artikel 5 lid 1 (c) impliciet de assimilatie van minderheden beoogt. Dit blijkt vooral uit de eerste voorwaarde verbonden aan de uitoefening van onderwijsrechten door leden van minderheden. De vrijheid van onderwijs moet immers op zodanige wijze worden uitgeoefend dat begrip voor taal en cultuur van de samenleving als geheel en deelname aan maatschappelijke activiteiten gegarandeerd blijven. Bovendien mag de vrijheid van onderwijs van leden van minderheden niet uitgeoefend worden op een wijze die afbreuk doet aan de nationale soevereiniteit. De ratio van dit UNESCO Verdrag is de verzekering van het non-discriminatiebeginsel in het onderwijs, alsmede de verwezenlijking van gelijke kansen en gelijke behandeling. Artikel 5 lid 1 (c) blijft

172. Annex II, par. 52 .

173. Annex III, par. 20.

174. Annex II, par. 62.

175. Annex III, par. 20.

176. Zie ook M. Tabory, Language Rights as Human Rights, in: Israel Yearbook on Human Right:, voll. 10 (1980), pp. $167-223$, p. 184 . 
evenwel steken bij de erkenning van de rechten van leden van minderheden eigen onderwijsinstellingen te stichten. De staat verplicht zich slechts al die maatregelen te nemen die nodig zijn ter verzekering van het beginsel van de vrijheid van onderwijs. Dat volgt uit artikel 5 lid 2. Dat zal veelal geschieden door middel van wetgeving. Het Verdrag verplicht de staat niet tot het nemen van bijzondere maatregelen ten gunste van de verwezenlijking van de onderwijsrechten van minderheden.

Gezien het grote belang van de materie welke door de Conventie werd geregeld $\mathrm{kwamen}$ de verdragsluitende partijen overeen dat bij deze overeenkomst geen voorbehouden werden toegestaan. 177

Tegelijk met het vaststellen van de tekst en het sluiten van het Verdrag werd een Aanbeveling door de Algemene Conferentie van de UNESCO aanvaard. De tekst van deze Aanbeveling is identiek aan die van de Conventie, haar juridisch karakter is evenwel verschillend. $\mathrm{Zij}$ is juridisch niet bindend. Een aantal leden van de Algemene Conferentie achtte een Aanbeveling noodzakelijk, omdat het voor federale staten moeilijk zo niet onmogelijk zou zijn de Conventie te ratificeren. Onderwijs is meestal een kwestie die onder de bevoegdheid van de verschillende deelstaten valt. Een federale regering kon voor de deelstaten van de federatie op dat terrein geen verdragsverplichtingen aangaan. ${ }^{178}$ Bovendien bood de Aanbeveling staten die niet meteen aan de normen van het Verdrag konden voldoen de mogelijkheid om eerst geleidelijk de bepalingen van de Aanbeveling uit te voeren. Op deze manier kon de overgang naar de normen van de Conventie op flexibele wijze verlopen. ${ }^{179}$ Artikel 6 bepaalt dat de verdragspartijen bij de toepassing van de bepalingen uit het Verdrag de verplichting op zich nemen de grootst mogelijke aandacht te schenken aan de relevante aanbevelingen welke door de Algemene Conferentie van UNESCO zullen worden aanvaard. ${ }^{180}$

De Conventie trad in werking op 22 mei 1962 . Op 1 januari 1991 hadden 76 staten het Verdrag geratificeerd. ${ }^{181}$

177. Artikel 9 luidt: 'Reservations to this Convention shall not be permitted', Zie ook Annex II, par. 31; en Annex III, par. 22.

178. Zie Annex II, par. 20; Saba, a.w. p. 651; Juvigny, a.w. pp. 62,53.

179. Juvigny, a.w. p. 54.

180. Er zijn geen Aanbevelingen aanwaard die een nadere interpretatie opleveren van de Conventie. Wel zijn or Aanbevelingen angenomen die raakpunten hebben met de problematiek van de Conventie. Daarbij valt te denken aan de Recommendation Concerning the Status of Teachers (1966), de Recommendation concerning Education for International Understanding, Co-operation and Peace and Education relating to Human Rights and Fundamental Freedoms (1974) en de Recommendation on the Development of Adult Education (1976).

181. Eèn van de opvallendste afwezige staten in de lijst met partijstaten is Belgie. Dit heeft waarschijnlijk te maken met de staatkundige structuur van Belgie waar het Vlaamse en het $W$ aalse gewest in onderwijakweaties een grote mate van autonomie bezitten. Van de westerse staten ontbreken verder Oostenrijk, Zwitserland en Ierland, Verenigde Staten en Canada. Verder eijn alle Oosteuropese staten partij bij dit Verdrag. Als gevolg van de vereniging van de beide Duitslanden nam het aantal verdragsitaten met één af. 


\subsubsection{Samenvattende opmerkingen}

Het UNESCO Verdrag is een internationaal instrument dat geheel gewijd is aan de kwestie van de verwezenlijking van het recht op onderwijs. Naast de bestrijding van discriminatoire situaties in het onderwijs beoogt het Verdrag ook bij te dragen aan de bevordering van gelijke kansen en gelijke behandeling in het onderwijs. Dit vereist een nationaal beleid dat door de staat dient te worden ontwikkeld en uitgevoerd. Het betreft hier het sociale aspect van de verwezenlijking van het recht op onderwijs. Het vraagt van de overheid het wegnemen van de economische, financiële, maatschappelijke, politieke factoren die discriminatie in het onderwijs bestendigen. Het Verdrag heeft verder als kenmerk dat het tot in detail aangeeft wat wel en wat niet onder de noemer discriminatie in het onderwijs valt, hoewel wat dat betreft enige bepalingen voor discussie vatbaar zijn.

Dit geldt met name voor de juridische betekenis van de clausule 'when permitted in a State' aan het begin van artikel 2. Voorts kan artikel 2a, dat afzonderlijke scholen voor jongens en meisjes toestaat; leiden tot bestendiging van een situatie waarin het onderwijs aan meisjes van een mindere kwaliteit is dan dat aan jongens. En de Conventie schiet te kort in die zin dat geen bepaling is opgenomen over bijzondere maatregelen ten gunste van achtergestelde groepen in het onderwijs.

Daarnaast omschrijft het Verdrag gedetailleerd de verplichtingen van staten teneinde discriminatie op te heffen of te voorkomen. Tenslotte geeft het Verdrag een aantal bepalingen over het vrijheidsaspect van het recht op onderwijs en de rechten van minderheden hieromtrent. Aangaande de onderwijsrechten van leden van nationale minderheden heeft artikel 5 lid 1 sub $c$ slechts een beperkte reikwijdte. De bepaling doet geen recht aan de aspiraties van minderheden en verplicht de staat niet tot het nemen van positieve maatregelen ten gunste van leden van minderheden.

Het Verdrag sluit aan bij de betekenis en reikwijdte van het recht op onderwijs in andere internationale teksten, met name het IVESCR. Het Verdrag onderscheidt zich van andere mensenrechtenverdragen, omdat het specifiek aandacht besteedt aan vormen van 'static discrimination' die in het onderwijs hardnekkig zijn. Ook de uitwerking van het discriminatiebegrip en de verplichtingen van staten onderscheiden dit Verdrag van andere mensenrechtenverdragen.

\subsection{Het Internationaal Verdrag inzake Economische, Sociale en Culturele Rechten}

\subsubsection{Inleidende opmerkingen}

Het Internationaal Verdrag inzake Economische, Sociale en Culturele Rechten van 1966 bevat twee bepalingen die het recht op onderwijs tot onderwerp hebben. Dit zijn de artikelen 13 en 14 . Artikel 13 bepaalt dat partijen bij het Verdrag het recht van een ieder op onderwijs erkennen. Bovendien 
geeft deze bepaling een uitwerking van het sociale aspect en het vrijheidsaspect van het recht op onderwijs.

Artikel 14 betreft een uitvoeringsbepaling aangaande het opstellen van een plan voor de geleidelijke verwezenlijking van kosteloos primair onderwijs. Bij de analyse van de totstandkoming van de onderwijsbepalingen in dit Verdrag zal de meeste aandacht worden besteed aan artikel 13. Artikel 13 geeft een aantal algemene bepalingen over het recht op onderwijs, terwijl artikel 14 is toegespitst op de verwezenlijking van het primaire onderwijs. Hier zal verder geen aandacht worden besteed aan de doeleinden van het onderwijs zoals neergelegd in artikel 13 lid 1.

Verdragsbepalingen moeten primair worden geïnterpreteerd overeenkomstig de gewone betekenis van de termen van het Verdrag in hun context en in het licht van voorwerp en doel van het Verdrag. De ontstaansgeschiedenis van het Verdrag (de 'travaux préparatoires') kan dienen als aanvullend middel van interpretatie om de betekenis van bepalingen in de context van het Verdrag te verhelderen. ${ }^{182} \mathrm{Bij}$ de interpretatie van IVESCR bepalingen wordt vaker gebruik gemaakt van de 'travaux préparatoires', juist omdat betekenis en reikwijdte van deze bepalingen niet altijd even duidelijk zijn. ${ }^{183}$

In de Universele Verklaring van de Rechten van de Mens van 1948 was een aantal normen geformuleerd waaraan op het ogenblik van aanvaarding geen juridisch bindende kracht kon worden toegekend. Vervolgens werd binnen de VN, in het bijzonder de Commissie voor de Rechten van de Mens, onderzocht hoe de bepalingen uit de Verklaring konden worden uitgewerkt in verdragsbepalingen die juridische verplichtingen zouden opleggen aan staten. Tijdens de jaren 1951 en 1952 werd in de Commissie voor de Rechten van de Mens aan de onderwijsbepalingen gesleuteld, terwijl in 1957 de Derde Commissie van de Algemene Vergadering discussies voerde over dit onderwerp. De elementen van artikel 26 van de Universele Verklaring die een omschrijving beoogden te geven van het recht op onderwijs, zijn alle terug te vinden in artikel 13 IVESCR.

Bij het tot stand komen van de onderwijsbepalingen van dit Verdrag heeft de UNESCO een vooraanstaande rol gespeeld. Immers, éen van de taken aan de UNESCO in haar oprichtingsverdrag toebedeeld was:

('to) give fresh impulse to popular education and to the spread of culture; by collaborating with Members, at their request, in the development of educational activities; by instituting collaboration among the

182. Artikel 31 lid 1 en 32 Weens Verdragenverdrag, Trb. 1972,51 . Zie voorts M.J. Bossuyt, Guide to the "Travaux Preparatoires" of the International Covenant on Civil and Pollitical Rights, Dordrecht 1987, p. XVII.

183. Zie Ph. Alston, G. Quinn, The Nature and Scope of States' Parties Obligations under the International Covenant on Economic, Social and Cultural Rights, in: Human Rights Quarterly, vol. 9 (1987), pp. 156-229. 
nations to advance the ideal of equality of educational opportunity without regard to race, sex or any distinctions economic or social. ${ }^{184}$

Daarbij vormde het vaststellen van verplichtingen van staten aangaande de verwezenlijking van het recht op onderwijs in een bindend internationaal document een belangrijk hulpmiddel. ${ }^{185}$ Naast de UNESCO namen ook twee andere gespecialiseerde organisaties, namelijk de Internationale Arbeids Organisatie (ILO) en de Wereld Gezondheidsorganisatie (WHO) in 1951 deel aan een werkgroep van de Commissie voor de Rechten van de Mens. ${ }^{186}$ Deze werkgroep was belast met het opstellen van ontwerpbepalingen voor economische, sociale en culturele rechten. Ten aanzien van dit punt stonden de gespecialiseerde organisaties niet op één lijn. Dit verschil van inzicht werd door John Humphrey, de eerste directeur van de Mensenrechtendivisie van de Verenigde Naties, als volgt onder woorden gebracht

'What they (de ILO, A.C.) wanted, and this soon became quite obvious, was that these rights should be defined in the vaguest and most general terms possible. UNESCO and the World Health Organization, on the other hand, wanted detailed provisions stipulating explicit obligations. There was a difference between an established organization, with its traditional interests to protect, and the two new agencies, which felt that they needed all the help they could get form the United Nations in furthering their programs. 187

Het streven naar min of meer gedetailleerd omschreven verplichtingen voor staten is een voortdurend kenmerk geweest van de rol van de UNESCO tijdens de totstandkoming van de onderwijsbepalingen in het IVESCR.

3.6.2 Het sociale aspect van het recht op onderwijs tijdens de beraadslagingen in de Commissie voor de Rechten van de Mens (1951-1952)

Ten behoeve van de zevende zitting (1951) van de Commissie voor de Rechten van de Mens werden door een aantal staten alsmede de UNESCO tekstvoorstellen gepresenteerd ten behoeve van de formulering van het recht op on-

184. Artikel I lid 2(b) Constitutie UNESCO, tekst in: Louis B. Sohn (ed.) International Organisation and Integration, Student Edition, Dordrecht 1986, pp. 491-600.

185. Zie Torres Bodet, Directeur-General UNESCO, in de 'Working Group on Economic, Social and Cultural Rights', in: UN Doc. E/CN.4/AC.14/SR.1, pp. 13, 14 (17 mei 1951). De documenten waar in deze paragraaf over het IVESCR naar verwezen wordt eijn VN documenten.

186. Ingesteld krachtens ECOSOC Res. 349 (XII).

187. John P. Humphrey, Human Rights \& the United Nations; a great adventure. New York 1984, pp. 143, 144. Zie ook Juvigny (Frankrijk), UN Doc. E/CN.4/SR.286, p. 8. 
derwijs. ${ }^{188}$ Opvallend was dat sommige tekstvoorstellen heel uitvoerig waren, zoals die van Denemarken, Egypte en UNESCO. De bepalingen hadden gemeen dat ze het sociale aspect van het recht op onderwijs behandelden en een onderverdeling maakten naar primair, secundair en hoger onderwijs. Geen van de voorstellen bevatte het vrijheidsaspect van het recht op onderwijs, dat wil zeggen een bepaling inzake de vrijheid van de ouders aangaande de keuze van het soort (levensbeschouwelijk) onderwijs voor hun kinderen. De vrijheid om onderwijs te geven was evenmin opgenomen in de voorstellen. ${ }^{189}$

Omdat het UNESCO-voorstel representatief was voor de andere ingediende onderwijsbepalingen en vanwege de belangrijke rol die het in latere discussies heeft gespeeld ${ }^{190}$ is het zinvol het hier in zijn geheel weer te geven. De tekst was als volgt:

\section{'Article (a)}

The signatory States recognize:

1. that everyone has the right to education;

2. that primary education should be free and compulsory;

3. that secondary education, in its different forms, including technical and professional secondary education, should be generally available and should be made progressively free;

4. that higher education should be equally accessible to all on the basis of merit;

5. that education should encourage respect for human rights and understanding, and tolerance between all nations.

Each signatory State pledges itself to undertake progressively, with due regard to its organization and resources, and in accordance with the principle of non-discrimination enunciated in paragraph 1 of Article 1 of this Covenant, all measures necessary to attain these objectives in all the territories within its jurisdiction.

\section{Article (b)}

Each signatory State which, at the time of becoming a party to this Covenant, has not been able to secure in all territories under its jurisdiction compulsory primary education, free of charge, undertakes, within two years, to work out and adopt a detailed plan of action for the progressive implementation, within a number of years to be fixed

188. Zie Working Group on Economic, Social and Cultural Rights, Compilation of Proposals relating to Economic, Social and Cultural Rights, E/CN.4/AC.14/2/Add.4 (27 april 1951). Tekstvoorstellen van de Sovjet-Unie, Joegoslavie, Verenigde Staten, Dememarken, Egypte, Australliè en UNESCO.

189. Op dit vrijheidsaspect wordt in een volgende paragraaf ingegaan.

190. Het UNESCO-voorstel werd tijidens de beraadslagingen in de Commissie voor de Rechten van de Mens ingediend door Chili. 
in the plan, of the principle of compulsory primary education free of charge for all.

\section{Article (c)}

The signatory States undertake to encourage as far as possible the fundamental education of these persons who have not received or completed the whole period of primary education.'

Het voorstel omvatte een aantal essentiële elementen van het recht op onderwijs, te weten een uitsplitsing naar primair, secundair en hoger onderwijs, een verwijzing naar de doeleinden van onderwijs, en het non-discriminatie-beginsel, de verplichting tot geleidelijke verwezenlijking van de gestelde doelen en tenslotte een bepaling aangaande het fundamenteel onderricht. Het ontbreken van het vrijheidsaspect in het ontwerp van UNESCO werd verklaard uit het feit dat UNESCO daarvoor geen instructie had ontvangen van de Algemene Conferentie van de organisatie. De UNESCO-vertegenwoordiger in de Commissie meende evenwel dat de organisatie welwillend zou staan ten aanzien van een uitwerking van artikel 26(3) Universele Verklaring in een onderwijsbepaling in een toekomstig verdrag. ${ }^{191}$

Alhoewel de door de UNESCO voorgestelde bepaling nogal gedetailleerd was, was het toch onmogelijk gebleken elk onderwijsniveau nauwkeurig te definiëren. Dat zou in tegenspraak zijn geweest met de diversiteit van onderwijsstelsels in verschillende staten en zou aanleiding hebben gegeven tot uitgebreide veranderingen van die stelsels. Dat was niet de bedoeling van het UNESCO voorstel. ${ }^{192}$

UNESCO suggereerde voorts een in algemene bewoordingen gestelde definitie van het recht op onderwijs:

'The right of access to the knowledge and training which are necessary to full development as an individual and as a citizen. ${ }^{193}$

Van essentieel belang was de betekenis van de term 'to recognize' in de door UNESCO voorgestelde tekst, omdat daarmee het juridisch karakter van de onderwijsbepaling werd aangeduid. De UNESCO-vertegenwoordiger meende dat:

'recognition meant first and foremost that States should accept the obligation to do all in their power to achieve certain clearly defined aims, without, however, undertaking to attain them in a specified $\mathrm{p}$ eriod. Admittedly, they could be achieved only by slow degrees, and 
the time involved would vary according to the relative magnitude of the problems of each country and the means at its disposal. ${ }^{194}$

Het gaat hier om een verplichting tot het opzetten en uitvoeren van een bepaald beleid tot verwezenlijking van het recht op onderwijs voor een ieder. De verplichting betekent dat staten een bepaald programma dienen uit te voeren waarbij zij zelf middelen en methoden kunnen kiezen, maar waarbij het resultaat vast staat, te weten de invoering van primair, secundair en hoger onderwijs. Het betreft hier een 'obligation of result'. Uit de door de vertegenwoordiger van de UNESCO gegeven toelichting bleek dat het niet de bedoeling was té gedetailleerde verplichtingen voor staten op te nemen in een onderwijs-artikel. Dat was meer een taak voor regeringen in samenwerking met UNESCO. Algemene verplichtingen waren evenwel noodzakelijk aangaande de verwezenlijking van het primaire en het fundamentele onderwijs. Het ging om een urgent probleem waarmee veel mensen te kampen hadden, namelijk het analfabetisme zowel van kinderen als van volwassenen. ${ }^{195}$

De Joegoslavische vertegenwoordiger in de Commissie makte bezwaar tegen een verwijzing in het UNESCO-voorstel naar de verwezenlijking van het recht op onderwijs op nationaal niveau 'with due regard to its organization and resources'. Hij meende dat dit een ontsnappingsclausule was die staten de mogelijkheid zou bieden de nationale implementatie van de onderwijsbepaling uit te stellen. ${ }^{196}$ Elvin (UNESCO) antwoordde hierop dat deze clausule opgenomen was als erkenning van de noodzaak rekening te houden met de verscheidenheid in structuur tussen de verschillende landen. ${ }^{197}$

Een Chileense tekst, gebaseerd op de UNESCO-voorstellen en tijdens de discussies naar voren gebrachte amendementen, vormde de basis voor de stemming op het einde van de zevende zitting van de Commissie voor de Rechten van de Mens. Voor zover het voorstel het sociale aspect van het recht op onderwijs vastlegde luidde het als volgt:

194. Zie noot 192.

195. Elvin (UNESCO), E/CN.4/SR.226, pp. 15, 16 ( 4 mei 1951).

196. Jevremovic (Joegoslavie), E/CN.4/SR.228, p. 4 (5 mei 1951) en E/CN.4/SR.229, p. 4 (7 mei 1951).

197. Elvin (UNESCO), E/CN.4/SR.228, p. 14 (5 meì 1951).

Uruguay stelde voor, als aanvulling op het UNESCO-ontwerp, aan lid 4 van artikel (a) het volgende element toe te voegen 'and should be made professively free'. De afgevaardigde van Uruguay argumenteerde dat hij een voorstander was van kosteloos onderwijs op zowel primair, secundair als hoger niveau. Hij realiseerde zich echter dat dit niet haalbaar was en dat een dergelijk ideaal geen algemene steun zou krijgen. Het Uruguayaanse amendement werd niet opgenomen in een later ontwerpvoorstel van Chili, maar later, bij de stemmingen, toch aanvaard. Zie doc.

E/CN.4/605 (4 mei 1951); Chiasullo (Uruguay), E/CN.4/SR.228, pp. 15, 16 (5 mei 1951).Zie ook E/CN.4/613/Rev.1 (7 mei 1951); en de opmerkingen van Santa Cruz (Chili), E/CN.4/SR.229, p. 15 (7 mei 1951). 
'The States Parties to the Covenant recognize:

1. that everyone has the right to education;

2. that educational facilities shall be accessible to all in accordance with the principle of non-discrimination enunciated in paragraph $\mathbb{1}$ of $\mathrm{Ar}$ ticle 1 of this Covenant;

3. that primary education should be free and compulsory;

4. that secondary education, in its different forms, including technical and professional secondary education, should be generally available and should be made progressively free;

5. that higher education should be equally accessible to all on the basis of merit.

Each State party to the Covenant pledges itself to undertake progressively, with due regard to its organization and resources, all measures necessary to attain these objectives in all the territories within its jurisdiction.

The States parties to the Covenant undertake to encourage as far as possible the fundamental education of those persons who have not received or completed the whole period of primary education."

$\mathrm{Bij}$ de stemming ${ }^{198}$ over dit Chileense voorstel in de Commissie voor de Rechten van de Mens werd een aantal wijzigingen aangebracht in bepaalde formuleringen, maar deze deden geen afbreuk aan de belangrijkste elementen uit de tekst. De strekking bleef dan ook gehandhaafd. Een aantal amendementen dient hier genoemd te worden. In de gehele onderwijsbepaling van het Chileense voorstel werd de term 'should' vervangen door de term 'shall'. Deze wijziging werd zonder noemenswaardige discussie door de Commissie aanvaard. ${ }^{199}$ Wel merkte Mevr. Roosevelt op dat het woord 'shall' een sterkere juridische binding impliceert dan het woord 'should'. De term is mandatoir van aard. ${ }^{200}$ In het bijzonder ten aanzien van de verwezenlijking van het hoger onderwijs zou dit in sommige staten problematisch kunnen worden, vooral ook omdat de Commissie een Uruguayaans voorstel, dat beoogde hoger onderwijs geleidelijk kosteloos in te voeren, aanvaardde ${ }^{201}$. Voorts werd een bepaling die verwees naar het concept van fundamenteel onderricht opgenomen in het onderwijs-artikel. ${ }^{202}$

Verworpen werd de paragraaf die verwees naar 'due regard to its organization and resources' bij de verwezenlijking van het recht op onderwijs in alle gebieden onder de rechtsmacht van de staat.

198. Zile E/CN.4/SR.229 (7 mei 1951), pp. 17-27.

199. Op, cit. p. 19.

200. Op. cir. p. 20.

201. Op. cit. p. 20.

202. Deze bepaling was afkomatig uit een amendement van de Verenigde Staten, zie E/CN.4/ 593/Rev.2 (7 meil 1951). 
De onderwijsbepaling uit het Chileense ontwerpvoorstel werd aanvaard met 15 tegen 0 stemmen bij 3 onthoudingen met inachtneming van de overeengekomen wijzigingen. ${ }^{203}$ De tekst van het artikel, voor zover het ging om het sociale aspect van het recht op onderwijs luidde aldus: ${ }^{204}$

'The States Parties to the Covenant recognize:

1. the right of everyone to education;

2. that educational facilities shall be accessible to all in accordance with the principle of non-discrimination enunciated in paragraph 1 of Article 1 of this Covenant;

3. that primary education shall be compulsory and available free to all;

4. that secondary education, in its different forms, including technical and professional secondary education, shall be generally available and shall be made progressively free,

5. that higher education shall be equally accessible to all on the basis of merit and shall be made progressively free;

6. that fundamental education for those persons who have not received or completed the whole period of their primary education shall be encouraged as far as possible."

Deze paragrafen bevatten de belangrijkste elementen van het sociale aspect van het recht op onderwijs. In bovenstaande formulering is in latere fasen van de wordingsgeschiedenis van het onderwijs-artikel geen wezenlijke verandering meer gekomen. De strekking van het sociale aspect stond in 1951, op het einde van de zevende zitting van de Commissie voor de Rechten van de Mens, in feite reeds vast. De ontwerpbepaling werd als artikel 28 geregistreerd. ${ }^{205}$

Samengevat speelden met name de tekstvoorstellen van UNESCO en van Chili een belangrijke rol tijdens de eerste beraadslagingen in de Commissie voor de Rechten van de Mens over de onderwijsbepalingen. Kenmerkend was dat vooral werd gewezen op het belang van gedetailleerde verplichtingen voor staten.

Tijdens de achtste zitting van de Commissie voor de Rechten van de Mens in 1952 kwam een aantal staten met nieuwe voorstellen voor een onderwijsbepaling. De Algemene Vergadering van de Verenigde Naties had namelijk tijdens haar zesde zitting (1951-1952) in een resolutie uitgesproken dat de formulering van de ontwerpbepalingen inzake economische, sociale en culturele rechten verbetering behoefde. ${ }^{206}$

203. E/CN.4/SR.229, p. 27 (7 mell 1951).

204. Volledige tekst opgenomen in document $\mathrm{E} / \mathrm{CN} .4 / \mathrm{L} .19 / \mathrm{Add} .4$ (8 meil 195.1).

205. Zie Doc. E/1992, Report of the Seventh Session of the Commission on Human Rights (24 mei 1951), zie Annex 1, p. 71 . Men ging toen nog uit van én verdrag waarin zowel burger- en politieke rechten als economische, sociale en culturele rechten opgenomen zouden worden.

206. General Asiembly Res. 544 (VI), 5 febr. 1952. 
Deze nieuwe voorstellen verschilden op sommige punten in belangrijke mate van het tijdens de zevende zitting (Commissie Rechten van de Mens) aanvaarde artikel 28. Dit ontwerpartikel leek vrijwel algemene instemming van de Commissie te hebben. Sommige lidstaten streefden evenwel naar een geheel nieuwe onderwijsbepaling. ${ }^{207}$

Deze tendens tot herziening van de bestaande overeenstemming werd ook veroorzaakt door wijzigingen in de samenstelling van de Commissie. Tot de Commissie traden toe Polen en België, terwijl Denemarken en Guatemala uit de Commissie verdwenen. Bovendien kreeg de Libanese delegatie een tweede vertegenwoordiger, Azkoul, naast de Commissievoorzitter Malik, die tijdens de zitting in 1952 met Libanese voorstellen voor de dag kwam. Ook vond er een wisseling van de wacht plaats in de afvaardiging van het Verenigd Koninkrijk. Miss Bowie werd na onenigheid met het Britse Ministerie van Buitenlandse Zaken opgevolgd door Mr. Hoare, een onderminister op Binnenlandse Zaken. ${ }^{208}$ Juist Polen, Libanon en het Verenigd Koninkrijk kwamen in 1952 met amendementen op artikel 28 die de bestaande overeenstemming over deze bepaling op losse schroeven zetten. Eén van de amendementen op ontwerpartikel 28 was afkomstig van het Verenigd Koninkrijk. Het nieuwe tekstwoorstel van de Britten werd ingegeven door de wens de onderwijsbepaling compacter en beknopter te formuleren. De Britse afgevaardigde Hoare merkte in dit verband op: 'All the Covenant had to do was to recognize a right and state an obligation. ${ }^{209}$

De relevante wijzigingen uit het Britse voorstel luidden aldus:

'The State Parties to the Covenant recognize:

(1) The right of everyone to access to educational facilities;

(2) That primary education shall be compulsory within appropriate limits of age, and shall be free to all in State schools, but shall not preclude the requirement of payment for ancillary services. ${ }^{210}$

De Britse tekst beoogde niet zozeer het recht van een ieder op onderwijs vast te leggen, als well het recht van iedereen om toegang tot dat onderwijs te krijgen op gelijke voorwaarden. ${ }^{211}$

Tevens probeerde dit voorstel de bemoeienis van de overheid met het primaire onderwijs in financiële zin te beperken. Het was zeker niet de bedoeling dat op privê-scholen eveneens kosteloos onderwijs mogelijk zou zijn. ${ }^{212}$ Dus alleen kosteloos primair onderwijs in overheidsscholen. Verder ontbrak in de Britse tekst een verwijzing naar fundamenteel onderricht,

207. Zie E/CN.4/SR.288, p. 5 (9 mei 1952), dat was althans de indruk van Whitlam, rapporteur.

208. Zie hierover Humphrey, a.w. p. 145.

209. Hoare (VK), E/CN.4/SR.285, p. 5 (8 mel 1952).

210. E/CN.4/L.85 (2 meï 1952).

211. E/CN.4/SR.285, p. 4. Zie ook Hoare, E/CN.4/SR.289, P. 9 (12 mei 1952).

212. E/CN.4/SR. 285, p. 5 . 
omdat dit in de term 'educational facilities' begrepen zou zijn. Hoare gaf toe dat zijn voorstel beantwoordde aan de situatie van het onderwijs in het Verenigd Koninkrijk. Het stond evenwel open voor wijzigingen in de formulering, maar niet in de essentie. ${ }^{213} \mathrm{Ik}$ denk dat Hoare zich realiseerde dat zijn voorstellen voor de andere Commissieleden niet aanvaardbaar waren. Ze werden over het algemeen kritisch onthaald. ${ }^{214}$ Zo achtte de UNESCOvertegenwoordiger het zeker geen verbetering van de tekst van ontwerpartikel 28: 'Access to educational facilities might be interpreted to mean that school attendance was permitted where schools existed, but that States were not obliged to build schools.,215 Deze interpretatie moest zeker voorkomen worden. Bovendien achtte hij het ontbreken van een bepaling betreffende fundamenteel onderricht ernstig. Juist deze vorm van onderwijs beschouwde hij als essentieel in een tijd waarin het vele volwassenen ontbrak aan elementaire kennis. ${ }^{216}$ Ondanks mogelijke onvolkomenheden in de vorm achtte UNESCO de oorspronkelijke tekst van ontwerpartikel 28 bevredigend. ${ }^{217}$ De Franse afgevaardigde Juvigny was eveneens tevreden over de tekst van artikel 28 . Hij was van mening dat de formuleringen niet overdreven gedetailleerd moesten zijn, omdat dit ten koste zou gaan van de universaliteit van de betreffende bepaling. ${ }^{218} \mathrm{Hij}$ werkte evenwel niet uit wat hij daarmee bedoelde.

Ook de Libanese afgevaardigde deed in het debat over artikel 28 van zich spreken. Hij merkte op dat er in de Commissie geen fundamenteel verschil van mening bestond over de tekst van het onderwijs-artikel. Hij was evenwel van mening, dat het noodzakelijk was enkele ondubbelzinnigheden uit de tekst te halen, want 'in such a juxtaposition of obligations, guarantees and standards, it was difficult to establish a logical link or to distinguish clearly what was imposed as an obligation and what was, merely the abstract recognition of a right ${ }^{2}$. ${ }^{219}$ Hij suggereerde met name de structuur van de bepaling te veranderen zodat de verplichtingen van staten duidelijker omschreven zouden zijn. Het Libanese amendement ${ }^{220}$ was opgebouwd uit

213. Op. cit. p. 4.

214. Zie bijv. Valenzuela (Chili), op citt. p. 13.

215. Op. cir. p. 9.

216. Op. cit. p. 10.

217. Op. clt. p. 8. Zile ook E/CN.4/655/Add.4 (17-4-1952), Observations by UNESCO on the proposed Covenant on Economic, Social and Cultural Rights, p. 5 .

218. Juvigny (Frankrijk), E/CN.4/SR.286, p. 8 (8 mei 1952).

219. Azkoul (Libanon), E/CN.4/SR.286, p. 11; zie ook E/CN.4/SR.287, pp. 10, 11 (9 mei 1952).

220. E/CN.4/L.96 (8 mei 1952). Het is mogelijk dat het Libanese amendement eigenlijk uit de koker kwam van het Secretariaat van de Mensenrechten Divisie van de VN, maar door de Libanese delegatie werd ingediend.

Humphrey wijst in zijn boek op de goede relaties tussen hem en Commissie-voorzitter Malik. Hij schrijft: 'The Secretariat had always worked very closely with him

(Wordt verrolgd...) 
drie delen. Het eerste gedeelte refereerde aan de erkenning van het recht op onderwijs, het tweede gedeelte noemde enkele stappen die staten dienden te nemen om het recht op onderwijs te verwezenlijken. Het derde gedeelte tenslotte noemde enkele onmiddellijke verplichtingen van staten aangaande de doeleinden van onderwijs en het respect voor de keuzevrijheid van ouders. Wat betreft het sociale aspect van het recht op onderwijs luidde de tekst van het Libanese amendement als volgt:

'I. The States Parties to the Covenant recognize the right of everyone to education, including:

(a) the right of everyone to primary, secondary and higher education;

(b) the right to fundamental education of all who have not received or completed their primary education.

II. The steps to be taken by the States Parties to this Covenant to achieve the realization of the right to education shall include the necessary measures:

(a) to make primary education compulsory and free;

(b) to make secondary education, in its different forms, including technical and professional secondary education, generally available, and to make it free.

(c) to make higher education equally accessible to all on the basis of merit and irrespective of the resources of the individual;

(d) to encourage fundamental education and to make it accessible to all who require it.'

Het eerste gedeelte impliceert niet meer dan de erkenning van een recht. Deel twee daarentegen vereist een aantal concrete stappen en duidt op de geleidelijke verwezenlijking van het recht op onderwijs door het nemen van de noodzakelijke maatregelen. Deze maatregelen moeten leiden tot de resultaten genoemd in $a, b, c$ of $d$. Het betreft hier een voorbeeld van een 'obligation of result".

De UNESCO-vertegenwoordiger bepleitte de handhaving van de onderwijsbepaling van ontwerpartikel 28 . Hij realiseerde zich dat:

'while it was not possible under existing economic and educational conditions to establish the ideal system of education immediately, it was possible to define its aims and to make those aims as binding as possible upon the State Parties. ${ }^{.221}$

220.( (. .vervolg)

(Malik, A.C.) and continued to do so. Representing a mall country, he did not have rigid instructions and usually welcomed a good idea. When I or aomeone else in the Division thad one, I often took it to him, and more often than not he picked it up.' Humphrey, a.w. p. 141. Wellicht dat men bimnen het Secretariat ontevreden was over ontwerpartikel 28 en poogde met behulp van de Libanese delegatie daar wat aan te doen.

221. Saba (UNESCO), E/CN.4/SR.287, p. 9 (9 mei 1952). 
Daarom was in de paragrafen 2 tot en met 7 , van ontwerpartikel 28 de mandatoire term 'shall' gebruikt. Daarentegen was het Libanese amendement veel minder verplichtend omdat het slechts voorzag in 'steps to be taken' ${ }^{222}$ Een aantal afgevaardigden achtte het Libanese amendement dan ook geen verbetering. ${ }^{223}$

Een kwestie waarover de meningen in de Commissie sterk verdeeld waren was de vraag of er in de onderwijsbepaling een verwijzing opgenomen moest worden naar het non-discriminatiebeginsel dat in ontwerpartikel 1 was vastgelegd. In ontwerpartikel 28 was in lid 2 een dergelijke verwijzing wel opgenomen. De verdeeldheid liep grofweg langs ideologische lijnen. De communistische staten waren vóór het behoud van de non-discriminatie-clausule in artikel 28. De westerse staten waren veelal voor het schrappen van de desbetreffende bepaling. In dit verband merkte de Poolse vertegenwoordiger Boratynski op:

'That there was great discrimination in certain countries, particularly in education, was a matter of common knowledge. It was therefore essential that Article 28 of the Covenant should provide special guarantees in that respect. The general provisions of Article 1 were not sufficient, as some appeared to think. (...). ... (c)ertain delegations showed a tendency to oppose every liberal or progressive provision that the commission had so far inserted in the draft Covenant. ${ }^{224}$

De Amerikaanse afgevaardigde, Mevr. Roosevelt, meende daarentegen dat:

'... it would weaken the significance of the non-discrimination clause in Article 1 to repeat it in the article on the right to education while omitting any special reference to it from the articles on social security, housing and standards of living (...) To repeat that clause with respect to specific questions might, merely promote fresh discrimination., 225

In een later stadium van de beraadslagingen in de Commissie werd een verwijzing in de onderwijsbepaling naar het non-discriminatie-beginsel in artikel 1 verworpen met 10 tegen 8 stemmen. ${ }^{226}$

De Poolse delegatie diende een amendement ${ }^{227}$ in dat beoogde duidelijk omschreven verplichtingen aan staten op te leggen. Dat betekende echter ook

222. Op. cit. p. 9 .

223. Zie Metha (India), E/CN.4/SR.287, p. 10, Morozov (USSR) p. 13, Juvigny (Frankrijk), E/CN.4/SR.288, p. 8, Kovalenko (Ukraine), p. 11.

224. Boratynski (Polen), E/CN.4/SR.228, p. 7 ( 9 meï 195.2).

226. Mevr. Roosevelt (USA), E/CN.4/SR.289, p. 11 (12 mei 1952).

226. E/CN.4/SR.290, p. 10 (12 mei 1952).

227. E/CN.4/L.99 (9 mei 1952). 
dat de bemoelenis van de staat met het onderwijs aanzienlijk zou zijn. ${ }^{228}$ Deze overheidsbemoeienis was in de volgende termen geformuleerd:

'Delete the whole of paragraph II of the Lebanese amendment and substitute the following:

and it is understood:

(a) that primary education shall be compulsory and free to all, and that the State must ensure this right, in particular by providing the necessary school system;

(b) that secondary education in its different forms including technical and professional secondary education shall be generally available and shall be made progressively free, and that the State must ensure this right, in particular by providing the necessary school system;

(c) that higher education shail be equally accessible to all on the basis of merit and shall be made progressively free and that the State must ensure this right, in particular by a system of scholarships and by the necessary system of higher educational institutions;

(d) that fundamental education for those persons who have not received or completed the whole period of their primary education shall be encouraged as far as possible.'

Besloten werd dat het Poolse amendement ${ }^{229}$ het onderwerp zou vormen van stemming. Ten behoeve van de stemming werden de onderdelen $a, b$ en c elk gesplitst in drieèn waarover afzonderlijk werd gestemd, te weten de openingszin, de clausule 'and that the State must ensure this right', en de slotzin. Voor zowel $\mathrm{a}, \mathrm{b}$ als $\mathrm{c}$ werd de openingsclausule steeds met ruime meerderheid aangenomen. De twee overige zinnen, 'and that the State must ensure this right, in particular by providing the necessary school system' werden steeds met een nipte meerderheid verworpen. ${ }^{230}$ Sub-paragraaf (d) aangaande het fundamentele onderricht werd met ruime meerderheid aangenomen. De gewijzigde paragraaf uit het Poolse voorstel werd uiteindelijk aanvaard met 10 tegen 8 stemmen. ${ }^{231}$

De formuleringen uit het Poolse amendement die een grote rol aan de overheid toebedeelden bij de verwezenlijking van het recht op onderwijs waren dus voor een meerderheid van de Commissie, zij het een kleine, niet aanvaardbaar. Met name de westerse staten waren beducht voor een (te) grote in-

228. Boratynski (Polen), E/CN.4/SR.290, p. 6 (12 mei 1952): 'A great deal could be done: in the field of education by State action. Polland was a striking example of that fact." Deze nadrukkelijke rol en invloed van de staat bij de verwezenlijking van het recht op onderwijs vormde ook de essentie van een amendement van de vijde van de Sovjet-Unie; E/CN.4/L.51/Corr.1 ( 7 mei 1952) dat evenwel in de Commissie nauwelijks. een onderwerp vormde van diecussie.

229. E/CN.4/L.99.

230. Zie E/CN.4/SR.290, Pp. 13, 14m

231. Zie E/2256, par. 119-124, Commission on Human Rights. Repart of the Eighth Sesion (1952). 
vloed van de staat op het onderwijs als ook afkerig van een grote financiële overheidsbemoeienis. Deze ideologische en financiële invloed van de staat op het onderwijs lag namelijk opgesloten in de term "to ensure" (verzekeren, waarborgen), alsmede in de clausule 'in particular by providing the necessary school system'. De term 'to ensure' verplicht tot meer dan bijvoorbeeld 'to recognize" of 'to respect'. Dit ging de westerse staten veel te ver. Het zou een inbreuk betekenen op de vrije ontwikkeling van het individu. Tevens zou dit een beperking van de vrijheid tot het stichten van eigen scholen betekend hebben. Kortom, de westerse staten hielden vast aan de pluriformiteit in het onderwijs, waarbij zij zich ook in financieel opzicht terughoudend wensten op te stellen. De Libanese afgevaardigde betreurde het dat de Commissie een tekst aanvaard had waarin het element van de geleidelijke invoering van kosteloos secundair en hoger onderwijs opgenomen was. ${ }^{232}$ Dit element had ontbroken in het oorspronkelijke Libanese tekstvoorstel. ${ }^{233}$ Naar zijn mening bevatte het aanvaarde Poolse amendement geen directe, noch indirecte verplichtingen. Een aantal leden van de Commissie was van mening dat de uitdrukking 'it is understood' in het aanvaarde Poolse amendement nauwelijks juridische betekenis had. ${ }^{234}$ Een aanzienlijk gedeelte van de Commissie achtte de aanvaarde tekst van de onderwijsbepaling onbevredigend, maar had toch vóór gestemd, omdat dit het best haalbare compromis betekende. Sommigen uitten de wens tot revisie van de tekst in een later stadium. ${ }^{235}$

De formulering van het sociale aspect van het recht op onderwijs in de door de Commissie aangenomen tekst luidde aldus:

'It is understood:

(a) That primary education shall be compulsory and available free to all;

(b) that secondary education, in its different forms, including technical and professional secondary education, shall be generally available and shall be made progressively free;

(c) that higher education shall be equally accessible on the basis of merit and shall be made progressively free;

(d) that fundamental education for those persons who have not received or completed the whole period of their primary education shall be encouraged as far as possible. ${ }^{236}$

232. Aqkoul (Libanon), E/CN.4/SR.290, pp. 15, 16.

238. E/CN.4/L.96,E/CN.4/L.96/Rev.1.

234. Zie de opmerkingen van de afgevaardigden Whitlam, Juvigny en Hoare, E/CN.4/ SR.291, pp. 3, 4 .

235. Op. cit. pp. 3, 4, 5 .

236. E/CN.4/666/Add.4 (ontwerpartikel 14). Zie ook A/2929 (1955). 
Geconcludeerd kan worden dat de Commissie voor de Rechten van de Mens tijdens haar zitting in 1952 wel een aantal wijzigingen aanbracht in de ontwerptekst inzake het recht op onderwijs, maar dat de centrale elementen van het sociale aspect werden gehandhaafd.

Met het aanvaarden van deze tekst sloot de Commissie voor de Rechten van de Mens haar bemoeienis met het opstellen van een onderwijsbepaling ten behoeve van het Internationaal Verdrag inzake Economische, Sociale en Culturele Rechten af. Deze bepaling zou op een later tijdstip nog door de Derde Commissie van de Algemene Vergadering bestudeerd worden. ${ }^{237}$

3.6.3 Het vrijheidsaspect van het recht op onderwijs tijdens de beraadslagingen in de Commissie voor de Rechten van de Mens (1951-1952)

De eerste ontwerpen voor een onderwijs-artikel ten behoeve van de op te stellen mensenrechtenverdragen bevatten geen bepaling die het vrijheidsaspect van het recht op onderwijs stipuleerde. In de Derde Commissie van de Algemene Vergadering in 1950 werd dit punt ter sprake gebracht door de Nederlandse vertegenwoordiger Prof. Beaufort. Hij vroeg zich af waarom de Commissie voor de Rechten van de Mens in haar ontwerpvoorstellen geen uitwerking had gegeven aan artikel 26(3) van de Universele Verklaring. ${ }^{238} \mathrm{Hij}$ merkte op dat bepaalde rechten 'could be universally guaranteed because they were independent of special circumstances or a given level of civilization". ${ }^{239}$ Tot deze categorie rekende hij ook de keuzevrijheid van de ouders inzake het onderwijs voor hun kinderen. Beaufort herinnerde eraan dat mede op Nederlands initiatief dit vrijheidsaspect was opgenomen in de Europese ontwerp-conventie voor de rechten van de mens. Hij verzocht dan ook dringend de genoemde vrijheid in het VN ontwerpverdrag op te nemen.

Ook in het overzicht van voorstellen aangaande de formulering van sociale, economische en culturele rechten ten behoeve van de zevende zitting van de Commissie voor de Rechten van de Mens in 1951 was geen enkel voorstel terug te vinden dat het vrijheidsaspect van het recht op onderwijs behandelde. ${ }^{240}$ In het UNESCO-voorstel ontbrak eveneens een dergelijke bepaling. De reden hiervoor was dat het Secretariaat van UNESCO geen instructie had van de Algemene Conferentie betreffende deze specifieke kwestie. Het zou eerder een taak zijn voor Commissieleden om met voorstellen op dit punt te komen. ${ }^{241}$

237. Op de Twaalfde Zitting van de Algemene Vergadering in 1957.

238. Beaufort (Nederland), A/C.3/SR.290, par. 18 (20-10-1950).

239. Op. cilt. par. 17.

240. E/CN.4/AC.14/2/Add 4, Section IX (27 april 1951).

241. Elvin (UNESCO), E/CN.4/SR.226, p. 13 ( 4 mei 1951), zie hoofdatuk 3.6 .2 supra. 
De Chileense afgevaardigde, tevens sponsor van het UNESCO-voorstel, verzette zich tegen het opnemen van het idee van artikel 26 (3) Universele Verklaring in het ontwerpverdrag. Hij meende dat dit uitgelegd zou kunnen worden als zouden ouders het recht hebben het curriculum van het onderwijs voor hun kinderen te bepalen. ${ }^{242}$ De Amerikaanse vertegenwoordiger, Mevr. Roosevelt, daarentegen toonde zich een voorstander van de keuzevrijheid van ouders inzake het onderwijs voor hun kinderen. ${ }^{243} \mathrm{De}$ vertegenwoordiger van Uruguay in de Commissie sympathiseerde met het idee van artikel 26 (3) Universele Verklaring, maar waarschuwde tevens dat

'while that right existed in the free democracies, its exercise might involve certain difficulties in countries where education had a political or religious bias or where Governments tried to influence the minds of the parents. ${ }^{244}$

Het Egyptische Commissielid, Azmi Bey, achtte de reikwijdte van artikel 26 (3) te ruim en stelde voor de keuzevrijheid van de ouders te beperken tot het godsdienstonderwijs. Dat was namelijk het terrein bij uitstek waar de rechten van de ouders noodzakelijk waren. ${ }^{245}$ De Deense afgevaardigde, Sørensen, sloot zich aan bij deze opmerking. Hij meende dat de keuzevrijheid van ouders een fundamenteel recht was dat zich evenwel op verschillende wijze manifesteerde in afzonderlijke staten. Hij wilde daarom deze keuzevrijheid beperken tot het godsdienstonderwijs. Dat was, naar zijn mening,

'the only aspect of the question on which unlimited freedom could be granted, 246

Hij stelde daarop het volgende amendement op het UNESCO voorstel voor:

'1. The obligations of States to establish a system of free primary education shall not be deemed incompatible with the liberty of parents to choose for their children privately established systems of education which conform with minimum standards laid down by the State.

2. In the exercise of any functions which the State assumes in the field of education it shall have regard to the liberty of parents to ensure the religious education of their children in conformity with their own convictions. ${ }^{247}$

242. Santa Crus (Chili), E/CN.4/SR.226, p. 23 (4 mei 1951). Zie ook Santa Cruz, E/CN.4/ SR.227, pp. 4; 5 .

249. Roosevelt (VS), E/CN.4/SR.226, p. 24.

244. Ciasullo (Uruguay), op. cit. p. 24.

245. Azmi Bey (Egypte), E/CN.4/SR.227, p. 6 (4 meil 1951).

246. Sorensen (Denemarken), E/CN.4/SR.227, pp. 8,9.

247. E/CN.4/600 (Denemarken) ( 4 mei 1951). 
Het Deense amendement was er op gericht het vrijheidsaspect van het recht op onderwijs vast te leggen. Het amendement beoogde enerzijds de vrijheid van ouders te garanderen eigen scholen te kiezen voor hun kinderen, de zogenaamde privé-scholen. Het amendement sprak in dit verband alleen van 'primary education' en had dus geen betrekking op andere geledingen van het onderwijs. Anderzijds bepaalde het wijzigingsvoorstel de keuzevrijheid van de ouders aangaande de godsdienstige opvoeding van hun kinderen. Indien het eerste lid zou worden aanvaard achtte Sørensen het tweede lid noodzakelijk, omdat:

'With a system of State schools it was necessary to ensure that children should not be compelled to undergo the particular form of religious instruction which those schools offered. ${ }^{248}$

Het Deense wijzigingsvoorstel toonde sterke overeenkomst met het ontwerpvoorstel voor een onderwijsbepaling in het Europees Verdrag voor de Rechten van de Mens waaraan gedurende het jaar 1951 gesleuteld werd. Denemarken probeerde dus een ontwerpbepaling uit het regionale Europese kader over te brengen naar het mondiale kader van de Verenigde Naties.

Mevr. Roosevelt verklaarde zich in beginsel een voorstander van de rechten van de ouders zoals gedefinieerd in het Deense amendement. Het had evenwel êen tekortkoming waarvoor zij zelf ook nog geen oplossing had gevonden, te weten:

'(I)t did not cover the point that the ultimate aim of ensuring parental responsibility was to safeguard the rights and interests of the child himself. ${ }^{249}$

Met andere woorden, er moest een waarborg zijn dat bij de uitoefening van de rechten van de ouders de belangen van het kind zouden prevaleren. Het Deense wijzigingsvoorstel voorzag niet in dit punt. Daarom was zij genoodzaakt tegen dit amendement te stemmen. Het Deense voorstel werd evenwel ongewijzigd opgenomen in het Chileense ontwerpartikel ${ }^{250}$ dat de basis vormde voor stemming.

248. Sørensen, E/CN.4/SR.228, p. 17 (5 mei 1951).

Een formulering in de trant van lid 2 uit het Deense amendement werd ook gesuggereerd door de Franse vertegenwoordiger Cassin, E/CN.4/SR.227, p. 21.

Het idee van de keuzevrijheid van ouders werd krachtig ondersteund door vertegenwoordigers van religieuze non-gouvernementele organisaties van Protestante, Roomskatholieke en Joodse signatuur. Zie E/CN.4/SR.228, p. 18. Zie ook E/CN.4/660, par.16. Tijdens de beraadslagingen in de Commissie voor de Rechten van de Mens in 1951 en 1952 over het vrijheidsaspect van het recht op onderwijs werd niet gesproken over de vrijheid van individuele personen en instellingen bijzondere scholen te stichten. Dit punt kwam pas in 1957 nadrukkelijk aan de orde in de Derde Commissie van de Algemene Vergadering naar aanleiding van teekstvoorstel van Ierland, Doc. A/C.3/L.617.

249. Roosevelt (VS), E/CN.4/SR.229, p. 11 (7 mei 1951).

250. E/CN.4/613/Rev.1 (7 mei 1951). 
De Zweedse afgevaardigde stelde voor de term 'convictions' te vervangen door 'confessions', daarmee aanduidend dat alleen religieuze overtuigingen bescherming verdienden. Dit voorstel had te maken met het bestaan van een staatskerk en staatsgodsdienst in Zweden. Zweedse kinderen werd slechts toegestaan godsdienstonderwijs buiten deze kerk te volgen indien de ouders konden aantonen dat zij een andere godsdienst practiseerden. De Chileense en Franse leden van de Commissie wezen dit idee af. Ook nietreligieuze overtuigingen, bijwoorbeeld filosof ische of humanistische, verdienden bescherming. 251

De voorzitter van de Commissie, de Libanees Malik, stelde voor de term 'have regard to the liberty of parents' te vervangen door de term 'have respect for the liberty of parents'. Dit impliceerde een sterkere verplichting voor de staat. 'if parents were to enjoy the freedom in question, the State must have "respect for" and not just "regard to" it'. Het voorstel van de voorzitter werd aanvaard. ${ }^{252}$

Beide paragrafen uit het oorspronkelijk Deense amendement werden met ruime meerderheid aanvaard, met inachtneming van de aangebrachte wijzigingen. ${ }^{253}$ De tekst van ontwerpartikel 28 luidde als volgt:

8. The obligations of States to establish a system of free and compulsory primary education shall not be deemed incompatible with the liberty of parents to choose for their children schools other than those established by the state which conform to minimum standards laid down by the State;

9. In the exercise of any functions which the State assumes in the field of education it shall have respect for the liberty of parents to ensure the religious education of their children in conformity with their own convictions. ${ }^{254}$

2.51. E/CN.4/SR.229, p. 25 (7 mei 1951).

Het $\mathrm{Z}$ weedse voorstiel werd bij de stemming verworpen met 10 tegen 2 stemmen bij 6 onthoudingen. Zweden nam hier hetzelfde standpunt in als bij de totatandkoming van de onderwijgbepaling in het EVRM, vgl. hoofdstuk 3.4 .5 supra.

252. E/CN.4/SR.229, p. 26.

Het voorstel van de voorzitter werd aangenomen met 8 tegen 6 stemmen bij 4 onthoudingen. Het betrof hier kwestie die tijdens het opstellen van de Europese Conventie voor de Rechten van de Mens leidde tot discussie en interpretatieverschillen, vgl. hoofdatuk 3.4.5 supra. Naar mijn mening hadden niet alle Commissieleden door dat het hier niet alleen ging om een tekstueel versichil, maar om een verschil in juridische betekenis van de betreffende termen.

253. In paragraaf' 1 werden de woorden 'and compulsory' toegevoegd, zodat de tekst nu luidde 'a syatem of free and compulsory education'. Paragraaf 1 werd aanvaard met 13 tegen 0 stemmen bij 5 onthoudingen.

Paragraaf 2 werd aangenomen met 10 tegen 0 stemmen bij 8 onthoudingen, E/CN.4/ SR.229, pp. 24 en 26.

254. Zie E/CN.4/L.19/Add.4 (8 mei 1951) en E/1992 Annex I, Draft Article 28. 
Tijdens de achtste zitting van de Commissie voor de Rechten van de Mens in mei 1952 probeerde een aantal delegaties de formulering van het vrijheidsaspect te verbeteren, overeenkomstig de opdracht van Resolutie 544 (VI) van de Algemene Vergadering.

Zo was er een Brits amendement op ontwerpartikel 28 dat beoogde de bepaling beknopter te maken door par. 8 en 9 , in elkaar te schuiven. Bovendien was de beperking tot het primair onderwijs (par. 8) losgelaten. De relevante passage luidde aldus:

'(5) That in the exercise of any functions which the State assumes in the field of education, it shall have respect for the liberty of parents to choose for their children schools other than those established by the State which conform to minimum standards laid down by the State, and to ensure the religious education of their children in conformity with their own convictions. ${ }^{25.5}$

Ook was er een Australisch amendement dat suggereerde de term 'minimum standards laid down by the state' uit ontwerpartikel 28 te vervangen door de zinsnede 'minimum educational standards approved by the state' ${ }^{256}$ De bedoeling hiervan was tegemoet te komen aan de formele situatie zoals die in verschillende landen gold. In verschillende staten, waaronder Australië, bepaalde de staat niet de minimumnormen op het gebied van het onderwijs voor privé-scholen, maar keurde ze slechts goed indien ze voldeden aan de minimumnormen voor overheidsscholen. ${ }^{25}$ De Belgische delegatie stelde voor de term 'State' en 'establish' in paragraaf 8 van ontwerpartikel 28 te vervangen door de zinsnede 'the public authorities in each State to ensure', zodat paragraaf 8 er als volgt zou komen uit te zien:

'The obligations of the public authorities in each State to ensure a system of free and compulsory education shall not be deemed incompatible with the liberty of parents to choose for their children schools other than those established by the public authorities which conform to minimum standards laid down by the State. ${ }^{258}$

De bedoeling van het Belgische amendement was om duidelijk te maken dat in een aantal landen het onderwijs niet direct werd georganiseerd en verzorgd door de centrale overheid. Meestal werd deze taak overgelaten aan de regionale of lokale overheidsinstanties. De centrale overheid beperkte zich

255. E/CN.4/L.85 (2 meil 195.2).

256. E/CN.4/L.89 (2 meil 1952).

257. Whitlam (Australie), E/CN.4/SR.285, p. 6 (8 mei 1952); wie ook E/CN.4/SR.288, p. 7 (9 mei 1952.)

2.58. E/CN.4/L.95 (Belgie) (7 mei 1952) (de gecuraiveerde woorden zijn in de ariginele tekst onderstreept). 
tot het scheppen van de algemene voorwaarden ten behoeve van de structuur van het onderwijs. ${ }^{259}$

Bovendien suggereerde de Belgische afgevaardigde een ruimere formulering van de keuzevrijheid van de ouders aangaande het onderwijs voor hun kinderen. Een ruimere formulering was noodzakelijk om recht te doen aan de garantie van artikel 26 (3) Universele Verklaring. ${ }^{260}$ Het wijzigingsvoorstel luidde als volgt:

9. In the exercise of any functions which the State assumes in the field of education it shall respect the liberty of parents to ensure the education of their children in conformity with their own religious and philosophical convictions. ${ }^{261}$

Zowel het Britse, het Australische als de Belgische amendementen werden overgenomen in een Libanees ontwerpartikel voor een onderwijsbepaling. ${ }^{262}$ Het vrijheidsaspect van het recht op onderwijs was in de volgende woorden geformuleerd:

'In the exercise of any functions which they assume in the field of education, the States Parties to the Covenant undertake:

(b) to have respect for the right of parents to choose for their children schools other than those established by the public authorities which conform to the minimum educational standards approved by the State and to ensure the education of their children in conformity with their religious and philosophical convictions.'

De Libanese afgevaardigde lichtte toe dat het hier een onmiddellijke verplichting voor staten betrof, niet onderhevig aan de algemene beperking aangaande de verwezenlijking van economische, sociale en culturele rechten. ${ }^{263}$ De term 'undertake' was karakteristiek voor deze onmiddellijke verplichting. De uitbreiding van de bescherming tot filosofische overtuigingen werd door de Libanese Azkoul met de volgende woorden verdedigd:

'Some parents had strong convictions which might not necessarily be religious ones; it would be unfair to make an exception in favour of religious-minded parents alone. ${ }^{264}$

259. Nisot (België), E/CN.4/SR.285, p. 7 (8 mei 1952).

260. Op. cit.

261. E/CN.4/L.95; (de gecursiveerde woorden zijn in de originele tekst onderstreept).

262. E/CN.4/L.96 (8 meil 1952).

263. Azkoul (Libanon), E/CN.4/SR.286, pp. 11, 12 (8 mei 1952). Zie ook Azkoul, A/C.3/ SR.675, par. 31 (5 nov. 1954).

264. Aakoul (Libanon), E/CN.4/SR.287, p. 13 ( 9 mei 1952). 
Deze uitbreiding van de garantie tot filosof ische overtuigingen kon bij een aantal Commissieleden geen genade vinden. Zo stelde de Franse afgevaardigde onder meer:

'If the word "philosophical" was used to mean a concept of man and his destiny, freedom of choice in that respect might render States powerless in the face of abuses.

Freedom in education might lead to the establishment of schools teaching a philosophy completely opposed to (the aims of education) and producing a generation of racialists and totalitarians. ${ }^{265}$

De Libanese vertegenwoordiger Azkoul realiseerde zich waarschijnlijk dat zijn voorstel tot uitbreiding van de keuzevrijheid van ouders weinig kans zou maken in de Commissie. Daarom herzag hij zijn amendement en beperkte het tot de vrijheid ('liberty') van de ouders 'to ensure the religious education of their children in conformity with their own convictions" ${ }^{266}$ Dit impliceerde een beperking tot de religieuze aspecten van onderwijs en opvoeding. Over het woord 'religious' werd op verzoek van Joegoslavië af zonderlijk gestemd. Het werd door de Commissie aanvaard met 12 tegen 1 stem bij 5 onthoudingen. ${ }^{267}$

Nadat de Libanese afgevaardigde had toegestemd in enkele tekstuele wijzigingen in zijn amendement, werd het volgende ontwerpvoorstel aan de Commissie voorgelegd ter stemming:

'In the exercise of any functions which they assume in the field of education, the States Parties to the Covenant undertake to have respect for the liberty of parents, and, when applicable, legall guardians to choose for their children schools other than those established by the public authorities which conform to such minimum educational standards as may be laid down or approved by the State and to ensure the religious education of their children in conformity with their own convictions. $^{268}$

Deze bepaling vond brede instemming in de Commissie en werd aangenomen met 17 tegen 0 stemmen bij 1 onthouding. ${ }^{269}$

265. Juvigny (Frankrijk), E/CN.4/SR.288, p 9 (9 mei 1952). Zie ook de kritiek van Mevr. Roosevelt (V.S.), E/CN.4/SR.287, P. 7 (9 mei 1952).

De Egyptische afgevaardigde diende een sub-amendement in dat beoogde de strekking van de oorspronkelijike paragraaf 9 van het ontwerpartikel 28 te herstellen. Zie E/CN.4/L.97, en toelichting door het Egyptissche Commissielid Ammi Bey, E/CN.4/ SR.288, p. 5 (9 meil 1952).

266. E/CN $4 /$ L .96/Rev.1 (12 mei 1952).

267. E/CN.4/SR.290, p. 15 (12 mei 195.2).

268. E/CN.4/666/Add.4.

269. E/CN.4/SR.290, p. 15. Zie ook E/2256, par. 119-124, Commission on Human Rights. Report of the Eighth Session (1952). 
Geconcludeerd kan worden dat de discussie over het vrijheidsaspect van het recht op onderwijs in de Commissie langs dezelfde lijnen verliep als die in de verschillende organen van de Raad van Europa aangaande de totstandkoming van artikel 2 Eerste Protocol EVRM. De verschillende tekstvoorstellen waren met name afkomstig van vertegenwoordigers van westerse staten. De ontwerptekst die de Commissie aanvaardde was voor een deel gebaseerd op dat artikel 2 Eerste Protocol EVRM.

\subsubsection{Het sociale aspect van het recht op onderwijs tijdens de beraadsla-} gingen in de Derde Commissie van de Algemene Vergadering (1957)

Het duurde meer dan vijf jaren voordat de Derde Commissie van de Algemene Vergadering een bespreking kon wijden aan de onderwijsbepaling die inmiddels als ontwerpartikel 14 geregistreerd stond. Dat gebeurde op uitvoerige wijze. De Commissie had een achttal bijeenkomsten nodig om tot een slot-oordeel over artikel 14 te komen. ${ }^{270}$ De grote meerderheid van de delegaties betuigde instemming met ontwerpartikel 14. Ook makkten afgevaardigden van deze gelegenheid gebruik om voor een wereldforum duidelijk te maken dat de onderwijssituatie in hun land in overeenstemming was met de bepalingen van ontwerpartikel 14 . In het bijzonder de communistische en Latijnsamerikaanse staten lieten in dit opzicht van zich horen. ${ }^{271}$ Aan de andere kant was er een aantal ontwikkelingslanden dat te kennen gaf dat het nog geruime tijd zou vergen voor de bepalingen van artikel 14 in hun land werkelijkheid zouden zijn. ${ }^{272}$

Zoals gezegd onderschreven vrijwel alle staten de grondgedachte van artikel 14. Er bestonden slechts bezwaren tegen een aantal detailpunten in de tekst die evenwel van groot belang waren voor de toepassing en uitwerking van artikel 14 . Wat betreft het sociale aspect waren een paar amendementen relevant. Zo steldle het Verenigd Koninkrijk voor de aanhef van lid 2 van artikel 14 die oorspronkelijk luidde 'It is understood' te vervangen door de woorden 'the States Parties to the Covenant recognize'. ${ }^{273} \mathrm{De}$ bedoeling van deze wijziging was een term te gebruiken die een sterkere juridische betekenis zou hebben. Dit amendement was reeds door de Engelse vertegenwoordiger in de Commissie voor de Rechten van de Mens in 1952 aangekondigd.

270. Zie A/3664, par. 6. Report of the Third Committee, General Assembly, Twelfth Session (1957). Inmiddels was de beslissing genomen orm twee afzonderlijke verdragen op te stellen. Oorspronkelijk ontwerpartikel 28 had nu nummer 14.

271. Zie bijwoorbeeld de opmerkingen van de afgevaardigde van Bulgarije, A/C.3/SR.782, par. $10(16-10-1957)$, respectievelijk van de vertegenwoordiger van Venezuela, op. cit. par. 37.

272. Zile bijwoorbeeld de opmerkingen van de Irakese afgevaardigde, A/C.3/SR.783, par.
$42,44(16-10-1957)$. 273. A/C.3/L.621 (Verenigd Koninkrijk). 
Een ander substantieel wijzigingsvoorstel was afkomstig van Nederland. Het had betrekking op lid $2 b$ en $2 c$ van de door de Commissie voor de Rechten van de Mens aanvaarde tekst. Nederland stelde voor de woorden 'and shall be made progressively free' in beide bepalingen te vervangen door de zinsnede 'and measures shall be taken to ensure that no one shall be deprived of secondary education (higher education) for financial reasons only". ${ }^{274} \mathrm{De}$ Nederlandse vertegenwoordiger in de Derde Commissie, Prof. Beaufort, gaf de volgende toelichting bij het amendement:

'Its essence was that no person should be deprived of secondary or higher education for financial reasons only. The ways and means whereby that purpose was to be achieved were of secondary importance. ... the Netherlands delegation considered that it was not essential to grant free education in all cases and it believed that the contracting parties should have a certain measure of latitude in the methods used to achieve the purpose of the article. ${ }^{.275}$

Bij sommige delegaties in de Derde Commissie kon dit voorstel niet op begrip rekenen. Zo vond Tunesië het geen verbetering van de bestaande ontwerptekst van artikel 14. Volgens deze staat impliceerde het Nederlandse amendement 'that Governments were under an obligation to supply financial support for secondary or higher education to any persons lacking sufficient personal means for such education'.276

Ook de Belgische delegatie kwam met een amendement van dezelfde strekking als het Nederlandse. In dat wijzigingsvoorstel was evenwel het element van geleidelijke invoering van kosteloos onderwijs opgenomen, hetgeen ontbrak in het Nederlandse voorstel. ${ }^{277}$ De Belgische woordvoerder meende dat 'the provision of free education should be regarded as a means rather than an end in itself, since in higher education, for example, the same result could be achieved by instituting an in-training wage'. ${ }^{278}$

274. A/C.3/L.618 (Nederland).

Dit amendement was gebaseerd op het commentas van de Nederlandse regering op de ontwerp-mensenrechtenverdragen zoals die door de Commissie voor de Rechten van de Mens waren opgesteld. Zie A/2910/Add.3 (13-09-1955).

275. Beaufort (Nederland), A/C.3/SR.781, par. 2, 3 (15-10-1957).

Het amendement beoogde de tekst van artikel 14 in overeenstemming te brengen met de situatie in Nederland.

276. Messadi (Tunesië), A/C.3/SR.783, par. 3 (16-10-1957).

Ook de Poolse vertegenwoordiger maakte om andere redenen bezwaar tegen het $\mathrm{Ne}$ derlandse amendement, A/C.3/SR.783, par. 22. Zie anderzijds de ondersteunende opmerkingen van de Britge afgevaardigde Hoare, op. cit. par. 50 en 51.

277. A/C.3/L.623 (België).

Het amendement luiddle als volgt:

"2(b) That secondary education, in its different forms, including technical and professional secondary education, shall be made generally available and aceessible to all by various methods, including the progressive introduction of free education.'

Dezelfde termen werden gebruikt voor het hoger onderwijs.

278. Ciselet (België), A/C.3/SR.782, par. 17 (16-10-1957). 
De Roemeense delegatie stelde voor een nieuw lid aan artikel 14 toe te voegen. Het voorstell luidde als volgt:

'The States Parties to this Covenant undertake to ensure enjoyment of the right to education by such measures as the development of a system of schools at all levels, an adequate fellowship system and the continuous improvement of the material conditions of the teaching staff so as to enable them properly to discharge their functions. ${ }^{279}$

De Roemeense vertegenwoordiger in de Commissie rechtvaardigde het opnemen van een nieuwe bepaling in artikel 14 op de volgende wijze:

'it was not enough to state principles; it was necessary to specify the measures that should be taken by the State if the right to education was not to remain an empty promise. 280

In feite betrof het Roemeense voorstel een aantal implementatie-bepalingen ten behoeve van de verwezenlijking van het recht op onderwijs op nationaal niveau. De Roemeense suggestie stuitte op grote bezwaren bij voornamelijk westerse staten. Het werd niet wenselijk geacht nog een bepaling toe te voegen aan een toch al lang artikel. Bovendien impliceerde het Roemeense voorstel een onmiddellijke verplichting in plaats van het voorschrijven van geleidelijk te nemen maatregelen. Een ander punt was dat rechten in algemene termen geformuleerd dienden te worden; specifieke implementatie maatregelen waren in dat verband niet op hun plaats. Ook achtte men de bepaling aangaande het verbeteren van de materiële omstandigheden van onderwijzend personeel in artikel 14 misplaatst. Tenslotte zou het Roemeense voorstel herhalend zijn ten opzichte van de bepalingen 7 ('just and favourable conditions of work') en 11 ('adequate standard of living'). ${ }^{281}$

De Commissie stelde een werkgroep in die probeerde de verschillende amendementen en de bestaande tekst van ontwerpartikel 14 met elkaar in overeenstemming te brengen. ${ }^{282}$ De werkgroep kwam aangaande het sociale aspect van het recht op onderwijs met de volgende aangepaste tekst:

279. A/C.3/L.620 (Roemeniê).

280. Malitga (Romenie), A/C.3/SR.782, par. 21 (16-10-1957).

281. De bezwaren zijn vooral onder woorden gebracht door de Britse vertegenwoordiger Hoare. Zie A/C.3/SR.783, par. 52 (16-10-1957) en A/C.3/SR.788, par. 37 (23-101957). Ook de Nederlandse afgevaardigde Beaufort keerde zich tegen de Roemeense - uggestie, tie hierover de Rede van Beaufort in Commissie III op 22 oktober 1957; tekst in: Uitgaven van het Ministerie van Buitenlandae Zaken, No. 54, p. 419 (Bijlage 76). Nederland zou dan ook later tegen deze tekst (artikel 14(2) sub e) stemmen. Andere staten, zoals Canada, Chill, El Salvador, Frankrijk, India, Japan, Australië en Nieuw-Zeeland, waren eveneens tegen.

282. Zie A/3664, par. 27, 28 (Report of the Third Committee, 1957). 
'The States Parties to the Covenant recognize:

(a) That primary education shall be compulsory and available free to all.

(b) That secondary education, in its different forms, including technical and vocational secondary education, shall be made generally available and accessible to all by every appropriate means, and in particular the progressive introduction of free education.

(c) That higher education shall be made equally accessible to all, on the basis of capacity, by every appropriate means, and in particular the progressive introduction of free education.

(d) That fundamental education shall be encouraged or intensified for those persons who have not received or completed the whole period of their primary education.

(e) That, to achieve these objectives, the development of a system of schools at all levels shall be actively pursued, an adequate fellowship system shall be established, and the material conditions of teaching staff shall be continuously improved. ${ }^{283}$

Gesteld kan worden dat de tekst van de paragrafen $2 b$ en $2 c$ enigszins in de richting gaat van het Nederlandse amendement. ${ }^{284}$ Om evenwel te concluderen, zoals het Nederlandse Ministerie van Buitenlandse Zaken deed, dat in de desbetreffende bepalingen de 'grondgedachte van het Nederlandse amendement was verwerkt' of dat de tekst 'het wezenlijke van het $\mathrm{Ne}$ derlandse amendement bevatte 285 is naar mijn mening nogal overdreven. Eerder lijkt het Belgische amendement de basis te zijn geweest voor de uiteindelijke formulering, vooral omdat het Belgische voorstel sprak van 'various methods, including the progressive introduction of free education". ${ }^{286}$

Artikel 14(2) zoals opgesteld door de Werkgroep, stipuleerde in de sub-paragrafen $b$ en $c$ dat secundair en hoger onderwijs 'shall be made generally available' respectievelijk 'shall be made equally accessible'. In de oorspronkelijke tekst van artikel $14(2 \mathrm{~b}$ en $\mathrm{c})$ stond daarentegen dat beide vormen van onderwijs, 'shall be generally available' respectievelijk 'shall be equally accessible'. De wijziging aangebracht door de Werkgroep introduceerde een element van geleidelijkheid bij de verwezenlijking van deze onderwijsgeledingen. ${ }^{287}$ Ook bevatte de ontwerptekst van de Werkgroep een nieuwe paragraaf (e) die uitdrukking gaf aan de elementen van het Roemeense voorstel.

283. A/C.3/L.625, Report of the Working Party on Article 14.

284. A/C.3/L.618.

285. Uitgaven Ministerie van Buitenlandse Zaken, No. 64, a.w. p. 196.

286. A/C.3/L.623.

287. Zie de opmerkingen van de vertegenwoordigster van Joegoslaviè, A/C.3/SR.784, par. 3 (18-10-1957) en van de afgevaardigde van Canada, A/C.3/SR.785, par. 14 (21-101957). De door de Werkgroep op dit punt aangebrachte wijgiging was gebaseerd op de tekat van het Belgische amendement, A/C.3/L.623. 
Naar aanleiding van de ontwerptekst voor artikel 14 zoals opgesteld door de werkgroep meende een aantal staten wijzigingen op deze tekst te moeten indienen. Zo stelde de Canadese delegatie voor aan de aanhef van lid 2 luidende: 'The State Parties to the Covenant recognize', de volgende formulering toe te voegen: 'with a view to achieving the full realization of this right". 288

Dit amendement beoogde te benadrukken dat de onderwijsniveaus genoemd in lid 2 op geleidelijke wijze ingevoerd konden worden. Dit bleek al duidelijk uit de tekst van lid $2 \mathrm{~b}$ en $2 \mathrm{c}$. De Canadese vertegenwoordigster makkte zich evenwel ook geen illusies over een snelle invoering van kosteloos primair onderwijs in verdragsstaten (lid 2a). Hoewel geformuleerd in mandatoire vorm, kon de bepaling niet onmiddellijk worden verwezenlijkt. ${ }^{289}$ Canada achtte het noodzakelijk artikel 14 zodanig te formuleren dat het in overeenstemming zou zijn met de algemene bepalingen van artikel 2(1) aangaande de verwezenlijking van de materiële rechten uit het Verdrag. 290

De Tunesische afgevaardigde was van mening dat de formulering van lid 2 (b) en (c):

'tended to impose upon each signatory State, not only the obligation of making secondary and higher education progressively free, but also the much wider and more indefinite obligation of making such education accessible to all by every appropriate means. ${ }^{291}$

Zulke veelomvattende verplichtingen konden jonge onafhankelijke landen onmogelijk op zich nemen. ${ }^{292} \mathrm{Er}$ werd ook een mondeling amendement gepresenteerd op artikel 14 (2d) door Saoedi-Arabië. Dit voorstel beoogde de woorden 'as far as possible' aan de tekst van de Werkgroep toe te voegen, 'since their elimination might have serious financial consequences for

288. A/C.3/L.627 (Canada); zie ook A/3764 en Add.1 (Report of the Third Committee, 1957), par. 33.

289. Quart (Canada), A/C.3/SR.785, par. 14 (21-10-1957).

290. Het Canadese amendement werd later aanvaard met 64 tegen 1 atem, bij 4 onthoudingen, zie A/C.3/SR.787, par. 45 (22-10-1957).

291. Messadi (Tunesie), A/C.3/SR.786, par. 20 (22-10-1957).

292. A/C.3/SR.786, par. 20. Tunesië stelde dan ook voor de oorspronkelijke formulering door de Commissie voor de Rechten van de Mens wan lid 2(b) en $2(c)$ te behouden. De Nederlandse afgevaardigde Beaufort benadrukte daarentegen nog eens dat het enige doell van de leden 2 (b) en 2 (c) zoals geformuleerd door de Werkgroep was 'to give to alll States a certain latitude in the choice of methods used to make secondary and higher education accessible to all'.

Zie A/C.3/SR.787, par. 7 (22-10-1957). De Tunesische afgevaardigde stemde uiteindelijk toch in met de door de Werkgroep voorgestelde tekst op voorwaarde dat staten en uitdrukkelijke keuzevrijheid zouden behouden aangaande de middelen ten behoeve van de invoering van secundair en hoger onderwijs, zie A/C.3/SR.787, par. 32 $(22-10-1967)$. 
States. ${ }^{293}$ In de Commissie bestond overeenstemming over de interpretatie van artikel 14 (2a). Men was het erover eens dat basisonderwijs slechts kosteloos diende te zijn in openbare scholen. ${ }^{294}$

Lid 2 van ontwerpartikel 14 , zoals gewijzigd, dat uitdrukking gaf aan het sociale aspect van het recht op onderwijs, werd door de Derde Commissie aangenomen met 64 stemmen vóor, geen stemmen tegen, bij 6 onthoudingen. ${ }^{295}$ Deze tekst werd later niet meer gewijzigd. $\mathrm{Zij}$ vormt nu lid 2 van artikel 13 van het IVESCR. De tekst luidt als volgt:

'The States Parties to the Covenant recognize that, with a view to achieving the full realization of this right:

(a) Primary education shall be compulsory and available free to all.

(b) Secondary education, in its different forms, including technical and vocational secondary education, shall be made generally available and accessible to all by every appropriate means, and in particular by the progressive introduction of free education.

(c) Higher education shall be made equally accessible to all, on the basis of capacity, by every appropriate means, and in particular by the progressive introduction of free education.

(d) Fundamental education shall be encouraged or intensified as far as possible for those persons who have not received or completed the whole period of their primary education.

(e) The development of a system of schools at all levels shall be actively pursued, an adequate fellowship system shall be established, and the material conditions of teaching staff shall be continuously improved.'

293. Baroody (Saoedi-Arabie), A/C.3/SR.785, par. 50 (21-10-1957). De woorden 'as far as possible' waren oorspronkelijk opgenomen in het ontwerpartikel 14 zoals opgesteld door de Commisaie voor de Rechten van de Mens. Het wijzigingavoorstel van SnoediArabië werd uiteindelijk bij de stemmingen aanvaard met 23 tegen 5 stemmen bij 39 onthoudingen.

294. Enige discussie ontstond naar aanleiding van een Panamees amendement dat luidde: 'Primary education shall be compulsory and shall be available free in the public schools', A/C.3/L.626. De meerderheid van de Commissie was van mening dat dit amendement overbodig was, omdat de oorspronkelijke tekst ook alleen betrekking had op kosteloos onderwijs in openbare scholen. Deze tekst impliceerde geen verplichting voor staten ook bijzondere acholen te aubsidiëren ten einde ook daar kosteloos onderwijs te verwezenlijken. Zie de opmerkingen van Chili, A/C.3/SR.785, par. 17 en die van de afgevaardigden van de Dominicaanse Republiek en van het Verenigd Koninkrijk A/C.3/SR.787, par 51 en 53 . De Nederlandse vertegenwoordiger merkte nog op dat de oorspronkelijke tekst niet verhinderde dat ataten niet-openbare scholen konden subsidiëren, als zij dat wensten, zie A/C.3/SR.787, par. 54. Het Panamese amendement werd verworpen met 30 tegen 20 stemmen bij 17 onthoudingen, sie op. cit. par. 50.

295. A/C.3/SR.788, par. 9 (23-10-1957).

De staten die sich onthielden van stemming waren Japan, Nederland, Tunesië, het Verenigd Koninkrijk, de Verenigde Staten en Australië. Nederland onthield qich van stemming, omdat het onowerkomelijke bezwaren had tegen lid $2(e)$ dat een aantal implementatiebepalingen bevatte, zie Uitgaven Buitenlandse Zaken No. 54, a.w. p. 198. 
Samenvattend kan worden gezegd dat de amendementen aangaande het sociale aspect van het recht op onderwijs die in de AV van 1957 ter sprake kwamen het geleidelijke karakter van de verplichting tot realisering van de verschillende onderwijsgeledingen benadrukten. Staten waren vooral hujverig grote financiële verplichtingen aan te gaan en bedongen een bepaalde mate aan beleidsvrijheid.

\subsubsection{Het vrijheidsaspect van het recht op onderwijs tijdens de beraadsla- gingen in de Derde Commissie van de Algemene Vergadering (1957)}

Het vrijheidsaspect van het recht op onderwijs zoals dat door de Commissie voor de Rechten van de Mens was geformuleerd omvatte de keuzevrijheid van de ouders aangaande het onderwijs voor hun kinderen, in het bijzonder ten aanzien van het godsdienstonderwijs. Over het algemeen vond deze bepaling instemming bij de leden van de Derde Commissie. Deze bepaling, ontwerpartikel 14 lid 3 , luidde als volgt:

'In the exercise of any functions which they assume in the field of education, the States Parties to the Covenant undertake to have respect for the liberty of parents and, when applicable, legal guardians, to choose for their children schools other than those established by the public authorities which conform to such minimum educational standards as may be laid down or approved by the State and to ensure the religious education of their children in conformity with their own convictions. ${ }^{296}$

Voor de Belgische delegatie was de keuzevrijheid van de ouders een principiële zaak. Godsdienstonderwijs mocht onder geen enkele omstandigheid verplicht worden gesteld. De Belgische vertegenwoordiger wenste deze keuzevrijheid niet slechts te beperken tot ouders met godsdienstige overtuigingen. $\mathrm{Zij}$ stelde dan ook voor lid 3 van ontwerpartikel 14 te wijzigen in de volgende termen 'in conformity with their religious and philosophical convictions', ${ }^{297}$ Deze formulering omvatte ook respect voor de keuzevrijheid van ouders met agnostische overtuigingen. ${ }^{298}$

De lerse afgevaardigde stelde voor in ontwerplid 3 het woord 'liberty" te vervangen door de term 'right'. ${ }^{299}$ Op deze wijze zou beter het recht van ouders tot uitdrukking worden gebracht hun kinderen volgens hun eigen wensen en overtuigingen op te voeden. Dit zou ook de mogelijkheid van thuisonderricht garanderen. ${ }^{300}$

296. A/2929 (1955), Chapter VIII, tekat van artikel 14 , in het bijzonder lid 3 .

297. A/C.3/L.623 (Belgie).

298. Ciselet (België), A/C.3/SR.782, par. 17 (16-10-1957).

299. A/C.3/L.617, punt 1 (Ierland).

300. MacEntee (lerland), A/C.3/SR.779, par. 15 (11-10-1957). 
Op juridische gronden maakte de vertegenwoordiger van El Salvador bezwaar tegen dit lerse amendement. Hij merkte in dit verband op:

'In legal terms, if a right was granted to one party, another party incurred a corresponding obligation. Accordingly, if parents had the right to ensure the religious education of their children in conformity with their own convictions, the State by implication incurred the obligation of providing such education on request. The real intention of the provision, however, was to leave parents free to ensure religious education outside State schools. ${ }^{, 301}$

De Ierse delegatie kwam nog met een ander voorstel. $\mathrm{Zij}$ suggereerde aan ontwerpartikel 14 een nieuw lid toe te voegen dat de vrijheid van particulieren zou inhouden eigen onderwijsinstellingen, waaronder vormen van thuis-onderwijs, te stichten en te beheren. De tekst van het Ierse voorstel was als volgt:

'No part of this Article shall be construed so as to interfere with the right of individuals or bodies to establish and control educational institutions, subject always to the requirement that every child shall receive that minimum of education established in the preceding paragraphs. ${ }^{302}$

Het voorstel beoogde het recht om te onderwijzen toe te voegen aan ontwerpartikel 14 dat veeleer het recht op toegang tot het onderwijs omschreef. ${ }^{303}$

De werkgroep uit de Commissie, belast met het reviseren van ontwerpartikel 14 aan de hand van de ingediende amendementen, ontwikkelde de volgende teksten ten behoeve van het vrijheidsaspect van het recht op onderwijs:

lid 3: 'The States Parties to the Covenant undertake to have respect for the right of parents and, when applicable, legal guardians, to choose for their children schools other than those established by the public authorities which conform to such minimum educational standards as may be laid down or approved by the State and to ensure the religious and moral education of their children in conformity with their own convictions.'

lid 4: 'No part of this Article shall be construed so as to interfere with the liberty of individuals and bodies to establish and direct educational institutions, subject always to the observance of the principles set forth

301. Lima (El Salvador), A/C.3/SR.783, par. 37 (16-10-1957). Zie in develfde zin Maheu (UNESCO), A/C.3/SR.781, par. 12 (15-10-1957).

302. A/C.3/L.617, punt 2 (Ierland).

303. MacEntee (lerland), A/C.3/SR.779, par, 14. Bij de sluiting van het Eerste Protocol EVRM maakte Ierland een voorbehoud bij de onderwijsbepaling (artikel 2) dat zelfde strekking had als de hier voorgestelde tekst, vgl. hoofdstuk 3.4 .5 supra. 
in paragraph 1 and to the requirement that the education given in such institutions shall conform to such minimum standards as may be laid down by the State. ${ }^{.304}$

De essentie van de Ierse en Belgische amendementen was opgenomen in het voorstel van de werkgroep. De vertegenwoordiger van El Salvador bleef bij zijn bezwaren tegen de term 'right' in lid 3. Hij diende een (mondeling) amendement in dat beoogde de term 'liberty' in lid 3 te behouden. ${ }^{305} \mathrm{Bij}$ de stemming over ontwerpartikel 14 werd dit amendement aangenomen met 34 tegen 19 stemmen, bij 15 onthoudingen. ${ }^{306}$ In de Commissie was men het erover eens dat lid 3 'should not be understood as imposing upon States Parties to the Covenant the obligation to provide religious education in public schools, ${ }^{307}$

In dit verband werd er nog eens door een aantal afgevaardigden op gewezen dat de vrijheid van ouders en de daarop gebaseerde onthoudingsverplichting van de staat een algemeen karakter hadden. Dat wil zeggen dat zij van toepassing waren op godsdienstig en zedelijk onderricht, zowel binnen als buiten schoolverband. ${ }^{308}$

De door de werkgroep opgenomen verwijzing in lid 3 naar 'moral education' leverde geen stof tot discussie meer op. Bij een afzonderlijke stemming werden deze woorden aangenomen met 39 tegen 9 stemmen bij 21 onthoudingen. ${ }^{309}$ Blijkbaar diende deze term om de niet haalbare verwijzing naar 'philosophical convictions' te compenseren.

Er waren slechts een paar staten die zich verzetten tegen de door de Werkgroep voorgestelde tekst voor lid 4, te weten de vrijheid van particulieren eigen onderwijsinstellingen te stichten. De kwestie werd door de meeste staten in het debat niet meer aangeroerd. Hieruit kan onverschilligheid of instemming met de betreffende clausule worden afgeleid. Tegen lid 4 werd onder meer aangevoerd dat de tekst overbodig zou zijn, omdat dezelfde vrijheid van particulieren ook al impliciet besloten lag in lid $3 .^{310}$ De Poolse afgevaardigde waarschuwde voor een wildgroei van particuliere scholen indien lid $4 \mathrm{zou}$ worden aanvaard. Dat zou evenwel onaanvaardbaar zijn voor landen met alleen maar staatsscholen. ${ }^{311}$ De Saoedi-Arabische verte-

304. A/C.3/L.625.

305. Lima (El Salvador), A/C.3/SR.785, par. 46.

306. A/3764 and Add.1, Report of the Third Committee, G.A. (XII) 1957, par. 49.

307. Idem, par. 47. Zie ook de opmerking van Isradlische afgevaardigde, A/C.3/SR.788. par. 21.

308. Zie over dit punt Uitgaven Miniaterie van Buitenlandse Zaken No. 54, a.w. p. 198.

909. A/3764 and Add.1, par. 49.

310. Zie over de opmerkingen van de afgevaardigde van Saodi-Arabie, A/C.3/SR.785, par. 45 en van de vertegenwoordiger van Marokko, A/C.3/SR.786, par. 16.

311. Krajewski (Polen), A/C.3/SR.785, par. 1. Hij voegde er aan toe dat hoewel Polen niet tot die groep landen behoorde, Polen toch tegen lid 4 zou stemmen. 
genwoordiger achtte het zelfs gevaarlijk particulieren de vrijheid te verlenen eigen scholen te stichten. Dat zou kunnen ontaarden in propaganda door allerlei belangengroeperingen. ${ }^{312}$

Lid 4 werd aangenomen met 27 stemmen vór, waaronder Nederland, en 23 stemmen tegen bij 25 onthoudingen. Het grote aantal onthoudingen gaf het gevoel van twijfel aan dat veel afgevaardigden hadden ten aanzien van de inhoud van lid 4 . De uiteindelijk aanvaarde leden 3 en 4 van de onderwijsbepaling luidden aldus:

lid 3: 'The State Parties to the Covenant undertake to have respect for the liberty of parents and, when applicable, legal guardians, to choose for their children schools other than those established by the public authorities which conform to such minimum educational standards as may be laid down or approved by the State and to ensure the religious and moral education of their children in conformity with their own convictions.'

lid 4: 'No part of this Article shall be construed so as to interfere with the liberty of individuals and bodies to establish and direct educational institutions, subject always to the observance of the principles set forth in paragraph 1 and to the requirement that the education given in such institutions shall conform to such minimum standards as may be laid down by the State.'

Resumerend was de zitting van de Derde Commissie van de AV in 1957 met betrekking tot het vrijheidsaspect van belang, omdat artikel 14 werd uitgebreid met het recht van individuele personen en rechtspersonen privéonderwijsinstellingen te stichten en te beheren.

Artikel 14 als geheel werd in de Derde Commissie aangenomen met 71 stemmen vóór, geen stemmen tegen, terwijl Australië, Tunesië, het Verenigd Koninkrijk en de Verenigde Staten zich van stemming onthielden. ${ }^{313}$

\subsubsection{Samenvattende opmerkingen}

Artikel 13 IVESCR aangaande het recht op onderwijs kende, evenals de andere bepalingen uit dit Verdrag, een lange wordingsgeschiedenis.

Het is een uitgebreide bepaling die naast verplichtingen voor staten en rechten voor individuen ook de doeleinden van het onderwijs vastlegt. Het artikel bevat eveneens een aantal implementatiebepalingen. Het normstellende werk werd verricht in de jaren 1951 en 1952 door de Commissie voor de

312. Baroody (Saoedi-Arabië), A/C.3 SR.788, par. 33 (23-10-1957).

313. Bij de aanvaarding van het IVESCR door de plenaire Algemene Vergadering in december 1966 was ontwerpbepaling 14 inmiddels artikel 13 geworden.

Australie en het Verenïgd Koninkrijk onthielden zich van stemming, omdat sij het niet eens waren met artikel 14 lid 2 sub e. Zij beschouwden deze bepaling als een implementatiebepaling die in het artikel over het recht op onderwijs nlet thuis hoorde. Zie A/C.3/SR.788, par. 36 en 37 . 
Rechten van de Mens. Daarbij vervulde de UNESCO een vooraanstaande rol. Deze organisatie bepleitte de formulering van gedetailleerde verplichtingen voor staten om op deze wijze de verwezenlijking van het recht op onderwijs voor een ieder te bevorderen. In 1957 bracht de Derde Commissie van de Algemene Vergadering van de Verenigde Naties enkele belangrijke bijstellingen aan in de tekst. Over het algemeen vond artikel 13 bij de grote meerderheid van de lidstaten van de $\mathrm{VN}$ instemming. Het was evenwel duidelijk dat het onderschrijven van de tekst nog niet betekende dat de onderwijssituatie in bepaalde staten nu meteen in overeenstemming zou zijn met de aanvaarde verplichting. Met name gold dit voor communistische staten en ontwikkelingslanden.

Artikel 13 bevat twee aspecten van het recht op onderwijs. Het sociale aspect komt vooral tot uitdrukking in lid 2 . Het impliceert een zorgplicht van de overheid om primair, secundair en hoger onderwijs beschikbaar en toegankelijk te maken. Daarbij hebben staten een zekere beleidsmarge, een zekere vrijheid in de keuze der middelen met het oog op de geleidelijke verwezenlijking van de vastgestelde doeleinden. Deze verplichtingen van de staat kunnen worden aangeduid als 'obligations of result'.

Het vrijheidsaspect is terug te vinden in lid 3 en 4 . Lid 3 kent twee aspecten: het recht van ouders onderwijs voor hun kinderen te kiezen dat niet van overheidswege wordt aangeboden, met daarnaast het recht van ouders de godsdienstige en zedelijke opvoeding van kinderen te verzekeren overeenkomstig hun eigen overtuigingen, ongeacht of men kiest voor openbaar dan wel voor niet door de staat verzorgd onderwijs. In lid $\mathbf{4}$ is de vrijheid tot het stichten van onderwijsinstellingen door particulieren uitdrukkelijk erkend. Dit vrijheidsaspect impliceert een onthoudingsplicht van de staat. De overheid heeft hier geen vrijheid in de keuze der middelen, voorall ook omdat het een onmiddellijke verplichting betreft.

\subsection{Het Internationaal Verdrag inzake Burger- en Politieke Rechten}

\subsubsection{Artikel 18 (4)}

Artikel 18 IVBPR kent een ieder het recht toe op vrijheid van denken, geweter en godsdienst. In lid 4 van deze bepaling verbinden staten zich de vrijheid van ouders of wettige voogden te eerbiedigen de godsdienstige en morele opvoeding van hun kinderen overeenkomstig hun eigen levensovertuiging te verzekeren. Het betreft hier een onthoudingsplicht voor de overheid met een onmiddellijk karakter.

Artikel 18 (4) maakte oorspronkelijk geen deel uit van de door de Commissie voor de Rechten van de Mens aanvaarde ontwerpbepalingen. ${ }^{314} \mathrm{Het}$ idee om een bepaling over de vrijheid van ouders aangaande de godsdien- 
stige en morele opvoeding van hun kinderen op te nemen in het Verdrag inzake Burger- en Politieke Rechten werd gelanceerd door Rapporteur Krishnaswami in zijn 'Study of Discrimination in the Matter of Religious Rights and Practices' uit $1960 .^{315}$ Hij suggereerde een bepaling op te nemen overeenkomstig ontwerpartikel 14 (3) van het Verdrag inzake Economische, Sociale en Culturele rechten.

Tijdens de Vijftiende Zitting van de Algemene Vergadering van de Verenigde Naties in 1960 diende de Griekse vertegenwoordigster in de Derde Commissie een amendement in dat beoogde aan artikel 18 een lid toe te voegen betreffende de keuzevrijheid van ouders. ${ }^{316}$ Het wijzigingsvoorstel was in vrijwel gelijke bewoordingen gesteld als ontwerpartikel 14(3) IVESCR. Een aantal afgevaardigden achtte een dergelijke bepaling in feite overbodig, omdat de betreffende vrijheid reeds werd gegarandeerd door artikel $14(3))^{317}$

Bovendien vroeg men zich af of een dergelijke bepaling wel op haar plaats was in een artikel betreffende de individuele vrijheid van denken, geweten en godsdienst. Het amendement voerde immers derden (ouders) ten tonele hetgeen afbreuk zou doen aan het idee van de individuele vrijheid. ${ }^{318}$ Anderzijds werd er op gewezen dat het in bepaalde gevallen aan te raden was in formulering sterk op elkaar lijkende bepalingen in elk der beide verdragen op te nemen. Het was immers niet denkbeeldig dat staten slechts bij één van beide verdragen partij zouden worden. ${ }^{319}$ Het Griekse voorstel voor een additionele paragraaf 4 werd in de Derde Commissie aanvaard met 30 tegen 17 stemmen bij 27 onthoudingen. ${ }^{320}$ Onder de tegenstemmers bevonden zich onder meer de communistische staten. Een groot aantal Derde Wereldlanden onthield zich van stemming. Nederland onthield zich eveneens, omdat de bepaling overbodig zou zijn ten opzichte van ontwerpartikel 14(3) IVESCR. Het uiteindelijk aangenomen artikel 18(4) luidde aldus:

'The States Parties to the present Covenant undertake to have respect for the liberty of parents and, when applicable, legal guardians to ensure the religious and moral education of their children in conformity with their own convictions.'

Volgens Van Boven heeft de term 'education' in artikel 13 (3) IVESCR een enge betekenis in de zin van 'teaching and instruction', dus betrekking

315. Vermeld door Th.C. van Bowen, De volkenrechtelijke bescherming van de godsdienstvrijheild, diss. Assen 1967, p. 156.

316. Zie Uitgaven van het Miniaterie van Buitenlandge Zaken, nr. 67, p. 127. Zie ook van Boven, aw. p. 156.

317. Zo ook de Nederlandse vertegenwoordiger in Commissie III, zie rede van de heer Boersma op 17 november 1960 . Uitgave mr. 67 , bijlage 78 .

318. Uitgave nr. 67, a.w. p.128.

319. Van Boven, a.w. p. 156.

320. Uitgave nr. 67, p. 129. 
hebbend op 'onderwijs'. De term 'education' in artikell 18 (4) IVBPR zou dan een ruimere betekenis hebben, betrekking hebbend op de meer intieme zaak van de opvoeding van de kinderen. ${ }^{321}$ De stellingname van Van Boven ten aanzien van artikel 18 (4) lijkt mij juist; op zijn opvatting ten aanzien van artikel $13(3)$ is wel het een en ander af te dingen. De Nederlandse vertaling van artikel 13 (3) IVESCR spreekt namelijk van "godsdienstige en zedelijke opvoeding'. Ook hier gaat het mijns inziens om het ruimere begrip 'education', dat zowel onderwijs als opvoeding omvat. In dit verband zij erop gewezen dat:

"paragraph 3 of Article 14 (nu 13, A.C.) represents what was felt to be the most realistic and equitable way of expressing the content of Article 26 , paragraph 3 , of the Universal Declaration of Human Rights. ${ }^{, 322}$

Artikel 26 (3) impliceert eveneens de ruimere betekenis van het woord 'education', in de Nederlandse vertaling 'opvoeding en onderwijs'.

Tenslotte dient te worden opgemerkt dat in artikel 18, lid 1,2 en 3 de term 'religion or belief' (godsdienst of levensovertuiging) wordt gebezigd. De betekenis van de woorden 'religious and moral education' in artikel 18 (4) moet dan ook worden geïnterpreteerd in de zin van de term 'religion or belief', gezien het gebruik van deze term in de overige leden van artikel $18 .^{923}$.

\subsubsection{Artikel 27}

Het Internationale Verdrag inzake Burger- en Politieke Rechten bevat nog een bepaling die genoemd moet worden bij een bespreking van de internationale regeling van het recht op onderwijs. Het gaat om artikel 27 dat aan leden van minderheden een aantal rechten toekent. Hoewel de bepaling niet expliciet het recht op onderwijs van leden van minderheden erkent ligt dit toch besloten in de formulering van de bepaling. ${ }^{324}$ Leden van etnische

321. Van Boven, a.w. p. 167.

322. A/2929, chapter VIII, par. 45 (1956). Zie ook hiervóor, hoofdituk 3.3.2.

32.3. Van Boven; a.w. p. 167.

324. De tekst van artikel 27 luidt:

In staten waar tich etnische, godsdienstige of linguiatiache minderheden bevinden, mag aan personen die tot die minderheden behoren niet het recht worden ontegd, in gemeenschap met de andere leden van hun groep, hun eigen cultuur te belleven, hun eigen godedienst te belijden en in de praktijk toe to passen, of aich van hun eigen taal te bedienen.'

Zie over onderwijerechten van minderheden: F. Coomans, Volkenrechtelijke aspecten van onderwijarechten van minderheden, in: Nederlands Tijdschrift voor Onderwijsrecht, 1990, pp. 5-21. Zile voorta over artikel 27, C. Tomuachat, Protection of Minorities under Article 27 of the International Covenant on Civil and Political Rights, in: Volkerrecht als Rechtsordnung Internationale Gerichtsbarkeit Menschenrechte; Festschrift fur Herman Mosler, Heidelberg 1983, pp. 949-980, en L.B. Sohn, The Rights of Minorities, in: L. Henkin (ed.), The International Bill of Rights, The Covenant on Civil and Political Rights, New York 1981, pp. 270-289. 
minderheden streven er veelal naar de eigen cultuur in al haar veelvormigheid en verscheidenheid te bewaren, dan wel te versterken. Linguïstische minderheden beogen de eigen taal te behouden en te gebruiken. Religieuze minderheden willen garanties voor de beleving van hun godsdienst door onder meer de eredienst en onderricht. Bij al deze aspecten van de eigen identiteit van minderheden speelt het onderwijs een centrale rol. Onderwijs vormt immers één van de essentiële middelen tot het behoud van de identiteit en levensstijl van de minderheden.

Over het algemeen stellen staten zich terughoudend op ten aanzien van de erkenning van specifieke rechten van minderheden. Deze terughoudendheid vindt haar oorsprong in de vrees van staten dat de uitoefening van deze rechten zou kunnen leiden tot een groeiend zelf bewustzijn van minderheden met als gevolg aanspraken op autonomie en zelf beschikking. In de opvatting van staten zijn die aanspraken onverenigbaar met het streven naar of het behoud van nationale eenheid. Bovendien zou de territoriale integriteit daarmee op het spel worden gezet. Onderwijs in de eigen taal en cultuur van de minderheid zou het besef van de eigen identiteit alleen maar versterken. Staten waren bereid rechten van individuen te erkennen, maar geen collectieve rechten van minderheden. ${ }^{325}$

De kwestie van onderwijsrechten van leden van minderheden speelde een rol tijdens de bijeenkomsten van de Sub-Commissie inzake Voorkoming van Discriminatie en Bescherming van Minderheden en de Commissie voor de Rechten van de Mens die gewijd waren aan het opstellen van het IVBPR. De basis voor de beraadslagingen in de Commissie was een resolutie van de Sub-Commissie waarin gesuggereerd werd de volgende bepaling in een verdrag op te nemen:

'Persons belonging to ethnic, religious or linguistic minorities shall not be denied the right, in community with the other members of their group, to enjoy their own culture, to profess and practise their own religion, or to use their own language. ${ }^{326}$

De zinsnede 'persons belonging to' had de bedoeling duidelijk te maken dat niet minderheden als zodanig dragers van rechten waren, maar integendeel individuele leden van minderheden. De clausule 'in community with the other members of their group' handhaafde daarentegen het idee van minderheden als afzonderlijke groepen. ${ }^{327}$

325. Zie hierover, M. Moskowitz The Politics and Dynamics of Human Rights, Dobs Ferry, New York 1968, pp. 155-173.

326. Sub-Commission on the Prevention of Discrimination and Protection of Minoritiea, Fourth Session (1951), Res. E (III). Zie ook UN Doc. E/2256, Annex II.

327. Beïde zinsnedes werden gesuggereerd door Mevr. Monroe, deskundige uit het Verenigd Koninkrijk. In mensenrechtenverdragen wordt steeds gesproken over de individuele leden van minderheden als dragers van rechten, weliswaar in gemeenschap met de andere leden van de groep. De mensenrechtenverdragen kennen geen rechten toe

(Wordt vervolgd...) 
De Commissie voor de Rechten van de Mens besteedde tijdens haar negende zitting in 1953 aandacht aan de minderhedenbepaling. De SovjetUnie kwam tijdens de zitting met een voorstel waarin het recht van minderheden op eigen onderwijsvoorzieningen een prominente plaats had gekregen. De tekst luidde aldus:

'The State shall ensure to national minorities the right to use their native tongue and to possess their national schools, libraries, museums and other cultural and educational institutions. ${ }^{328}$

Dit voorstel gebruikte heel bewust de term 'to ensure', dat wil zeggen 'verzekeren', om aan te geven dat de staat verplicht was tot het nemen van positieve maatregelen ten behoeve van de eigen onderwijsinstellingen voor minderheden. De Sovjet-vertegenwoordiger in de Commissie, Morosov, was van mening dat de culturele ontwikkeling van minderheden onmogelijk was zonder geschikte onderwijsinstellingen. ${ }^{329}$ Hij merkte verder op dat de tekst van de Sub-Commissie opgesteld was in negatieve termen en niet inging op de implementatie van de rechten. Hij voegde daar aan toe:

'It was necessary to make it plain that the rights of minorities should be assured to them by special legislation by the State concerned. ${ }^{330}$

Morosov maakte niet duidelijk of de verzekering van de rechten van minderheden door de staat ook financiële verplichtingen impliceerde. Immers, voor sommige minderheden heeft het recht op eigen onderwijsinstellingen pas praktische betekenis indien de staat de oprichting van die instellingen financieel ondersteunt.

Een ander voorstel waarin de onderwijsrechten van minderheden omschreven waren was afkomstig van Joegoslavië. Hoewel het recht op eigen onderwijsinstellingen niet uitdrukkelijk opgenomen was lag dit wel besloten in de strekking van de tekst. Het voorstel luidde als volgt:

'Every person shall have the right to show freely his membership of an ethnic or linguistic group, to use without hindrance the name of his group, to learn the language of this group and to use it in public or

3:27. (...vervolg)

an minderheidsgroepen als zodanig. Dit uitgangspunt wordt ook hier gebezigd. Indien sprake is van rechten van minderheden dan worden de individuele leden van die minderheidsgroeperingen bedoeld.

328. Doc. E/CN.4/L.222.

329. Morosov, E/CN.4/SR.368, p. 4

Het Sovjet-vooratel werd sterk ondersteund door de vertegenwoordiger van Polen. Hij onderstreepte dat de rechten van minderheden niet het karakter haddem van privilegee, sie E/CN.4/SR.369, p. 4.

330. Morosov, E/CN.4/SR.370, p. 11. I.L. Claude, National Minorities: an international problem, Cambridge, Mass. 1965, pp. 165, 166 gat nader in op het officiële Sovjetstandpunt ten gunste van de toekenning van positieve rechten aan minderheden. 
private life, to be taught in this language, as well as the right to cultural development together with other members of this group, without being subjected on that account to any discrimination whatsoever, and particularly such discrimination as might deprive him of the rights enjoyed by other citizens of the same State. ${ }^{, 331}$

Het Joegoslavische voorstel ging uit van het individu als lid van de groep, zonder evenwel rechten toe te kennen aan de groep als zodanig. De tekst erkent de rechten van leden van minderheden, maar geeft de staat geen opdracht bij te dragen aan de verwezenlijking van deze rechten.

In de Commissie voor de Rechten van de Mens waren vooral de communistische staten pleitbezorgers van de rechten van minderheden. $\mathrm{Zij}$ waren ook voorstander van de verplichting voor staten positieve matregelen te nemen ter bescherming van de rechten van minderheden. De meerderheid van de staten die vertegenwoordigd waren in de Commissie, in het bijzonder de westerse en de Latijnsamerikaanse landen, streefden naar assimilatie van minderheden. Bijzondere rechten voor minderheden werden door die groep afgewezen. ${ }^{332} \mathrm{Zij}$ wensten slechts een garantie van non-discriminatie, van negatieve gelijkheid voor minderheden. Verder wilden zij niet gaan. Deze opvatting werd treffend onder woorden gebracht door Diaz-Casanueva, afgevaardigde van Chili. Hij merkte op:

'Certain minorities might seek more than non-discrimination, wishing to secure privileges which would evolve into a different type of rights from those enjoyed by the national community as a whole. The recognition by the State of what he would describe as 'super' rights would imply the provision of special services and special institutions at extra expense, and entailing special legislation. That process might well culminate in a minority's claiming autonomy within the State. His delegation was fully prepared to concede the principle of non-discrimination, but it was firmly opposed to the grant of special prerogatives which might well create many difficult problems. ${ }^{, 333}$

Het verzet van de westerse en Latijnsamerikaanse landen richtte zich ook tegen een mogelijk actieve betrokkenheid van de staat bij het stichten van onderwijsvoorzieningen voor minderheden. De Franse vertegenwoordiger, Juvigny, gaf hierover de volgende uiteenzetting:

331. Doc. E/CN.4/L.225.

332. Zie woor het westers standpunt, Claude, a.w. p. 166.

333. Diaz-Casanueva (Chili), E/CN.4/SR.368, p. 9.

De westerse delegatie keerden zich vooral tegen het Sovjet ontwerpvoorstel, zie bijvoorbeeld de opmerkingen van de Britse afgeviardigde Hoare, E/CN.4/SR.389, pp. 5, 6. 
'Another problem of balance was that of the right of minorities to their own educational establishments. It was a right which, as the Yugoslav representative had correctly pointed out, must be combined with the right of minority members to attend schools intended for the seneral population. There was a danger, however, in asking a State to guarantee the right of minorities to their own educational establishments; for a State might deliberately encourage a policy designed to isolate the different population groups, a process which, while it might perhaps protect the culture of the minority group, would also limit its members' opportunities of entering the public service. The safeguarding of the cultural interests of the minority group would then conflict with the protection of its right to full participation in the public life of the nation. . $^{334}$

Ten aanzien van de kwestie van onderwijsrechten wilde de meerderheid van de Commissie niet verder gaan dan de formulering zoals voorgesteld door de Sub-Commissie. Het Philippijnse lid van de Commissie interpreteerde deze tekst als een recht voor linguïstische minderheden 'to use their language among themselves and in their schools, but would not commit governments to providing special schools for them, ${ }^{335}$ De meerderheid van de Commissie was dus voorstander van beperkte rechten van minderheden op eigen onderwijsvoorzieningen. Die konden door de minderheden zelf gesticht worden met eigen kapitaal, zonder financiële betrokkenheid van de staat. Men hield vast aan het non-discriminatiebeginsel ter verwezenlijking van de negatieve gelijkheid. Bijzondere maatregelen met het oog op het tot stand brengen van positieve gelijkheid en bescherming van minderheden vonden in de Commissie onvoldoende steun. ${ }^{336}$

Chili stelde voor het tekstvoorstel van de Sub-Commissie vooraf te laten gaan door de volgende formulering: "In those States in which ethnic,

394. Juvigny (Frankrijk), E/CN.4/SR.368, p. 16.

336. Ingles (Philippijnen), E/CN.4/SR.370 p. 9.

336. Het Sovjet vooratel werd verworpen met 8 tegen 4 stemmen, bij 4 onthoudingen. Het voorstel van de Sub-Commisile, later gewijzigd door een amendement van Chili, werd viteindelijk aanvaard met 12 tegen 1 stem, bij 3 onthoudingen. De tekst van het latere artikel 27 stiond toen vast. Zie E/CN.4/SR.371, pp.6, 7.

Het beleld van de Verenigde Naties ten anzien van minderheden werd door Claude als volgt gekarakteriseerd (p. 169):

"It is to be the international policy to stablish a standard of human rights to be granted to all persons on an equal basis, to refrain from recognizing any right of minorities to expect from their governments a pattern of differential treatment favorable to the perpetuation of their culture, and implicitly to endorse domestic policies of assimilation."

Claude is verder van mening dat het minderheden-vraagstuk bij uitstek een politiek probleem is. Hij merkt op dat de kwestie in de ideologiache strijd tussen de SovjetUnie en de Verenigde Staten en hun bondgenoten een belangrijke rol speelde. Het vraagstuk werd door beide mogendheden voor het forum van de VN gebracht, niet met de bedoeling om er een oplossing voor te vinden, maar om het te gebruiken als politiek wapen. Zie Claudle, a.w. pp. 169-176. 
religious or linguistic minorities exist: ${ }^{\mathbf{3 3 7}}$ Daarmee beoogdle Chili aanspraken van immigranten op eigen rechten als minderheden tegen te gaan. Op deze wijze moest de nationale eenheid van staten worden behouden en het streven van immigranten om de status van afzonderlijke gemeenschappen te verwerven worden beteugeld. De minderhedenbepaling zou slechts betrekking moeten hebben op de traditionele minderheden die van oudsher in een staat woonachtig waren. Het Chileense voorstel werd in de Commissie aanvaard zodat de minderhedenbepaling nu als volgt luidde: ${ }^{338}$

'In those States in which ethnic, religious of linguistic minorities exist, persons belonging to such minorities shall not be denied the right, in community with the other members of their group, to enjoy their own culture, to profess and practise their own religion, or to use their own language.'

De minderhedenbepaling zoals die was aanvaard door de Commissie voor de Rechten van de Mens stond in 1961 ter discussie in de Derde Commissie van de Algemene Vergadering van de VN. De bepaling werd door het overgrote deel van de delegaties onderschreven. Men betuigde instemming met het beginsel van non-discriminatie; de gedachte om positieve maatregelen te nemen door de staat met het oog op de bescherming van minderheden vond nauwelijks steun. ${ }^{339}$ Het mag dan ook geen verbazing wekken dat de ontwerpbepaling ook in de Derde Commissie brede instemming vond. $\mathrm{Zij}$ werd zonder wijzigingen aangenomen met 80 stemmen vóor geen tegen bij éen onthouding. ${ }^{340}$ Deze bepaling werd later artikel 27 IVBPR.

\subsubsection{Internationale jurisprudentie over onderwijsrechten van minderhe- den: Minderhedenscholen in Albanië}

Het vraagstuk van de bescherming van leden van minderheden is al een oud probleem dat reeds vóór de Tweede Wereldoorlog door internationale overeenkomsten geregeld werd. In deze paragraaf zal worden ingegaan op

337. Doc. E/CN./4/L.261; later mondeling gewijgigd door de Chileense afgevaardigde: gie Doc. E/CN.4/SR.371., p. 4.

338. Doc. E/CN.4/SR.371. p. 6. Het Chileense amendement werd aangenomen met 5 tegen én bij tien (1) onthoudingen.

339. Zie Doc. A/C.3/SR.1103 en 1104. Zile in dit verband R. Cholewinski, State Duty towards Ethnic Minorities: Positive or Negative?, in: Human Rights Quarterly, Vol. 10 (1988), pp. \$44-371. Uit de praktijk van staten zoals deze blijkt uit statenrapporten op grond van het IVBPR en de praktijk van het Mensenrechtencomite concludeert Cholewinski dat artikel 27 IVBPR dynamisch gelnterpreteerd moet worden. Dat wil zeggen, artikel 27 impliceert een plicht voor staten positieve maatregelen te nemen ten gunste van minderheden. Zie in gelijke zin, Coomans, a.w. pp. 13-18.

340. Doc. A/C.3/SR.1104, par. 52. Ook de vertegenwoordiger van de Sovjet-Unie ondersteunde de ontwerpbepaling. Wel waarschuwde hij tegen gedwongen assimilatie van minderheden.

Zie A/C.3/SR.1104, par. 10, 11. 
de bescherming van rechten van leden van minderheden, in het bijzonder op hun onderwijsrechten. Dat gebeurt aan de hand van de bespreking van een uitspraak van het Permanente Hof van Internationale Justitie over minderhedenscholen in Albanië. Deze kwestie komt op deze plaats aan de orde, omdat dit vraagstuk aansluit bij de bespreking van (onderwijs)rechten van leden van minderheden ingevolge artikel 27 IVBPR.

De moderne bescherming van de rechten van minderheden nam een aanvang met de zogenaamde minderhedenverdragen van ná de Eerste Wereldoorlog gesloten onder auspiciën van de Volkenbond. ${ }^{341}$ Deze internationale overeenkomsten tussen de geallieerde mogendheden enerzijds en nieuwe of territoriaal vergrote staten anderzijds bevatten belangrijke bepalingen aangaande de bescherming van etnische, godsdienstige en linguistische minderheden. Deze verdragen stoelden op twee algemene beginselen betreffende de behandeling van minderheden. Enerzijds legden de verdragen het non-discriminatiebeginsel vast. $\mathrm{Zij}$ beoogden de verwezenlijking van gelijke behandeling van leden van minderheidsgroeperingen en de meerderheid van de bevolking. Dit idee kan worden omschreven als het beginsel van 'negative equality'. Anderzijds bevatten de overeenkomsten bepalingen betreffende bijzondere maatregelen ten gunste van de bescherming van leden van minderheden. Deze gedachte kan worden aangeduid als het beginsel van 'positive equality. ${ }^{, 342}$ Deze laatste term impliceert de daadwerkelijke, feitelijke gelijkheid van leden van minderheden ten opzichte van andere inwoners van de staat. Daartoe dienden staten positieve maatregelen te nemen.

Ten aanzien van de kwestie van onderwijsrechten waren de verdragen tamelijk uitvoerig. De minderhedenverdragen bevatten alle het recht van leden van minderheden om op eigen kosten, scholen te stichten ${ }^{343}$ Het betrof hier een aspect van 'negatieve gelijkheid'. Elk minderhedenverdrag kende daarnaast een tweetal bepalingen dat de positieve gelijkheid van leden van minderheden beoogde te verzekeren ten opzichte van de meerderheid van de bevolking. De staat diende, in de gebieden waar de minderheid leefde, zorg te dragen voor onderwijs in de taal van de minderheid, althans in het openbaar lager onderwijs, naast onderwijs in de officiële nationale taal. Bovendien bevatten de verdragen een verplichting voor de staat financieel bij te dragen aan de verwezenlijking van onderwijsfaciliteiten voor minderheden. ${ }^{344}$ De Azcárate merkt op dat minderheden over het

341. Zie over de bescherming van minderheden in het interbellum, W. Mckean, Equality and Discrimination under International Law, Oxford 198s, hoofdatuk 1 en 2.

342. Zie F. Capotorti, Study on the Right of Persons belonging to Ethnic, Religious and Linguiatic Minorities, UN Doc. E/CN.4/Sub.2/384/Rev.1 (Sales no. E. 78 XIV. 1), par. 99, 100; zie ook P. de Azcarate, League of Nations and National Minorities, an experiment, Washington $1946, \mathrm{pp}, 59,60$ en I.L. Claude, National Minorities: an international problem, Cambridge, Mass. 1969 (1955), pp. 18, 19.

343. Zie de publikatie van de Volkenbond, The League of Nations and the Protection of Minorities of Race, Language and Religion, Geneva 1927, p. 22.

344. Zie League of Nations publikatie, a.w. p. 23 en Capotorti, a.w. par. 99. 
algemeen meer belang hechtten aan hun recht eigen scholen te stichten zonder inmenging van de staat dan aan hun recht op financiële ondersteuning door de overheid. Dit laatste impliceerde immers ook bemoeienis van en controle door de staat met het functioneren en de inhoud van het onderwijs. In hun eigen scholen konden minderheden meer en beter inhoud geven aan het onderwijzen van de eigen taal en cultuur dan in het openbare stelsel. ${ }^{345}$

Het Permanente Hof van Internationale Justitie heeft in het interbellum een aantal belangrijke 'advisory opinions' gegeven over de status en de rechten van minderheden volgens regels van internationaal recht. Het betrof veelal de interpretatie van bepalingen uit de minderhedenverdragen van ná de Eerste Wereldoorlog. Ook de kwestie van de onderwijsrechten van minderheden werd door het Hof geanalyseerd. De verzekering van het onderwijs en de opvoeding in de geest en volgens de traditie van de groep vormden volgens het Hof in dit verband de essentie van de rechten van minderheden. ${ }^{346}$

Het Hof heeft zich voorts uitvoerig met de kwestie van onderwijsrechten van minderheden bezig gehouden in de zaak van de Minderhedenscholen in Albanië. ${ }^{347}$ Kort samengevat waren de feiten in deze zaak als volgt. In 1933 werd de Albanese grondwet gewijzigd. Deze wijziging hield onder meer in de afschaffing van alle vormen van privé-onderwijs in Albanië. ${ }^{348}$ In de Albanese Eenzijdige Verklaring aangaande de Bescherming van Minderheden van 2 oktober 1921 was evenwel de volgende bepaling opgenomen:

'Article 5(1):

Albanian nationals who belong to racial, religious or linguistic minorities will enjoy the same treatment and security in law and fact as other

345. De Azcarate, a.w. pp. 83, 84; zie ook pp. 77-80. De Azcarate was in die tijd directeur van de Minderhedenafdeling van de Volkenbond.

346. Zile Permanent Court of International Justice, Advisory Opinion in the Greco-Bulgarian Communities Case, 31 juli 1930 (Series B, no, 17, 1930). Tekst in: Hudson, World Court Reports, vol. 2 (1935), p. 641 e.v.

347. Permanent Court of International Justice, Advisory Opinion on Minority Schools in Albania, 6 April 1935 (Series A-B, no. 64). Tekst in: Hudson World Court Reports, vol. 3 (1938), pp. 484-512. Zie over deze zaak M. Vierheilig, Minority Schools in Albania (Advisory Opinion), in: R. Bernhardt (ed.), Encyclopedia of Public International Law, vol. 2, Amsterdam 1981, pp. 191-192. Andere 'advisory opinions', ower minderheden-kwesties waren bijvoorbeeld: Access to German Minority Schools in Polish Upper Silesia, (P.C.I.J) 1931, Series A-B no. 40; en Treatment of Polish Nationals and other Persons of Polish Origin or Speech in Danzig, (P.C.I.J.) 1932, Series A-B no. 44.

348. Het relevante artikel uit de (gewijzigde) grondwet van 1933 luidde aldus:

"The instruction and education of Albanian aubjects are reserved to the State and will be given in State schools. Primary education is compulsory for all A.lbanian nationals and will be given free of charge. Private schools of all categories at present in operation will be closed."

Tekst bij Hudson, vol. 3, p. 493. 
Albanian nationals. In particular they shall have an equal right to maintain, manage and control at their own expense or to establish in the future, charitable, religious and social institutions, schools and other educational establishments, with the right to use their own language and to exercise their religion freely therein. ${ }^{349}$

De Griekse minderheid in Albanië verzette zich tegen de afschaffing van het privé-onderwijs en stuurde petities aan de Volkenbond. Naar aanleiding van deze petities vroeg de Volkenbond-Raad een advies aan het Hof. De Albanese regering was van mening dat de gewijzigde tekst van de grondwetsbepaling niet discriminatoir was ten opzichte van minderheden. De maatregelen waren immers van toepassing op zowel de meerderheid als de minderheid. Het Hof verwierp evenwel de redenering van de Albanese regering. Naar het oordeel van het Hof was de gedachte die ten grondslag lag aan de minderhedenverdragen:

'to secure for certain elements incorporated in a State, the population of which differs from them in race, language or religion, the possibility of living peaceably alongside that population and co-operating amicably with it, while at the same time preserving the characteristics which distinguish them from the majority, and satisfying the ensuing special needs. ${ }^{, 350}$

Volgens het Hof waren de onderwijsinstellingen voor minderheden onmisbaar om gelijke behandeling van meerderheid en minderheid te verwezenlijken, volgens de wet én in de praktijk. Het Hof vervolgde:

'The abolition of these institutions, which alone can satisfy the special requirements of the minority groups, and their replacement by government institutions, would destroy this equality of treatment, for its effect would be to deprive the minority of the institutions appropriate to its needs, whereas the majority would continue to have them supplied in the institutions created by the State.

Far from creating a privilege in favour of the minority, as the Albanian Government avers, this stipulation ensures that the majority shall not be given a privileged situation as compared with the minority. ${ }^{351}$

De uitspraak van het Hof ging uit van de twee fundamenten die ten grondslag lagen aan de minderhedenverdragen uit het interbellum, te weten het voorkomen van discriminatie en de bescherming van minderheden. Met

349. Tekst bij Hudson, vol. 3, p. 511. Dergelijke eenzijdige verklaringen werden afgelegd door Albanië, Letland en Litouwen bij hun toelating tot de Volkenbond. Daarbiji verplichtten zij zich maatregelen te nemen tot toepassing van de beginselen van de Minderhedenverdragen.

350. Hudson, voll. S, p. 496.

351. Idem, p. 499 . 
andere woorden, naast de formele gelijkheid ("equality in law") vereiste de bescherming van minderheden, ook de daadwerkelijke, feitelijke gelijkheid ('equality in fact'). In de woorden van het Hof:

'Equality in law precludes discrimination of any kind; whereas equality in fact may involve the necessity of different treatment in order to attain a result which establishes an equilibrium between different situations. ${ }^{\mathbf{3 5 2}}$

Indien een minderheid (in dit geval de Griekse minderheid in Albanië) het recht zou worden ontzegd eigen scholen te stichten, zou het hele idee van minderhedenbescherming illusoir blijken te zijn en van alle inhoud en betekenis ontbloot. De essentie van de verwezenlijking van gelijkheid tussen meerderheid en minderheid vereiste niet alleen non-discriminatie, maar juist ook een verschillende behandeling, dat will zeggen bijzondere bescherming. Deze bescherming komt tot uitdrukking in het recht van minderheden eigen scholen te stichten, zonder dat de staat verplicht is positieve maatregelen te nemen, bijvoorbeeld bij te dragen in de financiering van deze scholen. Volgens het Hof vormde het recht van leden van minderheden eigen scholen te stichten, ingevolge artikel 5 lid 1 van de Albanese verklaring een minimum vereiste met het oog op het waarborgen van 'effective and genuine equality' tussen meerderheid en minderheid. ${ }^{353}$

Het wezenlijke van de minderhedenverdragen was dat zij de daadwerkelijke gelijkheid van leden van minderheden en de meerderheid van de bevolking beoogden te verwezenlijken. In de zaak betreffende de minderhedenscholen in Albanië ging het om een maatregel (de afschaffing van privéonderwijs) die betrekking had op zowel de meerderheid van de bevolking als de minderheidsgroepen. De maatregel voldeed daarmee aan gelijkheid de jure, maar resulteerde in de facto ongelijkheid. Het belang van de opinie van het Hof in deze zaak is dat de verwezenlijking van 'effective and genuine equality' twee aspecten kent. Gelijke behandeling impliceert niet slechts het voorkomen van discriminatie, maar vereist ook bijzondere beschermingsmaatregelen. Speciale rechten en bijzondere maatregelen ten gunste van leden van minderheden leveren geen discriminatie op indien zij deze echte gelijkheid beogen te verwezenlijken. $\mathrm{Na}$ de Tweede Wereldoorlog heeft deze gedachte centraal gestaan in de ontwikkeling van het internationale recht inzake de rechten van de mens. $\mathrm{Zij}$ is onder meer terug te vinden in het Verdrag inzake de Uitbanning van alle Vormen van Rassendiscriminatie (artikel 1 lid 4 en 2 lid 2), alsmede in het Verdrag inzake de Uitbanning van alle Vormen van Discriminatie van Vrouwen (artikel 4). 


\subsection{Het Verdrag inzake de Uitbanning van alle Vormen van Discriminatie van Vrouwen}

Het Verdrag inzake de Uitbanning van alle Vormen van Discriminatie van Vrouwen, in 1979 tot stand gekomen in het kader van de VN, bevat een belangrijke bepaling gericht op het verwezenlijken van gelijke rechten voor vrouwen op het gebied van onderwijs en vorming. ${ }^{354}$ De onderwijsbepaling, artikel 10 van het Verdrag, komt voor een deel overeen met artikel 9 van de Declaratie tot Uitbanning van Discriminatie tegen Vrouwen die in 1967 door de Algemene Vergadering van de $\mathrm{VN}$ werd aanvaard. ${ }^{355}$ Artikel 10 luidt als volgt:

'States Parties shall take all appropriate measures to eliminate discrimination against women in order to ensure to them equal rights with men in the field of education and in particular to ensure, on a basis of equality of men and women:

a. The same conditions for career and vocational guidance, for access to studies and for the achievement of diplomas in educational establishments of all categories in rural as well in urban areas; this equality shall be ensured in pre-school, general, technical, professional and higher technical education, as well as in all types of vocational training;

b. Access to the same curricula, the same examinations; teaching staff with qualifications of the same standard and school premises and equipment of the same quality;

c. The elimination of any stereotyped concept of the roles of men and women at all levels and in all forms of education by encouraging coeducation and other types of education which will help to achieve this aim and, in particular, by the revision of textbooks and school programmes and the adaptation of teaching methods;

d. The same opportunities to benefit from scholarships and other study grants;

354. Verdrag van 18 december 1979 . In werking getreden op 3 september 1981 . Engelse en Nederlandee tekst in Trb. 1981, no 61 . Vgl. ook artikel 14 lid 2 sub d.

355. Declaration on the Elimination of Discrimination Against Women, G.A. Resolution 2263 (XXII) van 7 november 1967.

Artikel 9 luidt:

'All appropriate measures shall be taken to ensure to girls and women, married or unmarried, equal rights with men in education at all levels, and in particular:

a. equal conditions of access to, and study in, educational institutions of all types, including universities and vocational, technical and professional schools;

b. the mame choice of curricula, the same examinations, teaching staff with qualifications of the same standards, and school premises and equipment of the same quality, whether the institutions are co-educational or not;

c. equal opportunities to benefit from scholarshipe and other study grants;

d. equal opportunities for access to programmes of continuing education, including adult literacy programmes;

e. access to educational information to help in ensuring the health and well-being of children.' 
e. The same opportunities for access to programmes of continuing education, including adult and functional literacy programmes, particularly those aimed at reducing, at the earliest possible time, any gap in education existing between men and women;

f. The reduction of female student drop-out rates and the organization of programmes for girls and women who have left school prematurely; g. The same opportunities to participate actively in sports and physical education;

h. Access to specific educational information to help to ensure the health and well-being of families, including information and advice on family planning.'

Bij de totstandkoming van artikel 10 werd uitgegaan van artikel 9 van de Declaratie. Daarnaast had België een ontwerpartikel geformuleerd dat tijdens de discussies in de $\mathrm{VN}$-Commissie inzake de Status van de Vrouw een belangrijke rol speelde. ${ }^{356}$ Het Belgische voorstel was gebaseerd op teksten die waren opgesteld door de Belgische Consultatieve Commissie voor de Status van de Vrouw, een adviesorgaan van de Belgische regering, in samenwerking met de Vereniging voor Vrouwelijke Juristen. ${ }^{357}$ Het Belgische voorstel beoogde de reikwijdte van de onderwijsbepaling uit te breiden tot een aantal specifieke gebieden waar de gelijke behandeling van mannen en vrouwen in het bijzonder vorm zou moeten krijgen. Het Belgische ontwerp verwees naar de bevordering van beroepskeuzemogelijkheden voor vrouwen en naar de gelijke toegang tot het beroep van onderwijsgevende. Daarnaast beoogde het voorstel de snelle ontwikkeling van co-educatievormen en het verminderen van de kenniskloof tussen mannen en vrouwen, alsmede het verminderen van het aantal 'drop-outs' onder meisjes. Tenslotte verwees de Belgische tekst naar de toegankelijkheid van sexuele opvoeding en onderwijs. Deze Belgische voorstellen zijn gedeeltelijk terug te vinden in artikel 10.

De onderwijsbepaling ademt tevens de geest van het Wereld Actieplan voor de Implementatie van de Doeleinden van het Internationaal jaar van de Vrouw (1975), en van het Programma voor het VN Decennium voor Vrouwen. ${ }^{358}$ De strekking van artikel 10 kan als volgt worden omschreven. Vrouwen dienen dezelfde toegang tot onderwijsvoorzieningen te hebben als mannen. Kwaliteitsnormen op het terrein van het onderwijs, in het bijzonder betreffende programma's, examens, niveaus en geledingen dienen voor vrouwen dezelfde te zijn als die voor mannen. Gemengd onderwijs moet bevorderd worden. Het dient gericht te zijn op veranderingen in

356. UN Doc. E/CN.6/591/Add.1 (25-8-1976); Verslag van de discuseies in UN Doc. E/CN.6/SR.640 en SR.642 van 21 en 23 september 1976.

357. Zie het referaat van $\mathrm{O}$. Buntinckx, artikel 10 van het $\mathrm{VN}$-Verdrag inzake Vrouwendiscriminatie en de Belgische Wetgeving en Praktijk, gehouden tijdens het Congres "Mensenrechten en onderwijs voor vrouwen', Brussel 22 oktober 1988 (niet gepubliceerd").

358. Dit Actieplan werd in 1975 in Mexico City aanvaard. Eveneens in 1975 begon het VN Decennium voor Vrouwen. 
stereotype ideeën over sociaal-culturele patronen, in het bijzonder de rol van de man/vrouw in de samenleving. Ten einde deze doeleinden te verwezenlijken biedt artikel 4 van de Conventie partijstaten de mogelijkheid tijdelijke positieve actie-maatregelen te nemen met als doel het realiseren van een feitelijke gelijkheid tussen mannen en vrouwen. Ingevolge de artikelen 2 en 3 zijn staten verplicht hun wetgeving aan de gedetailleerde verdragsnormen aan te passen en ook praktische maatregelen te nemen om discriminatie van vrouwen uit te bannen en te voorkomen.

Artikel $10 \mathrm{kan}$ op een belangrijk punt worden vergeleken met artikel 2(a) van het UNESCO Verdrag tot Bestrijding van Discriminatie in het Onderwijs. Laatst genoemd artikel bepaalt dat het oprichten of in stand houden van afzonderlijke onderwijsstelsels of -instellingen voor jongens en meisjes niet beschouwd wordt als discriminatie indien deze onderwijsstelsels op gelijke wijze ('equivalent') toegang geven tot het onderwijs en gelegenheid geven tot het volgen van dezelfde of gelijkwaardige ('the same or equivalent') studieprogramma's. Artikel 10 daarentegen spreekt in alle onderdelen van dezelfde mogelijkheden inzake toelating tot het onderwijs en van toegang tot dezelfde studieprogramma's. Artikel 2(a) belet staten niet verschillende vormen van onderwijs alleen aan jongens of alleen aan meisjes aan te bieden zo lang ze maar gelijkwaardig ('equivalent') zijn. Volgens deze bepaling kan een staat bijvoorbeeld opleidingen voor berocpen in de technische sector alleen toegankelijk maken voor jongens en opleidingen voor beroepen in de verzorgende sector alleen voor meisjes, zo lang ze maar recht geven op een gelijkwaardig diploma.

De VN Commission on the Status of Women was ten tijde van het opstellen van het UNESCO Verdrag dan ook voorstander van een verwijzing naar identieke curricula in de tekst. ${ }^{359}$ De term 'gelijkwaardig' is rekbaar en veel minder strikt dan de term 'dezelfde' ('same'). De term 'equivalent' wordt niet gedefinieerd in het Verdrag en kan naar goeddunken van de staat worden ingevuld. Op dit punt heeft artikel 10 een ondubbelzinnige betekenis. Burrows concludeert in dit verband dat de UNESCO Conventie 'does not meet the problem of sex-role stereo-typing in education'. ${ }^{360}$ Artikel 10 impliceert dan ook een belangrijke vooruitgang op dit punt.

Concluderend kan men zeggen dat artikel 10 op verschillende punten richtlijnen geeft en ijkpunten bevat ten behoeve van de uitbanning van hardnekkige discriminatie van vrouwen in het onderwijs.

359. Zie UN Doc. E/CN.4/Sub.2/210, Annex II, par. 38. Zie met betrekking tot het opstellen van de Verklaring tot Uitbanning van Discriminatie van Vrouwen, W. McKean Equality and Discrimination under International Law, Oxford 1983, p. 134 .

360. Zle N. Burrows, The 1979 Convention on the Elimination of All Forms of Discrimination against Women, in: Netherlands International Law Review, 1985, pp. 419-460, op pp. 435-437. Zie over de implementatie van artikel 10. M. Wadstein, Implementation of the UN Convention on the Elimination of All Forms of Discrimination against Women, in: SIM Newsletter vol. 6 (1988), no. 4, pp. 5-22, op p. 15.

Een artikel dat in het algemeen ingaat op discriminatie van vrouwen in het onderwijg is dat van D.L. Shelton, Women and the right to Education, in: Human Rights Journal/Rerue des Droits de l'Homme vol. 8 (1975), pp. 51-70. 


\subsection{Het Protocol inzake Economische, Sociale en Culturele Rechten bij de Amerikaanse Conventie inzake de Rechten van de Mens (Protocol van San Salvador)}

Op 14 november 1988 kwam een Protocol tot stand bij de Amerikaanse Conventie inzake de Rechten van de Mens. Deze overeenkomst, het Protocol van San Salvador, is geheel gewijd aan de bescherming van economische, sociale en culturele mensenrechten. Zoals hiervóor ${ }^{361}$ al is opgemerkt bevat de Amerikaanse Conventie inzake de Rechten van de Mens slechts een algemene verwijzing naar de verwezenlijking van economische, sociale en culturele rechten. Artikel 26 van deze Conventie verwijst naar de economische, sociale en culturele normen zoals die zijn vastgelegd in het Handvest van de $\mathrm{OAS}^{362}$.

Begin jaren tachtig begon de OAS te werken aan de formulering van een ontwerp-protocol inzake economische, sociale en culturele rechten. Met name de Inter-Amerikaanse Commissie voor de Rechten van de Mens nam daarbij het voortouw. De Commissie was de mening toegedaan dat een niet- of gebrekkige verwezenlijking van economische, sociale en culturele rechten in veel gevallen de oorzaak was van het toenemende geweld en sociale conflicten in veel Latijnsamerikaanse landen. ${ }^{363}$ Vandaar dat verwezenlijking van deze rechten prioriteit verdiende. De Commissie was van oordeel dat economische, sociale en culturele rechten:

'are attributes of the human person as such, and they therefore cannot be considered the byproduct of the success of given economic of social policies. As human rights, economic, social and cultural rights are thus imposed imperatives and not merely desirable development goals. ${ }^{, 364}$

Met andere woorden, zij zijn inherent aan de menselijke waardigheid.

Het Protocol bevat het hele scala van economische, sociale en culturele rechten zoals dat ook in het IVESCR is vastgelegd. Ik noem hier slechts het recht op werk, vakbondsrechten het recht op voedsel en gezondheid. Twee bepalingen dienen hier met name vermeld te worden, te weten de rechten van bejaarden (artikel 17) en de rechten van gehandicapten (artikel 18). Deze bepalingen zijn bijzonder, omdat zij niet eerder werden opgenomen

361. Zie hoofdstuk 3.2 supra.

362. Artikelen 46, 47, 48 van het Handvest van de OAS. Deze bepalingen werden toegevoegd aan het Handvest door middel van het Protocol van Buenos Aires (1967). Vgl. cok de artikelen XII, XXX en XXXI van de Amerikaanse Verklaring inzake de Rechten van de Mens. Alle Amerikaanse teksten zijn te vinden in de meerdelige uitgave 'Human Rights - The Inter-American System", Dobbs Ferry New York, edited by Th. Buergenthal en R.E. Norris (losbladig).

363. Zie hoofdstuk 2.3 supra.

364. Inter-American Commission on Human Rights, Toelichting bij het ontwerp-protocol inzake ecomomische, sociale en culturele rechten, in: Inter-American Yearbook on Human Rights, Dordrecht/Boston/London 1986, p. 318. 
in enige internationale overeenkomst tot bescherming van de rechten van de mens. Het recht op onderwijs is vastgelegd in artikel 13.

De eerste ontwerpen voor een protocol bevatten twee afzonderlijke bepalingen ten aanzien van het recht op onderwijs. Eën bepaling omvatte het recht op onderwijs, dat will zeggen het sociale aspect, en sloot aan bij artikel 13 lid 1 en 2 IVESCR. De andere bepaling formuleerde in hoofdzaak de rechten van ouders ten aanzien van het onderwijs voor hun kinderen, dat wil zeggen het vrijheidsaspect. Deze laatste bepaling was in sterke mate gebaseerd op artikel 13 lid 3 en 4 IVESCR. De ontwerpbepalingen luidden als volgt: ${ }^{365}$

Article 14

Right to education

1. Everyone has the right to education.

2. The States Parties to the present Protocol agree that, in general, education shoull be directed towards the full development of the human personality and human dignity, and ought to strengthen respect for human rights, fundamental freedoms and peace. They agree, also, that education ought to equip all persons in the task of achieving a decent existence and enabling one to participate effectively in a democratic society.

3. The States Parties to the present Protocol recognize that, in order to achieve the complete exercise of the right to education:

a. Primary education shall be compulsory and accessible to all without cost;

b. Secondary education in its different forms, including technical and professional secondary education, shall be made generally available and accessible to all by every appropriate means, and in particular, by the progressive introduction of free education;

c. Higher education shall be made equally accessible to all, on the basis of capacity, by every appropriate means, and in particular, by the progressive introduction of free education;

d. Basic education shall be encouraged or intensified as far as possible for those persons who have not received or completed the whole cycle of primary instruction;

e. Programs of special education shall be established for the handicapped, so as to provide special instruction and training for persons with physical disabilities or mental deficiencies.

Article 15

Right to freedom of education

1. The State Parties to this Protocol undertake to respect the liberty of parents and, where applicable, legal guardians to choose for their children schools other than those established by the public author-

36.5. Tekat wan het ontwerp-protocol in: Inter-American Yearbook on Human Rights, 1986, a.w. pp. 326-344. 
ities, provided they conform to such minimum educational standards as which may be laid down or approved by the State, and to ensure the religious and moral education of their children in conformity with their own convictions.

2. No provision of this Article shall be construed so as to interfere with the freedom of individuals and organizations from establishing and directing educationall institutions, subject to the observance of the principles set forth above and to the requirement that the education given in such institutions shall conform to such minimum standards as may be laid down by the State.

Er dient op gewezen te worden dat artikel 14 geformuleerd is in gebiedende vorm door het gebruik van het mandatoire 'shall'. Met name artikel 15 lid 1 riep bij sommige staten verzet op. Sommige Latijnsamerikaanse landen, zoals Mexico, erkenden wel de vrijheid van godsdienst, maar niet de vrije keuze van godsdienstonderwijs in overeenstemming met de overtuigingen van de ouders. Deze landen kenden een strikte scheiding tussen Kerk en staat die ook in het (openbare) onderwijs gold. Met andere woorden, deze staten verkeerden niet in de mogelijkheid de vrije keuze van de ouders ten aanzien van het godsdienstonderwijs voor hun kinderen te eerbiedigen.

Dit verzet leidde ertoe dat in het eerste lid van artikel 15 een verwijzing naar de nationale wetgeving van partijstaten werd opgenomen. Dat betekent dat de vrijheid van ouders ten aanzien van de keuze van het onderwijs onderworpen werd aan de bepalingen van de nationale wetgeving. Een zelfde beperkende wijziging werd geformuleerd ten aanzien van artikel 15 lid 2, de vrijheid van individuen en instellingen eigen scholen te stichten. Ook deze vrijheid werd onderworpen aan de nationale wetgeving van partijstaten. ${ }^{366}$

Er zij hier aan herinnerd dat eenzelfde discussie speelde bij de totstandkoming van het UNESCO Verdrag tot Bestrijding van Discriminatie in het Onderwijs, in het bijzonder ten aanzien van artikel $2:^{367} \mathrm{Na}$ ampel overleg werd besloten de beide aspecten van het recht op onderwijs in éen artikel onder te brengen. De definitieve onderwijsbepaling zoals die door de staten werd aanvaard luidde als volgt: ${ }^{368}$

366. Zie over de totitandkoming van deze wijzigingen, Permanent Council of the OAS, Committee on Juridical and Political Affairs, doc. CP/CAJP-694/87 van 2 oktober 1987 en doe. CP/CAJP -728/88 corr. 1 van 17 oktober 1988.

367. Zie hoofdstuk 3.5.2. supra.

368. Tekst van het Protocol van San Salvador in: ILM, Vol. 28 (1989), p. 156 e.vi: Het: Protocol treedt in werking indien 11 staten het geratificeerd hebben. Op 01-01-1991 had alleen Suriname dat gedaan.

Op 01-01-1991 hadden 13 staten het Protocol ondertekend. Zie over dit protocol C. Medina in: Netherlands Quarterly of Human Right vol. 7 (1989), pp. 241, 242. Zie over de problematiek van economische, sociale en eulturele rechten in een Latijnsamerikaanse context, H. Gros Espiell, Los Derechos económicos, sociales y culturales en el sistema Interamericano, San José, Costa Rica 1986. 
Article 13

Right to education

1. Everyone has the right to education.

2. The States Parties to this Protocol agree that education should be directed towards the full development of the human personality and human dignity and should strengthen respect for human rights, ideological pluralism, fundamental freedoms, justice and peace. They further agree that education ought to enable everyone to participate effectively in a democratic and pluralistic society and achieve a decent existence and should foster understanding, tolerance and friendship among all nations and all racial, ethnic or religious groups and promote activities for the maintenance of peace.

3. The States Parties to this Protocol recognize that in order to achieve the full exercise of the right to education:

a. Primary education should be compulsory and accessible to all without cost;

b. Secondary education in its different forms, including technical and vocational secondary education, should be made generally available and accessible to all by every appropriate means, and in particular, by the progressive introduction of free education;

c. Higher education should be made equally accessible to all on the basis of individual capacity, by every appropriate means, and in particular, by the progressive introduction of free education;

d. Basic education should be encouraged or intensified as far as possible for those persons who have not received or completed the whole cycle of primary instruction;

e. Programs of special education should be established for the handicapped, so as to provide special instruction and training to persons with physical disabilities or mental deficiencies.

4. In conformity with the domestic legislation of the States Parties, parents should have the right to select the type of education to be given to their children, provided that it conforms to the principles set forth above.

5. Nothing in this Protocol shall be interpreted as a restriction of the freedom of individuals and entities to establish and direct educational institutions in accordance with the domestic legislation of the States Parties.

Wat opvalt is dat in de definitieve tekst het mandatoire 'shall' in lid 3 is vervangen door het meer vrijblijvende 'should'. ${ }^{369}$ Het is onduidelijk hoe de term 'should' zich verhoudt tot de algemene verplichting van staten maatregelen te nemen ter verwezenlijking van de materiële rechten uit het Protocoll. Deze algemene verplichting is vastgelegd in artikel 1 :

369. De reden voor dege wijziging heb ik in de mij ter beschikking staande documenten niet kui.nen traceren. 
'The States Parties to this Additional Protocol to the American Convention on Human Rights undertake to adopt the necessary measures; both domestically and through cooperation among the States, especially economic and technical, to the extent allowed by their available resources, and taking into account their degree of development, for the purpose of achieving progressively and pursuant to their internal legislations, the full observance of the rights recognized in this Protocol.'

De kern van deze bepaling is de verplichting tot geleidelijke verwezenlijking. De strekking is dezelfde als die van artikel 2 lid 1 IVESCR. De term 'should' in artikel $13 \mathrm{lid} 2$ zwakt de verplichting tot het nemen van matregelen krachtens artikel 1 af.

Artikel 16 geeft ook nog een verwijzing naar het recht op onderwijs. Deze bepaling handelt over de rechten van kinderen en de bescherming die zij nodig hebben van gezin, gemeenschap en de staat. Dit artikel bepaalt voorts dat 'every child has the right to free and compulsory education, at least in the elementary phase, and to continue his training at higher levels of the educational system'. Deze formulering heeft een mandatoir karakter en staat in tegenstelling tot de term 'should' in de passage over lager onderwijs in artikel 13.

Een belangrijk aspect van dit protocol is het toezicht op de naleving van de bepalingen door staten. De Amerikaanse Conventie inzake de Rechten van de Mens kent een individuele klachtenprocedure, die is vastgelegd in de artikelen 44-51 en 61-69 van de Conventie in geval van een beweerde schending van een van de rechten uit de Conventie door een partijstaat. Daarbij gaat het om burger- en politieke rechten. De vraag was of deze individuele klachtenprocedure ook van toepassing kon zijn op de beweerde schending van economische, sociale en culturele rechten. Volgens de Inter-Amerikaanse Commissie voor de Rechten van de Mens zou dat inderdaad mogelijk zijn:

'when a violation occurred because of direct action by the government, that is when the violation might be imputed directly and immediately to the government, and changing the situation would depend on it. ${ }^{370}$

Het karakter van andere rechten leidt ertoe dat een rapportageverplichting voor staten de beste toezichthoudende methode is. Dat is het geval bij die rechten 'whose full effectiveness takes time and will make it possible to evaluate the progress achieved'.371

370. Commentaar van de Inter-Amerikaanae Commiasie voor de Rechten van de Mens op de wenselijkheid van en protocol inzake economische, ociale en culturele rechten, in: IACHR, Annual Report 1984-1985 (origineel: Spaans), vertaling in het Engels bij Buergenthal/Norris, a.w. deel 1, Sectie 3.2 (november 1986), pp. 21, 22.

371. Ibid.

In dezelfde zin het Inter-Amerikaanse Hof voor de Rechten van de Mens, Annual Report to the General Assembly, 24 oktober 1985 (origineel: Spaans), Engelse vertaling bij Buergenthal/Norris, a.w. deel 1, Sectile 3.2 (nov. 1986), pp. 23, 24. 
Deze opvatting heeft ertoe geleid dat het individuele klachtrecht van toepassing is op artikel $8 \mathrm{a}$ (de vrijheid van vakvereniging) en artikel 13 (het recht op onderwijs) indien het gaat om een schending 'directly attributable to a State Party to this Protocol'.372 Voor andere bepalingen dan artikel $8 \mathrm{a}$ en 13 geldt een rapportageprocedure ingevolge artikel 19 lid $1-5$. Ten aanzien van artikel 13 moet worden opgemerkt dat in de eerste ontwerpen voor een protocol het individuele klachtrecht alleen betrekking had op ontwerpartikel 15 (de vrijheid van onderwijs, zie hierboven). Bij samenvoeging van de ontwerpartikelen 14 en 15 tot artikel 13 werd het individuele klachtrecht ook van toepassing op lid 1,2 en 3 van artikell 13, namelijk het sociale aspect. Er bestaat mijns inziens een tegenstelling tussen de tamelijk vrijblijvende term 'should' in lid 2, 3 en 4 van artikel 13 en de verplichting tot geleidelijke verwezenlijking op grond van artikel 1 enerzijds, en de onderwerping van het gehele recht op onderwijs aan het individuele klachtrecht anderzijds. Op grond van het klachtrecht is het recht op onderwijs immers afdwingbaar ten opzichte van de staat. Dat zal ten aanzien van lid 4 en 5 (het vrijheidsaspect) heel wel mogelijk zijn. Ten aanzien van het sociale aspect zal het evenwel niet gemakkelijk zijn een beweerde schending direct toe te schrijven aan een handeling van de staat. Krachtens artikel 1 heeft de staat immers een zekere mate van beleidsvrijheid. Er kunnen factoren zijn (beperkte financiële middelen, externe factoren, overmacht) die het moeilijk maken een beweerde schending direct toe te schrijven aan een handeling van de staat. Het is aan de Inter-Amerikaanse Commissie voor de Rechten van de Mens de reikwijdte en betekenis van het individuele klachtrecht met betrekking tot het recht op onderwijs te bepalen. Daartoe moet evenwel eerst het Protocol in werking treden en vervolgens een zaak aanhangig worden gemaakt bij de Commissie. Van groot belang is dat het individuele klachtrecht nu is opgenomen in een internationale overeenkomst die geheel gewijd is aan de verwezenlijking van economische, sociale en culturele rechten, $\mathrm{zij}$ het dat dit recht vooralsnog alleen maar van toepassing is op een tweetal bepalingen van het Protocol. Deze uitbreiding van het individuele klachtrecht tot bepaalde economische, sociale en culturele rechten draagt er in ieder geval toe bij dat het traditionele uitgangspunt ondergraven wordt dat het klachtrecht alleen maar van toepassing kan zijn op schendingen van burger- en politieke rechten.

372. Artikel 19 lid 6 Protocol van San Salvador. De tekst van deze bepaling luidt: "Any instance in which the rights established in paragraph a) of Article 8 and in Article 13 are violated by action directly attributable to a State Party to this Protocol may give rise, through participation of the Inter-American Commission on Human Righte and, when applicable, of the Inter-American Court of Human Rights, to application of the system of individual petitions governed by Articles 44 through 51 and 61 through 69 of the American Convention on Human Rights'. 


\subsection{Documenten in het kader van de Conferentie over Veiligheid en Samenwerking in Europa (CVSE)}

In 1975 kwam de Slotakte van Helsinki $\mathrm{i}^{373}$ tot stand als resultaat van een onderhandelingsproces tussen alle Europese staten (met uitzondering van Albaniè) de Verenigde Staten en Canada, de zogenaamde Conferentie over Veiligheid en Samenwerking in Europa (CVSE). In de Slotakte werden afspraken gemaakt over veiligheid en samenwerking in Europa. ${ }^{374}$ Ook werd aandacht besteed aan de rechten van de mens. Tijdens Vervolgconferenties in Madrid (1981-1983) en in Wenen (1986-1989) werd onder meer de naleving van de rechten van de mens in de deelnemende staten besproken en werden nieuwe afspraken gemaakt op velerlei terreinen. De CVSEdocumenten zijn geen verdragen in de zin van artikel $2(1)$ van het Weense Verdragenverdrag. ${ }^{375} \mathrm{Zij}$ moeten beschouwd worden als documenten die staten in politieke zin binden. Wel wordt in deze teksten verwezen naar bepalingen die zijn opgenomen in verdragen die voor de staten juridisch bindend zijn. Zo wordt onder meer ten aanzien van economische, sociale en culturele mensenrechten verwezen naar het Internationaal Verdrag inzake Economische, Sociale en Culturele Rechten. De juridische binding van de deelnemende staten volgt dan uit het feit dat de desbetreffende staten partij zijn bij het met name genoemde internationale verdragsrecht inzake de rechten van de mens. ${ }^{376}$

In de Slotakte van Helsinki en in het Slotdocument van Madrid (1983) wordt in het bijzonder de vrijheid van denken, geweten, godsdienst of geloof erkend. De vrijheid van onderwijs wordt niet expliciet genoemd. Tijdens de debatten in Wenen over de naleving van de bepalingen van de Slotakte van Helsinki werd door de westerse landen kritiek geuit op de schendingen van de godsdienstvrijheid in Oosteuropese landen. De kritiek betrof onder meer de onmogelijkheid voor ouders de godsdienstige en zedèlijke opvoeding van hun kinderen te verzekeren in overeenstemming met hun eigen overtuigingen. ${ }^{377}$ Deze vrijheid wordt gegarandeerd in artikel 18(4) IVBPR en in artikel 13(3) IVESCR. In een aantal socialistische landen werden ouders die hun kinderen godsdienstonderricht wilden laten volgen uit de ouderlijke macht ontzet. ${ }^{378}$ In Oosteuropese staten was er bovendien sprake van dis-

373. Alle relevante CVSE-teksten die tot en met 1989 zijn aanvaard, zijn vermameld in: $A$. Bloed (ed.), From Helainki to Vienna: Basic Documents of the Helsinki Process, Dordrecht 1990. Zie over kenmerken en ontwikkeling van het CVSE-proces, Bloed, pp. 1-27.

374. Zie hierover P. van Dijk, The Final Act of Helsinki - Basis for a Pan-European System?, in: Netherlands Yearbook of International Law, voll. 11 (1980), pp. 97-124.

375. Zie van Dijk, a "w" PP. 106-110.

376. Zie het Zevende Beginsel van de Slotakte van Helsinki; zie ook Bloed, a.w. p. 11 .

377. Zie hiervoor W.J.M. van Genugten "Ontwikkelingen tijdens de derde toetsingaconferentie van de Slotakte van Helsinki, in: Civis Mundi, 1988, no. 1, pp. 24-29, op p. 25.

378. Zie A. Bloed, CVSE in Wemen: hoogtepunt in Helsinki-proces, in: Internationale Spectator, juni 1989 , Pp. $392-400$, op p. 395 . 
criminatie op grond van etnische afkomst, of politieke dan wel godsdienstige overtuiging bij de toegang tot het hoger onderwijs. ${ }^{379}$

Tijdens de Conferentie in Wenen (1986-1989) lanceerde een aantal westerse staten voorstellen ten einde de bescherming van de godsdienstvrijheid uit te breiden. ${ }^{380}$ De tekst van het Slotdocument van Wenen ${ }^{381}$ over de vrijheid van godsdienst is uitvoerig en getuigt duidelijk van westerse invloed. Eén yan de uitwerkingen yan de godsdienstvrijheid in het Slotdocument betreft het recht van een ieder op het geven of ontvangen van godsdienstonderricht, in de taal wan zijn keuze, alleen of in gemeenschap met anderen (Beginsel 16.6). Daarnaast wordt de vrijheid van ouders (niet van voogden) erkend de religieuze en zedelijke opvoeding van hun kinderen te verzekeren in overeenstemming met hun eigen overtuigingen (Beginsel 16.7). Dit betekent niet dat staten nu ook verplicht zijn godsdienstonderricht in het schoolcurriculum op te nemen. Deze aspecten richten zich op de privêsfeer, met name in gezinsverband en binnen kerkgenootschappen. Bij de Sovjet-Unie bestond de vrees dat erkenning van deze rechten zou leiden tot een versterking van het emancipatiestreven van etnische, religieuze en linguïstische groepen. ${ }^{382}$ Ten aanzien van dit aspect van de vrijheid van godsdienst reiken de CVSE-teksten vooralsnog minder ver dan artikel 18 lid 4 IVBPR, artikel 13 lid 3 IVESCR en artikel 2 Eerste Protocol EVRM, omdat deze laatste bepalingen niet alleen betrekking hebben op de privésfeer. $\mathrm{Zij}$ leveren een aanspraak op ten opzichte van de staat ten aanzien van alle activiteiten die de staat onderneemt aangaande onderwijs en opvoeding (voornamelijk in schoolverband).

Wat betreft het recht op onderwijs is er in het Slotdocument van Wenen ook vooruitgang geboekt. Bij de verwezenlijking van economische, sociale en culturele rechten zullen de deelnemende staten bijzondere aandacht besteden aan problemen op het gebied van onder meer het onderwijs (Beginsel 14). In de sectie van het Slotdocument die handelt over samenwerking en uitwisseling op onderwijsgebied verzekeren de staten onder meer de toegang van een ieder tot de verschillende typen en niveaus van onderwijs zonder discriminatie (par. 63).

Bijzondere aandacht verdient de problematiek van de rechten van minderheden. Het Slotdocument van Wenen vermeldt dat de deelnemende staten de etnische, culturele, linguïstische en godsdienstige identiteit van nationa-

379. Zie hierover, J. Ziman, P. Sieghart, J. Humphrey, The World of Science and the Rule of Law, Oxford 1986, hoofdstuk 4.

380. Zie over deze vooratellen A. Bloed, Human Rights st the CSCE Follow-up Meeting in Vienna, in: SIM Newaletter, no. 18 (juni 1987), pp. 3-15, op p. 12. Zie voorts over de totstandkoming van het Slotdocument van Wenen, W.J.M. van Genugten, Helsinki is overal, Nijmegen/Amsterdam 1990, in het bijzonder de hoofdstukken 3 en 4.

381. Slotdocument van Wenen van 15 januari 1989. Tekst in Bloed (1990), a.w. pp. 181-262.

382. Zie H. Tretter, Die Menachenrechte im Abschliessenden Dokument des Wiener KSZE-Folgetreffens vom 15 Januar 1989, in: Europdische Grundrechte Zeitung, 1989, pp. $79-85$, op p. 82 . 
le minderheden op hun grondgebied beschermen en voorwaarden scheppen voor de bevordering hiervan. Voorts zullen de deelnemende staten de vrije uitoefening van rechten door tot zodanige minderheden behorende personen eerbiedigen en hun volledige gelijkheid met anderen verzekeren (Beginsel 19). Deze bepaling beperkt zich niet tot de verzekering van een nondiscriminatoire behandeling van leden van minderheden. Staten dienen ook positieve maatregelen te nemen ter bescherming en bevordering van de identiteit van minderheden als zodanig. ${ }^{383}$ Ten aanzien van het onderwijs en minderheden bepaalt het Slotdocument van Wenen dat staten dienen te verzekeren dat personen, behorende tot nationale minderheden of regionale culturen op hun grondgebied, onderricht kunnen geven en ontvangen betreffende hun eigen cultuur, met inbegrip van onderricht door overdracht van taal, godsdienst en culturele identiteit door ouders aan hun kinderen (par. 68).

De rechten van (leden van) nationale minderheden kwamen uitvoerig aan de orde tijdens de Conferentie inzake de Menselijke Dimensie die in juni 1990 in Kopenhagen plaatsvond. Dit was een moeilijk en gevoelig onderwerp dat voor sommige staten van vitaal belang was. Immers, juist in de periode die vooraf ging aan de Conferentie in Kopenhagen begonnen veel minderheden in Oosteuropese landen, die jarenlang onderdrukt waren en monddood gemaakt, zich te roeren en op te komen voor hun rechten en behoud van hun identiteit. Voor een aantal landen zoals de Sovjet-Unie, Joegoslavië, Roemenië, Griekenland, maar ook voor een land als Frankrijk (Corsica, Bretagne), staat de nationale en territoriale integriteit op het spel. In Kopenhagen werd een relatief groot aantal bepalingen over de positie en rechten van nationale minderheden aanvaard. Er bestaat geen andere intergouvernementele tekst die de rechten van leden van nationale minderheden zo uitvoerig vastlegt, zij het dat sommige bepalingen een nogal beperkte betekenis hebben.

In het Slotdocument van Kopenhagen is naast de garantie van non-discriminatie (par. 31) ook de gedachte van de bevordering van de identiteit van nationale minderheden door middel van positieve overheidsmaatregelen vastgelegd (par. 33). Volgens par. $32.2 \mathrm{komt}$ aan leden van minderheden het recht toe

'to establish and maintain their own educational, cultural and religious institutions, organizations or associations, which can seek voluntary

383. Zie Th. Buergenthal, The Copenhagen CSCE Meeting: A New Public Order for Europe, in: Human Rights Law Journal, vol. 11 (1990), pp. 217-232, op p. 227. Zie over de rechten van minderheden in het slotdocument van Wenen, M. Tabory, Minority Rights in the CSCE context, in: Israel Yearbook on Human Rights, wol 20 (1990), pp. 197-221, met name pp. 208-217.

384. Buergenthal, a.w. p. 227, zie ook A. Bloed, Successful Meeting of the Conference on the Human Dimension of CSCE, in: Netherlands Quarterly of Human Rights, vol. 8 (1990), pp. 235-261, op p. 249. De tekat van het Slotdocument van Kopenhagen is gepubliceerd in de Netherlands Quarterly of Human Rights, vol. 8 (1990), pp. 302326. 
financial and other contributions as well as public assistance, in conformity with national legislation.'

Dit is éen van de bepalingen die de leden van nationale minderheden beschermen tegen assimilatie. Voorts komt aan leden van nationale minderheden het recht toe godsdienstonderricht in hun eigen taal te onderwijzen (par. 32.3). Positieve overheidsmaatregelen ten gunste van leden van nationale minderheden zijn nader omschreven ten aanzien van het onderwijs:

'The participating States will endeavour to ensure that persons belonging to national minorities, notwithstanding the need to learn the official language or languages of the State concerned, have adequate opportunities for instruction of their mother tongue or in their mother tongue, as well as wherever possible and necessary, for its use before public authorities, in conformity with applicable national legislation. In the context of teaching and history and culture in educational establishments, they will also take account of the history and culture of national minorities.' (par. 34)

De verwijzingen in de hierboven geciteerde bepalingen naar de nationale wetgeving van de deelnemende staten en zulke clausules als 'to endeavour to ensure' zwakken het bindend karakter van de bepalingen af. Het zijn ontsnappingsclausules die het mogelijk maakten tot een tekst te komen die voor alle staten aanvaardbaar was. ${ }^{385}$

Toch moet de conclusie zijn dat de bepalingen over (onderwijs) rechten van leden van nationale minderheden een belangrijke vooruitgang betekenen ten opzichte van artikel 27 IVBPR en artikel 5 lid 1 sub c UNESCO Verdrag tot Bestrijding van Discriminatie in het Onderwijs. Deze laatste immers hebben slechts een beperkte reikwijdte. Juist de minderhedenbepalingen in het Slotdocument van Kopenhagen vormen een aanzet tot positieve maatregelen van de zijde van de staat.

\subsection{ILO Conventies betreffende Inheemse Volken}

Zo'n 200 tot 250 miljoen mensen op deze wereld behoren tot de zogenaamde inheemse volken. De bekendste voorbeelden zijn de Indianen in Noorden Zuid-Amerika, de Aborigines in Australië, de Saami in Scandinavië en de verschillende inheemse groepen in India. Daarnaast is er nog een groot aantal kleinere inheemse volken dat binnen de grenzen van nationale staten leeft. ${ }^{386}$ In 1957 werd de 'Indigenous and Tribal Populations Convention'

385. Zie Bloed, a.w. (Netherlands Quarterly of Human Fights 1990) p. 249.

388. Zie de verschillende rapporten van de Minority Rights Group, een niet-gouvernementele organisatile die opkomt voor de belangen van onder andere deze volken. Zie bijvoorbeeld $H$. Beach, The Starni of Lapland, 2nd edition, London 1988 en R. Dunbar Ortiz, The Miskito Indians of Nicaragua, London 1988. 
gesloten. ${ }^{387}$ Dit Verdrag, tot stand gekomen onder auspiciën van de ILO, is het enige internationale document dat in zijn geheel en expliciet gewijd is aan de rechten van inheemse volken. De Conventie beoogde de bescherming van inheemse volken door middel van hun integratie in de nationale gemeenschap van het land waarin zij leven. Deze gedachte werd in de preambule van het Verdrag als volgt omschreven:

'... there exist in various independent countries indigenous and other tribal and semi-tribal populations which are not yet integrated into the national community and whose social, economic or cultural situation hinders them from benefiting fully from the rights and advantages enjoyed by other elements of the population.'

De Conventie bevat bepalingen die van invloed zijn op de leef-en werkomstandigheden van inheemse volken, zoals bepalingen over landrechten, arbeidsomstandligheden, sociale zekerheid, gezondheid en onderwijs. Midden jaren tachtig besloot de ILO tot een herziening van de Conventie van 1957, omdat de wijze waarop het Verdrag de rechten van inheemse volken trachtte te waarborgen achterhaald was. ${ }^{388}$ Vertegenwoordigers van inheemse volken uitten kritiek op de Conventie, omdat het Verdrag onvoldoende waarborgen bood tegen inbreuken op hun rechten. Bovendien bood het Verdrag geen of te weinig mogelijkheden aan vertegenwoordigers van inheemse volken tot invloed op en inspraak bij het door de staten te voeren beleid. Het Verdrag had als uitgangspunt de integratie van deze groepen, terwijl veranderde inzichten en opvattingen in de jaren zeventig en tachtig juist meer belang gingen hechten aan het bewaren van de eigen identiteit en het streven naar autonomie en zelfbeschikking. Daarnaast eisten vertegenwoordigers van inheemse volken invloed op de herziening van de ILO Conventie. ${ }^{389}$ In 1989 werd de herziening van Conventie no. 107 afgerond

387. De volledige benaming luidt "Conwention concerning the Protection and Integration of Indigenous and Other Tribal and Semi-Tribal Populations in Independent Countries' van 26 juni 1957 (ILO Conventie no. 107). Tekst in: ILO, International Labour Conventions and Recommendations 1919-1981, Geneva 1982. Het Verdrag trad in werking op 2 juni 1959 .

388. Zie S. Stenfert Kroese, De Internationale Arbeidsorganisatie en inheemge volken, in: NJCM-Bulletin 15-5 (1990), Pp. 539-555, en S. Leckie, Indigenous Peoples: Recent: Developments in the International Labour Organization, in: SIM Newsletter no. 16, november 1986, pp. 22-46. Binnen de Veremigde Naties wordt sedert 1982 door sen werkgroep van de Sub-Commissie ingake de Voorkoming van Discriminatie en de Bescherming van Minderheden gewerkt aan ontwerp-Verklaring inzake de Rechten van Inheemse Volken; zie hierover UN Doc. E/CN.4/Sub.2/1991/40, Report of the Working Group on Indigenous Populations on itte ninth session (1991).

389. Over de vertegenwoordiging en de participatie van vertegenwoordigers van inheemse volken en NGO's in het proces van herziening wan ILO Conventie 107 bestond nogal wat onenigheid en discussie. Zie hierover, Th. van Boven, The Role of Non-Governmental Organizations in International Human Rights Standard-Setting: a Prerequisite of Democracy, in: California Western International Law Journal, vol. 20 (1989-1990), pp. 207-225, op pp. 222-223. Zie voorts H.R. Berman, The International Labour 
en werd de 'Indigenous and Tribal Peoples Convention, 1989 gesloten. ${ }^{390}$ Dit Verdrag neemt afstand van de verdragsnormen uit 1957 die gericht waren op assimilatie van inheemse volken en erkent

'the aspirations of these peoples to exercise control over their own institutions, ways of life and economic development and to maintain and develop their identities, languages and religions, within the framework of the States in which they live. ${ }^{\$ 391}$

Hieronder zullen enige algemene verdragsbepalingen uit 1957 met de overeenkomstige clausules uit 1989 vergeleken worden. Vervolgens zal ik ingaan op de onderwijsbepalingen uit beide Verdragen.

Ingevolge artikel 2 lid 1 van het Verdrag van 1957 heeft een staat de eerste verantwoordelijkheid maatregelen te nemen gericht op de bescherming en integratie van inheemse bevolkingen. Artikel 3 lid 1 bepaalt voorts dat zolang de sociale, economische en culturele omstandigheden van inheemse bevolkingen hen beletten te profiteren van de voordelen die de algemene wetgeving van het land biedt, bijzondere maatregelen genomen moeten worden ter bescherming van hun belangen. Met andere woorden, indien inheemse bevolkingen geintegreerd zijn in de nationale gemeenschap zijin bijzondere beschermende maatregelen niet langer nodig. Het herziene Verdrag van 1989 stelt hier tegenover (artikel 2 lid 1) dat de regeringen, met de participatie van de inheemse volken, verantwoordelijk zijn voor het ontwikkelen van maatregelen ter bescherming van hun rechten en ter waarborging van respect voor hun integriteit. Daarnaast bepaalt artikel 4 dat bijzondere maatregelen genomen moeten worden 'as appropriate' ter bescherming van de (belangen van) inheemse volken. Deze bijzondere maatregelen zijn niet langer gebonden aan een bepaalde termijn, maar de term 'as appropriate' ('waar passend') bevat een ontsnappingsmogelijkheid voor staten ook daadwerkelijk maatregelen te nemen. Van belang in het herziene artikel 2 lid 1 is dat de inheemse volken nu ook betrokken worden bij het uitzetten van beleid en het nemen van maatregelen die hen zelf aan-

389. (..vervolg)

Organization and Indigenous Peoples: Revision of ILO Convention no. 107 at the 75 th Sesaion of the International Labour Conference, 1988 , in: The Review of the International Commission of Juriats no. $41 / 1988, p p .48-58$. Zie ook de reactie wan $K$. Samson en L. Swepston op het artikel van Berman, in: The Review of the International Commiesion of Juriste no. $42 / 1989$, pp. $43-46$.

390. De volledige benaming luidt 'Convention concerning Indigenous and Tribal Peoples in Independent Countries" $\operatorname{van} 27$ juni 1989 (ILO Conventie no. 169), tekst in: Trb. 1990, 39. Er dient hier op gewezen te worden dat Conventie 169 niet langer de term 'populations" gebruikt, maar epreekt van "peoples". Deze laatate term heeft in het internationale recht een betekenis in relatie tot het recht op zelfbeschikking. Vertegenwoordigers van inheemse volken pleitten ervoor de term 'peoples' in het Verdrag te gebruiken, terwijl de vertegenwoordigers van staten dat afwezen. Zie over dese kwestio en de uiteindelijk in de Conventie geformuleerde oplossing, Stenfert Kroese, a.w. pp. $546,547$.

391. Preambule Conventie no. 169. 
gaan. ${ }^{392}$ De belangrijkste wijzigingen hebben betrekking op de regeling van de landrechten van inheemse volken en de kwestie van het zelfbeschikkingsrecht die hier evenwel niet nader besproken kunnen worden.

De onderwijsbepalingen in de Conventie van 1957 waren gericht op de integratie van de inheemse bevolkingsgroepen in de nationale gemeenschap. Bovendien gaven zij blijk van een zekere mate van minderwaardigheid en ondergeschiktheid van de inheemse bevolking ten opzichte van andere bevolkingsgroepen. Dit komt met name tot uiting in de bepalingen over het onderwijs in de moedertaal van de inheemse bevolking. Zo bepaalde artikel 22 lid 1, 'Education programmes for the populations concerned shall be adapted, as regards methods and techniques, to the stage these populations have reached in the process of social, economic and cultural integration into the national community'. Artikel 23 lid 2 bepaalde dat 'provision shall be made for a progressive transition from the mother tongue or the vernacular language to the national language or to one of the official languages of the country'. Deze laatste bepaling is bij uitstek een geschikt middel om de assimilatie van de inheemse bevolkingsgroepen te bewerkstelligen. $\mathrm{Zij}$ draagt bij aan het verlies van de maatschappelijke en culturele identiteit van de inheemse bevolkingsgroepen. ${ }^{393}$

De herziene tekst van de Conventie van 1989 biedt ten aanzien van de onderwijsbepalingen op enkele punten vooruitgang. Het betreft de participatie van inheemse volken bij de inrichting en organisatie van het onderwijs die in de tekst van 1957 ontbrak (artikel 27 lid 1). In dit opzicht zullen leden van inheemse volken worden betrokken bij het opzetten en uitvoeren van onderwijsprogramma's en zullen ze daartoe worden opgeleid. Een en ander vindt plaats met het oog op de geleidelijke overdracht van verantwoordelijkheden op het terrein van het onderwijs aan inheemse volken waar dit passend is (artikel 27 lid 1 en 2). Voorts wordt het recht van inheemse volken tot het stichten en in stand houden van eigen onderwijsinstellingen erkend (artikel 27 lid 3). Dat is een belangrijke bepaling die in de tekst van 1957 ontbrak. Een verbetering is verder dat onderwijsprogramma"s voor deze groepen '(shall) address their special needs, and shall incorporate their histories, their knowledge and technologies, their value systems and their further social, economic and cultural aspirations* (artikel 27 lid 1). Deze bepaling draagt bij tot behoud van de eigen culturele identiteit en de overdracht daarvan aan de jeugd. Inheemse kinderen ontvangen onderwijs in hun eigen taal voor zover dit uitvoerbaar is ('wherever practicable'). Dit is geen harde verplichting voor de staten en biedt een.onvoldoende garantie voor de inheemse volken zelf (artikel 28 lid 1). Daarnaast dienen er maatregelen genomen te worden opdat inheemse volken de gelegenheid hebben

392. Deze betrokkenheid van inheemse volken is uitgewerkt in artikel 6 van de herziene tekst, zoals rasdplegingsprocedures, maar de vraag blijft of dit voldoende is.

393. Zie over de gebreken van het onderwijs an inheernse volken de studie van J.R. Martiner Cobo, Study of the Problem of Discrimination against Indigenous Populations, United Nations, New York 1987 (sales number E.86.XIV.3), pp. 9-11. 
bedreven te geraken in de nationale taal (artikel 28 lid 2). Ook dienen er maatregelen genomen te worden tot behoud en bevordering van de ontwikkeling en het gebruik van de inheemse talen (artikel 28 lid 3). Tenslotte dienen onderwijsmaatregelen binnen de gehele nationale gemeenschap erop gericht te zijn vooroordelen uit te bannen en het begrip en de tolerantie tussen de verschillende groepen in de samenleving te bevorderen (artikel 31).

Ontegenzeggelijk is er op het terrein van de formulering van de onderwijsbepalingen sprake van enige vooruitgang die tegemoet komt aan de belangen van inheemse groepen. De scherpe kantjes van het integratiebeleid zijn er af, maar de vraag blijft of regeringen daadwerkelijk bereid zijn positieve maatregelen te nemen ten gunste van inheemse volken. Over de vraag of de herziene tekst een verbetering inhoudt lopen de meningen uiteen. ${ }^{394}$ Mijns inziens betekent de herziene Conventie een vooruitgang ten opzichte van de oude tekst. De ratio van het oude Verdrag, assimilatie van inheemse volken, is geschrapt, en de herziene tekst doet meer recht aan het idee van zelfbestuur, eigen verantwoordelijkheid en het behoud van de inheemse identiteit op sociaal, economisch en cultureel terrein. Toch moet hier verwezen worden naar artikel 7 lid 1 ingevolge waarvan inheemse volken slechts 'wanneer dit mogelijk is' een recht op zeggenschap over hun economische, sociale en culturele ontwikkeling hebben. De vraag blijft of de herziene Conventie voldoende harde verplichtingen voor partijstaten bevat gezien de ontsnappingsclausules die in de verschillende bepalingen, ook in de onderwijsbepalingen, voorkomen.

\subsection{De Conventie inzake de Rechten van het Kind}

De Conventie inzake de Rechten van het Kind werd gesloten op 20 november $1989^{396}$, precies 30 jaar na de aanvaarding van de Verklaring van de Rechten van het Kind door de Algemene Vergadering van de VN. ${ }^{396} \mathrm{Het}$ Verdrag beoogt een aanvulling te zijn op deze Verklaring door aan de rechten van het kind nadere uitwerking te geven. Bovendien is het Verdrag veel uitgebreider dan de Verklaring. Daarnaast is het Verdrag een juridisch bindend document, terwijl de Verklaring in de vorm van een resolutie is gegoten, en dus geen juridisch bindend karakter heeft. De Conventie trad in werking op 2 september 1990.

394. Berman, aw. pp. 52-56 is zeer kritisch ten aanzien van de herziene tekst, evenala Sitenfert Kroese, a.w. p. 550. Van Boven, a.w. p. 217 heeft meer waardering voor het heriene Verdrag.

395. Tekst van de Conventie in: Trb. 1990, 46. De Conventie werd op 20 november 1989, zonder stemming, aanvaard door de Algemene Vergadering vam de VN door middel van Res. 44/25. Nederland ondertekende het Verdrag op 26 januari 1990.

396. Zie over de Verklaring van de Rechten van het kind. P. van Dijk, De Internationale bescherming van de rechten van het kind, in: Familie- en jeugdrecht, jaargang 1
$(1979)$, pp. 16:-180. 
De Conventie kwam tot stand na tien jaar onderhandelen, een periode die begon in 1979 tijdens het internationale jaar van het kind. ${ }^{397}$ Het Verdrag pretendeert een alomvattende regeling van de rechten van het kind te geven. ${ }^{398}$ Artikel 1 omschrijft een kind als elke persoon beneden de leeftijd van 18 jaar, tenzij volgens het nationale recht meerderjarigheid op een eerdere leeftijd al wordt bereikt. Deze bepaling geeft een algemene norm, maar sanctioneert tevens de mogelijkheid van een afzonderlijke afwijkende nationale regel. Naast een groot aantal burger- en politieke rechten, legt de Conventie ook belangrijke economische, sociale en culturele rechten vast. Tot die laatste groep behoort het recht op onderwijs. Dit recht is neergelegd in een drietal bepalingen, te weten de artikelen 14, 28 en 29. Het sociale aspect van het recht op onderwijs is geformuleerd in artikel 28 . De tekst van artikel 28 luidt als volgt:

1. States Parties recognize the right of the child to education, and with a view to achieving this right progressively and on the basis of equal opportunity, they shall, in particular:
a. Make primary education compulsory and available free to all;
b. Encourage the development of different forms of secondary edu- cation, including general and vocational education, make them available and accessible to every child, and take appropriate measures such as the introduction of free education and offering financial assistance in case of need;
c. Make higher education accessible to all on the basis of capacity by every appropriate means; d. Make educational and vocational information and guidance avail- able and accessible to all children;
e. Take measures to encourage regular attendance at schools and the reduction of drop-out rates.

2. States Parties shall take all appropriate measures to ensure that school discipline is administered in a manner consistent with the child's human dignity and in conformity with the present Convention.

3. States Parties shall promote and encourage international co-operation in matters relating to education, in particular with a view to contributing to the elimination of ignorance and illiteracy throughout the world and facilitating access to scientific and technical knowledge and modern teaching methods. In this regard, particular account shall be taken of the needs of developing countries.

397. Zie over de tatstandkoming van de Conventie, Jacqueline Smith, Op weg naar een Internationale Conventie voor de Rechten wan het kind, in: Nieuwsbrief Liga voor de rechten van de mens, nr. 27, maart 1.989, pp. 4-11 en A.J.M. Delisien, De rechten van het kind: na 10 jaar voorbereiding nu bij verdrag vastgelegd, in: NJCM-Bulletin 15-5 (1990), pp. 566-57.5.

398. Zie hierover Defence for Children International/UNICEF, Briefing Kit on the Future United Nations Convention on the Rights of the Child, Doc. 1, The Human Rights of Children. Geneva 1987, 2 pp. 
Deze bepaling vertoont qua opzet en inhoud overeenkomst met artikel 13 IVESCR. De partijstaten erkennen het recht van het kind op onderwijs. Daartoe gaan zij een aantal concrete verplichtingen aan. $\mathrm{Zij}$ dienen steeds nader tot de verwezenlijking van het recht op onderwijs te komen, op grond van gelijke kansen voor een ieder, met behulp van alle beschikbare middelen. ${ }^{39}$ Het primaire onderwijs dient voor iedereen verplicht en kosteloos gemaakt te worden. Het voortgezet onderwijs dient voor elk kind beschikbaar en toegankelijk gemaakt te worden. Ook dienen passende maatregelen genomen te worden om die toegankelijkheid te verwezenlijken, zoals de invoering van kosteloos onderwijs en het verlenen van financiële steun aan hen die dat nodig hebben. Het hoger onderwijs dient voor een ieder, op grond van individuele capaciteit, toegankelijk te worden gemaakt eveneens door middel van alle passende maatregelen.

Bij de totstandkoming van artikel 28 uitte de Nederlandse afgevaardigde zijn bezorgdheid over de verwijzing in de ontwerptekst naar de (geleidelijke) invoering van kosteloos secundair en hoger onderwijs, vooral indien de term 'free education' moest worden verstaan als kosteloos onderwijs in de letterlijke betekenis van het woord. De Japanse afgevaardigde was van mening dat de verwijzing naar kosteloos onderwijs slechts een voorbeeld was van hoe het onderwijs voor allen toegankelijk kon worden gemaakt. De invoering van kosteloos onderwijs was volgens hem geen verplichting voor staten. De vertegenwoordiger van Finland was van oordeel dat het idee van geleidelijke invoering (van kosteloos onderwijs), dat gebaseerd was op het IVESCR, inmiddels achterhaald was. Resultaat van deze discussie was dat de invoering van kosteloos onderwijs in het secundair onderwijs als mogelijke maatregel wordt genoemd, terwijl ten aanzien van het hoger onderwijs de geleidelijke invoering van kosteloos onderwijs werd geschrapt: ${ }^{400}$

Naast deze bekende verplichtingen voor de staat bevat artikel 28 ook een aantal nieuwe elementen die in artikel 13 IVESCR ontbreken. Het gaat hier om zaken als beroepskeuzevoorlichting, het verminderen van het aantal uitvallers, en het handhaven van de discipline op school op een wijze die in overeenstemming is met de menselijke waardigheid en met de strekking van de Conventie. Dit laatste element is gericht op de bescherming van het kind indien schooldiscipline zou ontaarden in wrede en vernederende behandeling. ${ }^{401}$ Ook benadrukt deze bepaling het bevorderen van internationale samenwerking met het oog op de uitbanning van onwetendheid en analfabetisme. Op dit punt dient in het bijzonder rekening te worden gehouden met de behoeften van ontwikkelingslanden. Dit laatste is eveneens een nieuw element en geeft uiting aan de grote problemen waarmee Derde Wereldlanden geconfronteerd worden.

399. Artikel 28 (1) jo. artikel 4.

400. Zie ovar de totstandkoming van artikel 28 het Report of the Working Group on a draft convention on the righta of the child, UN Doc. E/CN.4/1989/48 (2 maart 1989), pp. $79-84_{n}$ op pp. 82,83 .

401. Zie UN Doe. E/CN.4/1989/48, p. 89. 
Artikel 29(1) somt de doeleinden van het onderwijs op waarbij het gaat om de plaats van het kind in het maatschappelijk leven. ${ }^{402}$ Deze doelstellingen zijn gebaseerd op artikel 13(1) IVESCR. Artikel 29(2) betreft een aspect van de klassieke vrijheid van onderwijs, te weten de vrijheid privéonderwijsinstellingen te stichten en in stand te houden. Bij de totstandkoming van deze bepaling uitte de Nederlandse afgevaardigde zijn ongerustheid over het feit dat de Conventie geen bepaling bevatte aangaande de vrije schoolkeuze van ouders, analoog aan artikel 13 lid 3 IVESCR. Een aantal andere westerse landen onderschreef deze opmerking. ${ }^{403}$ Ten aanzien van de opvoeding en de ontwikkeling van het kind legt artikel 18(1) de eerste verantwoordelijkheid daarvoor bij de ouders of wettelijke voogden. Zij dienen daarbij uit te gaan van de 'best interests of the child'.

In dit verband dient artikel 14 vermeld te worden dat aan elk kind de vrijheid van gedachte, geweten en godsdienst garandeert. Ouders, dan wel voogden hebben in dit opzicht het recht het kind richting te verschaffen bij de uitoefening van deze vrijheid, 'in a manner consistent with the evolving capacities of the child'. 40 .

De bepaling gaat niet uit van de rechten van ouders de zedelijke en godsdienstige opvoeding van hun kinderen te verzekeren volgens hun eigen overtuigingen zoals in andere verdragen. De bepaling stelt daarentegen de uitoefening van het recht door het kind zelf centraal onder begeleiding van de ouders; dan wel voogden. Die begeleiding dient in overeenstemming te zijn met de zich ontwikkelende vermogens van het kind, dat wil onder andere zeggen, met de groeiende zelfstandigheid van het kind. Over deze kwestie ontspon zich een discussie die beschouwd moet worden in het licht van de reikwijdte van de vrijheid van godsdienst. Een aantal (Islamitische)

402. Artikel 29 luidt:

1. States Parties agree that the education of the child shall be directed to:

a. The development of the child's personality, talents and mental and phyaical abilitie to their fullest potential;

b. The development of respect for human rights and fundamenttal freedomi, and for the principles enshrined in the Charter of the United Nations;

c. The development of respect for the child's parents, his or her own cultural identity language and values, for the national values of the country in which the child is living, the country from which he or she may originate, and for civilizations different from his of her own:

d. The preparation of the child for responsible life in al free society, in the apirit of understanding, peace, tolerance, equality of sexes, and friendship among all peoples, ethnic, national and religious groups and persons of indigenous origin;

e. The development of respect for the natural environment.

2. No part of the present Article or Article 28 shall be conatrued so as to interfere with the liberty of individuals and bodies to establish and direct educational inatitutions, subject always to the observance of the principles set forth in paragraph 1 of the present Article and to the requirements that the education given in such institutions shall conform to such minimum standards as may be laid down by the State.

403. Zie UN Doc. E/CN.4/1989/48, pp. 86, 87.

404. Artikel 14 lid 2 luidt: 'States $P$ arties shall respect the rights and duties of the parents and, when applicable, legal guardians, to provide direction to the child in the excercise of his or her right in a manner consistent with the evolving capacities of the child." 
landen maakte bezwaar tegen het recht van het kind een eigen godsdienst te kiezen. Voorts wilden deze landen een bepaling opnemen waarin het recht van de ouders de godsdienstige en zedelijke opvoeding en onderwijs van hun kinderen te verzekeren werd gegarandeerd, analoog aan artikel 18 lid 4 IVBPR. Andere staten waren voorstander van het recht van kinderen een eigen godsdienst te kiezen analoog aan artikel 18 lid 1 IVBPR. Bovendien kozen zij voor een grotere zelfstandigheid en onafhankelijkheid voor kinderen aangaande opvoeding en onderwijs. Het resultaat van deze discussie was een compromis dat niet het recht van kinderen erkent zelf een godsdienst te kiezen, maar dat aan ouders of voogden niet langer een beslissende invloed geeft bij de uitoefening van de vrijheid van godsdienst, maar hen een begeleidende rol toekent (artikel 14 lid 2). ${ }^{405}$

De Conventie bevat verder een belangrijke bepaling over de bescherming van kinderen tegen economische uitbuiting en kinderarbeid die het voor het kind onmogelijk maken (volledig) aan het onderwijs deel te nemen. ${ }^{406}$ Een belangrijke bepaling ten slotte is artikel 41 . Deze bepaling stipuleert dat nationale dan wel internationale regels die het meest gunstig zijn voor het kind toegepast moeten worden ongeacht de bepalingen van de Conventie. Ook ten aanzien van de verwezenlijking van het recht op onderwijs kan deze clausule van belang zijn gezien de specifieke regeling van het recht op onderwijs in andere mensenrechtenverdragen. De vraag is bijvoorbeeld wat de meest gunstige bepaling is aangaande de zedelijke en godsdienstige opvoeding en onderwijs van kinderen. Het gaat hier om de verhouding tussen artikel 18 lid 4 IVBPR en artikel 13 lid 3 IVESCR enerzijds en artikel 14 lid 2 Conventie inzake de Rechten van het Kind anderzijds. De bepalende rol van de ouders aangaande opvoeding en onderwijs kan in sommige gevallen voor kinderen het meest gunstig zijn, terwijl in andere gevallen de keuze van het kind zélf bepalend kan zijn. Een eensluidend antwoord op de hier gestelde vraag is niet te geven. Het hangt af van de gezinssituatie en de culturele en godsdienstige omstandigheden die een specifieke ouderkind relatie beïnvloeden. Een ander punt met betrekking tot de betekenis van artikel 41 is dat de vrije schoolkeuze van ouders bescherming vindt in artikel 13 lid 3 IVESCR, terwijl die in de hier besproken Conventie ontbreekt. Ten aanzien van de verwezenlijking van het primaire onderwijs is artikel 13 lid 2 sub a IVESCR dwingender geformuleerd (gebruik van de term 'shall') dan artikel 28 lid 1 sub a Conventie inzake de Rechten van het Kind waarin de gedachte van geleidelijke verwezenlijking meer is benadrukt (gebruik van de term 'make'). Artikel 13 biedt op dit punt meer bescherming. Voor het overige biedt de Conventie inzake de Rechten van het Kind een bescherming die op hetzelfde niveau ligt als die van artikel 13 IVESCR. Wel is het zo dat artikel 28 van de Conventie enige aspecten bevat (zoals ten aanzien van de handhaving van de discipline op school alsmede de bescherming tegen economische uitbuiting en kinderarbeid) die in

405. Zie hierover Delissen, a.w. pp. 570, 571.

406. Artikel 32 lid 1. 
oudere mensenrechtenovereenkomsten ontbreken. Dat zijn aspecten die van waarde zijn voor de bescherming van de belangen van kinderen en zij betekenen dan ook een vooruitgang.

De internationale implementatieprocedure van de verdragsbepalingen komt in sterke mate overeen met die van andere mensenrechtenverdragen. ${ }^{407} \mathrm{Er}$ is een rapportageplicht voor staten voorzien aangaande de maatregelen genomen ter verwezenlijking van de rechten van het kind. Een 'Committee on the Rights of the Child', bestaande uit 10 deskundigen, bestudeert de rapporten (artikel 43). Gespecialiseerde organisaties, UNICEF en andere $\mathrm{VN}$-organen kunnen een adviserende rol spelen in deze procedure. Het Comité kan suggesties en aanbevelingen van algemene aard formuleren ten behoeve van verdragsstaten en rapporteert verder aan de Algemene Vergadering van de VN.

\subsection{Analyse van het recht op onderwijs in internationale verdragen en verklaringen}

In het internationale recht inzake de rechten van de mens dat na de Tweede Wereldoorlog tot stand kwam is het recht op onderwijs in verschillende documenten verankerd. De grondslag daarvoor vormde de regeling van dit recht in een aantal grondwetten van staten. Reeds in de $19 \mathrm{e}$ eeuw kenden Europese staten de garantie van de vrijheid van onderwijs. Deze werd aangevuld met de opdracht aan de staat zorg te dragen voor inrichting en bekostiging van een onderwijsstelsel. Na aanvaarding van de Universele Verklaring van de Rechten van de Mens in 1948 vormde artikel 26 de basis voor de uitwerking van het recht op onderwijs in verschillende internationale teksten.

De internationale bepalingen inzake het recht op onderwijs kunnen op verschillende, elkaar deels overlappende, wijzen ingedeeld worden. In de eerste plaats kunnen mondiale (Universele Verklaring, IVESCR, IVBPR) en regionale documenten (EVRM, Afrikaans Handvest, Amerikaanse teksten, CVSE-documenten) waarin het recht op onderwijs is vastgelegd onderscheiden worden. In de tweede plaats heeft uitwerking plaats gevonden aan de hand van bepaalde thema's zoals discriminatie in het onderwijs (UNESCO Conventie), discriminatie op grond van religie of overtuiging (Verklaring inzake de uitbanning van alle vormen van onverdraagzaamheid en van discriminatie op grond van godsdienst of overtuiging). In de derde plaats is er een aantal bijzondere groepen van individuen waarvoor onderwijsrechten op afzonderlijke wijze zijn vastgelegd (vrouwen, kinderen, leden van minderheden, inheemse volken, vluchtelingen). Deze verschillende indelingen veronderstellen een universele aanvaarding van de waarde en het belang van het recht op onderwijs als mensenrecht. Daarbij moet worden aangete- 
kend dat slechts een klein aantal Derde Wereldlanden actief heeft deelgenomen aan het opstellen van mondiale teksten, zoals de Universele Verklaring, de UNESCO Conventie en het IVESCR. Een deel van de tegenwoordige Derde Wereldlanden was toen nog niet onafhankelijk. De invloed van Derde Wereldlanden op de totstandkoming van deze internationale teksten was dan ook beperkt. Het waren bijvoorbeeld voornamelijk voorstellen van westerse en Oosteuropese staten die ten grondslag hebben gelegen aan artikel 13 IVESCR. Een belangrijke bijdrage daaraan werd ook geleverd door de UNESCO. In ieder geval heeft een groot deel van de internationale gemeenschap van staten het recht op onderwijs formeel aanvaard door partij te worden bij de desbetreffende verdragen. Dit betekent evenwel nog niet dat de daadwerkelijke verwezenlijking van dit recht in landen met verschillende politieke, sociaal-economische en culturele stelsels inmiddels een feit is.

De benadering die een onderscheid maakt tussen burger- en politieke rechten enerzijds en economische, sociale en culturele rechten anderzijds heeft tegenwoordig aan belang ingeboet. De moderne benadering die stelt dat beide groepen mensenrechten één en ondeelbaar zijn komt treffend tot uitdrukking in het recht op onderwijs. Dit omvat immers aspecten van zowel kllassieke rechten als van sociale rechten.

In het algemeen kan gesteld worden dat de internationale normen aangaande het recht op onderwijs tamelijk gedetailleerd en specifiek van aard zijn. De meeste internationale teksten aangaande het recht op onderwijs behelzen zowel het vrijheidsaspect als het sociale aspect. Het vrijheidsaspect, onder meer geformuleerd in artikel 13 lid 3 en 4 IVESCR en in artikel 2 Eerste Protocol EVRM, impliceert een onmiddellijke verplichting voor de staat en daarmee een directe aanspraak van het individu ten opzichte van de staat. Het vrijheidsaspect is een typisch kenmerk van een democratische, pluriforme samenleving. Zijn oorsprong ligt in liberale ideeën en denkbeelden.

Eèn van de facetten van het vrijheidsaspect betreft de verplichting voor de staat de overtuigingen van de ouders te respecteren ten aanzien van de opvoeding van en het onderwijs aan hun kinderen (vergelijk bijvoorbeeld artikel 2 Eerste Protocol EVRM, artikel 26(3) Universele Verklaring, artikel 13(3) IVESCR, artikel 18(4) IVBPR). Genoemde bepalingen gaan uit van de rechten van ouders dan wel wettelijke voogden. De morele en religieuze overtuigingen van de ouders of voogden zijn de bepalende factor voor opvoeding en onderwijs van hun kinderen. Dit uitgangspunt is het sterkst geformuleerd in artikel 26(3) Universele Verklaring. Deze bepalingen moeten beoordeeld worden in historisch perspectief, dat wil zeggen ze moeten begrepen worden vanuit de historische context waarin ze tot stand kwamen. De sterke bescherming van de rechten van de ouders/voogden is verklaarbaar als reactie op de indoctrinaire invloeden van het nationaalsocialistische regime op de jeugd in Duitsland in de jaren dertig en in de Tweede Wereldoorlog. Bovendien moest de expliciete erkenning van de rechten van ouders en voogden dienen als schild tegen mogelijke communistische invloeden op school en in de maatschappij. Het gevoel van bedreiging 
door het communistische gevaar was in de jaren veertig en vijftig immers prominent aanwezig. Dit punt speelde met name een rol gedurende de totstandkoming van artikel 2 Eerste Protocol EVRM (zie hoofdstuk 3.4.5.)

De Conventie inzake de Rechten van het $\mathrm{Kind}$ is in een heel andere tijdgeest tot stand gekomen. Artikel 14(1) verleent de vrijheid van gedachte, geweten en godsdienst aan het kind zelf. Lid 2 omschrijft de rol van de ouders in termen van het richting geven aan het kind bij de uitoefening van dit recht. Ten opzichte van de oudere teksten is de rol van de ouders/voogden dus gerelativeerd. ${ }^{408}$ De eigen keuze van het kind staat in artikel 14 voorop. Men kan zeggen dat hier sprake is van een ontwikkeling in andere richting dan de bevestiging van ouderrechten. Het kind wordt meer subject dan object. Deze tendens naar de erkenning van de eigen rechten van het kind op dit gebied alsmede het ontbreken van een verwijzing naar de rechten van ouders in de onderwijsbepaling dienen naar mijn mening positief beoordeeld te worden. Op deze wijze kan ernst worden gemaakt met het ontwikkelen van de eigen meningsvorming en het geleidelijk vergroten van de eigen verantwoordelijkheden van het kind. De ouders/voogden kunnen het daar in bijstaan.

De vrijheid om privé-onderwijsinstellingen te stichten en in stand te houden vindt uitdrukkelijke erkenning in artikel 13(4) IVESCR en in het nagenoeg identieke artikel 29(2) Conventie inzake de Rechten van het Kind. Artikel 2, Eerste Protocol EVRM erkent deze vrijheid niet expliciet, maar zij ligt er wel impliciet in opgesloten. In feite vloeit zij voort uit het recht van de ouders andere dan door de staat ingestelde scholen voor hun kinderen te kiezen (vgl. artikel 13(3) IVESCR, artikel 5 sub b UNESCO Conventie). Deze vrijheid vormt één van de grondslagen voor een pluralistisch onderwijsbestel in een democratische samenleving.

Het sociale aspect, onder meer vastgelegd in artikel 13(2) IVESCR, houdt in dat het recht op onderwijs alleen dan substantiële inhoud krijgt indien de staat zelf actief optreedt. Dit betekent dat de staat een verplichting heeft tot geleidelijke verwezenlijking van dit recht. Het betreft hier een instructienorm waarbij de staat in beginsel de vrijheid heeft zelf de middelen te bepalen om aan de internationale verplichting te voldoen (vgl. artikel 2(1) IVESCR). Dit impliceert dat de burger in dit geval geen directe aanspraak heeft ten opzichte van de staat. Een uitzondering op de verplichting tot geleidelijke verwezenlijking vormt artikel 13 lid 2 sub a: het primaire onderwijs dient voor allen verplicht en kosteloos beschikbaar te zijn. Deze bepaling heeft een sterk gebiedend karakter. De verplichting tot geleidelijke verwezenlijking daarentegen van het voortgezet en het hoger onderwijs valt mede af te leiden uit het gebruik van het werkwoord 'to make' in artikel 13 lid 2 sub b en c IVESCR. Het is opmerkelijk dat zowell artikel 4 sub

408. De Verklaring ingake Godsdienstige Onverdraagzaamheid, tot stand gekomen in 1981, benadrukt in artikel 5 de roll en de opvattingen van ouders aangaande de opvoeding van en het onderwijs aan hun kinderen. Het kind zelf heeft daarover geen zeggenschap. 
a UNESCO Conventie als artikel 28 lid 1 sub a Conventie inzake de Rechten van het Kind ten aanzien van het primaire onderwijs wel een vervoeging van het werkwoord 'to make' bevatten. Op dit punt zijn deze bepalingen juridisch zwakker dan artikel 13 lid 2 sub a IVESCR, omdat de term 'to make' een aspect van geleidelijke verwezenlijking impliceert en minder dwingend is voor partijstaten. Het idee van een effectieve bescherming van de rechten van de mens impliceert dat voor een staat die partij is bij beide verdragen artikel 13 lid 2 sub a moet prevaleren ${ }^{409}$.

Het non-discriminatiebeginsel speelt bij de verwezenlijking van de rechten van de mens een centrale rol. In de woorden van Pieters:

'Het gelijkheidsbeginsel/discriminatieverbod is niet herleidbaar tot een onthoudingsplicht of een plicht tot positief optreden daar het gelijkheidsbeginsel gerespecteerd kan worden zowel door onthouding van bevoordeling van één categorie als door toekenning van het voordeel aan de gediscrimineerde categorie. ${ }^{.410}$

Beide aspecten van dit beginsel vinden we terug bij de verwezenlijking van het recht op onderwijs. In dit opzicht is het UNESCO Verdrag van bijzonder belang. De toegankelijkheid van het onderwijs dient voor een ieder gegarandeerd te zijn. Daarnaast mag de vrijheid van onderwijs in beginsel niet beperkt worden. Het bevorderen van gelijke kansen en een gelijke behandeling in het onderwijs is eveneens nauw verbonden met het nondiscriminatiebeginsel. Positieve maatregelen gericht op het doen verdwijnen van achterstanden van bepaalde groepen in het onderwijs, zoals van vrouwen of van leden van minderheden, kunnen in dit verband genoemd worden. 411

De nationale implementatie van het recht op onderwijs kan op verschillende manieren plaats vinden. Er is niet éen strategie of methode aan te wijzen volgens welke de verwezenlijking van het recht op onderwijs gestalte dient te krijgen. De meeste internationale teksten erkennen dit punt en verlenen aan staten een bepaalde beleidsvrijheid om de gestelde doeleinden te verwezenlijken. Bovendien kent elke staat een onderwijsstelsel met eigen kenmerken en eigenaardigheden. De UNESCO Conventie erkent dan ook de diversiteit van nationale onderwijsstelsels. ${ }^{412}$

409. Vgl. in dit verband artikel 41 Conventie inzake de Rechten wan het Kind, besproken in hoofdatuk 3.12 .

410. D. Pieters, Sociale grondrechten in de grondwetten van de landen van de Europese Gemeenschap, Antwerpen 1985 , p. 60 noot 126.

411. Vergelijk artikel 10 jo. artikel 4 Verdrag inzake Uitbanning van alle Vormen van Discriminatio van Vrouwen.

412. Zie de preambule. 
De totstandkoming van de internationale teksten aangaande het recht op onderwijs is langs verschillende kanalen verlopen en door verschillende organen ter hand genomen. Een vergelijking van deze internationale teksten leidt tot de conclusie dat een aantal elementen in vrijwel alle teksten terugkomt. Daarbij gaat het om de erkenning van het recht op onderwijs en de opdracht aan de staat de toegankelijkheid en de beschikbaarheid van de verschillende onderwijsgeledingen te verwezenlijken. Voorts kunnen als gemeenschappelijke elementen genoemd worden de vrije keuze van onderwijs, het respect voor de overtuigingen van ouders/voogden door de staat en tenslotte de vrijheid om privé-onderwijsinstellingen te stichten. In de loop der jaren heeft de internationale regelgeving op het terrein van het recht op onderwijs steeds een patroon gevolgd rond het sociale en het vrijheidsaspect. De teksten tot stand gekomen in het kader van universele organisaties zijn wat dit betreft het meest uitgebreid. De regionale documenten zijn daarentegen nogal summier, met uitzondering van het Protocol van San Salvador. Naar mijn mening moeten de internationale teksten aangaande het recht op onderwijs positief beoordeeld worden. In het bijzonder de mondiale teksten zijn concreet en veelomvattend. Dat er ook een bepaalde ontwikkeling valt waar te nemen in de internationale regeling van het recht op onderwijs bewijst de recente Conventie inzake de Rechten van het Kind. Dit Verdrag heeft een aantal tendensen te zien gegeven die beantwoorden aan de veranderende maatschappelijke ontwikkelingen en legt meer nadruk op de belangen van het kind zoals blijkt uit de bepaling over de relatie kinderarbeid-onderwijs.

Over het algemeen vertonen de recente internationale teksten over het recht op onderwijs, zoals de Conventie inzake de Rechten van het Kind en het Protocol van San Salvador, sterke overeenkomst met oudere teksten, zoals de Universele Verklaring en het IVESCR. Dezelfde elementen komen steeds terug. De tendens om voor verschillende maatschappelijke groepen afzonderlijke verdragen op te stellen is wellicht noodzakelijk vanuit het oogpunt van een effectieve internationale bescherming van deze groepen. Het gevolg is wel dat er een versnipperd beeld ontstaat van de internationale bescherming van het recht op onderwijs. Het is dan niet altijd even gemakkelijk vast te stellen welke tekst in een bepaald geval de meeste bescherming biedt. Ook is het niet altijd duidelijk wat nieuwe teksten nog toevoegen aan de reeds bestaande verdragsbepalingen en verklaringen over het recht op onderwijs.

Op één terrein is het mijns inziens noodzakelijk dat het normstellende werk wordt voortgezet. Dat betreft de (onderwijs) rechten van leden van minderheden. De bestaande verdragsbepalingen op dit gebied (artikel 5 lid 1 sub c UNESCO Verdrag tot Bestrijding van Discriminatie in het Onderwijs en artikel 27 IVBPR) hebben slechts een beperkte juridische reikwijdte. Het Document van Kopenhagen, tot stand gekomen in het CVSE-kader, bevat tamelijk uitgewerkte bepalingen over rechten van leden van nationale minderheden en geeft tevens een aanzet tot positieve verplichtingen voor staten. Van belang in dit verband is dat de rechten van afzonderlijke minderheden op etnische, religieuze of linguïstische grondslag worden gedefi- 
nieerd. Binnen de Raad van Europa wordt momenteel gewerkt aan het opstellen van een internationale tekst over regionale en minderheidstalen in Europa. ${ }^{413}$ Deze ontwerptekst bevat ook een onderwijsbepaling over het beschikbaar maken van de verschillende geledingen van het onderwijs in de regionale of minderheidstaal. Voor Nederland heeft dit betrekking op de Friese taal. Op grond van deze ontwerptekst dienen staten positieve maatregelen te nemen tot invoering van het onderwijs in de minderheidstaal.14 Het is van belang te onderstrepen dat in de Europese regio nu serieus werk wordt gemaakt van de formulering van (onderwijs)rechten van leden van minderheden. Wellicht verdient een regionale benadering de voorkeur boven het tot stand brengen van een wereldwijde tekst over rechten van leden van minderheden.

De bestaande teksten over het recht op onderwijs als mensenrecht mogen dan uitgebreid en concreet zijn, de betekenis van bepaalde termen is een probleem. Hoe is vast te stellen of het primaire onderwijs verplicht en kosteloos is? Welke criteria dient men daarbij te hanteren? Wat is de betekenis van de clausule dat het voortgezet onderwijs voor een ieder toegankelijk en algemeen beschikbaar dient te zijn? Met andere woorden, welke indicatoren, kwantitatieve dan wel kwalitatieve, zijn bruikbaar om te kunnen toetsen of een staat aan zijn verplichtingen heeft voldaan? Dit zijn vragen die van belang zijn om te kunnen vaststellen of en zo ja in welke mate een staat voortgang heeft geboekt bij de verwezenlijking van het recht op onderwijs. Zij zullen in hoofdstuk 6 nader besproken worden.

413. Zie Council of Europe, Ad Hoc Committee of Experts on Regional and Minority Languages in Europe (CAHLR), Draft Report, Doc. CAHLR 90 (9) prow. van 28 september 1990 .

414. Het is nog onduidelijk of deze tekst zal worden gegoten in de vorm van een aanbeveling asn de lidstaten van de Raad van Europa of in de vorm van een verdrag. 


\section{HOOFDSTUK 4}

\section{De internationale implementatie van het recht op onderwijs}

\subsection{Internationale jurisprudentie over het recht op onderwijs: het Europees Verdrag tot Bescherming van de Rechten van de Mens}

\subsubsection{Inleidende opmerkingen}

Het recht op onderwijs is nog maar een relatief gering aantal malen onderwerp geweest van een internationale juridische procedure, waarbij een staat werd aangeklaagd wegens schending van deze bepaling. Het is voornamelijk het Europees Verdrag voor de Rechten van de Mens geweest dat de grondslag vormde voor internationale jurisprudentie over het recht op onderwijs.

Ingevolge artikel $25 \mathrm{EVRM}$ kan ieder natuurlijk persoon, iedere organisatie of groep van particulieren een klacht indienen tegen een verdragsstaat die het individueel klachtrecht heeft aanvaard, inzake een beweerde schending door die staat van een van de rechten uit het EVRM. Klachten moeten worden gericht aan de Europese Commissie voor de Rechten van de Mens. De Commissie onderzoekt of de klacht ontvankelijk kan worden verklaard (artikel 27 EVRM). Indien dat het geval is gaat zij over tot een nader onderzoek van de feiten. Vervolgens probeert zij tot een minnelijke schikking te komen (artikel 28 EVRM). Indien het geschil tussen partijen niet kan worden opgelost stelt de Commissie een rapport op over de feiten en geeft haar mening over de vraag of een schending van het Verdrag heeft plaatsgevonden (artikel 31). Het rapport wordt toegezonden aan het Comité van Ministers en de desbetreffende staat. Binnen drie maanden na toezending van het rapport aan het Comité van Ministers kunnen de Commissie, of de staat tegen wie de klacht is gericht, dan wel de staat van wie het beweerde slachtoffer onderdaan is de zaak aanhangig maken bij het Europese Hof voor de Rechten van de Mens (artikelen 47, 48 EVRM). Indien binnen drie maanden na toezending van het rapport aan het Comité van Ministers de zaak niet is voorgelegd aan het $\mathrm{Hof}$ ingevolge artikel 48 , neemt het $\mathrm{Co}$ mité van Ministers een beslissing over de vraag of het Verdrag al dan niet geschonden is (artikel 32 EVRM).

De Europese Commissie en het Europese Hof voor de Rechten van de Mens interpreteerden in een drietal belangrijke zaken artikel 2 Eerste Protocol EVRM. De eerste zaak waarin artikel 2 Eerste Protocol uitvoerig werd ge- 
analyseerd betrof de Belgische Taalzaak (1968). ${ }^{1}$ Andere zaken waarin artikel 2 centraal stond waren kwesties betreffende het onderwijs in de sexuele opvoeding in Deense staatsscholen, de zaak K jeldsen e.a. $(1976)^{2}$ en lijistraffen op scholen in Schotland, de zaak Campbell and Cosans (1982). ${ }^{3}$ In een aantal andere zaken werd ook geklaagd over schending van artikel 2, maar deze zaken bereikten het Hof niet. ${ }^{4}$

Het Internationaal Verdrag inzake Economische, Sociale en Culturele Rechten kent geen individuele klachtprocedure, alleen een rapportageverplichting voor staten. Artikel 13 uit dit Verdrag, dat het recht op onderwijs vastlegt, kan dus niet direct in een internationale procedure ingeroepen worden. Dit is wel op indirecte wijze mogelijk via de algemene non-discriminatiebepaling van artikel 26 IVBPR. Wel bestaat er éen uitspraak van het Mensenrechtencomité waarbij artikel 18(4) IVBPR aan de orde was.

Dit betekent dat jurisprudentie over het recht op onderwijs eenzijdig Westeuropees van karakter is. Bovendien is Europa een regio met een vrij hoog ontwikkeld onderwijsstelsel. Problemen zoals die in Derde Wereldlanden ten aanzien van de verwezenlijking van het recht op onderwijs bestaan, zijn in Europa over het algemeen onbekend. In Europese landen is de infrastructuur voor een onderwijsstelsel over het algemeen goed ontwikkeld. De Westeuropese jurisprudentie betreft dan ook aspecten van het recht op onderwijs die typisch zijn voor de inrichting van het onderwijs in westerse landen. Men kan zich in dit verband afvragen wat de relevantie van deze jurisprudentie is voor de verwezenlijking van het recht op onderwijs in landen buiten Europa. Uiteindelijk zijn de organisatie en inrichting van het onderwijs in Europa verschillend van die in bijvoorbeeld Aziatische landen. In de navolgende bespreking van de Straatsburgse jurisprudentie over het recht op onderwijs zal niet uitgebreid ingegaan worden op de inhoudelijke aspecten van de verschillende zaken. De bedoeling van deze paragrafen is om enkele algemene aspecten ten aanzien van de interpretatie van het recht op onderwijs te bespreken zoals die in de jurisprudentie van Commissie en Hof naar voren komen. De volgende punten zullen daarbij

1. Belgian Linguistic Case, Case relating to certain aspects of the laws on the use of languages in education in Belgium, Judgment of the European Court on Human Rights, 23 July 1968. Publiestione of the Court Series A, vol. $B$ (hierna de Belgische Taalraak).

2. Case of Kjeldsen, Busk Madsen and Pedersen, Judgment of 7 December 1976, Publications of the Court Series A, voll. 23 (hierna de zaak Kjeldsen e.a.).

3. Case of Campbell and Cosans, Judgment of 25 February 1982, Publications of the Court Series A, vol. 48 (hierna de zaak Campbell and Cosans).

4. Zle bijwoorbeeld de saak nr. 4733/71, Karnell en Hardt tegen Zweden (minnelijke schikking) en de zaak nr. 2209/64, Inhabitants of Les Fourons tegen Belgie (Res. DH (74) 1 op grond van artikel 32 van de Europese Conventie).

Zie voor een uitvoerige bespreking van de jurisprudentie over artikel 2 door Commisgie on Hof, P. v. Dijk, G.J.H. v. Hoof, Theory and Practice of the European Convention on Human Rights, 2nd edition, Deventer-Boston 1990, pp. 467-478.

Zle ook P.W.C. Akkermans, Onderwijs ale constitutioneel probleem, Alphen aan den Rijn/Brussel 1980, pp. 169-180. 
aan de orde komen. Ten eerste zal worden ingegaan op de definitie door de Europese Commissie en het Europese Hof van enkele fundamentele termen ten aanzien van het recht op onderwijs. Ten tweede zal worden stil gestaan bij het algemene juridische karakter en de reikwijdte van artikel 2, Eerste Protocol. Daarbij staat de zorgplicht van de staat centraal (het sociale aspeet van het recht op onderwijs). Als derde tenslotte, wordt het vrijheidsaspect van het recht op onderwijs besproken. Hierbij gaat het om zulke noties als de (onthoudings)verplichting van de staat en de rechten van de ouders.

\subsubsection{Definitie van termen}

De Belgische Taalzaak was een langdurige procedure die begon in 1962 en eindigde met het oordeel van het Hof in 1968. Daarbij ging het in hoofdzaak om de vraag of de Belgische taalwetgeving met betrekking tot het onderwijs in strijd was met de artikelen 8,14 EVRM en artikel 2 Eerste Protocol EVRM. De klagers, een aantal Franstalige inwoners (ouders) van Nederlandstalige gemeenten in België, beweerden dat de Belgische staat geen Franstalig onderwijs verzorgde in de steden en dorpen waar de klagers woonden. Voorts klaagden zij erover dat de Belgische staat financiële steun onthield aan onderwijsinstellingen in de desbetreffende gebieden die niet voldeden aan de voorwaarden betreffende de taalwetgeving voor scholen. Ook zou de Belgische staat weigeren diploma's te erkennen van scholen die niet voldeden aan de taalwetgeving. Bovendien stond de Belgische staat de kinderen van klagers niet toe elders Franstalig onderwijs te volgen. Deze houding van de Belgische staat leidde ertoe dat de klagers verplicht werden hun kinderen in te schrijven bij lokale scholen die niet voldeden aan de wensen van de ouders, dan wel gedwongen waren hun kinderen naar scholen in "Groot Brussel" te sturen wat praktische problemen opleverde.

De Belgische regering was in eerste instantie van oordeel dat de Straatsburgse organen niet ontvankelijk waren in de klacht. Het onderwerp van de klacht zou binnen de zogenaamde 'domaine réservë' van staten vallen en de bepalingen van het EVRM en het Eerste Protocoll zouden dus niet van toepassing zijn. In een uitspraak over deze kwestie verwierp het Hof de opvatting van de Belgische regering. Het Hof was van oordeel dat de klachten van de ouders betrekking hadden op de interpretatie van bepalingen uit de Conventie en het Protocol. Staten waren op grond van de Conventie en het Protocol gehouden de verdragsnormen in acht te nemen ten opzichte van personen die onder hun rechtsmacht vallen. ${ }^{5}$

In de zaak $\mathrm{K}$ jeldsen, Busk Madsen en Pedersen verzetten de klagers, ouders van leerplichtige leerlingen, zich tegen het onderwijs in de sexuele opvoeding dat in Deense openbare scholen geïntegreerd met andere vakken werd gegeven. Tot augustus 1970 was dit onderwijs facultatief en werd als

5. Case relating to certain aspects of the laws on the use of languages in education in Belgium (Preliminary Objection), Judgment of 9th february 1967 Publications of the Court Series A, vol. 5, p. 19; zie ook J.G. Merrills, The development of international law by the European Court of Human Rights, Manchester 1988, pp. 44, 45. 
afzonderlijk vak onderwezen. Met het oog op het verminderen en het voorkomen van kwesties als abortus, geslachtsziekten en het aantal ongehuwde moeders achtte de Deense regering invoering van verplicht onderwijs in de sexuele opvoeding noodzakelijk. Dit kwam met name aan de orde in de vakken Deens, kennis van het Christendom en biologie. Een ander gedeelte van het onderwijs in de sexuele opvoeding werd als afzonderlijke vak gegeven. Klagers verzetten zich tegen het verplichte, geïntegreerde gedeelte van het vak, omdat dit in conflict kwam met hun religieuze en filosofische overtuigingen. Vanwege het verplichte karakter van het vak konden zij geen vrijstelling krijgen. Op ethische gronden wilden zij hun kinderen zelf een sexuele opvoeding geven. De Europese Commissie verklaarde hun klachten ontvankelijk op het punt dat de wet van 1970, die verplicht en geïntegreerd onderwijs in de sexuele opvoeding invoerde, onverenigbaar was met artikel 2 Eerste Protocol EVRM.

De zaak van Campbell and Cosans had betrekking op het gebruik van lijfstraffen als een vorm van disciplinaire maatregelen op openbare scholen in Schotland. De beide leerlingen Campbell en Cosans hadden zelf weliswaar geen lijfstraffen ondergaan, maar hun ouders hadden geweigerd hun kinderen te onderwerpen aan een regime van lichamelijke bestraffingen. $\mathrm{Zij}$ beriepen zich daarbij op respect voor hun filosofische overtuigingen. Vanwege financiële en praktische redenen waren de ouders niet in staat hun kinderen naar een andere dan een openbare school te sturen. Eén van beide leerlingen, Jeffrey Cosans, was bovendien geschorst van school, nadat hij geweigerd had een lichamelijke bestraffing te ondergaan en zijn ouders verlangden dat hun zoon niet aan een dergelijke straf onderworpen zou worden indien hij zou terugkeren naar school. Uiteindelijk heeft Jeffrey Cosans de school niet meer bezocht. In mei 1977 werd hij zestien jaar en was hij niet meer leerplichtig. De ouders van beide leerlingen voerden schending aan van artikel 3 EVRM (verbod van onmenselijke en vernederende behandeling of bestraffing) en van de tweede zin van artikel 2 Eerste Protocol. Voorts werd ten aanzien van Jeffrey Cosans geklaagd dat zijn schorsing van school een schending opleverde van zijn recht op onderwijs ingevolge de eerste zin van artikel 2 Eerste Protocol.

In de zaak Campbell and Cosans heeft het Hof een definitie gegeven van de termen 'education' en 'teaching':

$\therefore$ the education of children is the whole process whereby, in any society, adults endeavour to transmit their beliefs, culture and other values to the young, whereas teaching or instruction refers in particular to the transmission of knowledge, and to intellectual development. ${ }^{46}$

6. Zaak Campbell and Cosans, Publications of the Court Series A, vol. 48 , p. 14. 
Het betreft hier een ruime definitie, waarbij het niet alleen gaat om onderwijs, maar ook om opvoeding, alsmede de wijze waarop deze aan de kinderen worden overgebracht.

De term 'recht op onderwijs' werd door het Hof in de Belgische Taallzaak als volgt omschreven: 'the right to avail (oneself) of the means of instruction existing at a given time"7, dat wil zeggen het recht om gebruik te maken van de op een bepaald tijdstip beschikbare onderwijsvoorzieningen.

Deze korte formulering werd nader uitgewerkt:

'The first sentence of Article 2 of the Protocol consequently guarantees, in the first place, a right of access to educational institutions existing at a given time, but such access constitutes only a part of the right to education. For the "right to education" to be effective, it is further necessary that, inter alia, the individual who is the beneficiary should have the possibility of drawing prof it from the education received, that it is to say, the right to obtain, in conformity with the rules in force in each State, and in one form or another, official recognition of the studies which he has completed. 8

De term 'recht op onderwijs' dient dus niet in enge zin geïnterpreteerd te worden. Het gaat niet alleen om de formele toegang tot het onderwijs. De term betekent ook dat het onderwijs in al zijn fases en geledingen open moet staan voor die personen die daartoe de bekwaamheid bezitten en die het recht dienen te hebben dat onderwijs ook te voltooien, alsmede erkenning te verkrijgen van de genoten opleiding.

De term 'philosophical convictions' in de tweede zin van artikel 2 was, zoals wij gezien hebben, bij de totstandkoming van deze bepaling in het begin van de vijftiger jaren een heet hangijzer. ${ }^{9}$ Het Hof en de Commissie hebben in de Belgische Taalzaak, en vooral in de zaken Kjeldsen e.a. en Campbell and Cosans nadere invulling gegeven aan de term 'philosophical convictions'. De term omvat in ieder geval niet het onderwijs in een bepaalde door de ouders gewenste taal. ${ }^{10}$ De Europese Commissie had in haar opinie in de Belgische Taalzaak verwezen naar de 'travaux préparatoires' van artikel 2 en stelde dat de term alleen betrekking had op de bescherming van godsdienstige opvattingen, maar dat de verwijzing naar filosofische opvattingen in een later stadium was toegevoegd met het oog op de bescherming van agnostische opvattingen. ${ }^{11}$

7. Belgische Taalraak, Publications of the Court Series A, vol. 6 " p. 31 .

8. Ibid.

9. Zie het overzicht van de diacussie in hoofdstuk 3.4 .5 supra.

10. Belgische Taalraak, a.w. p. 32.

11. Opinie van de Commissie van 24 juni 1965, Belgische Taalzaak, Publications of the Court Series B, vol. 3 par. 379, p. 282. 
In haar opinie in de zaak Campbell and Cosans komt de Commissie terug op haar standpunt inzake de betekenis van de term 'philosophical convictions.' $\mathrm{Zij}$ erkent dat haar eerdere opvatting te eng was, en formuleert een definitie die veel ruimer is:

"the "concept of philosophical convictions" must be understood to mean those ideas based on human knowledge and reasoning concerning the world, life, society etc., which a person adopts and professes according to the dictates of his or her conscience. These ideas can more briefly be characterised as a person's outlook on life including, in particular, a concept of human behaviour in society. ${ }^{, 12}$

In de zaak Campbell and Cosans definieerde het Hof de uitdrukking 'philosophical convictions' als volgt:

'Having regard to the Convention as a whole, including Article 17, the expression "philosophical convictions" in the present context denotes, in the Court's opinion, such convictions as are worthy of respect in a "democratic society" (...) and are not incompatible with human dignity; in addition, they must not conflict with the fundamental right of the child to education, the whole of Article 2 being dominated by its first sentence $(\ldots) .13$

De interpretatie die Commissie en Hof aan de term 'religieuze en filosofische overtuigingen' hebben gegeven is zeer ruim van karakter. Beide organen hebben op creatieve wijze inhoud gegeven aan de term. Voorop staat dat de overtuigingen waarop ouders zich beroepen niet in strijd mogen zijn met het recht op onderwijs van het kind. Voorts moet het gaan om overtuigingen die passen in een democratische samenleving. Het betreft de zeer persoonlijke opvattingen en ideeën van mensen over leven en de maatschappij en de plaats van het individu daarin. Van belang is dat ouders die geen religieuze redenen voor hun overtuigingen kunnen aanvoeren zich kunnen beroepen op serieuze opvattingen die zij volgens hun eigen geweten uitdragen over zaken die binnen de term 'filosof ische overtuigingen' vallen. ${ }^{14}$ In de zaak Campbell and Cosans bepaalde het Hof dat de opvattingen van ouders over lijfstraffen op Schotse openbare scholen op deze gronden bescherming verdienden. Akkermans heeft zich in dit verband afgevraagd of

12. Opinie van de Commissile van 16 mei 1980, in de zaak Campbell and Cosans, Publications of the Court Series B, vol. 42, p. 37 .

13. Zaak Campbell and Cosant, a.w. p. 16 .

Zie over deze zak o.m. H.G. Schermers, Lijfatraffen op achool, in: Ex Iure, Veertien Opstellen bij het Veertiende Lustrum van Societas Iuridica Grotius en de Vierhonderdenvijfde geboortedag van Grotius, Arnhem 1987, pp. 169-179.

14. Zie D.M. Clarke, Freedom of thought and educational rights in the European Convention, in: The Iriah Juriat, vol. XXII, new geries Part 1 (1987), pp. 28-5.5, op p. 49. 
in de Nederlandse verzuilde onderwijsstructuur elke filosofische overtuiging wel tot haar recht kan komen. ${ }^{15}$

Voorts verdient de aandacht dat het Hof in de Belgische Taalzaak de linguïstische opvattingen van ouders, dat wil zeggen de voorkeur voor onderwijs in een door hen gewenste taal, heeft uitgesloten van de term 'filosofische overtuigingen. De Witte heeft hierover opgemerkt dat de wens van ouders om hun kinderen op te voeden en te laten onderwijzen in de taal van de eigen keuze een zekere filosofische overtuiging vormt, althans deel uitmaakt van een bepaalde levensvisie. Ook kan men de vraag stellen of een bepaalde taal een bepaalde filosofie belichaamt of vertegenwoordigt. ${ }^{16}$ Gezien de ruime interpretatie van de term 'filosofische overtuigingen' in de zaak K jeldsen e.a. alsmede in de Campbell and Cosans zaak kan men het met De Witte eens zijn als hij stelt dat er geen reden is de linguïstische voorkeuren van ouders uit te sluiten van de term 'filosof ische overtuigingen'. ${ }^{17}$

\subsubsection{De reikwijdte van artikel 2: het sociale aspect van het recht op on- derwijs}

Het Hof en de Commissie hebben met name in de hiervór genoemde uitspraken de inhoud en het karakter van het recht op onderwijs geïnterpreteerd. Ook zijn beide organen ingegaan op de reikwijdte van artikel 2, Eerste Protocol. Artikel 2 staat niet volledig op zichzelf, maar moet mede gelezen en toegepast worden in het licht van de artikelen 8, 9 en 10 van de Conventie. ${ }^{18}$ Dit betekent dat het recht op onderwijs moet worden beschouwd in de context van de rechten van het gezin, dat wil zeggen de relatie ouderskinderen (artikel 8). Voorts bepaalt artikel 9 de vrijheid van geweten en godsdienst; dit is van belang in verband met de rechten van ouders aangaande het onderwijs aan hun kinderen in overeenstemming met hun religieuze en godsdienstige overtuigingen. Artikel 10 tenslotte regelt de vrijheid van meningsuiting; daaronder is begrepen de vrijheid om inlichtingen of denkbeelden te ontvangen. Dit laatste aspect staat in verband met het recht van elk kind onderwijs te ontvangen. Bovendien is de relatie tussen de rechten en vrijheden uit de Conventie en artikel 14 EVRM van belang. Artikel 14 garandeert het genot van rechten en vrijheden zonder enige vorm van discriminatie. Het Hof makte over de relatie tussen artikel 2, Eerste Protocol en artikel 14 de volgende opmerkingen:

15. Zie P.W.C. Akkermans, Onderwijs en recht, in: J.A. van Kemenade (red.), Onder-

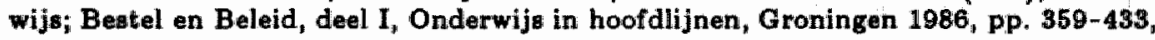
op p. 391.

16. Zie B. de Witte, The Protection of Linguistic Diversity through Fundamental Righta, Thesis, 1985 (niet gepubliceerd), pp. 427-431.

17. De Witte, a.w. p. 430.

18. De zaak Kjeldsen e.a., a.w. p. 26. 
'While it is true that this guarantee has no independent existence in the sense that under the terms of Article 14 it relates solely to "rights and freedoms set forth in the Convention", a measure which in itself is in conformity with the requirements of the Article enshrining the right or freedom in question may however infringe this Article when read in conjunction with Article 14 for the reason that it is of a discriminatory nature. ${ }^{19}$

Gelijke behandeling is aldus geen afzonderlijk recht ten opzichte van de andere rechten van het EVRM, maar een aanvullende dimensie ten opzichte van andere rechten. ${ }^{20}$ Dit betekent bijvoorbeeld dat een persoon niet de oprichting van een bepaalde school of onderwijstype van de staat kan eisen. Het is, bij wijze van voorbeeld, de staat well verboden discriminatoire maatregelen te nemen in de zin van artikel 14 met betrekking tot de toegang tot de bestaande onderwijsinstellingen. Niet elk onderscheid is evenwel discriminatoir van aard. Dat is het geval indien het onderscheid een 'objective and reasonable" rechtvaardiging kent: "The existence of such a justification must be assessed in relation to the aim and effects of the measure under consideration, regard being had to the principles which normally prevail in democratic societies". ${ }^{21}$

Ten aanzien van de problematiek die in de Belgische Taalzaak aan de orde was oordeelde het Hof:

'that Article 14, even when read in conjunction with Article 2 of the Protocol, does not have the effect of guaranteeing to a child or his parent the right to obtain instruction in a language of his choice. The object of these two Articles, read in conjunction, is more limited: it is to ensure that the right to education shall be secured by each Contracting Party to everyone within its jurisdiction without discrimination on the ground, for instance, of language. This is the natural and ordinary meaning of Article 14, read in conjunction with Article 2. Furthermore, to interpret the two provisions as conferring on everyone within the jurisdiction of a State a right to obtain education in the language of his own choice would lead to absurd results, for it would be open to anyone to claim any language of instruction in any of the territories of the Contracting Parties. ${ }^{22}$

19. Belgische Tasimaak, a.w. p. 33.

20. De Witte a.w. p. 579.

21. Belgische Taalzaak, a.w. p. 94 .

22. Idem, p. 35. Zie ook L. Wildhaber, To what extent has the right to education evolved?, in: Proceedings of the Fourth International Colloquy about the European Convention on Human Rights, Rome, 5-8 november 1975 , Strasbourg 1976, pp. 143$183_{"}$ op p. 167; A.Kiss, La protection internationale du droit de l'enfant al l'éducation, in: Revue des Droits de l'Homme, vol. 6 (1973), pp. 467-486, op p. 477. 
Met andere woorden, het Hof wijst een positieve verplichting voor staten om tegemoet te komen aan de linguîstische voorkeur van ouders van de hand.

Naar de mening van de Commissie heeft het recht op onderwijs in artikel 2 primair betrekking op het basis (lager) onderwijs en niet noodzakelijk op vervolgstudies. ${ }^{23}$ Dit lijkt mij een te enge opvatting van de term 'onderwijs'. Bij het opsteilen van artikel 2 had men weliswaar alleen het lager onderwijs voor ogen, maar de opvatting van de Commissie vindt geen steun in de tekst van artikel 2. Bovendien spreekt het Hof van de 'means of instruction existing at a given time'. ${ }^{24}$ Gezien de expansie en verscheidenheid van het onderwijs in de lidstaten van de Raad van Europa ligt het voor de hand dat artikel 2 betrekking heeft op iedere bestaande vorm van onderwijs en op elk niveau van onderwijs in een lidstaat. ${ }^{25} \mathrm{Er}$ bestaat mijns inziens geen enkele reden de bescherming die artikel 2 biedt te beperken tot het lager onderwijs.

De Commissie heeft in een al wat oudere zaak bepaald dat alleen natuurlijke personen rechten kunnen ontlenen aan artikel 2. Rechtspersonen kunnen geen dragers zijn van de rechten krachtens artikel $2{ }^{26}$ Organisaties van ouders, een kerkgenootschap of andere groeperingen kunnen artikel 2 niet inroepen. $\mathrm{Zij}$ kunnen niet als klager of benadeelde worden beschouwd. De rechten van specifieke ouders moeten geschonden zijn; deze ouders kunnen zich wel aaneensluiten en samen optreden. De procedure in de Belgische Taalzaak is hiervan een voorbeeld. Het standpunt van de Commissie betekent ook dat een organisatie als rechtspersoon niet de klacht van ouders kan overnemen en procederen namens de ouders. In de literatuur is deze opvatting van de Commissie gekritiseerd. Vaak is het zo dat de effectieve verwezenlijking van de rechten van ouders het best op collectieve basis kan gebeuren. Verschillende auteurs pleiten er dan ook voor verenigingen van ouders te erkennen in een klachtprocedure voor de Europese organen. ${ }^{27}$

De juridische reikwijdte van artikel 2, Eerste Protocol stond volop ter discussie in de Belgische Taalzaak. Met name ging het om de interpretatie van de eerste zin van deze bepaling die als volgt luidt: "No person shall be de-

23. Zaak 5962/72, X. v. Verenigd Koninkrijk, Decisions and Reports 2 (1975), p. 50.

24. Belgische Taalzaak, a.w. p. 31.

25. Zie Van Dijk, Van Hoof, a.w. p. 468.

26. Zaak 3798/68, Church of Scientology $v$. Verenigd Koninkrijk, in: Yearbook of the European Convention on Human Rights, vol. XII, p. 306. De zaak werd op deze grond niet-ontvankelijk verklaard.

27. Zie Wildhaber, a.w. p. 171; E.A. Alkema, Studies over Europese Grondrechten. Deventer 1978 , pp. 88, 89; T. Opsahl . The Convention and the right to respect for family life, particularly as regards the unity of the rights of parentis and guardians in the education of children, in: A.H. Robertson (ed.), Privacy and Human Righte, Manchester 1973 , pp. 182-255, op p. 241, en Akkermans (1980), a.w. p. 174. 
nied the right to education.' De vraag deed zich voor of deze bepaling een zuiver vrijheidsrecht inhoudt dat voor de staat slechts een onthoudingsverplichting impliceert, of dat in de formulering van artikel 2, eerste zin ook een sociaal aspect besloten zit dat voor de staat positieve verplichtingen schept. Deze vraag gold in feite voor alle in de Europese Conventie opgenomen rechten en vrijheden. ${ }^{28}$ De vage formulering van de eerste zin van artikel 2 maakte het voor Commissie en Hof noodzakelijk aan te geven welke verplichtingen daar voor een partijstaat uit voortvloeien.

De Belgische regering was van oordeel dat de eerste zin van artikel 2 slechts een negatieve verplichting impliceerde. Staten waren niet verplicht scholen te stichten of onderwijsinstellingen te financieren:

'It is a matter of meeting a negative obligation in the context of the "status libertatis", the status of freedom."29

De meerderheid van de Commissie verwierp daarentegen het idee dat de in de Conventie gegarandeerde rechten en vrijheden slechts een negatief karakter hebben:

'Thus it cannot be maintained, ...., that a matter is not covered by the Convention simply because the Convention lays down no positive obligations. One must examine each question and interpret each provision in its own right, without being led astray by legal theories, and certainly not by out-of-date ones. The theory in this case may still have a certain philosophical value when it is a question of describing certain of the rights laid down. But it is in no way normative. ${ }^{.30}$

De Commissie achtte derhalve het traditionele strikte onderscheid tussen klassieke vrijheidsrechten enerzijds en sociale rechten anderzijds achterhaald. Zo kan gesteld worden dat van oorsprong klassieke rechten, zoals de vrijheid van onderwijs, positieve verplichtingen voor de staat kumnen inhouden, of anders gezegd, de staat kunnen opdragen een bepaalde prestatie te leveren. ${ }^{31}$

Mede op grond van de "travaux préparatoires' kwam de meerderheid van de Commissie tot de slotsom dat artikel 2 geen positieve verplichtingen

28. De verwezenlijking van burger- en politieke rechten kan het noodzakelijk maken dat de staat actief optreedt; ter verwezenlijking van de vrijheid van meningsuiting $k a n$ de otaat bijvoorbeeld door financièle maatregelen het pluralisme in de pers bevorderen.

29. Prol. P. Guggenheim, namens Belgid, Publications of the Court Series B, voll. 3, p. 494, Zie cok F. Castberg, The European Convention on Human Rights, Leiden 1974, p. 179.

30. Prof. M. Sørensen, namems de Commissie, Publications of the Court Series B, vol. 3, pp. 518,519 .

31. Q.J. Wiarda, Extensieve en restrictieve verdragstoepassing door het Europees Hof voor de rechten van de mens; een middenkoers?, in: Verspreide Geschriften van G.J. Wiarda, 's-Gravenhage 1986, pp. 235-250, op p. 242. Wiarda verwijst naar de Belgische Taaleask als voorbeeld van deze ontwikkeling. 
voor de partijstaten impliceert. ${ }^{32}$ Bij de totstandkoming van artikel 2 in 1950 en 1951 werd een positieve formulering immers ondubbelzinnig van de hand gewezen. ${ }^{33}$ De minderheid van de Commissie was van mening dat een afwijzing van positieve verplichtingen ten aanzien van artikel 2 in strijd is met de aard van het recht op onderwijs en met zijn universeel karakter. Dat laatste wil zeggen dat in elke partijstaat onderwijsinstellingen bestaan die materieel en financieel voor een ieder binnen bereik zijn. Omdat individuele middelen daartoe ontoereikend zijn dient de staat middelen ter beschikking te stellen om voor iedereen onderwijsinstellingen toegankelijk te maken. ${ }^{34}$ De Commissie liet het verder aan het Hof over om het juridisch karakter van de bepaling nader vast te stellen. Het Hof kwam in zijn uitspraak in de Belgische Taalzaak tot het volgende overwegingen.

Ondanks de negatieve formulering is het Hof van mening dat het bij artikel 2 wel degelijk om een recht handelt, een recht dat evenwel nader ingevuld moet worden. De negatieve formulering impliceert wel dat 'the Contracting Parties do not recognise such a right to education as would require them to establish at their own expense, or to subsidise, education of any particular type or at any particular level'. ${ }^{35}$ Maar op indirecte wijze erkent het Hof dat artikel 2 een positieve verplichting voor staten impliceert. Het Hof gaat uit van de bestaande onderwijsstelsells in de lidstaten van de Raad van Europa. Alle lidstaten van de Raad van Europa kennen immers een algemeen en officieel onderwijsstelsel. Er is dus geen sprake van het volledig inrichten en instellen van een dergelijk stelsel, maar van het handhaven van de bestaande voorzieningen. Burgers hebben het recht van die bestaande onderwijsinstellingen gebruik te maken. Het recht op onderwijs moet tenminste, wil het enige betekenis hebben, het recht inhouden onderwezen te worden in de nationale taal (of talen) van het land. Het Hof bepaalt verder dat de aard van het recht op onderwijs overheidsbemoeienis impliceert. Deze kan verschillen al naar gelang de maatschappelijke en economische mogelijkheden en behoeften van de gemeenschap en van individuen in de lidstaten. Binnen dit kader is er sprake van een recht op onderwijs dat afdwingbaar is ten opzichte van de staat. ${ }^{36}$

32. Opinie Commissie, 24 juni 1965, Belgische Taalraak, Publications of the Court Series B, vol. 3, pp. 278-279.

33. Zie hoofdstuk 3.4 .4 supra.

34. Minderheidsopvatting van de Commissieleden Balta, Jansen-Pertschin, Ermacora, zie Publications of the Court Series B, vol. 3, pp. 284-286.

35. Belgische Taalzaak, Judgment of the Court, Publications of the Court Series A, vol. 6, pp. $30-32$.

36. Het recht op onderwijs is positief van karakter volgens Wildhaber (1976), a.w. p. 152, Kiss, a.w. pp. 471,476 en J.A. Frowein, W. Peukert, Europalische Mensenrechtskonvention: EMRK Kommentar, Kehl am Rhein 198.5, p. 284. Zie ook, E.A. Alkema, Studies over Europese grondrechten, Deventer 1978 , p. 89. 
Bij zijn interpretatie baseerde het Hof zich niet op de 'travaux préparatoires'. Evenmin steunde het Hof op het traditionele karakter van de grondrechten als 'status libertatis', dat wil zeggen vrijheidsrechten die van de staat onthouding vereisen. Dit laatste standpunt werd verkondigd door de Belgische regering. Het Hof interpreteerde daarentegen veeleer dynamisch, zich daarbij baserend op het doel van de Conventie, te weten de bescherming van de rechten van de mens. Bovendien hechtte het Hof bijzondere aandacht aan de maatschappelijke en technologische ontwikkelingen van deze tijd die het noodzakelijk kunnen maken de interpretatie van bepaalde verdragsbepalingen aan te passen met het oog op het idee van de effectieve bescherming van de rechten van de mens. Dit betekent dat de oorspronkelijke wil van de verdragsluitende partijen niet langer maatgevend hoeft te zijn. $^{37}$

Gezien de aard van het EVRM als een 'law-making treaty' ('traité normatif') ligt het voor de hand een bijzondere betekenis toe te kennen aan 'object and purpose' van de bepaling en het Verdrag. Ook de preambule speelt dan een belangrijke rol ${ }^{38}$ Dat betekent dat aan bepalingen van het Verdrag een interpretatie moet worden toegekend die, met het oog op de bescherming van individuele rechten, het grootste effect sorteert. In de Belgische Taalzaak heeft het Hof gekozen voor een teleologische interpretatie gericht op de effectieve bescherming van het recht op onderwijs, aangepast aan veranderende opvattingen en maatschappelijke omstandigheden in WestEuropa. Het Hof heeft tevens op extensieve wijze het Verdrag geïnterpreteerd, daarmee blijk gevend van een dynamische stellingname met een zeker rechtsscheppend karakter. ${ }^{39}$ Daarbij moet men in het oog houden dat extensieve interpretatie niet uitmondt in het toevoegen van nieuwe

37. Belgiache Taalzaak, a.w. p. 32.

38. Zie artikel $31(1)$ (2) Weens Verdragenverdrag Zie over het belang van artikel 31 voor de Europese Conventie, H. Mosler, Problems of Interpretation in the Case Law of the European Court of Human Rights, in: Essayis on the Development of the International Legal Order, In Memory of Haro F. van Panhuys, Alphen aan den Rijn 1980, pp. $149-167$, op p. 154 .

Zie ook Wiarda, a.w. p. 236 en Merrills, a.w. pp. 63-81.

39. Zie over de benadering wan het Hof in deze zaak uitvoerig de volgende literatuur: $\mathrm{L}$. Wildhaber, Der Belgische Sprachenstreit vor dem Europaischen Gerichtshof fur Menschenrechte, in: Schweizerisches Jahrbuch fur Internationales Recht. Band 28 (1969), pp. 9-38, in het bijzonder pp. 21-29; A. Khol, Zur Diskriminierung in Erziehungswesen, in: Zeitschrift für Ausländisches und Oeffentliches Recht und Völkerrecht, Band 30 (1970), pp. 263-299, in het bijgronder pp. 279-286;

R. Pelloux, l'Arrêt de la Cour Eiuropèenne des Droits de l'Homme dans l'Affaire Lingulistique Belge, in: Annuaire Français de Droit International Public, 1968, pp. 201216, in het bijronder, Pp. 208, 209,

E. Suy, Het Arrest van Straatsburg over de taalregeling in het Belgisch Onderwijs, in: Tijdschrift voor bestuurswetenschappen en publiekrecht, 1969, pp. 240-247, in het bijzonder p. 241.

Zite verder Mosler, a.w. p. 156. 
verplichtingen die de verdragspartijen niet wensten. ${ }^{40}$ Naar het oordeel van Rechter Wold, in zijn 'dissenting opinion' bij het arrest in de Belgische Taalzaak, was de meerderheid van het Hof juist deze gevaarlijke weg ingeslagen. De door het Hof op indirecte wijze afgeleide positieve verplichting, voortvloeiende uit artikel 2, vond volgens Wold geen grondslag in het Verdrag. Voor hem was artikel 2 uitsluitend een absoluut vrijheidsrecht, dat een negatieve verplichting voor de staat impliceerde. Hij was in dit opzicht van oordeel dat 'this right cannot go further than to a freedom for the individual to choose the education he wants without interference by the State'. ${ }^{41}$ Bovendien was hij van mening dat het recht op onderwijs in alle lidstaten van de Raad van Europa dezelfde inhoud moest hebben. Het onderwijsstelsel van de lidstaten is een interne aangelegenheid. De rechten uit het Verdrag hebben geen betrekking op interne politieke kwesties van de lidstaten van de Raad van Europa, aldus Wold. ${ }^{42}$ Vierdag acht de interpretatie van rechter Wold enigszins overdreven in het licht van de opvatting van het Hof dat er grenzen zijn aan de afdwingbaarheid van het recht op onderwijs. Die afdwingbaarheid reikt niet verder dan de op een bepaald tijdstip bestaande onderwijsvoorzieningen. ${ }^{43}$ Anders dan de strikte interpretatie van Wold kan men de opvatting van Wildhaber onderschrijven die beantwoordt aan de plaats van het recht op onderwijs in de veranderende maatschappelijke verhoudingen in de lidstaten:

'A cautious, sober development of the right to education in the light of objective change and consequently, a carefully hedged "dynamic" interpretation is likely to be fair and to correspond in the last analysis to the will of the Contracting States. ${ }^{94}$

Een dynamische interpretatie kortom, die uitgaat van de veranderende plaats en inhoud van het onderwijs in Europa en de toegenomen taken en verantwoordelijkheid van de staten op dit terrein verdient naar mijn mening de voorkeur boven een traditionele, statische interpretatie met slechts een onthoudingsplicht voor de staat.

40. Zie Mosler, a.w. 160. Prof. Guggenheim waarschuwde voor deze mogelijke tendeng wn pleitte yoor en restrictieve interpretatie, zie Publications of the Court Series $\mathrm{B}_{\mathrm{r}}$ vol. 3, p. 501 .

Zie ook Wiarda, a.w. pp. 249, 250, alsmede de opvatting van Sir Gerald Fitzmaurice zoals geciteerd bij Merrills, a.w. p. 70 .

41. Belgische Taalzaak, Judgment of the Court, Publications of the Court Series $A$, vol. 6, pp. 103-109, op p. 104. (Dissenting Opinion Judge Wold).

42. Idem, pp. $105,106$.

43. E.W. Vierdag, The legal nature of the rights granted by the International Covenant on Economic, Social and Cultural Rights, in: Netherlands Yearbook of International Law, 1978, pp. 69-105, op pp. 89, 90.

44. Willhaber (1976), a.w. p. $153_{\| \prime}$ zie ook Khol, a.w. p. 285. 
4.1.4 De tweede zin van artikel 2: het vrijheidsaspect van het recht op onderwijs

De tweede zin van artikel 2, Eerste Protocol is onderwerp geweest van een tweetal belangrijke zaken voor de Commissie en het Hof, te weten de zaken K jeldsen e.a. en Campbell and Cosans. Beide organen hebben een aantal kwesties betreffende de interpretatie van de tweede zin verduidelijkt en uitgelegd. Deze bepaling riep onder meer de volgende vraagpunten op:

1. Welke plichten voor de staat vloeien voort uit de tweede zin van artikel $2 ?$

2. Hoe moeten de rechten van de ouders, in het bijzonder het respect voor hun religieuze en filosof ische overtuigingen, geïnterpreteerd worden?

3. Wat is de betekenis van artikel 2 voor het privé-onderwijs?

4. Is een leerplicht verenigbaar met artikel 2 ?

\subsubsection{De plichten voor de staat ingevolge de tweede zin van artikel 2}

Volgens het Hof wordt de uitoefening van functies door de staat in verband met opvoeding en onderwijs begrensd door respect voor de religieuze en filosofische overtuigingen van de ouders. Daarbij bestaat er geen onderscheid tussen onderwijs van staatswege en privé-onderwijs. ${ }^{45}$ Bovendien mag de staat geen onderscheid maken bij het respect voor de overtuigingen van de ouders tussen godsdienstonderwijs en andere vakken. De staat heeft de verplichting de overtuigingen van de ouders te respecteren voor wat betreft het gehele, van overheidswege, vereiste programma. ${ }^{46}$ De term 'any functions' (alle functies) in de tweede zin van artikel 2 moet volgens de Commissie niet te eng worden opgevat. Hij heeft niet alleen betrekking op de inhoud van het onderwijsprogramma. Het gaat om alle functies die de staat met betrekking tot de opvoeding van kinderen vervult. Het begrip 'opvoeding' (education) omvat ook 'the development and moulding of children's character and mental powers" ${ }^{*}{ }^{47}$ Het feit dat de tweede zin van artikel 2 spreekt van 'education and teaching' pleit eveneens voor een ruime interpretatie van het begrip 'opvoeding'. Het disciplineren (tuchtigen) van kinderen vormt tevens 'a natural and inseparable part of the parental duties to educate and teach their children: ${ }^{48}$ Hieruit volgt, aldus de Commissie, dat disciplinemaatregelen op openbare scholen beschouwd moeten worden als een functie in de zin van de tweede zin van artikel 2.

45. Zaak Kjeldeen e.a., Judgment of the Court, Publications of the Court Series A, vol. 23. p. 24; zaak Campbell en Cosang, Judgment of the Court, Publications of the Court Serien A, vol. 48, p. 14 .

46. Zaak Kjeldsen e.a., Judgment of the Court " a.w. p. 25.

47. Zask Ciampibell and Cosans, Rapport van de Commissie, 16 mei 1980, Publications of the Court Series B, vol. 42, p. 33 .

48. Idlem, p. 34. 
Voorts dient de staat bij zijn bemoeienis met het onderwijs er voor te waken dat objectiviteit en pluralisme gegarandeerd zijn en dat indoctrinatie wordt voorkomen: 'That is the limit that must not be exceeded.49 Daarnaast vereist het Verdrag dat er een zekere afbakening bestaat tussen de bemoeienis van de staat die bijvoorbeeld tot uiting komt in het onderwijs enerzijds, en de privé-sfeer van het individu en het gezin anderzijds. Deze zelfde afbakening is ook inherent aan de artikelen 8,9 en 10 EVRM $^{50}$

De staat dient het recht van de ouders te eerbiedigen ('to respect'). Deze term kwam tijdens het opstellen van artikel 2 in de plaats van de term 'to have regard to'. De term 'to respect' betekent volgens het Hof meer dan slechts een negatieve verplichting voor de staat; hij impliceert ook een zekere positieve verplichting. ${ }^{51}$ De vraag kan gesteld worden op welke wijze de staat de rechten van de ouders dient te respecteren. Daarbij gaat het om het in stand houden van een evenwicht tussen de bevoegdheid van de staat het onderwijs in te richten en te reguleren enerzijds, en de verplichting de rechten van de ouders te respecteren anderzijds:

'Two considerations seem to be of importance in order to achieve this balance. The first is that the State must have good reasons for the introduction of a subject in the public schools which may interfere with the religious or philosophical convictions of some parents. Secondly, and most important, the State must show respect for these convictions in the way in which the subject is taught. Respect must therefore mean tolerance towards the different religious and philosophical convictions which are involved in a particular subject. ${ }^{52}$

Een methode om de rechten van de ouders te respecteren is vrijstelling te verlenen voor specifieke onderdelen van het onderwijsprogramma. Verplicht onderwijs zonder de mogelijkheid van vrijstelling is in strijd met artikel 2. Artikel 2 verbiedt staten relligieus of anderszins levensbeschouwelijk onderwijs in welk deel van het onderwijsprogramma dan ook in te voeren zonder dat er een praktische mogelijkheid tot vrijstelling bestaat. ${ }^{53}$ Maar het kan en mag niet zo zijn dat vrijstelling wordt verleend voor alle vakken die een raakpunt hebben met religieuze of filosof ische overtuigingen. Dan zou de staat het recht op onderwijs niet kunnen garanderen op grond van de functies die het uitoefent volgens artikel 2, aldus de Commissie in de zaak K jeldsen. ${ }^{54}$

49. Zaak Kjeldsen e.a., Judgment of the Court, a.w. P. 26, 27.

50. Merrills, a.w. p. 131.

51. Zaak Campbell en Cosans, Judgment of the Court, a.w. p. 18.

52. Zaak Kjeldsen e.a., Rapport van de Commisaie, 21 maart 1975 , Fublications of the Court Series B, vol. 21, p. 46.

53. Clarke, a.w. p. 50 .

54. Zaak Kjeldsen, Rapport van de Commisaie, a.w. p. 47. 
In een andere zaak die voor de Commissie speelde was de vraag aan de orde of een kind van atheistische ouders in Zweden vrijgesteld kon worden van het volgen van godsdienstonderwijs op een openbare school. De klagers voerden onder meer aan dat de leerling gedwongen werd een christelijke denkwijze te aanvaarden, omdat haar geen vrijstelling werd verleend. Van belang is hier het voorbehoud dat Zweden maakte bij artikel 2. Dit houdt in dat $\mathrm{Z}$ weden:

'could not grant to parents the right to obtain, by reason of their philosophical convictions, dispensation for their children from the obligation of taking part in certain parts of the education in the public schools, and also to the effect that the dispensation from taking part in the teaching of Christianity in these schools could only be granted for children of another faith than the Swedish Church in respect of whom a satisfactory religious instruction had been arranged.'

De praktijk in $Z$ weden was dat er wel vrijstellingen werden verleend aan joodse of rooms-katholieke leerlingen en nog enkele andere gemeenschappen. Voor deze leerlingen was er ander religieus onderricht beschikbaar in overeenstemming met het Zweedse voorbehoud. Atheistische leerlingen vielen evenwel buiten de categorie waarvoor vrijstelling mogelijk was. In het licht van het Zweedse voorbehoud oordeelde de Commissie dat zij niet bevoegd was te onderzoeken of het beleid ten aanzien van vrijstellingen in overeenstemming is met artikel 2 Eerste Protocol EVRM. De Commissie verklaarde de klacht niet-ontvankelijk. ${ }^{55}$

De reikwijdte van de verplichting voor de staat op grond van de tweede zin van artikel 2 werd door de Commissie als volgt kernachtig omschreven:

'... Article 2 not only prohibits the State from preventing parents from arranging the education of their children outside the public schools, but also requires the State actively to respect parental convictions within the public schools. This requirement is then obviously not met simply by the observance by the respondent Government of the prohibition, and by the availability of private schools or alternative means of education other than the public schools. ${ }^{, 56}$

Bij de uitoefening van functies met betrekking tot het onderwijs heeft de staat derhalve positieve verplichtingen ten opzichte van de ouders. Eén van de mogelijkheden daartoe is vrijstelling te verlenen.

55. Zaak nr. 10491/8\$ (Angelenï v. Zweden), 3 december 1986, Decisilons and Reports no.
51, pp. 41-51.

56. Zask Kjeldoen e.a., Rapport van de Commissie, a.w. p. 44.

Zie ook Frowein/Peukert, a.w. p. 285. 
4.1.4.2 De rechten van de ouders, in het bijzonder het respect voor hun religieuze en filosofische overtuigingen

Artikel 2 erkent, zij het niet direct, het fundamentele recht van de ouders op het opvoeden van hun kinderen. Het Hof heeft dit recht in de zaak Kjeldsen e.a. bevestigd en benadrukt. ${ }^{57}$ Ten aanzien van de rechten van de ouders stelde de Commissie:

'... the exercise of the parental right, recognised in the second sentence, is to "ensure/assure" the right of the child to education where there is State intervention, and in particular in State schools. ${ }^{.58}$

De ouders hebben de plicht en de verantwoordelijkheid te handelen in het belang van het kind en treden op als beschermers tegen totalitaire en/of indoctrinaire invloeden van de staat op het individu en het gezin. Deze rechten en plichten van de ouders zijn gebaseerd op natuurrechtelijke overwegingen hetgeen ook gedurende de ontstaansgeschiedenis van artikel 2 naar voren kwam.

Ik ben het in dit verband eens met Wildhaber die van opvatting is dat artikel 2 als eenheid geïnterpreteerd moet worden. Tegenover de ouderrechten staat de aanspraak van het kind op onderwijs. Afhankelijk van de persoon van het kind kan dit als zelfstandige drager van het recht op onderwijs beschouwd worden. De rechten van de ouders zijn dan ook in geen geval absoluut. $\mathrm{Zij}$ dienen primair als bescherming tegen indoctrinaire invloed van de staat, en niet als rechtvaardiging voor paternalistische opvattingen en ideeën. ${ }^{69}$

In de zaak K jeldsen e.a. bestond er binnen de Commissie verschil van mening over de vraag of het onderwijs in de sexuele opvoeding op Deense openbare scholen voldeed aan het respect voor de religieuze en filosofische overtuigingen van de ouders. De verdeeldheid over dit onderwerp bleek uit

57. De zaak Kjeldsen e.a., Judgment of the Court, a.w. p. 28.

58. De zaak Kjeldsen e.a. Rapport van de Commissie, a.w. p. 43.

69. Zie L. Wildhaber, Die danischen Sexual-Erziehunga-Ftlle, in: Europäische Grundrechte Zeitung, 1976, pp. 493-496, op p. 496. Zie ook Opsahl, a.w. p. 226, Kise, a.w. p. 479 , Akkermans; ; w. p. 178.

Een Oosteuropese commentator vraagt zich af of deze rechten wan de ouders well bescherming verdienen:

"The question may be raised again: is the right of decision making really a 'human' right? (...) but it may be asked, whether the implementation of this right is not, in a sense, the children's slawery towards their parents? (...) Invoking the spectre of totalitarianism was a godsend; by adducing it children can be subjected to the total terror of the parents religious outlook. It stands to reason that it is the Church which benefits mainly from these provisione."

I. Szabó, Cultural Rights, Leiden/Budapest 1974, p. 56.

Men hoeft het niet eens te zijn met de nogal extreme opvatting van Suabó om te onderkemnen dat ouderrechten kunnen ontaarden in misbruik. Dat kan het geval iijn indien ouders hun eigen belangen swaster laten wegen ten koste van de belangen en de bescherming van het kind. Zie hierover Opsahl, a.w. pp. 226, 227. 
de stemverhouding binnen de Commissie: zeven tegen zeven stemmen waarbij de voorzitter de beslissende stem uitbracht ten gunste van de opvatting dat er geen sprake was van een schending van artikel 2. Volgens de meerderheid van de Commissie was de tweede zin van artikel 2 gericht op de bescherming van kinderen ten opzichte van verplicht religieus dan wel filosofisch georiënteerd onderwijs dat niet gericht is op het aanbieden van feitelijke informatie, maar op indoctrinatie van kinderen in onaanvaardbare gedachten, overtuigingen of ideologieën. Volgens de meerderheid had het Deense onderwijs in de sexuele opvoeding beslist niet dat doel. Het doel van dit onderwijs was daarentegen het aanbieden van objectieve informatie over biologische en andere feiten betreffende het leven. Het Deense onderwijs had dan ook zeker niet de bedoeling een bepaalde ethische of zedelijke visie aan kinderen op te leggen. ${ }^{60}$

De minderheid van de Commissie ging met name in op de reikwijdte van het onderwijs in de sexuele opvoeding. Dit onderwijs was bedoeld voor leerlingen van ongeveer negen tot elf jaar. Volgens de minderheid had dit onderwijs, dat onder meer inging op anticonceptie-methoden, direct betrekking op religieuze en filosof ische overtuigingen van de ouders. Het ging daarbij niet om onderricht van feiten; onderricht ten aanzien van het voorkomen van zwangerschap bevat zedelijke aspecten en daarmee ontstaat een verband met de religieuze en filosofische overtuigingen van de ouders. ${ }^{61}$

Naar het oordeel van het Hof was er in de zaak Kjeldsen e.a. tegen de Deense Staat geen sprake van schending van de rechten van de ouders. De sexuele opvoeding zoals die geïntegreerd was in het vakkenpakket was niet zodanig van karakter dat zij in conflict zou komen met de religieuze en filosof ische overtuigingen van de ouders. Volgens het Hof beoogde de Deense staat met het onderwijs in de sexuele opvoeding kinderen te waarschuwen tegen maatschappelijke ontwikkelingen die hij als ongewenst beschouwde, zoals de geboorten van onwettige kinderen, het groeiend aantal abortussen en geslachtsziekten. Daarbij ging het wel om zedelijke aspecten, "but they are very general in character and do not entail overstepping the bounds of what a democratic State may regard as the public interest'. ${ }^{62}$ De Deense wetgeving op dit punt was, naar het oordeel van het Hof, niet gericht op indoctrinatie of het aanbevelen van een bepaalde vorm van sexueel gedrag. Het betreffende onderwijs 'does not make a point of exalting sex or inciting pupils to indulge precociously in practices that are dangerous for their stability, health or future or that many parents consider reprehensible'.63 Het onderwijs in de sexuele opvoeding makkte geen inbreuk op het fundamentele recht van de ouders hun kinderen op te voeden volgens hun eigen religieuze of filosofische overtuigingen. Bovendien kende de Deense wet de

60. Zaak Kjeldsen e.a., Rapport van de Commissie, a.w. pp. 45-47.

61. Idem, pp. 67, 61.

62. Kjeldsen e.8., Judgment of the Court, a.w. p. 27.

63. Ibild. 
mogelijkheid privé-onderwijs of thuis-onderwijs te volgen indien ouders hun kinderen, op grond van hun overtuigingen, niet aan het geïntegreerde onderwijs in de sexuele opvoeding op openbare scholen wensten te laten deelnemen. ${ }^{64}$ Het Hof interpreteerde teleologisch, rekening houdend met maatschappelijke ontwikkelingen en veranderingen ten aanzien van sexuele en zedelijke normen en vragen in Denemarken. Deze ontwikkelingen legitimeerden, in de opvatting van het Hof, de integratie van de sexuele opvoeding in het curriculum. Het oordeel van het Hof getuigt van een liberale benadering van de Deense onderwijssituatie.

Volgens rechter Verdross, in een 'dissenting opinion', dient er ten aanzien van het onderwijs in de sexuele opvoeding een onderscheid gemaakt te worden tussen feitelijke informatie over sexualiteit, bijvoorbeeld in het kader van de biologische wetenschappen, enerzijds en informatie over de sexuele praktijk, waaronder de anticonceptie anderzijds. ${ }^{65}$ Het eerste type informatie is in zedelijk opzicht neutraal, terwijl informatie over de sexuele praktijk dat niet is. Deze laatste vorm is volgens Verdross van invloed op de ontwikkeling van het geweten, zelfs indien zij op objectieve wijze wordt aangeboden. Dit betekent volgens Verdross dat 'even objective information on sexual activity when given too early at school can violate the Christian convictions of parents'. ${ }^{66}$ Ouders hebben aldus het recht daartegen bezwaar te maken.

Verdross zet zich af tegen de opvatting van het Hof dat artikel 2 slechts onderwijs verbiedt dat het doel heeft te indoctrineren. Artikel 2 rechtvaardigt een dergelijke beperkte interpretatie niet: "it makes no distinction at all between the different purposes for which the education is provided'. ${ }^{67}$ Dit betekent dat het Hof, aldus Verdross, had moeten nagaan of de wijze waarop het verplichte onderwijs in de sexuele opvoeding in Deense openbare scholen wordt gegeven in strijd kan komen met de religieuze of filosof ische overtuigingen van ouders, ervan uitgaande dat dit onderricht niet de bedoeling had te indoctrineren. ${ }^{68}$ In de opvatting van Verdross was dit inderdaad het geval; de ouders beriepen zich in deze zaak immers op 'a well established Christian doctrine whereby anything affecting the development of children's consciences, that is their moral guidance, is the responsibility of parents'. ${ }^{69}$

De kwesties die in de $\mathrm{K}$ jeldsen zaak aan de orde waren betreffen vragen waarover de opvattingen in af zonderlijke landen, maar ook de opvattingen

64. 'Separate opinion' $v a n$ rechter Verdross in de zaak Kjeldsen e.a., Judgment of the Court, a.w. p. 32.

65. 'Separate opinion' wan rechter Verdrose in de zaak Kjeldsen e.a., Judgment of the Court, a.w. p. 32.

66: Ibid.

67. Ibid.

68. Ibid. en Clarke, a.w. p. 45.

69. Idem, p. 31 . 
tussen landen sterk uiteen lopen. Ik deel dan ook de opvatting van Wildhaber dat ten aanzien van onderwerpen als sexuele normen en praktijken er sprake moet zijn van een zeker pluralisme in de Europese context. Dat betekent dat de Straatsburgse organen zich terughoudend moeten opstellen ten aanzien van rechtsvorming op dit terrein die voor de gehele Europese regio bepalend zou zijn. ${ }^{70}$ Op dit punt dient het Hof rekening te houden met de wijze waarop normen en waarden in de verschillende verdragsstaten hun uitwerking en toepassing vinden.

In de $\mathrm{K}$ jeldsen-zaak heeft het Hof verder aangegeven hoe eerbied voor de religieuze en filosofische overtuigingen van de ouders moet worden ingepast in het onderwijsstelsel. Het Hof stelde dat de planning en de inrichting van het curriculum primair binnen de bevoegdheid van de staat vallen. Het Hof preciseerde:

'In particular, the second sentence of Article 2 of the Protocol does not prevent States from imparting through teaching or education information or knowledge of a directly or indirectly religious or philosophical kind. It does not even permit parents to object to the integration of such teaching or education in the school curriculum, for otherwise all institutionalised teaching would run the risk of proving impracticable. In fact, it seems very difficult for many subjects taught at school not to have, to a greater or lesser extent, some philosophical complexion or implications. The same is true of religious affinities if one remembers the existence of religions forming a very broad dogmatic and moral entity which has or may have answers to every question of a philosophical, cosmological or moral nature. ${ }^{71}$

Een staat kan derhalve informatie in het curriculum opnemen die hij van belang acht voor de algemene ontwikkeling van kinderen. De rechten van de ouders zijn dan ook niet absoluut, maar dienen afgewogen te worden tegen andere belangen, zoals de verantwoordelijkheid van de staat voor de inrichting van het curriculum.

In de Campbell en Cosans zaak concludeerde het Hof dat de discipline op school een integraal en zelfs onmisbaar onderdeel is van het onderwijsstelsel. Discipline is én van de functies die de staat in verband met opvoeding en onderwijs op zich neemt. ${ }^{72}$ De opvatting van de ouders over de gehanteerde methoden bij het handhaven van de discipline op school, te weten lijfstraffen, valt onder de beschermde filosofische overtuigingen. In casu verzetten de ouders zich tegen het toepassen van fysiek geweld om de discipline op school te handhaven. In de woorden van het Hof:

70. Wildhaber, in: Europäiache Grundrechte Zeitung, 1976, a.w. p. 496.

71. Kjeldsen e.a., Judgment of the Court, a.w. p. 26.

72. Zaak Campbell en Cosans, Judgment of the Court, a.w. p. 15. 
'The applicants' views relate to a weighty and substantial aspect of human life and behaviour, namely the integrity of the person, the propriety or otherwise of the infliction of corporal punishment and the exclusion of the distress which the risk of such punishments entails. ${ }^{73}$

Zoals we in paragraaf 1.2 van dit hoofdstuk gezien hebben gaf het Hof in de zaak Campbell and Cosans in navolging van de Commissie, een ruime interpretatie aan de term 'filosof ische overtuigingen', zodat ook de opvattingen van ouders over de gehanteerde disciplinemaatregelen op school daaronder gebracht konden worden. Het Hof bepaalde voorts in deze zaak dat de "travaux préparatoires' weinig licht konden verschaffen ten aanzien van de betekenis van de term 'filosof ische overtuigingen' ${ }^{74}$ Dat is een opvatting die op gespannen voet staat met de opvatting van het Hof in de Kjeldsen e.a. zaak waarin het belang van de 'travaux préparatoires' voor de interpretatie van artikel 2 juist werd benadrukt. ${ }^{75}$ Rechter Sir Vincent Evans nam in een deels afwijkende opinie bij de uitspraak in de Campbell en Cosans zaak afstand van de ruime interpretatie die het Hof aan de term 'filosofische overtuigingen' had gegeven. ${ }^{76} \mathrm{Hij}$ baseercle zich op de 'travaux préparatoires' van artikel 2 en op de enge interpretatie van de term 'religieuze en filosofische overtuigingen' door het Hof in de Belgische Taalzaak en de Kjeldsen zaak. Op grond daarvan meende hij dat de tweede zin van artikel 2 geinterpreteerd moet worden in de zin van de bescherming van kinderen tegen ideologische indoctrinatie door de staat. De tweede zin van artikel 2 heeft volgens Evans betrekking op 'the content of information and knowledge imparted to the child through education and teaching and the manner of imparting such information and knowledge (...) ${ }^{77}$ De opvattingen van de ouders over de toepassing van lijfstraffen op openbare scholen vallen volgens Evans buiten het bereik van die bepaling. Een extensieve interpretatie van de tweede zin van artikel 2 zoals het Hof dat deed in de Campbell en Cosans zaak leidt er volgens Evans toe dat 'all manner of other strongly held views regarding the way in which schools are organised and administered' ook onder de term 'filosofische overtuigingen' moeten worden gebracht. ${ }^{78}$ Daar zouden bijvoorbeeld de opvattingen van ouders over afzonderlijke scholen voor jongens en meisjes onder kunnen vallen. Dat ging volgens Evans veel te ver en was nooit de bedoeling geweest van de opstellers van artikel 2.

Uit de 'travaux préparatoires' valt mijns inziens geen duidelijke interpretatie van de term 'filosof ische overtuigingen' af te leiden. ${ }^{79}$ Voor zowel

73. Idern, p. 17 .

74. Zaak van Campbell and Cosans, Judgment of the Court, a.w. p. 16.

75. Zakk Kjeldsen e.a., Judgment of the Court, a.w. p. 24.

76. Zaak Campbell and Cosans, Partly dissenting opinion of Judge Sir Vincent Evans, Publications of the Court Series A, vol. 48, pp. 21-25.

77. Iderm, P. 22 .

78. Ibid.

79. Zie hoofdatuk 3.4.5 supra. 
een enge als een ruime interpretatie zijn argumenten te vinden in de ontstaansgeschiedenis van artikel 2. Merrills concludeert dat de onwil van het Hof in de Campbell en Cosans zaak de 'travaux préparatoires' te gebruiken niet is terug te voeren op de genoemde redenen in de uitspraak, maar op het voornemen van het Hof een andere interpretatie te rechtvaardigen. ${ }^{80}$

In deze zaak stelde de Engelse regering, met een beroep op het Engelse voorbehoud bij artikel 2 , dat het niet mogelijk was te voldoen aan de wens van de ouders van Campbell en Cosans om hun kinderen niet te hoeven onderwerpen aan het regime van lijfstraffen. ${ }^{81}$ Bovendien poneerde de Engelse regering dat zij de rechten van de ouders had gerespecteerd door een beleid te voeren dat lijfstraffen gaandeweg zou afschaffen. Beide argumenten werden door Commissie en Hof van de hand gewezen. Het Hof merkte op dat een beleid gericht op de geleidelijke afschaffing van het regime van lijfstraffen niet beantwoordde aan de verplichting voor de staat de overtuigingen van de ouders te respecteren. ${ }^{82}$ Bovendien had, naar het oordeel van Commissie en Hof, de Engelse regering niet duidelijk gemaakt dat respect voor de overtuigingen van de ouders onverenigbaar zou zijn met de termen van het voorbehoud, te weten 'efficient instruction and training and the avoidance of unreasonable public expenditure'.

Het Hof erkende dat een stelsel met afzonderlijke scholen voor kinderen van ouders die bezwaar maakten tegen het ondergaan van lijfstraffen onverenigbaar zou zijn met het Britse voorbehoud. ${ }^{83}$ Volgens het Hof kon evenwel een stelsel van vrijstelling van lijfstraffen voor individuele leerlingen op een bepaalde school heel goed mogelijk zijn zonder met het voorbehoud in conflict te komen. ${ }^{84}$ Het Verenigd Koninkrijk werd veroordeeld wegens schending van artikel 2 van het Eerste Protocol. Indien ouders de overtuiging hebben dat de opvoeding van hun kinderen zonder geweld vorm moet krijgen, dan betreft dit een filosof ische overtuiging. De staat dient deze overtuiging te respecteren. Het regime van lijfstraffen op openbare scholen dat toegepast zou kunnen worden op deze kinderen komt dan in strijd met artikel 2. In zijn gedeeltelijk afwijkende opinie in deze zaak makte Sir Vincent Evans bezwaar tegen de opvatting van het Hof over de wijze waarop de Britse regering kon voldoen aan artikel 2. Volgens hem kon de Britse regering zich met recht baseren op het voorbehoud bij artikel 2 tenzij aannemelijk is dat een (andere) praktische mogelijkheid voorhan-

80. Merrills, a.w. p. 85 .

81. Het Engelse voorbehoud luidde aldus:

'... in view of certain provisions of the Education Acts in force in the United Kingdom, the principle affirmed in the second sentence of Article 2 is accepted by the United Kingdom only so far as it is compatible with the provision of efficient instruction and training, and the avoidance of unreasonable public expenditure.'

82. Zaak van Campbell en Cosans, Judgment of the Court, a.w. p. 17.

83. Idem, p. 18.

84. Rapport van de Commisaie in de zaak Campbell en Cosans van 16 meil 1980 , P. 33. Judgment of the Court in derelfde zaak, a.w. p. 18. 
den is die verenigbaar is met "efficient instruction and training and the avoidance of unreasonable public expenditure' ${ }^{85}$ Een stelsel van individuele vrijstelling van lijfstraffen voor leerlingen in een zelfde klas was volgens Evans geen praktische mogelijkheid die verenigbaar is met het Britse voorbehoud. Het zou leiden tot een in de ogen van de leerlingen oneerlijke behandeling van kinderen. Bovendien zou het handhaven van de discipline op deze wijze ook voor de leerkracht problematisch zijn. Kinderen zouden het willekeurig en onrechtvaardig vinden 'if Johnny is exempted simply because his Mum or Dad says so ${ }^{86}$ In 1986 , vier jaren ná de uitspraak in deze zaak werd een wetswijziging van kracht die inhield dat het recht van het onderwijzend personeel om lijfstraffen toe te passen werd afgeschaft. Deze wijziging gold voor alle scholen waarvoor de staat verantwoordelijkheid draagt. ${ }^{87}$ De Commissie verklaarde eind 1990 twee zaken ontvankelijk waarbij de aansprakelijkheid van de Britse staat voor lijfstraffen in Britse privé-scholen aan de orde is. Klagers deden evenwel geen beroep op artikel 2, Eerste Protocol EVRM, maar op de artikelen 3 en 8 EVRM. $^{88}$

\subsubsection{De betekenis van artikel 2 voor het privé-onderwijs}

De vraag of in artikel 2 de vrijheid om privé scholen te stichten gelezen kan worden valt niet eensluidend te beantwoorden. Noch de eerste zin van artikel 2, noch de tweede zin maakt een onderscheid tussen openbaar en privé-onderwijs. Bij de totstandkoming van artikel 2 in 1951 en 1952 speelde de vrijheid om privé-onderwijsinstellingen te stichten weliswaar een belangrijke rol in de discussies, maar de uiteindelijk aanvaarde tekst noemde die vrijheid niet uitdrukkelijk. ${ }^{89}$ De tweede zin van artikel 2 richtte zich op:

'safeguarding the possibility of pluralism in education, which possibility is essential for the preservation of the "democratic society" as conceived in the Convention. ${ }^{90}$

85. Partly dissenting opinion of Sir Vincent Evans. Publications of the Court Series A, vol. 48 ; p. 23.

86. Idem, p. 24

87. Zie Schermers, a.w. pp. 171,172 en $\mathrm{S}$. Gandhi, Spare the rod: corporal punishment in achools and the European Convention on Human Rights in: International and Comparative Law Quarterly, vol. 33 (1984), pp. 488-494.

88. Europese Commissie voor de Rechten van de Mens, beslissingen van 13 december 1990 over de ontvankelijkheid van de zaken $13134 / 87$ en $14229 / 88$, beiden tegen het Verenigd Koninkrijk. Zie: Human Rights Law Journal vol. 12, no. 1-2 (28-2-1991), pp. $61-64$.

89. De zaak Kjeldisen e.a. Judgment of the Court, p. 25.

Zie hoofdstuk 3.4.5 supra (laatste gedeelte) voor de gevoerde diacussies.

90. Zaak Kjeldsen e.a. Judgment of the Court, p. 25 . 
De onduidelijkheid van artikel 2 ten aanzien van de vrijheid om privé-onderwijs te stichten werd onderstreept door de lerse Verklaring bij ondertekening van het Protocol. ${ }^{91}$ Deze verklaring stelde dat artikel 2 niet voldoende expliciet was ten aanzien van het recht van ouders op privé-onderwijs voor hun kinderen.

De vrijheid privé-scholen te stichten wordt impliciet erkend, indien ouders het recht hebben de opvoeding en het onderwijs voor hun kinderen te verzekeren welke overeenstemmen met hun eigen religieuze en filosofische overtuigingen. ${ }^{22}$ De Commissie neemt een duidelijker standpunt in. In haar rapport in de zaak $K$ jeldsen e.a. stelde zij onder meer dat artikel 2: 'prohibits the State from preventing parents from arranging the education of their children outside the public schools'. ${ }^{93}$ Deze uitspraak erkent de mogelijkheid van niet-openbaar onderwijs.

Een andere aanwijzing voor de impliciete, indirecte erkenning van het recht om privé-scholen te stichten ligt in de volgende uitspraak van het Hof:

'(...) the Danish state preserves an important expedient for parents who, in the name of their creed or opinions, wish to dissociate their children from integrated sex education; it allows parents either to entrust their children to private schools, which are bound by less strict obligations and moreover heavily subsidised by the State $(.$.$) , or to educate them$ or have them educated at home, subject to suffering the undeniable sacrifices and inconveniences caused by recourse to one of those alternative solutions. ${ }^{.94}$

Hieruit kan worden afgeleid dat een staat privé-onderwijs kan toestaan, maar daartoe ingevolge de tweede zin van artikel 2 niet verplicht is. ${ }^{95}$

Volgens Opsahl beschermt artikel 2 het recht om privé-scholen te stichten. Dit volgt niet alleen uit de tweede zin van artikel 2, maar ligt ook impliciet besloten in de eerste zin. Volgens Van Dijk en Van Hoof volgt de vrijheid om privé-scholen te stichten niet uit de tweede zin van artikel 2, omdat die bepaling ziet op alle bemoeienis van de overheid met het onderwijs en daarbij niet noodzakelijk van de mogelijkheid van het geven van privé-onderwijs uitgaat. Die vrijheid kan wel worden afgeleid uit de jurisprudentie van Commissie en Hof. ${ }^{96}$ Wildhaber noemt de opvattingen van Errera, Partsch en Vasak volgens welke 'a State monopoly of schools might satisfy the re-

91. Zis hoofdat ulk 3.4.6 supra voor de tekst van de verklaring.

92. Zie Frowein/Peukert, a.w. p. 283.

93. Rapport van de Commiasie in de zaak Kjeldsen e.a., Publications of the Court Series $B$, vol. 21 , p. 44.

94. Zaak Kjeldsen e.a., Judgment of the Court, p. 28.

96. De Witte, a.w. p. 434.

96. Van Dijk/Van Hoof, a.w. p. 470 . 
quirements of the Convention so long as these public schools are structured and organised so as to safeguard the religious and philosophical convictions of the parents'. ${ }^{97}$ In mijn opvatting is in democratische landen die lid zijn van de Raad van Europa en waar pluralisme en objectiviteit behoren tot de fundamenten van het onderwijs, het privé-onderwijs een instrument om die waarden te behouden en te versterken.

Volgens Commissie en Hof verplicht artikel 2 de staat niet het privé-onderwijs te subsidiëren. ${ }^{98}$ Wordt evenwel een bepaalde vorm van onderwijs financieel ondersteund, dan mag de staat niet discrimineren tussen openbaar en privé-onderwijs. Dit volgt uit het discriminatieverbod van artikel $14 .{ }^{99}$ In een andere zaak hadden Zweedse ouders hun kinderen naar een privé-school gestuurd die onderwijs verzorgde volgens een bepaalde pedagogische methode. $\mathrm{Zij}$ makkten vervolgens aanspraak op een financiële tegemoetkoming voor hun kinderen zoals die ook werd verleend aan kinderen die openbare of andere privé-scholen bezochten. Zij voerden een schending aan van artikel 2 jo. artikel $14 .^{100}$ De Commissie bepaalde dat een staat niet verplicht is een financiële toelage te verstrekken aan ouders om te voldoen aan het respect voor hun religieuze of filosofische overtuigingen. Staten handelen in overeenstemming met hun verplichtingen volgens artikel 2 indien zij de stichting van privé-scholen toestaan. Bovendien werd in deze zaak de betreffende privé-school financieel ondersteund door de staat. Ten aanzien van de, in de ogen van de klagers, discriminerende behandeling van leerlingen van de betreffende privé-school ten opzichte van leerlingen die openbare of andere privé-scholen bezochten was de Commissie van oordeel dat de lokale autoriteiten een grote mate van onafhankelijkheid en beleidsvrijheid hadden. Deze waren gebaseerd op een bepaalde traditie en gesanctioneerd door de nationale wetgeving. Deze nationale wetgeving had als uitgangspunt dat lokale autoriteiten de meest aangewezen instanties waren om beslissingen te nemen ten aanzien van onderwijskwesties. De Commissie concludeerde dat het verschil in behandeling tussen leerlingen van de desbetreffende privé-school en andere leerlingen ten aanzien van de financiële toelage een objectieve en redelijke grondslag had. Er was derhalve geen sprake van een schending van artikel 2 jo. artikel 14.

97. Zie Opaahl, a.w. p. 243, Van Dijk en Van Hoof, a.w. p. 470 en Wildhaber (1976), a.w. p. 157 .

98. Zie het Rapport van de Commiasie in de Belgische Taalzaak, 24 juni 1965, Publica tions of the Court Series B, vol. 3, p. 279.

Zie ook de uitspraak van het Hof in de Belgische Taalsaak, Publications of the Court Series A, vol. 6, p. 49.

99. Zie Van Dijk/Van Hoof, a.w. p. 470.

100. Zaak nr. 10476/83, W en K.L. v. Zweden, beslissing van 11 december 1985, in: Decisions and Reporte $\mathrm{nr} .45, \mathrm{pp} .143-160$.

Een vergelijkbare zaak speelde enkele jaren later voor het Mensenrechtencomite op grond van het Facultatieve Protocol bij het IVBPR, zie hoofdatuk 4.2 hierna. 
Een staat heeft tenslotte het recht bepaalde minimumeisen te stellen aangaande de erkenning van een instelling als onderwijsinstelling. Deze eisen kunnen gebaseerd zijn op de normen zoals die zijn vastgelegd in artikel 5 van het UNESCO Verdrag nopens de bestrijding van discriminatie in het onderwijs. ${ }^{101}$

\subsubsection{Is een leerplicht verenigbaar met artikel 2 ?}

Is er sprake van strijd met artikel 2 indien een staat een leerplicht kent, met andere woorden, openbaar dan wel privé-onderwijs verplicht stelt voor personen tot een bepaalde leeftijd? Kortom, hoe verhoudt zich het recht op onderwijs, alsmede de vrije keuze van onderwijs tot het verplichte karakter daarvan? De Commissie oordeelde dat artikel 2 een recht voor de staat impliceert de leerplicht in te voeren. De Commissie merkte bovendien op dat artikel 2 aan ouders geen absoluut recht geeft kinderen te onderwijzen in overeenstemming met hun filosofische overtuigingen, maar slechts een recht op respect voor die overtuigingen. Op grond daarvan kunnen ouders verplicht worden mee te werken aan een zekere bemoeienis van de staat met het onderwijs aan hun kinderen. Deze is erop gericht 'to ensure a certain level of literacy and numeracy, whilst, nevertheless, allowing them to educate their children at home .... ${ }^{102}$ Van Dijk en Van Hoof hebben er in dit verband terecht op gewezen dat de Commissie de nadruk legt op de verantwoordelijkheid van de staat voor een bepaald niveau van het onderwijs en minder op de vorm van het onderwijs (openbaar, privé-scholen, thuis-onderwijs). De reikwijdte van het verplicht onderwijs wordt immers beperkt door het recht van kinderen en ouders op privé-leven. ${ }^{103}$ De mogelijkheid van thuis-onderwijs zou daarom open moeten staan voor ouders die zich op grond van hun religieuze dan wel filosofische overtuigingen verzetten tegen inrichting en functioneren van het reguliere onderwijsstelsel. Voorwaarde is wel dat thuis-onderwijs gepaard gaat met een vorm van toezicht daarop door de staat. ${ }^{104}$

101. Zaak nr. 3798/68, 27 dec. 1968, Church of Scientology w. United Kingdom, Yearbook of the European Convention on Human Rights, vol. XII (1969), p. 322.

102. Zaak nr. 10233/83, Familie H. v. Verenigd Koninkrijk, 6 maart 1984, Decisions and Reports nr. 97, pp. 105-112, op p. 108.

Zie ook Alkema, a.w. (noot 27) p. 89. Onder verwijeing naar de rechten van minderjarigen meent Alkema "zal men ook bereid moeten zijn een dergelijke leerplicht af te wegen en eventueel zelfs op te heffen als deze indruist tegen het privé-leven van een bijna volwassene."

103. Van Dijk/Van Hoof, anw. p. 470.

104. Opsahl, a.w. p. 230 last de mogelijkheid van thuila-onderwijs impliciet open, evenals de Commissie in de in noot 102 genoemde zaak, op p. 108. Wildhaber daarentegen verzet gich tegen elke vorm van privé-onderwijs thuis, Wildhaber (1976), a.w. p. 157. 


\subsection{Internationale jurisprudentie over het recht op onderwijs: het Internationaal Verdrag inzake Burger- en Politieke Rechten}

Het Internationaal Verdrag inzake Burgerrechten en Politieke Rechten (IVBPR) kent, zoals we hiervoor hebben gezien, geen bepaling inzake het recht op onderwijs. Wel garandeert artikel 18(4) de vrijheid van de ouders of voogden de godsdienstige en zedelijke opvoeding van hun kinderen te verzekeren overeenkomstig hun eigen levensovertuiging. Deze vrijheid vloeit voort uit de gewetens- en godsdienstvrijheid.

Op grond van het Facultatieve Protocol bij het IVBPR kunnen individuele personen een klacht indienen bij het Mensenrechtencomité over vermeende schending van de bepalingen van dit Verdrag. Over artikel 18(4) is slechts een enkele maal een klacht ingediend. Het betrof een zaak waarin een Finse onderwijzer een klacht indiende over de inrichting van het curriculum op Finse scholen. ${ }^{105}$ De klager achtte het verplichte onderwijs in de geschiedenis van de godsdiensten en de ethiek in strijd met de overtuigingen van atheïstische ouders. De klager beoogde een wijziging van de Finse onderwijswetgeving in die zin dat het betreffende onderwijs op een neutrale wijze gegeven zou moeten worden, dan wel facultatief diende te zijn. De Finse wetgeving bood de mogelijkheid vrijstelling te krijgen voor het godsdienstonderwijs en het onderwijs in de geschiedenis van de godsdiensten en de ethiek, mits onderwijs van een vergelijkbare aard buiten school om voor de leerlingen geregeld kon worden.

Het Mensenrechtencomité was van mening dat de Finse staat het onderwijs in de geschiedenis van de godsdiensten en de ethiek als verplicht onderdeel van het curriculum kon opnemen, omdat bijvoorbeeld atheïstische ouders die zich verzetten tegen onderwijs van religieuze aard de mogelijkheid hebben vergelijkbaar onderwijs buiten schooltijd om voor hun kinderen te regelen. Het Comité stelde hierbij als voorwaarde dat het onderwijs in de geschiedenis van de godsdiensten en de ethiek op een objectieve en neutrale wijze onderwezen wordt en de overtuigingen van atheïstische ouders worden gerespecteerd. ${ }^{106}$

Met die opvatting over de rechten van de ouders aangaande de godsdienstige en zedelijke opvoeding van hun kinderen volgt het Mensenrechtencomité opinies en uitspraken van de Europese Commissie en het Europese Hof voor de Rechten van de Mens. De opvatting van het Mensenrechten-

105. Klacht no. 40/1978 (Erkki Hartikainen v. Finland), 'Views' van het Mensenrechtencomite van 9 april 1981, gepubliceerd in ICCPR - Human Rights Committee, Selected Decisions under the Optional Protocol (Second - Sixteenth sessions), CCPR/C/ OP/1, New York 1985, pp. 74-76. Deze klager kon zijn zaak (in 1978) niet aanhangig maken bij de Europese Commissie in Straatsburg, omdat Finland toen nog geen partij was bij het EVRM. Dat gebeurde pas in 1989.

106. Zie overweging 10.4 . 
comité ligt in de lijn van de opvattingen van beide Europese organen in de zaak van K jeldsen, Busk Madsen en Pedersen tegen Denemarken over de integratie van de sexuele opvoeding in het schoolcurriculum (zie de paragrafen 1.4.1 en 1.4.2 van dit hoofdstuk).

Een andere zaak die aan het Mensenrechtencomité werd voorgelegd had betrekking op een beweerde discriminerende behandeling van een bepalde privé-onderwijsinstelling in Zweden. ${ }^{107}$ Deze zaak kwam in sterke mate overeen met een klacht die enkele jaren eerder speelde voor de Europese Commissie voor de Rechten van de Mens. ${ }^{108}$ In de zaak die aan de orde was voor het Mensenrechtencomité beweerden de klagers (ouders) dat artikel 26 IVBPR geschonden was vanwege de beweerde discriminatie van privé-onderwijs ten opzichte van andere onderwijsinstellingen in Zweden. Artikel 26 bevat een algemeen discriminatieverbod. Het verbiedt discriminatie in recht en praktijk op elk terrein van overheidszorg. Het Mensenrechtencomite had in een eerdere zaak bepaald dat artikel 26 een zelfstandige betekenis heeft. Het heeft niet alleen betrekking op de burger- en politieke rechten van het IVBPR, maar ook op andere rechten, bijvoorbeeld sociale rechten, die in andere verdragen zijn vastgelegd. ${ }^{109}$ Dat betekent dat de klacht van de Zweedse ouders aan het Mensenrechtencomité kon worden voorgelegd, hoewel het IVBPR geen bepaling over het recht op onderwijs bevat. De kinderen van de ouders bezochten privé-scholen in Norrköping en Stockholm. De ouders klaagden erover dat hun geen financiële toelage door de lokale overheidsinstanties werd toegekend ten behoeve van schoolboeken en schoolmaaltijden, terwijl ouders van kinderen die openbare scholen in dezelfde stad bezochten of privë-scholen in andere gemeenten die toelage wèl ontvingen. Het Mensenrechtencomitê overwoog dat in Zweden het openbaar onderwijs, met de bijbehorende faciliteiten zoals kosteloze schoolboeken en schoolmaaltijden voor alle kinderen beschikbaar is. ${ }^{110}$ De Zweedse staat heeft geen verplichting diezelfde faciliteiten ook aan leerlingen ter beschikking te stellen die privé-onderwijs volgen: 'the preferential treatment given to public sector schooling is reasonable and based on objective criteria' ${ }^{111}$ Zweden kent, aldus het Comité, een vrije keuze tussen openbaar en privé-onderwijs. De keuze voor privé-onderwijs

107. Klacht nr. 298/1988 en $299 / 1988$ van G. en L. Lindgren e.a. tegen Zweden.

108. Zaak nr. 10476/83 van W. en K.L. tegen Zweden. Het ging in deze aak om dezelfde prive-onderwijainatelling, maar andere ouders dienden de klacht in, gie hoofdstuk 4.1.4.3 supra.

109. Klacht nr. $172 / 1984$ van S.W.M. B tegen Nederland. Inzichten van het Mensenrechtencomite van 9 april 1987. Deze zaak is gepubliceerd in: NJCM-Bulletin 12-5 (1987), pp. 377-391, met noot van T. Zwart. Zie ook het "general comment' 18[37] van het Mensenrechtencomité van 9 november 1989 over de non-discriminatiebepalingen van het IVBPR, gepubliceerd als UN Doc. CCPR/C/21/Rev.1/Add.1.

110. Klacht nr. 298/1988 en 299/1988; Insichten van het Mengenrechtencomité van 9 november 1990, gepubliceerd in: Human Rights Law Journal, vol. 12, no. 1-2 (1991), pp. $24,25$.

111. Idem, overweging 10.3 . 
betekent dat bepaalde voorzieningen door de ouders betaald moeten worden. Het Comité overwoog dat 'a State Party cannot be deemed to discriminate against parents who freely choose not to avail themselves of benefits which are generally open to all". ${ }^{112}$

Van discriminatie van de betreffende privé-school ten opzichte van andere privé-onderwijsinstellingen in Zweden was volgens het Comité geen sprake. ${ }^{113}$ Lokale overheidsinstanties hebben in $Z$ weden bevoegdheden ten aanzien van het functioneren van het onderwijsstelsel. $\mathrm{Zij}$ beslissen ook over de vraag of ten behoeve van privé-scholen financiële toelagen worden verstrekt. De beslissing in de onderhavige zaak om geen toelagen te verstrekken was gebaseerd op 'objective and reasonable' criteria. Deze stellingname wordt niet verder uitgewerkt. Het Comité concludeerde dat er in deze zaak geen sprake was van een schending van artikel 26 IVBPR. Het Comité volgde met deze redenering de opvatting van de Europese Commissie in de eerdere, vergelijkbare zaak. ${ }^{114}$ De opinie van de Europese Commissie is naar mijn oordeel evenwel uitvoeriger en overtuigender gemotiveerd.

\subsection{De UNESCO klachtenprocedure}

De UNESCO kent een unieke procedure die omschreven kan worden als een vorm van internationaal toezicht op de naleving van de rechten van de mens. De procedure werd vastgesteld in $1978,{ }^{115}$ door de Uitvoerende Raad van UNESCO. ${ }^{116}$ Op grond van deze beslissing kan het Committee on Conventions and Recommendations (het Comité) klachten ("Communications') ontvangen van bijvoorbeeld schrijvers, artiesten, onderwijsgevenden of niet-gouvernementele organisaties betreffende vermeende schendingen van de rechten van de mens die binnen de bevoegdheid van UNESCO vallen. Alle lidstaten zijn onderworpen aan de procedure, op grond van hun lidmaatschap van de organisatie. De procedure kan gekarakteriseerd worden als een vorm van conciliatie. Het Comité speelt in geen geval de rol van

112. Ibid.

113. Overweging 10.4 .

111. Zie noot 100 supra.

115. Zie over de ontstansgeschiedenis van deze procedure, $\mathbf{S}$. Bastid, La mise en ouvre d'un recours concernant les droits de I'homme dans le domaine relevant de la compétence de I'UNESCO, in: Vollkerrecht al Rechtsordnung Internationale Gerichtisbarkeit-Menschenrechte, Festischrift fur Herman Mosler, Berlin 1983, pp. 45-67. Zie ook A.A. Cançado Trindade, Co-Existence and Co-ordination of Mechaniemi of International Protection of Human Righte at Global and Regional Levele, in: Recueil des Cours, Tome 202 (1978-II), pp. 9-436 in hoofdstuk X, en S. Marks, The Complaint Procedure of the United Nations Educational Scientific and Cultural Organization, in: H. Hannum (ed.), Guide to International Human Right Practice, London 1984, pp. 94-107. Recente, zij het oppervlakkige informatie geeft G.H. Dumont, UNESCO' practical action on human rights, in: International Social Science Journal, no. 122 (nov. 1989), pp. 585-595.

116. UNESCO Dac. 104 EX/Decision 3.3 (1978). 
een rechtsprekend orgaan. ${ }^{117}$ De rol van het Comite is het zoeken van een oplossing voor individuele gevallen of kwesties die aan de organisatie worden voorgelegd. Het onderzoek richt zich op het bereiken van een minnelijke schikking. Methoden om een minnelijke schikking te verwezenlijken zijn onder meer humanitaire bemoeienis door de directeur-generaal van UNESCO, consultaties met de regering van de lidstaat waartegen de klacht zich richt en het aanbod van goede diensten door prominente personen. ${ }^{118}$ De gehele procedure is confidentieel; het Comité houdt daar streng de hand aan, zodat bijzonder weinig over deze procedure bekend is. ${ }^{119}$ Het Comite behandelde in het verleden een aantal gevallen betreffende aspecten van het recht op onderwijs, dan wel vormen van discriminatie in het onderwijs. Deze zaken hadden onder meer betrekking op de toekenning van diploma's, de weigering van studietoelagen, de verantwoordelijkheid van de staat ten aanzien van privé-onderwijsinstellingen, uitzetting van studenten, het recht op permanente educatie, erkenning van diploma's en graden en onderwijs aan kinderen van zigeuners. ${ }^{120}$ Deze procedure kan naar mijn mening in bepaalde, politiek gevoelige, zaken tot een bevredigende oplossing leiden die recht doet aan het respect voor de rechten van de mens.

\subsection{Het recht op onderwijs in statenrapporten: het Internationaal Verdrag inzake Economische, Sociale en Culturele Rechten}

\subsubsection{Algemeen}

Het internationale toezicht op de naleving door staten van de internationaal vastgelegde normen op het gebied van de rechten van de mens wordt gekenmerkt door een zekere dichotomie. Het traditionele onderscheid ten aanzien van het juridisch karakter van economische, sociale en culturele rechten enerzijds en burger- en politieke rechten anderzijds manifesteert zich in verschillende internationale implementatie procedures. Verdragen die burger- en politieke rechten vastleggen geven veelal aan burgers de mogelijkheid klachten in te dienen bij internationale organen over vermeende schendingen van die rechten. Daarnaast kennen die verdragen ook het staten-klachtrecht, waarbij de ene staat een ander partijstaat kan aanklagen over beweerde schendingen. Voorbeelden hiervan zijn het Internationaal

117. Doc. 104 EX/Decision 3.3, par. 7.

118. Zie UNESCO Doc. $120 \mathrm{EX} / 17$, par. 39 (10 sept. 1984).

119. Idem, par. 12.

120. Idem, par. 41-50. 
Verdrag inzake Burger- en Politieke Rechten en het Europees Verdrag voor de Rechten van de Mens. ${ }^{121}$

Het toezicht op de naleving van economische, sociale en culturele rechten betreft hoofdzakelijk een rapportageverplichting voor staten gecombineerd met een vorm van bestudering en bespreking van die rapporten door een internationaal orgaan. ${ }^{122}$ Eén van de doeleinden van de rapportageprocedure is dat een staat zich voor een internationaal forum verantwoordt voor het gevoerde beleid en de aanvaarde wetgeving aangaande de verwezenlijking van de rechten van de mens. Ook dient de staat bij het opstellen van het rapport bij zich zelf te rade te gaan of de nationale wetgeving en het gevoerde of te voeren beleid in overeenstemming zijn met de normen die het Verdrag stelt. ${ }^{123}$ Bij deze vorm van toezicht staan de staten centraal. De individuele burger komt geen rol toe in deze procedure. De rapportageplicht als vorm van internationale implementatie vinden we met name terug in het Internationaal Verdrag inzake Economische, Sociale en Culturele Rechten en in het Europees Sociaal Handvest. ${ }^{124}$ Hieronder zal ik in het kort uiteen zetten hoe de rapportageprocedure werkt op grond van het IVESCR. Vervolgens zal voor een selectie van landen worden bekeken hoe, op grond van de informatie weergegeven in de statenrapporten, het recht op onderwijs in die staten vorm is gegeven, alsmede de bespreking van die rapporten door het toezichthoudende orgaan. De internationale implementatie van het UNESCO Verdrag tot Bestrijding van Discriminatie in het Onderwijs komt in een afzonderlijke paragraaf aan de orde.

\subsubsection{De internationale implementatie ingevolge het Internationaal Ver- drag inzake Economische, Sociale en Culturele Rechten}

De internationale implementatieprocedure verbonden aan de rechten vastgelegd in het IVESCR vindt men in deel IV van het Verdrag, in het bijzonder de artikelen 16-23. Krachtens artikel 16 zijn partijstaten verplicht rapporten in te dienen over de maatregelen die zij hebben genomen en de

121. Het individueel klachtrecht is geregeld in het Facultatieve Protocol bij het IVBPR, in het bijzonder artikel 1 en 2 en in artikel 25 EVRM. Het facultatieve statenklachtrecht is geclausuleerd in artikel 41 IVBPR en in artikel 24 EVRM.

122. Een uitzondering hierop vormen de gedetailleerde vormen van toesicht op de naleving van de verdragen van de Internationale Arbeidsorganisatie. Zie voor een algemeen overzicht van de internationale toezichthoudende procedures inzake het IVESCR, ESH en ILO verdragen, Ph. Harvey, Monitoring Mechaniame for international agreements respecting economic and social human rights, in: Yale Journal of International Law, vol. 12 (1987), pp. 396-420.

123. Zie General Comment no. 1 (1989) van het Comité inzake Economische, Sociale en Culturele Rechten over de rapportageverplichting op grond van artikel 16 en 17 IVESCR, in: UN Doc. E/1989/22, Committee on Economic, Social and Cultural Rights, Report on the Third Session, Annex III.

124. Zie de artikelen 16, 17 IVESCR en de artikelen $21,22,24$ ESH. 
vorderingen die zij hebben gemaakt bij de verwezenlijking van de materiêle rechten uit het Verdrag. Volgens artikel $17(2)$ kunnen de rapporten ook factoren en omstandigheden aangeven die op ongunstige wijze de verwezenlijking van de materielle rechten uit het Verdrag hebben beïnvloed of beinvloeden. Rapporten moeten worden ingediend bij de Secretaris-Generaal van de Verenigde Naties die afschriften daarvan stuurt aan de Economische en Sociale Raad. Dit hoofdorgaan van de VN stelde in 1976 een tijdschema op voor een fase-gewijze rapportageprocedure. Er diende gerapporteerd te worden in drie fasen. De eerste fase omvat de artikelen 6-9, de tweede fase beslaat de artikelen 10-12 en de derde fase heeft betrekking op de artikelen 13-15. Een staat diende om de twee jaren te rapporteren, zodat na zes jaren de hele cyclus was doorlopen. ${ }^{125}$ Het rapportage-schema werd in 1988 zodanig gewijzigd dat om de vijf jaar een rapport ingediend moet worden dat de artikelen 6-15 omvat en waarbij tevens aandacht dient te worden geschonken aan de artikelen $1-5$. Het eerste rapport moet twee jaar na het van kracht worden van het Verdrag voor de betreffende staat ingediend worden. ${ }^{126}$

Bestudering van de rapporten van de staten is toegewezen aan de Economische en Sociale Raad. Bij het in werking treden van het Verdrag in 1976 werd deze taak gedelegeerd aan een 'Sessional Working Group' van de Raad, bestaande uit vertegenwoordigers van regeringen. ${ }^{127}$ Later werd de samenstelling van deze werkgroep zodanig gewijzigd dat regeringsdeskundigen voor het lidmaatschap in aanmerking kwamen. ${ }^{128}$ Men had namelijk ondervonden dat leden van de werkgroep over de nodige expertise dienden te beschikken om op behoorlijke wijze de bestudering van statenrapporten ter hand te kunnen nemen. Rapporten werden door de leden van de werkgroep besproken in openbare zittingen. Vertegenwoordigers van de regering van het land waarvan het rapport besproken wordt zijn daarbij aanwezig om vragen te kunnen beantwoorden en het rapport toe te lichten. Rapporten dienden te worden opgesteld volgens de richtlijnen, opgesteld door de Secretaris-Generaal. ${ }^{129}$

126. Zie de Resolutie van de Economische on Sociale Raad E/1988 (LX) (1976). Zie over de oorspronkelijke opset van het rapportage-stelsel zoals dat in 1976 door de Economische en Sociale Raad was anvaard, B.G. Ramcharan, Implementation of the International Covenant on Economic, Social and Cultural Rights, in: Netherlands International Law Review, vol. 23 (1976), pp. 151-161. Zie verder A. Glenn Mower Jr., International Cooperation for Social Justice. - Global and Regional Protection of Economic Social Rights, Westport, Connecticut 1985 , pp. 22-25 en pp. $31-46$.

126. Zle Res. E/1988/4.

127. Res. E/1988 (LX), par. 9 a.

128. Res. E/1981/168.

129. Zie Doc. E/1988/5, General Guidelines for Reports on Article 13 to 15 of the International Covenant on Economic and Social Rights, prepared in accordance with Economic and Social Council Resolution 1988 (LX). 
Krachtens artikel 18 IVESCR kunnen gespecialiseerde organisaties gevraagd worden te rapporteren over de vooruitgang die binnen deze organisaties is geboekt op het terrein van de materiële rechten uit het Verdrag die binnen het kader van hun werkzaamheden vallen. Daarbij valt onder meer te denken aan de juridische instrumenten die binnen deze organisaties zijn aanvaard. Gespecialiseerde organisaties ontvangen ook de rapporten van staten over de rechten die binnen het mandaat van de organisatie vallen. ${ }^{130}$ Voor wat betreft de artikelen 13-15 IVESCR is de UNESCO de meest voor de hand liggende gespecialiseerde organisatie. Vertegenwoordigers van deze organisaties kunnen deelnemen aan de bespreking van statenrapporten door de werkgroep indien het rechten betreft die binnen haar bevoegdheden vallen. ${ }^{131}$ De Economische en Sociale Raad rapporteert aan de Algemene Vergadering van de VN over de ontvangen statenrapporten en kan tevens aanbevelingen van algemene aard doen. ${ }^{132}$

Het IVESCR trad in werking in 1976. De 'Sessional Working Group' begon in 1980 met de bestudering van de eerste statenrapporten. Gedurende een aantal jaren werd ervaring opgedaan met de bespreking daarvan. ${ }^{133} \mathrm{Tij}$ dens een bijeenkomst van de Raad in mei 1985 werd deze ervaring geëvalueerd. De algemene indruk was een zekere ontevredenheid over het functioneren van de werkgroep. De redenen hiervoor waren onder meer de volgende. ${ }^{134}$

De bestudering van de rapporten door de leden van de werkgroep was vluchtig, oppervlakkig en gepolitiseerd van toon. De werkgroep bleef in gebreke bij het formuleren van aanbevelingen van substantiële aard; discussies en conclusies waren veelal procedureel van karakter. De werkgroep bleek niet in staat om aan te geven of een staat aan de verplichtingen van het IVESCR voldeed. Leden van de werkgroep deden weinig moeite om de werkelijkheid te achterhalen die vaak verborgen zit achter wettelijke bepalingen en overheidsbeleid zoals geformuleerd in statenrapporten. Vragen

190. Artikel 16(2 sub b) IVESCR. Over de rol van de gespecialiseerde organísaties, zie Ramcharan, a.w. pp. 157-160.

131. Rea. E/1988 (LX), par. $9 \mathrm{~b}$.

132. Artikel 21 IVESCR.

133. Voor beoordeling van de gittingen wan de werkgroep in 1980 en 1981 zie het commentaar in de 'Review' van de International Commission of Jurists no. 27, december 1981, pp. 26-39.

134. Het hierna volgende overzicht is gebabeerd op het in de vorige noot genoemde commentaar alsmede op $\mathrm{Ph}$. Alstion, Out of the Abyss: The Challenges Confronting the new U.N. Committee on Economic, Social and Cultural Rights, in: Human Rights Quarterly, vol. 9 (1987), pp. 332-381, op pp. 341-342.

Zie ook, G. Westerveen, Towards a System for Supervising States' Compliance with the Right to Food, in: Ph. Alston, K. Tomaseveki (eds), The Right to Food, Utrecht 1984 , pp. 119-135, op pp. $125-126$.

Zie ook, D. Turp, Le controle du respect du Pacte International relatif aux Droits Economiques, Sociaux et Culturels, in: Le Droit International au Service de la Paix, de la Justice et du. Développement, Mélanges Michel Virally, Paris 1991, op pp. 465482. 
van werkgroepleden aan de vertegenwoordigers van de staten waren vaak ad hoc van aard, zonder verwijzing naar de relevante verdragsbepalingen. De werkgroep verzuimde serieus in te gaan op rapporten van gespecialiseerde organisaties. Leden van de werkgroep waren, hoewel vaak experts, toch steeds vertegenwoordigers van regeringen. Met andere woorden: het waren geen onafhankelijke personen. Door de vaak wisselende samenstelling van de werkgroep in de zeven jaar van haar bestaan (1979-1986) ontbrak een zekere continuïteit waardoor een bepaalde mate van blijvende expertise goeddeels af wezig was. Tekenend voor de wijze waarop de Werkgroep functioneerde is het feit dat de Economische en Sociale Raad niet in staat is gebleken om rapporten aan de Algemene Vergadering van de VN te sturen zoals die mogelijkheid wordt geboden in artikel 21 IVESCR. Deze rapporten zouden aanbevelingen van algemene aard kunnen bevatten alsmede samenvattingen van de rapporten van staten en van gespecialiseerde organisaties. Genoemde omstandigheden hebben niet bijgedragen tot de veronderstelling als zou de werkgroep een even gezaghebbend orgaan zijn als het Mensenrechtencomité onder het IVBPR.

In 1985 besloot de Economische en Sociale Raad de samenstelling en organisatie van de werkgroep te herzien. ${ }^{135}$ De werkgroep werd vervangen door een nieuw 'Comitê inzake Economische, Sociale en Culturele Rechten.' Het ledental werd verhoogd van 15 naar 18 . Belangrijke verandering was evenwel dat het nieuwe Comité diende te worden samengesteld uit experts met erkende bekwaamheid op het gebied van de rechten van de mens die optreden in hun persoonlijke hoedanigheid. ${ }^{136}$ De bedoeling van deze wijziging was om werkwijze en functioneren van het nieuwe Comité te baseren op die van het Mensenrechtencomite - onder het IVBPR. ${ }^{137}$ Het nieuwe Comite startte zijn werkzaamheden in 1987. Zijn mandaat is het bestuderen van statenrapporten en daarover verslag uitbrengen aan de Economische en Sociale Raad. Daarnaast dient het Comité suggesties en aanbevelingen van algemene aard te formuleren naar aanleiding van de bestudering van statenrapporten en rapporten van gespecialiseerde organisaties. ${ }^{138}$

De hierna volgende bespreking en analyse van de rapportage over de verwezenlijking van artikel 13 IVESCR handelt voor een deel over statenrapporten, besproken door de 'Sessional Working Group'. Een ander gedeelte betreft rapporten die door het Comité inzake Economische, Sociale en Culturele Rechten besproken werden.

135. Zie hierover Alston (1987), a.w., pp. 345-349.

136. Res. $\mathrm{E} / 1985 / 17$.

137. Zie Ph. Alston on B. Simma, First Session of the UN Committee on Economic, Social and Cultural Righte, in: American Journal of International Law, vol. 81 (1987), 747756, op p. 748 .

138. Res. $E / 1985 / 17$, sub f. 


\subsubsection{Het recht op onderwijs in statenrapporten ingevolge het IVESCR}

Onderstaande analyse van de implementatie van het recht op onderwijs (artikel 13) is gebaseerd op een selectie van statenrapporten. Daarbij is gepoogd uit vrijwel alle werelddelen een aantal staten te kiezen. Er is evenwel een groot aantal staten dat nog steeds geen rapport heeft ingediend en daarmee de rapportageverplichting niet nakomt.

Op 1 oktober 1991 waren 99 staten partij bij het IVESCR. Het tijdstip waarop een staat een eerste, respectievelijk tweede rapport over de artikelen 13-15 dient in te leveren is afhankelijk van de datum waarop het IVESCR voor die staat van kracht werd. Op 14 december 1990 hadden 36 staten hun eerste periodieke rapport over de artikelen 13-15 IVESCR (nog) niet ingediend en waren daarmee in gebreke. ${ }^{139}$ Op diezelfde datum hadden 50 staten hun tweede periodieke rapport over de artikelen 13-15 (nog) niet ingezonden en voldeden daarmee niet aan hun verplichtingen. Immers, drie jaar na het eerste rapport over de artikelen 13-15 dienen staten een tweede rapport in te leveren over de verwezenlijking van deze rechten. ${ }^{140}$ Tien staten hadden wel een tweede rapport over de artikelen 13-15 ingezonden. Eind 1990 hadden vijf staten een 'overall' rapport over de artikelen 1-15 aan de VN doen toekomen in overeenstemming met de herziene rapportageprocedure zoals die in 1988 was afgesproken. Op 1 januari 1991 waren er 30 partijstaten die in ernstige mate hun rapportageverplichtingen hadden verzuimd: zij hadden nog geen enkel rapport over de implementatie van het IVESCR ingediend. Dat waren onder meer België, Congo, Griekenland, Egypte, El Salvador, Honduras, IJsland, Kenia, Vietnam, Libanon, Marokko, Uruguay en Suriname. Bij deze 30 staten gaat het veelal om ontwikkelingslanden, maar het betreft ook enkele geïndustrialiseerde landen. Staten die zich in positieve zin onderscheiden zijn Tsjecho-Slowakije, Hongarije, Wit-Rusland, Polen, de Sovjet-Unie, Finland, Noorwegen, Zweden en Spanje. Deze staten hebben zowel een eerste als een tweede rapport over de verwezenlijking van de artikelen $13-15$ ingezonden.

De 24 door mij gekozen staten ${ }^{141}$ vertegenwoordigen verschillende zowel politieke als sociaal-economische en met name ook culturele stelsels. Verondersteld mag worden dat de verwezenlijking van het recht op onderwijs op een aantal punten beinvloed wordt door de specifieke nationale context. De nationale onderwijsstelsels kunnen dan ook onderling sterke verschillen vertonen. De internationale normen uit artikel 13 geven veelal een minimum niveau aan dat voor het nationale beleid richtinggevend dient te zijn.

139. Zie het overzicht in UN Doc. E/1991/23, Annex I.

140. Decision $1985 / 132 \operatorname{van}$ ECOSOC.

141. De geselecteerde staten eijn de volgende: DDR, Hongarije, Sovjet-Unie, Joegonlavië, Polen, Verenigd Koninkrijk, Porkugal, Oostenrijk, Nederland, Zweden, Chili, Nicaragua, Jamaica, Mexico, Nederlandae Antillen, Irak, India, Iran, Philippijnen, Japan, Libie, Zaire, Senegal, Rwanda. 
Rapporten over de implementatie van artikel 13 dienen te worden opgesteld aan de hand van de richtlijnen die zijn aanvaard door de Economische en Sociale Raad. ${ }^{142}$ Volgens de (oude) richtlijnen dienen de rapporten de algemene situatie aangaande de verwezenlijking van het recht op onderwijs weer te geven. Daarbij moet niet alleen aandacht worden besteed aan de wetgeving op dit terrein, maar ook aan de feitelijke situatie en ontwikkelingen. In het bijzonder betreft het de door de staat genomen maatregelen ter verwezenlijking van het recht op onderwijs. Het rapport dient ook in te gaan op de ondervonden hindernissen en problemen bij het gevoerde beleid. Waar mogelijk dient het rapport te zijn onderbouwd met statistische informatie. De richtlijnen over artikel 13 onderscheiden de volgende onderdelen die in de rapporten aan de orde moeten komen, te weten:

1. de belangrijkste wetgeving en rechtspraak,

2. maatregelen ter verwezenlijking van de doeleinden van het onderwijs,

3. informatie betreffende het recht op primair, secundair en hoger onderwijs,

4. informatie aangaande de verwezenlijking van een alomvattend nationaal onderwijsstelsel, een beurzenstelsel alsmede maatregelen genomen ter verbetering van de materiële omstandigheden van het onderwijzend personeel. Tot slot wordt informatie verlangd over:

5. het recht op vrije schoolkeuze en de vrijheid om privé-onderwijsinstellingen te stichten.

Grofweg kan worden gezegd dat de categorieën 1-4 het sociale aspect van het recht op onderwijs betreffen, terwijl categorie 5 handelt over het vrijheidsaspect. Bijzondere vermelding verdient de eis om in het rapport aandacht te besteden aan de uitoefening van het recht op onderwijs zonder enige vorm van discriminatie in de zin van de artikelen 2(2) en 3 IVESCR.

\section{Algemene aspecten van het recht op onderwijs}

De statenrapporten benadrukken zonder uitzondering dat er geen sprake is van discriminatoire bepalingen in de onderwijswetgeving of administratieve regelingen. Vormen van actieve discriminatie komen niet voor. Wel bestaan er in een aantal staten vormen van passieve discriminatie: sociaaleconomische factoren en bepaalde traditionele cultuurgebonden denkbeelden beperken gelijke kansen en gelijke behandeling in het onderwijs. We komen hier nog over te spreken. In de constituties van de meeste landen is

142. General Guidelines for Reports on Articles 13 to 15 of the International Covenant on Economic, Social and Cultural Rights, gereproduceerd in UN Doc. E/1988/5. Inmiddels heeft het Comit inzake Economische, Sociale en Culturele Rechten in december 1990 nieuwe richtlijnen aanvaard; deze zijn gepubliceerd in UN Doc. E/C.12/1991/1 en in het rapport van het Comite over de vijfde zitting, UN Doc. E/1991/23, Annex IV. Zie hierover hoofdstuk 6, par. 5, infra. De hier te bespreken statenrapporten zijn opgesteld volgens de oude richtlijnen. 
het recht op onderwijs opgenomen: het is een zorgplicht voor de staat. ${ }^{143}$ Uit de rapporten van de (voormalige) communistische staten valt af te leiden dat in deze landen het genot van het recht op onderwijs tot op een hoger niveau gegarandeerd is dan artikel 13 vereist. Ook voor westerse staten kan op grond van de statenrapporten worden geconcludeerd dat de situatie van het onderwijs in grote lijnen voldoet aan artikel 13 IVESCR. Ontwikkelingslanden melden veelal in hun rapporten dat de verwezenlijking van het recht op onderwijs achter blijft bij de norm. Over de redenen voor deze ontwikkeling komen we nog te spreken.

Bijzondere vermelding verdient de situatie in India. In de Indiase constitutie is het non-discriminatiebeginsel aangaande de toegang tot en het genot van het onderwijs in een aantal bepalingen verankerd. Sedert 1986 kent India een nieuw, alomvattend onderwijsbeleid. Het plan legt vooral de nadruk op het bevorderen van gellijke kansen voor een ieder in het onderwijs, in het bijzonder van kwetsbare groepen. De traditioneel hiërarchische maatschappij in India wordt gekenmerkt door evidente discriminatie van bepaalde kasten, in het bijzonder de onaanraakbaren, in stamverband levende groepen, vrouwen, leden van minderheden en gehandicapten. Hoewel discriminatie officieel verboden is, is er in de praktijk sprake van een sterk discriminerende behandeling van deze groepen. Zo geeft de Indiase maatschappij van oudsher prioriteit aan het onderwijs aan mannen boven onderwijs aan vrouwen, hoewel de opvattingen hierover aan het veranderen zijn. De houding van de Indiase bevolking ten aanzien van de onaanraakbaren blijft evenwel conservatief en kan slechts veranderen door in het onderwijs te werken aan mentaliteitsverandering. ${ }^{144}$

De verscheidenheid tussen staten met verschillende politieke, sociaal-economische en culturele stelsels komt ook tot uitdrukking in de inrichting vaan het onderwijs. Westerse staten hebben een onderwijsstelsel dat steunt op de ideeën van democratie en pluralisme. De inrichting van het onderwijs in communistische landen was doortrokken van de socialistische ideologie. ${ }^{145}$ In veel ontwikkelingslanden staat het onderwijs in het teken van de ontwikkeling van het land, ${ }^{146}$ vaak in revolutionaire zin. ${ }^{147}$ In Derde Wereldlanden die een één-partijstelsel kennen heeft die ene toegestane partij ook een grote invloed op het onderwijs; pluralisme ontbreekt dan goeddeels. ${ }^{148}$ In landen waar de Islam tevens staatsgodsdienst en staatsfi-

143. Zie bijv. UN Doc. E/1982/3/Add.37 (Oostenrijk), p. 2, UN Doc. E/1982/3/Add.31 (Nicaragua), p. 4 en UN Doc. E/1982/3/Adld.43 (Iran), p. 2.

144. Zie het rapport van India, UN Doc. E/1988/5/Add.5 en de bespreking van dit rapport door het Comite inzake Economische, Sociale an Culturele Rechten in UN Doc. E/C.12/1990/SR.16 en SR.17.

145. Zie bijv. UN Doc. E/1982/3/Add.15 (DDR), p. 2.

146. Zie bijv. UN Doc. E/1982/3/Add.8 (Mexico), p. 2.

147. Zie UN Doc. E/1982/3/Add.31 (Nicaragua), p. 5.

148. Zie UN Dac. E/1982/3/Add.41 (Zaire), pp. $2,3$. 
losofie is, is het onderwijs ook sterk religieus georiënteerd, alsmede nationalistisch en revolutionair van opzet. ${ }^{149}$

\section{De verwezenlijking van het recht op primair onderwijs}

Volgens artikel 13(2a) IVESCR dient het primaire onderwijs verplicht te worden gesteld. Indien er een verplichting tot het volgen van primair onderwijs bestaat, dan moet dit onderwijs ook beschikbaar zijn. Dit betekent voor de staat de plicht zorg te dragen voor scholen, onderwijzend personeel, onderwijsmateriaal, kwaliteitsnormen, faciliteiten voor leerlingen etc. Naast het verplichte karakter van het primaire onderwijs dient het ook kosteloos te zijn. Dit betreft een aspect van de toegankelijkheid van het onderwijs. Indien kinderen leerplichtig zijn mag van de overheid worden verwacht dat deze zich zal inspannen om die maatregelen te nemen die het ook daadwerkelijk mogelijk maken dat men aan het onderwijs kan deelnemen.

In het algemeen kan men stellen dat de meeste westerse landen reeds sedert lange tijd een leerplicht voor het primair onderwijs en een gedeelte van het secundaire onderwijs kennen. De beweging het primaire onderwijs verplicht en kosteloos te maken is van Europese oorsprong. Het mag dan ook geen verbazing wekken dat de westerse staten uit de groep van 24 geselecteerde landen in hun rapporten melden dat het verplicht en kosteloos primair onderwijs een verworvenheid is. Maar ook de Oosteuropese staten beroepen zich op hun prestaties op dit gebied. In deze landen is vaak niet alleen het primaire onderwijs kosteloos, maar ook het voortgezet en het hoger onderwijs. Een aantal Europese landen meldt dat er voorzieningen bestaan voor leden van minderheden om het primaire onderwijs in de eigen taal te volgen. ${ }^{150}$ In Joegoslavië wordt het lager onderwijs aangeboden in de talen van de negen nationaliteiten die het land kent. Ook zijn er tweetalige scholen. ${ }^{151}$

De rapporten van Derde Wereldlanden melden vrijwel zonder uitzondering problemen bij de verwezenlijking van het recht op primair onderwijs. Deze landen trachten wel een stelsel van lagere scholen van de grond te krijgen, maar de norm neergelegd in artikel 13(2a) is voor hen nog veelal onbereikbaar. De nationale wetgeving mag dan wel het primaire onderwijs verplicht stellen, dat wil nog niet zeggen dat alle kinderen van de leerplichtige leeftijd ook daadwerkelijk dit onderwijs (kunnen) volgen. Over het algemeen

149. Zie bijv. UN Doe. E/1982/3/Add.6 (Libië), p. 3, en de situatie in Iran, UN Doc. E/C.12/1990/SR.42, par. 36. Een ander voorbeeld van de band tussen tast en godsdienst in een land betreft Chili was al het onderwijg dient te worden geinspireerd door de westerse, christelijke traditie, wie UN Doc. E/1982/3/Add.40, p. 22.

150. Zie bijv. het rapport van Hongarije, UN Doc. E/1982/3/Add.10, p. 3, het rapport van het Verenigd Koninkrijk, E/1982/3/Add.16, p. 3, het rapport van Nederland, E/1982/3/Add.35, p. 11 .

161. Rapport van Joegoslaviè, UN Doc. E/1982/3/Add.39, p. 8. 
beroepen ontwikkelingslanden zich op de negatieve invloed van de mondiale financieel-economische crisis, in het bijzonder de schuldenproblematiek, op hun toch al beperkte middelen. Overeenkomsten met de internationale financiële instellingen als het Internationaal Monetair Fonds en de Wereldbank als ook met commerciële banken maken bezuinigingen op nationaal niveau noodzakelijk. Deze programma's impliceren vaak bezuinigingen op gemeenschapsvoorzieningen zoals het onderwijs. De benarde financieel-economische situatie in Jamaica noopte tot een gefaseerde invoering van verplicht en kosteloos primair onderwijs. In 1988 was dit in 8 van de 14 districten van het land ingevoerd. ${ }^{152}$ Het rapport van Zaïre maakte melding van het afschaffen van het kosteloze lager- en voortgezet onderwijs. Gezien de moeilijke economische omstandigheden besloot de Zaïrese regering aan de ouders een bijdrage te vragen. ${ }^{163}$ Tijdens de bespreking van het Zaïrese rapport door het Comité inzake Economische, Sociale en Culturele Rechten werd om opheldering gevraagd over deze maatregel. De strekking van de opmerkingen van de Comitéleden was dat Zaïre op deze wijze in strijd met de bepalingen van het IVESCR, in het bijzonder artikel 13(2a), handelde. ${ }^{154}$ In de woorden van Alston, rapporteur van het Comité:

'The provision of such education was an obligation which remained incumbent upon a State Party whatever economic system it had adopted. ${ }^{, 155}$

Ook in het rapport van Rwanda kwam naar voren dat het primaire onderwijs niet geheel kosteloos was. ${ }^{156}$ Bij de bespreking van dit rapport merkte de $R$ wandese vertegenwoordiger op dat $R$ wanda bij artikel 13 een voorbehoud had gemaakt. Het voorbehoud bepaalt dat Rwanda, voor wat betreft het onderwijs, zich alleen gebonden acht aan de bepalingen van de Rwandese Constitutie. Het idee van kosteloos onderwijs wordt in die Constitutie onderworpen aan een aantal voorwaarden cq. beperkingen. Verplichte bijdragen van ouders zijn op basis van die grondwetsbepalingen mogelijk. ${ }^{167}$ In de Philippijnen daarentegen kan een burger in beginsel de verplichting tot het voorzien in kosteloos onderwijs ten opzichte van de staat afdwingen, omdat de bepalingen van het IVESCR in de grondwet zijn opgenomen. ${ }^{158}$

152. Rapport wan Jamaica, UN Doc. E/1988/5/Add.3, par. 72.

153. Zie het rapport van Zaire, UN Doc. E/1982/3/Add.41, pp. 3, 4 en het anvullende rapport van Zatre, E/1989/5, pp. 9,10.

154. Zie UN Doc. E/C.12/1988/SR.17, par. 27 (Neneman), par. 40 (Texier), par. 41 (Wimer Zambrano), par. 48 (Alston).

15.5. UN Doc. E/C.12/1988/SR.19, par. 10.

156. Zie UN Dac. E/1982/3/Add.42, p. 10.

157. Zie UN Doc. E/C.12/1989/SR.11, par. 96 en E/C.12/1989/SR.12, par. 7. Tekst van het Rwandese voorbehoud in Doc. E/C.12/1988/1, P. 16 .

158. Zie UN Dloc. E/C.12/1990/SR.9, par. 43. 
Uit de rapporten van met name Derde Wereldlanden kan een aantal factoren afgeleid worden dat een negatieve invloed heeft op de volledige implementatie van het recht op primair onderwijs. Een eerste punt is dat door de bevolkingsgroei de autoriteiten niet in staat zijn te voldoen aan de groeiende vraag naar onderwijs. Daarnaast bestaan er bijvoorbeeld in Mexico scholen die slechts een onvolledig curriculum aanbieden. Dit wordt niet veroorzaakt door een tekort aan financiële middelen, maar door een tekort aan onderwijskrachten voor scholen in afgelegen gebieden. Vaak is het streven naar verplicht lager onderwijs in strijd met de traditionele praktijk op het platteland om jonge kinderen in te schakelen in het arbeidsproces, vooral in de seizoenarbeid. Ook bestaat er in een aantal landen nog het denkbeeld dat meisjes in de eerste plaats werk moeten verrichten in de sfeer van gezin en het huishouden of het eigen bedrijf. Dat heeft tot gevolg dat meisjes verstoken blijven van het recht op ontplooiing. Er is vaak sprake van een onvoldoende bewustzijn bij ouders over het belang van het onderwijs voor de ontwikkeling van kinderen. Het betreft hier een situatie van passieve discriminatie als gevolg van bepaalde sociaal-economische factoren. ${ }^{159}$

Een ander probleem deed zich voor in de Nederlandse Antillen waar onderwezen wordt in de Nederlandse taal aan kinderen voor wie het Nederlands niet de moedertaal is. $80 \%$ van de bevolking spreekt daar Papiamentu, terwijl maar $6 \%$ thuis Nederlands spreekt. ${ }^{160}$ Het gaat hier om een probleem dat voortvloeit uit het koloniale verleden dat ook in andere Derde Wereldlanden niet ongewoon is. In een ander opzicht dienen de Nederlandse Antillen hier ook genoemd te worden. Het lager onderwijs is er nog niet verplicht gesteld volgens de wet. Daar staat tegenover dat het overgrote deel van de jeugd wel deelneemt aan het lager onderwijs. Het Antilliaanse rapport vermeldt dat de regering zich ervan bewust is dat de Antillen met het niet verplichte karakter van het primaire onderwijs internationaal gezien een uitzonderingspositie innemen. In de Antillen is inmiddels een discussie gaande over het invoeren van de leerplicht. ${ }^{161}$ Op Curaçao heeft de regering besloten tot geleidelijke invoering van de leerplicht met ingang van het schooljaar 1991-1992. ${ }^{162}$

De gevolgen van de problemen die Derde Wereldlanden ondervinden bij de verwezenlijking van het recht op primair onderwijs zijn bekend. Het analfabetisme is aanzienlijk; dit blijkt onder meer uit een toenemend (functioneel) analfabetisme in de beroepspraktijk. Door deze ontwikkeling neemt

159. Zie bijwoorbeeld de rapporten van India, Jamaica, Iran, Mexico, ZaIre, Rwanda, Senegal (E/1982/3/Add.17), Philippijnen (E/1988/5/Add.2).

160. Zie UN Doc. E/C.12/1989/SR.14, par. 52.

161. Zie UN Doc. E/C.12/1989/SR.15, par. 84; zie ook het rapport van de Nederlandae Antillen, E/1982/3/Add.44, par. 45 en 46. De Antilliaanse afgevaardigde noemde bij de bespreking van het rapport een aantal weinig overtuigende redenen voor het niet verplicht stellen van het lager onderwijs. Zie UN Doc. E/C.12/1989/SR.14, par. 55.

162. Zie NRC Handelsblad van 30-3-1991. 
de behoefte aan volwassenen-educatie sterk toe. Een ander probleem is het grote aantal leerlingen dat een onderwijsachterstand oploopt of nog erger, voortijdig afhaakt. Een gevolg hiervan is weer dat het percentage leerlingen dat deelneemt aan het voortgezet onderwijs relatief laag is. Veel van deze problemen zijn typerend voor ontwikkelingslanden, maar ook in westerse landen doen zich soortgelijke ontwikkelingen voor, zij het in minder ernstige mate. ${ }^{163}$

Samenvattend kunnen we zeggen dat de verwezenlijking van het recht op primair onderwijs in de zin van artikel $13(2 a)$ in de bestudeerde staten nog niet overal bereikt is; met name in ontwikkelingslanden doen zich daarbij de grootste problemen voor. Gezien de beperkte middelen van deze landen, en de invloed van bepaalde traditionele denkbeelden ligt het oplossen van deze problemen op de korte termijn niet voor de hand.

\section{De verwezenlijking van het recht op secundair onderwijs}

De verwezenlijking van het recht op secundair onderwijs richt zich op het algemeen beschikbaar en toegankelijk maken van het voortgezet onderwijs, het beroepsonderwijs daarbij inbegrepen. Van de staat wordt verwacht dat hij voortgezet onderwijs in verschillende richtingen en op verschillende niveaus aanbiedt. Uit de statenrapporten blijkt dat dit voor een aantal staten inderdaad het geval is. ${ }^{164}$ Andere staten zijn op weg om de genoemde doeleinden te verwezenlijken. Een voorbeeld is Portugal dat in de eerste helft van de tachtiger jaren een reorganisatie begon van het voortgezet onderwijsstelsel. Daarbij werd vooral aandacht besteed aan de her-introductie van het technisch beroepsonderwijs dat midden jaren zeventig was afgeschaft. Portugal werd bij dit beleid geconfronteerd met een tekort aan financiële middelen en met het probleem van de ontwikkeling van een netwerk van cursussen dat in overeenstemming diende te zijn met de behoeften van de maatschappij en belangen van studenten. Ook nam het aantal leerlingen in het voortgezet onderwijs af, omdat zij gingen deelnemen aan het arbeidsproces, met name in het familie-agrarisch bedrijf..$^{165}$

Een aantal staten heeft inmiddels een dusdanig voorzieningenniveau bereikt dat het voortgezet onderwijs kosteloos kan worden aangeboden. ${ }^{106}$ Andere staten vragen een bijdrage van de ouders. In Nederland is het voortgezet onderwijs kosteloos tot de leeftijd van 16 jaar. ${ }^{167}$ In het Verenigd

163. Zie het rapport van Portugal, $\mathbb{E} / 1982 / 3 /$ Add.27/Rev.1, par. 100, 101; het rapport van Nederland E/1982/3/Add.35, par. 24.

164. Bijvoorbeeld in de Sovjet-Unie, Polen, DDR, Zweden, Joegorlavie, Nederland, Verenigd Koninkrijk.

165. Zie UN Doc. E/1982/Add.27/Rev.l, par. 122 e.v., 151. Zie ook Doc. E/1985/WG.1/ SR.9, par. 62.

166. Bijvoorbeeld in de Sovjet-Unie, Polen, DDR, Zweden, Joegoslavie, Libie, Nicaragua.

167. UN Doc. E/1982/3/Add.35, par. 23. 
Koninkrijk is het van overheidswege voorziene onderwijs kosteloos; voor privé-onderwijs dient betaald te worden. ${ }^{168}$ Een enigszins bijzondere positie wordt op dit punt ingenomen door Japan. Dit land makte een voorbehoud bij artikel 13(2b en c) IVESCR, inhoudende niet gebonden te zijn aan de clausule "in particular by the progressive introduction of free education'. ${ }^{169}$ In Japan volgt een groot deel van de leerlingen privé-onderwijs. De Japanse samenleving hecht veel belang aan het stelsel van privé-onderwijs. Volgens de Japanse regering is het dan ook redelijk om iedereen die de hogere niveaus van het voortgezet of hoger onderwijs volgt, hetzij openbaar, hetzij privé, te laten bijdragen aan de kosten van het privé-onderwijs. De Japanse regering zou niet in staat zijn het privé-onderwijs volledig te bekostigen. Over het algemeen is het privé-onderwijs immers duurder dan het openbare onderwijsstelsel. ${ }^{170}$ In het bijzonder de Oosteuropese leden van de Werkgroep die het rapport van Japan besprak waren kritisch ten aanzien van dit aspect van het Japanse onderwijssysteem. Met name vanuit het oogpunt van gelijke kansen en gelijke behandeling van een ieder ten aanzien van het onderwijs viel er wel het een en ander op deze maatregelen aan te merken. ${ }^{171}$ De vraag is ook of de Japanse argumenten steekhoudend zijn gezien de economisch sterke positie van dit land. Duidelijk is in ieder geval dat de situatie van het Japanse onderwijs op dit punt op gespannen voet staat met de bepalingen van het IVESCR, maar dat deze als gevolg van het voorbehoud aanvaard moet worden.

Voor veel landen in Afrika is de situatie nog een stuk gecompliceerder. Zaïre heeft, zoals al eerder besproken, de kosteloosheid van het onderwijs afgeschaft. De afgevaardigde van $R$ wanda meldde dat dit land behoort tot de groep van minst ontwikkelde landen en niet in staat is het IVESCR volledig na te leven. Hoewel de regering een beleid voerde dat gericht was op deelname aan het voortgezet onderwijs was het registratie-percentage voor deze geleding van het onderwijs slechts 8 à $10 \%$, terwijl dit voor het primair onderwijs $\pm 60 \%$ bedroeg. ${ }^{172}$ Het tekort aan financiële middelen werd aangevoerd als belangrijkste obstakel op de weg naar volledige implementatie van het recht op secundair onderwijs. De regering van $R$ wanda was dan ook niet van plan secundair onderwijs kosteloos te maken. ${ }^{173}$

Kortom, wat betreft de verwezenlijking van het recht op secundair onderwijs is er sprake van een scheidslijn tussen Noord en Zuid, waarbij de beschikbaarheid van financiële middelen een bepalende factor is.

168. UN Dae. E/1982/3/Add.16, par. 22.

169. Zie het rapport van Japan, UN Doc. E/1982/3/Add.7, par.16.

170. Zie UN Doc. E/1982/WG.1/SR.12, par. 47 en E/1982/WG.1/SR.13, par. 12.

171. Zie UN Doc. E/1982/WG.1/SR.12, par. 57 en 64 .

172. Zie UN Doc. E/C.12/1989/SR.10, par. 6-13.

173. Zie het rapport van Rwanda, UN Doc. E/1982/\$/Add.42, p. 16. 


\section{Het recht op hoger onderwijs}

Uit de analyse van statenrapporten blijkt dat alle landen een of ander systeem van hoger onderwijs hebben. West- en Oosteuropese landen kennen in het algemeen een hoog ontwikkeld stelsel dat zich over vele terreinen van beroepsonderwijs en universitaire studies uitstrekt. Derde Wereldlanden hebben veelal ook een systeem van hoger onderwijs zij het op een meer bescheiden schaal. Lang niet alle staten geven in hun rapporten uitvoerige informatie over inrichting en functioneren van het hoger onderwijsstelsel. In een aantal rapporten ontbreekt deze informatie zelfs goeddeels. ${ }^{174}$

De staten verzekeren dat de toegang tot het hoger onderwijs non-discriminatoir is. Selectie vindt alleen plaats op grond van bekwaamheid waarbij de resultaten behaald in het secundair onderwijs meestal bepalend zijn. In een enkel land worden toelatingsexamens afgenomen. ${ }^{175}$ Actieve discriminatie mag dan overal zijn uitgebannen, dat wil nog niet zeggen dat iedereen ook gelijke kansen en een gelijke behandeling ten aanzien van de toegang tot het hoger onderwijs geniet. Met andere woorden, vormen van passieve discriminatie komen zeker nog voor. Ten gevolge van sociale, economische en culturele factoren zijn bijvoorbeeld vrouwen nog steeds ondervertegenwoordigd in het hoger onderwijs. ${ }^{176}$ Het is voorts bekend dat in de voormalige communistische landen de toegang tot het hoger onderwijs bepaald werd door het partijlidmaatschap en/of de politieke opvattingen van de student. Een andere oorzaak van ongelijke kansen in het hoger onderwijs is de geografische spreiding van deze onderwijsinstellingen. Deze zijn vaak geconcentreerd in stedelijke gebieden in de nabijheid van industriële, financiële en handelscentra. Op deze wijze blijven de meer afgelegen gebieden en de daar woonachtige plattelandsbevolking verstoken van de toegang tot het hoger onderwijs. ${ }^{177}$

Gelijke kansen en gelijke behandeling voor iedereen in het hoger onderwijs kunnen worden bevorderd door de toegankelijkheid te bevorderen. Eén van de middelen daartoe is verlaging dan wel afschaffing van alle kosten voor de student. Opvallend is dat er een ontwikkeling gaande is in een aantal landen om het hoger onderwijs kosteloos te maken. In sommige landen is het hoger onderwijs reeds kosteloos. ${ }^{178}$ In andere landen bestaat er een beleid om door middel van financiële tegemoetkomingen aan studenten dit doel te bereiken. ${ }^{179}$ Opmerkelijk is dat een land als $\mathrm{R}$ wanda wel streeft

174. In de rapporten van Chili, Zalre, Libië, Senegal en Nicaragua.

175. Bijvoorbeeld in Polen en Hongarije.

176. Zie het rapport van Nederland E/1982/3/Add.36, par. 30, en het rapport van Rwranda waar vrouwen zeer sterk onderwertiegenwoordigd zijn. Zie Doc. E/1982/3/Add.42, p. 18.

177. Zo is de situatie bijvoorbeeld in Mexico: Doc. E/1982/3/Add.8, par. 84.

178. Bijvoorbeeld in de Sowjet-Unie, Zweden, Joegoslaviě, Libie, Polen, Irak.

179. Bijvoorbeeld in het Verenigd Koninkrijk en Rwanda: 
naar kosteloos hoger onderwijs, maar voor het primair en secundair onderwijs financiële bijdragen vraagt. Een land als Japan zal, met een beroep op het voorbehoud bij artikel $13(2 \mathrm{~b}, \mathrm{c})$ niet overgaan tot invoering van kosteloos hoger onderwijs. Maar ook Nederland meldde in zijn rapport dat het beleid er niet op gericht is tot afschaffing van college-gelden over te gaan. ${ }^{180}$ In Hongarije en Portugal is het hoger onderwijs nog niet voor iedereen kosteloos. ${ }^{181}$ Het rapport van Zaïre is op dit punt niet duidelijk. Enerzijds werd gezegd dat het stelsel waarbij iedereen recht had op een beurs is afgeschaft. Anderzijds stelde het rapport dat het beginsel van kosteloos hoger onderwijs wordt toegepast. ${ }^{182}$ Het rapport van Chili meldde dat alle niveaus van onderwijs kosteloos worden aangeboden. ${ }^{183}$ Het gaat verder in het geheel niet op het hoger onderwijs in. Tijdens de bespreking van dit rapport door het Comité werd duidelijk dat er wel financiële bijdragen van studenten werden gevraagd. Dit had geleid tot een vermindering van het aantal studenten uit arme sociale groepen. Vroeger was het onderwijs in Chili nagenoeg kosteloos. ${ }^{184}$ Een ander punt betreffende de situatie van het hoger onderwijs in Chili ten tijde van het Pinochet-regime waren de benoemingen van hoge militairen tot rector van een universiteit. Op deze wijze probeerde de regering greep te krijgen op het verzet van studenten en docenten. ${ }^{185}$

In India is het genot van hoger onderwijs voornamelijk slechts bereikbaar voor de elite. Met name de hoge kosten die de private hogere onderwijsinstellingen in rekening brengen zijn voor het arme gedeelte van de bevolking niet op te brengen. ${ }^{186}$ Bovendien belet het hiërarchische kastestelsel de mobiliteit van potentiële studenten. Studenten uit lagere kasten worden door de rijke studenten afkomstig uit hogere kasten uit de universiteiten geweerd en gediscrimineerd.

Ook in de Philippijnen is het hoger onderwijs slechts betaalbaar voor de elite. Studenten van rijke ouders kunnen studeren aan hoog gekwalificeerde universiteiten. Studenten uit arme gezinnen daarentegen komen niet veel verder dan instellingen die de kwalificatie 'universiteit' niet verdienen, omdat het niveau van het onderwijs daar aanzienlijk lager ligt. ${ }^{187}$

180. UN Doc. E/1982/3/Add.35, par. 29.

181. UN Doc. E/1982/3/Add.10, par. 50 (Hongarije), en Doc. E/1982/3/Add.27/Rev.l, par. 164 (Portugal).

182. Rapport van Zarre, E/1982/Add.41, par. 4

183. Rapport van Chili, E/1982/3/Add.40, par. 3.

184. Zile de opmerkingen van Comitelid Wimer Zambrano, UN Doc. E/C.12/1988/SR.13, par. 7.

185. Bbid.

186. UN Doc. E/C.12/1990/SR.16, par. 65.

187. Opmerkingen van Comitélid Simma die als bron een artikel in een tijdschrift noemt om zijn beweringen te staven. Zie UN Doc. E/C.12/1990/SR.8, par. 42-45. Het rapport van de Philippijnen gaat in het geheel niet in op het hoger onderwijs. De vertegenwoordiger van de Philippijnse regering ontkende een dergelijk kwaliteits- en niveauverschil tussen hogere onderwijsinstellingen, sie UN Dac. E/C.12/1990/SR.9, par. 29. 
In vergelijking met het primaire en het secundaire onderwijs is de omvang en de kwaliteit van de informatie over het hoger onderwijs in de statenrapporten aan de mager kant. Dit valt te betreuren. Op deze wijze ontstaat de indruk dat sommige staten minder waarde hechten aan het functioneren van het hoger onderwijsstelsel, of dat de situatie van het hoger onderwijs niet in overeenstemming is met de internationale verplichtingen. Het is aan het toezichthoudend orgaan om hier alert op te zijn.

\section{Het recht op fundamenteel onderricht}

Artikel 13(2d) IVESCR bepaalt dat het fundamenteel onderricht zoveel mogelijk dient te worden gestimuleerd of geïntensiveerd. Dit type onderwijs is bedoeld voor personen die geen lager onderwijs hebben genoten of dit niet hebben voltooid. De meeste staten geven in hun rapporten aan dat het analfabetisme, ook op latere leef tijd, een serieus probleem is. Bij oudere mensen manifesteert zich dit vaak in functioneel analfabetisme. ${ }^{188}$ In het bijzonder vrouwen en immigranten vormen op dit punt kwetsbare groepen. Een uitgebreid onderwijsstelsel is dus geen garantie dat ook iedereen met dit onderwijs bereikt wordt of voldoende kennis opdoet om te kunnen participeren in de maatschappij. De bestudeerde rapporten onderstrepen dan ook het belang van alfabetiseringscampagnes en vormen van volwassenen-educatie. ${ }^{189}$ Deze programma's dragen niet alleen bij tot bestrijding van vormen van discriminatie en tot bevordering van gelijke kansen en een gelijke behandeling in het onderwijs. Zij dragen ook bij tot de ontplooiing van het individu en tot het genot van andere mensenrechten.

\section{De vrijheid van onderwijs}

De vrijheid van onderwijs zoals neergelegd in artikel 13 lid 3 en 4 IVESCR omvat drie elementen. Ten eerste het recht van ouders op vrije schoolkeuze; ten tweede het recht van de ouders de religieuze en zedelijke opvoeding van hun kinderen te bepalen, en als derde de vrijheid om privé-onderwijsinstellingen te stichten.

Uit de statenrapporten van de communistische landen, gedateerd vóór de omwentelingen van 1989, valt af te leiden dat er één onderwijsstelsel bestond dat van staatswege werd verzorgd. Er was geen pluralisme in het onderwijs en er bestond geen vrijheid om privé-scholen te stichten. Het recht op vrije schoolkeuze vond in deze landen in het algemeen geen bescher-

188. In Joegoslavië was in 1981 bijna $10 \%$ van de bewolking analfabeet, zie Doc. $\mathbb{E} / 1982 /$ 3/Add.39, p. 43, noot 4. In de Nederlandse Antillen had in 1989 ongeveer $20 \%$ van de bevolking te kampen met functioneel analfabetisme, zie UN Doc. E/C.12/1989/ SR.15, par. 86. Voor de problemen in Mexico zile Doc. E/1982/Add.8, par. 6.

189. Zie het rapport van het Verenigd Koninkrijk, $\mathbb{E} / 1982 / 3 / A d d .16$, par, 12-20, het rapport van Irak E/1982/Add.26, par. 36-42, en het rapport van Mexico, par. 23-27. 
ming. Buiten de school konden de ouders de religieuze en morele opvoeding kiezen die ze an hun kinderen wilden geven. Deze religieuze en morele opvoeding vond veelal in familie-verband plaats. Men kende een scheiding tussen kerk en school. Het onderwijs dat in deze landen door de stat werd verzorgd was seculier van aard. De scheiding tussen kerk en staat impliceerde de garantie van het recht op onderwijs door de staat 'irrespective of citizens' attitude towards religion'. ${ }^{100}$ In sommige Oosteuropese landen hadden kerken het recht eigen instellingen voor godsdienstonderwijs, bijvoorbeeld zondagsscholen, te stichten. Dit was het geval in Hongarije, Joegoslavië en Polen. Deze scholen functioneerden vrijwel allemaal buiten het officiele stelsel om, en dus ook buiten schooltijd. In Hongarije bijvoorbeeld maakten overeenkomsten tussen kerk en staat het mogelijk kinderen een religieuze opvoeding te geven. Ouders konden hun kinderen naar een school voor voortgezet onderwijs sturen (niet: lagere scholen en hoger onderwijs) die door de kerk werden beheerd en geleid. In 1981 waren er 10 van zulke scholen met 2500 leerlingen in totaal. ${ }^{191}$ In Polen bestond een overeenkomstig systeem. ${ }^{192}$ In de Sovjet-Unie werd pluralisme in het onderwijs in de vollgende woorden van de hand gewezen:

'In a country in which high quality free education of every type was available to everyone at all levels, private schools, which were extremely costly to finance and operate, could hardly compete. ${ }^{193}$

De politieke en maatschappelijke veranderingen die zich sedert 1989 in de Oosteuropese landen hebben voorgedaan hebben ook hun invloed doen gelden op de situatie van het onderwijs. Wat dat betreft zijn de toon en de inhoud van rapporten die onder communistisch bewind tot stand kwamen voor een belangrijk gedeelte achterhaald. Een aantal Oosteuropese landen heeft inmiddels een tweede rapport over de artikelen 13-15 IVESCR ingediend. Deze recente rapporten gaan weliswaar in op de gewijzigde politieke en sociale context, maar de veranderingen ten aanzien van het recht op onderwijs zijn nog maar beperkt. Het tweede rapport van Tsjecho-Slowakije is gedateerd 13 december 1989 , dus ná de politieke omwentelingen van november 1989. ${ }^{194}$ Het rapport is summier en maakt geen melding van veranderingen. Het is waarschijnlijk nog opgesteld door het oude ambtenarenapparaat. Men zou kunnen verwachten dat de nieuwe Tsjechoslowaakse regering het rapport zou intrekken. In ieder geval was het rapport achterhaald op het moment van verschijnen. Het tweede rapport van Pollen maakt wel melding van maatschappelijke veranderingen, maar de uitwerking naar het onder-

190. Aapport van de Sovjet-Unie, E/1982/3/Add.1, p. 4.

191. Rapport van Hongarije, E/1982/3/Add.10, par. 78, 79 .

192. Zie UN Doc. E/1983/WG.1/SR.10, par. 8.

193. UN Doc. E/1982/WG.1/SR.12, par. 25.

194. UN Doc. E/1990/7/Add.6. 
wijs stelt teleur. ${ }^{196}$ Het rapport noemt enige aanzetten tot decentralisatie in het onderwijs, een toenemende eigen verantwoordelijkheid van onderwijsgevenden en een groeiende invloed van ouders. Daarnaast verwijst het rapport naar het akkoord tussen de Poolse regering en de oppositie van april 1989. Volgens dit akkoord moet het toekomstige onderwijsprogramma gebaseerd zijn op de beginselen van de grondwet en de Universele Verklaring van de Rechten van de Mens. ${ }^{196}$

Het tweede rapport van de Sovjet-Unie over de artikelen 13-15 IVESCR bevat een korte uiteenzetting over veranderingen in de maatschappij onder invloed van 'glasnost' en 'perestroika'. ${ }^{197}$ Deze hebben ook hun uitwerking gehad op het onderwijs. Volgens het rapport dient er gestreefd te worden naar de democratisering van het onderwijs op alle niveaus. Bovendien moet de decentralisatie in het onderwijs bevorderd worden hetgeen zich moet manifesteren in een groeiende autonomie van onderwijsinstellingen ten aanzien van de samenstelling van het curriculum. Ook moet er meer onderwijs komen in de moedertaal van de leerlingen. ${ }^{198}$ Volgens het rapport vonden de belangrijkste veranderingen plaats op het gebied van de erkenning en uitoefening van het recht op en de vrijheid van onderwijs: 'whereas previously these rights and freedoms were taken to mean equality of educational opportunity within a uniform school system, today the school system is turning towards accommodating the varied educational requirements of pupils and their parents. ${ }^{199}$ Dit komt vooral tot uitdrukking in meer aandacht voor de eigen cultuur van ouders en leerlingen in het onderwijs. Het tweede rapport van Hongarije besteedt aandacht aan de veranderingen in de Hongaarse maatschappij en geeft aan dat dat proces nog in volle gang is. ${ }^{200}$ Ten aanzien van het onderwijs betekent dit dat een wet in voorbereiding is waarin de vrije keuze van ouders met betrekking tot het ideologisch en godsdienstig onderwijs voor hun kinderen wordt erkend. Praktisch gezien betekent dit de invoering van facultatief godsdienstonderwijs op school en het recht godsdienstonderricht te geven buiten schooltijd. ${ }^{201}$ In 1990 vonden in de Sovjet-Unie en in Polen veranderingen in de wetgeving plaats die meer ruimte geven aan de vrijheid van godsdienst en ouders het recht verlenen hun kinderen een godsdienstige opvoeding te geven. In de Sovjet-Unie heeft dit betrekking op de privé-sfeer of op onderwijsinstellingen door kerken gesticht. In Polen bestaat nu ook de mogelijkheid godsdienstonderwijs op openbare scholen te volgen. ${ }^{202} \mathrm{De}$ vier, hier genoemde, recente rapporten van Oosteuropese landen over de verwe-

195. UN Doc. E/1990/7/Add.9 van 14-2-1990.

196. Idem, par. 27 en 30.

197. UN Doc. E/1990/7/Add.8 van 26-1-1990.

198. Idem, par. 14, 15.

199. Idem. par. 16.

200. UN Doc. E/1990/T/Add.10 van 30-5-1990.

201. Idem, par. 21.

202. Zie verder hoofdatuk 5 , par. 6 infra. 
zenlijking van de artikelen 13-15 IVESCR zijn nog niet besproken door het Comité inzake Economische, Sociale en Culturele Rechten. Opvallend is dat geen enkel van deze rapporten een kritische analyse bevat over de situatie van het recht op onderwijs ten tijde van de communistische regimes en de toetsing daarvan aan de internationale normen.

Wat betreft de vrijheid van onderwijs in andere staten ontstaat het volgende beeld. In een aantal staten bestaat zowel openbaar als privé-onderwijs. ${ }^{203}$ Het hoeft geen verwondering te wekken dat het daarbij veelal gaat om hoog ontwikkelde landen met een democratische staatsinrichting. De situatie in deze landen voldoet over het algemeen aan de normen van artikel 13 lid 3 en 4 . Nicaragua kent ook een pluralistisch onderwijsstelsel. Ouders hebben het recht hun kinderen naar de school van hun eigen keuze te sturen. Wel bestaat er een scheiding van kerk en staat: religieus onderricht wordt niet op staatsscholen gegeven. ${ }^{204}$ Ook in $R$ wanda hebben religieuze groeperingen en privé-personen het recht eigen scholen te stichten. Een groot percentage van de bestaande scholen is ingericht door de katholieke kerk. $\mathrm{Zij}$ vormen een erfenis uit het koloniale verleden onder Belgische heerschappij. De $R$ wandese regering ondersteunt en stimuleert deze vormen van privé-onderwijs. In Mexico wordt het oprichten van privé-onderwijsinstellingen door belastingmaatregelen aangemoedigd. Vanwege historische redenen worden religieuze instellingen evenwel niet toegestaan scholen te stichten. Priesters op persoonlijke titel kunnen wel lesgeven op school. ${ }^{205}$

In het rapport van Zaïre ontbreekt informatie over de vrijheid van onderwijs goeddeels. Er bestaat zowel openbaar als privé lager en voortgezet onderwijs. Hoger onderwijs kan alleen van staatswege worden ingesteld, hoewell dit aan particulieren gedelegeerd kan worden. Het feit dat Zaïre een éen-partij-staat is impliceert dat het onderwijs slechts onder supervisie van die partij (de MPR) en volgens haar ideologie gegeven kan worden. ${ }^{206} \mathrm{Op}$ deze manier wordt de vrije schoolkeuze natuurlijk een lege huls evenals de vrijheid om privé-instellingen te stichten. Van een effectieve bescherming van het recht van de ouders om de godsdienstige en morele opvoeding van hun kinderen te verzekeren is dan ook geen sprake meer. Kortom, er bestaat geen inhoudelijk pluralisme in het onderwijs.

Het onderwijsstelsel van Chili onder het Pinochet-regime werd geïnspireerd door: 'the moral, ethical and spiritual values of the Western Christian,

203. Zweden, Oostenrijk , Verenigd Koninkrijk, Nederland, Portugal en Japan.

204. Zie UN Doc. E/1985/WG.1/SR.15, par. 32.

205. Rapport van Mexico, UN Doc. E/1982/3/Add.8, par. 111, 112, en Doc. E/1982/ WG.1/SR.15, par. 3 .

206. Zie het aanvullend rapport van Zaire, UN Doc. E/1989/5, antwoord 19. 
humanist cultural tradition. ${ }^{207}$ Het godsdienstonderwijs was er facultatief. Het onderwijsprogramma kende slechts een relatief pluralisme. Een achttal denominaties werd in het curriculum aangeboden. Deze zijn, met uitzondering van het Jodendom, allen christelijk georiënteerd. Niet-westerse godsdiensten waren niet toegestaan. Een Comitélid vroeg zich af of de regering van Chili het recht had een bepaalde godsdienstige, i.c. een christelijke, oriëntatie en inrichting van het onderwijs voor te schrijven. ${ }^{208}$ De vrijheid privé-scholen te stichten werd vooral aangegrepen door de katholiek kerk; zij beheert heel wat scholen. ${ }^{209}$ Het Chileense rapport vermeldde dat: 'no political force, because it is in power, may oblige educational establishments to teach its doctrines. ${ }^{210}$

Men kan zich afvragen hoe deze uitspraak zich verhoudt tot de inrichting van het onderwijs volgens christelijke waarden. De vrijheid van onderwijs wordt beperkt door eisen van 'morality, decency, public order and national security'. ${ }^{211}$ Deze beperkingen boden de staat nogal wat mogelijkheden om niet welgevallige tendensen in het onderwijs de mond te snoeren.

Drie staten dienen hier nog besproken te worden, omdat zij het privé-onderwijs afschaften. Het gaat om Libië, Irak en Iran. In Libië werd in 1978 het privé-onderwijs voor en door Libische onderdanen afgeschaft. Vreemdelingen mochten wel scholen voor zichzelf oprichten. Redenen hiervoor waren onder meer de fysieke condities in dergelijke scholen die beneden de norm zouden zijn, onvoldoende kwaliteit van het onderwijzend personeel, en het streven van de Libische regering de eenheid onder de bevolking te versterken en maatschappelijk onderscheid uit te bannen dat in de toekomst zou kunnen leiden tot conflicten. ${ }^{212}$ In Irak werd het privé-onderwijs in 1975 afgeschaft. Al het onderwijs wordt door de staat verzorgd. Het besluit tot afschaffing was een gevolg van de beslissing in 1974 om het onderwijs voor alle niveaus kosteloos te maken, en was complementair aan dit besluit. De bestaande privé-scholen mochten blijven voortbestaan, maar vielen verder onder de verantwoordelijkheid van de staat. Het stichten van nieuwe privé-onderwijsinstellingen was niet in overeenstemming met de heersende onderwijsfilosofie in Irak. ${ }^{213}$

207. Rapport van Chüli, UN Doc. E/1982/3/Add.40, par. 98.

208. Zie de opmerkingen van Mr. Muterahejuru, UN Doc. E/C.12/1988/SR.13, par. 33.

209. Rapport van Chili, a.w. par. 135, 136.

210. Idem, par. 138.

211. Idem, par. 137 .

212. Zie de opmerkingen van de Libische afgevaardigde Burwin, in UN Doc. E/1983/ WG.1/SR.16, par. 62 .

213. Zie de opmerkingen van de Irakese afgevaardigde Yonis, in UN Doc. E/1985/WG.1/ SR.4, par. 39 en 57. 
Ook in Iran werden alle vormen van privé-onderwijs na de Islamitische Revolutie van 1979 afgeschaft ${ }^{214} \mathrm{Na}$ enkele jaren werden wel weer privé-instellingen in het hoger onderwijs toegestaan. ${ }^{215}$ Religieuze minderheden hebben hun eigen scholen. De grondwet erkent slechts drie minderheden, te weten de Zoroastrians, de Joden en de Christenen. ${ }^{216}$ In een islamitisch land neemt de godsdienstige en zedelijke opvoeding een belangrijke plaats in in het onderwijs. Het volgen van (islamitisch) godsdienstonderwijs is verplicht, maar niet voor de religieuze minderheden. ${ }^{217} \mathrm{Bij}$ de bespreking van het Iraanse rapport door het Comité vroegen verschillende leden zich af of de vrije keuze van (godsdienst) onderwijs mogelijk is in een sterk islamitisch land. ${ }^{218}$ Een aantal vragen van Comitêleden betrof de positie van de Bahaiminderheid en de Koerdische minderheid met betrekking tot de toegang tot het onderwijs. ${ }^{219}$ De vertegenwoordiger van Iran ontkende vervolgens dat de Bahai's een religieuze minderheid vormen; in feite waren ze helemaal geen minderheid. ${ }^{230}$ In zijn slotcommentaar op het Iraanse rapport legde het Comité een verband tussen de verslechterende situatie met betrekking tot burger-en politieke rechten in Iran en de negatieve invloed die daarvan uitging op sociale en culturele rechten i.c. het recht op onderwijs. Met andere woorden, sommige Iraanse burgers werd het recht op onderwijs ontzegd, omdat zij tot een etnische of religieuze minderheid behoorden. ${ }^{221}$

Het is evident dat staten als Libië, Irak en Iran in strijd hebben gehandeld met de verplichtingen voortvloeiend uit artikel 13, lid 3 en 4 jo. artikel 2(1) IVESCR. Zij hebben immers een bestaande vrijheid teruggedraaid en traden daarmee in een sfeer waar individuele burgers rechten bezitten die bescherming verdienen tegen inmenging door de staat. Waar het gaat om het vrijheidsaspect van het recht op onderwijs dient de staat zich immers van dwang te onthouden. Wat de praktijk in de voormalige socialistische landen van Oost-Europa betreft kan gezegd worden dat deze eveneens op gespannen voet stond met artikel 13 lid 3 en 4 . Ook daar immers was het voor een individu niet mogelijk de hem verleende vrijheid van onderwijs uit te oefenen. Het vrijwel totale ontbreken van pluralisme in het on-

214. Zie UN Doc. E/1982/3/Add.43, par. 37 .

215. UN Doc. E/C.12/1990/SR.43, par. 23 en 36 .

210. UN Doc. E/C.12/1990/SR.42, par. 50.

217. Idem, par, 51 .

218. Idem, par. 73 (Marchan Romero), par. 76 (Neneman), par. 83 (Texier).

Vergelijk de opmerkingen van Comitelid Neneman: 'If 98 percent of the population was Muslim and favoured religious instruction, that $w$ as well and good. The Committee's task, however, was to ascertain whether the right of the remaining 2 percent of the population to have instruction in another religion, or to have no religious instruction at all, was being safeguarded'. UN Doc. E/C.12/1990/SR.43, par. 38.

219. UN Doc. E/C.12/1990/SR.42, par. 61 (Simma) en par. 68, 70 (Alston), en par. 56 (Alvares Vita).

220. UN Doc. E/C.12/1990/SR.43, par. 17.

221. UN Doc. E/C.12/1990/SR.45, par. 10. 
derwijs is in strijd met de normen van artikel 13 lid 3 en 4 . De recentelijk doorgevoerde hervormingen op dit terrein in de Sovjet-Unie en Polen betekenen een eerste positieve stap in de richting van die internationale minimumnormen. Nadere maatregelen blijven noodzakelijk.

\subsubsection{Evaluatie van de statenrapporten}

Evaluerend kan gezegd worden dat de kwaliteit van statenrapporten over artikel 13 nogal wisselend is. Een aantal rapporten is nogal legalistisch, beschrijvend, vaak alleen maar wetsbepalingen opsommend zonder dat de werkelijke situatie met betrekking tot de verwezenlijking van het recht op onderwijs duidelijk wordt. Andere rapporten zijn oppervlakkig, kort en summier of onvolledig waardoor het moeilijk wordt inzicht te verwerven in de structuur van het onderwijsbestel. Ook zijn deze rapporten vaak te algemeen, geven ze te weinig details en specificering, of alleen maar beleidsvoornemens (bijvoorbeeld in het rapport van India). Het ontbreekt vaak ook aan statistieken, tabellen etc, die een helder beeld zouden kunnen geven over de implementatie van het recht op onderwijs in de praktijk. Bovendien zijn er rapporten die verouderde informatie bevatten (bijvoorbeeld dat van de Philippijnen). Een groot deel van de rapporten verzuimt de problemen te vermelden die gerezen zijn bij de verwezenlijking van het recht op onderwijs, waardoor de indruk kan ontstaan dat het proces van implementatie rimpelloos verloopt. Een aantal landen blinkt zelfs uit in het zichzelf lof toezwaaien voor de enorme prestaties die verricht zijn. ${ }^{222}$ Een enkele staat onderscheidde zich in negatieve zin door bij de bespreking van het rapport vage verklaringen af te leggen en ontwijkende antwoorden te geven. Sommige vragen van Comitéleden werden niet beantwoord. ${ }^{223} \mathrm{Na}-$ tuurlijk zijn er ook rapporten die kwalitatief goed zijn, de problemen onderkennen en ook daarvoor durven uit te komen. $\mathrm{Zij}$ bespreken op uitvoerige wijze de onderwijsstructuur, geillustreerd aan de hand van voorbeelden en details waardoor de verwezenlijking van het recht op onderwijs ook voor de lezer van deze rapporten concreet en duidelijk wordt. ${ }^{224}$ Een andere aanwijzing voor de kwaliteit van rapporten en de vraag in hoeverre staten de rapportageverplichting serieus nemen betreft het navolgen van de 'guide-

222. Zie de opmerkingen van Werkgroeplid Bouzouri bij het rapport van de DDR; 'The report also gave the impression that all problems had been solved. In practice, there were always problems; indeed, the more developed a society became, the more problems it encountered. The report submitted by the German Democratic Republic demonstrated a lack of modesty and a somewhat selfsatisfied attitude". UN Doc. E/ 1983/WG.1/SR.5, par. 49.

223. Dat was het geval bij de bespreking van het rapport van Iran.

224. Voorbeelden van kwalitatief goede rapporten zijn die van Joegoslavié, Rwanda, Mexico, Nederland. Kwalitatief slechte rapporten werden ingediend door Chili, Zalre, DDR, Libie, Senegal. In het geval van Chili probeerden de grote omvang en het beschrijvende karakter van het rapport het gebrek aan kwaliteit en de ernstige situatie van de rechten van de mens in dat land te verhullen. 
lines; de richtlijnen voor het opstellen van rapporten. Van de 24 geanalyseerde rapporten volgden er 13 op min of meer consequente wijze de richtlijnen. De overige 11 volgden niet of in onvoldoende mate de richtlijnen. Het niet volgen van deze richtlijnen betekende ook dat over het algemeen deze landen het aangeven van moeilijkheden bij de verwezenlijking van het recht op onderwijs achterwege lieten. In een aantal gevallen waren de rapporten onvolledig, omdat informatie aangaande artikel 13 lid 3 en 4 ontbrak.

De kwaliteit en het niveau van de bespreking van de statenrapporten door het toezichthoudend orgaan variëren nogal. Leden van de 'Sessional Working Group' stelden veelal vrij oppervlakkige vragen die neerkwamen op verzoeken om aanvullende informatie. Over het algemeen was de werkgroep weinig kritisch. De meest kritische vragen en opmerkingen waren afkomstig van de Oost- en Westeuropese leden van de werkgroep. Toetsing aan de internationale normen van artikel 13 vond niet of nauwelijiks plaats. Rapporten die echt van onvoldoende kwaliteit waren of geen inzicht gaven in de werkelijke situatie werden door de werkgroep wel kritisch besproken. Dit was het geval bij de rapporten van de DDR en Senegal. Een opvallend voorval was dat twee leden van de werkgroep, de afgevaardigden van de Sovjet-Unie en van Libië, tevens de vertegenwoordigers van hun regering waren bij de bespreking van het rapport betreffende hun staat. In feite functioneerden deze personen met twee petten op, hetgeen de status van de werkgroep niet bevorderde. Deze praktijk deed ook afbreuk aan de objectiviteit waarmee statenrapporten bestudeerd en besproken moeten worden. Wellicht was de dubbelfunctie van het Libische lid van de werkgroep ook de reden dat er weinig kritische vragen werden gesteld bij het Libische rapport dat van volstrekt onvoldoende kwaliteit was. Besprekingen in de werkgroep eindigden abrupt, zonder enige conclusie of afrondende opmerking.

De bespreking van statenrapporten aangaande artikel 13 door het Comité inzake Economische, Sociale en Culturele Rechten laat een tendens zien tot het stellen van concrete, toegespitste vragen. ${ }^{225}$ Het Comité zoekt naar de werkelijke situatie betreffende de verwezenlijking van het recht op onderwijs en hecht vooral belang aan problemen en beperkingen die staten daarbij ondervinden. Ook wordt telkens gevraagd naar tabellen en statistieken om een betrouwbaar beeld te krijgen van de ontwikkelingen op onderwijsterrein. Vaak wordt een verzoek tot aanvullende (schriftelijke) informatie gedaan, omdat het Comite de sterke indruk heeft dat de feitelijke situatie in een bepaald land niet in overeenstemming is met de norm, of omdat er behoefte is aan verduidelijking van de positie van bepaalde ach-

225. Tijdens vijf zittingen (1987-1990) zijn vijftien rapporten over de implementatie van artikel 19 besproken. 
tergestelde groepen in de samenleving. ${ }^{226}$ In het bijzonder bij de rapporten van Chili, Zaire en Iran werden scherpe vragen gesteld. Leden van het $\mathrm{Co}$ mité toetsen de nationale ontwikkelingen aan de internationale normen van artikel 13. Men hecht veel waarde aan informatie over de vrijheid van onderwijs in de zin van artikel 13 lid 3 en 4 . Bij ontbreken van deze informatie wordt ernaar gevraagd. Ook het beginsel van verplicht en kosteloos lager onderwijs komt in de discussies als centraal en essentieel punt regelmatig naar voren. Comitéleden wijzen staten op dit punt op hun verplichtingen ingevolge artikel 13 lid $2 \mathrm{a}$ en artikel $14{ }^{227}$ De kwestie van de internationale samenwerking bij de verwezenlijking van het recht op onderwijs, zoals voorzien in artikel 22, 23 en 2(1) IVESCR, komt in de statenrapporten en in de bespreking daarvan slechts sporadisch aan de orde. De UNESCO, als één van de gespecialiseerde organisaties, heeft in de internationale implementatieprocedure van artikel 13 tot nu toe niet of nauwelijks een rol gespeeld. Deze gang van zaken valt te betreuren, te meer omdat het Verdrag aan gespecialiseerde organisaties een informatieve en ondersteunende rol toekent. Het is de taak van het Comité inzake Economische, Sociale en Culturele Rechten om in overleg met de ge-specialiseerde organisaties afspraken te maken over een effectieve participatie, zowel in woord als geschrift, van deze organisaties aan de internationale implementatieprocedure. Enige aanzetten daartoe zijn reeds gedaan en komen in hoofdstuk 6 ter sprake.

\subsection{De internationale implementatie van het recht op onderwijs: Het UNESCO Verdrag tot Bestrijding van Discriminatie in het Onderwijs}

De grondslag voor de internationale implementatie van dit Verdrag is gelegen in artikel $7^{228}$ Volgens deze bepaling dienen staten te rapporteren aan de Algemene Conferentie van de UNESCO over de voortgang die zij hebben geboekt, maar ook over de ondervonden moeilijkheden bij de toepassing van de verdragsbepalingen. Daarnaast is er in de Constitutie van UNESCO een algemene rapportageplicht voor lidstaten vastgelegd over maatregelen genomen ter uitvoering van Aanbevelingen en Conventies aanvaard door de Algemene Conferentie van de UNESCO. Bovendien moet elke lidstaat Aanbevelingen en Conventies binnen één jaar na aanvaarding voorleggen aan de bevoegde nationale instanties. ${ }^{229}$ Dit betekent dat alle

226. Vgl. de opmerkingen naar aanleiding van het rapport van India UN Doc. E/C.12/ 1990/SR.19, par. 41, het rapport van de Phillippijnen, UN Doc. E/C.12/1990/SR.11, par. 41, en het rapport van Iran, UN Doc. E/C.12/1990/SR.45, par. 10 en 13 .

227. Zie de bespreking van het rapport van Zaire, UN Doc. E/C.12/1988/SR.17, par. 44, het rapport van Rwanda, E/C.12/1989/SR.12, par. 16 en het rapport van Iran, E/C.12/ 1990/SR.45, par. 12 .

228. Trb. 1964, no 69.

229. Artikel VIII en IV lid 4 en 6 UNESCO Conatitutie. 
lidstaten verplicht zijn te rapporteren over maatregelen genomen tot bestrijding van discriminatie in het onderwijs. Immers, gelijktijdig met de aanvaarding van de Conventie werd een Aanbeveling met gelijke tekst aangenomen. Op deze wijze worden ook de lidstaten bereikt die geen partij zijn bij de Conventie. ${ }^{230}$

Het Verdrag trad in werking op 22 mei 1962. Sedertdien hebben vier consultatierondes plaatsgevonden. Dit houdt in dat regeringen vier maal geacht werden te rapporteren over de toepassing van de bepalingen van Verdrag dan wel Aanbeveling in hun land. ${ }^{231}$ De rapporten dienen te worden opgesteld aan de hand van een gedetailleerde questionnaire. De ingezonden rapporten worden bestudeerd door een comité bestaande uit vertegenwoordigers van regeringen. Dit 'Committee on Conventions and Recommendations' (hierna het Comité) is een bijzonder orgaan van de Uitvoerende Raad van UNESCO. Het Comité stelt een rapport op over elke consultatieronde en dit wordt met het commentaar van de Uitvoerende Raad, doorgezonden naar de Algemene Conferentie. Opvallend is dat de samenstelling van het Comité gedurende een consultatieronde kan veranderen. Het Comité is samengesteld uit vertegenwoordigers van de lidstaten die zitting hebben in de Uitvoerende Raad. Het kan dus zijn dat als gevolg van verkiezingen voor de Uitvoerende Raad ook de samenstelling van het Comité tijdens een consultatieronde wisselt. Zo'n ronde duurt immers al gauw een drie à vier jaar. Het kan dus voorkomen dat een vertegenwoordiger van een staat slechts gedurende een gedeelte van een consultatieronde lid is van het Comité. Bovendien zitten er personen in het Comite waarvan de eigen staat geen partij is bij de Conventie. Ook kunnen er afgevaardigden lid zijn van het Comité zonder dat de betrokken staat een rapport heeft ingediend. Deze samenstelling en werkwijze doen denken aan de werkzaamheden van de 'Sessional Working Group of Governmental Representatives' die in de eerste jaren toezag op de naleving van het IVESCR. Naar mijn mening komt deze procedure het gezag van het Comitế niet ten goede.

De praktijk van vier consultatierondes laat zien dat een flink aantal staten in gebreke blijft ten aanzien van zijn rapportageverplichtingen. Gedurende de vierde consultatieronde bijvoorbeeld hebben 86 staten rapporten ingezonden. Van deze 86 staten waren er 49 partij bij de Conventie. De overige staten rapporteerden op grond van de Aanbeveling. Bij het begin van de vierde consultatieronde telde UNESCO 155 leden. Dat betekent dat 69 lidstaten, waarvan 25 partijstaten bij de Conventie, niet aan hun rapportageverplichting hebben voldaan. In vergelijking met de vorige consultatierondes was het aantal rapporterende staten wel stijgende. Bovendien was de

230. Per 1-1-1991 waren 76 ataten partij bij de Conventie.

231. De eerate ronde vond plasts tussen 1965 en 1968 ; de tweede van 1971 tot $1972_{\text {| }}$ de derde ronde tussen 1975 en 1980 en de vierde tussen 1982 en 1985 . Een vijfde ronde werd gestart in 1987 en moet beëindigd zijn in 1991. 
geografische spreiding van de rapporterende staten evenwichtiger. Met name het aantal Derde Wereldstaten dat rapporten inzond nam toe. ${ }^{232}$

Als verklaring voor de onvoldoende participatie van lidstaten aan de consultatierondes kunnen de volgende factoren genoemd worden. Het is voor staten soms moeilijk om antwoorden op vragen te verkrijgen van de verschillende bevoegde autoriteiten op onderwijsgebied. Bovendien ontvangen staten een groeiend aantal questionnaires van de UNESCO en sommige landen hebben onvoldoende gekwalificeerd personeel om de vragen te beantwoorden. Omdat het opstellen van een rapport samenwerking vereist tussen de verschillende takken van het overheidsapparaat zijn regeringen vaak niet in staat tijdig aan hun rapportageverplichting te voldoen. Een andere reden was volgens het Comite dat discriminatie in het onderwijs zich niet op dezelfde wijze in alle landen voordoet en dat in een aantal landen discriminatie in het geheel niet voorkomt. ${ }^{233}$

Een positief punt in de UNESCO-rapportageprocedure is het gebruik van de questionnaire. ${ }^{234}$ Deze vraagt staten te antwoorden op specifieke, concrete vragen, waardoor de antwoorden ook gedetailleerder kunnen zijn. De vraagstelling bevat reeds aanwijzingen die het antwoord kunnen structureren en het voor de staat gemakkelijker maken relevante informatie aan te dragen. Bovendien geeft de questionnaire mogelijke factoren en ontwikkelingen aan die een obstakel kunnen vormen bij het uitbannen van discriminatie in het onderwijs. Een opvallend verschil met de rapportage onder het IVESCR is dat staten onder de UNESCO rapportage procedure nogal eerlijk en open problemen signaleren die in IVESCR rapporten veelal verborgen blijven. Deze laatste rapporten waren vaak in te algemene en oppervlakkige bewoordingen gesteld. Mede debet hieraan waren de oude 'guidelines" voor rapportage over het IVESCR die vaak in te algemene termen waren gesteld en niet uitnodigden tot het gedetailleerd signaleren van problemen. In 1990 heeft het Comité inzake Economische, Sociale en Culturele Rechten de oude richtlijnen herzien (zie hierover hoofdstuk 6, par. 2).

De kwaliteit van de rapporten die gedurende de vier consultatierondes door het Comité werden verzameld was nogal verschillend. Een toenemend aantal staten signaleerde specifieke, praktische problemen, maar er waren ook staten die volstonden met de mededeling dat er geen discriminatie in het onderwijs van die landen voorkwam. ${ }^{235}$ Een vroege waarnemer van het rapportagestelsel op grond van de Conventie heeft erop gewezen dat

232. Zie UNESCO Doc. $23 \mathrm{C} / 72$ (aug. 1985) Fourth Consultation of Member States on the Implementation of the Convention and Recommandation against Discrimination in Education, Report of the Committe on Conventions and Recommendations, par. 304-313.

233. UNESCO Dac. $21 \mathrm{C} / 27$ (juli 1980), rapport van het Comite over de derde consultatieronde, par. 95, 96.

234. De questionmaire behorend bij de vierde consultatieronde is gepubliceerd in Doc. 23 C/72 Annex $A$.

235. Doc. 23 C/72, par. 314. 
nationale wetgeving, noch het van kracht worden van de Conventie kunnen verhullen dat op het terrein van het onderwijs geraffineerde vormen van discriminatie kunnen bestaan. Het beeld van het onderwijs in de verschillende lidstaten van UNESCO dat valt af te leiden uit de staten rapporten kan dan ook niet altijd als helder worden gekarakteriseerd. ${ }^{236}$

In de uiteenzetting die volgt zullen enkele problemen worden besproken die staten ondervinden bij hun pogingen vormen van discriminatie in het onderwijs uit te bannen. Daarbij baseer ik me op de rapporten van het Comité, samengesteld op grond van statenrapporten. Zoals in deze studie al eerder is aangegeven dienen twee vormen van discriminatie in het onderwijs onderscheiden te worden. ${ }^{237}$ Van actieve discriminatie is sprake bij een opzettelijke intentie en handelen van de overheid. De artikelen 1, 2 en 3 van de Conventie hebben betrekking op bestrijding van deze vorm van discriminatie. Bij passieve discriminatie daarentegen gaat het veelal om het onbedoelde onvermogen van de overheid om op te treden als gevolg van economische, maatschappelijke en culturele factoren die gelijke kansen en gelijke behandeling van elke persoon in het onderwijs vooralsnog beperken. De artikelen 4 en 5 van de Conventie beogen gelijke kansen en gelijke behandeling te verwezenlijken.

Op grond van een analyse van statenrapporten in verschillende consultatierondes concludeert het Comité dat er, op een enkele uitzondering na, geen sprake meer is van wettelijk vastgelegde vormen van actieve discriminatie in het onderwijs. ${ }^{238}$ Toch meent het Comité dat sommige situaties omschreven in statenrapporten discriminatoir van aard zijn:

'although it has not always been possible to determine whether such situations result from a deficiency in the law or from specific infringements of it. 239

Eên van die uitzonderingen die op gespannen voet staat met de bepalingen van de artikelen 1 en 2 van de Conventie is mijns inziens de situatie in Iran van ná de islamitische revolutie van 1979. Toen werd de co-educatie van jongens en meisjes afgeschaft, evenals alle privé-onderwijsinstellingen. 240 Deze maatregelen zijn een duidelijke achteruitgang in bescherming en een aantasting van verworven rechten.

236. Zie P. Mertens, l'Application de la Convention et de la recommendation de l'UNEsCO concernant la lutte contre la discrimination dans le domaine de l'enseignement; un bilan provisoire', în: Revue des Droits de l'Homme, Tomé 1 (1968), pp. 91-108, op p. 106.

237. Zie hoofdstuk 3.5.2 supra.

238. Zie UNESCO Doc. $20 \mathrm{C} / 40$ (1978), par. 317 en Doc. $23 \mathrm{C} / 72$, par. 319.

239. Doc. $23 \mathrm{C} / 72$, par. 320 .

240. Zie Doc. 23 C/72, Annex D, p. 90. 
Vormen van passieve discriminatie in het onderwijs zijn veelal toe te schrijven aan ontwikkelingen die structureel van aard zijn. In het bijzonder in Derde Wereldlanden worden pogingen tot bestrijding van discriminatie in het onderwijs vaak gefrustreerd door factoren die moeilijk aan te pakken zijn. Hierna zullen enkele van deze factoren genoemd worden.

Eên van de voornaamste oorzaken van passieve discriminatie is financieel-economisch van aard. Het ontbreekt veel landen gewoon aan voldoende financiële middelen om verschillende niveaus van onderwijs op te zetten en vooral ook in stand te houden. Dit tekort manifesteert zich onder meer in onvoldoende schoolgebouwen en onderwijsmateriaal alsmede in een gebrek aan goed opgeleide leerkrachten. In landen waar bijvoorbeeld het lager onderwijs niet kosteloos is kan dit betekenen dat kinderen van onderwijs verstoken blijven, omdat ouders geen schoolgeld kunnen betalen. Er kan dan wel een leerplicht bestaan, maar deze kan door bepaalde kinderen niet nageleefd worden. ${ }^{241}$ Financiële tekorten kunnen een regering ertoe noodzaken bepaalde keuzes te maken. In een gebied waar slechts een beperkt aantal scholen beschikbaar is kan het voorkomen dat de autoriteiten prioriteit geven aan het onderwijs voor jongens ten koste van meisjes. Er mag dan geen sprake zijn van actieve discriminatie, maar het effect is wel dat meisjes achtergesteld worden. Bepaalde tradities in zo'n gebied kunnen ertoe bijdragen dat een dergelijke keuze van de autoriteiten de instemming heeft van de ouders. Het is duidelijk dat een dergelijke ontwikkeling in strijd is met de letter en geest van de Conventie. ${ }^{242}$ Een sociaal-economische factor die in een aantal landen een grote rol speelt is de inschakeling van leerplichtige kinderen in het arbeidsproces op het platteland en in urbane gebieden. ${ }^{243}$ Het aantal leerlingen dat ingeschreven wordt voor het lager onderwijs kan dan relatief hoog zijn, anderzijds is het aantal 'drop-outs' ook hoog. Zo kan in perioden van seizoenarbeid het aantal plattelandskinderen dat naar school gaat beduidend afnemen. Daardoor ontstaan verspilling en onderwijsachterstand met in veel gevallen analfabetisme als resultaat. In stedelijke gebieden is het aantal zwerfkinderen, soms wezen, soms verstotenen, een groeiend probleem. Om in leven te blijven dienen zij de kost te verdienen en dit bestaan verdraagt zich niet met het volgen van onderwijs. De praktijk in sommige landen waarbij kinderen worden ingezet als soldaten in de gewapende strijd betekent dat voor hen het recht op een opvoeding en onderwijs volstrekt illusoir is.

Een andere vorm van passieve discriminatie in het onderwijs heeft zijn oorsprong in bepaalde tradities. Daarbij gaat het vaak om religieuze of culturele redenen die er bijvoorbeeld de oorzaak van zijn dat meisjes in het

241. Zo was in Angola het onderwijs kostelon tot het Bchooljaar 1982-1983. Sedert dat jaar moet voor schoolboeken en andere aanvullende voorzieningen weer betaald worden. Zie UNESCO Doc. 23 C/72, Annex D, pp. 199-204.

242. Zie UNESCO Doc. $15 \mathrm{C} / 11$ (1968), par. 149, rapport van het Comité n.a.v. de eerste consultatieronde.

243. Doc. 23 C/72, par. 331 . 
geheel niet aan het onderwijs mogen deelnemen of hetzelfde niveau van onderwijs als jongens niet mogen volgen. ${ }^{244}$ Veelal bepaalt de gewoonte dat wrouwen ondergeschikt zijn aan mannen en dat deze verhouding zeker niet veranderd mag worden door meis jes mondig te maken met behulp van onderwijs. Ook gescheiden onderwijs voor meisjes en jongens impliceert vaak dat het onderwijs aan eerstgenoemden van een mindere kwaliteit is. Tot slot kunnen hier geografische factoren genoemd worden die passieve discriminatie in de hand werken. Het algemeen beschikbaar maken van met name het voortgezet onderwijs wordt vooral beperkt door de grootte van een land en de ongelijke geografische verdeling van de bevolking. Geïsoleerde bevolkingsgroepen en nomaden blijven veelal verstoken van primair onderwijs en dus ook van secundair onderwijs. Het ontbreken van een goed ontwikkelde infrastructuur in veel ontwikkelingslanden op technisch-en onderwijsgebied komt hier duidelijk naar voren. In het bijzonder ontbreekt het vaak aan leerkrachten die in afgelegen gebieden werkzaam willen zijn.

\subsection{Het recht op onderwijs; norm en naleving}

Indien een staat het recht op onderwijs aanvaardt door partij te worden bij bijvoorbeeld het IVESCR betekent dat veelal nog niet dat de situatie van het onderwijs in overeenstemming is met de internationale norm. Weliswaar biedt die norm de mogelijkheid van geleidelijke verwezenlijking en van een zekere beleidsvrijheid, dat betekent geenszins dat de verwezenlijking van het recht op onderwijs een vrijblijvende zaak is. De taakstelling voor de staat is duidelijk: de verschillende vormen van onderwijs dienen in toenemende mate algemeen toegankelijk en beschikbaar te worden gesteld. Bovendien moet de staat de vrijheid van onderwijs respecteren. De grondwet van zo'n staat mag dan formeel het recht op onderwijs aan elke burger toekennen, de werkelijkheid is vaak dat lang niet iedereen ook daadwerkelijk het genot van dat recht ondervindt. Met andere woorden, de nationale implementatie van de internationale norm laat vaak te wensen over. Een aantal internationale teksten aangaande het recht op onderwijs (artikelen 13, 14 IVESCR, UNESCO Conventie) werd opgesteld vanuit de verwachting dat binnen een afzienbare periode de gestelde doeleinden ook verwezenlijkt konden worden. Deze verwachting werd gesteund door optimisme inzake de groei van de economie in de jaren vijftig en zestig. ${ }^{245}$

Hoewel vormen van actieve discriminatie in het onderwijs goeddeels zijn uitgebannen bleken vormen van passieve discriminatie evenwel hardnekki-

244. Doc. $23 \mathrm{C} / 72$, annex $\mathrm{D}$, p. 68 over de situatie in Egypte. Het rapport van Nigeria meldt dat door vroegtijdige huwelijken meisjes ontmoedigd worden deel te nemen an het onderwijs, dan wel verder te leren, Annex D, p. 125.

245. Zie C. Tomuschat, Human Rights in a World-Wide Framework - Some Current Issues, in: Zeiltschrift fur Ausländisches offentliches Recht und Völkerrecht, Vol. 45 (1985), pp. 547-584, op p. 566 . 
ger dan toentertijd werd verwacht. Veelal zijn economische, sockile en culturele factoren daarvan de oorzaak. Westerse landen enerzij js en Derde Wereldlanden anderzijds kennen in dit verband heel verschillende problemen. In rijke landen is handhaving van het hoge niveau van onderwijsvoorzieningen vaak niet meer betaalbaar en moeten prioriteiten worden gesteld. Daarnaast verdient de bevordering van de participatie van achtergestelde groepen, zoals vrouwen en immigranten, in het hoger onderwijs alle aandacht. In ontwikkelingslanden daarentegen moet een samenhangend stelsel van onderwijsvoorzieningen vaak nog ontwikkeld en uitgevoerd worden. Daartoe ontbreekt veelal de materiële en personele infrastructuur. Door de internationale monetaire problemen van een groot aantal ontwikkelingslanden, in het bijzonder hun schuldenlast, is de beschikbaarheid van financiële middelen voor basisvoorzieningen, waaronder onderwijs, in sterke mate verminderd. Ook hier worden staten gedwongen prioriteiten te stellen. Hun af hankelijkheid van internationale financiële instellingen en com= merciële banken betekent dat staten niet langer meer de volledige vrijheid hebben om collectieve voorzieningen financieel te blijven ondersteunen. 246 Dat leidt ertoe dat internationale onderwijsnormen voor Derde Wereldlanden de betekenis hebben van maximumnormen waaraan pas in de verre toekomst kan worden voldaan.

Wat betreft de internationale implementatie van het recht op onderwijs kunnen jurisprudentie en het statenrapportage-stelsel onderscheiden worden. De weinige internationale jurisprudentie die er over het recht op onderwijs bestaat heeft betrekking op staten met hoog ontwikkelde onderwijsstelsels. De jurisprudentie over artikel 2 Eerste Protocol EVRM van de Straatsburgse organen geeft een dynamische interpretatie te zien van inhoud en reikwijdte van het recht op onderwijs. De bedoeling van de opstellers van artikel 2 was de klassieke vrijheid van onderwijs te garanderen in de lijn van de overige klassieke rechten en vrijheden in het EVRM. Overheidsbemoeienis bij de verwezenlijking van het recht op onderwijs werd afgehouden en kreeg toen onvoldoende steun. Door de jurisprudentie van Commissie en Hof heeft het recht op onderwijs in Europees verband een dynamische betekenis gekregen (zie par. 4.1). De veranderende opvattingen over het onderwijs in democratische, hoog-ontwikkelde samenlevingen, de toenemende invloed van de staat op dit terrein, alsmede de plaats van het individu in een pluralistische maatschappij hebben daartoe bijgedragen. Mijn inziens kan de Europese jurisprudentie over het recht op onderwijs richtinggevend zijn voor andere regio's zoals het Latijnsamerikaanse continent. In het bijzonder de interpretatie van de verplichtingen van de staat die voortvloeien uit het recht op onderwijs (bijvoorbeeld de verplichting 'to respect'), alsmede de uitleg van de term 'religieuze of filosofische overtuigingen" kunnen voor andere toezichthoudende organen, bijvoorbeeld de Interamerikaanse mensenrechtenorganen of het Comité inzake Economi- 
sche, Sociale en Culturele Rechten, een belangrijke bron van inspiratie vormen.

Een andere vorm van internationale implementatie van het recht op onderwijs vindt plaats door middel van statenrapporten en de bespreking daarvan door toezichthoudende organen. De waarde en de effectiviteit van deze procedure zijn allereerst afhankelijk van de kwaliteit van de rapporten en van de opstelling van de regering. ${ }^{247}$ Ten aanzien van het recht op onderwijs waren de statenrapporten in een aantal gevallen oppervlakkig van inhoud en legalistisch van opzet. Ze gaven niet altijd de feitelijke situatie weer. Bovendien kan men zich afvragen of de verschafte informatie altijd betrouwbaar is. ${ }^{248}$ Daarnaast worden de waarde en de effectiviteit van het rapportage-stelsel bepaald door de takopvatting en de deskundigheid van het toezichthoudende orgaan. Ten aanzien van het recht op onderwijs zijn de ervaringen nogal wisselend geweest. De werkzaamheden van de 'Sessional Working Group of Governmental Experts' die van 1980-1986 de rapporten over artikel 13 en 14 IVESCR besprak getuigden van weinig expertise en diepgang. De werkzaamheden van het 'Committee on Economic, Social and Cultural Rights' geven de indruk dat dit orgaan kritischer te werk gaat en zijn taak serieuzer opvat. Ook de deskundigheid lijkt door de samenstelling van het Comité beter te zijn gewaarborgd. Uit het bestudeerde materiaal bleek mij dat bij de bespreking van statenrapporten het $\mathrm{Co}$ mité minder aandacht besteedde aan de verwezenlijking van het recht op onderwijs dan aan andere sociaal-economische rechten. De reden hiervoor kan zijn dat het Comité zich eerst en vooral heeft geconcentreerd op de zogenaamde fundamentele rechten zoals het recht op voedsel, en op arbeidsnormen. Het is van groot belang dat in de toekomst de aandacht evenwichtiger wordt verdeeld. De rol van het 'Committee on Conventions and $\mathrm{Re}-$ commendations' in de internationale implementatieprocedure van de UNESCO Conventie beperkt zich tot het bestuderen en samenvatten van statenrapporten. Er heeft geen dialoog plaats met vertegenwoordigers van regeringen. Door deze beperking is deze procedure minder relevant. Een positief aspect van deze procedure is evenwel dat de gehanteerde gedetailleerde questionnaire uitnodigt tot specifieke antwoorden op de gestelde vragen. De rol van de UNESCO en van niet-gouvernementele organisaties in de IVESCR implementatieprocedure is tot nog toe onvoldoende geweest. Hun participatie dient in de toekomst in sterke mate bevorderd te worden. In hoofdstuk 6 kom ik op dit punt terug.

Het is mijn opvatting dat de formulering van internationale normen aangaande het recht op onderwijs inmiddels vrijwel voltooid is (zie par. 3.13).

247. Zie Th.C. van Boven, Die uberfrachtete Agenda, Aufgaben der Vereinten Nationen bei Schutz und Fơrderung der Menschenrechte, in: Vereinten Nationen, Jahrgang 37 (1989), pp. 185-191, op p. $18 \%$.

248. Dit geldt in het bijzonder voor de rapporten, gedateerd vóór 1990, van de communistische landen van Oost-Europa. 
De internationale implementatie van economische, sociale en culturele rechten verkeert evenwel nog in een fase van ontwikkeling. In dit verband speelt een aantal vragen en kwesties. Hoe valt bijvoorbeeld te toetsen of een staat aan zijn internationale verplichtingen aangaande het recht op onderwijs heeft voldaan? Met andere woorden, onder welke omstandigheden kan men spreken van een schending van het recht op onderwijs? Zijn de internationale normen op dit punt voldoende duidelijk? Wellicht kunnen de internationale verplichtingen van een staat ten aanzien van de verwezenlijking van het recht op onderwijs nader worden geïnterpreteerd. En welke rol kunnen de toezichthoudende organen spelen op dit terrein? Deze vragen en andere zullen in het volgende hoofdstuk aan de orde komen. 


\section{HOOFDSTUK 5}

\section{Naar de verwezenlijking van het recht op onderwijs}

\subsection{Inleidende opmerkingen}

Hoofdstuk 5 is gewijd aan verschillende aspecten die te maken hebben met de verwezenlijking van het recht op onderwijs. In dit hoofdstuk staat artikel 13 IVESCR centraal. Paragraaf 2 bouwt voort op het tweede hoofdstuk waarin de sleutelbepaling van het IVESCR, artikel 2 lid 1, werd geanalyseerd. Gepoogd wordt aan te geven welke verplichtingen voor staten voortvloeien uit artikel 13 jo. 2 lid 1 IVESCR. Paragraaf 3 bouwt eveneens voort op het tweede hoofdstuk waarin een typologie van verplichtingen werd voorgesteld met betrekking tot de implementatie van mensenrechten. Paragraaf 3 geeft een uitwerking van de verplichtingen 'to respect', 'to protect' en 'to fulfil' met betrekking tot het recht op onderwijs. Beide paragrafen benadrukken het belang van verplichtingen van staten terzake van de verwezenlijking van economische sociale en culturele rechten. Nauw verbonden met de verwezenlijking van het recht op onderwijs is de vraag wanneer gesproken kan worden van een schending van dit recht. Paragraaf 4 geeft daartoe enige ijkpunten en illustreert de kwestie van schending van het recht op onderwijs aan de hand van enkele voorbeelden. Inherent aan de verwezenlijking van economische, sociale en culturele mensenrechten is hun af hankelijkheid van de beschikbare financiële middelen. De vraag rijst dan hoe een verminderde bescherming van sociale rechten, als gevolg van de afname van beschikbare middelen, zich verhoudt tot het beginsel van geleidelijke verwezenlijking van economische, sociale en culturele rechten zoals dat is neergelegd in artikel 2 lid I IVESCR. Dit punt kan worden geillustreerd aan de hand van de verenigbaarheid van de Nederlandse Les- en Cursusgeldwet met artikel 13 IVESCR (paragraaf 5). In paragraaf $6 \mathrm{komt}$ de vraag aan de orde of het recht op onderwijs als een universeel recht gekarakteriseerd kan worden. Deze vraag wordt vanuit verschillende gezichtspunten benaderd. Eén van die punten is of het recht op onderwijs een universele acceptatie ondervindt. In deze paragraaf wordt ook ingegaan op de verhouding tussen het recht op onderwijs en de leerplicht zoals die in vele landen gemeengoed is. Paragraaf 6 eindigt met een betoog dat het recht op onderwijs het karakter heeft van een sleutelrecht dat als instrument kan dienen ten behoeve van de verwezenlijking van andere rechten en vrijheden. Tot slot wordt in paragraaf 7 betoogd dat staten hun verdragsverplichtingen met betrekking tot sociale rechten ook in economisch slechte tijden serieus moeten nemen, en in dat opzicht hun verantwoordelijkheden moeten nemen. 


\subsection{Verplichtingen van de staat en de verwezenlijking van het recht op onderwijs}

\subsubsection{Algemeen}

De verwezenlijking van de rechten van de mens dient, zoals gezegd, uit te gaan van de veronderstelling dat burger- en politieke rechten alsmede economische, sociale en culturele rechten ondeelbaar en onderling afhankelijk zijn (vergelijk hoofdstuk 2.4). Deze benadering kan worden aangeduid als een 'unified approach" die is gebaseerd op het begrip "human dignity'." Mensenrechten beogen de verwezenlijking van een menswaardig bestaan. Deze grondgedachte is terug te vinden in zowel de Universele Verklaring van de Rechten van de Mens als in beide VN-verdragen van 1966. Inherent aan economische, sociale en culturele rechten is het idee dat de staat een zekere verplichting heeft zorg te dragen voor het welzijn van de burgers. De erkenning van dit uitgangspunt in internationaal verband heeft ertoe bijgedragen dat economische, sociale en culturele waarden als rechten in het volkenrecht zijn aanvaard. In dit verband kan worden gesproken van 'social welfare rights' die een aanspraak maken op universele acceptatie." Deze rechten van het individu en de daarmee corresponderende verplichtingen van de staat beogen aan die individuen een minimumniveau van welzijn te garanderen. ${ }^{3}$ Dit minimumniveau kan ook worden aangeduid als een normatieve kerninhoud dat elk recht in zich draagt:

'Each right must therefore give rise to an absolute minimum entitlement, in the absence of which a State Party is to be considered to be in violation of its obligations. ${ }^{, 4}$

Dit minimumniveau is niet alleen van toepassing op burger-en politieke rechten, maar geldt ook voor economische, sociale en culturele rechten. Anders gezegd, elk mensenrecht impliceert een minimum inhoud die de kern vormt van een recht. Dat is de minimumnorm waaraan de staat ten opzichte van de mensen die onder zijn rechtsmacht vallen moet voldoen.

1. Zie D. Turk, Special Rapporteur Realization of Economic, Social and Culturall Rights, UN Doc. E/CN.4/Sub.2/1989/19. par. 22-27 en par, 34.

2. Zie D. Trubek, Economic, Social and Cultural Rights in the Third World: Human Rights Law and Human Needs Programs, in: Th. Meron (ed.), Human Rights in International Law: Legal and Policy Issues, vol. I, Oxford 1984, pp. 205-271, op p. 205.

3. Idem, pp. 206, 207, en hoofdstuk 2.5.1 supra.

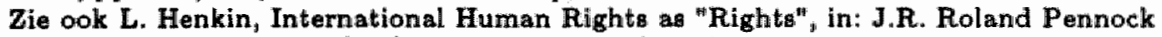
and John W. Chapman (eds), Human Rights, New York and London 1981, pp. 257281, op p. 274 .

4. Ph. Alaton, Out of the Abys: The Challenges Confronting the New UN Committee on Economic, Social and Cultural Rights, in: Human Rights Quarterly, wol. 9 (1987), pp. 332-382, op pp. 352, 353. 
Zonder die minimum anspraak verliest een toegekend recht zijn werkelijke inhoud en betekenis. ${ }^{5}$

Een belangrijke bijdrage aan het verwezenlijken van een menswaardig bestaan en de ontplooiing van het individu wordt geleverd door het genot van onderwijs. We hebben reeds gezien dat de staat een essentielle taak heeft met betrekking tot het beschikbaar stellen van onderwijs. Vanuit juridisch oogpunt bezien is het interessant de vraag te stellen welke verplichtingen een staat heeft ten aanzien van de verwezenlijking van het recht op onderwijs. Is het mogelijk om, op grond van zowel universele als regionale verdragen waarin het recht op onderwijs is vastgelegd aan te geven welke verplichtingen daar voor een staat uit voortvloeien? Kan de veelal vage normatieve betekenis van economische, sociale en culturele rechten, in het bijzonder het recht op onderwijs in die zin verduidelijkt worden? Op deze wijze kan inzicht worden verkregen in de minimum inhoud van het recht op onderwijs. Met deze minimum kerninhoud corresponderen een aantal verplichtingen van de staat. Het is evenwel niet voldoende om minimum aanspraken en verplichtingen vast te stellen. Het recht op onderwijs krijgt immers pas substantiële inhoud wanneer de nationale implementatie van het sociale aspect en het vrijheidsaspect gegarandeerd zijn. In dat opzicht hebben enerzijds de internationale normen inzake de zorgplicht van de staat het karakter van maximumnormen die voor de staat niet altijd even makkelijk zijn na te leven, omdat hun verwezenlijking de inzet van schaarse middelen vereist. Anderzijds hebben de normen betreffende het vrijheidsaspect het karakter van minimumnormen.

\subsubsection{De reikwijdte van artikel 13 IVESCR}

Artikel 13 IVESCR beoogt een universele reikwijdte te hebben en is tamelijk gedetailleerd in vergelijking met andere materiële rechten uit het Verdrag. De artikelen 13 en 14 IVESCR geven een uitwerking van de matregelen die vereist zijn om het recht op onderwijs te verwezenlijken, zowel met betrekking tot het sociale aspect als het vrijheidsaspect. In het bijzonder blijkt dit uit artikel 13 lid 2 waar een concrete opsomming wordt gepresenteerd van maatregelen of anders gezegd van verschillende stappen om tot de volledige verwezenlijking van dit recht te komen. Dit blijkt ook uit de aanhef van lid 2, die luidt: 'with a view to achieving the full realization of this right'.

Een voorbeeld van een andere maatregel die onder artikel 2 lid 1 IVESCR valt te brengen is het ontwikkelen van beleidsplannen en het stellen van prioriteiten. Een dergelijke maatregel is te vinden in artikel 14 waarin het gaat om een plan voor de invoering van kosteloos primair onderwijs, dat binnen twee jaar na inwerkingtreding van het Verdrag voor een staat moet worden opgesteld. Het Comité inzake Economische, Sociale en Culturele

5. Zie ook General Comment no. 3 (1990), par. 10 van het Comite inzake Economische, Sociale en Culturele Rechten, in: UN Doc. E/1991/23, Annex III. 
Rechten, dat toezicht houdt op de naleving van het Verdrag, is van oordeel dat planning en beleid ook ten aanzien van andere rechten geboden is. In zijn eerste 'general comment', een gezaghebbende interpretatie van verdragsbepalingen, over het rapporteren door verdragsstaten merkte het $\mathrm{Co}$ mité op, met een verwijzing naar artikell 14:

'a comparable obligation "to work out and adopt a detailed plan of action for the progressive implementation" of each of the rights contained in the Covenant is clearly implied by the obligation in Article 2, paragraph 1 "to take steps ... by all appropriate means ...". :6

Zoals bleek in hoofdstuk 2.6.2 heeft de verplichting maatregelen te nemen ingevolge artikel 2 lid 1 een onmiddellijk karakter. Dat wil zeggen dat staten terstond na het van kracht worden van het Verdrag maatregelen moeten nemen met het oog op de verwezenlijking van de materielle rechten. ${ }^{7}$ Eén van die maatregelen is het opstellen van een plan waarnaar verwezen wordt in artikel 14. Opmerkelijk in dit verband is dat artikel 14 alleen spreekt over het opstellen en aanvaarden van een plan, maar niet over de uitvoering daarvan. Een dergelijke verplichting zou in de lijn van artikel 13 jo. artikel 2 lid 1 gelegen hebben.

Specifieke maatregelen gericht op de implementatie van het recht op onderwijs worden gesuggereerd in de richtlijnen ten behoeve van het opstellen van statenrapporten over artikel 13 en $14 .^{8}$ Naast wetgeving in algemene zin kunnen bestuursmaatregelen en collectieve overeenkomsten of afspraken worden genoemd. Bovendien kan het gaan om bijzondere maatregelen ten behoeve van onderwijsvoorzieningen voor meisjes, kinderen uit lage inkomensgroepen, plattelandskinderen, gehandicapten, migranten en leden van minderheden. Deze maatregelen zijn een vorm van positieve actie gericht op de bestrijding van discriminatie, achterstanden in het onderwijs en van armoede. ${ }^{9}$ Ook kan gedacht worden aan praktische maatregelen zoals financiële steun aan scholieren en studenten, programma's voor volwasseneneducatie en de bestrijding van analfabetisme. Het bouwen van scholen door de staat en het ter beschikking stellen van onderwijsmateriaal zijn eveneens concrete maatregelen die bijdragen aan de implementatie van het recht op onderwijs. Een andere belangrijke maatregel is het creëren van de mogelijkheid om onderwijsgevenden door middel van overleg en inspraak te betrekken bij het beleid dat door de staat wordt gevoerd. Ook moet er in dat proces een plaats worden toebedeeld aan ouderverenigingen en aan studenten. Meer in het algemeen vereist een samenhangend

6. Committee on Economic, Social and Cultural Rights, General Comment No. 1 (1989), par. 4, Reporting by States Parties, in: UN Doc. E/1989/22, Annex III.

7. Zie de Limburg Principles, a.w. nr. 16, en 'general comment' no. 3 van het CESCR.

8. De nieuwe richtlijnen voor het opstellen van rapporten over de artikelen 13-15. IVESCR. gijn te vinden in UN Doc. E/C.12/1991/1, en in UN Doc. E/1991/23, Annex IV.

9. Vergelijk Limburg Principles nr. 14. 
onderwijsbeleid het opzetten van plannen gericht op lange termijn ontwikkelingen en -doelstellingen.

Op grond van artikel 2 lid 1 IVESCR heeft een staat de verplichting alle hem ter beschikking staande middelen in te zetten ten behoeve van de verwezenlijking van de materiële rechten uit het Verdrag (vergelijk hoofdstuk 2.6.2). Ten aanzien van de verwezenlijking van het recht op onderwijs valt in dit verband te denken aan financiële middelen ten behoeve van scholen, onderwijsmateriaal, opleiding en salarissen van leerkrachten. Ook financiële steun voor kwaliteitsverbetering van het onderwijs kan hiertoe gerekend worden. Daarnaast zijn er personele middelen, zoals de beschikbaarheid en de inzet en motivatie van gekwalificeerde onderwijsgevenden. In eerste instantie zullen de (financiële) middelen door de staat ter beschikking gesteld moeten worden, omdat de staat als enige de capaciteit heeft een samenhangend onderwijsbestel in te richten en vooral ook in stand te houden. Maar daarnaast kunnen ook particuliere middelen worden ingezet zoals bij de oprichting en instandhouding van scholen voor privé-onderwijs. Eén van de implicaties van de vrijheid van onderwijs is immers dat niet-openbare scholen in beginsel ook financieel onafhankelijk moeten kunnen zijn indien ze dat wensen. Op grond van de verschillende internationale teksten over het recht op onderwijs heeft de staat geen verplichting het privé-onderwijs financieel te ondersteunen.

\section{Verplichtingen 'to respect' en 'to recognizes}

Zoals we in hoofdstuk 2 hebben gezien was éen van de argumenten binnen de traditionele benadering van economische, sociale en culturele rechten dat hun verwezenlijking overheidsingrijpen vereist. Voor de verwezenlijking van burger- en politieke rechten daarentegen zou overheidsonthouding noodzakelijk zijn. In tegenstelling tot deze traditionele benadering ben ik met Alston en Quinn van mening dat een dergelijk onderscheid weinig zinvol is en ook praktisch niet goed mogelijk. De mate van betrokkenheid van de staat, noodzakelijk voor de verwezenlijking van een mensenrecht, is eerder afhankelijk van de aard van het desbetreffende recht. In de woorden van Alston en Quinn, 'the relevant question to pose is not whether any particular kind (burger-, politieke dan wel economisch-sociaal A.C.) requires positive state action but rather the extent to which it can subsist as a meaningful right without such active state support" ${ }^{10}$ Met andere woorden, het is steeds geboden om elk afzonderlijk recht nauwkeurig te analyseren om te bepalen welke specifieke verplichtingen de staat heeft.

Ten aanzien van de regeling van het recht op onderwijs in internationale teksten komt een tweetal verplichtingen steeds terug. Ten eerste gaat het om de verplichting 'to respect'. De staat is gehouden de vrijheid van ouders of voogden te eerbiedigen ('to respect') inzake de opvoeding en het 
onderwijs van hun kinderen. Deze verplichting komt voor in artikel 13 lid 3 IVESCR, artikel 18 lid 4 IVBPR, artikel 2 Eerste Protocol EVRM en artikel 5 lid 1 sub b UNESCO Verdrag. Deze verplichting heeft op het eerste gezicht slechts een negatieve betekenis in de zin van een verbod van inmenging door de staat. Uit de totstandkoming van het EVRM en latere jurisprudentie van de Straatsburgse organen is duidelijk geworden dat de verplichting 'to respect' in positieve zin moet worden geinterpreteerd. Zij vereist een positieve, tolerante houding van de staat. ${ }^{11}$ Deze interpretatie moet ook van toepassing worden geacht op artikel 13 lid 3 IVESCR. De verplichting 'to respect' heeft het karakter van een minimum verplichting die nauw aansluit bij de formuleringen van burger- en politieke rechten. In de hierboven genoemde bepalingen gaat het steeds om het vrijheidsaspect van het recht op onderwijs met als strekking een staatsvrije sfeer te garanderen. Artikel 13 lid 3 IVESCR impliceert een onmiddellijke verplichting. Lid 3 vereist van de staat slechts eerbied voor de overtuigingen van de ouders of voogden. Er zijn geen nadere uitvoeringshandelingen noodzakelijk opdat deze bepaling binnen de rechtsorde van een staat kan werken. ${ }^{12}$ Naar mijn mening lenen de hier genoemde bepalingen inzake het vrijheidsaspect van het recht op onderwijs waarin de term 'to respect' voorkomt zich voor afdwinging voor een nationale rechterlijke instantie. ${ }^{13}$

In de tweede plaats treffen we in de internationale teksten over het recht op onderwijs de term 'to recognize" aan. Dit is het geval in artikel 13 lid 1 en 2 IVESCR, artikel 5 lid 1 sub c UNESCO Conventie, artikel 13 lid 3 Protocol van San Salvador, artikel 28 Conventie inzake de Rechten van het Kind. Bovendien spreekt artikel 2 lid 1 IVESCR, de paraplu-bepaling, ook over 'the rights recognized in the present Covenant'. Zoals we bij de analyse van de totstandkoming van artikel 13 IVESCR hebben gezien is de term 'to recognize' nauw verbonden met het idee van geleidelijke verwezenlijking. Dit blijkt onder meer uit het gebruik van dit woord in artikel 2 lid 1 IVESCR. Daarnaast spreekt artikel 13 lid 2 aanhef ook van 'to recognize', waarbij deze term gekoppeld is aan de volledige verwezenlijking ('full realization') van het recht op onderwijs. Tijdens de ontstaansgeschiedenis van artikel 13 werd de oorspronkelijke aanhef van lid 2 van artikel 13, luidende 'It is understood' veranderd in 'The States Parties to the Covenant recognize'. De verandering beoogde een term te gebruiken met een

11. Zie hoofdstuk 3.5.5 en 4.1.3. supra; voor artikel 13 IVESCR gie hoofdstuk 3.6.3. supra.

12. Een dergelijke opvatting vindt steun in de 'travaux préparatoires". De Libanese afgevaardigde Azkoul merkte hierover op:

'As was clear from the four qualification in Article $2_{n}$ the economic, social and cultural rights were neither absolute nor immediately enforceable, but of progressive application. The idea of progressive application had intentionally been eliminated with regard to certain articles'. Tot die latatste categorie rekende hij artikel 13 lid 3 IVESCR. Zie UN Doc. A/C.3/SR.575, par. 31 (5-11-1954).

13. Het CESCR is van mening dat artikel 13 lid 3 en lid 4 IVESCR zich voor onmiddellijke toepassing in nationale rechtsatelsels lijken te lenen. Zie General Comment no. 3 (1990), a.w. par. 5. 
sterkere juridische betekenis. ${ }^{14}$ Bovendien werd de clausule "with a view to achieving the full realization of this right" toegevoegd om het idee van de geleidelijke verwezenlijking van primair, secundair, hoger onderwijs en andere geledingen van onderwijs nog eens te benadrukken. Deze toevoeging werd ingegeven door de overweging dat het van weinig realiteitszin zou getuigen indien er een verplichting zou bestaan de verschillende geledingen binnen het onderwijs onmiddellijk te verwezenlijken. De onderwijsbepaling diende in overeenstemming te zijn met artikel 2 lid $1 .{ }^{15}$

Binnen artikel 13 lid 2 IVESCR dient een nuancering aangebracht te worden. Lid $2 a$, handelend over primair onderwijs, impliceert een juridisch sterkere verplichting dan de overige delen van dit lid. De verplichting is onvoorwaardelijk, zonder een aspect van geleidelijkheid, alsmede duidelijk omschreven. De andere delen, te weten lid 2 b en $2 c$ over het secundair en hoger onderwijs, bevatten vervoegingen van het werkwoord 'to make', en dit impliceert het karakter van geleidelijke verwezenlijking. ${ }^{16}$ Het belang van de verwezenlijking van kosteloos en verplicht primair onderwijs wordt onderstreept in artikel 14. Bij de bespreking van statenrapporten op grond van het IVESCR benadrukten verschillende leden van het Comite inzake Economische, Socialle en Culturele Rechten het grote belang van de beschikbaarheid van kosteloos en verplicht primair onderwijs. Het betreft hier een minimale voorziening die in stand gehouden moet worden ongeacht het financieel-economische beleid van een regering en de beschikbare financiële middelen. ${ }^{17}$ Volgens het Comité lijkt artikel 13 lid $2 \mathrm{a}$ zich voor directe toepassing in de rechtsorde van veel staten te lenen. ${ }^{18}$

Een ander aspect van de vrijheid van onderwijs, te weten de vrijheid van individuele personen of rechtspersonen om onderwijsinstellingen op te richten is vastgelegd in artikel 13 lid 4 . Deze vrijheid impliceert voor de staat de verplichting geen inbreuk te maken op dat recht. Het is met andere woorden een ander voorbeeld van een minimale verplichting die naar mijn mening niet onderhevig is aan het regime van geleidelijke verwezenlijking. Deze bepaling heeft een onmiddellijk karakter. $\mathrm{Zij}$ vereist van de staat slechts het vaststellen van minimumnormen voor particuliere onderwijsinstellingen. Lid 4 verbiedt de staat artikel 13 zodanig te interpreteren dat deze vrijheid wordt aangetast.

Al met al kan worden gesteld dat het vrijheidsaspect van het recht op onderwijs zich leent voor onmiddellijke toepassing, terwijl de verwezenlijking van het sociale aspect over het algemeen een geleidelijk karakter heeft,

14. Zie hoofdstuk 3.6.4. en verder 3.6.2 supra (over de betekenis van de term 'to recognize').

15. Zie hoofdatuk 3.6.4 supra.

16. Zie over de betekenis van de term 'to make' in dit verband, hoofdstuk 3.13 supra.

17. Zie bijvoorbeeld de opmerkingen van Comité-leden over de situatie in Zaire in hoofdstuk 4.5.3. supra.

18. CESCR, General Comment no. 3 (1990), a.w. par. 5 . 
met uitzondering van de realisering van verplicht en kosteloos primair onderwijs.

\section{'Obligations of conduct' en 'obligations of result'}

De reikwijdte en inhoud van verdragsverplichtingen met betrekking tot het recht op onderwijs kunnen, zoals in hoofdstuk 2 werd betoogd, nader geanalyseerd worden met behulp van het onderscheid naar "obligations of conduct' en 'obligations of result'. ${ }^{19}$ 'Obligations of conduct' verplichten de staat tot een specifieke, in de verdragsbepaling genoemde handeling of tot een bepaald gedrag. 'Obligations of result' verplichten de staat een in de verdragsbepaling genoemd resultaat te verwezenlijken, maar laten de staat verder vrij in de keuze der middelen. Het resultaat staat vast, de weg ernaar toe niet; de staat heeft een bepaalde beleidsvrijheid methoden en middelen te kiezen die hem goeddunken ten einde het vereiste resultaat te verwezenlijken. Een aantal economische, sociale en culturele rechten is geformuleerd als 'obligation of result' zoals het recht op voedsel en het recht op huisvesting (beide in artikel $1 \mathbb{1}$ (1) IVESCR). Voordeel hiervan is dat staten een aanzienlijke mate van beleidsvrijheid hebben maatregelen te nemen die het best passen bij de nationale situatie. Anderzijds is het moeilijk vast te stellen of een staat een dergelijke verplichting ook naleeft, omdat de verplichting zelf geen ijkpunten bevat ${ }^{20}$. Andere rechten hebben meer het karakter van 'obligations of conduct', zoals het recht op een goede lichamelijke en geestelijke gezondheid (artikel $12(2)$ IVESCR). Deze bepaling bevat een uitwerking van de maatregelen die een staat moet nemen om dat recht te verwezenlijken. Van andere materiële rechten uit het IVESCR is niet zonder meer te zeggen of het gaat om een 'obligation of conduct', dan wel een 'obligation of result'. Binnen één verdragsartikel kunnen beide vormen voorkomen.

Dat is ook het geval bij artikel 13, de onderwijsbepaling. De eerste zin van lid 1 bepaalt dat partijstaten het recht van een ieder op onderwijs erkennen. Deze algemene formulering impliceert, mede door het gebruik van de term 'erkennen' ('to recognize'), een verplichting tot geleidelijke verwezenlijking in de zin van artikel 2 lid 1 . Op grond daarvan kan men hier spreken van een 'obligation of result". Lid 2 definieert het recht op onderwijs in termen van verplichtingen van de staat. Deze bepaling geeft op concrete wijze de stappen of maatregelen aan die noodzakelijk zijn voor de verwezenlijking van het recht op onderwijs. In die zin is lid 2 in zijin geheel een 'obligation of conduct". ${ }^{21}$ De verschillende elementen van het recht op onderwijs worden expliciet genoemd en er wordt concreet aangegeven

19. Voor een algemene uiteenzetting van beide begrippen, gie hoofdstuk 2.4 supra.

20. A. Eide, Realization of Social and Economic Rights, The Minimum Threshold Approach, in: The Review of the International Commision of Jurists, no. 43 (1989), pp. $40-53$, op p. 41.

21. Zie ook Alston/Quinn, a.w. p. 185. 
waartoe de staat verplicht is. Genoemde stappen zijn gericht op de volledige verwezenlijking van het recht op onderwijs. Lid 2 voldoet naar mijn mening aan de criteria die de International Law Commission stelt aan een 'obligation of conduct':

'.... it is not enough for the obligation to require of the State a course of conduct determined in some unspecific manner. The determination must, on the contrary, be extremely precise, in other words, the obligation must determine in a "particular" manner what is required of a given branch of the State machinery. ${ }^{422}$

Voor de verschillende onderdelen van lid 2 geldt dat lid $2 a$, d en e, respectievelijk handelend over primair onderwijs, fundamenteel onderwijs en de ontwikkeling van een stelsel van scholen, ook kunnen worden aangemerkt als 'obligation of conduct'. Deze bepalingen bevatten immers een specifiek aangeduide gedragslijn voor de staat. Lid $2 b$ en $c$, handelend over respectievelijk voortgezet en hoger onderwijs, hebben meer het karakter van 'obligations of result', omdat de staat in dit geval een grote beleidsvrijheid heeft met het oog op de geleidelijke verwezenlijking van deze vormen van onderwijs. De teksten spreken immers van 'alle passende maatregelen'. Het door de verplichting vereiste resultaat, te weten beschikbaar en toegankelijk onderwijs staat vast. De staat kan dat met zelf gekozen maatregelen bereiken. Dat kan door wetgeving, maar ook andere maatregelen zijn mogelijk. Van essentieel belang bij deze soort verplichting is dat voldaan wordt aan het vereiste resultaat; de weg daar naar toe is van ondergeschikt belang. In de woorden van de ILC:

'so long as the State has not failed to achieve in concreto the result required by an international obligation, the fact that it has not taken a certain measure which would have seemed especially suitable for that purpose - in particular, that it has not enacted a law - cannot be held against it as a breach of that obligation. ${ }^{23}$

Artikel 13 lid 3 en 4 IVESCR hebben het karakter van "obligations of conduct', omdat de staat een specifiek gebod, respectievelijk verbod wordt opgelegd. In lid 3 gaat het om de verplichting de keuzevrijheid van ouders te eerbiedigen, terwijl lid 4 aantasting van de vrijheid om particuliere onderwijsinstellingen op te richten verbiedt. In beide gevallen ligt een specifieke gedragslijn voor de staat vast. Ook artikel 14 IVESCR is een 'obligation of conduct'. Specifiek aangeduide handelingen worden in de bepaling omschreven, het gaat immers om een uitvoeringsbepaling. Geconcludeerd kan worden dat het onderscheid naar 'obligations of conduct' en 'obligations of result' nuttig is, omdat het inzicht verschaft in het karakter van de

22. Yearbook of the International Law Commission, 1977, Vol. II, part Two, p* 18 (Draft Articles on State Responsibility with Commentaries).

23. Idem, p. 23. 
verplichtingen van staten. Met behulp van deze tweedeling kan worden aangegeven welk gedrag en welke handelingen van de staat mogen worden verwacht en welke beleidsvrijheid zij bezitten met betrekking tot de realisering van het recht op onderwijs. Zo kan tevens worden beoordeeld of staten hun verplichtingen ook naleven. ${ }^{24}$

\subsection{Een typologie van verplichtingen met betrekking tot de implementatie van het recht op onderwijs}

In hoofdstuk 2.5.2 werd een typologie van verplichtingen voorgesteld aan de hand van waarvan de verplichtingen van staten aangaande de verwezenlijking van de rechten van de mens kunnen worden gespecificeerd. Deze typologie van verplichtingen ('to respect', 'to protect' en 'to fulfil') kan voor elk mensenrecht nader ingevuld worden. Ten aanzien van het recht op onderwijs kunnen de drie niveaus van verplichtingen gerelateerd worden aan de twee aspecten van het recht op onderwijs, te weten het sociale aspect en het vrijheidsaspect. Voor beide aspecten kan een aantal elementen van het recht op onderwijs onderscheiden worden. Dit zijn voor het sociale aspect de elementen toegankelijkheid en beschikbaarheid. Bij het vrijheidsaspect gaat het om de keuzevrijheid (van ouders) en de vrijheid privé onderwijsinstellingen te stichten en daaraan leiding te geven (de vrijheid van oprichting). Op deze wijze kan een matrix voor de verwezenlijking van het recht op onderwijs geconstrueerd worden (zie p. 234). ${ }^{25}$

De matrix geeft geen uitputtende weergave van concrete verplichtingen van de staat. De in de matrix voorgestelde maatregelen geven een illustratie van mogelijke opties voor de staat. Andere maatregelen kunnen worden ingevuld afhankelijk van de onderwijssituatie in een land. De drie niveaus van verplichtingen kunnen gekoppeld worden aan artikel 13 jo. artikel 2 IVESCR. Zo is de verplichting 'to respect' in verband te brengen met artikel 13 lid 1 jo. artikel 2 lid 2 , en met artikel 13 lid 3 en 4 . De verplichting 'to protect' staat in verband met artikel 13 jo. artikel 2 lid 1 , en met artikel 13 lid 3 en 4 . De verplichting 'to fulfill' tenslotte kan gekoppeld worden aan artikel 13 lid 2 jo. artikel 2 lid 1 , in het bijzonder artikel 13 lid 2 sub d en e. De vier elementen van het recht op onderwijs zijn eveneens terug te voeren op artikel 13. De elementen toegankelijkheid en beschikbaarheid komen voort uit artikel 13 lid 2, terwijl de keuzevrijheid en de vrijheid van oprichting hun grondslag hebben in artikel 13 lid 3 en 4 . Ook de te nemen maatregelen moeten uiteindelijk zijn terug te voeren op de normen van artikel 13. De verplichting 'to respect' houdt in dat de staat zelf de verschillende elementen van het recht op onderwijs moet respecte-

24. Zie Th. Meron, Human rights and humanitarian norms ag cubitomary law, Oxford 1989, pp. $182-188$, op p. 183.

25. Voor het recht op voedsel heeft Eide een 'Food Security Matrix* opgesteld, zie zijn eindrapport uit 1987 op p. 29 . Mijn matrix voor het recht op onderwije is gebaseerd op zijn idee. 


\begin{tabular}{|c|c|c|c|c|}
\hline \multirow{2}{*}{ 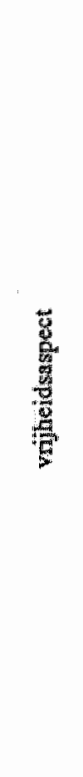 } & 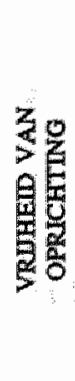 & 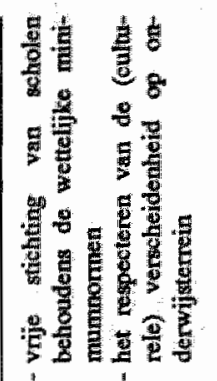 & 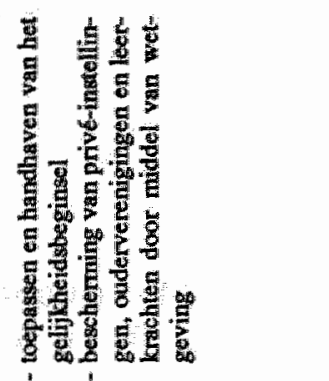 & 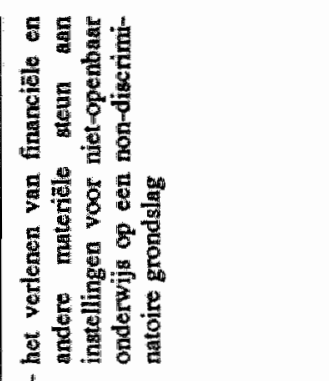 \\
\hline & 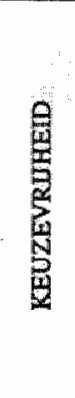 & 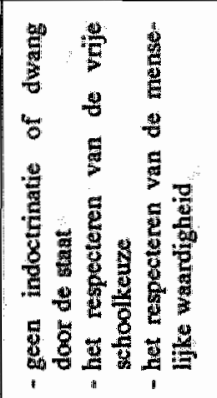 & 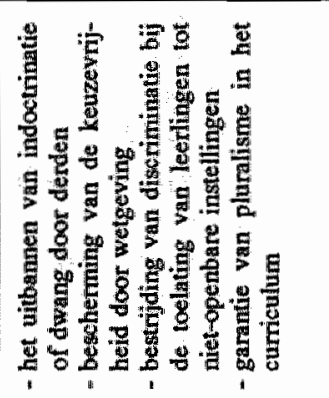 & 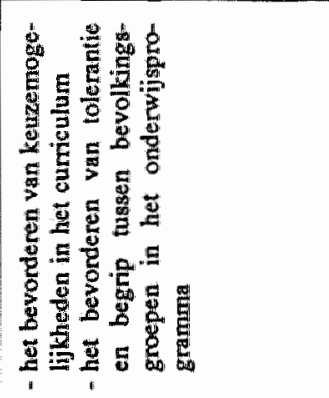 \\
\hline \multirow{2}{*}{ 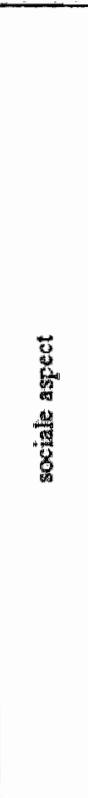 } & 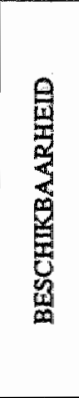 & 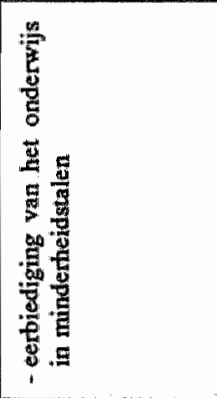 & 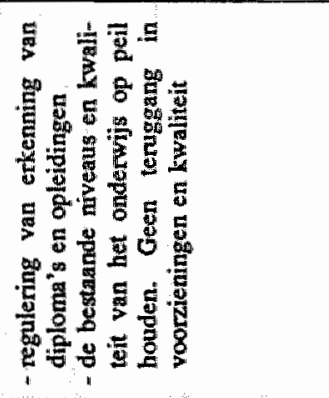 & 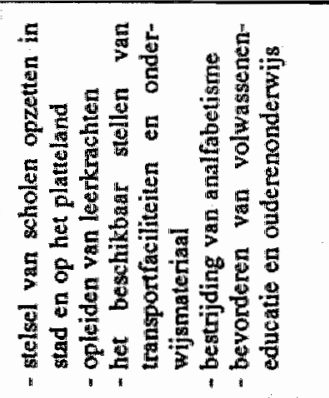 \\
\hline & 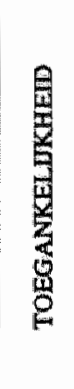 & 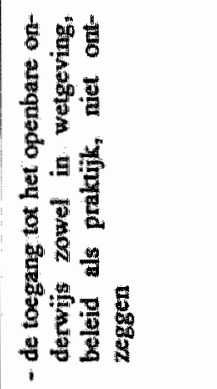 & 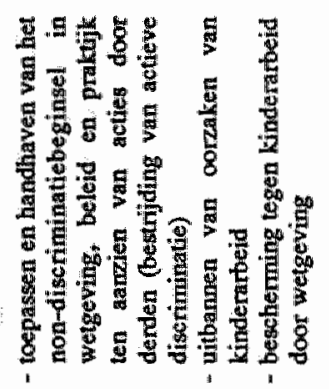 & 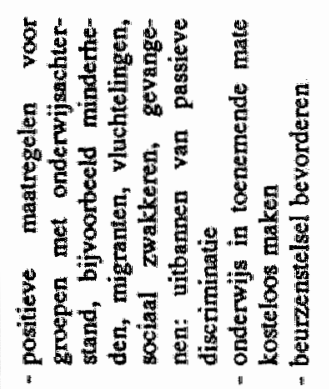 \\
\hline 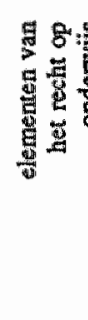 & & 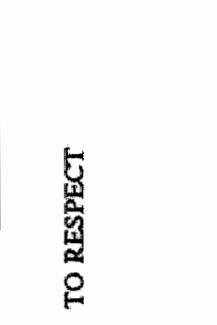 & $\begin{array}{l}\mathbf{E} \\
\text { 总 } \\
\text { 怘 } \\
\text { 。 }\end{array}$ & $\begin{array}{l}\text { 亚 } \\
\text { 至 } \\
\end{array}$ \\
\hline
\end{tabular}


ren in de door de overheid opgezette ondlerwijsinstellingen. Op grond van de verplichting 'to protect' dient de staat beschermende maatregelen te nemen door middel van wetgeving en beleid om te voorkomen dat anderen (derden) of de staat zelf het genot van het recht op onderwijs beperken (ook ter bestrijding van actieve discriminatie). Volgens de verplichting 'to fulfil' dient de staat een beleid te voeren dat gericht is op de verwezenlijking van het recht op onderwijs in al zijn facetten. Dat vereist positieve maatregelen, o.a. gericht op de uitbanning van vormen van passieve discriminatie. De staat heeft een zorgplicht. Veelal gaat het om doeleinden die slechts geleidelijk verwezenlijkt kunnen worden. Het betreft een programma-verplichting die ook lange termijn doeleinden omvat. De verplichtingen 'to respect' heeft een onmiddellijk karakter. De verplichtingen 'to protect' en "to fulfil' hebben daarentegen een geleidelijk karakter. Dat betekent dat de verplichting 'to respect' afdwingbaar is voor een nationale rechterlijke instantie, terwijl de andere twee verplichtingen dat veelal niet zullen zijn, omdat bepaalde voorzieningen (nog) niet gerealiseerd zijn.

De typologie van verplichtingen ten aanzien van het recht op onderwijs is niet voorbehouden aan een specifieke inrichting van de maatschappij bijvoorbeeld socialistisch of kapitalistisch, of een bepaalde politieke structuur. De typologie is even goed toepasbaar op de verwezenlijking van het recht op onderwijs in Derde Wereldlanden als in rijke landen met reeds een hoog ontwikkeld onderwijsniveau. In die laatste groep van landen blijft het immers zaak het bestaande niveau van onderwijs te handhaven en maatregelen te nemen tegen achteruitgang van voorzieningen waardoor bijvoorbeeld de toegankelijkheid en de beschikbaarheid in gevaar kunnen komen. Wel dient ervoor gewaakt te worden de verplichtingen ten aanzien van het recht op onderwijs in de matrix niet te gedetailleerd te formuleren, omdat er grote sociaal-economische, politieke en culturele verschillen bestaan tussen staten. De typologie van verplichtingen wil niet tornen aan de verscheidenheid van de inrichting en het functioneren van nationale onderwijsstelsels. $\mathrm{Zij}$ beoogt een hulpmiddel te zijn bij de uitwerking van verplichtingen van staten. Daarnaast biedt deze typologie de mogelijkheid vast te stellen of een staat zijn verplichtingen ook naleeft.

\subsection{Schending van het recht op onderwijs}

\subsubsection{Criteria voor een schending}

De vraag kan gesteld worden onder welke omstandigheden er sprake kan zijn van een schending van het recht op onderwijs. Met andere woorden, wanneer is de situatie van het onderwijs in een staat dusdanig dat men op goede gronden kan zeggen dat het internationaal erkende recht op onderwijs geschonden wordt? Veelal zal een schending van een burger- of politiek recht duidelijker zijn vast te stellen, omdat de naleving van dat recht door de staat een specifiek, welomschreven gedrag vereist. In veel gevallen zal dat een gebod zijn tot onthouding van dwang of ongeoorloofde bemoei- 
enis met de uitoefening van vrijheidsrechten. In die gevallen is een schending van een bepaald recht makkelijker te traceren, bijvoorbeeld in gevallen van censuur, marteling, inbreuken op de demonstratievrijheid of afwezigheid van eerlijke verkiezingen. De staat mag geen misbruik van macht maken en dient te handelen volgens de "rule of law". Voor economische, sociale en culturele rechten daarentegen is het bijzonder moeilijk om vast te stellen of er sprake is van een schending. ${ }^{26}$ Daar is een aantal redenen voor aan te geven. Verschijnselen als armoede, ondervoeding, ongeletterdheid zijn zulke algemene problemen dat ze nauwelijks worden onderkend als schendingen van economische, sociale en culturele rechten. Er is wel veel bekend over deze problemen die zich met name in Derde Wereldlanden voordoen, maar ze worden niet of nauwelijks opgevat als een mensenrechtenkwestie, eerder als een ontwikkelings-economisch vraagstuk. Over dit onderwerp wordt ook bijzonder weinig geschreven. ${ }^{27}$ Bovendien bezitten staten een aanzienlijke mate van beleidsvrijheid bij de verwezenlijking van economische, sociale en culturele rechten. De wijze van verwezenlijking van deze rechten is afhankelijk van de specifieke nationale context. Daar komt nog bij dat de internationale normen aangaande economische, sociale en culturele rechten nog veelal vaag zijn zodat ijkpunten aan de hand waarvan een schending kan worden vastgesteld ontbreken. Een gezaghebbende interpretatie van deze normen door een internationaal orgaan heeft zich in het verleden slechts op een aantal specifieke terreinen ontwikkeld, zoals de arbeidsnormen in het kader van de ILO. Ten aanzien van het recht op onderwijs ontbreekt een dergelijke interpretatie, bijvoorbeeld door de UNESCO, goeddeels. Bovendien bestaat er maar een klein aantal internationale procedures die een individu de mogelijkheid bieden een klacht in te dienen over een vermeende schending van het recht op onderwijs.

De 'Limburg Principles' bieden een aanknopingspunt om de notie van schendingen van economische, sociale en culturele rechten te concretiseren. ${ }^{28}$

26. Zie K. Tomasevski, Measuring compliance with human rights obligations, in: L.A. Rehof and C. Gulmann (edo), Human Rights in Domestic Law and Development Assistance Policies of the Nordic Countries, Dordrecht 1989, pp. 109-123 " op p. 117.

27. Meestal komt men slechts een enkele, korte passage tegen over de problematiek van achendingen van economische, sociale en culturele rechten, zie bijvoorbeeld A. Eide, Realization of Social and Economic Fights; The Minimum Threshold Approach, in: The Review of the International Commission of Jurists no. $43 / 1989, \mathrm{Pp}_{.} 40-63$, op p. 47, en B. Simma, S. Bennigsen, Wirtschaftiche; soeiale und kulturelle Rechte im Volkerrecht, in: Festschrift fur Ernst Steindorf zum 70. Geburtstag, herausgegeben von J.F. Baur, K.J, Hopt und K.P. Mailknder, Berlin-New York 1990, pp. 1477-15102, op p. 1491.

28. De rellevante passages uit de Limburg Principles luiden als volgt:

70. A fallure by a State party to comply with an obligation contained in the Covenant is, under international law, a violation of the Covenant.

71. In determining what amounts to a fallure to comply, it must be borme in mind that the Covenants affords to a State party a margin of discretion in selecting the means for carrying out it: objects, and that factors beyond its reasonable control may adversely affect its capacity to implement particular rights.

(Wordt vervolgd...) 
De centrale gedachte daarbij is dat er sprake is van een schending van een economisch, sociaal of cultureel recht indien de staat opzettelijk handelt in strijd met de bepalingen van het IVESCR, hoewel zij wel in staat is te voldoen aan de internationale norm. Dat kan gebeuren door actief te handelen in strijd met de verdragsbepalingen, dan wel na te laten specifieke maatregelen te nemen die het IVESCR vereist. Ook is er sprake van een schending indien de staat de geleidelijke verwezenlijking van rechten opzettelijk ophoudt of stopzet. Het probleem bij de kwalificatie 'opzettelijk' is dat bijzonder moeilijk is aan te tonen dat een staat inderdaad op die wijze heeft gehandeld. Overmacht kan een staat niet aangerekend worden en leidt dus niet tot internationale aansprakelijkheid. Van overmacht ('force majeur') is bijvoorbeeld sprake indien een staat onvoldoende (financiële) middelen beschikbaar heeft voor de geleidelijke verwezenlijking van de materiële rechten. Dat kan bijvoorbeeld het geval zijn indien de internationale economische situatie financiële beperkingen aan een staat oplegt. In een situatie van overmacht mag worden verwacht dat een staat toch zoveel mogelijk rekening houdt met de positie van de zwakkeren in de samenleving in het te voeren beleid. ${ }^{29}$

Ten einde een schending van het recht op onderwijs te kunnen vaststellen is het noodzakelijk ijkpunten te formuleren waaraan een bepaalde situatie kan worden getoetst. Dergelijke ijkpunten kunnen worden vervat in het begrip 'minimum kerninhoud van het recht op onderwijs'. ${ }^{30}$ Elk recht moet een absolute minimum aanspraak inhouden. Indien een staat de minimum

28. (....vervolg)

72. A State party will be in violation of the Covenant, inter alla, if:

- it fails to take a step which it is required to take by the Covenant;

- it fails to remove promptly obstacles which it is under a duty to remove to permit the immediate fulfilment of a right;

- it fails to implement without dellay a right which it is required by the Covenant to provide immediately;

- it wilfully fails to meet a generally accepted international minimum standard of achievement, which is within its powers to meet;

- it applies a limitation to a right recognized in the Covenant other than in accordance with the Covenant;

- it deliberately retards or halts the progressive realization of a right " unless it is acting within a limitation permitted by the Covenant or it does due to a lack of available resources or force majeur;

- it fails to submit reports as required under the Covenant.'

Er zij hier nogmaals op gewezen dat de Limburg Principles alleen een interpretiatie geven van het IVESCR.

Zie ook de bundel Mensenrechten voor armen weggelegd? Mensenrechten, ontwikkeling en demacratie in Noord-Zuid perspectief. Uitgave van de Evert Vermeerstichting, Amsterdam 1989, pp. 105, 106, 119.

29. Bundel Mensenrechten voor armen weggelegd?, a.w. p. 106.

30. Het Comité inzake Economische, Sociale en Culturele Rechten spreekt in dit verband van 'minimum core obligations" voor staten, zie General Comment no. 3 (1990), par. 10. Het Comite merkte op: 'If the Covenant were to be read in such way not to establish such a minimum core obligation, it would be largely deprived of its raison d'être'. 
kerninhoud niet naleeft is er sprake van een schending van een recht ${ }^{31}$. Bovendien kan de typologie van verplichtingen ('to respect, to protect, to fulfil') behulpzaam zijn bij de beoordeling van de vraag of een schending van het recht op onderwijs heeft plaatsgevonden omdat deze typologie verplichtingen nader omschrijft. Op grond van onze beschouwingen over het karakter van het recht op onderwijs en de verplichtingen die daar voor een staat uit voort vloeien kan aan het recht op onderwijs een bepaalde minimum inhoud worden gegeven. Daarbij moeten twee aspecten onderscheiden worden, te weten het vrijheidsaspect en het sociale aspect. Het vrijheidsaspect impliceert als minimum aanspraak de vrije keuze van onderwijs zonder dwang van de staat of derden, in het bijzonder maar niet uitsluitend, ten aanzien van godsdienst of levensovertuiging. Het sociale aspect houdt als minimum aanspraak in dat niemand het recht op onderwijs mag worden ontzegd. Dat wil zeggen dat de toegankelijkheid van het beschikbare onderwijs op een non-discriminatoire grondslag gegarandeerd moet zijn. Ten aanzien van het beschikbare onderwijs dient het primaire onderwijs verplicht en kosteloos te zijn. Het primaire onderwijs is zo elementair voor de verdere ontwikkeling en ontplooiing van het individu dat dit met recht als minimum aanspraak kan worden geformuleerd. Indien een staat in wetgeving of praktijk deze minimum elementen niet naleeft is er sprake van een schending van het recht op onderwijs. Niet-naleving van deze minimum elementen betekent immers dat de kern van het recht op onderwijs wordt aangetast. Een dergelijke inbreuk houdt in dat de formele aanvaarding van het recht op onderwijs door een staat zijn inhoudelijke betekenis verliest. Kortom, een schending van het recht op onderwijs impliceert dat het wezenlijke van dit recht wordt aangetast. ${ }^{32}$ Discriminatoire onderwijswetgeving die bijvoorbeeld beperkingen oplegt aan de toegankelijkheid van het onderwijs voor bepaalde groepen uit de bevolking kan zonder meer worden aangemerkt als een schending. Deze wetgeving dient onmiddellijk te worden afgeschaft indien een staat partij wordt bij het IVESCR ${ }^{33}$ Eenzelfde redenering geldt voor discriminerende praktijken, bijvoorbeeld bij de toelating van leerlingen tot een school of studenten tot hogere onderwijsinstellingen.

Een schending van het vrijheidsaspect van het recht op onderwijs is wellicht makkelijker vast te stellen, omdat dit een onthoudingsverplichting voor de staat impliceert. Alle handelingen van de staat die daar tegen in gaan zullen al snel een schending opleveren. Een schending van het sociale aspect van het recht op onderwijs zal daarentegen veel moeilijker te bepalen zijn, omdat naleving daarvan positieve verplichtingen van de staat inhoudt. Veelal heeft de staat een aanzienlijke beleidsvrijheid om aan die internationale verplichtingen in de nationale context te voldoen. Maar die beleidsvrijheid is niet onbeperkt. Ik onderschrijf in dit verband de opvatting van het $\mathrm{Co}_{0}$ mité inzake Economische, Sociale en Culturele Rechten dat een beroep van

31. Zie Ph. Alston, Out of the Abyss, a.w. pp. 952, 353.

32. Vergelijk artikel 4 IVESCR en Limburg Principles, a.w. nr. 66 .

33. Vergelijk artikel 2(2) IVESCR en Limburg Principles, a.w. nr. 35 en 37. 
een staat op een gebrek aan financiële middelen als rechtvaardiging voor het niet nakomen van zijn minimum kernverplichtingen moet voldoen aan de eis dat die staat duidelijk maakt dat alle beschikbare middelen zijn ingezet om, met prioriteit, die minimum verplichtingen na te leven. ${ }^{34}$

\subsubsection{Voorbeelden van schendingen van het recht op onderwijs}

In deze paragraaf zal ik ingaan op een aantal situaties die naar mijn opvatting een schending betekenen van het recht op onderwijs. De selectie van de voorbeelden is mede bepaald door de beschikbaarheid van informatie over de situatie van het onderwijs in de desbetreffende landen. Bij de bespreking daarvan maak ik een onderscheid tussen het vrijheidsaspect en het sociale aspect van het recht op onderwijs, en zal ik refereren aan de typologie van verplichtingen.

\section{Afghanistan}

Ten aanzien van het vrijheidsaspect zij hier verwezen naar de situatie van het onderwijs in Afghanistan ten tijde van de militaire aanwezigheid van de Sovjet Unie in dat land. Het onderwijsstelsel dat onder controle stond van de communistische partij, voor zover niet vernietigd door het oorlogsgeweld, kenmerkte zich door een dialectisch-materialistisch geïnspireerd curriculum. Het traditionele systeem, dat sterk was gebaseerd op de rol van de Islam in de maatschappij, onderging een sovjetisering. ${ }^{35}$ In deze context kon van een werkelijke keuzevrijheid voor ouders ten aanzien van het onderwijs voor hun kinderen geen sprake meer zijn. De communistische indoctrinatie ging zover dat Afghaanse kinderen voor een communistische opvoeding naar 'socialistische broederlanden' werden gezonden. Voor een deel gebeurde dat met instemming van de ouders, voornamelijk leden van de communistische partij. Voorts ging het om wezen wier ouders omgekomen waren in de oorlog. Er zijn evenwel ook gevallen bekend van kinderen die tegen de uitdrukkelijke wil van hun ouders op instellingen werden geplaatst die hen voorbereidden op een studieverblijf in een ander (communistisch) land. Ook kinderen van gevangen tegenstanders van het bewind ondergingen dit lot. De kinderen kregen een door de communistische partij georganiseerde opleiding die deels in het buitenland plaats vond. Deze praktijken waren vooral gericht op kinderen tussen de acht en tien jaar. De beoogde opleiding zou tien jaar moeten duren. Ongeveer 15.000 kinderen zouden een tijd in het buitenland hebben moeten doorbrengen. ${ }^{36}$

34. General Comment no. 3 (1990), a.w. par. 10.

35. Zie NRC-Handelsblad 2-7-1987 en 4-11-1988.

36. Informatie verzameld door F. Ermacora, de Bijzondere Rapporteur van de Commissie voor de Rechten van de Mens over de mensenrechtensituatie in Afghanistan, in: UN Doc. E/CN.4/1986/24, par. 64-66. Afghanistan is partij bij het IVESCR. 
Hier is sprake van een manifeste schending van de vrijheid van onderwijs, omdat de staat op ontoelaatbare wijze de keuzevrijheid van ouders te niet deed en de kinderen indoctrineerde en tot gehoorzamen dwong. Bovendien worden hier de verplichtingëh 'to respect' en 'to protect' niet nageleefd.

\section{Egypte, Tibet, Roemenië}

Voorbeelden van godsdienstige onverdraagzaamheid op het terrein van het onderwijs worden gemeld door de Bijzondere Rapporteur inzake godsdienstige onverdraagzaamheid. Hij noemde de situatie van de Koptische leerlingen in Egypte die discriminatie ondervonden in het onderwijs. Ook maakte hij melding van de situatie in Tibet waar de Chinese autoriteiten elke vorm van religieus onderricht verbieden. ${ }^{37}$

Leden van minderheden ondervinden vaak moeilijkheden om onderwijs in hun eigen taal te kunnen volgen. Een voorbeeld van deze problematiek betreft de situatie van de Hongaarse minderheid in Roemenië. In de jaren tachtig, onder het regime Ceausescu, werd het aantal klassen en onderwijsinstellingen waarin Hongaarstalig onderwijs werd gegeven stelselmatig verminderd. Het aantal Hongaars sprekende leerkrachten werd eveneens teruggebracht. ${ }^{38}$ Ook werd het leerlingen van Hongaarse afkomst verboden verder te studeren. ${ }^{39}$ Daarnaast werden groepen Hongaarstalige leerlingen uit Transsylvanië, waar de Hongaarse minderheid voornamelijk woont, overgeplaatst naar Roemeenstalige gebieden terwijl Roemeenstalige leerlingen gedwongen werden scholen in Transsylvaniè te bezoeken. ${ }^{40} \mathrm{Niet}$ alleen is hier sprake van een schending van de rechten van de leden van een linguistische minderheid om onderwijs in de eigen taal te volgen, op grond van artikel 27 IVBPR. Het gaat hier ook om een vorm van discriminatie op grond van taal en nationale afkomst die een schending van de vrijheid van onderwijs impliceert. Immers, de vrije keuze van de leden van de Hongaarse minderheid voor het bestaande Hongaarstalige onderwijs wordt onmogelijk gemaakt. Bovendien was hier duidelijk sprake van opzettelijk handelen van de Roemeense regering met de bedoeling de Hongaarse culturele identiteit te elimineren en assimilatie te bewerkstelligen. Al met al is hier sprake van schending van de drie verplichtingen uit de typologie.

\section{De bezette Arabische gebieden}

Een ander probleem betreffende het vrijheidsaspect van het recht op onderwijs handelt over de situatie van het onderwijs in de door Israël bezette

37. Rapport van A. Vidal d'Almeida Ribeiro, UN Doc. E/CN.4/1988/45, par. 51.

38. Zie het rapport van de Minority Rights Group, Romania's Ethnic Hungarians, April 1990, pp. 12-14 en p. 17.

39. NRC-Handelsblad 15-9-1988.

40. NRC-Handelsblad 19-11-1988, en Minority Rights Group Report, a.w. p. 17. 
gebieden, te weten Oost-Jeruzalem, de West-oever van de Jordaan, de Golanhoogten en de Gazastrook. Het betreft hier een bijzonder complexe materie, mede omdat de Israëlische bezettingsautoriteiten op verschillende manieren het onderwijs in de bezette gebieden beïnvloeden. De vraag rijst hoe de Israëlische maatregelen tegen onderwijsinstellingen, leerkrachten, leerlingen en studenten zich verhouden tot het toepasbare internationale recht. Eerst dient men zich af te vragen welke regels van internationaal recht in deze situatie van toepassing zijn. Primair zijn regels van internationaal humanitair recht relevant. Zowel Israël als Jordanië, Egypte en Syrië zijn partij bij de Geneefse Conventies van 1949. In het bijzonder betreft het hier de Vierde Geneefse Conventie aangaande de bescherming van burgers in oorlogstijd. Sectie III van deze Conventie handelt over de bezette gebieden. Artikel 50 bepaalt onder meer dat 'the Occupying Power shall, with the co-operation of the national and local authorities, facilitate the proper working of all institutions, devoted to the care and education of children'. Deze bepaling lijkt vooral betrekking te hebben op het lager en middelbaar onderwijs en niet zozeer op het hoger onderwijs. Opvallend is dat het Verdrag verder geen bepalingen bevat over organisatie en werking van het onderwijsstelsel. Naast het humanitaire recht zijn er ook internationale mensenrechtenverdragen die van toepassing (kunnen) zijn in de bezette gebieden. Ten aanzien van het recht op onderwijs zijn de volgende overeenkomsten relevant. Zowell Israël als Egypte en Jordanië zijn partij bij het UNESCO Verdrag tot Bestrijding van Discriminatie in het Onderwijs (1960). Syrië is geen partij bij dit Verdrag. Daarnaast zijn Jordanië, Egypte en Syrië partij bij het IVESCR. Israël heeft deze overeenkomst wel ondertekend, maar (nog) niet bekrachtigd. Bovendien zijn alle vier de staten gebonden aan het Internationaal Verdrag inzake de uitbanning van alle Vormen van Rassendiscriminatie. De opvatting van Israël over de toepasbaarheid van deze internationale normen is de volgende. ${ }^{41}$ Het UNESCO Verdrag is van toepassing in de bezette gebieden; daar worden geen voorwaarden aan verbonden. Ten aanzien van de andere hier genoemde internationale overeenkomsten inzake de rechten van de mens is de Israëlische regering van mening dat deze niet van toepassing zijn vanwege de uitzonderlijke politieke omstandigheden en de emotionele aspecten verbonden aan de problematiek. Er is dan ook sprake van een sui generis situatie in de opvatting van de Israëlische regering. Israël acht zich daarentegen wel feitelijk, maar niet juridisch gebonden aan de regels van humanitair recht zoals onder meer vastgelegd in de Vierde Geneefse Conventie 'which balance the needs of humanity with the requirements of international law to

41. Het Isrsellisch standpunt ten aanzien van de toepasbaarheid van het internationale recht inzake de rechten van de mens, gedateerd 12-9-1984, is als appendix opgenomen in een veralag van een onderzoeksmissie naar de bezette gebieden ondernomen door de World University Service en de Internationale Commissie wan Juristen.

Zie Academic Freedom under Israeli Military Occupation, Report of WUS/ICJ Mig sion of Enquiry into Higher Education in the West Bank and Gaza, by A. Roberts, B. Joergensen, F. Newman, London and Geneva 1984 . 
administer the area whilst maintaining public order, safety and security". ${ }^{2}$ In feite is hier sprake van een de facto toepassing van de regels van humanitair recht. $E r$ is in de redenering van de Israëlische regering sprake van een onderscheid tussen humanitair recht en het recht inzake de rechten van de mens. Dat laatste recht kan niet van toepassing zijn in situaties van gewapende conflicten tussen staten.

In de voorbije twee decennia heeft Israël verschillende malen, soms zeer ingrijpende, maatregelen genomen tegen onderwijsinstellingen, studenten en leerkrachten. In het bijzonder sedert het ontketenen van de Palestijnse opstand, de Intifadah, in december 1987 zijn de Israëlische maatregelen nogal drastisch geworden. Deze maatregelen betekenden een kwalitatieve achteruitgang van het onderwijs. Als voorbeelden kunnen genoemd worden het ingrijpen in lesmateriaal en onderwijsprogramma's, onvoldoende niveau en beschikbaarheid van onderwijsondersteunend materiaal en schoolgebouwen, de overvolle klassen, het gebrek aan onderwijsgevenden. ${ }^{43}$ Maatregelen die de vrijheid van onderwijs aantastten waren onder meer het willekeurige ontslag of deportatie van leerkrachten, arrestatie van studenten en onderwijsgevenden, het sluiten van scholen en universiteiten. ${ }^{44}$

Vaak draagt dit soort maatregelen slechts bij tot een escallatie van geweld en schieten zij hun beoogde doel voorbij te weten het handhaven van orde en rust. De Palestijnse universiteiten in de bezette gebieden werden bij het begin van de opstand gesloten en pas in juni 1990 werd de eerste faculteit heropend. ${ }^{45}$ De Israëlische autoriteiten voerden veiligheidsredenen aan als rechtvaardiging voor deze sluitingen. De universiteiten werden beschouwd als broeinesten van opstand en onrust. Een andere maatregel gericht tegen de Palestijnse universiteiten was de eis aan buitenlandse docenten een anti-PLO verklaring te tekenen voordat aanstelling plaats kon vinden. ${ }^{46}$

Naast concrete maatregelen die gericht waren op specifieke gevallen hebben de Israëlische autoriteiten in het verleden militaire orders uitgevaardigd die betrekking hebben op het reguliere functioneren van de uni-

42. Report of WUS/ICJ Mission of Enquiry, a.w. p. 81.

43. Zie UN Doc. A/41/680 (20-10-1986), Report of the Special Committee to investigate Iaraeli practices affecting the human rights of the population of the occupied territories, p. 51 .

44. Idem.

46. Zie NRC-Handelsblad 18-6-1990.

Een overzicht van korte, dan wel langdurige sluitingen van universiteiten tot de eerste helft van 1984 wordt gegeven in het Report of WUS/ICJ Mission of Enquiry, a.w. p. 67. Zie ook het rapport van Al Haq, Punishing a Nation; Human Rights violations during the Palestinian Uprising, december 1987 december 1988, Al Haq, december 1988, Ramallah, in het bijeonder hoofdstuk 8 . Ook scholen voor lager en mididelbaar onderwijs bleven het grootste deel van 1988 gesloten 'until further notice'. Zie het Al Haq rapport pp. 311-316.

46. Zie Report of WUS/ICJ Mission of Enquiry, a.w. pp. 62-64. 
versiteiten in de bezette gebieden. ${ }^{47}$ Op deze wijze worden de universiteiten sterk afhankelijk van de bezettingsautoriteiten en wordt hun functioneren tot een kwestie van handhaving van de openbare orde gemaakt. ${ }^{48}$

De vraag rijst of deze Israëlische maatregelen in overeenstemming zijn met het toepasbare internationale recht. Daarbij gaat het zowel om het internationale humanitaire recht als het internationale recht inzake de rechten van de mens. Op grond van artikel 64 van de Vierde Geneefse Conventie heeft de bezettende mogendheid de bevoegdheid die maatregelen te nemen ten opzichte van de bevolking die noodzakelijk zijn om het ordelijk bestuur van het gebied te handhaven en de veiligheid van de bezettende mogendheid te verzekeren. ${ }^{49}$ Hieruit kan men afleiden dat de bezettende mogendheid een zekere mate van supervisie over het onderwijs kan uitoefenen voor zover het gaat om kwesties die direct de militaire bezetting of vijandelijkheden raken. ${ }^{50}$ Von Glahn werkt deze algemene regel als volgt uit:

'There can be little doubt that the occupying power may prevent any and all teaching which serves to provoke hostility toward the occupant's forces, disrespect to the latter and to their commands, or passive resistance to the lawful order given to the civilian population. A second concept, sanctioned by some governments through official instructions, affirms that the occupant may suspend the discussion of political matters in the schools during the period of occupation ....,

Een dergelijke algemene regel is mijns inziens niet altijd toepasbaar. Steeds zal moeten worden gekeken naar de kenmerken en context van het specifieke geval om te kunnen bepalen of de bemoeienis van de bezettingsautoriteiten met het onderwijs niet de kern van het recht op onderwijs aantast. Daar kan, mij dunkt, sprake van zijn in geval van militaire interventie en sluiting van scholen of universiteiten, zeker indien deze langdurig van aard zijn. ${ }^{52}$ Ook bij arrestatie van studenten zal steeds in concrete gevallen het recht op onderwijs van de individuele student en de vrijheid van de leerkracht moeten worden afgewogen tegenover de veiligheidsredenen waarop de bezettingsautoriteiten zich beroepen. In het bijzonder de toegankelijkheid van het onderwijs

47. Militaire orders van 6 juli 1980. Zie Report of WUS/ICJ Mission of Enquiry, a.w. pp. 59-62.

48. Idem, p. 61.

49. Vgl. ook de artikelen 43 en 56 van de Hague Convention of 18 October 1907 and Annexed Regulations concerning the laws and customs of war on land.

50. Zie G. von Glahn, The Occupation of Enemy Territory, Minneapolis, Minnesota, 1957, pp. 62-67, aangehaald in Report of WUS/ICJ Mission of Enquiry, a.w. p. 28.

51. Von Glahn, a.w. p. 63, geciteerd bij E.R. Cohen, Human rights in the Israell-occupied territories 1967-1982, Manchester 1985, p. 223. Cohen onderschrijft de opvatting van Von Glahn, zie pp. 286, 287.

52. Zie ook Report of WUS/ICJ Mission of Enquiry, a.w. pp. 66, 57, en Al Haq rapport, Punishing a Nation, a.w. p. 304. 
op een non-discriminatoire grondslag dient niet lichtvaardig prijs gegeven te worden. Een complete reorganisatie van het onderwijs door de bezettende mogendheid die uitgaat boven haar strikte veiligheidsbelangen lijkt in ieder geval in strijd met het humanitaire recht. ${ }^{63}$ De vraag in hoeverre de bezettingsautoriteiten gerechtigd zijn om in te grijpen in de inhoud van het onderwijs is eveneens afhankelijk van de specifieke situatie. Dinstein suggereert dat de bezettende mogendheid schoolboeken mag onderzoeken en zonodig veranderen, opdat zij geen vijandige propaganda bevatten. ${ }^{54}$

De Israëlische maatregelen tegen Palestijnse onderwijsinstellingen, leerkrachten, scholieren en studenten werden in internationaal verband sterk veroordeeld. De Algemene Vergadering van de VN achtte bijvoorbeeld het sluiten van scholen en universiteiten en het Israëlisch toezicht op de toelating van studenten en op de benoeming van universitaire medewerkers in strijd met de Vierde Geneefse Conventie. ${ }^{55}$ Ook de Europese Gemeenschap was van oordeel dat het gesloten houden van scholen op de West-oever van de Jordaan in strijd is met het recht op onderwijs. ${ }^{56}$

Ten aanzien van de toepassing van het internationale recht inzake de rechten van de mens biedt de UNESCO Conventie tot bestrijding van discriminatie in het onderwijs de beste aanknopingspunten. Een sterke reden voor toepassing van deze Conventie is immers het feit dat Israël daarbij partij is, evenals Jordanië en Egypte. Israël zelf acht deze Conventie van toepassing. ${ }^{57}$ Naar het mij voorkomt zijn de Israëlische maatregelen tegen Palestijnse onderwijsinstellingen, scholieren, studenten en leerkrachten in strijd met artikel 1 UNESCO Conventie. Er is immers sprake van een ongelijke behandeling die zich manifesteert in uitsluiting en beperking op grond van politieke of andere overtuiging alsmede op grond van nationale afkomst die tot doel en tot gevolg heeft dat de gelijkheid van behandeling van Palestijnen in het onderwijs teniet wordt gedaan of wordt aangetast. Met name wordt het individuele personen en groepen onmogelijk gemaakt om onderwijs te volgen. Bovendien moeten de Palestijnse scholieren, studenten en docenten genoegen nemen met onderwijs van een 'inferior standard'. 58

53. Cohem, a.w. p. 223 geeft en roorbeeld.

54. Zie Y. Dinstein, Cultural Rights, in: Iarael Yearbook on Human Rights, vol. 9 (1979), Pp. 58-81, op p. 81.

56. Zie AV. Res. 43/58G van dec. 1988, aangenomen met 147 stemmen vobr, twee tegen (V.S. en Iraal) bij drie onthoudingen (Zaire, Chilí, Liberia).

66. Zie UN Doc. A./44/299 van 1 juni 1989 .

57. Zie Report of WUS/ICJ Mission of Enquiry, a.w. p.81.

58. Artikel 1 lid 1 aub b UNESCO Conventie. Zie ook Report WUS/ICJ Mision of Enquiry, a.w. pp. $70,73,76$.

Cohen, a.w. pp. 220 en 224 , is een andere mening toegedaan. Zij benadrukt de inapanningen van de Israëliers om het onderwijs in de begette gebieden te ontwikkelen en te bevorderen. $Z i j$ concludeert dat dese inspanningen beantwoorden aan de normen vastigelegd in artikel 13(2) IVESCR. 
De Israëlische maatregelen betekenen een inbreuk op de minimum kerninhoud van het recht op onderwijs, te weten de toegankelijkheid van het bestaande onderwijs, alsmede op de vrijheid om onderwijs te geven. Ook is het mijns inziens duidelijk dat hier geen sprake is van overmacht, maar dat daarentegen de Israëlische autoriteiten opzettelijk handelen kan worden toegeschreven. Daarnaast kan men zich afvragen of de Israëlische maatregelen nog in overeenstemming zijn met de doeleinden van het onderwijs. Deze beogen de volledige ontplooiing van de mens, het besef van zijn waardigheid en eerbied voor de rechten van de mens. Het onderwijs dient ook het begrip, de verdraagzaamheid en de vriendschap tussen volkeren te bevorderen. ${ }^{59}$ De besproken maatregelen lijken eerder afbreuk te doen aan deze doeleinden. Afsluitend kan worden gezegd dat Israël ten aanzien van de genomen maatregelen tegen het onderwijs in de bezette gebieden zijn verplichtingen aangaande het recht op onderwijs als mensenrecht schendt. De genomen maatregelen richten zich tegen het functioneren van het onderwijs als zodanig, en kunnen niet in alle gevallen worden gerechtvaardigd door een beroep op veiligheidsbelangen.

\section{Zuid-Afrika}

De situatie van het onderwijs in Zuid-Afrika wordt gekenmerkt door een structuur die op fundamentele punten in strijd is met het recht op onderwijs zoals dat onder meer in de Universele Verklaring is vastgelegd. Alle onderwijsniveau's in Zuid-Afrika zijn georganiseerd volgens een strikte segregatie van bevolkingsgroepen. Zwarten, kleurlingen, Indiërs en blanken hebben elk hun eigen onderwijsinstellingen. Een blanke school is bijvoorbeeld niet toegankelijk voor zwarten, de omgekeerde situatie is eveneens het geval. Dat betekent dat zwarten worden gediscrimineerd, omdat het onderwijs voor blanken in alle opzichten, zowel wat betreft de beschikbaarheid, de toegankelijkheid en de kwaliteit van het onderwijs, op een aanzienlijk hoger niveau staat. ${ }^{60}$ De discriminatie van zwarten in het onderwijs, zowel in kwantitatief als in kwalitatief opzicht, is vastgelegd in wetgeving en praktijk. Deze gescheiden systemen voor de ontwikkeling van de jeugd van de verschillende bevolkingsgroepen is de hoeksteen van het apartheidsbewind. Door apart onderwijs voor blanken in stand te houden, dat ook nog kwalitatief beter is, kan de blanke bevolkingsgroep haar heersende positie in de Zuidafrikaanse maatschappij handhaven en versterken. Het beleid dat de regering voert stoelt op deze vorm van discriminatie. Zo geeft de Zuidafrikaanse regering vijf maal zoveel uit aan elke blanke leerling in vergelijking met een zwarte leerling. ${ }^{61}$

69. Vgl. artikel 26(2) Uniwersele Verklaring, artikel 13(1) IVESCR en artikell 5 lid $\mathbb{1}$ sub a UNESCO Conventie.

60. Zie het Report of the Ad Hoc Working Group of Experts, Violations of human rights in South Africa, UN Doc. E/CN.4/1989/8, par. 399-413.

61. Zie Interim Report of the Ad Hoc Working Group of Experts on Southern Africa, UN Doc. E/CN.4/1990/7, par. 143. 
Voor blanke leerlingen is het onderwijs tot de leeftijd van 16 jaar kosteloos, terwijl zwarte leerlingen allerlei kosten zelf moeten financieren. ${ }^{62}$ Terwijl het lager onderwijs voor blanken algemeen verplicht is gesteld, is dit voor zwarten nog steeds niet het geval. Men kan zich in dit verband afvragen of verplicht onderwijs voor de zwarte bevolking wel zoveel zin heeft zolang de kwaliteit ervan slecht is. Er zijn dan ook veel ouders en leerkrachten die verplicht onderwijs volgens het huidige stelsel afwijzen ${ }^{63}$. Bovendien kan men de vraag stellen of zwarten überhaupt moeten deelnemen aan een onderwijssysteem dat gebaseerd is op discriminatie van bevolkingsgroepen en de ongelijkheid tussen hen in stand houdt. Het is dan ook duidelijk dat het onderwijsstelsel onder het systeem van apartheid op geen enkele wijze bijdraagt aan de doeleinden van het onderwijs zoals geformuleerd in artikell 26 lid 2 van de Universele Verklaring. Sterker, het apartheidsonderwijs doet deze doeleinden teniet. Bevordering van verdraagzaamheid en ontplooiling van de mens zijn termen die niet voorkomen in het woordenboek van de apartheid. ${ }^{.4}$ Ook ten aanzien van de kwaliteit van het onderwijs is er sprake van grote verschillen tussen blanke en zwarte voorzieningen. Er is een tekort aan schoolgebouwen voor zwarten, de bestaande klassen zijn overvol en veel leerlingen moeten geweigerd worden. Er is te weinig lesmateriaal en ook het aantal leerkrachten is bij lange na niet toereikend. Ook laat de kwaliteit van de schoolgebouwen veel te wensen over, met name ten aanzien van de electriciteitsvoorziening en de sanitaire voorzieningen. De situatie in de zogenaamde thuislanden is er nog slechter aan toe. Daar staat tegenover dat de onderwijsvoorzieningen die voor blanken beschikbaar zijn niet altijd optimaal benut worden. ${ }^{65}$

Op grond van de van kracht zijnde noodtoestand werden in 1988 vergaande maatregelen afgekondigd die het onderwijs troffen. $\mathrm{Zij}$ betekenden dat de autoriteiten een volledige greep kregen op het onderwijs, de scholen, scholieren, studenten en leerkrachten. In het bijzonder impliceerden deze maatregelen dat de veiligheidstroepen een aanzienlijke bemoeienis met het onderwijs kregen. Studentenprotesten richtten zich vooral tegen de aanwezigheid van veiligheidstroepen in schoolgebouwen en het feit dat ettelijke honderden studenten de toegang tot zwarte scholen was geweigerd na hun

62. Zie M. Smit, Zwart-wit onderwijs in Zuid-Afrika, uitgave Anti-Apartheidsbeweging Nederland, Amsterdam z.j. , pp. $32_{0,3} 3$, en UN Doc. E/CN.4/1989/8, par. 402.

69. Smit, a.w. p. 26.

64. Zie M. Raoul, Un systeme d'éducation visant a maintenìr le 'status quo", in: M. Raoul, Déclaration universelle des droits de l'homme te réalités sud-africaines, UNESCO, Paris 1983 , pp. 77-86, op p. 85.

65. Zie NRC-Handelsblad 20-2-1990, D.J. Eppink, Onderwijs in Zuid-Afrika is 'educathion for liberation'.

Zie ook UN Doc. E/CN.4/1990/7, par. 143, alsmede Violations of human rights in South Africa: Report of the Ad Hoc Working Group of Experts, UN Doc. E/CN.4/ 1989/8, par. 410 . 
vrijlating uit gevangenschap ${ }^{66}$. Evaluerend kan worden gezegd dat het Zuidaf rikaanse onderwijssysteem op verschillende punten in strijd is met de onderwijsbepaling uit de Universele Verklaring. Het is mijns inziens evident dat de Zuidafrikaanse regering de minimum kerninhoud van het recht op onderwijs schendt. Immers, het beginsel van non-discriminatie staat haaks op de apartheidspolitiek. Het is de tegenpool van dit beginsel die aan de basis ligt van de organisatie van de Zuidafrikaanse matschappij. Deze discriminatie in wetgeving en praktijk komt ook tot uiting in het onderwijs. De toegankelijkheid en de beschikbaarheid van het onderwijs worden op een apert discriminerende wijze aangetast. Ook de vrije keuze van onderwijs is onder het systeem van gedwongen segregatie een lege huls. De Zuidafrikaanse wetgeving en beleid voldoen dan ook niet aan de normen van de typologie van verplichtingen ten aanzien van het recht op onderwijs. Het feit dat Zuid-Afrika bij vrijwel geen enkel mensenrechtenverdrag partij is, betekent niet dat deze staat niet gebonden zou zijn aan de algemene beginselen die de Universele Verklaring vastlegt. Bovendien beschouwt het volkenrecht massale schending van het beginsel van rasgelijkheid, zoals die zich in het apartheidssysteem manifesteert, als een "crime against humanity'. ${ }^{67}$ Indien het apartheidssysteem kan worden aangeduid als een 'crime against humanity' heeft het beginsel van rasgelijkheid het karakter van een norm van jus cogens. ${ }^{68}$

De hierboven besproken voorbeelden tonen onder meer aan dat een schending van het recht op onderwijs valt te constateren wanneer een staat maatregelen neemt tegen onderwijsinstellingen, leerkrachten, leerlingen en studenten die het onderwijs gebruiken om bepaalde, veelal politieke, doeleinden te verwezenlijken. Groepen scholieren en studenten gebruiken het onderwijssysteem en de instellingen daarbinnen om het bestaande politieke dan wel militaire gezag te ondermijnen. Dat is bijvoorbeeld het geval in Zuid-Afrika en de door Israël bezette gebieden. Het streven naar (politieke) emancipatie vindt een goede voedingsbodem in scholen en universitei-

66. UN Doc. E/CN.4/1989/8, par. 415 .

Zie over de maatregelen tegen onderwijsinstellingen, scholieren, studenten en leerkrachten in thet kader van de noodtoestand, par. 423-437. Inmiddele lijkt or enige beweging in het Zuidafrikaanee onderwijsbestel te komen. Sedert 1 januari 1991 hebben blanke scholen de keuze ook leerlingen met een andere huidskleur toe te laten. Ongeveer 200 van de 2000 blanke scholen hebben besloten zwarte leerlingen toe te laten (zie NRC Handelsblad 11-1-1991). Bovendien kan de afschaffing begin 1991 van de groepsgebiedenwet, die de verschillende raciale groepen scheidde met betrekking tot hun woonplaats, ertoe leiden dat de rassenscheiding op scholen ondergraven wordt. De zwarten zijn nu immers niet meer verplicht te wonen in de veelal verpauperde woongebieden als de 'townships" en de thuislanden. In beginsel kunnen wij zich nu ook vestigen in gebieden met blanke acholen.

67. Vgl. artikel I International Convention on the Suppresion and Punilhment of the Crime of Apartheid. Zile ook artikel II sub c, dat een verwijging naar het recht op onderwijs bevat: Tekat in: ILM 1974, p. 50 e.v.

68. B.V.A. Roling, Volkenrecht en Vrede, Deventer 1985, p. 82. Vgl. ook de uitspraak van het Internationaal Gerechtshof in de Barcelona Traction Company Case, in: ICJ Reports (1970) 3, op p. 32. 
ten. Kortom, het onderwijssysteem kan een belangrijke rol spelen in het verzet van bepaalde groepen tegen de bestaande politieke en maatschappelijke verhoudingen. Daarnaast zullen repressieve staten sneller geneigd zijn het recht op onderwijs verregaand te beperken indien bepaalde groepen uit de bevolking, bijvoorbeeld een minderheid, proberen door middel van het onderwijs hun eigen identiteit (bijvoorbeeld een etnische of een linguïstische) te profileren. Vaak biedt het onderwijs goede mogelijkheden de negatieve effecten van een assimilatie-beleid zoveel mogelijk tegen te gaan. Staten zullen dan juist proberen het functioneren van die onderwijsinstellingen te frustreren zodat de eigen identiteit van die instellingen verloren gaat. Dat was het geval met de Hongaarse minderheid in Roemenië. Men kan tenslotte ook spreken van een schending van het recht op onderwijs indien een staat het onderwijs in een bepaalde politiek-ideologische richting organiseert en kennis op een indoctrinerende wijze aan leerlingen presenteert.

\subsection{Een Nederlands voorbeeld: De Les- en Cursusgeldwet en het recht op onderwijs ${ }^{69}$}

In hoofdstuk 2, paragraaf $6 \mathrm{kwam}$ de vraag aan de orde hoe een verminderde bescherming van sociale rechten, als gevolg van de afname van beschikbare (financiële) middelen, zich verhoudt tot het beginsel van geleidelijke verwezenlijking vervat in artikel 2 lid 1 IVESCR. In de hierna volgende paragraaf wil ik, bij wijze van illustratie, deze vraag bearitwoorden ten aanzien van de verenigbaarheid van de Nederlandse Les- en Cursusgeldwet met artikel 13 IVESCR. Dit is een mooi voorbeeld, mede omdat er een recente rechterlijke uitspraak bestaat over deze kwestie.

\subsubsection{Inleiding}

In juli 1987 trad in Nederland de Les- en Cursusgeldwet in werking. ${ }^{70}$ Op grond van deze wet zijn ouders of voogden verplicht lesgeld of cursusgeld te betalen voor hun 16- en 17-jarige kinderen die enigerlei vorm van voortgezet of beroepsonderwijs volgen. Betaling van les- en cursusgeld dient als een soort toegangsbewijs voor het volgen van onderwijs gedurende éen schooljaar. Tegelijk met het in werking treden van de Les- en Cursusgeldwet werd de School- en Cursusgeldwet 1972 ingetrokken. Er zij aan herinnerd dat Nederland sedert 11 december 1978 partij is bij het IVESCR.

69. Deze paragraaf is gebaseerd op een bijdrage van J.F.R. Jangen en mijzelf in het NJCM-Bulletin 16-3 (1991), pp. 187-197, met als titel Recht op kosteloos onderwijs?

70. Stb. 1987, 343. Wet van 7 juli 1987 tot uitbreiding van de lesgeldregeling tot de groep 16- en 17-jarigen, vervanging van en intrekking van de Lesgeldwet voor boven 17-jarigen alsmede intrekking van de School- en Cureusgeldwet 1972. 
De Les- en Cursusgeldwet betekent voor veel inkomensgroepen een duidelijke verhoging van, wat genoemd kan worden, de 'onderwijsbijdrage'. Ter illustratie moge het volgende rekenkundige voorbeeld dienen. Onder de oude regeling diende een betalingsplichtige met een inkomen tussen 47.000 en 47.999 gulden voor twee kinderen in de leeftijdsgroep die vatbaar is voor belasting conform de school- en cursusgeldwet, een onderwijsbijdrage te voldoen van $2 \times f 539,-=f 1078,-$ per schooljaar. Onder de nieuwe regeling moet de hierboven genoemde betalingsplichtige, met een vergelijkbaar inkomen van $f 47.310$ en twee kinderen in de betreffende leef tijdsgroep, een bedrag betalen van maar liefst 2 x $f 1133,-=f 2266$,per schooljaar. ${ }^{71}$

De vraag doet zich hier voor hoe de verplichting tot betaling van lesgeld op grond van de Les- en Cursusgeldwet zich verhoudt tot artikel 13 IVESCR waarin het recht op onderwijs van een ieder is vastgelegd. In het bijzonder rijst de vraag of sociale grondrechten, in casu artikel 13 lid 2 sub b IVESCR althans onderdelen daarvan, rechtstreekse werking toekomt. Artikel 13 lid 2 sub b bepaalt. 'De Staten die partij zijn bij dit Verdrag erkennen dat, ten einde tot een volledige verwezenlijking van dit recht te komen: b. Het secundaire onderwijs, in zijn verschillende vormen, waarbij inbegrepen het secundaire technische onderwijs en het beroepsonderwijs, door middel van alle passende maatregelen en in het bijzonder door de geleidelijke invoering van kosteloos onderwijs algemeen beschikbaar en voor allen toegankelijk dient te worden gemaakt'. Artikel 93 van de $\mathrm{Ne}$ derlandse Grondwet bepaalt dat bepalingen van verdragen en van besluiten van volkenrechtelijke organisaties, die naar haar inhoud een ieder kunnen verbinden, verbindende kracht hebben nadat zij zijn bekendgemaakt. Dat betekent dat een justitiabele zich voor een Nederlandse rechterlijke instantie rechtstreeks kan beroepen op zo'n bepaling. Is er sprake van een rechtstreeks werkende bepaling, dan zal de litigieuze wetgeving aan de internationale norm getoetst kunnen worden. Indien aldus wordt vastgesteld dat een binnen het Koninkrijk geldende wettelijke bepaling niet verenigbaar is met een een ieder verbindende bepaling van een verdrag of van een besluit van een volkenrechtelijke organisatie, dan zal het nationaal wettelijke voorschrift buiten toepassing worden gelaten. ${ }^{72}$ Ten aanzien van sociale grondrechten, in casu bepalingen uit het IVESCR, kan men niet generaliserend stellen dat aan dergelijke bepalingen per definitie geen rechtstreekse werking toekomt. De jurisprudentie op dit punt neigt naar een dergelijke negatieve opvatting, maar men zal steeds per artikel, per lid, of afzonderlijk onderdeel dan wel zinsnede, moeten bezien welke werking het toe-

71. Deze berekeningen zijn gebaseerd op de bedragen zosle genoemd in de laatste versie wan de School- en curausgeldwet 1972 en de bedragen die worden vermeld in de brochure "Tegemoetkoming studiekosten: ook voor U: definitieve normen 1990/1991" een publikatie van de Informatiseringsbank, juli 1990. De Minister van Onderwijs was van plan het les-en cursusgeld in 1992 verder te verhogen, ele NRC Handelsblad van 4 en 13 dec. 1990, maar daar bleek geen meerderheid voor te bestian in het parlement, zie NRC Handelsblad wan 11 nov. 1991.

72. Artikel 94 Grondwet. 
komt. Uit de jurisprudentie is slechts een enkel geval bekend waarbij aan sociale rechten rechtstreekse werking werd toegekend. ${ }^{73}$

In deze paragraaf zal een aantal kwesties aan de orde worden gesteld. In de eerste plaats wordt artikel 13 lid 2 sub b IVESCR getoetst aan algemene criteria voor directe werking zoals die in literatuur en jurisprudentie gedefinieerd zijn. In de tweede plaats wordt, mede aan de hand van doel en strekking van het IVESCR, ingegaan op de betekenis van deze onderwijsbepaling. Tot slot bespreek ik een uitspraak van de Haagse rechtbank. In deze zaak stelde eiser dat de verplichting tot betaling van lesgeld voor zijn 16 -jarige zoon in strijd is met artikel 13 lid 2 sub b IVESCR. ${ }^{74}$

\subsubsection{Toetsingseriteria}

In de literatuur bestaat eenstemmigheid over de criteria waaraan een internationale bepaling moet voldoen wil er sprake zijn van een direct werkende bepaling. Vereist is dat inhoud, aard, strekking en bewoordingen van een bepaling zodanig zijn dat zij zich voor rechtstreekse werking leent. ${ }^{75}$ Daarbij kunnen vragen worden gesteld als:

- Leggen zij de staat een duidelijke verplichting op?

- Is naleving mogelijk zonder dat nadere rechtshandelingen van de staat nodig zijn?

- Laten zij de staat beleidsvrijheid bij de uitvoering van de internationale verplichting?

Ten aanzien van deze criteria is nog een verfijning mogelijk: Niet alleen dient men af te vragen of inhoud, aard, strekking en bewoordingen van de internationale norm zich leent voor rechtstreekse werking, ook moet men zich de vraag stellen of de rechtstoestand die aan de internationale norm getoetst wordt, zich voor rechtstreekse werking leent. Men kan dus nooit van een internationale norm generaliserend stellen dat zij wel of niet rechtstreeks werkt: "... de casus waarop en de context waarin toepassing van die verdragsbepaling wordt gevraagd [moet] voldoende gestructureerd en geconcretiseerd [zijn], ${ }^{76}$

73. Zie HR 30 mei 1986, NJ 1986, nr. 688 ten anzien van artikell 6 lid Europees Sociaal Handvest (atakingsrecht).

74. Vonnis van 14 november 1990 van de Rechtbank te 's-Gravenhage in de gevoegde zaken rolnummers $89 / 7932$ en $90 / 6595$ van Flinterman tegen de Staat der Nederlandem. De uitsprank is nitet gepubliceerd.

75. Zile bijvoorbeeld A.T.J.M. Jacobs, De rechtstreekse werking van internationale normen in het sociaal recht, Preadvies voor de Vereniging voor Arbeidsrecht. Alphen a/d Rijn 1985, pp. 12-14 en de daar aangehaalde literatuur.

76. CRrB 16 februari 1989 , AB 1989, nr. 164 . 
Aangaande de mogelijke directe werking van artikel 13 lid 2 sub b IVESCR verdienen de volgende vragen de aandacht

\section{a. Legt zij de staat een duidelijke verplichting op?}

De duidelijke verplichting die aan de staat wordt opgelegd zit, in tegenstelling tot datgene wat in het algemeen wordt aangenomen, wel degelijk besloten in artikel 13 lid 2 sub $b$. Door de formulering dat het secundair onderwijs algemeen beschikbaar en voor allen toegankelijk dient te worden gemaakt, door middel van alle passende maatregelen en in het bijzonder door de geleidelijke invoering van kosteloos onderwijs, hebben de verdragssluitende partijen de duidelijke verplichting aanvaard in ieder geval geen verhoging van de kosten voor het secundair onderwijs in te voeren.

In de woorden van Cohen:

'Aantasting van de verworven kosteloosheid is rechtstreeks in strijd met het in de verdragstekst als enige en met name genoemde middel om het onderwijs op dit niveau voor ieder toegankelijk te maken. Gebruik van het woord "geleidelijk" (de Engelse tekst spreekt van "the progressive introduction of free education') maakt het vervolgens bij uitstek moeilijk om juist regressief te handelen.77

b. Is naleving mogelijk zonder dat nadere rechtshandelingen van de staat nodig zijn?

Naleving is zeker mogelijk zonder dat nadere rechtshandelingen van de staat nodig zijn: De staat dient zich volledig te onthouden in die zin dat geen nieuwe, voor de burger onderwijskostenverhogende regelgeving, tot stand wordt gebracht. In dit verband bestaat er bijvoorbeeld een zekere analogie met artikel 12 EEG Verdrag. Volgens deze bepaling moeten de staten zich onthouden van de invoering van nieuwe douanetarieven en van de verhoging van de bestaande tarieven. Zowel artikel 13 lid 2 sub b IVESCR als artikel 12 EEG Verdrag omvat een naww omschreven verplichting gericht tot de staten. Van artikel 12 EEG Verdrag heeft het Hof van Justitie van de EG bepaald dat ook burgers zich er op kunnen beroepen. ${ }^{78}$ Dat geldt ook voor artikel 13 lid 2 sub b IVESCR.

c. Laten zij de staat beleidsvrijheid bij de uitvoering van de internationale verplichting?

Beleidsvrijheid bestaat ten aanzien van het algemeen beschikbaar en voor allen toegankelijk maken van het onderwijs. Hiervoor kunnen verschillende middlelen worden gebruikt ('... by every appropriate means ...').

77. M.J. Cohen, Besuinigingen en het recht op onderwijs, in: NJCM-Bulletin, 1983, pp. 379-388, op pp. 385, 386. Zie ook G.P. Kleijn en M. Kroes, Mensenrechten in de Nederlandse Rechtapraktijk, Zwolle 1986, p. 131.

78. Van Gend en Loos $v$. de Nederlandse Administratie der Belastingen, arrest van 5 februari 1963. 
Geen beleidsvrijheid bestaat op het punt van eventuele verhoging van de onderwijskosten. De tekst van het Verdrag is hier duidelijk over. Voorts kan worden gesteld dat beleidsvrijheid bestaat ten aanzien van het tempo waarin het onderwijs kosteloos wordt gemaakt. Dit betekent dat het de staat in beginsel vrij staat het voorzieningenniveau, dat bestaat op het moment dat het Verdrag voor die staat in werking treedt, gedurende de tijd die vanuit beleidsoogpunt noodzakelijk wordt geacht, te handhaven. Regressief handelen moet uitgesloten worden geacht, tenzij zulks onder het regime van artikel 4 IVESCR kan worden gebracht. Het is merkwaardig dat de Nederlandse regering nog nooit een reële poging heeft gedaan de onderwijskostenverhogende maatregelen te rechtvaardigen volgens de criteria van artikel 4. Hieruit mag men afleiden dat een beroep op artikel 4 niet haalbaar wordt geacht. Indien sprake is van, wat o.a. Heringa een 'minimumvoorschrift' noemt, kan geen sprake zijn van beleidsvrijheid:

'Artikel 13 lid 2 IVESCR geeft zo'n minimumnorm. Het verplicht de staten onder andere zorg te dragen voor kosteloosheid van het primaire onderwijs. Daarenboven moet het secundair en hoger onderwijs geleidelijk kosteloos gemaakt worden. In dit laatste streven kan een verbod besloten worden geacht om in plaats van het onderwijs geleidelijk kosteloos te maken, de kosten voor het onderwijs voor de individuele burger juist te verhogen. ${ }^{79}$

Met de wijziging van een voorganger van de Les- en Cursusgeldwet, namelijk de School- en Cursusgeldwet 1972, werd beoogd de schoolgeldheffing uit te breiden tot de niet meer leerplichtige leerlingen in het voortgezet onderwijs. De regering was van mening dat de uitbreiding van de schoolgeldheffing niet opgevat kon worden als een beperking van de rechten uit het IVESCR. De regering voegde daaraan toe dat 'zelfs al zou wel sprake zijn van een beperking van rechten, dan nog geldt, dat er geen strijd is met artikel 13, tweede lid, letter $b$, van het Verdrag. Beperking van de rechten uit het Verdrag is immers geoorloofd te achten bij een aantoonbare teruggang van de economische omstandigheden, een situatie die zich, (...), thans voordoet in ons land'. ${ }^{80}$ Deze motivering is, naar het mij voorkomt, weinig overtuigend. Het IVESCR bepaalt nergens dat beperking van rechten geoorloofd is bij een verslechterde economische situatie. Het Verdrag heeft immers als ratio dat de mate van verwezenlijking van sociale rechten moet groeien, zowel in goede als in slechte tijden. De regering was wel van mening dat de formulering van artikel 13 lid 2 sub a ('het primaire onderwijs dient voor allen verplicht en kosteloos beschikbaar te zijn') zich verzet tegen een schoolgeldheffing voor leerlingen van de leerplichtige leeftijd. Dat is in de opvatting van de regering de grens die niet overschreden mag worden. ${ }^{81}$

79. A.W. Heringa, Sociale Grondrechten (hun plaats in de gereedschapakist van de rechter), diss. 's-Gravenhage 1989, p. 91.

80. TK vitting $1982-1983,17942$, nr. 3 (MvT), p. 4.

81. Zie TK zitting $1982-1983,17942$, nr. 5 , p. 8. 
d. Leent de concrete situatie die aan de internationale norm getoetst wordt, zich voor directe toepassing?

Volgens artikel 3 lid 2 van de Les- en Cursusgeldwet is lesgeld verschuldigd door de leerling dan wel, indien deze de leeftijd van 18 jaar nog niet heeft bereikt en minderjarig is, door zijn wettelijke vertegenwoordiger. De lesgeldaanslag impliceert een verplichting tot betalen. Nadat het lesgeld is betaald wordt de leerling ingeschreven voor het cursusjaar. ${ }^{82}$ Het niet betalen van het lesgeld betekent dat de leerling geen onderwijs kan volgen. Een en ander houdt in dat er sprake is van een concreet, geindividualiseerd geval dat zich voor directe toepassing van de internationale norm leent.

$\mathrm{Na}$ de hierboven uitgewerkte toetsing kan de conclusie niet anders luiden dan dat aan het relevante deel van artikel 13 lid 2 sub b IVESCR, rechtstreekse werking moet worden toegekend nu duidelijk is geworden dat aan de voorwaarden die hieraan worden verbonden, is voldaan.

\subsubsection{Materiēle interpretatie van artikel 13 IVESCR}

Artikel 13 erkent het recht van een ieder op onderwijs. Om tot een volledige verwezenlijking van dit recht te komen dient het secundair onderwijs, in het bijzonder door de geleidelijke invoering van kosteloos onderwijs, algemeen beschikbaar en voor allen toegankelijk te worden gemaakt. Met andere woorden, de geieidelijke invoering van kosteloos onderwijs is een essentieel middel om tot een volledige verwezenlijking van dit recht te komen. Het is in feite een onmisbaar element. Men zou kunnen stellen dat zonder de invoering van kosteloos onderwijs het volledige genot van het recht op onderwijs niet mogellijk is. De aard van de verplichting voor de staat voortvloeiend uit artikel 13 is gebiedend. Dit blijkt uit het gebruik van het mandatoire 'shall' in plaats van het meer vrijblijvende 'should'. Ook uit de ontstaansgeschiedenis van artikel 13, zoals besproken in hoofdstuk 3 paragraaf 6.4 , bleek dat de term 'shall' een sterkere juridische binding heeft dan 'should'. De verplichting voor de staat wordt in artikel 13 nog eens versterkt doordat de invoering van kosteloos onderwijs expliciet geboden is. Daarnaast hebben staten de vrije keuze om ook andere middelen te gebruiken ten einde het voortgezet onderwijs algemeen beschikbaar en algemeen toegankelijk te maken. Uit de ontstaansgeschiedenis van artikel 13 bleek ook dat Nederland zich verzette tegen de uitdrukkelijke verwijzing naar de geleidelijke invoering van kosteloos onderwijs in de tekst. Toch werd die formulering in de definitieve tekst, mede naar aanleiding van een Belgisch voorstel, opgenomen.

Een staat heeft een zekere beleidsvrijheid om het voortgezette onderwijs algemeen beschikbaar en toegankelijk te maken. Indien evenwel een beleid gevoerd wordt dat haaks staat op het algemeen beschikbaar en toegankelijk

82. Artikel 5 lid 1 Les- en Cursusgeldwet. 
maken van het voortgezette onderwijs, is er geen sprake meer van een geleidelijke positieve implementatie, maar eerder van een negatieve, dat wil zeggen, een stap terug. De invoering van kosteloos onderwijs heeft nu juist primair als doel het onderwijs voor allen toegankelijk te maken en is daartoe een bij uitstek geschikt middel ${ }^{83}$ Op grond van artikel 2 lid 1 IVESCR heeft een staat de plicht om: 'Met volledige gebruikmaking van de hem ter beschikking staande hulpbronnen, ten einde met alle passende middelen, steeds nader tot een algehele verwezenlijking van de in dit Verdrag erkende rechten te komen' (cursivering door A.C.). De Engelse tekst luidt: 'with a view to achieving progressively the full realization of the rights ... ${ }^{84} \mathrm{De}$ strekking van het Verdrag is de hierboven gecursiveerde passage. Het IVESCR werd opgesteld in de jaren vijftig en begin jaren zestig toen er in de wereld optimisme heerste over de groei van de economie. Er zouden altijd wel voldoende financiële middelen beschikbaar zijn om de materiële rechten te verwezenlijken. Met de af name van de economische groei, een recessie en een vermindering van de beschikbare middelen is toen niet of nauwelijks rekening gehouden. Bij de goedkeuringsbehandeling van dit Verdrag merkte de regering op dat artikel 2 lid 1 'toch ook als richtsnoer in tijden van gelijkblijvende of dalende welvaart' geldt. ${ }^{85}$ Op grond van artikel 2 lid 1 heeft de staat de voortdurende verplichting te werken aan de volledige verwezenlijking van de materiële rechten uit het Verdrag. In het te voeren beleid dient de realisering van deze rechten voorop te staan, zeker nu er in $\mathrm{Ne}-$ derland weer sprake is van een flinke reële economische groei. ${ }^{86}$

Van belang in dit verband is nog het volgende punt. Nederland heeft bij ratificatie van het IVESCR geen voorbehoud gemaakt bij artikel 13 . Gezien de totstandkoming van deze bepaling en de rol van Nederland daarbij, in het bijzonder de bezwaren van Nederlandse zijde, had het maken van een voorbehoud een optie kunnen zijn. Vanuit de optiek van de regering was een voorbehoud evenwel niet nodig, omdat men geen strijd zag met artikel 13 lid 2. Andere landen, te weten Japan en Rwanda, hebben wel een voorbehoud gemaakt bij artikel 13 lid $2{ }^{87} \mathrm{Zij}$ achten zich niet gebonden aan de geleidelijke invoering van kosteloos voortgezet en hoger onderwijs.

83. Volgens de Nederlandee vertegenwoordiger in de Commisaie, Prof. Beaufort, was het doel van artikel 13 'Dem Túchtigen freie Bahn', dat wil zeggen, geef an de talentvollen alle mogelijkheden. Het gaat echter niet alleen om de talentvollen, maar om ledereen, dat wil zeggen ook de minder begaafden en zwakkeren in de samenleving. Rede van prof. L.J.C. Beaufort O.F.M. in de Derde Commiseïe van de Algemen Vergadering, 16 oktober 1967 , tekst in: Uitgave nr. 54 van het Ministerie van Buitenlandse Zaken, p. 416.

84. Zie over deze problematiek ook: Cohen, a.w. p. 383 ,

85. TK zitting 1975-1976, 13932 (R 1037) nr. 3 (MvT), p. 45.

86. Zle hierover o.a. The Limburg Principles on the Implementation of the International Covenant on Economic; Social and Cultural Rights. Deze beginselen geven een belangrijke interpretatie van de algemene bepalingen uit het IVESCR. De beginselen vijn gepubliceerd in UN Doc. E/CN.4/1987/17 en in de Human Rights Quarterly, vol. 9 (1987), pp. 122-135. Zie in dit verband met name beginselen 16,21 en 23 .

87. Zie het overzicht van de woorbehouden bij het IVESCR in UN Doc. E/C.12/1988/1. 
De implicatie van de Les en Cursusgeldwet, alsmede van haar voorgangers, de School en Cursusgeldwet $1972^{88}$ en de Lesgeldwet voor boven 17 jarigen $^{89}$, is dat het na te streven kosteloze karakter van het secundaire onderwijs steeds meer wordt ondergraven. In feite gaan de hier genoemde wetten in tegenovergestelde richting. $\mathrm{Zij}$ betekenen immers een verhoging van de kosten voor het secundaire onderwijs. Deze ontwikkeling werd in gang gezet ondanks het voornemen van de regering in 1975 , te willen streven naar een gefaseerde afschaffing van de school-, cursus- en examengelden. ${ }^{90}$ Bovendien was de regering toen van mening 'dat het uitgangspunt van het beleid moet zijn, dat onderwijs een gemeenschapsvoorziening is, die in principe ten laste van de algemene middelen moet komen' ${ }^{91}$ In 1986, bij de bespreking van het Nederlandse rapport over de implementatie van de artikelen 13-15 IVESCR door een werkgroep van Regeringsdeskundigen van de Verenigde Naties, kwam de kwestie van het school- en cursusgeld ook ter sprake. Eén van de deskundigen, de vertegenwoordiger van de Sovjet Unie, merkte toen op:

'According to the report, it seemed that education was free only with regard to primary education. He inquired whether that imposed an unfair financial burden on certain members of society, such as unemployed workers and whether all parents were able to pay for the education of their children. ${ }^{92}$

Uit deze woorden spreekt een vermoeden dat de situatie van het voortgezet en het hoger onderwijs in Nederland op gespannen voet staat met de verplichtingen voortvloeiend uit artikel 13 lid 2 sub $b$ en $c$.

De invoering van de Les- en Cursusgeldwet werd door de regering gemotiveerd met een beroep op financieel-economische omstandigheden, te weten de toestand van 's Rijks financiën, alsmede de ontwikkelingen op het gebied van de studiefinanciering. Met andere woorden, het gaat hier om een kwestie van (politieke) begrotingsdiscipline. ${ }^{93}$ Artikel 4 IVESCR biedt de mogelijkheid de materiële rechten uit het Verdrag te beperken 'alleen voor zover dat niet in strijd is met de aard van deze rechten en uitsluitend met het doel het algemeen welzijn in een democratische samenleving te bevorderen'. De Lesgeldregeling kan in strijd komen met de aard van het recht op onderwijs, dat wil zeggen met de kern van dit recht, indien de toegankelijkheid wordt aangetast omdat vanwege financiële redenen kin-

88. Stb.1983, 360.

89. Stb. $1986,250$.

90. MvT, a.w. p.54.

91. TK zitting 1977, 13932 (R 1037) nr. 8 (MvA), p. 27.

92. Zie UN Doe. E/1986/WG.1/SR.14, par. 70.

98. TK zitting 1986-1987, 19879, nr. 3 (MvT), p. 1. 
deren afzien van het volgen van voortgezet onderwijs. ${ }^{94}$ Redenen zoals door de regering aangevoerd bij de invoering van de wet, kunnen in de huidige periode van sterke economische groei in Nederland geen motivering vormen voor het handhaven, dan wel verhogen van het les- en cursusgeld. Ook de staat ondervindt immers de positieve effecten van eerder gememoreerde economische groei. Weliswaar kent de Les- en Cursusgeldwet een stelsel van tegemoetkoming in het verschuldigde lesgeld, maar dit doet niet af aan de verplichting de kosten voor de burger te verminderen. Bovendien kan men zich afvragen of de door de regering aangevoerde redenen van rechtvaardiging voldoen aan het criterium van het bevorderen van het algemeen welzijn, dat wil zeggen van het welzijn van de bevolking in haar geheel. ${ }^{95}$ Kortom, in een discussie tussen regering en parlement over een voorgenomen beperking van rechten dienen de verdragsnormen, in het bijzonder artikel 2 lid 1 , centraal te staan. Bovendien moet er ruimte zijn voor een zorgvuldige afweging van belangen en gevolgen. ${ }^{96}$

\subsubsection{Recente jurisprudentie}

In de jurisprudentie is aan artikel 13 IVESCR tot nog toe directe werking ontzegd. ${ }^{97}$ In de recente uitspraak van 14 november 1990 overwoog de Haagse rechtbank ten aanzien van artikel 13:

'Uit de redactie blijkt reeds, dat deze bepaling niet is een bepaling, die een ieder kan verbinden als bedoeld in artikel 93 Grondwet, omdat deze bepaling zich richt tot gedaagde en betrekking heeft op door gedaagde ter uitvoering van die bepaling te nemen maatregelen en die bepaling zonder die maatregelen in de Nederlandse rechtsorde bezwaarlijk kan functioneren.'

Met deze overweging volgt de rechtbank het oordeel van de HR in het Harmonisatiewet-arrest. De rechtbank overwoog verder dat artikel 13 lid 2 aanhef en sub b geen recht geeft op kosteloos onderwijs, 'maar verplicht gedaagde het secundair onderwijs geleidelijk kosteloos te maken. Het artikel laat gedaagde vrij die geleidelijke wijze te kiezen die hem afhankelijk van de beschikbare middelen en van andere door hem te behartigen belangen goeddunkt'. Naar onze mening moet die beleidsvrijheid in zodanige zin worden verstaan dat de staat positieve maatregelen moet nemen, dat wil zeggen maatregelen die de kosten van het onderwijs voor de burger verlagen in plaats van verhogen. Met andere woorden, maatregelen dienen in

94. Zie Limburg Principles, a.w. met betrekking tot artikel 4 sie beginsel nr. 56.

95. Zie Limburg Principles, a.w. begingel nr. 52.

96. Heringa, a.w. pp. 198, 139, en hoofdstuk 2, paragraaf 6.6 supra.

97. Pres. Rb. Amsterdam, 21 oktober 1981, RvdW/KG 1981, nr. 156 en 157; ARRS 29 november 1982, weekoversicht RvS 1982, nr. 3.2105; recentelijk HR. 14 april 1989, AB 1989, nr. 207 (Harmonisatiewet-arrest). 
overeenstemming te zijn met doel en strekking van de verdragsbepaling, te weten het voor een ieder toegankelijk maken van het voortgezet- en beroepsonderwijs.

Volgens de rechtbank vormt het lesgeld, gelet op de tegemoetkoming die daarin kan worden verkregen, geen belemmering het secundaire onderwijs te volgen. Voor bepaalde inkomensgroepen is dit inderdaad juist. Voor andere groepen uit de bevolking die niet of slechts gedeeltelijk in aanmerking komen voor een tegemoetkoming worden de onderwijskosten wèl hoger. Het vergoedingenstelsel is niet of slechts in beperkte mate van toepassing op mensen met een inkomen van ongeveer $f 46.000,-$ en hoger. De overweging van de rechtbank overtuigt dan ook niet, te meer daar de regering het voornemen heeft het les- en cursusgeld in de toekomst verder te verhogen. ${ }^{98}$

Ten aanzien van het argument van eiser dat de invoering van het lesgeld een stap terug is en daarmee in strijd met artikel 2 lid 1 van het IVESCR gaf de rechtbank geen duidelijk antwoord. $\mathrm{Zij}$ overwoog '( D) laargelaten dat artikel 2 van het Verdrag en ook artikel 13 lid 2 aanhef en sub b in dit opzicht geen bepalingen zijn die een ieder kunnen verbinden (...) ${ }^{99}$ Daarmee lijkt de rechtbank directe werking van deze bepalingen in andere gevallen niet helemaal uit te sluiten. Ook de HR heeft vorig jaar in een zaak bepaald dat artikel 2 IVESCR niet eraan in de weg behoeft te staan dat aan bepalingen van het Verdrag rechtstreekse werking toekomt. ${ }^{100}$ De deur naar directe werking van IVESCR bepalingen wordt daarmee op een kier gelaten. De rechtbank concludeerde dat er geen sprake is van een uitbreiding van verplichtingen ingevolge de Les- en Cursusgeldwet ten opzichte van de School- en Cursusgeldwet 1972 en dat de eerstgenoemde wet dan ook geen maatregel is die strijdig is met de bedoeling van het IVESCR. De vordering van eiser tot opheffing van de verplichting tot betaling van lesgeld en de terugbetaling van het reeds betaalde lesgeld werd dan ook afgewezen.

Mijn conclusie is dat artikel 13 lid 2 sub b IVESCR heel wel rechtstreekse werking kan bezitten. De zinsnede 'In het bijzonder door de geleidelijke inwoering van kosteloos onderwijs' impliceert een verbod voor de staat een tegenovergestelde koers te varen. De term 'geleidelijke invoering' geeft ook aan dat een achteruitgang in bestaande niveaus van voorzieningen niet mogelijk moet worden geacht. ${ }^{101}$ De hier aan de orde zijnde bepaling uit het IVESCR is concreet en specifiek genoeg om voor de staat een verplichting in te houden waarop een burger zich rechtstreeks kan beroepen. ${ }^{102}$ Een

98. Zie NRC Handelsblad van 4 en 13 december 1990 , en 11 november 1991.

99. Mijn cursivering, A.C.

100. HR 20 april 1990, RvdW 1990, 88.

101. Zie ook Cohen, supra moot 77 .

102. Zie ook Heringa, a.w. p. 91; en p. 251-254. 
zekere beleidsmarge lijkt mij op dit punt dan ook niet voorhanden. Eên middel om het doel van de toegankelijkheid van het voortgezette onderwijs te verwezenlijken wordt expliciet genoemd. ${ }^{103}$

De Les- en Cursusgeldwet gaat tegen de letter en de geest van het IVESCR in. Het valt te betreuren dat tijdens de parlementaire behandeling van deze wet de internationaalrechtelijke aspecten niet aan de orde zijn geweest. Evenmin heeft de regering getracht de invoering van de wet te rechtvaardigen in de zin van artikel 4 IVESCR.

\subsection{Het recht op onderwijs als universeel mensenrecht?}

\subsubsection{Algemeen}

In de voorafgaande hoofdstukken hebben we ons beziggehouden met de internationale regeling van het recht op onderwijs in verdragen en verklaringen. Ook besteedden we aandacht aan de internationale implementatie van dit recht aan de hand van jurisprudentie en statenrapporten. In dit hoofdstuk is bovendien onderzocht welke verplichtingen een staat heeft met betrekking tot de verwezenlijking van het recht op onderwijs. De vraag rijst nu of het recht op onderwijs beschouwd kan worden als een recht dat, ongeacht de verschillende politieke, sociale, economische en culturele stelsels in de wereld, een algemene aanvaarding ondervindt. Met andere woorden, betreft het recht op onderwijs een norm, een juridische aanspraak die wereldwijd wordt erkend en onderschreven? Het gaat hier om de vraag naar het mogelijke universele karakter van het recht op onderwijs als mensenrecht. Meer in het algemeen betreft het de vraag naar de betekenis van het begrip universaliteit van de rechten van de mens en de wijze waarop deze mogelijke universaliteit kan worden onderzocht. Deze vragen zijn van belang, omdat het universele karakter van de rechten van de mens het mogelijk maakt staten, waar ook ter wereld, aan te spreken en verantwoordelijk te houden voor de wijze waarop zij deze rechten nalleven.

De term 'universaliteit' wordt in verschillende disciplines op even zovele verschillende manieren geïterpreteerd. Ik noem hier de filosofie, de sociologie, de politicologie en het volkenrecht. ${ }^{104} \mathrm{Ik}$ wil mij hier beperken tot een juridisch onderzoek naar het mogelijke universele karakter van het recht op onderwijs. Hierbij dient te worden aangetekend dat de hierna volgende uiteenzetting slechts enkele aspecten behandelt van de meer algemene vraag naar het beweerde universele karakter van de rechten van de

103. Heringa, a.w. p. 91.

104. Zie bijvoorbeeld over de verschillende opvattingen, Universaliteit wan Grondrechten, Verslag van een Symposium gehouden op 18 oktober 1988 ter gelegenheid van het ere-doctoraat verleend aan Prof.mr.dr. Th.C. van Boven door de Erasmus Universiteit Rotterdam. Mededelingen van het Juridisch Instituut van de Erasmus Universiteit Rotterdam, Nr. 48 (1989). 
mens. Een diepgravende analyse zou onder meer aandacht moeten besteden aan de rol van het onderwijs in de verschillende maatschappelijke stelsels, waarbij ingegaan zou moeten worden op filosofische, sociologische en onderwijskundige vragen. Die bedoeling heeft mijn uiteenzetting niet. Mijn betoog laat zien hoe vanuit een juridische invalshoek de vraag naar het mogelijke universele karakter van het recht op onderwijs vanuit verschillende gezichtspunten kan worden benaderd. Deze uiteenzetting moet dan ook worden gezien in het licht van de vraag naar het beweerde universele karakter van de rechten van de mens in brede zin. In subparagraaf 5.6.2 ga ik in op de vraag of het recht op onderwijs een universele geldigheid en acceptatie toekomt. De daarop volgende subparagraaf 5.6.3 maakt een onderscheid tussen een materieel en een formeel aspect van de term universaliteit en relateert dit aan het recht op onderwijs. Subparagraaf 5.6.4 stelt de vraag aan de orde hoe het recht op onderwijs zich verhoudt tot een leerplicht. In subparagraaf 5.6 .5 tenslotte betoog ik dat het recht op onderwijs het karakter heeft van een sleutelrecht dat in positieve zin bijdraagt tot zijn universele aanspraak.

\subsubsection{Universele geldigheid en acceptatie van het recht op onderwijs}

Een manier om het mogelijke universele karakter van het recht op onderwijs te onderzoeken is een onderscheid te maken tussen twee aspecten van de term universaliteit van de rechten van de mens. Ten eerste speelt de kwestie van de universele geldigheid van het recht op onderwijs en daarnaast de vraag naar de universele acceptatie van dit recht. ${ }^{105}$ Het eerste punt betreft de vraag of het recht op onderwijs voor een ieder geldt, anders gezegd, of iedereen een juridische aanspraak op onderwijs heeft. Het recht op onderwijs makt deel uit van de categorie van economische, sociale en culturele rechten die een behoorlijke levensstandaard garanderen. $\mathrm{Zij}$ benadrukken de kwaliteit van het leven. ${ }^{106}$ Vanuit dat perspectief heeft een ieder, elke persoon, recht op onderwijs, geldt met andere woorden het recht op onderwijs voor iedereen. In zowel wereldwijde als regionale verdragen treft men deze bepaling aan, vaak in gelijkluidende termen. In beginsel wordt niemand uitgesloten van het recht op onderwijs. Deze toekenning van een recht wordt versterkt door de non-discriminatiebepalingen die in alle internationale mensenrechtendocumenten voorkomen. Daarnaast vermelden deze mensenrechtendocumenten personen behorend tot bijzondere groepen uit de samenleving aan wie het recht op onderwijs uitdrukkelijk wordt toegekend; zij bezitten als het ware een bijzondere bescherming. Te denken valt aan kinderen, vrouwen, leden van minderheden, vluchtelingen, gevangenen, en mensen die in hun jeugd het lager onderwijs niet

105. Zie Veralag Symposium, a.w. p. 99, stelling 1 van Th.C. van Boven.

106. Zie A. Glenn Mower Jr., International Cooperation for Social Justice; global and regional Protection of Economic/Social rights, Westport Connecticut 1985, p. 3. 
hebben kunnen volgen of voltooien. Deze gedachte werd als volgt omschreven in een verklaring over volwasseneneducatie:

(The right to learn)

'is a fundamental human right whose legitimacy is universal: the right to learn cannot be confined to one section of humanity; it must not be the exclusive privilege of men, or of the industrialized countries, or the wealthy classes, or those young people fortunate enough to receive schooling. ${ }^{107}$

Bij het tweede punt, dat van de universele acceptatie, gaat het om de vraag of de waarde van het onderwijs door alle politieke, sociale, religieuze en culturele gemeenschappen wordt geaccepteerd. Dat is weliswaar geen strikt juridische vraag, maar is wel nauw verbonden met de universele aanspraak van mensenrechtennormen. De sterkte van de aanspraak van een individu op onderwijs wordt mede bepaald door de waarde die in een maatschappelijke context of gemeenschap aan onderwijs wordt toegekend. In het algemeen kan men stellen dat de waarde en het belang van het onderwijs voor de ontwikkeling en de ontplooiing van het individu in alle maatschappelijke stelsels worden onderschreven. Geschoolde mensen kunnen een belangrijke bijdrage leveren aan de ontwikkeling van het land waarin zij wonen. In de woorden van de UNESCO: 'Education is increasingly recognized as a basic human right and as one of the dimensions and essential means of development'. ${ }^{108}$ In westerse landen heeft het recht op onderwijs een belangrijke plaats verworven in het maatschappelijk bestel en is het vastgelegd in de grondwet. Het Europees Verdrag voor de Rechten van de Mens versterkt de positie en de garantie van het recht op onderwijs in de lidstaten van de Raad van Europa. In het bijzonder de jurisprudentie van de Straatsburgse organen heeft daar aan bijgedragen. Andere culturele en maatschappelijke stelsels en regio's onderschrijven en accepteren eveneens de waarde van onderwijs en het recht op onderwijs als éen van de rechten van de mens. In veel Afrikaanse landen heeft het recht op onderwijs een gemeenschapsfunctie. Het is een plicht voor de (dorps)gemeenschap zorg te dragen voor de opvoeding en opleiding van het kind. Deze is gericht op de rol van het kind als een goed lid van de groep (familie, dorp, stam). Opvoeding en opleiding zijn niet de exclusieve rechten van de ouders; de hele familie neemt aan dat proces deel. ${ }^{109}$ Als gevolg van de kolonisatie hebben van oorsprong westerse ideeën en opvattingen over onderwijs en opvoeding ook in Afrikaanse landen het onderwijsstelsel beïnvloed. ${ }^{110}$ Naast

107. Declaration of the Fourth International Conference on Adult Education, $\mathbf{P a r i s}_{\text {, }}$ 19-29 March 1985, UNESCO Doc. ED/MD/81, p. 67.

108. UNESCO, Second Medium-Term Plan (1984-1989), Doc. 4XC/4, p. 67.

109. Kéba M'Baye, Human Rights in Africa, in: K. Vasak and $P h$. Alston (eds), The Intermational Dimensions of Human Rights, Westport Connecticut/Paris 1982, Vol. 2, pp. 583-601, op p. 591 .

110. M'Baye, a.w. p. 591. 
lokale gemeenschappen speelt in Afrika de staat alls centraal orgaan in het onderwijsbestel steeds meer een vooraanstaande rol. Het onderwijs beoogt bij te dragen aan natievorming en gemeenschapsgevoel. In veel Engelstalige landen van Afrika is het recht op onderwijs niet grondwettelijk verankerd. Wel onderschrijven deze landen het idee en de waarde van het onderwijs. Het onderwijs heeft een collectief karakter en is minder gericht op het individu. ${ }^{111}$ Eenzelfde beeld gaat op voor de Franstalige staten in Afri$\mathrm{ka}$. Wel kent deze groep een aantal landen waar het recht op onderwijs is opgenomen in de grondwet. De waarde van het onderwijs wordt erkend mede als instrument om de economische ontwikkeling van het land te bevorderen. De staat heeft tot taak het niveau van het onderwijs te verhogen. Dit betekent veelal dat de invloed van de staat op het onderwijs groot is. In het bijzonder probeert de staat de controle op privé-onderwijsinstellingen te versterken. ${ }^{112}$ Ten aanzien van Afrika dient nog vermeld te worden dat in artikel 17 van het Afrikaanse Handvest inzake de Rechten van de Mens en de Rechten van Volken het recht op onderwijs, zij het op summiere wijze, is vastgelegd.

De Islam beschouwt het recht op onderwijs als een basisrecht dat bepalend is voor het genot van andere rechten. Het onderwijs is noodzakelijk 'for developing the latent faculties and enabling the individual to function as an effective member of society'. ${ }^{113}$ Het onderwijs in landen die de Islam als staatsideologie kennen is opgebouwd en ingericht volgens de islamitische leer. Het recht om te leren betekent primair alles wat noodzakelijk is om de godsdienst te belijden en daarnaast de kennis en vaardigheden om deel te nemen aan het dagelijkse leven. De Islam garandeert gelijkheid tussen man en vrouw bij de uitoefening van het recht op onderwijs. ${ }^{114}$ Dat deze gelijkheid evenwel gerelativeerd moet worden moge blijken uit het volgende. Tijdens een seminar over de plaats van de rechten van de mens in de Islam werd ook aandacht besteed aan het onderwijs. ${ }^{115}$ Volgens één van de aanbevelingen dienen vrouwen de gelegenheid te hebben studies te volgen op elk gewenst gebied mits dit geschiedt volgens de Islamitische beginselen. In de praktijk betekent dit een beperking van gelijke kansen en gelijke behandeling van vrouwen op het terrein van het onderwijs, omdat vrouwen in een Islamitische maatschappij veelal een ondergeschikte positie innemen.

111. Zie F. Ermacora, Menschenrechte in der sich wandelnden Welt, Band II: Theorie und Praxis, Die Verwirklichung der Menschenrechte in Afrika und im Nahen Osten, Wien 1983, pp. 156 en 214. De grondwet van Somalië bevat wel bepalingen over het onderwijs, zie Ermacora, a.w. p. 156.

112. Idem, pp. 286-289.

113. Humayun Kabir, Human Rights: the Islamic tradition and the problems of the world today (1947), herdrukt in: Human Right Teaching, Vol. IV (1985), pp. 18-19, op p. 18.

114. Ali Abdel Wahid Wafi, The problem of human rights in the Islamic tradition (1963), herdrukt in: Human Rights Teaching, Vol. IV (1985), pp. 38-44, op p. 40.

115. Human Rights in Islam, Report of a seminar held in Kuwait, December 1980, Geneva 1982, International Commission of Jurists, pp. 14, 15. 
Op dit punt ontstat een conflict met de internationale regeling van het recht op onderwijs die voorziet in dezelfde toegankelijkheid en kwaliteit van het onderwijs voor mannen en vrouwen (vergelijk artikel 10 van het Verdrag inzake de Uitbanning van Alle Vormen van Discriminatie van Vrouwen). Een andere aanbeveling waarschuwt tegen het gevaar van een onderwijsstelsel dat gebaseerd is op een scheiding van staat en godsdienst. In Islamitische landen zijn staat en godsdienst juist sterk met elkaar verweven. Het hoeft dan ook niet te verbazen dat in Irak en Iran het particuliere onderwijs in 1975 respectievelijk 1979 werd afgeschaft. ${ }^{116}$ Tot slot roept éen van de aanbevelingen Islamitische staten op partij te worden bij internationale verdragen over ondlerwijs en andere economische, sociale en culturele rechten voor zover deze verdragen in overeenstemming zijn met Islamitische beginselen. Dat betekent dat het Islamitische recht boven het internationale recht gesteld wordt. Deze aanbevelingen geven aanleiding te veronderstellen dat de Islamitische leer toegespitst op het onderwijs zeker niet op alle punten in overeenstemming is met de internationale bepalingen over dit onderwerp.

Volgens de traditionele socialistische opvatting inzake de rechten van de mens vormen economische, sociale en culturele rechten de grondslag voor de verwezenlijking van rechten op andere gebieden, zoals burger- en politieke rechten. ${ }^{117}$ De mate van verwezenlijking van economische, sociale en culturele rechten is afhankelijk van het ontwikkelingsniveau van de socialistische economie en wordt bepaald door de produktieve arbeid van de burgers. ${ }^{118}$ Volgens deze leer neemt het onderwijs een centrale plaats in in een socialistische maatschappij: alleen door de socialistische invulling van dit recht kan het zijn optimale implementatie bereiken. ${ }^{119}$ Het onderwijs is gericht op de systematische ontwikkeling van de socialistische maatschappij. ${ }^{120}$ Het onderwijssysteem in communistische staten is op alle terreinen ingericht volgens de marxistisch-leninistische ideologie. Men kan spreken van ideologische indoctrinatie. ${ }^{121}$ Bovendien is de organisatie en

116. Zie: UN Doc. E/1982/s/Add. 26, par. 13, Report by Iraq on the implementation of Artieles 13-15 of the International Covenant on Economic, Social and Cultural Rights; voor Iran gle UN Doc. E/1982/3/Add. 43, par. 37.

117. Zie W.J.M. van Genugten, In naam van de vrijheid, diss. 1988, Amsterdam, pp. 184, 185 en G.P. van den Berg, Sovjet Staat en Recht in Beweging, deel 1, Nijmegen 1991. pp. 351-356. Hij bespreekt ook recente wijzigingen in het traditionele socialistirehe concept, zile pp. 356-364.

118. L. Lobrincz, Economic, Social and Cultural Rights, in: I. Szabo (ed.), Socialist Concept of Human Righte, Budapest 1966, pp. 197-227, op p. 210.

119. Zie E. Poppe, u.a., Grundrechte des Burgers in der sozialistischen Gesellschaft, Berlin DDR 1980, p. 198 .

120. Idem, p. 199.

121. Zie NRC-Handelsblad 13-4-1984: Russische scholieren krijgen meer ideologische vorming, en J. Ziman, P. Sieghart, J. Humphrey, The World of Science and the Rule of Law, Oxford 1986, pp. 56-60.

Zie voorts de Sovjet-uitgave, Schule und Leben, Morkau 1988, pp. 63, 64, een handboekje voor leraren en opvoeders in opleiding. 
de inrichting van het onderwijs sterk anti-religieus, atheïstisch van aard. Tolerantie ten aanzien van religieuze groeperingen die aanspraak maken op eerbiediging van hun overtuigingen wordt afgewezen. Er is dus niet alleen sprake van een scheiding van kerk en staat op onderwijsgebied, maar juist van een sterk anti-religieuze stemming. De religieuze opvoeding van het kind door de ouders is weliswaar niet uitdrukkelijk verboden, maar is niet in het belang van het kind. Dit belang wordt dan gedefinieerd in termen van de communistische ideologie. ${ }^{122}$ In communistische landen heeft de staat het monopolie op het onderwijs. Vormen van privé-onderwijs zijn verboden. Ouders hebben geen mogelijkheid eigen onderwijsinstellingen te stichten die beantwoorden aan hun overtuigingen. Scholen op religieuze grondslag worden niet toegestaan. Er bestaat dus geen vrijheid van onderwijs. Het ontbreken van pluralisme in het onderwijs werd als volgt verdedigd: "The existence of private schools is considered to be socially divisive and injurious to the public system. It has led to the dilution of quality in some countries and to the perpetuation of class privileges". ${ }^{123}$

Wat betreft het vrijheidsaspect van het recht op onderwijs is het stelsel in communistische staten in strijd met de internationale bepalingen. Dit element van de vrijheid van onderwijs wordt in het traditionele socialistische mensenrechtenconcept niet aanvaard, hoewel de betreffende internationale bepalingen ook door deze landen zijn bekrachtigd.

Inmiddels zijn er, onder invloed van 'glasnost' en 'perestroijka' veranderingen op gang gekomen in de onderwijsstelsels van een aantal Oosteuropese landen. ${ }^{124}$ De roep om democratisering van het onderwijs wordt steeds sterker. Met name richten de bezwaren zich tegen het autoritaire, sterk gecentraliseerde systeem waar nauwelijks sprake is van een eigen verantwoordelijkheid van leraar en leerling. De ontplooiing van het individu zou op een meer democratische wijze in het onderwijs gestalte moeten krijgen. De marxistisch-leninistische indoctrinatie van het onderwijs, alsmede vormen van geschiedvervalsing in het onderwijsprogramma zouden uitgebannen moeten worden. In de voormalige DDR begon men vrij snel na de omwentelingen in november 1989 met deze hervormingen. De traditionele inhoud van het onderwijs kwam daar meer en meer aan kritiek bloot te staan. Enige inhoudelijke veranderingen, gericht op een meer pluriforme inhoud van het onderwijs en op het afschaffen van starre militaristische tendensen werden vrij snel doorgevoerd. ${ }^{125}$ In de Sovjetunie werd in oktober 1990

122. Zie O. Luchterhandt, UN-Menachenrechten Konventionen; Sow jetrecht-Sowjet Wirklichkeit, Baden-Baden 1980, pp. 105, 106 en 184-187.

123. V. Kartashkin, Implementation of the Cowenant on Economic, Social and Cultural Rights in light of differences among social systems, April 1984, p. 61 (niet gepubliceerd).

124. Zie voor de situatie in de Sovjetunie, A. Langeler, Perestroijka en onderwijs, in: Internationale Spectator, April 1989, pp. 241-247, en A.J. Treffers, De Russische onderwijshervorming in: NRC Handelsblad 22 meil 1990. Zie verder de bespreking van recente Oosteuropese statenrapporten ingevolge het IVESCR in hoofdatuk 4.4 .3 supra.

125. Zie D.J. Eppink, Militaristibch onderwije DDR is hellemaal van slag, in: NRC Handelsblad 20-12-1989. 
een wetsvoorstel inzake de vrijheid van godsdienst aangenomen waarin ook meer ruimte wordt gegeven aan het godsdienstonderricht. De vrijheid van ouders om hun kinderen een godsdienstige opvoeding te geven in overeenstemming met hun eigen overtuigingen werd erkend, evenals het recht van kerken om eigen (zondags)scholen te stichten. Vooral dit laatste punt is van belang voor leden van religieuze minderheden in de Sovjetunie. Ook kunnen religieuze organisaties op grond van deze wet instellingen stichten ten behoeve van de opleiding van geestelijken. De wet bepaalt voorts dat het onderwijs voor iedere burger toegankelijk is ongeacht zijn levensbeschouwelijke overtuiging. Burgers hebben ook het recht godsdienstonderricht te ontvangen in de taal van hun keuze, individueel of samen met anderen. De mogelijkheid van godsdienstonderwijs op staatsscholen werd evenwel afgewezen. ${ }^{126}$ In Polen werd die laatste mogelijkheid wel gecreëerd. Sedert september 1990 bestaat daar de mogelijkheid op vrijwillige basis godsdienstonderwijs op staatsscholen te volgen. Gezien het feit dat $90 \%$ van de Polen katholiek is zal dit waarschijnlijk een bijna-monopolie van de katholieke kerk in het onderwijs tot gevolg hebben. In Polen bestaat bij sommigen de vrees dat deze machtspositie van de katholieke kerk zal leiden tot intolerantie ten opzichte van niet-godsdienstige leerlingen en andere gelovigen en in het bijzonder tot discriminatie van Joodse ouders. ${ }^{127}$

In China wordt de maatschappelijke waarde van het onderwijs uitdrukkelijk erkend, zij het dat dit onderwijs in marxistisch-leninistische zin ingericht is. De grondwet bepaalt dat Chinese burgers het recht op onderwijs hebben; dit recht is gekoppeld aan de plicht onderwijs te volgen. ${ }^{128} \mathrm{Om}$ dat het marxisme-leninisme in China staatsideologie is bestaat er geen vrijheid van onderwijs zoals die is vastgelegd in de internationale mensenrechtenverdragen. Overigens is China bij geen enkel van deze verdragen partij.

Inherent aan de acceptatie van het recht op onderwijs als een mensenrecht met een universele aanspraak is de gedachte van de diversiteit van nationale onderwijsstelsels. De inrichting van het onderwijssysteem van een land moet beantwoorden aan specifieke geografische, sociale en culturele factoren. De diversiteit van nationale onderwijsstelsels wordt door de UNESCO

126. Zie NRC Handielsblad 2-10-1990 en vooruitlopend op deze ontwikkelingen, $P$. Weaterveld, Vrijheid van Godsdienst in de USSR. Drempels weg? Helsinki Rapport nr. 6 , Uitgave Nederlands Helsinki Comite, febr. 1990, pp. 9-11. Zie ook Van den Berg, a.w. pp. 433, 494. Zie voorts O. Luchterhandt en B.G. Tahzib, The CSCE Norms on Religious Freedom and their Effects on the Reform of Soviet Legislation on Religion, in: A. Bloed, P. van Dijk (eds), The Human Dimension of the Helsinki Process, Dordrecht 1991, pp. 162-196, op pp. 176-196. Luchterhandt en Tahrib concluderen dat deze Sovjet 'Law on Freedom of Conscience" verenigbaar is met de internationale verplichtingen van de Sovjet Unie op dit gebied (pp. 195, 196). Een belangrijke vraag is ovenwel hoe deze wet in de praktijk zal worden toegepast.

127. Zie P. Michielsen, Godsdienstonderwijs terug op Poolse scholen, in: NRC Handelsblad 7-8-1990.

128. Zie R. Randle Edwarda, Civil and Social Rights: Theory and Practice in Chinese Law Today, in: R.R. Edwarde, L. Henkin, A.J. Nathan, Human Righte in Contemporary China, New York 1986, pp. 41-75, op pp. 71, 72. 
uitdrukkelijk erkend. ${ }^{129}$ Deze nationale verscheidenheid is een essentieel element van het idee van de universele aanspraak van het recht op onderwijs. ${ }^{130}$ Universaliteit betekent immers geenszins dat ook uniformiteit vereist is.

Afrondend kan gezegd worden dat de aanspraak op onderwijs in verschil- lende politieke, maatschappelijke en culturele systemen acceptatie ondervindt. De staat heeft onmiskenbaar een taak bij de verwezenlijking van dat recht. De waarde van onderwijs voor de ontwikkeling van het individu en de samenleving wordt onderschreven. De ideologische oriëntatie van de samenleving heeft in bepaalde landen en regio's een grote invloed op inrichting en organisatie van het onderwijs. Dit geldt in het bijzonder voor communistische en islamitische landen. Op sommige punten is er zonder twijfel sprake van een situatie die in strijd is met de internationaalrechtelijke bepalingen. Hier wordt met name gedoeld op het ontbreken van de vrijheid van onderwijs. Een en ander betekent dat de waarde van onderwijs en de aanspraak op onderwijs een universeel karakter hebben, maar dat de vrijheid van onderwijs (nog) geen universele acceptatie ondervindt.

\subsubsection{Formele en materiële aspecten van het universele karakter van het recht op onderwijs}

Een andere benadering om een uitspraak te doen over het beweerde universele karakter van het recht op onderwijs is een onderscheid te maken naar een formeel en een materieel aspect van de term universaliteit. Formele universaliteit betreft dan de vraag of het recht op onderwijs in formele zin in voldoende mate door staten wordt onderschreven. Men kijkt dan bijvoorbeeld naar het aantal ratificaties van verdragen waarin het recht op onderwijs is opgenomen. Het materiële aspect van het mogelijke universele karakter van het recht op onderwijs heeft betrekking op de vraag of dit recht ook wereldwijd daadwerkelijk verwezenlijkt is. Met andere woorden, het gaat hier om de implementatie van dit mensenrecht. Deze benadering valt in zoverre van de indeling naar geldigheid en acceptatie te onderseheiden dat nu gekeken wordt naar de juridische gebondenheid van staten aan de internationale norm enerzijds en de feitelijke naleving van de norm anderzijds.

Wat het formele aspect betreft kan vastgesteld worden dat een behoorlijk aantal staten partij is bij een universeel verdrag als het IVESCR. Zo"n 100 staten hebben dit Verdrag bekrachtigd, dat is bijna 60 procent van de ge-

129. Preambule UNESCO Verdrag tot Bestrijding van Discriminatie in het Onderwije en artikel 1(3) UNESCO Constitutie.

130. Verslag Symposium, a.w. p. 100, stelling 7 van Th.C. van Boven; zie aok Limburg Principles on the Implementation of the International Covenant on Economic, Social and Cultural Right, UN Doc. E/CN.4/1987/17, beginsel nr. 6. 
meenschap van staten. Daarbij ontbreken echter belangrijke landen als de Verenigde Staten en China. Uit statenrapporten bij het IVESCR blijkt dat landen het belang van onderwijs onderschrijven en pogingen ondernemen hun nationaal onderwijsbeleid af te stemmen op de onderwijsbepalingen uit het Verdrag. Belangrijk is dat staten uit alle werelddelen, met verschillende economische, sociale, culturele en politieke systemen zich formeel gebonden hebben aan dit Verdrag. Het aantal voorbehouden bij artikel 13 IVESCR is gering en tast geenszins de kern en de waarde van het recht op onderwijs aan. Slechts eén staat (Congo) verklaarde zich niet gebonden te achten aan het vrijheidsaspect van het recht op onderwijs, vervat in lid 3 en lid 4. Drie andere staten maakten een voorbehoud ten aanzien van de verwezenlijking van het recht op primair onderwijs vanwege financiële redenen (Zambia, Barbados en Madagascar). Japan acht zich niet gebonden aan de geleidelijke invoering van kosteloos voortgezet en hoger onderwijs. ${ }^{131}$ Rwanda tenslotte, acht zich met betrekking tot het onderwijs slechts gebonden aan de bepalingen van de eigen grondwet.

Een andere indicatie voor de formele aanvaarding van het recht op onderwijs als universeel mensenrecht betreft het lidmaatschap van de UNESCO. Vrijwel de gehele gemeenschap van staten is lid van deze organisatie en onderschrijft daarmee haar doelstellingen. Eén van die doelstellingen is de verwezenlijking van onderwijsmogelijkheden voor een ieder en de bevordering van gelijke kansen en een gelijke behandeling. ${ }^{132}$ In de praktijk richten het beleid en het programma van UNESCO zich in hoofdzaak op de verwezenlijking van primair onderwijs voor kinderen en op de bevordering van alfabetisme en fundamenteel onderwijs voor volwassenen. ${ }^{133}$ $\mathrm{Bij}$ het UNESCO Verdrag tot Bestrijding van Discriminatie in het Onderwijs zijn 76 staten partij; dat wil zeggen, bijna de helft van het aantal lidstaten van de UNESCO. Behalve in mondiale overeenkomsten is het recht op onderwijs vastgelegd in regionale mensenrechtenverdragen waarbij een groot aantal lidstaten van respectievelijk de Raad van Europa, de Organisatie van Afrikaanse Eenheid en de Organisatie van Amerikaanse Staten partij is. Het belang van het recht op onderwijs in samenhang met de uitbanning van het analfabetisme werd nog eens benadrukt door de Algemene Vergadering van de VN bij de instelling van 1990 als het Internationaal Alfabetiseringsjaar. ${ }^{134} \mathrm{De} \mathrm{AV}$-resolutie spreekt van 'the inalienable right of everyone to education', en erkent dat de uitbanning van analfabetisme een vereiste vormt voor de verzekering van het recht op onderwijs. Er kan, kortom, naar mijn mening weinig twijfel over bestaan dat de formele aanvaarding van het recht op onderwijs door een groot deel van de gemeenschap van staten een feit is.

131. Zie UN Doc. E/C.12/1988/1 voor overzicht van de voorbehouden bij het IVESCR.

132. Zie artikel $1(2)$ sub b UNESCO Constitutie.

139. UNESCO General Conference, 25th Session, Paris 1989, Draft Medium-Term Plan (1990-1995), Doe. $26 \mathrm{C} / 4$, p. 17.

134. AV Res. 42/104 van 7 december 1987. 
Het materiële aspect van het beweerde universele karakter van het recht op onderwijs ziet op de feitelijke verwezenlijking van dit recht, met andere woorden op de implementatie ervan. We hebben gezien dat de verwezenlijking van het recht op onderwijs mede bepaald wordt door de inrichting en organisatie van het nationale onderwijsstelsel. Bovendien is zij afhankelijk van de sociaal-economische ontwikkeling van een land. De vraag in hoeverre de staat zelf actief kan bijdragen tot de implementatie van het recht op onderwijs wordt bepaald door de beschikbaarheid van personele en materiële middelen. Binnen het beschikbare kader moeten prioriteiten gesteld worden. Dát de staat een verplichting heeft zelf actief op te treden vloeit voort uit de verschillende internationale bepalingen. De problemen die zich in een groot deel van de wereld voordioen ten aanzien van de implementatie van het recht op onderwijs geven aan dat wat het materiële aspect betreft zeker nog niet gesproken kan worden van een universeel karakter. Veel overheden, niet uitsluitend in ontwikkelingslanden, bezuinigen op de onderwijsuitgaven met als gevolg dat de kosten worden afgewenteld op ouders en leerlingen. Dit soort beleid heeft een negatieve invloed op de toegankelijkheid van het onderwijs. Sociaal-economische en culturele problemen als kinderarbeid en zwerfkinderen, de achterstand van migranten in urbane gebieden, om maar enkele kwesties te noemen, getuigen van grote tekortkomingen. Als gevolg van kinderarbeid bijvoorbeeld bezoeken kinderen niet of onregelmatig de school. Indien een kind de lessen volgt betekent dat een vermindering van het gezinsinkomen, omdat het dan niet kan werken. Bovendien bestaat in sommige lokale gemeenschappen het geloof dat onderwijs niet veel helpt bij het vinden van een geschikte baan. Daarom komen jonge kinderen vaak meteen al op de arbeidsmarkt terecht, zodat ze wat kunnen verdienen. ${ }^{135}$ Vaak is het alleen mogelijk om scholen voor primair onderwijs in stand te houden, onder meer wegens gebrek aan voldoende gekwalificeerde leerkrachten. Vormen van beroepsonderwijs en ander voortgezet onderwijs hebben dan een lagere prioriteit. Anderzijds zijn er ook landen waar uit prestige-overwegingen alle aandacht wordt gegeven aan instellingen voor hoger onderwijs ten koste van voorzieningen aan de basis. Dit staat duidelijk op gespannen voet met het recht op onderwijs voor iedere burger. Daarnaast komen vormen van actieve discriminatie op grond van taal, geslacht, godsdienst en ras nog steeds voor in het onderwijs. We hoeven alleen maar te verwijzen naar discriminatie van leden van minderheden ${ }^{136}$ en vrouwen. Vormen van passieve discriminatie in het onderwijs, zoals de ondervertegenwoordiging van bepaalde sociale groepen in het hoger onderwijs doen zich juist voor in staten met een hoog ontwikkeld onderwijsstelsel.

135. Zie de ILO studie Combating Child Labour, edited by Assef a Bequele and Jo Bioyden, Geneva 1988, p. 6. Dit boek bevat een aantal landenstudies over kinderarbeid.

136. Het onderwijs voor leden van minderheden moet beantwoorden an hun eigen taal, religie of cultuur. Zie hierover mijn bijdrage, Volkenrechtelijke aspecten van onderwijsrechten van minderheden, in: Nederlands Tijdschrift voor Onderwijarecht, 1990, pp. 5-21. 
Een andere kwestie is dat het onderwijs dient aan te sluiten bij de cultuur van een bepaald land of bepaalde bevolkingsgroep. Het onderwijs moet beantwoorden aan de specifieke situatie en belangen van degenen die het onderwijs volgen alsmede aan de nationale en culturele omstandigheden. Het onderwijssysteem van een voormalig moederland voldoet zeker niet in alle opzichten aan de onderwijsbehoeften van nieuwe staten. Toch is dat nu net hetgeen gebeurde bij de onafhankelijkheid van Afrikaanse staten in de jaren zestig. ${ }^{137}$ Het onderwijs was onvoldoende afgestemd op de lokale situatie, bijvoorbeeld wat betreft de taal. Lokale minderheden moeten primair onderwijs in hun eigen taal kunnen volgen. Daarnaast kan onderwijs in de nationale, officiêle taal, meestal die van de vroegere koloniale mogendheid overwogen worden. In Suriname bijvoorbeeld vindt het onderwijs nog steeds in het Nederlands plaats, terwijl voor geen van de bevolkingsgroepen het Nederlands de moedertaal is. Het gevolg hiervan is onder meer een relatief hoog percentage zittenblijvers. ${ }^{138}$

Ten aanzien van de vrijheid van onderwijs hebben we hierboven reeds gezien dat deze in bepaalde politieke en culturele stelsels niet of in onvoldoende mate gerealiseerd is (Islamitische landen, en vooralsnog de Oosteuropese landen, China, verschillende landen in Afrika).

Afrondend kan gesteld worden dat de materiële verwezenlijking van het recht op onderwijs op verschillende punten nog veel te wensen overlaat. Alleen al het feit dat ongeveer 900 miljoen mensen lezen noch schrijven kunnen laat zien hoever de (internationale) norm en de praktijk van elkaar verwijderd zijn. Wil deze kloof worden overbrugd dan moet het maatschappelijk draagvlak voor de verwezenlijking van het recht op onderwijs worden verbreed. Maatschappelijke organisaties, groepen en gemeenschappen moeten worden betrokken bij de voorbereiding, besluitvorming en uitvoering van het onderwijsbeleid op nationaal, regionaal en plaatselijk niveau. ${ }^{139}$ In concrete termen betekent dit dat ouders, leerkrachten, leerlingen, lokale overheden, dorpsgemeenschappen, bedrijven, religieuze groeperingen en vrijwilligers in dit proces een rol zullen moeten spelen. De afstand tussen 'de staat' en 'het onderwijs' kan verkleind worden door een grotere participatie van de direct betrokkenen. Dit mag er evenwel niet toe leiden dat de staat zich aan zijn verantwoordelijkheden onttrekt. Maar het is duidelijk dat 'partnerships' tussen de staat enerzijds en niet-gouvernementele actoren en de particuliere sector anderzijds veel meer kunnen betekenen voor de verwezenlijking van het recht op onderwijs dan een beleid dat uitsluitend door de centrale overheid wordt vastgesteld en uitgevoerd.

197. Zie J. van Beurden, Afrikaans onderwijs verkeert in een crisis, in: Internationale Samenwerking (uitgave Ministerie van Buitenlandse Zaken, "B-Gravenhage), juli 1990, pp.. 2.5-30.

198. Zie H. Buddingh", Suriname heeft het hoogste onderwijsbudget ter wereld, in: NRC Handelsblad 7 augustus 1990.

139. Vergelijk de 'World Declaration on Education for All", Jomtien, Thailand 9 maart 1990. 


\subsubsection{Recht op onderwijs versus leerplicht}

De Amerikaanse Verklaring inzake de Rechten en Plichten van de Mens uit 1948 bepaalt in artikel XII dat een ieder het recht heeft op kosteloos primair onderwijs. Artikel XXXI voegt daar aan toe dat it is the duty of every person to acquire at least an elementary education'. En artikel XXX bepaalt dat het de plicht is van ouders hun kinderen op te voeden.

De vraag kan gesteld worden hoe het recht op onderwijs als mensenrecht zich verhoudt tot de algemeen aanvaarde leerplicht tot een bepaalde leeftijd. Deze vraag is relevant met betrekking tot het beweerde universele karakter van het recht op onderwijs dan wel de vrijheid van onderwijs. In de literatuur wordt door sommigen de opvatting verkondigd dat het recht op onderwijs geen onvervreemdbaar mensenrecht is omdat het tot (leer)plicht geworden is. Het feit dat een recht verplicht uitgeoefend moet worden zou dan betekenen dat het niet in termen van de klassieke betekenis van de rechten van de mens begrepen kan worden. Dat laatste wil zeggen dat de vrijheid moet bestaan om van de uitoefening van dat recht af te zien. ${ }^{140}$ In de woorden van Kühnhardt:

'Entweder muss, (...), die Schulpflicht als eine Verletzung des Menschenrechts auf Bildung angesehen werden, da sie Bildung zu einem Zwangsinstrument erklärt, oder aber die Schulpflicht wird von ihrer besonderem moralischen Bedeutung befreit, indem sie nicht länger für Menschenrechtsideale in Anspruch genommen und das Bildungsbedürfnis nicht länger als Menschenrecht postuliert wird., ${ }^{, 141}$

Strikt genomen zou men inderdaad vanuit de klassieke gedachte van de rechten van de mens kunnen argumenteren dat het recht op onderwijs ook de vrijheid moet inhouden om van de uitoefening van dat recht af te zien. Daar kunnen evenwel andere overwegingen tegen in gebracht worden die ervoor pleiten dat het recht op onderwijs verenigbaar is met een leerplicht. Enerzijds beoogt de leerplicht te waarborgen dat niemand het kind ervan kan weerhouden onderwijs te volgen. Vanuit dit idee dient de leerplicht als bescherming tegen nadelige invloed van de ouders, het gezin of de staat op de belangen van het kind. Het volgen van onderwijs moet immers worden beschouwd als een bijdrage aan de individuele ontplooiing, en daarmee aan de uitoefening van andere rechten. ${ }^{142}$ De leerplicht kan tevens gelegitimeerd worden vanuit het gelijkheidsbeginsel: de leerplicht beoogt gelijke kansen voor een ieder in het onderwijs en in de maatschappij. Anderzijds kan men betogen dat het een plicht van de ouders en de staat is er zorg voor te dragen dat een kind onderwijs kan volgen. Anders gezegd, de ouders treden op als behartiger van de belangen van het kind, omdat het kind dat

140. Zie L. Kühnhardt, Die Universalitat der Menschenrechte, Munchen 1987, P. 340.

141. Ibid.

142. Vgl. de discussies over dit punt tijdens de totatandkoming van artikel 26 Universele Verklaring, zie hoofdstuk 3.4.4 supra. 
zelf op jonge leeftijd niet kan. Bovendien kan meespelen dat een kind op jonge leeftijd tegen zichzelf in bescherming moet worden genomen.

Als consequentie van het recht op onderwijs heeft de staat de verplichting zorg te dragen voor de beschikbaarheid en de toegankelijkheid van scholen. Dat wil zeggen dat het kind ook feitelijk de mogelijkheid moet hebben onderwijs te voigen indien de staat het tot een bepaalde leef tijd verplicht stelt. De bevoegdheid van de staat het onderwijs verplicht te stellen betekent echter niet dat die staat een monopolie heeft met betrekking tot het onderwijs. De staat kan ouders niet dwingen hun kinderen onderwijs te laten volgen dat in strijd komt met hun religieuze dan wel filosofische overtuigingen. Ouders moeten de mogelijkheid hebben te kiezen tussen openbaar onderwijs en particuliere onderwijsinstellingen. Indien de staat het lager onderwijs verplicht stelt hebben ouders meer dan wie ook het recht het soort van onderwijs te kiezen dat aan hun kinderen zal worden gegeven. ${ }^{143}$ Deze gedachte ligt ten grondslag aan artikel 26 lid 3 Universele Verklaring van de Rechten van de Mens. Een en ander impliceert ook dat tegenover verplicht onderwijs het pluralisme in het openbaar onderwijs gegarandeerd moet zijn. Dat wil zeggen dat het openbaar onderwijs vrij moet zijn van indoctrinatie door de staat. De staat kan verplicht onderwijs invoeren. In het openbaar onderwijs moet dan wel ontheffing mogelijk zijn indien dit onderwijs in conflict komt met de overtuigingen van de ouders of voogden. Het stelsel van verplicht onderwijs impliceert eveneens dat de staat (kwaliteits)eisen kan stellen aan privé-onderwijsinstellingen. Ook indien thuisonderwijs is toegestaan moet dit voldoen aan de door de staat vast te stellen normen.

Ik concludeer dat er goede gronden zijn aan te voeren om het recht op onderwijs te koppelen aan een leerplicht. Het verplicht lager onderwijs bestaat met het oog op de ontwikkeling en vorming van het kind. Deze vorming kan niet alleen in familieverband plaats vinden. In de huidige maatschappij kan een individu zonder schoolopleiding niet of slechts met moeite participeren. Bemoeienis van de staat met de ontplooiing van het land is mijns inziens, onder bepaalde waarborgen, dan ook gerechtvaardigd.

\subsubsection{Het recht op onderwijs als sleutelrecht}

De universele aanspraak van het recht op onderwijs kan verder onderbouwd worden door te wijzen op zijn betekenis als sleutelrecht. Van oorsprong betrof het recht op onderwijs de vrijheid van onderwijs, later ontwikkelde zich de aanspraak op door de staat gefinancierd onderwijs. Het recht op onderwijs zoals dat sedert 1948 in internationale teksten is vastgelegd bezit

143. Zie T. Opsahl, The Convention and the right to respect for family life, particularly as regards the unity of the family and the protection of the rights of parents and guardians. in the education of children, in: A.H. Robertson (ed.), Privacy and Human Rights, Mancheater 1973, pp. 182-255, op p. 230. 
beide aspecten. Veelal wordt dit mensenrecht beschouwd als een sociaal recht, maar in feite heeft het kenmerken van zowel burger- en politieke rechten, als van sociale rechten. Het bijzondere van het recht op onderwijs is dat de eenheid en de onderlinge afhankelijkheid van de rechten van de mens hierin duidelijk tot uitdrukking komen.

Het bijzondere karakter van het recht op onderwijs houdt in dat het gekoppeld is aan andere rechten van de mens. De uitoefening van het recht op onderwijs impliceert in feite een relatie tussen een drietal actoren, namelijk het kind, de ouders of voogden en de staat. Zo is de vrijheid van onderwijs verbonden met de uitoefening van familierechten. Immers, de ouders of voogden hebben de eerste verantwoordelijkheid voor de opvoeding van en het onderwijs aan het kind. Voorts dient de keuze van onderwijs te geschieden in een staatsvrije sfeer, waarbij respect voor het priveleven vereist is. Tevens draagt de vrijheid van onderwijs elementen in zich van de vrijheid van meningsuiting, namelijk de vrijheid van instellingen en personen eigen scholen te stichten en in stand te houden gebaseerd op bepaalde (onderwijskundige) opvattingen. Daarnaast heeft de vrijheid van onderwijs een onmiskenbare verwantschap met de vrijheid van geweten en godsdienst. De mens kiest het soort onderwijs dat in overeenstemming is met zijn godsdienstige of filosof ische overtuigingen. De staat is verplicht die overtuigingen te respecteren.

Ook op een ander vlak vervult het recht op onderwijs een centrale rol. Het heeft het karakter van een zogenaamd 'empowerment right', dat wil zeggen de uitoefening van het recht op onderwijs stelt een persoon in staat het genot van andere rechten te ondervinden. Of, met andere woorden, een 'empowerment right' verschaft de mens controle over zijn eigen levensloop en in het bijzonder controle over de staat. ${ }^{144}$ Een 'empowerment right' als het recht op onderwijs stelt de mens in staat actief deel te nemen aan het maatschappelijk leven. In de woorden van Donnelly en Howard:

'the key to social action in defense of rights, (...) is an educated citizenry, able to spread its ideas and to organize in defense of its rights., ${ }^{145}$

Het kenmerkende van het recht op onderwijs is dat het het karakter heeft van een sleutelrecht. Een aantal burger- en politieke rechten, zoals de vrijheid van meningsuiting, de vrijheid van vereniging en het recht op politieke participatie krijgen pas inhoud en betekenis indien een persoon een opleiding heeft gehad. Het genot van het recht op onderwijs levert een bijdrage aan de individuele ontplooiing en mondigheid. Zo kunnen goed opgeleide en mondige burgers een bedreiging vormen voor een regime dat de

144. Zie J. Donnelly en R.E. Howard, Assessing national human rights performance: a theoretical framework, in: Human Rights Quarterly, Vol. 10 (1988), pp. 214-248, op p. 215. Andere 'empowerment rights' aijn de wrijheid van vereniging en de persvrijheid zie pp. $234-243$.

145. Idem, pp. 234, 235. 
eigen bevolking onderdrukt. Daarom hebben sommige regimes er geen behoefte aan noch belang bij om veel geld en aandacht te besteden aan onderwijs. Een ander punt is dat het voortduren van armoede kan leiden tot ondermijning van democratische structuren. Burgers komen in opstand tegen de bestaande onrechtvaardige sociaal-economische orde. Onderwijs kan ervoor zorgen dat het patroon van individuele armoede doorbroken wordt en aldus op indirecte wijze bijdraagt aan stabiele democratische verhoudingen.

Indien een persoon onderwijs heeft gevolgd ligt deelname aan het culturele leven dichter binnen bereik. Met name voor etnische en linguistische minderheden is het onderwijs onmiskenbaar een middel tot behoud van de eigen culturele identiteit. Voorts heeft een persoon die kan lezen en schrijven een grotere kans maatschappelijk hogerop te komen. Onderwijs bevordert de mobiliteit en biedt mensen de mogelijkheid zich te onttrekken aan discriminatie op grond van maatschappelijke afkomst of sociale status. Tenslotte vormt het (recht op) onderwijs de motor van het economische en sociale ontwikkelingsproces van het land en de gemeenschap. In termen van individuele rechten betekent dit dat onderwijs de verwezenlijking van sociale rechten in sterke mate bevordert. Daarbij valt te denken aan het recht op voedsel: het leren de eigen voedselvoorziening veilig te stellen. Maar ook andere sociale rechten zijn hier in het geding, zoals het recht op arbeid, het recht op een zo goed mogelijke lichamelijke en geestelijke gezondheid en het recht op een behoorlijke levensstandaard. De verwezenlijking van deze rechten komt immers een stuk dichterbij indien een persoon kan lezen en schrijven en daardoor leert in zijn eigen behoeften te voorzien. Kortom, het recht op onderwijs draagt bij tot de verwezenlijking van de kerngedachte van de rechten van de mens, namelijk leven in waardigheid. Deze overwegingen leiden ertoe dat het recht op onderwijs beschouwd moet worden als sleutelrecht, hetgeen zijn universele waarde versterkt.

\subsection{Conclusies}

In dit hoofdstuk werden de reikwijdte en de betekenis van de onderwijsbepaling van het IVESCR geanalyseerd. Ik bepleitte een dynamische interpretatie van artikel 13 jo. artikel 2 lid 1 IVESCR gericht op een effectieve bescherming van het recht op onderwijs. De kracht van het recht op onderwijs is dat het een sleutelrol vervult met betrekking tot de verwezenlijking van andere rechten. Door de uitoefening van het recht op onderwijs komen andere rechten beter binnen het bereik van mensen. Wil het recht op onderwijs ook werkelijk uitgeoefend kunnen worden, dan dient, in volkenrechtelijke zin, de implementatie ervan beschouwd te worden in termen van verplichtingen van staten. Juist artikel 13 jo. artikel 2 lid 1 IVESCR bieden daartoe goede aanknopingspunten. Deze bepalingen hebben het karakter van programma-verplichtingen. Het idee van geleidelijke verwezenlijking dient in het te voeren beleid centraal te staan. Het is dan zaak deze verplichtingen van staten te preciseren in termen van te nemen maatrege- 
len. Niet alle elementen van het recht op onderwijs zijn onderhevig aan geleidelijke verwezenlijking. De vrijheid van onderwijs alsmede de verplichting tot invoering van verplicht en kosteloos primair onderwijs lenen zich voor onmiddellijke toepassing. Bovendien zijn de norm dat niemand het recht op onderwijs mag worden ontzegd en de niet-discriminatoire verwezenlijking van dat recht eveneens onmiddellijk toepasbaar. Deze punten betreffen de minimum kerninhoud van het recht op onderwijs.

De nadere definiëring van verplichtingen van staten is mogelijk met behulp van een typologie van verplichtingen zoals die in paragraaf 3 van dit hoofdstuk gepresenteerd werd. Deze typologie kan bijdragen tot de versterking van het universele karakter van het recht op onderwijs. De nadere uitwerking van verplichtingen geeft immers concreet aan wat van staten mag worden verwacht. Indien bekend is welke concrete maatregelen een staat behoort te nemen worden er stappen gezet om de kloof tussen de norm en de praktijksituatie te overbruggen. Maar dan moeten die maatregelen vervolgens ook worden uitgevoerd. Wil de aanvaarding van het recht op onderwijs door staten niet zonder betekenis en inhoud blijven dan dient een staat (op zijn minst) de minimum kerninhoud van dat recht te verzekeren. Die verplichting geldt ongeacht de financieel-economische situatie waarin een staat verkeert. In het beleid dat de staat voert met betrekking tot de verzekering van die minimum kerninhoud moet het non-discriminatiebeginsel centraal staan. Dat wil zeggen dat geen maatregelen genomen mogen worden waarvan het effect is dat bepaalde (leden van) maatschappelijke, etnische of linguïstische groepen eenzijdig benadeeld worden. Zo mag een staat de toegang tot het beschikbare onderwijs niet enkel voorbehouden aan bepaalde (bevoorrechte) sociale klassen.

Het begrip 'schendingen van economische, sociale en culturele rechten' is nog niet erg helder. Schendingen zijn moeilijk vast te stellen. De Limburg Principles bieden aanknopingspunten dit concept te concretiseren, maar nader onderzoek is zeker nog nodig. Ten aanzien van het recht op onderwijs suggereerde $i k$, in navolging van deze beginselen, dat er sprake kan zijn van een schending van dat recht indien de staat (opzettelijk) de minimum kerninhoud niet naleeft. De criteria die de Limburg Principles geven dienen te worden toegepast op andere rechten uit het IVESCR. Het is verder noodzakelijk dat het sociaal-economisch beleid van staten ook wordt begrepen en gedefinieerd in termen van mensenrechten. Zo moet bijvoorbeeld het feit dat mensen geen of slechts een gebrekkige scholing hebben gehad niet uitsluitend worden beschouwd vanuit een ontwikkelings-economisch perspectief, maar tevens worden opgevat als een belemmering van de uitoefening van het recht op onderwijs. Het beleid van staten kan dan worden getoetst aan de internationale mensenrechtennormen.

De verwezenlijking van het recht op onderwijs is een proces dat van de staat op verschillende terreinen grote inspanningen vereist. Ten einde het genot van het recht op onderwijs aan ieder mens te kunnen garanderen zijn wetgeving en beleid gericht op een non-discriminatoire behandeling niet voldoende. Een staat dient door positieve maatregelen de participatie van 
personen en groepen in het onderwijs te bevorderen en de beschikbaarheid van het onderwijs op verschillende niveaus te verzekeren. De uitwerking van dergelijke positieve maatregelen dient te voldoen aan de normen van artikel 13 en 14 IVESCR. Met een dergelijk beleid krijgt het genot van het recht op onderwijs daadwerkelijk inhoud en betekenis en kan er pas sprake zijn van feitelijke gelijkheid.

Voor veel landen geldt tegenwoordig evenwel dat zij niet (langer) in staat zijn middelen ter beschikking te stellen ten behoeve van die positieve maatregelen. De financieel-economisch gezien problematische situatie waarin veel (ontwikkelings)landen verkeren maakt het voor hen vaak onmogelijk te voldoen aan hun verdragsverplichtingen ten aanzien van de verwezenlijking van economische, sociale en culturele rechten. De aanpassingsprogramma's volgens het recept van het IMF en de Wereldbank die zij noodgedwongen moeten doorvoeren maken bezuinigingen op de overheidsuitgaven noodzakelijk. Dat kan betekenen dat bepaalde uitgaven, bijvoorbeeld voor onderwijs, niet meer door de staat (kunnen) worden gedaan. Het gevolg kan zijn dat de financiering wordt overgelaten aan de onderwijssector zelf: scholen moeten zelf voor de benodigde financiële middelen zorgen. Dat brengt met zich mee dat financiële bijdragen gevraagd moeten worden aan diegenen die onderwijs willen volgen. Met andere woorden, een deel van de kosten voor onderwijs wordt afgewenteld op de privé-sector. ${ }^{146}$ De uitoefening van het recht op onderwijs wordt op deze wijze afhankelijk van de financiële draagkracht van het individu of het gezin. Dit staat op gespannen voet met de aard van de rechten van de mens, namelijk dat zij aan een ieder toekomen zonder discriminatie op grond van maatschappelijke of andere status. ${ }^{147}$

Tomuschat heeft erop gewezen dat de praktijk in de voormalige communistische Oosteuropese staten heeft getoond dat van de staat niet alle heil verwacht mag worden. Hij meent dat de staat zich moet beperken tot het garanderen van bepaalde algemene randvoorwaarden die de maatschappelijke groeperingen de gelegenheid bieden op eigen initiatief in bepaalde behoeften te voorzien. Hij is van oordeel dat het IVESCR teveel belooft, omdat het aan een ieder rechten toekent. ${ }^{148} \mathrm{Ik}$ ben het eens met zijn conclusie dat de staat zich in eerste instantie moet richten op de positie van kwetsbare groepen die zonder hulp van de staat een menswaardig bestaan moeten ontberen. ${ }^{149}$ De staat mag zijn verantwoordelijkheden dan ook niet

146. Vgl. bijvoorbeeld het rapport van de Wereldbank uit 1988 , Education in Sub-Saharan Africe.

147. Zie K. Tomasevski, The World Bank and Human Righte, in: M. Nowak en Th. Swinehart, Human Rights in Developing Countries, 1989 Yearbook, Kehl/Strassbourg 1989, pp. $75-102$, op pp. $98,99$.

148. Zie C. Tomuschat, Bewahrung, Stärkung, Ausgestaltung; Zur künftigen Menschenrechtapolitik Deutschlands in der Weltorganisation, in: Vereinte Nationen 1991-1, pp. 6-11, op pp. 9 en 10.

149. Idem, p. 10. 
ontlopen met het argument dat rechten niet gehonoreerd kunnen worden, omdat realisering ervan teveel geld zou kosten. Wel kunnen 'partnerships' tussen de staat en niet-gouvernementele actoren bevorderlijk zijn voor de realisering van het recht op onderwijs. Daarbij valt te denken aan participatie van niet-gouvernementele actoren bij de beleidsvoorbereiding en uitvoering op plaatselijk en regionaal niveau, waardoor de doelmatigheid van het beleid kan worden vergroot.

Verdragen worden gesloten tussen staten waarbij deze verplichtingen aangaan ten opzichte van elkaar. Er zijn nu bijna 100 staten partij bij het IVESCR. Het is de vraag of staten in voldoende mate beseffen dat zij verdragsverplichtingen zijn aangegaan die een grote invloed (kunnen) hebben op het nationale sociaal-economisch beleid met vergaande financiële implicaties. ${ }^{150}$ Met andere woorden, het feit dat een staat partij is moet serieus worden opgevat in het besef dat de verdragsverplichtingen ook in tijden van financiële beperkingen overeind blijven. Indien een staat prioriteiten moet stellen, als gevolg van financieel-economische tegenslag, behoren de verdragsverplichtingen te fungeren als richtsnoer voor beleid. Dat wil zeggen dat deze verplichtingen expliciet in de beleidsafweging een rol moeten spelen. ${ }^{151}$

150. Zie hierover L. Henkin, International Law: Politics, Values and Functions, in: Recueil dea Cours de l'Académie de Droit International de La Haye, Tomé 216 (1989-IV), p. 238. Henkin noemt een aantal mogelijke redenen waarom staten partij worden bij het IVESCR: 'Perhaps States committed to such rights programmes at home are willing to commit themselves internationally so as to derive international kudos and other" benefits. Perhaps adherence to this Covenant in particular serves as a manifesto and a promise to the State's own people. Perhaps it is a banner identifying that State with a political-economic ideology both domestically and within the international system' (p. 238).

151. Zie de bespreking van dit aspect in hoofdstuk 2.6 .5 supra. 


\title{
HOOFDSTUK 6
}

\author{
Verbetering van het internationale toezicht \\ op de verwezenlijking van het recht op onderwijs
}

\subsection{Algemeen}

Dit hoofdstuk is gewijd aan mogelijkheden tot verbetering van het internationale toezicht op de verwezenlijking van het recht op onderwijs. De hier te bespreken suggesties hebben betrekking op de supervisie van de rechten uit het IVESCR. In deze internationale implementatieprocedure spelen staten en het Comité inzake Economische Sociale en Culturele Rechten (hierna het Comite) de hoofdrol. Daarnaast is de participatie van gespecialiseerde organisaties noodzakelijk ten einde het toezicht op de naleving van de IVESCR normen een daadwerkelijke inhoud en betekenis te geven.

Verschillende aspecten van het internationale toezicht op de verwezenlijking van het recht op onderwijs komen aan bod. In paragraaf 2 worden enige voorstellen gedaan voor de wijze waarop de rapportage over het recht op onderwijs door staten kan worden verbeterd. Daarbij wordt onder meer ingegaan op de rol van de richtlijnen ('guidelines') aan de hand waarvan staten rapporten dienen op te stellen. In de derde paragraaf komt de rol van de UNESCO in de internationale supervisieprocedure aangaande het recht op onderwijs aan de orde. Voortbouwend op de participatie van de ILO in de internationale implementatieprocedure van het IVESCR wordt aangegeven hoe de betrokkenheid van de UNESCO bij het IVESCR kan worden versterkt. De rol van niet-gouvernementele organisaties in de IVESCR implementatieprocedure is tot nog toe beperkt geweest. In de vierde paragraaf volgen enkele suggesties hoe niet-gouvernementele organisaties een bijdrage kunnen leveren aan het internationale toezicht op de naleving van economische, sociale en culturele rechten, in het bijzonder het recht op onderwijs. In de vijfde paragraaf worden enkele aanbevelingen gedaan met betrekking tot de taak van het Comité ten aanzien van de bestudering van statenrapporten. In het bijzonder de rol van kwantitatieve indicatoren bij het bepalen van vooruitgang dan wel achteruitgang inzake de verwezenlijking van het recht op onderwijs wordt belicht. Dit hoofdstuk besluit met de vraag op welke wijze een individu een vermeende schending van het recht op onderwijs op het internationale niveau aan de kaak kan stellen.

\subsection{Het opstellen van statenrapporten}

Het internationale toezicht op de naleving van het recht op onderwijs vindt hoofdzakelijk plaats door middel van statenrapporten. Staten rapporteren 
periodiek over de stand van zaken met betrekking tot de verwezenlijking van het recht op onderwijs. We hebben gezien dat het IVESCR een belangrijke internationale overeenkomst is op grond waarvan staten behoren te rapporteren over de nationale implementatie van het recht op onderwijs. ${ }^{1}$ Sedert 1987 functioneert het Comité inzake Economische, Sociale en Culturele Rechten dat toeziet op de naleving van economische, sociale en culturele rechten in de afzonderlijke partijstaten. De ervaring met statenrapporten over economische, sociale en culturele rechten heeft geleerd dat deze rapporten nogal legalistisch van opzet zijn, vaak in onvoldoende mate de werkelijke situatie weergeven, en nogal oppervlakkig van inhoud zijn. Deze kwalificaties zijn meestal ook van toepassing op de rapportage over het recht op onderwijs. De vraag doet zich voor op welke wijze de internationale implementatie van het recht op onderwijs verbeterd kan worden. Het Comité inzake Economische, Sociale en Culturele Rechten heeft inmiddels enkele aanzetten tot verbetering gedaan. Ik wil hier een aantal specifieke suggesties aan toevoegen gericht op kwalitatief betere statenrapporten inzake het recht op onderwijs.

De rapportageverplichting heeft o.a. als doel dat een staat, op nationaal niveau, kritisch onderzoekt of de nationale wetgeving, regels en procedures in overeenstemming zijn met de normen uit het Verdrag. Ook de praktijk dient te voldoen aan de bepalingen uit het Verdrag. Dit onderzoek dient te worden uitgevoerd door de ministeries die het meest vertrouwd zijn met de materiële rechten, i.c. het ministerie dat onderwijszaken in zijn takenpakket heeft. ${ }^{2}$ Daar behoort immers de vereiste kennis aanwezig te zijn om de nationale context te beoordelen in het licht van de internationale normen. Het opstellen van een statenrapport biedt de nationale instanties de gelegenheid het gevoerde en te voeren beleid kritisch te beschouwen in het licht van de verdragsnormen. In dit verband dient te worden nagegaan welke prioriteiten er gesteld zijn c.q. gesteld moeten worden. Een voorbeeld is artikel 14 IVESCR dat een prioriteit aangeeft voor het opstellen van een plan ter verwezenlijking van kosteloos en verplicht primair onderwijs voor een ieder. Rapportage dient ertoe bij te dragen dat staten bij het ontwikkelen van beleid voor een bepaalde sociaall-economische sector rekening houden met de verplichtingen die men in internationaal verband is aangegaan. Rapportage kan ertoe leiden dat staten situaties op nationaal niveau signaleren die een belemmering betekenen voor de volledige verwezenlijking van het recht op onderwijs. Over gerezen problemen bij implementatie dienen sta-

\section{Zie hoofdstuk 4.4 supra.}

2. Zie General Comment no. 1 (1989) van het Comité inzake Economische, Sociale en Culturele Rechten dat handelt over het rapporteren door partijstaten, zie UN Doc. E/1989/22, Committee on Economic, Social and Cultural Rights, Report on the Third Session, Annex III. Zie voorts over de doeleinden van de rapportageverplichting, $\mathrm{Ph}$. Alston, The purposes of reporting, in: Manual on Human Rights Reporting, United Nations, New York 1991, pp. 13-17. 
ten gedetailleerd te rapporteren. ${ }^{3}$ Met behulp van deze informatie krijgt het toezichthoudende orgaan een beter inzicht in de gemeenschappelijke dan wel specifieke factoren die een volledige verwezenlijking van het recht op onderwijs in de afzonderlijke staten bevorderen, dan wel belemmeren.

Het opstellen van rapporten ten behoeve van bestudering door het Comité inzake Economische, Sociale en Culturele Rechten wordt meestal gecoördineerd door het Ministerie van Buitenlandse Zaken. Voor een diepgaand en gedetailleerd rapport is een bijdrage van vakministeries onontbeerlijk. Ten einde een zinvolle bijdrage te leveren aan de rapportageprocedure is het noodzakelijk dat ambtenaren van de vakministeries goed op de hoogte zijn van het doel van het rapportagestelsel. $\mathrm{Zij}$ dienen vertrouwd te zijn met de wijze waarop de rapporten moeten worden opgesteld, dat will zeggen aan de hand van richtlijnen van het Comitê. Bovendien is het van groot belang dat bijvoorbeeld ambtenaren, van het ministerie dat met onderwijskwesties belast is, zich bewust zijn van het belang van de internationale verplichtingen die een staat op het terrein van de mensenrechten is aangegaan. $\mathrm{Zij}$ zouden daartoe enige scholing moeten ontvangen, opdat zij op de hoogte zijn van de specifieke informatie die in een statenrapport behoort te worden opgenomen. In het kader van het VN 'Advisory Services' programma op het terrein van de rechten van de mens heeft in het verleden al een aantal regionale trainingscursussen plaats gevonden voor ambtenaren belast met de voorbereiding en het opstellen van periodieke statenrapporten. Deze bijeenkomsten werden gehouden in Costa Rica (voor de Spaanstalige landen in Midden-Amerika en het Caribisch gebied, 1987), Senegal (voor de Franssprekende Afrikaanse landen, 1986), Manila (voor de landen in Azië, 1986) en Zambia (voor de Engelstalige Afrikaanse landen, 1987). Ten einde het ambtenarenapparaat van verdragsstaten te scholen in de wijze van rapporteren heeft de VN bovendien recentelijk een handboek uitgebracht over rapportageprocedures ingevolge zes belangrijke mensenrechtenverdragen. ${ }^{4}$

Een schaduwzijde van het stelsel van statenrapporten is dat de veelheid aan rapportageprocedures over economische, sociale en culturele rechten de staten, in het bijzonder de vakministeries, boven het hoofd dreigt te groeien. Dan rijst de vraag of die rapportageprocedures nog wel te overzien zijn en door staten voldoende serieus worden genomen. Indien een staat partij is bij bijvoorbeeld het IVESCR, het UNESCO Verdrag tot Bestrijding van Discriminatie in het Onderwijs, het Verdrag tot Uitbanning van alle Vormen van Discriminatie van Vrouwen en de Conventie inzake de Rechten van

3: Vergelijk artikel 17 lid 2 IVESCR: 'Reports may indicate factors and difficulties affecting the degree of fulfilment of obligations under the present Covenant".

4. Zie United Nations Centre for Human Rights and United Nations Institute for Training and Research (UNITAR), Manual on Human Rights Reporting under six major international human righte instruments, New York 1991 (UN Sales no. E.91.XIV.I). 
het Kind wordt het rapportageproces een grote belasting, en zullen sommige staten hun rapportageverplichtingen niet langer (kunnen) nakomen. ${ }^{5}$

Het op elkaar afstemmen van de richtlijnen voor statenrapporten zou die belasting kunnen verminderen, in die zin dat staten bij de rapportage over dezelfde rechten ingevolge verschillende verdragen hetzelfde soort informatie (al dan niet bijgewerkt) kunnen verstrekken. In dit verband bepaalt artikel 17(3) IVESCR al dat indien staten reeds eerder relevante gegevens hebben verstrekt aan de $\mathrm{VN}$ of aan een gespecialiseerde organisatie het niet nodig is deze informatie nogmaals te verstrekken, maar dat dan kan worden volstaan met een nauwkeurige verwijzing naar die gegevens.

Het opstellen en indienen van een rapport behoort tot de bevoegdheden van de regeringen van de partijstaten bij het IVESCR. Het Verdrag voorziet niet in een rol voor andere actoren zoals niet-gouvernementele organisaties. In het kader van de verdragen van de Internationale Arbeidsorganisatie (ILO) is, dankzij de tripartite structuur van deze organisatie, wel een rol weggelegd voor organisaties van werkgevers en werknemers. Deze kunnen het rapport van een staat van commentaar voorzien. Dit commentaar wordt samen met het rapport aan de ILO gezonden. ${ }^{6}$ Het Europees Sociaal Handvest kent een soortgelijke mogelijkheid tot participatie van belangengroeperingen. ${ }^{7}$ Ten aanzien van de rapportage over de materiële bepalingen van het IVESCR is het gewenst dat bepaalde belangengroeperingen worden betrokken bij het opstellen van een rapport, en dat reeds in een vroeg stadium. Zo zou het een goede zaak zijn indien ten aanzien van het recht op onderwijs organisaties van bijvoorbeeld onderwijsgevenden, studentenorganisaties, alsmede overkoepelende organisaties van niet-openbare onderwijsinstellingen de gelegenheid worden geboden het ontwerp-rapport van

5. Zie over dit probleem de studie van $\mathrm{Ph}$. Alston "geschreven in opdracht van dle Secretaris-Generaal van de VN, getiteld Effective Implementation of International Instruments on Human Rights, including reporting obligations under International Instru ments on Human Rights, UN Doc. A/44/668 van 8 nov. 1989, par. 36-42.

6. Vergelijk ILO Verdrag no. 144.

In 1989 rapporteerde Nederland over de naleving van de artikelen 6-9 IVESCR. De vakbonden waren toen niet te spreken over het feit dat gij door het Nederlandse Ministerie van Buitenlandse Zaken niet waren betrokken bij het opotellen van het rapport. Het rapport $\mathrm{kw}$ am voor hen als een volslagen verrassing. Zij vroegen gich of wat de waarde van het Nederlandse rapport kon zijn als de vakbeweging geen inbreng had. Formeel gezien behoefde het Ministerie van Buitenlandae Zaken vakbonden niet te informeren over de rapportageprocedure. Men kan zich echter afvragen of het betrekken van de vakbeweging (evenals de werkgevers) niet wenselijk zou zijn geweest gezien de samenwerking tussen de drie partners die noodzakelijk is om de (arbeids)doelstellingen uit het Verdrag te verwezenlijken. Bovendien is er in het kader van ILO verdragen en het $\mathrm{ESH}$ wel aprake van die participatie. Zie over deze kwestie, $\mathrm{H}$. de Vrey, Vakbonden furieus over verzwijgen van Nederlands rapport voor VN, in: Trouw, 10-2-1989 en J.F.R. Jansen, Prietpraat vakbonden over 'verzwijgen' rapport mengenrechten, in: Trouw, 28-2-1989.

7. Vergelijk artikell 23 ESH. Zie over het toezicht op de naleving wan ESH bepalingen, 1 . Boerefijn, A.W. Heringa, J.G.C. Schokkenbroek, Verbetering van het toezichtmechanisme van het Europees Sociaal Handvest, in: NJCM-Bulletin 16-5 (1991), pp. 396411. 
een staat van commentaar te voorzien. Dit commentaar zou ook als afzonderlijk document aan het Comité inzake Economische, Sociale en Culturele Rechten gezonden moeten worden. Zo wordt bereikt dat de materiële rechten uit het Verdrag onderwerp worden van een publieke discussie. Op deze wijze kunnen belangenorganisaties bijdragen aan de ontwikkeling van het onderwijsbeleid mede in relatie tot de relevante bepalingen uit het IVESCR ${ }^{8}$.

De oude richtlijnen ten behoeve van de rapportage over de implementatie van de artikelen 13,14 IVESCR waren nogal eenzijdig gericht op regelgeving ter verwezenlijking van het recht op onderwijs ${ }^{9}$. In mindere mate vroegen zij naar de verwezenlijking van het recht op onderwijs in de praktijk. Evenmin was er veel aandacht voor gerezen problemen en moeilijkheden die daarbij werden ondervonden.

Het Comité inzake Economische, Sociale en Culturele Rechten heeft in de afgelopen jaren de oorspronkelijke richtlijnen herzien. Tijdens de vijfde zitting van het Comité in december 1990 werden de nieuwe richtlijnen aanvaard. ${ }^{10}$ De hierna volgende uiteenzetting over de richtlijnen ten behoeve van de rapportage over artikel 13 IVESCR is mede gebaseerd op de herziene versie van die richtlijnen. De belangrijkste wijziging is dat de nieuwe richtlijnen meer zijn toegespitst op de praktijksituatie met betrekking tot de verwezenlijking van economische, sociale en culturele rechten. Met behulp van de nieuwe richtlijnen wordt het voor de vakministeries duidelijker welke specifieke informatie van hen gevraagd wordt. Ten einde te kunnen beoordelen of er sprake is van vooruitgang bij de verwezenlijking van de materiële rechten is het noodzakelijk dat het rapport specifieke doeleinden van beleid aangeeft, die de criteria definiëren voor de verwezenlijking van de afzonderlijke rechten. Het Comite is dan in de gelegenheid de bestaande situatie in een land te toetsen aan de door de staat zelf opgestelde doeleinden. ${ }^{11}$ Ten aanzien van het recht op onderwijs kunnen als doeleinden van beleid worden genoemd de beschikbaarheid van verplicht en kosteloos primair onderwijs voor een ieder of het streven het analfabetisme in een land volledig uit te bannen. Ook valt te denken aan het bevorderen van de toegankelijkheid van het middelbaar en hoger onderwijs door het wegnemen van financiële belemmeringen voor scholieren en studenten. Dat kan bijvoorbeeld door deze vormen van onderwijs in toenemende mate kosteloos te maken of scholieren en studenten te voorzien van passende beurzen of andere financiële toelagen. Op deze wijze kan worden

8. Vergelijk de Lumburg Principles, a.w. nr. 76, 77, alsmede Generall Comment no. 1 van het Comité inzake Economische, Sociale en Culturele Rechten, a.w. par. 5.

9. Zie de oude richtlijnen ten behoeve van de rapportage over de artikelen 19 en 14 IVESCR in UN Doc. E/1988/5.

10. De thereiene richtlijnen zijn onder meer gepubliceerd in de bijdrage van Alston over het IVESCR in de Manual on Human Rights Reporting, a.w. pp. 39-79. Voorts zijn gepubliceerd in UN Doc. E/C.12/1991/1, en in UN Doc. E/1991/23, Annex IV.

11. Het Comité inzake Economiache, Sociale en Culturele Rechten spreekt in dit verband van 'bench-marks', zie General Comment no. 1 (1989), a.w. par. 6. 
bereikt dat scholieren en studenten uit alle lagen van de bevolking en maatschappelijke groeperingen deel kunnen nemen aan het onderwijs. Indien de doeleinden die de staat zelf opstelt, in het rapport worden vermeld kan het toezichthoudende orgaan bepalen of voortgang ten aanzien van de verwezenlijking van het recht op onderwijs heeft plaats gevonden. De grondslag voor de doeleinden die de staat zichzelf stelt ligt naturlijk steeds in de materiële bepalingen van het IVESCR.

De richtlijnen voor de rapportage over het recht op onderwijs besteden bijzondere aandacht aan de positie van kwetsbare en weinig geprivilegieerde maatschappelijke groepen. Daarbij valt te denken aan vrouwen, immigranten, gehandicapten, leden van etnische, religieuze of lingüstische minderheden en kinderen uit lage inkomensgroepen. Speciale aandacht dient er ook te zijn voor kinderen woonachtig in afgelegen gebieden en kinderen behorend tot inheemse volken. Het lot van zwerfkinderen en van kinderen in oorlogssituaties dient daarbij eveneens betrokken te worden. De staat dient in zijn rapport op concrete wijze aan te geven welke specifieke maatregelen genomen zijn om gelijke kansen en een gelijke behandeling van deze groepen in het onderwijs te bevorderen. Het recht op onderwijs voor deze achtergestelde groepen wordt immers pas tot realiteit indien de staat door middel van positieve maatregelen daartoe de voorwaarden schept. Het aangeven van deze specifieke maatregelen in het rapport moet niet beperkt worden tot de verwezenlijking van verplicht en kosteloos primair onderwijs. Ook voor andere geledingen in het onderwijs dient de staat concreet aan te geven welke maatregelen hij genomen heeft om leerlingen en studenten die in een achterstand positie verkeren te helpen. Ten einde deze maatregelen in het rapport op een heldere wijze aan te geven is het opnemen van relevant, bijgewerkt statistisch materiaal van groot belang. De verwezenlijking van het recht op onderwijs voor bijzondere groepen uit de bevolking of in bepaalde regio's wordt pas goed zichtbaar indien statistisch materiaal wordt gepresenteerd dat onderling vergelijkbaar is en dat bepaalde ontwikkelingen of trends, positieve dan wel negatieve, over een reeks van jaren laat zien. Relevante gegevens kunnen bijvoorbeeld betrekking hebben op het aantal ingeschreven leerlingen per schoolsoort met een onderverdeling naar meisjes en jongens, of de verhouding tussen van staatswege voorzien onderwijs en vormen van particulier onderwijs per schoolsoort. Van belang is eveneens een overzicht van het aantal onderwijsgevenden, onderverdeeld per schooltype. Verder is relevant het aantal onderwijsinstellingen per regio, onderverdeeld naar schooltype, mede in verhouding tot het aantal inwoners per regio. Voorts kunnen de rapporten ingaan op het feitelijk percentage aan het onderwijs deelnemende leerlingen in verhouding tot het aantal ingeschreven leerlingen. Wat betreft het analfabetisme is een verdeling tussen aantallen mannen en vrouwen relevant, alsmede naar leeftijd, naar sociaal-economische af komst en naar regio. Het rapport kan ook aandacht besteden aan de toekenning van beurzen en andere vormen van financiële steun, uitgesplitst naar geleding van het onderwijs en naar sociaal-economische afkomst van de leerling of student. Financiële gegevens kunnen betrekking hebben op de totale uitgaven voor 
het onderwijs als percentage van het Bruto Nationaal Produkt. Ook kan worden gevraagd naar de totale uitgaven voor het onderwijs als percentage van de totale overheidsuitgaven.

Ten aanzien van de vrijheid van onderwijs zijn de herziene richtlijnen mijns inziens nog onvoldoende. Gevraagd wordt slechts welk gedeelte van het onderwijs niet beheerd en bestuurd wordt door de overheid. En voorts of er knelpunten bestaan met betrekking tot de stichting van of de toegang tot privé-scholen. De rapporten zouden ook moeten ingaan op de (wettelijke) voorwaarden voor stichting van niet-openbare scholen en de financiering van dergelijke instellingen. Bovendien zouden staten in hun rapporten moeten aangeven of er bijzondere faciliteiten bestaan voor de stichting van scholen door en voor minderheden. Daarnaast zouden de rapporten aandacht dienen te besteden aan de organisatie van het godsdienst- dan wel levensbeschouwelijk onderwijs op scholen, alsmede de mogelijkheden tot vrijstelling van dat onderwijs. Natuurlijk moet niet slechts gerapporteerd over de regelgeving ten aanzien van deze onderwerpen, maar ook over de praktijksituatie.

Het is dus zaak dat een staat gedetailleerd rapporteert over gerezen problemen bij de verwezenlijking van het recht op onderwijs. Zo zou de staat aandacht moeten besteden aan de invloed van eventuele financiële aanpassingsprogramma's, gesloten in het kader van overeenkomsten met IMF en Wereldbank, op het bestaande en toekomstige niveau en kwaliteit van onderwijsvoorzieningen. Tot slot dienen de rapporten over het recht op onderwijs in te gaan op het gebruik van rechtsmiddelen en procedures om elementen van dit recht voor een nationale rechter af te dwingen. ${ }^{12}$

\subsection{De rol van de inter-gouvernementele organisaties, in het bijzonder de UNESCO en de ILO}

Krachtens artikel 18 IVESCR kunnen gespecialiseerde organisaties aan ECOSOC rapporteren over de verwezenlijking van do IVESCR normen die binnen het kader van hun werkzaamheden vallen. Daarmee vervullen zij een functie in de internationale implementatieprocedure van dit Verdrag.

De rol van de gespecialiseerde organisaties bij het internationale toezicht op de verwezenlijking van economische, sociale en culturele rechten volgens de IVESCR normen is in het verleden nogal beperkt van aard en inhoud geweest. ${ }^{19}$ Met uitzondering van de ILO hebben gespecialiseerde

12. Zie ook de Limburg Principles, a.w. nr. 78.

13. Enige achtergronden over de (potentiêle) rol van gespecialiseerde organisaties in de IVESCR internationale implementatie-procedure geeft $\mathrm{Ph}$. Alston in xijn artikel, The United Nations' Sperialized Agencies and Implementation of the International Covenant on Economic, Social and Cultural Rights, in: Columbia Journal of Transnational Law, vol. 18 (1979), pp. 79-118. 
organisaties als de FAO en de WHO slechts weinig of geen interesse getoond voor een actieve participatie in de internationale implementatieprocedure van economische, sociale en culturele rechten. ${ }^{14}$ Ook de UNESCO heeft een weinig opvallende rol op dit gebied gespeeld. De rapporten die de UNESCO produceerde over de verwezenlijking van onderwijsrechten en culturele rechten ten behoeve van de IVESCR rapportage waren hoofdzakelijk gewijd aan de juridische teksten die in UNESCO-verband door lidstaten waren aanvaard. ${ }^{15}$ Daarnaast bevatten zij informatie over de verwezenlijking van het recht op onderwijs in de staten die de Conventie tot Bestrijding van Discriminatie in het Onderwijs bekrachtigd hadden. De UNESCO rapporten bevatten eigenlijk niet meer dan een samenvatting van enige algemene trends en ontwikkelingen die het UNESCO Committee on Conventions and Recommendations op grond van deze informatie vaststelde. Deze informatie was niet toegespitst op de specifieke bepalingen van het IVESCR. Het betrof meer een compilatie van reeds uit andere bronnen beschikbare gegevens. Om een beeld te krijgen van de daadwerkelijke verwezenlijking van het recht op onderwijs in afzonderlijke landen was de waarde van deze gegevens dan ook betrekkelijk gering. Het gevolg was dat de UNESCO rapporten geen of nauwelijks een rol speelden bij de bespreking van statenrapporten door de 'Sessional Working Group of Governmental Experts' die tot 1985 belast was met het toezicht op de naleving van de IVESCR-bepalingen. Vanuit het oogpunt van de rol en de verantwoordelijkheid van de UNESCO ten aanzien van de verwezenlijking van het recht op onderwijs was haar participatie in de IVESCR implementatieprocedure beslist onvoldoende en onbevredigend. De precieze redenen voor de passieve participatie van met name FAO en in mindere mate de UNESCO en de WHO in de IVESCR implementatieprocedure zijn moeilijk te traceren. Alston suggereert als mogelijke verklaring:

'a lack of appreciation of the importance of the Covenant, a fear that involvement in human rights matters will bring unwanted politicization, an inability to understand the concept of economic rights (or) a concern to protect agency jurisdiction'. ${ }^{16}$

14. Zie Alston, Out of the Abyss, a.w. p. 367.

15. De UNESCO rapporten ingevolge de internationale implementatiebepalingen van het IVESCR zijn gepubliceerd als UN Doc. E/1982/10 (25-2-1982), E/1988/7 (6-1 1988 ) en $E / 1990 / 8(1-12-1989)$. Zie over de rol van de UNESCO in dit verband $A$. Glenn Mower Jr., International Cooperation for Social Justice, Westport 1985, pp. 115-123.

16. Alston, Out of the Abyss, a.w. p. 367, Zie ook de opmerkingen van D.D. Fischer, International Reporting Procedures, in: H. Hannum (ed.), Guide to International Human Right Practice, London 1984, Pp. 165-186, op p. 176: 'With the exception of the ILO, other UN specialized agencies are intergovernmental structurea ultimately subject to the wishes of their constituent governments, so it is perhaps not surpriaing that they have not yet contributed to implementation of the Covenant's reporting aystem. Officials of the agencies know there would be strong resistance if they tried to force the isaue'. 
Een belangrijke politieke factor is bovendien dat sommige (Oosteuropese) leden van de 'Sessional Working Group' de bespreking van de rapporten van gespecialiseerde organisaties probeerden tegen te houden en zelfs het spreekrecht van vertegenwoordigers van die organisaties trachten te ontkennen. Deze leden beschouwden de bemoeienis van de gespecialiseerde organisaties met de verwezenlijking van economische sociale en culturele rechten als een vorm van inmenging in de interne aangelegenheden van staten. Duidelijk was dat daarmee vooral gedoeld werd op de naleving van internationale arbeidsnormen en vakbondsrechten in Oosteuropese landen waarvoor de ILO zich sterk maakte. ${ }^{17}$ De weinig succesvolle participatie van gespecialiseerde organisaties in de internationale implementatieprocedure van economische, sociale en culturele rechten was derhalve deels te wijten aan de opstelling van de organisaties zelf. Voor een ander deel moet de oorzaak worden gezocht in overwegingen van politieke aard die hun grondslag vonden in verschillen van opvatting binnen het toezichthoudende orgaan.

In het voorafgaande is de rol van de ILO al enige malen aan de orde geweest. Hier zal zij verder worden belicht, omdat de wijze waarop de ILO rapporteert aan het Comitê inzake Economische, Sociale en Culturele Rechten als voorbeeld kan dienen voor andere gespecialiseerde organisaties, in het bijzonder de UNESCO. De ILO produceerde sedert 1978 meer dan tien IVESCR-rapporten die gekenmerkt werden door hun gedetailleerd karakter en duidelijke stellingnamen. ${ }^{18}$ De $\mathrm{ILO}$ rapporten werden opgesteld door het onafhankelijke Committee of Experts on the Application of Conventions and Recommendations. $\mathrm{Zij}$ zijn gebaseerd op de informatie die lidstaten van de ILO aanleveren over de toepassing van ILO verdragen en aanbevelingen in die staten. Daarnaast maakt het Comité van Deskundigen ook gebruik van de rapporten die staten indienen ingevolge de IVESCR-verplichtingen. Bovendien benut het ILO Comité de inlichtingen die verzameld zijn door ILO onderzoeksmissies of het materiaal afkomstig van andere ILO-organen zoals het 'Committee on the Freedom of Association'. Het Comite van Deskundigen houdt ook rekening met het commentaar dat organisaties van werkgevers en werknemers leveren op rapporten van ILO lidstaten.

Een rapport van de ILO ingevolge artikel 18 IVESCR handelt aver de staten waarvan de rapporten in een bepaald jaar besproken zullen worden door het Comité inzake Economische, Sociale en Culturele Rechten. Het geeft per IVESCR-bepaling aan welke relevante ILO Conventies een staat bekrachtigd heeft. Dit ILO rapport geeft verder informatie over de verwezenlijking van de relevante IVESCR arbeidsnormen in de besproken lan-

17. Alston, Out of the Abyrs, a.w. pp. 365-367. Zie het verslag van de discussies in de Sessional Working Group, UN Doc. E/1979/WG.1/SR.3 par. 21; E/1979/WG.1/SR.4 par $4,5,14,16,17 ; \mathrm{E} / 1979 / 64$, par. 16-18; E/1980/WG.1/SR.4, par. 43-47 en 66$57 ; \mathrm{E} / 1980 / \mathrm{WG} .1 / \mathrm{SR} .5$, par. $10-17$ on $51-58$.

18. Zie bijv. het eerste rapport van de ILO, UN Doc. E/1978/27 (6 april 1978) en het twaalfde rapport, UN Doc. E/1990/9 (30 november 1989). De hierna volgende uiteenzetting is hoofdzakelijk gebaseerd op deze twee rapporten. 
den. Het Comité van Deskundigen maakt in dat verband opmerkingen over zowel de implementatie van de internationale arbeidsnormen in het nationale recht als over de praktijksituatie. Het ILO Comité doet verder suggesties voor aanvullende maatregelen indien bijvoorbeeld de nationale wetgeving achterblijft bij de internationale norm. Het ILO Comité verwijst bovendien vaak naar het verzoek om aanvullende informatie over wetgeving, wetsvoorstellen of de praktijksituatie dat het reeds in een eerder stadium aan de betreffende staat heeft gedaan. Tensiotte verwijst het Comite van Deskundigen, indien noodzakelijk, naar het commentaar van niet-gouvernementele organisaties, bijvoorbeeld vakbonden, op het beleid van staten. In vergelijking met de door UNESCO vervaardigde rapporten zijn die van de ILO inhoudelijk uitgebreider en concreter. Bovendien geven zij informatie per land die vaak gedetailleerd van aard is. $\mathrm{Zij}$ vormen een belangrijk hulpmiddel voor het toezichthoudende orgaan bij de beoordeling van de verwezenlijking van economische en sociale rechten in afzonderlijke landen. De specifieke gegevens in ILO-rapporten stellen het Comité inzake Economische, Sociale en Culturele Rechten in staat beter de waarde en betrouwbaarheid van de informatie in rapporten van staten te beoordelen. Met andere woorden, de methodiek van de ILO rapporten vormt naar mijn opvatting een goed voorbeeld voor de toekomstige rapporten van andere gespecialiseerde organisaties aan het Comité inzake Economische Sociale en Culturele Rechten. De potentieel belangrijke rol die gespecialiseerde organisaties toekomt werd reeds in een vroegtijdig stadium onderkend door Jenks. Hij was van mening dat de gespecialiseerde organisaties 'are the executing agencies of the Covenant with a major share of the responsibility for its effective implementation." 19 Inderdaad kunnen economische, sociale en culturele rechten vaak slechts door een collectieve inspanning verwezenlijkt worden, dat wil zeggen, door middel van internationale samenwerking waarbij de gespecialiseerde organisaties een vooraanstaande rol spelen. Het Comité inzake Economische, Sociale en Culturele Rechten heeft in een 'general comment' het belang onderstreept van een grotere betrokkenheid van de gespecialiseerde organisaties bij de internationale implementatieprocedure.

Zoals gezegd vormt artikel 18 IVESCR de grondslag voor de participatie van de gespecialiseerde organisaties in de internationale implementatieprocedure. De rapporten van deze organisaties kunnen heel wel concrete en specifieke opmerkingen bevatten over de naleving van economische, sociale en culturele rechten in afzonderlijke landen. ${ }^{21}$ Artikel 18 bepaalt immers dat 'these reports may include particulars of decisions and recommenda-

19. C.W. Jenks, A new world of law? A study of the creative imagination in international Iaw, Londion 1969, p. 54.

20. General Comment no. 2 (1990) van het Comite getiteld International trechnical assistance measures (Article 22 of the Covenant)'. Zie Commititee on Economic, Social and Cultural Rights, Report on the Fourth Session UN Doc. E/ 1990/23, Annex III.

21. Zie Alston (1979), a.w. p. 113 en Trubek, a.w. p. 220 . 
tions on such implementation adopted by their competent organs;. ${ }^{22} \mathrm{De}$ betrokkenheid van de gespecialiseerde organisaties kan nog worden versterkt door vertegenwoordigers van deze organisaties het recht te geven deel te nemen aan de mondelinge bespreking van statenrapporten tijdens zittingen van het Comité inzake Economische, Sociale en Culturele Rechten. ${ }^{23}$ Het Comité is inmiddels deze weg ingeslagen. De procedureregels van het Comité bepalen dat een vertegenwoordiger van een gespecialiseerde organisatie het recht heeft verklaringen af te leggen tijdens de bespreking van een statenrapport door het Comité. De afgevaardigde van een staat heeft de vrijheid al dan niet op dit commentaar te reageren. Deze bevoegdheid geeft gespecialiseerde organisaties de mogelijkheid specifiek en concreet commentaar te geven op statenrapporten en gedurende de gehelle mondelinge bespreking van zo'n rapport een actieve rol te spelen. Zo kan een vertegenwoordiger van een gespecialiseerde organisatie op grond van deze procedure direct reageren op de uiteenzettingen van de regering waarvan het rapport besproken wordt. ${ }^{24}$

De werkzaamheden van het Comité inzake Economische Sociale en Culturele Rechten hebben binnen de UNESCO geleid tot een grotere interesse voor de internationale implementatieprocedure van het IVESCR. Met name is er sprake van een herbezinning op de rol en de participatie van de UNESCO in die procedure. In het licht van deze ontwikkelingen organiseerde de UNESCO in december 1989 in Ottawa een bijeenkomst waar een 15-tal deskundigen alsmede vertegenwoordigers van inter-gouvernementele en niet-gouvernementele organisaties van gedachten wisselden over UNESCO's

22. Mijn cursivering A.C.

23. Het belang hiervan wordt benadrukt in onder meer de Limburg Principles, a.w. nr. 94

24. Procedureregel 68 luidt als volgt:

'The specialized agencies concerned shall be invited to designate representatives to participate at the meetings of the Committee. Such representatives may make statements on mattera falling within the scope of the activitiea of their respective organizations in the course of the diacussion by the Committee of the report of each State party to the Covenant:. The representatives of the States parties presenting reports to the Committee shall be free to respond to, or take into account, the statements made by the apecialized agencies".

Intereseant in dit verband is dat een cerdere (voorlopige) versie van deze regel in de tweede volzin oprak van "general statements' die alleen op het einde ('at the end") van de bespreking van het rapport konden worden gedaan en niet gedurende de bespreking. De gewijzigde versie legt de procedure vast zoals die door het Comité wordit gevolgd, Zie UN Doc. E/1990/23, par. 293, Fourth Report of the Committee on Economic, Social and Cultural Rights. Zie voor de oorspronkelijke versie UN Doc. E/1989/22, Annex IV (Provisional Rules of Procedure), Rule 68, Third Report of the Committee on Economic Social and Cultural Rights. De definitieve versie, zoals goedgekeurd door ECOSOC, is gepubliceerd in UN Doc. E/C.12/1990/4.

De participatie van gespecialiseerde organisaties bij het internatiomale toezicht op de naleving van IVESCR-bepalingen werd reeds erkend, ${ }_{n}$ ij het in algemene termen, in resolutio 1988 (LX) van de Economische en Sociale Raad van 11 mei 1976, zie in het bijzonder par. 9 (b). Deze resolutie vormde de grondslag voor het internationale toegicht op de naleving van het IVESCR. 
rol in de IVESCR implementatieprocedure. ${ }^{25}$ Twee kwesties stonden tijdens de bijeenkomst centraal. De eerste betrof de vraag naar mogelijke methoden om de op- en aanmerkingen van UNESCO ten aanzien van de rapporten van staten ingevolge het IVESCR te verbeteren. De tweede kwestie handelde over de mogelijke verbetering van de eigen UNESCO rapporten aangaande de voortgang bij de verwezenlijking van de relevante IVESCR bepalingen, in casu het recht op onderwijs. ${ }^{26}$ Ten aanzien van de eerste kwestie deden de experts een aantal concrete suggesties die voor een groot deel waren gebaseerd op voorstellen afkomstig van UNESCO's 'Division of Human Rights and Peace'. UNESCO's commentaar ten aanzien van IVESCR statenrapporten zou moeten ingaan op de ratificatie, dan wel toetreding van een staat tot UNESCO Conventies, alsmede op mogelijke voorbehouden en verklaringen. Tevens zou moeten worden aangegeven of, en zo ja welke rapporten staten hebben ingediend ingevolge UNESCO conventies en aanbevelingen. Staten zouden in hun IVESCR rapporten statistisch materiaal moeten opnemen dat bepaalde trends laat zien aangaande de verwezenlijking van het recht op onderwijs. UNESCO zou dit statistisch materiaal kunnen analyseren en eventuele tekortkomingen signaleren. Het UNESCO commentaar zou verder kwalitatieve informatie kunnen geven, bijvoorbeeld in de vorm van UNESCO landenstudies over de ontwikkeling van het primair onderwijs. Een eerste aanzet tot een verbeterde opzet van het UNESCO-commentaar op IVESCR statenrapporten is te vinden in het derde UNESCO rapport ingevolge artikel 18 IVESCR ${ }^{27}$ Het rapport geeft een kort commentaar bij de rapporten van een drietal staten. Het commentaar is toegespitst op de ratificatie van UNESCO instrumenten, op statistische informatie, alsmede op UNESCO programma's die in het desbetreffende land worden uitgevoerd. De deskundigen in Ottawa spraken zich uit voor het opstellen van jaarlijkse rapporten door UNESCO die ingaan op de situatie van onderwijs- en culturele rechten in landen waarvan het rapport dat jaar door het Comité inzake Economische Sociale en Culturele Rechten besproken zal worden. Een goed voorstel derhalve, gebaseerd op de ILO-praktijk.

Ten aanzien van het gebruik van statistisch materiaal in statenrapporten is het van belang dat relevante gegevens van verschillende landen over een bepaald onderwerp onderling vergelijkbaar zijn. Indien staten statistische gegevens volgens nationale criteria verzamelen, rangschikken en interpreteren is vergelijking met gegevens uit andere staten niet goed mogelijk en ook weinig zinvol. Vandaar dat het gewenst is dat landen statistische gege-

25. De bijeenkomst vond plaats van 4-7 december 1989 en werd van UNESCO zijde georganiseerd door de 'Division of Human Rights and Peace'.

26. Zie UNESCO Doc. SHS-89/CONF.613/INF, 5 "International Meeting of Experts on the implementation in UNESCO's fields of competence of the International Covenants on Human Rights, Final Report and Recommendations" p. 1. Zie ook de opmerkingen van Dr. Kutukdjian van UNESCO' Division of Human Rights and Peace tijdens de vierde zitting van het Comité inzake Economische, Sociale en Culturele Rechten, in UN Doc. $\mathbb{E} /$ C.12/1990/SR.15, par. 32-39.

27. UN Doc. $\mathbb{E} / 1990 / 8$ van $1-12-1989$. 
vens verzamelen en ordenen op grond van in internationaal verband afgesproken standaarden en normen. Dergelijke standaarden zijn vastgelegd in een Aanbeveling die in 1978 door de lidstaten van de UNESCO werd aanvaard. ${ }^{28}$ Een andere optie is dat staten in hun rapporten gebruik maken van de statistische gegevens zoals die door de UNESCO worden verzameld en gerubriceerd in het jaarlijks te verschijnen UNESCO Statistical Yearbook. ${ }^{29}$ Het gebruik van onderling vergelijkbaar materiaal kan bijdragen tot het traceren van bepaalde trends en ontwikkelingen die, nationaal dan well regionaal, inzicht geven in aspecten van de verwezenlijking van het recht op onderwijs. UNESCO kan verder een waardevolle bijdrage leveren aan de internationale implementatieprocedure van het IVESCR door de ontwikkeling van kwalitatieve indicatoren of ijkpunten. Met behulp van deze indicatoren kan de voortgang bij de verwezenlijking van het recht op onderwijs worden gemeten. Het betreft hier begrippen als alfabetisme, kosteloos onderwijs, toegankelijkheid en beschikbaarheid van het onderwijs, de kwaliteit van het onderwijs, en de verhouding openbaar tot nietopenbaar onderwijs. De inhoud en betekenis van deze begrippen moet duidelijk zijn om de voortgang bij de verwezenlijking van het recht op onderwijs in af zonderlijke landen te kunnen beoordelen en vergelijken. ${ }^{30}$

Een belangrijke aanbeveling van de bijeenkomst van Ottawa was voorts dat de UNESCO, op verzoek van leden van het toezichthoudende orgaan bij het IVESCR, informatie zou moeten verstrekken over de mate van verwezenlijking van het recht op onderwijs in afzonderlijke landen en de in dit proces ondervonden moeilijkheden. Het betreft hier geen actie die de UNESCO op eigen initiatief kan verrichten, maar slechts op verzoek van het Comité inzake Economische, Sociale en Culturele Rechten. In dit verband verdient de aandacht dat de UNESCO geen onafhankelijke organen kent die op eigen titel kritische opmerkingen kunnen maken over het gedrag van staten. De ILO daarentegen kent wel organen van onafhankelijke deskundigen die de bevoegdheid bezitten het gedrag van staten kritisch te beoordelen en daarover te rapporteren. In het geval van het IVESCR heeft het ILO Committee of Experts on the Application of Conventions and Recommendations ook van die bevoegdheid gebruik gemaakt. Zoals gezegd ligt dat bij de UNESCO anders. Het Committee on Conventions and Recommendations is een orgaan van UNESCO's Uitvoerende Raad en bestaat uit vertegenwoordigers van regeringen. Deze zullen over het algemeen weinig geneigd zijn om zich kritisch uit te laten over de situatie van het onderwijs in lidstaten, omdat dit ook als een boemerang zou kunnen werken.

28. Revised Recommendation concerming the International Standardization of Educational Statigtics, anvaard door de Algemene Conferentie van UNESCO op 27 november 1978.

29. Een soortgelijke suggestie wardt gedaan in het derde UNESCO rapport ingevolge artikell 18 IVESCR, UN Dac. E/1990/8, par. 6.

30. De kwestie van de kwalitatieve indicatoren komt verderop in het betoog nogmaals an de orde. Zie ook het Final Report and Recommendations van de $O$ ttawa bijeenkomst, a.w. p. 4, m. 8 . 
Het politieke karakter van dit orgaan betekent dat het zal proberen moeilijkheden met lidstaten te voorkomen. Het UNESCO Comitê zal zich ervoor hoeden de kritiek van lidstaten over zich heen te krijgen. Dit zou immers kunnen leiden tot ongewenste politisering van onderwijskwesties in de Algemene Conferentie van de UNESCO. ${ }^{31}$ Een en ander impliceert naar mijn opvatting dat het UNESCO Comité slechts beperkte mogelijkheden heeft om de situatie van de verwezenlijking van het recht op onderwijs in afzonderlijke landen aan de kaak te stellen. De vraag blijft dan ook of de UNESCO de aanbeveling van de conferentie van Ottawa op dit punt zal overnemen. Wellicht dat bepaalde onderdelen van het UNESCO Secretariaat wel voorstander zijn van de voorgestelde procedure, zoals de 'Division of Human Rights and Peace'. ${ }^{32}$ Daarnaast kan men zich afvragen of een politiek orgaan als het UNESCO Comité überhaupt wel het aangewezen orgaan is om een rapportage over de verwezenlijking van het recht op onderwijs in de lidstaten op te stellen. Het rapport van het Comité moet immers worden goedgekeurd door UNESCO's Uitvoerende Raad. Ligt het niet meer voor de hand een comité van onafhankelijke deskundigen met deze taak te belasten dat dan rechtstreeks rapporteert aan de ECOSOC? In de ILO is een dergelijke procedure gebruikelijk. ${ }^{33}$ Op deze wijze kan een zekere mate van onafhankelijkheid en objectiviteit worden gewaarborgd. Het probleem is evenwel dat, zoals gezegd, UNESCO een dergelijk onafhankelijk comitê mist. Het verdient daarom aanbeveling dat op de langere termijn het UNESCO Comité wordt omgevormd tot een comité van onafhankelijke deskundigen dat zelfstandig te werk gaat en direct rapporteert aan ECOSOC. Vooralsnog dient naar mijn mening het UNESCO Secretariaat het opstellen van rapporten ingevolge artikel 18 IVESCR te coördineren. Vanuit een oogpunt van deskundigheid zou met name de 'Division on Human Rights and Peace' die coördinerende functie moeten vervullen. Rapportage aan ECOSOC zou moeten geschieden via de Directeur-Generaal van de UNESCO. Deze koers lijkt reeds te zijn ingezet bij het derde UNESCO rapport ingevolge artikel 18 IVESCR. $^{34}$ Deze wijze van rapporteren biedt tevens de mogelijkheid gebruik te maken van de schat aan informatie die binnen de verschillende afdelingen van het UNESCO Secretariaat beschikbaar is over de verwezenlijking van het recht op onderwijs in afzonderlijke landen. ${ }^{35}$

31. Interview met Dr. Kutukdjian, UNESCO Division of Human Rights and Peace, Parijo; 29 aeptember 1989.

32. Idem.

33. Vgl. over dit aspect, Alston (1979), a. pp. 110, 111. In de 1LO rapportieert het Comité van Deokundigen rechtstreeks aan ECOSOC, d.w.z. zonder tusisenkomst van de Raad van Beheer wan de ILO.

34. UN Dac. E/ $1990 / 8$.

35. Dit vereist evenwel een goede samenwerking tusgen de verschillende afdelingen van het Secretariaat. Dr. Kutukdjian makte in dit verband melding $v a n$ interne tegenwerking bij het opstellen van het derde UNESCO rapport. Bepaalde afdelingen van het Secretariaat waren weinig enthousiast over het initiatief van de 'Division on Fuman Rights and Peace' om de UNESCO rapportage ingevolge het IVESCR op een meer 
Het is mijns inziens gewenst dat binnen de "Division on Human Rights and Peace" de nationale en internationale implementatie van het recht op onderwijs uitgroeit tot een zwaartepunt van beleid. Daarmee wordt recht gedaan aan de betrokkenheid van UNESCO bij de verwezenlijking van het recht op onderwijs als mensenrecht. Dat proces moet immers niet slechts worden gezien als een onderwijskundige of bestuurlijke aangelegenheid.

Samengevat kan de rol van de UNESCO in de internationale implementatieprocedure van het recht op onderwijs op de volgende punten worden versterkt. De vertegenwoordiger van de UNESCO dient op actieve wijze deel te nemen aan de bespreking van statenrapporten door het Comité inzake Economische, Sociale en Culturele Rechten. Hij of zij kan commentaar leveren gedurende de discussies over een rapport. De UNESCO zou jaarlijks een rapport moeten opstellen over de landen waarvan de rapporten door het Comité zullen worden besproken, analoog aan de rapportageprocedure binnen de ILO. Voorts zou binnen de UNESCO serieuze aandacht moeten worden besteed aan de ontwikkeling van kwalitatieve indicatoren met behulp waarvan vorderingen aangaande de realisering van het recht op onderwijs kunnen worden gemeten. Een belangrijk punt is verder dat binnen de UNESCO een onafhankelijk comité van deskundigen moet worden ingesteld dat zelfstandig informatie inzake de naleving van onderwijs- en culturele rechten door staten kan verstrekken aan het Comité inzake Economische Sociale en Culturele Rechten. Daarbij kan de praktijk binnen de ILO als voorbeeld dienen. Tot slot is het gewenst dat binnen de UNESCO op een meer structurele en gecoördineerde wijze aandacht wordt besteed aan de internationale implementatieprocedure van onderwijsrechten ingevolge mensenrechtenverdragen.

\subsection{De rol van niet-gouvernementele organisaties}

Het IVESCR bevat geen bepalingen over de participatie van NGO's in de internationale implementatieprocedure. Dat is niet verwonderlijk, omdat de oorspronkelijke bedoeling was dat het internationale toezicht op de naleving van het Verdrag een aangelegenheid vormde die zich tussen staten onderling behoorde af te spelen. Daarbij kwam aan de gespecialiseerde organisaties een ondersteunende rol toe. NGO's waren wel betrokken geweest bij het opstellen van de Universele Verklaring van de Rechten van de Mens en de twee mensenrechtenverdragen uit 1966 . $\mathrm{Zij}$ produceerden documenten

35.(...vervolg)

zinvolle wijze aan te pakken. Waarschijnlijk is een en ander te herleiden tot een competentiestrijd tussen afdelingen met verschillende belangen; Interview met Dr. Kutukdjian, 29 september 1989.

Binnen UNESCO is inmiddels en 'Unit on Conventions' opgericht die de rapportageprocedures inzake internationale verdragen moet gaan cö̈rdineren en verbeteren. Dese afdeling valt onder de directe verantwoordelijkheid van de Directeur-Generaal. Brief van Dr. Kutukdjian aan de auteur, dd. 28 januari 1991. 
waarin zij hun opvattingen verkondigden, maar hadden niet het recht zelfstandig voorstellen te doen. ${ }^{36}$ Ten aanzien van het recht op onderwijs was met name sprake van bemoeienis van NGO's van joodse en christelijke signatuur. ${ }^{37}$

Vanaf het begin van de internationale bescherming van de rechten van de mens hebben veruit de meeste NGO's zich toegelegd op de bevordering van de naleving van burger-en politieke rechten. Slechts weinig NGO's zijn actief op het terrein van economische, sociale en culturele rechten. Dit is te verklaren vanuit het feit dat burger-en politieke rechten vooral in het kader van de VN traditioneel de meeste aandacht kregen. Schendingen van burger- en politieke rechten zijn gemakkelijker vast te stellen dan bijvoorbeeld de schending van het recht op arbeid of het recht op onderwijs. Bovendien werden gebrekkige sociaal-economische en culturele voorzieningen niet altijd opgevat als een mensenrechtenvraagstuk. Verder heeft een groot aantal NGO's slechts een beperkt mandlaat met betrekking tot de bescherming van de rechten van de mens, zoals Amnesty International. Andere organisaties hebben vaak uit het oog verloren dat de interdependentie tussen burger- en politieke rechten en economische, sociale en culturele rechten betekent dat ook de naleving van deze laatstgenoemde rechten aandacht verdient. ${ }^{38}$

In de loop der jaren is de bemoeienis van NGO's met de bescherming van de rechten van de mens in VN-verband zowel qua aantal als qua materie gegroeid. Op grond van ECOSOC resolutie 1296 (XLIV) (1968) kunnen NGO's die een consultatieve status bezitten bij ECOSOC schriftelijke verklaringen doen toekomen aan de Secretaris-Generaal van de VN. Deze zendt de verklaringen door aan het relevante mensenrechten-(sub)orgaan van de VN. Omdat het Comite inzake Economische Sociale en Culturele Rechten een orgaan is van ECOSOC is het Comite ook toegankelijk voor NGO's. De rol van NGO's in de internationale implementatieprocedure van het IVESCR is naderhand nog eens bevestigd door de ECOSOC. ${ }^{39}$ Resolutie 1296 (XLIV) biedt ook de mogelijkheid NGO's spreekrecht te verlenen gedurende zittingen. Het Comité heeft evenwel bepaald dat NGO's alleen het recht hebben schriftelijke informatie te overleggen. ${ }^{40}$ Vooralsnog zijn er maar weinig NGO's die een actieve betrokkenheid bij de werkzaamheden van het Comite hebben getoond. Het is voorall de Four Directions Council

36. Zie hierover Th. $\operatorname{van}$ Boven, The Role of Non-Governmental Organizations in International Human Rights Standard-Setting: a Prerequigite of Democracy, in: Califormia Weatern Intermational Law Journal, wol. 20, 1989-1900, Pp. 207-225, op pp. $211,212$.

37. Zie hoofdatuk 3.6.3, noot 246 supra.

38. Vgl. Alston, Out of the Abyss, a.w. p. 372 .

39. Zie ECOSOC Res. $1987 / 5$, par. 6 en Res. $1988 / 4$, par. 16.

40. Zle de procedureregels van het Comite, in het bijzonder regel 69, UN Dac. E/C.12/ 1990/4. Daamaast kunnen individuele leden van het Comite op informele wijze mondeling worden gelnformeerd of kan informatie-materiaal aan hen persoonlijk worden toegetzonden. 
die regelmatig een constructieve bijdrage levert aan de internationale implementatieprocedure van het IVESCR. ${ }^{41}$ Deze organisatie formuleerde ideeèn over de werkwijze van het Comité, de bespreking van statenrapporten en de verwezenlijking van het recht op werk. ${ }^{42}$ Ten aanzien van het recht op onderwijs hebben tot dusverre twee NGO's blijk gegeven van betrokkenheid bij de werkzaamheden van het Comité. De World Association for the School as an Instrument of Peace besteedde aandacht aan de doeleinden van het onderwijs ingevolge artikel 13 lid 1 IVESCR en formuleerde een aantal concrete suggesties voor de bevordering van het mensenrechtenonderwijs. Deze suggesties zouden voor het Comité een leidraad kunnen vormen bij de bespreking van statenrapporten. ${ }^{43}$ Een tweede bijdrage was afkomstig van de International Organization for the Development of Freedom of Education en bevatte een analyse van de vrijheid van onderwijs op grond van bestaande internationale teksten. ${ }^{44}$

Deze bijdragen zijn zeker belangrijk; NGO's kunnen evenwel veel meer doen om de internationale implementatie van economische, sociale en culturele rechten te versterken. Een goede beoordeling van de verwezenlijking van de rechten van de mens in een land vereist dat het Comite de beschikking heeft over alternatieve informatiebronnen, niet afkomstig van regeringen. NGO's kunnen de aandacht vestigen op verplichtingen van IVESCR partijstaten; zij kunnen commentaar leveren op statenrapporten en deze toetsen aan de verdragsverplichtingen. $\mathrm{Zij}$ kunnen zelfs schaduwrapporten opstellen over de situatie van economische, sociale en culturele rechten in een bepaald land. ${ }^{45}$ Daarnaast kunnen zij, samen met onderzoeksinstellingen, onderzoek doen naar de oorzaken van schendingen van deze rechten. Ook kunnen NGO's kritisch commentaar geven bij (positieve) economische en sociale ontwikkelingen en beleidsvoering, bijvoorbeeld over de vraag welk financieel-economisch beleid een staat voert in relatie tot de gestelde doeleinden. Een goed voorbeeld van informatievoorziening door NGO's over de verwezenlijking van mensenrechten in afzonderlijke landen is het 'Yearbook on Human Rights in Developing Countries' dat wordt samengesteld door onafhankelijke mensenrechteninstellingen in een vijftal landen. ${ }^{46}$ Het bevat onder meer betrouwbare, objectieve informatie over de mensenrechtensituatie in ontwikkelingslanden waarmee een aantal westerse staten

41. De Four Directions Council is een kleine Amerikaanse niet-gouvernementele organisatie die opkomt voor de rechten van inheemse volken, in het bijzonder de Indianen.

42. Zle UN Doc. $\mathrm{E} / \mathrm{CN} .4 / 1987 / \mathrm{NGO} / 68$, E/1988/NGO/2 en $\mathrm{E} / \mathrm{C} .12 / 1990 / \mathrm{NGO} / 2$. Over het recht op huisvesting zie de bijdragen van de Habitat International Coalition, UN Dac. E/1988/NGO/1 en E/C.12/1990/NGO/3.

43. UN Doc. E/C.12/1990/NGO/1.

44. UN Doc. $\mathrm{E} / \mathrm{C} .12 / 1990 / \mathrm{NGO} / 4$.

45. Zle bijvoorbeeld het rapport van de World University Service over het Palestijnse hoger onderwijs in de door Isräl bezette gebieden, UN Doc. E/CN.4/1990/NGO/64.

46. M. Nowak, Th. Swinehart (eds), Human Rights in Developing Countries 1989 Yearbook, compiled by human rights institutes in Norway, Denmark, the Netherlands, Finland and Canada, Kehl am Rheïn 1989. 
een ontwikkelingsrelatie onderhoudt. Het bevat ook relevant materiaal over de verwezenlijking van economische, sociale en culturele rechten in die ontwikkelingslanden. Het rapport is primair bedoeld voor beleidsmakers in de donorlanden, maar internationale toezichthoudende organen op het gebied van de rechten van de mens kunnen er eveneens veel bruikbare informatie uit putten.

Het Comite inzake Economische, Sociale en Culturele Rechten zou in overweging moeten nemen NGO's ook te raadplegen bij de bespreking van specifieke statenrapporten. ${ }^{47}$ Ten aanzien van de verwezenlijking van het recht op onderwijs is het allereerst zaak dat meer NGO's met een algemeen mandaat aandacht gaan besteden aan dit recht. Te denken valt in dit verband aan de Internationale Vierde Wereld Beweging die opkomt voor de mensenrechten van de allerarmsten in arme en rijke landen. Daarnaast zouden bijvoorbeeld organisaties die de bescherming van de vrijheid van godsdienst nastreven aandacht kunnen besteden aan de vrijheid van godsdienstonderwijs. Ook NGO's die het recht op ontwikkeling beogen te bevorderen zouden aandacht moeten hebben voor het recht op onderwijs als een essentieel element van dat recht op ontwikkeling. Het verdient aanbeveling dat NGO's het Comité inzake Economische, Sociale en Culturele Rechten informatie verschaffen over de situatie van het onderwijs in afzonderlijke landen. Daarbij dienen het beginsel van non-discriminatie en de positie van zwakke en kwetsbare groepen in de samenleving centraal te staan. Tevens kan het overheidsbeleid kritisch worden doorgelicht, met inbegrip van de financiële aspecten, met het oog op het vaststellen van vooruitgang dan wel achteruitgang ten aanzien van de verwezenlijking van het recht op onderwijs. Daarbij kan statistisch materiaal een nuttige functie vervullen. Een andere optie is voorts dat het Comité vertegenwoordigers van NGO's als deskundige uitnodigt een bijdrage te leveren aan de algemene discussies die het Comité over afzonderlijke rechten voert. Dat is in het verleden reeds gebeurd met betrekking tot het recht op voedsel en het recht op huisvesting. Tenslotte kunnen NGO's informatie van nationale belangengroepen in het onderwijs verzamelen en presenteren bij de bespreking van het statenrapport door het Comité.

\subsection{Uitbouw van taken van het Comité inzake Economische, Sociale en Culturele Rechten; enkele aanbevelingen}

\subsubsection{De beoordeling van statenrapporten}

De verwezenlijking van het recht op onderwijs is natuurlijk niet alleen een juridische aangelegenheid. Het is vooral een politieke en maatschappelijke kwestie waarbij economische, financiële en culturele factoren een rol spe-

47. Vgl. artikel 27 lid 2 ESH, en artikel 45 sub a Conventie inzake de Rechten van het Kind. 
len. Het toezicht op de verwezenlijking van het recht op onderwijs kan daarom niet beperkt worden tot incidentele juridische procedures. Het is zaak in een periodieke dialoog met staten inzicht te verkrijgen in de mate van verwezenlijking van het recht op onderwijs en de daarbij ondervonden moeilijkheden.

De rapportageverplichting op grond van het IVESCR biedt een goede mogelijkheid het proces van verwezenlijking van het recht op onderwijs in een bepaalde staat te volgen. De dialoog tussen het Comite en de verdragsstaat die volgt op het indienen van het rapport vormt een belangrijk onderdeel van deze internationale toezichtsprocedure. Het Comite is bij uitstek het orgaan dat het internationale toezicht op de verwezenlijking van het recht op onderwijs een zinvolle inhoud en betekenis kan geven. Bovendien bevat het IVESCR alomvattende bepalingen over het recht op onderwijs die een vrij gedetailleerd karakter hebben. Daarnaast is het IVESCR een universeel verdrag waarbij staten uit verschillende culturen en regio's zijn aangesloten. Door deze universele reikwijdte kan het Comitê een 'over-all' inzicht verwerven in de factoren die een verwezenlijking van het recht op onderwijs belemmeren. Deze paragraaf is dan ook toegespitst op de rol die het Comite kan spelen bij het internationale toezicht op de verwezenlijking van het recht op onderwijs.

Eên van de belangrijkste taken van het Comité is het bepalen van de bijdrage die het IVESCR kan leveren aan de verwezenlijking van economische, sociale en culturele rechten met name in tijden van economische teruggang. ${ }^{48}$ Bij deze taak kan het Comité gebruik maken van een tweetal functies van internationale supervisie bij de analyse en bespreking van de periodieke rapporten van staten ${ }^{49}$. Op de eerste plaats is dit de zogenaamde 'reviewfunction' van internationale supervisie. Daarbij gaat het er om het gedrag (wetgeving, beleid, praktijk) van staten te beoordelen op de vraag of het al of niet in overeenstemming is met de verdragsbepalingen van het IVESCR. ${ }^{50}$ Het gedrag van staten wordt getoetst aan de verdragsnormen. Ten einde deze beoordeling op een verantwoorde wijze te kunnen maken is betrouwbare informatie van belang. Aan de hand van de gegevens in het statenrapport, materiaal van de gespecialiseerde organisaties en van NGO's kan het Comité een beeld vormen van de vooruitgang, dan wel achteruitgang ten aanzien van de verwezenlijking van het recht op onderwijs in een bepaald land. Dit beeld kan dan worden vergeleken met dat van andere landen zodat een algemene indruk ontstaat. De tweede functie van internationale supervisie is de zogenaamde 'creative function'. Daarbij gaat het om de

48. Vgl. General Comment no. 1 (1989) van het CESCR, in: UN Doc. E/1989/22, Annex III en Res. 1990/17 van de Commissie voor de Rechten van de Mens. Vgl. ook de opvatting van Comitelid Simma, in: UN Doc. E/C.12/1990/SR.15, par. 7.

49. Zie G.J.H. van Hoof en K de Vey Mestdagh, Mechanisms of International Supervision, in: P. van Dijk (general editor), Supervisory Mechanisms in International Economic Organizations, Deventer 1984, pp. 3-45, op pp. 11-14.

50. Zie de bespreking van de IVESCR-rapportage over het recht op onderwija in hoofdstuk 4.4 supra. 
interpretatie en invulling van verdragsnormen. Vaak zijn internationale normen, ook die uit het IVESCR, vaag en abstract. Het Comité is dan bij uitstek het aangewezen orgaan deze verdragsbepalingen te concretiseren en te specificeren, zodat ze in de praktijk beter kunnen worden toegepast. Het gaat hier dus om een nadere bepaling van de juridische inhoud en reikwijdte van de verdragsnormen. Het CESCR is deze weg al ingeslagen en heeft tijdens de voorbije zittingen vooral aandacht besteed aan de analyse en betekenis van het recht op voedsel en het recht op huisvesting, twee rechten die in het IVESCR niet of nauwelijks zijn uitgewerkt. Daarnaast kan het Comité door middel van de zogenaamde 'general comments' de verdragsnormen uitleggen.

Ten aanzien van het recht op onderwijs kan worden opgemerkt dat dit op vrij uitvoerige wijze in het IVESCR is geformuleerd. Dat betekent evenwel niet dat er geen onduidelijkheden meer zouden bestaan aangaande de betekenis van de verdragstermen. Zo kan men zich afvragen wat de betekenis en reikwijdte is van een formulering als: 'The States Parties to the present Covenant recognize the right of everyone to education ${ }^{*} .^{51}$ Wanneer is er sprake van kosteloos primair onderwijs? Wat zijn passende maatregelen om het voortgezet en hoger onderwijs toegankelijk te maken? Wanneer is onderwijs eigenlijk voor een ieder toegankelijk? En, wat is een passend stelsel van studiebeurzen? ${ }^{52}$ Dit zijn vragen die niet in algemene zin zijn te beantwoorden, maar waarbij de situatie van het onderwijs in elk afzonderlijk land moet worden betrokken. De organisatie en inrichting van een onderwijsstelsel is immers een specifieke nationale aangelegenheid waarbij een grote mate van diversiteit bestaat tussen de afzonderlijke landen. Toch kan het Comité, naar mijn idee, wel een algemene interpretatie geven van enkele elementen van het recht op onderwijs, mede op grond van een vergelijking van de onderwijssituatie in verschillende landen. Dat is evenwel pas zinvol indien het Comité voldoende kennis en inzicht heeft verworven over de factoren die de verwezenlijking van het recht op onderwijs in afzonderlijke landen en regio's bevorderen dan wel belemmeren.

Opdat het Comité op een zinvolle wijze de verwezenlijking van het recht op onderwijs in de partijstaten bij het IVESCR kan bestuderen en analyseren verdienen de volgende overwegingen van procedurele aard de aandacht. Ten eerste dient het Comité meer gebruik te maken van informatie over de verwezenlijking van het recht op onderwijs die al in de $\mathrm{VN}$-organisatie aanwezig is. Te denken valt aan (statistisch) materiaal van de Wereldbank, UNICEF of rapporten over het onderwijs in afzonderlijke landen opgesteld door UNESCO. De procedure voor het indienen van rapporten is momenteel zo dat staten één maal in de vijf jaar rapporteren over alle relevante verdragsbepalingen (artikelen 1-15). Het gevaar bestaat dat bij de bespreking van deze 'overall' rapporten te weinig aandacht wordt besteed aan de af zonderlijke artikelen. Dit kan ten koste gaan van minder bekende

51. Artikel 13 lid 1 IVESCR (mijn cursivering, A.C.).

62. Al deze vragen xijn gebaseerd op artikel 13 lid 2 IVESCR. 
rechten, zoals het recht op onderwijs. Het is dan ook aan te bevelen dat alle rechten substantieel aan de orde komen tijdens de dialoog met de vertegenwoordiger van de staat. Sedert de vierde zitting in 1990 is het Comité ertoe overgegaan ten behoeve van de bespreking van elk rapport een zogenaamde 'discussion leader' uit de leden van het Comité aan te wijzen ${ }^{63}$. De keuze voor een bepaald lid wordt mede bepaald door zijn of haar deskundigheid ten aanzien van een bepaald recht. Daarnaast kan kennis van zaken over het betreffende land een rol spelen. Deze 'discussion lleader' formuleert een aantal concluderende opmerkingen over de situatie van bijvoorbeeld het recht op onderwijs in een bepaald land naar aanleiding van bestudering en bespreking van het rapport. Andere leden kunnen daar hun eigen opmerkingen aan toevoegen. Enerzijds is deze vorm van stroomlijnen van de discussie een goede zaak. Het bevordert de effectiviteit van de bespreking van de rapporten en leidt tot een duidelijke afronding van de discussie. Anderzijds gaat het hierbij deels om een subjectieve zaak, omdat één Comitélid hoofdzakelijk bepaalt hoe de conclusie over het staten-rapport zal luiden. Andere Comitéleden zullen zich immers veelal baseren op de opvatting van de discussieleider. Dit kan leiden tot een minder actieve participatie van die andere leden. Daar komt nog bij dat de opvattingen van de discussieleider de basis vormen voor de overwegingen van het gehele Comite in het algehele rapport over de zitting. Met andere woorden, deze procedure heeft duidelijk positieve aspecten, maar het gevaar van een zekere eenzijdigheid is zeker aanwezig. Als aanvulling dan wel alternatief zijn de volgende suggesties denkbaar. In plaats van éen discussieleider aan te wijzen zouden wellicht drie leden van het Comité gezamenlijk de concluderende opmerkingen kunnen voorbereiden. Bovendien zou het secretariaat van het Comité in Genève meer voorwerk kunnen verrichten. Het zou een voorbereidende analyse van statenrapporten kunnen uitvoeren, waarbij kan worden teruggegrepen op de bespreking van eerdere statenrapporten en op ander relevant materiaal, bijvoorbeeld informatie van NGO's. Dat vereist wel dat de staf van het secretariaat wordt uitgebreid. ${ }^{54}$

Voorts verdient het aanbeveling dat het Comitê zich in de toekomst verdiept in betekenis en reikwijdte van het recht op onderwijs en de belemmeringen voor de verwezenlijking ervan. Dat zou kunnen gebeuren analoog aan de discussies over het recht op voedsel en het recht op huisvesting gedurende één dag tijdens een zitting. Het Comité kan daarbij gebruik maken van de ervaringen opgedaan bij de bespreking van statenrapporten. Bovendien kunnen vertegenwoordigers van UNESCO, UNICEF en de Wereldbank op grond van hun expertise een waardevolle bijdrage leveren aan de discussie. Daarnaast is van belang dat het Comité bij de bespreking van

153. Zie de uiteensetting $v a n$ de methode van analyse en bespreking van tatenrapporten in het vierde rapport wan het CESCR, in: UN Doc. $E / 1990 / 23$, par. 17-32, in het bijsonder par. 29.

54. Het belang van ondersteuning van de werksaamheden van toegichthoudende organen door middel van een uitbreiding van de staf wordt onderstreept door Alston in zijn studie voor de $\mathrm{VN}_{\text {, }}$ UN Doc. A/44/668, par. 107-109. 
rapporten over het recht op onderwijs ingaat op de effectiviteit van wetgeving en beleid en dat niet wordt volstaan met legalistisch geaarde opmerkingen zoals in het verleden vaak het geval was. Het gaat om een kwalitatief en kwantitatief inzicht in datgene wat de staat reeds bereikt heeft en de daarbij ondervonden knelpunten. ${ }^{55}$

\subsubsection{Het gebruik van indicatoren}

Een belangrijke uitdaging voor het Comité vormt het bepalen van de vooruitgang ten aanzien van de verwezenlijking van economische, sociale en culturele rechten in afzonderlijke landen en tussen landen onderling. De mate van verwezenlijking van deze rechten kan wellicht met behulp van indicatoren gemeten worden. De term 'indicator' verwijst naar kwantitatieve, veelal statistische gegevens die inzicht geven over verschillende aspecten van de sociaal-economische ontwikkeling voor een bepaald geografisch gebied op een bepaald tijdstip of voor een bepaalde periode. Naast regeringen die hun eigen statistische gegevens verzamelen voor intern gebruik zijn het met name internationale organisaties die indicatoren verzamelen en gebruiken. Het zijn vooral de gespecialiseerde organisaties van de VN die door middel van indicatoren inzicht proberen te krijgen in economische, sociale, technische en gezondheidkundige ontwikkelingen. Deze organisaties zoals de Wereldbank, de FAO en de WHO gebruiken deze statistische gegevens evenwel niet met het doel om de mate van verwezenlijking van economische, sociale en culturele rechten te kunnen bepalen. Bij VN-organen die zich bezig houden met mensenrechten bestaat sedert een aantal jaren een toenemende belangstelling voor het gebruik van internationale indicatoren. Deze zouden een functie kunnen vervullen bij de beoordeling van de mate van verwezenlijking van economische, sociale en culturele rechten. De Bijzondere Rapporteur van de VN Subcommissie ter Voorkoming van Discriminatie en ter Bescherming van Minderheden, $D$. Türk, heeft in zijn tweede (voortgangs)rapport over de verwezenlijking van economische, sociale en culturele rechten uitvoerig aandacht besteed aan de mogelijke rol van internationale indicatoren. ${ }^{56}$ De Limburg Principles bevelen het gebruik van indicatoren als hulpmiddel om de vooruitgang bij de verwezenlijking van de bepalingen uit het IVESCR te beoordelen uitdrukkelijk aan. ${ }^{57}$ Omdat kwantitatieve indicatoren van oorsprong niet de bedoeling hebben de verwezenlijking van economische, sociale en culturele rechten te meten zal het een moeilijke opgave worden deze indicatoren te koppelen aan mensenrechtennormen. Veelal hebben indicatoren geheel andere doel-

55. Vgl. S. Skogly, The First Session of the Committee on Economic social and Cultural Rights - An NGO-representative"s Impressions, in: Nordic Journal on Human Rights, vol. 5 (1987), pp. 82-83, die een dergelijke trend reeds tijdens de eerste gitting van het Comite bespeurde.

56. Zie UN Doc. E/CN.4/Sub.2/1990/19, hoofdatuk 1 (Rapport Turk).

57. Limburg Principles, a.w. no. 89. 
einden, namelijk het meten van ontwikkelingen op bijvoorbeeld sociaal en economisch terrein die dan in kwantitatieve vorm worden omgezet. ${ }^{58}$

Indicatoren moeten dus aan mensenrechtennormen gekoppeld worden: "[T]o establish such a link means to re-evaluate the "objective" indicators from a human rights perspective and to translate the "subjective" requirements into quantifiable aims'. ${ }^{59}$ Well bestaat er een zekere gelijkenis tussen sociale, economische en culturele mensenrechtennormen en indicatoren die in statistieken gebruikt worden: '[I]t reflects the universal adherence to basic postulates, of governmental obligations towards the population'.60

Welk doel kan het gebruik van indicatoren door het Comitê dienen? Het gebruik van indicatoren heeft een tweeërlei doel. In positieve zin gaat het om de vooruitgang te meten ten aanzien van de verwezenlijking van economische, sociale en culturele rechten in een staat. Daartoe kan men aanknopen bij de formuleringen van artikel 2 IVESCR. ${ }^{61}$ Heeft een staat positieve maatregelen genomen met het oog op de verwezenlijking van economische, sociale en culturele rechten en zo ja welke? Voorts kunnen indicatoren dienen om de inspanningen van de staat te meten. Is er inderdaad sprake van een maximale inspanning? Indicatoren kunnen ook behulpzaam zijn bij het meten van de verwezenlijking van rechten gedurende een aantal jaren. Is er dan sprake van vooruitgang? Daarnaast kunnen indicatoren antwoord geven op de vraag of de verwezenlijking van een recht op een non-discriminatoire wijze geschiedt. Zijn er specifieke groepen in de bevolking die het genot van een bepaald recht moeten ontberen? ${ }^{62}$ Het tweede doel van het gebruik van indicatoren kan in negatieve zin worden gedefinieerd. Indicatoren kunnen dienen als drempel met het oog op het vast stellen van een (voortdurende) achteruitgang in voorzieningen. De vraag is dan of het niveau van de verworven rechten beneden een bepaald minimum komt. Bovendien kunnen indicatoren enige houvast bieden bij de beantwoording van de vraag of er sprake is van schendingen van economische, socialle en culturele rechten. Daarvoor is een vergelijking van ontwikkelingen in de tijd evenwel noodzakelijk. ${ }^{63}$

Het voorafgaande geeft wellicht de indruk dat het gebruik van indicatoren voor mensenrechten-doeleinden geen problemen oplevert. Dat zou een

68. Zie D. Harris, Commentary by the Rapporteur on the Consideration of States' Parties Reports and International Cooperation, in: Human Rights Quarterly, vol. 9 (1987), pp. 147-165, op p. 152. Vgl. ook de summiere discussie over indicatoren in het CESCR, in: UN Doc. E/1990/23, par. 271-275.

59. K. Tomaseviki, Human Rights Indicators: The Right to Food as a Test Case, in: $\mathbb{P h}$. Alston, K. Tomasevski (eds), The Right to Food, Utrecht 1984, pp. 135-168, op. p. 160.

60. Idem, p. 168.

61. Rapport Turk, a.w. par. 61-65.

62. Idem, par, 94.

63. Ibid. 
verkeerde conclusie zijn. Er kleven heel wat problemen aan het gebruik van indicatoren, en niet alleen ten behoeve van mensenrechten doeleinden. Enkele van deze problemen wil ik hier noemen. Ten eerste is er vaak een gebrek aan beschikbare en betrouwbare statistieken. Ten tweede worden sommige indicatoren niet universeel erkend. Ook worden vaak schattingen gebruikt, omdat nauwkeurige cijfers niet beschikbaar zijn. Verder is er soms sprake van ondeugdelijke of inconsistente criteria en methoden bij de selectie van indicatoren. Als vijfde punt kan worden genoemd dat statistische gegevens in eerste instantie vaak door de nationale autoriteiten van een staat verzameld zijn. In relatie tot mensenrechtennormen kan dit soms leiden tot subjectief cijfermateriaal. Tot slot geven indicatoren vaak een onvolledig of indirect beeld van datgene wat zij beogen te meten. Ze geven onvoldoende uitdrukking aan de situatie zoals mensen die feitelijk ervaren. Dat wil zeggen dat indicatoren een algemeen beeld geven van een bepaalde situatie op een bepaald moment, terwijl economische, sociale en culturele rechten gericht zijn op het individu. ${ }^{64}$

Welke criteria moet men dan hanteren bij de selectie van indicatoren, of met andere woorden, aan welke eisen moeten indicatoren voldoen willen ze een functie vervullen ten aanzien van de beoordeling van de verwezenlijking van economische, sociale en culturele rechten? Als eerste eis geldt dat gegevens met betrekking tot een indicator beschikbaar en betrouwbaar moeten zijn. Dat wil onder meer zeggen dat er voldoende landen moeten zijn waarvan de gegevens bekend en bruikbaar zijn. Daarnaast dient een indicator zodanig te worden gedefinieerd dat hij volgens eenzelfde methode dezelfde elementen meet in verschillende landen. Bovendien dient een indicator die aspecten te meten die een duidelijke relatie hebben met één of meer sociale, economische of culturele rechten. ${ }^{65}$ In het algemeen kan worden gezegd dat voor het toetsen van gedetailleerd omschreven juridische normen het gebruik van specifieke indicatoren noodzakelijk is. Met andere woorden, het nut van indicatoren neemt toe naarmate de juridische verplichtingen voor staten gedetailleerder zijn geformuleerd. ${ }^{66}$

In dit verband kan men zich afvragen of het gebruik van indicatoren zich vooral moet richten op de mate van verwezenlijking van de minimum inhoud van economische, sociale en culturele rechten. Zo kan men bijvoorbeeld veronderstellen dat het percentage geletterden van de bevolking een indicator is voor de mate van beschikbaarheid en toegankelijkheid van het (lager) onderwijs. Dan zou ook de instelling van een leerplicht zijn invloed moeten doen gelden op het aantal analfabeten.

Wat betreft de ontwikkeling van een nationaal onderwijsstelsel verzamelen verschillende internationale organisaties statistische gegevens. Hier-

64. Idem, par. 8 en 9.

65. Idem, par. 14 en 19.

66. Idem, par. 30. 
bij valt te denken an UNESCO, UNICEF en de Wereldbank. ${ }^{67} \mathrm{Zij}$ verzamelden gegevens over de onderwijssituatie in verschillende staten, maar realiseerden zich daarbij niet of onvoldoende dat deze gegevens ook betekenis kunnen hebben vanuit mensenrechtenoogpunt. Met name UNESCO heeft in het verleden veel werk verricht met betrekking tot het verzamelen van gegevens over het onderwijs. Binnen de UNESCO zijn richtlijnen opgesteld die dienen als hulpmiddel voor staten voor de verzameling en indeling van statistisch materiaal betreffende de nationale onderwijssituatie. ${ }^{68}$ Daarbij gaat het om statistieken betreffende (functioneel) alfabetisme en analfabetisme, statistieken betreffende het onderwijsniveau van de bevolking in termen van de hoogst bereikte graad of diploma en statistieken betreffende het aantal ingeschreven leerlingen/studenten, aantallen onderwijsgevenden en onderwijsinstellingen. Van belang is dat deze UNESCO Aanbeveling ook definities geeft van kernbegrippen als analfabetisme, het leerplichtige gedeelte van de bevolking, openbaar en niet-openbaar onderwijs. Deze Aanbeveling bevordert de uniformiteit en onderlinge vergelijkbaarheid van nationale gegevens. Dit laatste is van belang, omdat UNESCO voor de samenstelling van zijn eigen onderwijsstatistieken vaak gebruik moet maken van nationale gegevens.

Naar mijn opvatting kan een aantal indicatoren worden voorgesteld dat een duidelijk verband heeft met het recht op onderwijs als mensenrecht. $\mathrm{Zij}$ kunnen het Comité behulpzaam zijn bij het beoordelen van de mate van verwezenlijking van het recht op onderwijs in afzonderlijke landen. Deze mogelijke indicatoren zijn zeker niet zonder gebreken, maar zij zullen steeds betere hulpmiddelen voor het Comitë gaan vormen. Ik stel de volgende indicatoren voor.

1) Ten aanzien van de beoordeling van de mate van verwezenlijking van verplicht lager onderwijs denk ik in de eerste plaats aan het percentage analfabeten jonger dan 15 jaar. Het is daarbij van belang dit percentage te differentiëren naar geslacht, stedelijke en plattelandsbevolking, en linguistische en etnische afkomst. Door deze onderverdeling wordt een verband gelegd met de non-discriminatienorm in het IVESCR.

2) Vervolgens kan worden gedacht aan het percentage ingeschreven leerlingen in het lager onderwijs in een bepaalde leeftijdsgroep (bijvoorbeeld 6-12 jaar) in verhouding tot het totale aantal kinderen in die leeftijdsgroep voor een bepaald jaar. ${ }^{69}$ Ook hier is differentiatie naar bijvoorbeeld geslacht of sociaal-economische af komst gewenst.

67. Vergelijk onder meer het UNESCO Statiatical Yearbook on het jaarlijkse rapport van UNICEF, The State of the World"s Children.

68. Zie de Revised Recommendation concerning the Standardization of Educational Statistice (1978).

69. Het aantal ingeschreven leerlingen zegt evenwel niet alles, ingeschreven zijn betekent niet dat de leerling ook feitelijk onderwijs valgt ('dropmouts', seizoenarbeid). 
3) Het is voorts relevant te weten of in een staat een leerplicht is ingesteld. Natuurlijk krijgt men pas een goed beeld van bepaalde positieve dan wel negatieve ontwikkelingen na vergelijking van een aantal jaren.

4) Ten aanzien van een meer algemene beoordeling van de verwezenlijking van het recht op onderwijs kan verder worden gedacht aan het percentage analfabeten van 15 jaar en ouder onderverdeeld naar geslacht etc.

5) Daarnaast kan worden gekeken naar de totale overheidsuitgaven voor onderwijs per hoofd van de bevolking uitgedrukt in de nationale valuta en in dollars (om vergelijking met andere landen mogelijk te maken). ${ }^{70}$

Het is aan te bevelen dat UNESCO, steeds voorafgaande aan de bespreking van een statenrapport, 'up to date' statistische gegevens over deze indicatoren ter beschikking stelt van het Comité. Deze gegevens kunnen worden opgeslagen in een computerprogramma waarin ook statistisch materiaal van andere inter-gouvernementele organisaties kan worden opgenomen en dat ook voor andere mensenrechten supervisie-organen toegankelijk is. ${ }^{71}$

Het voordeel van de onderwijsbepalingen uit het IVESCR is dat zij tamelijk gedetailleerd zijn en voldoende elementen bevatten voor koppeling aan mogelijke andere, meer specifieke indicatoren. Dat vergt evenwel nadere studie. Aan de andere kant bevatten de artikelen 13 en 14 IVESCR ook een aantal elementen die moeilijk meetbaar zijn met behulp van indicatoren. Daarbij valt bijvoorbeeld te denken aan de vrijheid van onderwijs. De mate van verwezenlijking van dit vrijheidsaspect van het recht op onderwijs is niet goed vast te stellen door alleen maar te kijken naar de verhouding openbaar/niet-openbaar onderwijs. Het gaat hier veel meer om de garantie van deze vrijheid in wetgeving, alsmede om de effectiviteit van deze wetgeving in de praktijk. Dit valt niet goed aan te tonen met behulp van indicatoren. Een ander aspect dat verbonden is met het recht op onderwijs is de kwaliteit van het onderwijs en het niveau van onderwijsgevenden. Ook hier kunnen kwantitatieve indicatoren slechts in zeer beperkte mate een bijdrage leveren aan de beoordeling van dit aspect. Ook de mate van kosteloosheid van het (primaire) onderwijs valt moeilijk in kwantitatieve termen te definiëren. De situatie binnen en tussen landen kan zo sterk verschillen dat de ontwikkeling van een indicator voor dit aspect niet goed

70. De totale overheidsuitgaven voor onderwijs kunnen worden onderverdeeld naar de lopende uitgaven ('current expenditure') 0.a. salariasen van onderwijagevenden, schoolboeken en ander onderwijsmateriaal, beurzen, onderhoud van schoolgebouwen en naar kapitialuitgaven ('capital expenditure"), uitgaven voor $0 . a$. land, gebouwren, meubilair. Vgl. UNESCO Statistical Yearbook 1988, p. 4-1.

71. Het belang van een dergelijk computerprogramma werd onderstreept in een verklaring wan de voorzitters wan vijf toezichthoudende organen. Zie Conclusions and Recommendations of the Meeting of Chairpersons of Human Rights Treaty Bodies, Geneva 1-5 oktober 1990, o.m. gepubliceerd in: Netherlands Quaterly of Human Rights, Voll. 8 (1990), pp. 452-457, op p. 454. 
voorstelbaar is. ${ }^{72}$ Het is in dit verband noodzakelijk dat binnen UNESCO initiatieven worden genomen tot ontwikkeling van zowel kwantitatieve als kwalitatieve indicatoren die kunnen worden gekoppeld aan de elementen van het recht op onderwijs uit de internationale teksten. Het is mijns inziens de taak van het Comité inzake Economische, Sociale en Culturele Rechten, in samenwerking met UNESCO en deskundigen ('consultants'), het idee van het gebruik van indicatoren als graadmeter voor de verwezenlijking van het recht op onderwijs uit te werken. ${ }^{73}$ Dat is evenwel in hoofdzaak geen juridische kwestie, maar vooral een methodologisch probleem waarbij de expertise van sociale wetenschappers onmisbaar is.

\subsubsection{Een individueel klachtrecht bij het IVESCR?}

Op het internationale vlak zijn er slechts weinig procedures die burgers in staat stellen te klagen over de niet-naleving door staten van economische, sociale en culturele rechten. De laatste jaren zijn er op bescheiden schaal voorstellen gedaan tot het ontwikkelen van nieuwe internationale procedures met het oog op een betere internationale implementatie van economische, sociale en culturele rechten. Voor de Europese context heeft de Oostenrijkse regering daarover enige gedachten geformuleerd die evenwel nadere uitwerking missen. ${ }^{74}$

Een ander voorstel heeft betrekking op het mondiale niveau en behelst het ontwerpen van een facuitatief Protocol bij het IVESCR. ${ }^{75}$ De kern van dit voorstel is dat een internationale procedure gecreëerd wordt die een individueel klachtrecht instelt ten aanzien van schendingen van IVESCR-bepalingen. Ook binnen het Comité inzake Economische, Sociale en Culturele Rechten bestaat er discussie over dit onderwerp. ${ }^{76}$ Denkbaar zou zijn dat dit Comité krachtens dit protocol belast wordt met het in ontvangst nemen

72. Vergelijk bijvoorbeeld de criteria voor kostelow onderwija die UNESCO auggereert: schoolgeld, kosten voor schoolboeken en ander onderwijsmateriaal, aanvullende kosten voor het volgen van extra (bijwoorbeeld ondersteunende) lessen, kosten voor schoolmaaltijden, kosten voor vervoer van leerlingen van en naar school, kosten voor schooluniformen, kosten voor eventuele medische behandeling en uitgaven voor kostscholen. Zie UNESCO Doc. 23C/72, Annex A, questionnaire voor de vierde Consultatie van lidstiaten ten aanzien van de implementatie van de Conventie tot Bestrijding wan Discriminatie in het Onderwijs.

73. Het Comité zou tijdens zijn zeede zitting (december 1991) aandacht besteden aan het gebruik van indicatoren, maar deze discussie kon niet meer worden verwerkt in de onderhavige tudie.

74. Zile The Role of the Council of Europe in the further realisation of human rights; report submitted by the Austrian delegation to the European Ministerial Conference on Human Rights, Vienna $19 / 20$ March 1985 , in: Human Rights Law Journal, vol. 6 (1985), pp. 118-129, op pp. 129, 124 .

75. Het vooratel werd onder meer verkondigd door kringen binnen de regering van de Sovjet-Unie, zie A. Glukhow, A two-way street, in: International Affairs (Moscow),
July 1988, pp. 31-40, op p. 39.

76. Zie het verslag van de discussie in UN Doc. E/C.12/1990/SR.4. 
van individuele klachten waarbij het Comitê analoog aan het Mensenrechtencomite op grond van het IVBPR zou kunnen functioneren. Dat betekent dat een individuele klacht, indien ontvankelijk verklaard, door het Comité bestudeerd wordt en uitmondt in een opinie over de vraag of al dan niet een schending heeft plaatsgevonden. Wat betreft de procedurele aspecten van een individuele klacht ten aanzien van economische, sociale en culturele rechten zou aansluiting kunnen worden gezocht bij het IVBPR Facultatieve Protocol, bijvoorbeeld aangaande de ontvankelijksvereisten. Zo zouden slechts individuele personen een klacht kunnen indienen nadat eerst de nationale rechtsmiddelen, voor zover aanwezig, zijn uitgeput.

Ten aanzien van de criteria voor het vaststellen van een schending biedt het Inter-Amerikaanse Protocol van San Salvador enige aanknopingspunten. ${ }^{77}$ Artikel 19 lid 6 bepaalt dat handelen dat direct is toe te schrijven aan de staat een schending van o.a. het onderwijsartikel uit het Protocol kan opleveren. In hoofdstuk 5 paragraaf 4 hebben we verder gezien dat er sprake kan zijn van schending van een sociaal, economisch of cultureel recht indien de staat opzettelijk handelt in strijd met de internationale norm, terwijl die staat wel bij machte is te voldoen aan die internationale norm. Daarbij zou ook gedacht kunnen worden aan het ophouden dan wel het stopzetten van de geleidelijke verwezenlijking van materiële rechten. Ten aanzien van het recht op onderwijs zoals vervat in de artikelen 13 en 14 IVESCR, kan de minimum kerninhoud een graadmeter zijn voor het vaststellen van een schending. Dat betekent dat de vrije keuze van onderwijs, alsmede de religieuze en filosofische overtuigingen van ouders of voogden door de staat gerespecteerd moeten worden. Voorts mag niemand het recht op onderwijs worden ontzegd; in het bijzonder dient de toegang tot de bestaande onderwijsinstellingen, in overeenstemming met artikel 2 lid 2 IVESCR, op een non-discriminatoire wijze verzekerd te zijn. Wat betreft het sociale aspect dient het primaire onderwijs verplicht en kosteloos te zijn voor allen die daarvoor de leeftijd hebben. Het betreft hier immers een basisrecht voor ieder mens dat bovendien op dwingende wijze in artikel 13 IVESCR is geformuleerd. $\mathrm{Er}$ is sprake van een schending van het recht op onderwijs indien de staat opzettelijk handelt of nalaat te handelen in strijd met de elementen van de minimum kerninhoud van dat recht. Men zou daar nog aan toe kunnen voegen dat de weigering van de staat toestemming te verlenen voor de stichting van privé-onderwijsinstellingen eveneens een schending van artikel 13 kan opleveren. Dan zou vast moeten staan dat de groep of privé-persoon die een school wil stichten voldoet aan de inhoudelijke eisen en voorwaarden die de staat stelt, maar dat de weigering op willekeur is gebaseerd of discriminatoir van aard is. Bovenstaande gedachten zou het Comité inzake Economische, Sociale en Culturele rechten in overweging kunnen nemen indien een individueel klachtrecht bij het IVESCR werke- 
lijkheid zou worden en een klacht over een beweerde schending van het recht op onderwijs zich voordoet. ${ }^{78}$

Ik onderschrijf een dergelijk individueel klachtrecht, omdat het de verwezenlijking op het nationale niveau kan bevorderen: in een concreet, individueel geval worden wetgeving, beleid of praktijk van een staat getoetst aan de internationale norm. Bij een geconstateerde schending van het recht op onderwijs zal een staat zich genoodzaakt voelen wetgeving beleid of praktijk aan te passen. Voorts bevordert de optie een procedure aanhangig te maken tegen de eigen staat de betrokkenheid van individuele personen bij de realisering van economische, sociale en culturele rechten. En tenslotte wordt op deze wijze de verwezenlijking van economische, sociale en culturele rechten sterker geïnternationaliseerd.

\subsection{Slotopmerkingen}

Het internationale recht kan slechts een beperkte rol spelen in het proces van de feitelijke verwezenlijking van het recht op onderwijs. Wel geeft het de richting aan waarin dat proces zich dient te ontwikkelen. Tevens verschaft het internationale recht normen waaraan het beleid van staten en de praktijk binnen staten getoetst moet worden. In hoofdstuk 5 heb ik getracht die normen te specificeren in termen van verplichtingen van staten. De realisering van het recht op onderwijs en de ontwikkeling en uitbouw van een onderwijsstelsel zijn primair een binnenlandse kwestie. Indien een staat partij wordt bij het IVESCR betekent dit evenwel dat de verwezenlijking van het recht op onderwijs niet langer een zuiver interne aangelegenheid is. De staat moet zich immers periodiek verantwoorden voor de genomen maatregelen en het gevoerde beleid en de daarbij ondervonden moeilijkheden. Het internationale toezicht op de verwezenlijking van het recht op onderwijs heeft met de activiteiten van het Comite inzake Economische, Sociale en Culturele Rechten nieuwe impulsen gekregen. De bespreking van statenrapporten door het Comité en de constructieve dialoog met vertegenwoordigers van staten moeten voor staten een stimulans zijn de verwezenlijking van het recht op onderwijs op serieuze en voortvarende wijze ter hand te nemen. Het internationale toezicht op de naleving van het recht op onderwijs moet evenwel niet beperkt blijven tot een dialoog tussen het Comité en een verdragsstaat. Andere actoren, zoals de UNESCO en nietgouvernementele organisaties, kunnen het beleid van staten kritisch volgen en de weergave van het eigen beleid door staten van commentaar voorzien. Juist de betrokkenheid van deze andere actoren geeft de rapportageprocedure een meerwaarde.

78. Het Comité heeft zelf reeds opgemerkt dat onder meer de artikelen 13 lid 2 aub a, 13 lid 3 en 13 lid 4 IVESCR "would seem to be capable of immediate application by judicial and other organs in many national legal systems. Any suggestion that the provisions indicated are inherently non-self executing would seem to be difficult to sustain'. Zie General Comment no. 3 (1990), a.w. par. 5. 
Ook een individuele persoon kan de effectiviteit van het internationale toezicht op de naleving van het recht op onderwijs bevorderen indien hij het recht krijgt een klacht in te dienen over een vermeende schending van dit recht door de eigen staat. De versterking van het internationale toezicht draagt ertoe bij dat de internationale teksten inzake het recht op onderwijs ook buiten het niveau van de staat (regering) gaan leven en een eigen betekenis verwerven. 


\section{BIJLAGE}

\section{Internationale teksten aangaande het recht op onderwijs als mensenrecht}

\section{A. Universele Teksten}

1. Universal Declaration of Human Rights

Algemene Vergadering van de Verenigde Naties, Res. 217A (III), 10 december 1948, Trb. 1969, 99

Article 26

1. Everyone has the right to education. Education shall be free, at least in the elementary and fundamental stages. Elementary education shall be compulsory. Technical and professional education shall be made generally available and higher education shall be equally accessible to all on the basis of merit.

2. Education shall be directed to the full development of the human personality and to the strengthening of respect for human rights and fundamental freedoms. It shall promote understanding, tolerance and friendship among all nations, racial or religious groups, and shall further the activities of the United Nations for the maintenance of peace.

3. Parents have a prior right to choose the kind of education that shall be given to their children.

2. International Covenant on Economic, Social and Cultural Rights 19 december 1966, Trb. 1969, 100

Article 13

1. The States Parties to the present Covenant recognize the right of everyone to education. They agree that education shall be directed to the full development of the human personality and the sense of its dignity, and shall strengthen the respect for human rights and fundamental freedoms. They further agree that education shall enable all persons to participate effectively in a free society, promote understanding, tolerance and friendship among all nations and all racial, ethnic or religious groups, and further the activities of the United Nations for the maintenance of peace.

2. The States Parties to the present Covenant recognize that, with a view to achieving the full realization of this right:

a) Primary education shall be compulsory and available free to all; 
b) Secondary education in its different forms, including technical and vocational secondary education, shall be made generally available and accessible to all by every appropriate means, and in particular by the progressive introduction of free education;

c) Higher education shall be made equally accessible to all, on the basis of capacity, by every appropriate means, and in particular by the progressive introduction of free education;

d) Fundamental education shall be encouraged or intensified as far as possible for those persons who have not received or completed the whole period of their primary education;

e) The development of a system of schools at all levels shall be actively pursued, an adequate fellowship system shall be established, and the material conditions of teaching staff shall be continuously improved.

3. The States Parties to the present Covenant undertake to have respect for the liberty of parents and, when applicable, legal guardians to choose for their children schools, other than those established by the public authorities, which conform to such minimum educational standards as may be laid down or approved by the State and to ensure the religious and moral education of their children in conformity with their own convictions.

4. No part of this article shall be construed so as to interfere with the liberty of individuals and bodies to establish and direct educational institutions, subject always to the observance of the principles set forth in paragraph 1 of this article and to the requirement that the education given in such institutions shall conform to such minimum standards as may be laid down by the State.

\section{Article 14}

Each State Party to the present Covenant which, at the time of becoming a Party, has not been able to secure in its metropolitan territory or other territories under its jurisdiction compulsory primary education, free of charge, undertakes, within two years, to work out and adopt a detailed plan of action for the progressive implementation, within a reasonable number of years, to be fixed in the plan, of the principle of compulsory education free of charge for all.

\section{International Covenant on Civil and Political Rights}

19 december 1966, Trb. 1969, 99

\section{Article 18(4)}

The States Parties to the present Covenant undertake to have respect for the liberty of parents and, when applicable, legal guardians to ensure the religious and moral education of their children in conformity with their own convictions. 
Article 27

In those States in which ethnic, religious or linguistic minorities exist, persons belonging to such minorities shall not be denied the right, in community with the other members of their group to enjoy their own culture, to profess and practise their own religion, or to use their own language.

4. UNESCO Convention against Discrimination in Education 15 december 1960, Trb. 1964, 69

\section{Article 1}

1. For the purposes of this Convention, the term 'discrimination' includes any distinction, exclusion, limitation or preference which, being based on race, colour, sex, language, religion, political or other opinion, national or social origin, economic condition or birth, has the purpose or effect of nullifying or impairing equality of treatment in education and in particular:

a. Of depriving any person or group of persons of access to education of any type or at any level;

b. Of limiting any person or group of persons to education of an inferior standard;

c. Subject to the provisions of Article 2 of this Convention, of establishing or maintaining separate educational systems or institutions for persons or groups of persons; or

d. Of inflicting on any person or group of persons conditions which are incompatible with the dignity of man.

2. For the purpose of this Convention, the term 'education' refers to all types and levels of education, and includes access to education, the standard and quality of education, and the conditions under which it is given.

\section{Article 2}

When permitted in a State, the following situations shall not be deemed to constitute discrimination, within the meaning of Article 1 of this Convention:

a. The establishment or maintenance of separate educational systems or institutions for pupils of the two sexes, if these systems or institutions offer equivalent access to education, provide a teaching staff with qualifications of the same standard as well as school premises and equipment of the same quality, and afford the opportunity to take the same or equivalent courses of study;

b. The establishment or maintenance, for religious or linguistic reasons, of separate education systems or institutions offering an education which is in keeping with the wishes of the pupil's parents or legal guardians, if participation in such systems or attendance at such institutions is optional and if the education provided conforms 
to such standard as may be laid down or approved by the competent authorities, in particular for education of the same level;

c. The establishment or maintenance of private educational institutions, if the object of the institutions is not to secure the exclusion of any group but to provide educational facilities in addition to those provided by the public authorities, if the institutions are conducted in accordance with that object, and if the education provided conforms with such standards as may be laïd down or approved by the competent authorities, in particular for education of the same level.

\section{Article 3}

In order to eliminate and prevent discrimination within the meaning of this Convention, the States Parties thereto undertake:

a. To abrogate any statutory provisions and any administrative instructions and to discontinue any administrative practices which involve discrimination in education;

b. To ensure, by legislation where necessary, that there is no discrimination in the admission of pupils to educational institutions;

c. Not to allow any differences of treatment by the public authorities between nationals, except on the basis of merit or need, in the matter of school fees and the grant of scholarships or other forms of assistance to pupils and necessary permits and facilities for the pursuit of studies in foreign countries;

d. Not to allow, in any form of assistance granted by the public authorities to educational institutions, any restrictions or preference based solely on the ground that pupils belong to a particular group;

e. To give foreign nationals resident within their territory the same access to education as that given to their own nationals.

\section{Article 4}

The States Parties to this Convention undertake furthermore to formulate, develop and apply a national policy which, by methods appropriate to the circumstances and to national usage, will tend to promote equality of opportunity and of treatment in the matter of education and in particular:

a. To make primary education free and compulsory; make secondary education in its different forms generally available and accessible to all; make higher education equally accessible to all on the basis of individual capacity; assure compliance by all with the obligation to attend school prescribed by law;

b. To ensure that the standards of education are equivalent in all public educational institutions of the same level, and that the conditions relating to the quality of the education provided are also equivalent;

c. To encourage and intensify by appropriate methods the education of persons who have not received any primary education or who 
have not completed the entire primary education course and the continuation of their education on the basis of individual capacity; d. To provide training for the teaching profession without discrimination.

\section{Article 5}

1. The States Parties to this Convention agree that:

a. Education shall be directed to the full development of the human personality and to the strengthening of respect for human rights and fundamental freedoms; it shall promote understanding, tolerance and friendship among all nations, racial or religious groups, and shall further the activities of the United Nations or the maintenance of peace;

b. It is essential to respect the liberty of parents and, where applicable, of legal guardians, firstly to choose for their children institutions other than those maintained by the public authorities but conforming to such minimum educational standards as may be laid down or approved by the competent authorities and, secondly, to ensure in a manner consistent with the procedures followed in the State for the application of its legislation, the religious and moral education of the children in conformity with their own convictions; and no person or group of persons should be compelled to receive religious instruction inconsistent with his or their convictions;

c. It is essential to recognize the right of members of national minorities to carry on their own educational activities, including the maintenance of schools and, depending on the educational policy of each State, the use or the teaching of their own language, provided however:

i) That this right is not exercised in a manner which prevents the members of these minorities from understanding the culture and language of the community as a whole and from participating in its activities, or which prejudices national sovereignty;

ii) That the standard of education is not lower than the general standard laid down or approved by the competent authorities; and

iii) That attendance at such schools is optional.

2. The States Parties to this Convention undertake to take all necessary measures to ensure the application of the principles enunciated in paragraph 1 of this Article.

5. Convention on the Elimination of all Forms of Discrimination against Women

18 december 1979, Trb. 1980, 146

\section{Article 10}

States Parties shall take all appropriate measures to eliminate discrimination against women in order to ensure to them equal rights with men 
in the field of education and in particular to ensure, on a basis of equality of men and women:

a) The same conditions for career and vocational guidance, for access to studies and for the achievement of diplomas in educational establishments of all categories in rural as well as in urban areas; this equality shall be ensured in pre-school, general, technical, professional and higher technical education, as well as in all types of vocational training;

b) Access to the same curricula, the same examinations, teaching staff with qualifications of the same standard and school premises and equipment of the same quality;

c) The elimination of any stereotyped concept of the roles of men and women at all levels and in all forms of education by encouraging co-education and other types of education which will help to achieve this aim and, in particular, by the revision of textbooks and school programmes and the adaptation of teaching methods;

d) The same opportunities to benefit from scholarships and other study grants;

e) The same opportunities for access to programmes of continuing education, including adult and functional literacy programmes, particularly those aimed at reducing, at the earliest possible time, any gap in education existing between men and women;

f) The reduction of female student drop-out rates and the organization of programmes for girls and women who have left school prematurely;

g) The same opportunities to participate actively in sports and physical education;

h) Access to specific educational information to help to ensure the health and well-being of families, including information and advice on family planning.

6. Convention Concerning the Protection and Integration of Indigenous and other Tribal and Semi-Tribal Populations in Independent Countries 26 juni 1957, ILO Convention no. 107; ILO, International Labour Conventions and Recommendations, 1919-1981, Geneva 1982

Article 21

Measures shall be taken to ensure that members of the populations concerned have the opportunity to acquire education at all levels on an equal footing with the rest of the national community.

\section{Article 22}

1. Education programmes for the populations concerned shall be adapted, as regards methods and techniques, to the stage these populations have reached in the process of social, economic and cultural integration into the national community. 
2. The formulation of such programmes shall normally be preceded by ethnological surveys.

\section{Article 23}

1. Children belonging to the populations concerned shall be taught to read and write in their mother tongue or, where this is not practicable, in the language most commonly used by the group to which they belong.

2. Provision shall be made for a progressive transition from the mother tongue or the vernacular language or to one of the official languages of the country.

3. Appropriate measures shall, as far as possible, be taken to preserve the mother tongue or the vernacular language.

\section{Article 24}

The imparting of general knowledge and skills that will help children to become integrated into the national community shall be an aim of primary education for the populations concerned.

\section{Article 25}

Educational measures shall be taken among other sections of the national community and particularly among those that are in most direct contact with the populations concerned with the object of eliminating prejudices that they may harbour in respect of these populations.

7. Convention concerning Indigenous and Tribal Peoples in Independent Countries

ILO Convention no. 169, 27 juni 1989, Trb. 1990, 39

\section{Article 26}

Measures shall be taken to ensure that members of the peoples concerned have the opportunity to acquire education at all levels on at least an equal footing with the rest of the national community.

\section{Article 27}

1. Education programmes and services for the peoples concerned shall be developed and implemented in co-operation with them to address their special needs, and shall incorporate their histories, their knowledge and technologies, their value systems and their further social, economic and cultural aspirations.

2. The competent authority shall ensure the training of members of these peoples and their involvement in the formulation and implementation of education programmes, with a view to the progressive transfer of responsibility for the conduct of these programmes to these peoples as appropriate.

3. In addition, governments shall recognise the right of these peoples to establish their own educational institutions and facilities, provided that such institutions meet minimum standards established by the com- 
petent authority in consultation with these peoples. Appropriate resources shall be provided for this purpose.

\section{Article 28}

1. Children belonging to the peoples concerned shall, wherever practicable, be taught to read and write in their own indigenous language or in the language most commonly used by the group to which they belong. When this is not practicable, the competent authorities shall undertake consultations with these peoples with a view to the adoption of measures to achieve this objective.

2. Adequate measures shall be taken to ensure that these peoples have the opportunity to attain fluency in the national language or in one of the official languages of the country.

3. Measures shall be taken to preserve and promote the development and practice of the indigenous languages of the peoples concerned.

\section{Article 29}

The imparting of general knowledge and skills that will help children belonging to the peoples concerned to participate fully and on an equal footing in their own community and in the national community shall be an aim of education for these peoples.

\section{Article 31}

Educational measures shall be taken among all sections of the national community, and particularly among those that are in most direct contact with the peoples concerned, with the object of eliminating prejudices that they may harbour in respect of these peoples. To this end, efforts shall be made to ensure that history textbooks and other educational materials provide a fair, accurate and informative portrayal of the societies and cultures of these peoples.

\section{Convention on the Rights of the Child} 20 november 1989 , Trb. 1990,46

\section{Article 14}

1. States Parties shall respect the right of the child to freedom of thought, conscience and religion.

2. States Parties shall respect the rights and duties of the parents and, when applicable, legal guardians, to provide direction to the child in the exercise of his or her right in a manner consistent with the evolving capacities of the child.

3. Freedom to manifest one's religion or beliefs may be subject only to such limitations as are prescribed by law and are necessary to protect public safety, order, health or morals, or the fundamental rights and freedoms of others. 
Article 28

1. States Parties recognize the right of the child to education, and with a view to achieving this right progressively and on the basis of equal opportunity, they shall, in particular:

a) Make primary education compulsory and available free to all;

b) Encourage the development of different forms of secondary education, including general and vocational education, make them available and accessible to every child, and take appropriate measures such as the introduction of free education and offering financial assistance in case of need;

c) Make higher education accessible to all on the basis of capacity by every appropriate means;

d) Make educational and vocational information and guidance available and accessible to all children;

e) Take measures to encourage regular attendance at schools and the reduction of drop-out rates.

2. States Parties shall take all appropriate measures to ensure that school discipline is administered in a manner consistent with the child's human dignity and in conformity with the present Convention.

3. States Parties shall promote and encourage international co-operation in matters relating to education, in particular with a view to contributing to the elimination of ignorance and illiteracy throughout the world and facilitating access to scientific and technical knowledge and modern teaching methods. In this regard, particular account shall be taken of the needs of developing countries.

Article 29

1. States Parties agree that the education of the child shall be directed to:

a) The development of the child's personality, talents and mental and physical abilities to their fullest potential;

b) The development of respect for human rights and fundamental freedoms, and for the principles enshrined in the Charter of the United Nations.

c) The development of respect for the child's parents, his or her own cultural identity, language and values, for the national values of the country in which the child is living, the country from which he or she may originate, and for civilizations different from his or her own;

d) The preparation of the child for responsible life in a free society, in the spirit of understanding, peace, tolerance, equality of sexes, and friendship among all peoples, ethnic, national and religious groups and persons of indigenous origin;

e) The development of respect for the natural environment.

2. No part of the present article or article 28 shall be construed so as to interfere with the liberty of individuals and bodies to establish and direct educational institutions, subject always to the observance of the principles set forth in paragraph 1 of the present article and to the requirements that the education given in such institutions shall conform to such minimum standards as may be laid down by the State. 
9. Convention relating to the Status of Refugees 28 juli 1951, Trb. 1954, 88

\section{Article 22}

1. The Contracting States shall accord to refugees the same treatment as is accorded to nationals with respect to elementary education.

2. The Contracting States shall accord to refugees treatment as favourable as possible, and, in any event, not less favourable than that accorded to aliens generally in the same circumstances, with respect to education other than elementary education and, in particular, as regards access to studies, the recognition of foreign school certificates, diplomas and degrees, the remission of fees and charges and the award of scholarships.

10. Standard Minimum Rules for the Treatment of Prisoners Adopted by the First United Nations Congress on the Prevention Crime and the Treatment of Offenders on 30 August 1955 at Geneva, and approved by the Economic and Social Council by its Resolutions $663 \mathrm{C}$ (XXIV) of 31 July 1957 and 2076 (LXII) of 13 May 1977

77 (1) Provision shall be made for the further education of all prisoners capable of profiting thereby, including religious instruction in the countries where this is possible. The education of illiterates and young prisoners shall be compulsory and special attention shall be paid to it by the administration.

(2) So far as practicable, the education of prisoners shall be integrated with the educational system of the country so that after their release they may continue their education without difficulty.

11. Declaration on the Elimination of All Forms of Intolerance and of Discrimination based on Religion or Belief

Algemene Vergadering van de Verenigde Naties, Res. $36 / 55$ van 25 november 1981

\section{Article 5}

1. The parents or, as the case may be, the legal guardians of the child have the right to organize the life within the family in accordance with their religion or belief and bearing in mind the moral education in which they believe the child should be brought up.

2. Every child shall enjoy the right to have access to education in the matter of religion or belief in accordance with the wishes of his parents or, as the case may be, legal guardians, and shall not be compelled to receive teaching on religion or belief against the wishes of his parents or legal guardians, the best interests of the child being the guiding principle. 


\section{B. Regionale Teksten}

12. European Convention for the Protection of Human Rights and Fundamental Freedoms. First Protocol to the Convention 20 maart 1952, Trb. 1952, 80.

\section{Article 2}

No person shall be denied the right to education. In the exercise of any functions which it assumes in relation to education and to teaching, the State shall respect the right of parents to ensure such education and teaching in conformity with their own religious and philosophical convictions.

\section{African Charter on Human Rights and Peoples' Rights}

26 juni 1981, International Legal Materials, vol. XXI (1982), p. 59 e.v.

\section{Article 17}

1. Every individual shall have the right to education.

14. Protocol to the American Convention on Human Rights (Protocol of San Salvador)

14 november 1988, International Legal Materials, vol. XXVIII (1989), p. 156 e.v.

\section{Article 13}

1. Everyone has the right to education.

2. The States Parties to this Protocol agree that education should be directed towards the full development of the human personality and human dignity and should strengthen respect for human rights, ideological pluralism, fundamental freedoms, justice and peace. They further agree that education ought to enable everyone to participate effectively in a democratic and pluralistic society and achieve a decent existence and should foster understanding, tolerance and friendship among all nations and all racial, ethnic or religious groups and promote activities for the maintenance of peace.

3. The States Parties to this Protocol recognize that in order to achieve the full exercise of the right to education:

a. Primary education should be compulsory and accessible to all without cost;

b. Secondary education in its different forms, including technical and vocational secondary education, should be made generally available and accessible to all by every appropriate means, and in particular, by the progressive introduction of free education;

c. Higher education should be made equally accessible to all on the basis of individual capacity, by every appropriate means, and in particular, by the progressive introduction of free education; 
d. Basic education should be encouraged or intensified as far as possible for those persons who have not received or completed the whole cycle of primary instruction;

e. Programs of special education should be established for the handicapped, so as to provide special instruction and training to persons with physical disabilities or mental deficiencies.

4. In conformity with the domestic legislation of the States Parties, parents should have the right to select the type of education to be given to their children, provided that it conforms to the principles set forth above.

5. Nothing in this Protocol shall be interpreted as a restriction of the freedom of individuals and entities to establish and direct educational institutions in accordance with the domestic legislation of the States Parties. 


\section{Lijst van bronnen en aangehaalde literatuur}

\section{Bronnen}

- VN documenten

- Commissie voor de Rechten van de Mens:

tekstvoorstellen van regeringen, gespecialiseerde organisaties en nietgouvernementele organisaties, verslagen van bijeenkomsten van de

+ zesde zitting, 1950

+ zevende zitting, 1951

+ achtste zitting, 1952

+ negende zitting, 1953

- Derde Commissie van de Algemene Vergadering: tekstvoorstellen van regeringen, verslagen van bijeenkomsten van de

+ vijfde zitting, 1950

+ tiende zitting, 1955

+ twaalfde zitting, 1957

+ zestiende zitting, 1961

- Commissie inzake de Status van de vrouw: tekstvoorstellen en verslagen van bijeenkomsten van de

+ zesentwintigste zitting, 1976 .

- Verslagen van bijeenkomsten van de 'Sessional Working Group of Governmental Experts on the Implementation of the International Covenant on Economic, Social and Cultural Rights', 1979, 1980, 1982, 1983, 1985, 1986.

- Rapporten van staten en gespecialiseerde organisaties ingevolge artt. 16-18 IVESCR inzake de implementatie van art. 13 IVESCR, $1982 \mathrm{t} / \mathrm{m}$ 1990.

- Documenten, waaronder verslagen van bijeenkomsten en rapporten van het Comité inzake Economische, Sociale en Culturele Rechten, $1987 \mathrm{t} / \mathrm{m} 1990$ (eerste $\mathrm{t} / \mathrm{m}$ de vijfde zitting).

* UNESCO Documenten

- UN Doc. E/CN.4/Sub.2/210, Annex II en III, 5-1-1961, Note by the Director-General of UNESCO on the Convention and Recommendation against Discrimination in Education.

- doc. 15 C/11 (1968), Rapport van het Committee on Conventions and Recommendations naar aanleiding van de eerste consultatieronde van lidstaten over de implementatie van het Verdrag en de Aanbeveling tot Bestrijding van Discriminatie in het Onderwijs.

- doc. $20 \mathrm{C} / 40$ (1978), Rapport van het Committee on Conventions and Recommendations naar aanleiding van de tweede consultatieronde van lidstaten. 
- doc. 21 C/27 (1980), Rapport van het Committee on Conventions and Recommmendations naar aanleiding van de derde consultatieronde van lidstaten.

- doc. $23 \mathrm{C} / 72$ (1985), Rapport van het Committee on Conventions and Recommendations naar aanleiding van de vierde consultatieronde van lidstaten.

- doc. $120 \mathrm{EX} / 17$ (10-9-1984), Evaluation of the procedures adopted by the Executive Board for the examination of communications concerning violations of human rights falling within UNESCO's field of competence.

- doc. 4 XC/4, Second Medium-Term Plan (1984-1989).

- doc. 25 C/4, Draft Medium-Term Plan (1990-1995).

- doc. $\mathrm{ED} / \mathrm{MD} / 81$, Declaration of the Fourth International Conference on Adult Education, Paris, 19-29 March 1985.

- doc. SHS-89/CONF.613/3, 7-11-1989, International Meeting of Experts on the implementation in UNESCO's fields of competence of the International Covenants on Human Rights, Ottawa, 4-7 December 1989, Secretariat Working Document.

- doc. SHS-89/CONF.613/INF.5, 2-3-1990, International Meeting of Experts on the implementation in UNESCO's fields of competence of the International Covenants on Human Rights, Ottawa, 4-7 Dec. 1989, Final Report and Recommendations.

\section{Aangehaalde literatuur}

Ago, R., Sixth Report on State Responsibility by the Special Rapporteur of the International Law Commission, in: Yearbook of the International Law Commission, (1977) vol. II, part one, pp. 3-20.

Akkermans, P.W.C., Onderwijs en Recht, in: J.A. van Kemenade (red.), Onderwijs; Bestel en Beleid, deel I, Onderwijs in hoofdlijnen, Groningen 1986, pp. 359-433.

Akkermans, P.W.C., Onderwijs als constitutioneel probleem, diss., Alphen aan de Rijn/Brussel 1980.

Akkermans, P.W.C., De internationale dimensie van het Nederlandse onderwijsrecht, in: Nederlands Tijdschrift voor Onderwijsrecht, (1989) nr. 2, pp. 61-71.

Al Haq, Punishing a Nation; Human Rights violations during the Palestinian Uprising dec. 1987 - dec. 1988, Ramallah 1988.

Alkema, E.A., Studies over Europese Grondrechten, Deventer 1978.

Alkema, E.A., Schakelbepalingen: enige beschouwingen over de samenhang en de werking van de rechten van de mens, Oratie, Universiteit van Amsterdam, Deventer 1981.

Alkema, E.A., De internationale sociale rechten en het Nederlands recht, in: J.J.M. van der Ven e.a., Het Europees Sociaal Handvest, Nijmegen 1982, pp. 34-57.

Alkema, E.A., Het internationale gelijkheidsbeginsel en de Nederlandse staatsrechtelijke verhoudingen, in: Staatsrecht, Buitenlandse Betrekkin- 
gen en de internationale rechtsorde (Staatsrechtconferentie 1986), Nijmegen 1987, pp. 64-105.

Alston, Ph., United Nations Specialized Agencies and Implementation of the International Covenant on Economic, Social and Cultural Rights, in: Columbia Journal of Transnational Law, vol. 18 (1979), pp. 79-118. Alston, Ph., Prevention versus Cure as a Human Rights Strategy, in: Development, Human Rights and the Rule of Law. Report of a Conference held in The Hague on 27 April-1 May 1981, I.C.J. (1981), pp. 31-109.

Alston, Ph., Tomasevski, $K$. (eds), The right to food, The Hague/Utrecht 1984.

Alston, Ph., Eide, A., Advancing the right to food in international law, in: A. Eide, W.B. Eide c.s. (eds), Food as a human right, United Nations University, Tokyo 1984, pp. 249-260.

Alston, Ph., Out of the Abyss: The Challenges Confronting the New UN Committee on Economic, Social and Cultural Rights, in: Human Rights Quarterly, vol. 9 (1987), pp. 332-382.

Alston, Ph. en Simma, B., First Session of the UN Committee on Economic, Social and Cultural Rights in: American Journal of International Law, vol. 81 (1987), 747-756.

Alston, Ph., Quinn, G., The Nature and Scope of States' Parties Obligations under the International Covenant on Economic, Social and Cultural Rights, in: Human Rights Quarterly, vol. 9 (1987), pp. 156-229.

Alston, Ph., Effective Implementation of International Instruments on Human Rights, Including Reporting Obligations under International Instruments on Human Rights, UN Doc. A/44/668 (8 november 1989).

Alston, $\mathrm{Ph}$., US Ratification of the Covenant on Economic, Social and Cultural Rights: The Need for an entirely new strategy, in: American Journal of International Law, vol. 84 (1990), pp. 365-393.

Alston, Ph., The purposes of reporting, in: Manual on Human Rights Reporting, United Nations, New York 1991 (UN sales no. E.91.XIV.1), pp. 13-17.

Ammoun, C.D., Study of Discrimination in Education, United Nations, New York 1957 (UN sales no. 57.XIV.3).

Asbeck, F.M. van (ed.) The Universal Declaration of Human Rights and its predecessors (1679-1948), Leiden 1949.

Azcarate, P. de, League of Nations and National Minorities, an experiment, Washington 1945.

Bastid, S., La mise en oeuvre d'un recours concernant les droits de l'homme dans le domaine relevant de la compétence de l'UNESCO, in: Völkerrecht als Rechtsordnung Internationale Gerichtsbarkeit-Menschenrechte, Festschrift für Herman Mosler, Berlin 1983, pp. 45-57.

Beguele, A., Boyden, J. (eds), Combating Child Labour, ILO-study, Geneva 1988.

Berenstein, A., Economic and Social Rights: Their inclusion in the European Convention on Human Rights. Problems of Formulation and Interpretation, in: Human Rights Law Journal, vol. 2 (1981), pp. 257-281. 
Berg, G.P. van den en Guldenmund, R.M.A., The Right to work in East and West, in: A. Bloed en P. van Dijk, Essays in human rights in the Helsinki Process, The Hague 1985, pp. 103-127.

Berg, G.P. van den, Sovjet Stat en Recht in Beweging, deel 1, Nijmegen 1991.

Berman, H.R., The International Labour Organization and Indigenous Peoples: Revision of ILO Convention no. 107 at the 75th session of the International Labour Conference, 1988, in: The Review of the International Commission of Jurists, no. 41/1988, pp. 48-58.

Betten, L. en van Dijk, P., Lentezwaluw of dode mus? Enige beschouwingen over de wijzen waarop de doorwerking van internationale normen aangaande economische en sociale grondrechten binnen de Nederlandse rechtsorde wordt bevorderd, in: J.B.J.M. ten Berge (red.), Recht als norm en als aspiratie: Nijmegen 1986, pp. 266-286.

Beurden, J. van, Afrikaans onderwijs verkeert in een crisis, in: Internationale samenwerking (Uitgave Ministerie van Buitenlandse Zaken, 's-Gravenhage), juli 1990, pp. 25-30.

Bloed, A., Human Rights at the CSCE Follow-up Meeting in Vienna, in: SIM Newsletter, no. 18 (juni 1987), pp. 3-15.

Bloed, A., CVSE in Wenen: hoogtepunt in Helsinki-proces, in: Internationale Spectator, juni 1989 , pp. 392-400.

Bloed, A. (ed.), From Helsinki to Vienna: Basic Documents of the Helsinki Process, Dordrecht 1990.

Bloed, A., Succesful meeting of the Conference on the Human Dimension of CSCE, in: Netherlands Quarterly of Human Rights, voll. 8 (1990), pp. 235-261.

Blois, M. de, Europees Gemeenschapsrecht en Onderwijs, in: S.E.W. (Tijdschrift voor Europees en Economisch Recht), vol. 39 (1991), pp. 513538.

Boerefijn, I., Heringa, A.W., Schokkenbroek, J.G.C., Verbetering van het toezichtmechanisme van het Europees Sociaal Handvest, in: NJCMBulletin 16-5 (1991), pp. 396-411.

Bossuyt, M., La distinction juridique entre les droits civils et politiques et les droits, économiques, sociaux et culturels, in: Revue des Droits de l'Homme/Human Rights Journal, vol. VIII (1975), pp. 783-813.

Bossuyt, M., Guide to the 'Travaux Preparatoires' of the International Covenant on Civil and Political Rights, Dordrecht 1987.

Boven, Th.C. van, De volkenrechtelijke bescherming van de godsdienstvrijheid, diss., Assen 1967.

Boven, Th. van, Distinguishing Criteria of Human Rights, in: K. Vasak, Ph. Alston (eds), The International Dimensions of Human Rights, vol. I, Westport, Connecticut 1982, pp. 43-60.

Boven, Th. van, Die Ueberfrachtete Agenda, Aufgaben der Vereinten Nationen bei Schutz und Forderung der Menschenrechte, in: Vereinte Nationen, Jahrgang 37 (1989), pp. 185-191.

Boven, Th. van, The Role of Non-Governmental Organizations in International Human Rights Standard-Setting: a Prerequisite of Democracy, 
in: California Western International Law Journal, vol. 20 (1989-1990), pp. 207-225.

Brunet, $R$., La Garantie Internationale des Droits de l'homme, d'après la Charte de San Francisco, Génève 1947.

Buddingh", $H$., Suriname heeft het hoogste onderwijsbudget ter wereld in: NRC-Handelsblad, 7 augustus 1990 .

Buergenthal, Th. en Norris, R.E. (eds), Human Rights, The Inter-American system, Dobs Ferry, New York (losbladig).

Buergenthal, Th., The Copenhagen CSCE Meeting: A New Public Order for Europe, in: Human Rights Law Journal, vol. 11 (1990) pp. 217-232. Buntinckx, O., Artikel 10 van het VN-Verdrag inzake Vrouwendiscriminatie en de Belgische Wetgeving en Praktijk (referaat gehouden tijdens het Congres "Mensenrechten en onderwijs voor vrouwen"), Brussel, 21 oktober 1988 (niet gepubliceerd).

Burdeau, G., Les libertés publiques, 4e druk, Paris 1972 (1958).

Burgers, J.H., De rechten van de mens en het Nederlandse Buitenlandse Beleid, in: Ph.P. Everts, J.C. Heldring (red.), Nederland en de rechten van de Mens, Baarn (1981), pp. 53-75.

Burrows, N., The 1979 Convention on the Elimination of All Forms of Discrimination against Women, in: Netherlands International Law Review, vol. XXXII (1985) pp. 419-460.

Cançado Trindade, A.A., Co-Existence and Coordination of Mechanisms of International Protection of Human Rights at Global and Regional Levels, in: Recueil des Cours de l'Académie de Droit International de la Haye, Tomé 202 (1978-II).

Capotorti, F., Study on the Right of Persons belonging to Ethnic, Religious and Linguistic Minorities, United Nations, New York 1979 (UN sales no. E.78.XIV.1).

Cassese, A., International Law in a Divided World, Oxford 1988 (1986).

Castberg, $F_{\mathrm{s}}$, The European Convention of Human Rights, Leiden 1974.

Castermans-Holleman, M., Veertig jaar Universele Verklaring van de Rechten van de Mens. Een Nederlandse bijdrage van internationale normering?, in: Internationale Spectator, november 1988, pp. 696-702.

Chairpersons of Human Rights Treaty Bodies, Conclusions and Recommendations of the Meeting of Chairpersons of Human Rights Treaty Bodies, Geneva 1-5 oktober 1990, onder meer gepubliceerd in: Netherlands Quarterly of Human Rights, Vol. 8 (1990), pp. 452-457.

Cholewinski, R., State Duty towards Ethnic Minorities: Positive or Negative?, in: Human Rights Quarterly, vol. 10 (1988), pp. 344-371.

Clarke, D.M., Freedom of thought and educational rights in the European Convention, in: The Irish Jurist, Vol. 22, Summer 1987, pp. 28-54.

Claude, I.L., National Minorities; an International problem, Cambridge, Mass. 1969 (1955).

Cohen, M.J., Bezuinigingen en het recht op onderwijs, in: NJCM-Bulletin 8-5 (1983), pp. 379-389.

Cohen, E.R., Human Rights in the Israeli-occupied territories 1967-1982, Manchester 1985. 
Coomans, F., Volkenrechtelijke aspecten van onderwijsrechten van minderheden, in: Nederlands Tijdschrift voor Onderwijsrecht 1990, pp. 5-21.

Coomans, F., Jansen, J.F.R., Recht op kosteloos onderwijs?, in: NJCMBulletin 16-3 (1991), pp. 187-197.

Council of Europe, Collected Edition of the 'Travaux Preparatoires' of the European Convention on Human Rights, 8 Volumes Dordrecht 19751985.

Council of Europe, The Role of the Council of Europe in the further realization of human rights; report submitted by the Austrian Delegation to the European Ministerial Conference of Human Rights, Vienna 19/20 March 1985, in: Human Rights Law Journal, vol. 6 (1985), pp. 118-129.

Council of Europe, Digest of Strasbourg Case Law relating to the European Convention on Human Rights, vol. 5, Koln 1985.

Council of Europe, European Convention on Human Rights, Collected Texts, Dordrecht 1987.

Council of Europe, Ad Hoc Committee of Experts on Regional and Minority Languages in Europe (CAHLR), Draft Report Doc. CAHLR 90 (9) prov. van 28 september 1990.

Cranston, M., Human Rights, Real and supposed, in: D.D. Raphael (ed.), Political Theory and the Rights of Man, London 1967, pp. 43-53.

Delissen, A.J.M., De rechten van het kind: na tien jaar voorbereiding nu bij verdrag vastgelegd, in: NJCM-Bulletin $15-5$ (1990), pp. 566-576.

Dijk, P. van, De Internationale bescherming van de rechten van het kind, in: Familie- en jeugdrecht, vol. 1 (1979), pp. 165-180.

Dijk, P. van, The Final Act of Helsinki - Basis for a Pan-European System?, in: Netherlands Yearbook of Internationale Law, vol. 11 (1980), pp. 97-124.

Dijk, P. van, Hoof, G.J.H. van, Theory and Practice of the European Convention on Human Rights, 2nd edition, Deventer, Boston 1990.

Dinstein, Y., Cultural Rights, in: Israel Yearbook on Human Rights, Vol. 9 (1979), pp. 58-81.

Donnelly, J., Howard, R.E., Assessing national human rights performance: a theoretical framework, in: Human Rights Quarterly, Vol. 10 (1988), pp. 214-248.

Dumont, G.H., UNESCO's practical action on human rights, in: International Social Science Journal, no. 122 (nov. 1989), pp. 585-595.

Edwards, R.R., Civil and Social Rights: Theory and Practice in Chinese Law Today, in: R.R. Edwards, L. Henkin, A.J. Nathan, Human Rights in Contemporary China, New York 1986, pp. 40-75.

Eide, A., The Right to Adequate Food as a Human Right, UN Doc. E/CN.4/ Sub.2/1983/25 (Preliminary Report), E/CN.4/Sub.2/1984/22 (Progress Report), E/CN.4/Sub.2/1987/23 (Final Report).

Eide, A., Realization of Social and Economic Rights, The Minimum Threshold Approach, in: The Review of the International Commission of Jurists, no. 43 (1989), pp. 40-53; ook gepubliceerd in Human Rights Law Journal, Vol. 10 (1989), pp. 35-51. 
Eppink, D.J., Militaristisch onderwijs DDR is helemaal van slag, in: NRCHandelsblad, 20-12-1989.

Eppink, D.J., Onderwijs in Zuid-Afrika is 'education for liberation', in: NRC-Handelsblad, 20-2-1990.

Ermacora, F., Menschenrechte in der sich wandelnden Welt, Band II, Wien 1983, Band II: Die Entfaltung und Verwirklichung der Menschenrechtlichen Gedanken in Afrika.

Ermacora, F., Report on the situation of human rights in Afghanistan prepared by the Special Rapporteur of the Commission on Human Rights, UN Doc. E/CN.4/1986/24.

Errera, R., La Convention et les problèmes de la laïcitê et de l'enseignement, in: Revue des Droits de l'Homme/HRJ, vol. 3 (1970), pp. 572-595.

Evert Vermeerstichting, Mensenrechten voor armen weggelegd? Mensenrechten, ontwikkeling en democratie in Noord-Zuid perspectief, Uitgave van de Evert Vermeirstichting, Amsterdam 1989.

Fischer, D.D., International Reporting Procedures, in: H. Hannum (ed.), Guide to International Human Rights Practice, London 1984, pp. 165-186.

Foreign Ministers of the European Community, Declaration on Human Rights, 21 July 1986, in: SIM Newsletter no. 16 (november 1986), pp. 69-70.

Frowein, J.A., Peukert, W., Europalische Menschenrechtskonvention: EMRK Kommentar, Kehl am Rhein 1985.

Gandhi, S., Spare the rod: Corporal punishment in schools and the European Convention on Human Rights, in: International and Comparative Law Quarterly, vol. 33 (1984), pp. 488-494.

Ganji, M., International Protection of Human Rights, Génève/Paris 1962. Genugten, W.J.M. van, In naam van de vrijheid, diss., Amsterdam 1988.

Genugten, W.J.M. van, Ontwikkelingen tijdens de derde toetsingsconferentie van de Slotakte van Helsinki, in: Civis Mundi, 1988, no. 1, pp. 24-29.

Genugten, W.J.M. van, Helsinki is overal, over mensenrechten tussen politieke druk, volkenrechtelijke erkenning en filosofische herbezinning, Nijmegen/Amsterdam 1990, Cahier 47 Studiecentrum voor Vredesvraagstukken, Katholieke Universiteit Nijmegen.

Glahn, G. von, The Occupation of Enemy Territory, Minneapolis, Minnesota 1957.

Glenn Mower, A. Jr., International Cooperation for Social Justice: Global and Regional Protection of Economic/Social Rights, Westport/London 1985.

Glukhov, A., A two-way street, in: International Affairs (Moscow), July 1988, pp. $31-40$.

Goedkeuring van het te Rome op 4 november 1950 ondertekende Verdrag tot Bescherming van de Rechten van de Mens en de Fundamentele Vrijheden, alsmede van het te Parijs op 20 maart 1952 ondertekende Protocol bij dat Verdrag, TK Zitting 1952-1953, 3043. 
Goedkeuring van het op 15 december 1960 te Parijs tot stand gekomen Verdrag nopens de Bestrijding van Discriminatie in het Onderwijs, TK Zitting 1964-1965, 8052 (R 478).

Goedkeuring van het op 19 december 1966 tot stand gekomen Internationale Verdrag inzake Economische, Sociale en Culturele Rechten, TK Zitting 1975-1976, 13932 (R 1037).

Goodwin-Gill, G.S., Obligations of Conduct and Result, in: Alston/Tomasevski (eds), The Right to Food, The Hague/Utrecht 1984, pp. 111-119.

Graves, N.J., Dunlop, O.J., Torney Purta, J.V., Teaching for international understanding, peace and human rights, UNESCO Paris 1984.

Gros Espiell, H., Los Derechos economicos, sociales y culturales en el sistema Interamericano, San José, Costa Rica 1986.

Haag, D., The Right to Education: what kind of management?, UNESCO, Paris 1982.

Harris, D., Commentary by the Rapporteur on the Consideration of States' Parties Reports and International Cooperation, in: Human Rights Quarterly, vol. 9 (1987), pp. 147-155.

Harvey, P., Monitoring mechanisms for international agreements respecting economic and social human rights, in: Yale Journal of International Law, vol. 12 (1987), pp. 396-420.

Henkin, L., International Human Rights as "Rights" in: R. Pennock, J.W. Chapman (eds) Human Rights, (Nomos XXIII), New York, London 1981 , pp. $257-281$.

Henkin, L., International Law: Politics, Values and functions, in: Recueil des Cours de l'Académie de Droit International de La Haye, Tomé 216 (1989-IV).

Heringa, A.W., Equal Renumeration as a self-executing social right, in: SIM Newsletter, no. 8 (October 1984), pp. 10-16.

Heringa, A.W., Sociale grondrechten, hun plaats in de gereedschapskist van de rechter, diss., 's-Gravenhage 1989.

Hoof, G.J.H. van, The Legal Nature of Economic, Social and Cultural Rights: a Rebuttal of some Traditional Views, in: Ph. Alston, K. Tomasevski (eds), The Right to Food, The Hague/Utrecht 1984, pp. 97-111.

Hoof, G.J.H. van, de Vey Mestdagh, K., Mechanisms of International Supervision, in: P. van Dijk (general editor), Supervisory Mechanisms in International Economic Organizations, Deventer 1984, pp. 3-45.

Hoof, G.J.H. van, Een doorbraak voor het recht op voedsel?, in: NJCMBulletin 13-2 (1988), pp. 78-90.

Hudson, M.O., World Court Reports: a collection of the judgments, orders and opinions of the Permanent Court of International Justice. Washington, voll. 2 (1935), vol. 3 (1938).

Humphrey, J.P., Human Rights \& the United Nations; a great adventure, New York 1984.

Inter-American Commission on Human Rights, Annual Report, 1982-1983, Washington D.C. 1983. 
Inter-American Yearbook on Human Rights, 1986, Dordrecht/Boston/London 1988.

International Commission of Jurists, Human Rights in Islam, Report of a Seminar held in Kuwait, December 1980, Geneva 1982.

International Commission of Jurists, Implementation of the International Covenant on Economic, Social and Cultural Rights: ECOSOC Working Group, in: The Review of the International Commission of Jurists, no. 27 (december 1981), pp. 26-39.

International Conference on Education, Recommendations 1934-1977, UNESCO, Paris 1979.

International Labour Organization, International Labour Conventions and Recommendations, 1919-1981, Geneva 1982.

International Law Commission, Report on its twentyninth session, in: Yearbook of the International Law Commission, 1977, vol. II, part two.

Jacobs, A.T.J.M., De rechtstreekse werking van internationale normen in het sociaal recht, Preadvies voor de Vereniging voor Arbeidsrecht, Alphen a/d Rijn 1985.

Jansen, J.F.R., Prietpraat vakbonden over "verzwijgen" rapport mensenrechten, in: Trouw, 28-2-1989.

Jenks, C.W., A new world of law? A study of the creative imagination in international law, London 1969.

Jhabvala, F., On Human Rights and the Socio-Economic Context, in: Netherlands International Law Review, vol. XXXI (1984), pp. 149-182.

Juvigny, P., The fight against discrimination; towards equality in education, UNESCO, Paris 1963.

Kabir, H., Human Rights: The Islamic tradition and the problem of the world today (1947), herdrukt in: Human Rights Teaching, Vol. IV (1985), pp. $38-44$.

Kartashkin, V., Implementation of the Covenant on Economic, Social and Cultural Rights in light of differences among social systems, april 1984 (niet gepubliceerd).

Khol, A., Zur Diskriminierung in Erziehungswesen, in: Zeitschrift für Ausländisches und Deffentliches Recht und Volkerrecht, Band 30 (1970), pp. 263-299.

Kiss, A.C., La protection internationale du droit de l'enfant à l'éducation, in: Revue des Droits de l'Homme/Human Rights Journal, vol. VI (1973), pp. 467-487.

Klein, G.P., M. Kroes, Mensenrechten in de Nederlandse Rechtspraktijk, Zwolle 1986.

Klerk, Y.S., L. van Poelgeest, Ratificatie à contre coeur: de reserves van de Nederlandse regering jegens het Europese Verdrag voor de Rechten van de Mens en het individuele klachtrecht, in: R.M. Themis (1991), pp. 220-247.

Koopmans, T., Vrijheden in beweging, Rede, Zwolle 1977. 
Kühnhardt, L., Die Universalităt der Menschenrechte; Studie zur ideengeschichtlichen Bestimmung eines politischen Schlusselbegriffs, München 1987.

Langeler, A., Perestroijka en Onderwijs, in: Internationale Spectator, april 1989, pp. 241-247.

League of Nations, The League of Nations and the Protection of Minorities of Race, Language and Religion, Geneva 1927.

Leckie, S., Indigenous Peoples: Recent Developments in the International Labour Organization, in: SIM-Newsletter no. 16 (november 1986), pp. 22-46.

(The) Limburg Principles on the Implementation of the International $\mathrm{Co}-$ venant on Economic, Social and Cultural Rights, in: Human Rights Quarterly, vol. 9 (1987), pp. 122-135. Ook gepubliceerd als UN Document E/CN.4/1987/17.

Lörincz, L., Economic, Social and Cultural Rights, in: I. Szabó (ed.), Socialist Concept of Human Rights, Budapest 1966, pp. 197-227.

Luchterhandt, O., UN-Menschenrechtskonventionen Sowjetrecht - Sowjetwirklichkeit, Ein kritischer Vergleich, Baden-Baden 1980.

Luchterhandt, O., B.G. Tahzib, The CSCE Norms on Religious Freedom and their Effects on the Reform of Soviet Legislation on Religion, in: A. Bloed, P. van Dijk (eds), The Human Dimension of the Helsinki Process - The Vienna Follow-up Meeting and its Aftermath, Dordrecht 1991, pp. 162-196.

Marks, S., UNESCO and human rights: the implementation of rights relating to education, science, culture and communication, in: Texas international law journal, vol. 13 (1977), pp. 35-67.

Marks, S., The Complaint Procedure of the United Nations Educational Scientific and Cultural Organization, in: H. Hannum (ed.), Guide to International Human Rights Practice, London 1984, pp. 94-107.

M'Baye, K., Human Rights in Africa, in: K. Vasak and Ph. Alston (eds), The International Dimensions of Human Rights, Westport/Paris 1982, vol. 2, pp. 583-601.

Martinez Cobo, J.R., Study of the Problem of Discrimination against Indigenous Populations, United Nations, New York 1987 (UN sales no. E.86.XIV.3).

McKean, W., Equality and Discrimination under International Law, Oxford 1983.

Meron, Th., Human Rights and humanitarian norms as customary law, Oxford 1989.

Merrills, J.G., The development of international law by the European Court of Human Rights, Manchester 1988.

Mertens, P., L'application de la Convention et de la Recommendation de l'UNESCO concernant la lutte contre la discrimination dans le domaine de l'enseignement un bilan provisoire, in: Revue des Droits de l'Homme/ Human Rights Journal, Tomé 1 (1968), pp. 91-108. 
Michielsen, P., Godsdienstonderwijs terug op Poolse scholen, in: NRC-Handelsblad, 7-8-1990.

Minority Rights Group, Romania's Ethnic Hungarians, April 1990.

Moskowitz, M., The Politics and Dynamics of Human Rights, Dobs Ferry, New York 1968.

Mosler, H., Problems of Interpretation in the Case Law of the European Court of Human Rights, in: Essays on the Development of the International Legal Order, in memory of Haro F. van Panhuys, Alphen aan den Rijn 1980, pp. 149-167.

Newman, F.C., Weissbrodt, D. (eds), International human rights: law, policy and process, Cincinnati 1990.

NJCM-Bulletin, Redactioneel commentaar: Tussenbalans: voortgaande verwezenlijking van economische en sociale rechten?, in: NJCM-Bulletin 16-2 (1991), pp. 103-104.

Nowak, M., Th. Swinehart (eds), Human Rights in Developing Countries 1989 Yearbook, compiled by human rights institutes in Norway, Denmark, the Netherlands, Finland and Canada, Kehl am Rhein 1989.

Opsahl, T., The Convention and the right to respect for familiy life particularly as regards the unity of the family and the protection of the rights of parents and guardians in the education of children, in: A.H. Robertson (ed.), Privacy and Human Rights, Manchester 1973, pp. 182-254.

Page, G.T., J.B. Thomas, The International Dictionary of Education, London 1978 (1977).

Partsch, K.J., Die Rechte und Freiheiten der Europäischen Menschenrechtskonvention, Berlin 1966.

Pelloux, R., L'Arrêt de la Cour Européenne des Droits de l'Homme dans 1'Affaire Linguistique Belge, in: Annuaire Français de Droit International Public, 1968, pp. 201-216.

Pieters, D., Sociale grondrechten op prestaties in de grondwetten van de landen van de Europese Gemeenschap, Antwerpen 1985.

Poppe, E., Grundrechten des Bürgers in der sozialistischen Gesellschaft, Berlin DDR 1980.

Ramcharan, B.G., Implementation of the International Covenant on Economic, Social and Cultural Rights, in: Netherlands International Law Revieuw, vol. 23 (1976), pp. 151-161.

Raoul, M., Un système d'éducation visant a maintenir le status quo, in: $M$. Raoul, Déclaration universelle des droits de l'homme et réalités sudaf ricaines, UNESCO, Paris 1983, pp. 77-86.

Report of the Special Committee to investigate Israeli practices affecting the human rights of the population of the occupied territories, UN Doc. A/41/680 (20-10-1986).

Report of the $A d$ Hoc Working Group of Experts on Violations of human rights in South Africa, UN Doc. E/CN.4/1989/8. 
Report (Interim) of the $A d H o c$ Working Group of Experts on South Africa, UN Doc. E/CN.4/1990/7.

Roberts, A., B. Joergensen, F. Newman, Academic Freedom under Israeli Military Occupation, Report of WUS/ICJ Mission of Enquiry into Higher Education in the West Bank and Gaza, London, Geneva 1984.

Robertson, A.H., The European Convention on Human Rights: Recent Developments, in: British Yearbook of International Law, Vol. 28 (1951), pp. 359-365.

Robinson, N., The Universal Declaration of Human Rights. Its Origins, Significance, Application and Interpretation, World Jewish Congres, Institute of Jewish Affairs, New York 1958.

Rolling, B.Y.A., Volkenrecht en Vrede, Deventer 1985.

Saba, H., La Convention et la Recommendation concernant la lutte contre la discrimination dans le domaine de l'enseignement, in: Annuaire Français de Droit International, 1960, pp. 646-652.

Samson, K., Swepston, L., Response to Review 41 article on ILO Convention 107, in: The Review of the International Commission of Jurists, no. 42/1989, pp. 43-47.

Schermers, H.G., Lijfstraffen op school, in: Ex Iure, Veertien opstellen bij het Veertiende Lustrum van Societas Iuridica Grotius en de Vierhonderdvijfde geboortedag van Grotius, Arnhem 1987, pp. 169-179.

Schule und Leben (für Studenten), Moskau 1988.

Schermers, H.G., Het Europese Verdrag tot Bescherming van de Rechten van de Mens en de Fundamentele Vrijheden, Zwolle 1964.

Schwelb, E., Notes on the Early Legislative history of the measures of implementation of the Human Rights Covenants, in: Mélanges offerts à Polys Modinos, Paris 1968, pp. 270-290.

Shelton, D.L., Women and the right to Education, in: Human Rights Journal/Revue des Droits de l'Homme, vol. 8 (1975), pp. 51-70.

Shue, H., Basic Rights. Subsistence, Affluence, and U.S. Foreign Policy, Princeton 1980.

Sieghart, P., The International Law of Human Rights, Oxford 1983.

Sieghart, P., The Lawful Rights of Mankind, Oxford 1986.

Simma, B., Der Ausschuss für wirtschaf tliche, soziale und kulturelle Rechte (CESCR); Ein neues Menschenrechtsgremium der Vereinte Nationen, in: Vereinte Nationen 1989-6, pp. 191-197.

Simma, B./Bennigsen, S., Wirtschaftliche, soziale und kulturelle Rechte im Völkerrecht - Der Internationale Pakt von 1966 und sein Kontrollverfahren, in: Festschrift für Ernst Steindorf zum 70. Geburtstag am 13. März 1990, herausgegeben von J.F. Baur, K.J. Hopt und K.P. Mailänder. Berlin-New York 1990, pp. 1477-1502.

Skogly, S., The First Session of the Committee on Economic, Social and Cultural Rights - An NGO-representative's Impressions, in: Nordic Journal on Human Rights, vol. 5 (1987), pp. 82-83.

Smit, M., Zwart-wit onderwijs in Zuid-Afrika, Anti-Apartheids-beweging Nederland, Amsterdam, z.j. 
Smith, J., Op weg naar een Internationale Conventie voor de Rechten van het $K$ ind, in: Nieuwsbrief Liga voor de rechten van de mens, nr. 27, maart 1989, pp. 4-11.

Sohn, L.B., The Rights of Minorities, in: L.Henkin (ed.), The International Bill of Rights, The Covenant on Civil and Political Rights, New York 1981 , pp. $270-289$.

Sohn, L.B., The New International Law: Protection of the Rights of Individuals rather than States, in: The American University Review, vol. 32 (1982), pp. 1-64.

Sohn, L.B. (ed.), International Organisation and Integration, Student Edition, Dordrecht 1986.

Stenfert Kroese, S., De Internationale Arbeidsorganisatie en inheemse volken, in: NJCM-Bulletin 15-5 (1990), pp. 539-555.

Suy, E., Het arrest van Straatsburg over de taalregeling in het Belgisch onderwijs, in: Tijdschrift voor Bestuurswetenschappen en Publiekrecht, 1969 , pp. $240-247$.

Szab6, I., Cultural rights, Leiden/Budapest 1974.

Tabory, M., Language Rights as Human Rights, in: Israël Yearbook on Human Rights, vol. 10 (1980), pp. 167-223.

Tabory, M., Minority Rights in the CSCE context, in: Israel Yearbook on Human Rights, vol. 20 (1990), pp. 197-221.

Tomasevski, K., Human Rights Indicators: The Right to Food as a Test Case, in: Ph. Alston, K. Tomasevski (eds), The Right to Food, Utrecht 1984, pp. 135-168.

Tomasevski, K., Measuring compliance with human rights obligations, in: L.A. Rehof, C. Gulman (eds), Human Rights in Domestic Law and Development Assistance Policies of the Nordic Countries, Dordrecht 1989, pp. 109-123.

Tomasevski, K., The World Bank and Human Rights, in: M. Nowak en Th. Swinehart, Human Rights in Developing Countries, 1989 Yearbook, Kehl am Rhein, Strasbourg 1989, pp. 75-102.

Tomuschat, C., Protection of Minorities under Article 27 of the International Covenant on Civil and Political Rights, in: Volkerrecht als Rechtsordnung Internationale Gerichtsbarkeit Menschenrechte: Festschrift für Herman Mosler, Heidelberg 1983, pp. 949-980.

Tomuschat, C., International Standards and Cultural Diversity, in: Bulletin of Human Rights - Special Issue 1985, pp. 24-35.

Tomuschat, C., Human Rights in a World-Wide Framework - Some Current Issues, in: Zeitschrift für Auslandisches offentliches Recht und Volkerrecht, vol. 45 (1985), pp. 547-584.

Tomuschat, C., Bewahrung, Stărkung, Ausgestaltung; zur künftigen Menschenrechtspolitik Deutschlands in der Weltorganisation, in: Vereinte Nationen 1991-1, pp. 6-11.

Treffers, A.J., De Russische onderwijshervorming, in: NRC-Handelsblad 22 mei 1990. 
Tretter, H., Die Menschenrechte im Abschliessenden Dokument des Wiener KSZE-Folgetreffens vom 15 Januar 1989, in: Europalische Grundrechte Zeitung, 1989, pp. 79-85.

Trubek, D., Economic, Social and Cultural Rights in the Third World Human Rights Law and Human Needs Programs, in: Th. Meron (ed.), Human Rights in International Law, vol. 1, Legal and Policy Issues, Oxford 1984, pp. 205-271.

Türk, D., Realization of Economic, Social and Cultural Rights, Preliminary Report prepared by the Special Rapporteur of the UN Sub-Commission on Prevention of Discrimination and Protection of Minorities, UN Doc. E/CN.4/Sub.2/1989/19.

Türk, D., Realization of Economic, Social and Cultural Rights, Progress Report prepared by the Special Rapporteur of the UN Sub-Commission on Prevention of Discrimination and Protection of Minorities, UN Doc. E/CN.4/Sub.2/1990/19.

Turp, D., Le contrôle du respect du Pacte International relatif aux Droits Economiques, Sociaux et Culturels, in: Le Droit International au Service de la Paix, de la Justice et du Développement; Mélanges Michel Virally, Paris 1991, pp. 465-482.

Uitgaven van het Ministerie van Buitenlandse Zaken, 's-Gravenhage, vanaf 1947 , bevattende verslagen van de zittingen van de Algemene Vergadering van de Verenigde Naties, enkele zittingen van de Economische en Sociale Raad, de Veiligheidsraad, alsmede Bijzondere Zittingen en Conferenties, no. $16,29,54,67$ en 120 .

UNESCO, UNESCO's standard-setting instruments (losbladig), Paris 1986.

UNESCO Statistical Yearbook 1988.

UNESCO, Basis Education and Literacy, World Statistical Indicators 1990, UNESCO, Office of Statistics, Paris 1990.

United Nations, These Rights and Freedoms, New York 1950.

United Nations Centre for Human Rights and United Nations Institute for Training and Research, Manual on Human Rights Reporting under six major international human rights instruments, New York 1991 (UN sales no. E.91.XIV.1).

Universaliteit van Grondrechten, Verslag van een Symposium gehouden op 18 oktober 1988 ter gelegenheid van het ere-doctoraat, verleend aan Prof.mr.dr. Th.C. van Boven door de Erasmus Universiteit Rotterdam. Mededelingen van het Juridisch Instituut van de Erasmus Universiteit Rotterdam, nr. 48 (1989).

Verdoodt, A., Naissance et signification de la Déclaration Universelle des Droits de l'Homme, Louvain/Paris 1964.

Vidal d'Almeida Ribeiro, A., Report on the Implementation of the Declaration on the Elimination of all Forms of Intolerance and of Discrimination based on Religion or Belief prepared by the Special Rapporteur of the Commission on Human Rights. UN Doc. E/CN.4/1988/45.

Vierdag, E.W., The Concept of Discrimination in international law, with special reference to human rights, diss., Den Haag 1973. 
Vierdag, E.W., The Legal Nature of the Rights Granted by the International Covenant on Economic, Social and Cultural Rights, in: Netherlands Yearbook of International Law. Vol. 9 (1978), pp. 69-105.

Vierheilig, M., Minority Schools in Albania (Advisory Opinion), in: R. Bernhardt (ed.), Encyclopedia of Public International Law, vol. 2, Amsterdam 1981, pp. $191-192$.

Vincent, R.J., Human Rights and International Relations, Cambridge 1986.

Vrey, $H$. de., Vakbonden furieus over verzwijgen van Nederlands rapport voor VN, in: Trouw, 10-2-1989.

Waart, P.J.I.M. de, Veertig jaar economische, sociale en culturele mensenrechten, in: Rechtskundig Weekblad 1988-1989, nr. 32 (8 april 1989), pp. 1073-1078.

Wadstein, M., Implementation of the UN Convention on the Elimination of All Forms of Discrimination against Women, in: SIM Newsletter, vol. 6 (1988), no. 4, pp. 5-22.

Wahid Wafi, Ali Abdel, The Problem of human rights in the Islamic tradition (1963), herdrukt in: Human Rights Teaching, Vol. IV (1985), pp. $38-44$.

Westerveld, $P_{\star}$, Vrijheid van Godsdienst in de USSR, Drempels weg? Hellsinki Rapport nr. 6, Uitgave Nederlands Helsinki Comite, Utrecht, februari 1990.

Westerveen, G., Towards a System for Supervising States' Compliance with the Right to Food, in: Ph. Alston/K. Tomasevski (eds), The Right to Food, Utrecht 1984, pp. 119-135.

Wiarda, G.J., Extensieve en restrictieve verdragstoepassing door het Europees Hof voor de rechten van de mens; een middenkoers?, in: Verspreide Geschriften van G.J. Wiarda, 's-Gravenhage 1986, pp. 235-250.

Wildhaber, L., Der Belgische Sprachenstreit vor dem Europäischen $\mathrm{Ge}-$ richtshof für Menschenrechte, in: Schweizerisches Jahrbuch für Internationales Recht, Band 28 (1969), pp. 9-38.

Wildhaber, L., To what extent has the right to education evolved?, in: Proceedings of the fourth International Colloquy about the European Convention on Human Rights, Rome 5-8 november 1975 Council of Europe, Strasbourg 1976, pp. 141-183.

Wildhaber, L., Die Dänischen Sexual-Erziehungs-Fälle; Anmerkung zum Urteil des Europäischen Gerichtshofes für Menschenrechte, in: Europäische Grundrechte Zeitung 1976, pp. 493-496.

Witte, B. de, The Protection of Linguistic Diversity through Fundamental Rights, Thesis, 1985 (niet gepubliceerd).

Worldbank (International Bank for Reconstruction and Development), Education in Sub-Saharan Africa, Washington 1988.

Ziman, J., P. Sieghart, J. Humphrey, The World of Science and the Rule of Law, Oxford 1986. 


\section{Aangehaalde jurisprudentie}

\section{- Permanente Hof van Internationale Justitie}

- Advisory Opinion on the Exchange of Greek and Turkish Populations 21-2-1925 (series B, no. 10)

- Advisory Opinion in the Greco-Bulgarian Communities Case 31-7-1930 (Series B, no. 17)

- Advisory Opinion on Access to German Minority Schools in Polish Upper Silesia, 15-5-1931 (Series A/B, no. 40)

- Advisory Opinion on the Treatment of Polish Nationals and other persons of Polish Origin or Speech in the Danzig Territory, 4-2-1932, (Series A/B, no. 44)

- Advisory Opinion on Minority Schools in Albania, 6-4-1935 (Series A/B, no. 64)

- Europees Hof voor de Rechten van de Mens

- Case relating to certain aspects of the Laws on the use of languages in education in Belgium (preliminary objection), Judgment of 9 February 1967, Publications of the Court Series A, vol. 5

- Case rellating to certain aspects of the laws on the use of languages in education in Belgium (merits), Judgment of 23 July 1968, Publications of the Court, Series A, vol. 64

- Case of Kjeldsen, Busk Madsen and Pedersen, Judgment of 7 December 1976, Publications of the Court Series A, vol. 23

- Airey Case, Judgment of 9 October 1979, Publications of the Court Series A, vol. 32

- Case of Campbell and Cosans, Judgment of 25 February 1982, Publications of the Court, Series A, vol. 48

* Europese Commissie voor de Rechten van de Mens

- Rapport van 24 juni 1965 in de Belgische Taalzaak, Publications of the Court Series B, vol. 3 
- Zaak nr. 3798/68, Church of Scientology v. United Kingdom, in: Yearbook of the European Convention on Human Rights, Vol. XII (1969), pp. 306-324

- Zaak nr. 4733/71, Karnell and Hardt v. Sweden, in: Yearbook of the European Convention on Human Rights, Vol. XIV (1971) pp. 664-692

- Zaak nr. 2209/64, Inhabitants of Les Fourons v. Belgium, in: Yearbook of the European Convention on Human Rights, Vol. XVII (1974), pp. 542-618

- Zaak nr. 5962/72, X v. United Kingdom, in: Decisions and Report 2, pp. 50-52

- Rapport van 21 maart 1975 in de zaak Kjeldsen, Busk Madsen and Pedersen, Publications of the Court, Series B, vol. 21

- Rapport van 16 meil 1980 in de zaak Campbell and Cosans, Publications of the Court Series B, vol. 42 4.1.4.2 4.1.4.3 4.1 .4 .1

- Zaak nr. 10233/83, Family H. v. United Kingdom, in: Decisions and Reports 37, pp. 105-112

Decisions and Reports 45, pp. 143-150 and Reports 51, pp. 41-51

- Zaak nr. 13134/87, W. and J. Costello-Roberts v. United Kingdom, in: Human Rights Law Journal, vol. 12 (1991), pp. 61-64

- Zaak nr. 14229/88, $X$ and $Y$ v. United Kingdom, in: Human Rights Law Journal, vol. 12 (1991), pp. 61-64

\section{* Mensenrechtencomité}

- Zaak nr. 40/1978, Erkki Hartikainen v. Finland, 9-4-1981, in: Human Rights Committee, Selected Decisions under the Optional Protocol (Second Sixteenth sessions) CCPR/C/OP/1, New York 1985, pp. 74-76

- Zaak nr. 172/1984, S.W.M. B. v. Nederland, 9-4-1987, in: NJCM-Bulletin 12-5 (1987), pp. 377-391

- Zaak nr. 298/1988 en 299/1988, G. and L. Lindgren e.a. v. Sweden, 9-11-1990, in: Human Rights Law Journal vol. 12 (1991), pp. 24-25

* Nederlandse jurisprudentie

- HR 30 mei 1986, NJ 1986, 688

- HR 14 april 1989, AB 1989, 207

- HR 20 april 1990, RvdW 1990, 88 
- ARRS 29 november 1982, Weekoverzicht RvS 1982, nr. 3.2105

- CRvB 16 februari 1989, AB 1989, 164

- Pres. Rb. Amsterdam 21 oktober 1981, RvdW/KG 1981, 156, 157

- Rb. 's-Gravenhage 14 november 1990, rolnummers $89 / 7932$ en $90 / 6595$ 


\section{SUMMARY}

\section{The International Protection of the Right to Education}

The subject of this study is the international protection of the right to education. This right belongs to the category of economic, social and cultural human rights that entitle people to an adequate standard of living. The right to education has been laid down in a number of international texts on human rights. The meaning and scope of international norms in respect of economic, social and cultural rights, unlike those of civil and political rights, cannot always be clearly defined. This has consequences for the implementation of these rights in the legal order of states. Upon this basis, the following set of questions were formulated to be answered in this study: What is the content, the meaning and the scope of the right to education?; what obligations do the international texts on the right to education create for states?; and lastly, in what way can international supervision of the implementation of the right to education be improved?

With respect to the right to education, two aspects can be distinguished. On the one hand, realization of the right to education demands an effort on the part of the state to make education available and accessible. This is the social aspect. On the other hand, there is the personal freedom of individuals to choose between state-organized and private education, which can be translated, for example, in parents' and guardians' freedom to ensure their children's moral and religious education according to their own beliefs. From this stems the freedom of natural persons or legal entities to establish their own educational institutions. This is the aspect of freedom. It requires the state to follow a policy of non-interference in private matters.

Chapter 2 focuses on the (legal) character of economic, social and cultural rights. Initially, the prevailing view within the United Nations and in legal literature was that a more or less strict distinction could be made between economic, social and cultural rights, on the one hand, and civil and political rights, on the other. The former rights were thought to have a different legal character than the classic rights, and, consequently, the way in which they were to be implemented differed. One of the arguments for this distinction pertained to the role the state had to play. For securing civil and political rights, a policy of state non-interference was required. The realization of economic, social and cultural rights, however, necessitated an active role for the state. According to the traditional approach, civil and political rights could, as a result, be enforced before a national judicial institution, 
whereas this option would not exist in the case of economic, social and cultural rights.

Since the late seventies, as a result of the evolution of legal thinking on the realization of human rights and the shifting of emphases within the United Nations, a more subtle approach has prevailed, which is based on the indivisibility and the interdependence of human rights. A dynamic development can be discerned, in which application and enforcement of both groups of rights have increasingly converged. In keeping with this integrated approach, this study proposes, that the character, meaning and scope of separate rights be analyzed in terms of state obligations and less in terms of enforceability before a judicial institution. This concept may be made more concrete on the basis of a typology of obligations. Characteristic for the realization of economic, social and cultural rights, is its progressive nature and its dependence on available (financial) resources. This idea is reflected, for instance, in Article 2, paragraph 1, of the International Covenant on Economic, Social and Cultural Rights (ICESCR). This study treats the question of what state obligations arise from this core provision of the ICESCR. In this connection, the question emerges as to whether the concept underlying the ICESCR, i.e. an endeavour to achieve progressively higher levels of socioeconomic wellbeing, can be maintained in times of economic recession. If a state, as a result of a decline in available (financial) resources, wants to reverse the level of realization of certain rights, it must give reasons to justify the necessity of such action. This also implies that, in the policy-making process, obligations arising from international agreements should be explicitly considered.

Chapter 3 contains an analysis of the law on the right to education as found in international conventions and declarations. Both global and regional texts are treated. To gain more insight into the meaning and scope of the right to education, the legal history of the most important international texts is analyzed. The first provision discussed is Article 26 of the Universal Declaration of Human Rights. This provision formed the basis for the formulation of other international texts on the right to education. The drafting of three other important texts, namely Article 2 of the First Protocol ECHR (1952), Article 13 ICESCR and the UNESCO Convention against Diserimination in Education (1960) is comprehensively discussed. The long drafting process of Article 2 of the First Protocol ECHR is proof of the differences of opinion between the organs involved in the drafting, as to the exact legal meaning and scope of this provision. Article 13 ICESCR is the most detailed provision laying down a number of measures aimed at promoting full realization of the right to education. The UNESCO Convention not only seeks to ban all forms of discrimination, but also to promote equal opportunities and equal treatment in education for each individual. Subsequently, more recent international provisions relating to the right to education, such as those incorporated in the Protocol on Economic, Social and Cultural Rights to the American Convention on Human Rights (Protocol of San Salvador, 1988) and the Convention on the Rights of the Child (1989), 
are discussed. The international texts on the right to education contain a number of elements, which almost all, with varying degrees of specificity, feature in the texts discussed in this study. At issue here is, in the first place, the specific task of the state to make education available and accessible in a non-discriminatory way. In performing this task, the state has a degree of discretion within the norms formulated in the provision. Secondly, the state is bound to respect the convictions of parents or guardians with regard to the religious and moral education of their children. In addition, the state is required to allow for the establishment and maintenance of private educational institutions, provided they meet the nationall minimum standards in this field. Parents or guardians are free to select for their children either a form of state-organized education or a private educational institution. The right to education is a universal right, granted to every person, regardless of age, language, social or ethnic origin or other status. For the benefit of certain vulnerable groups, separate texts have been drafted in international law, in which the right to education is included. In fact, persons belonging to these groups enjoy special protection. This is the case with children, members of minorities and indigenous and tribal peoples.

Chapter 4 discusses the various procedures providing for international supervision of implementation of the right to education. The right of individuals to lodge a complaint as defined in the ECHR, has resulted in a number of cases before the European Commission and the European Court of Human Rights, alleging a violation of the right to education. The most important cases were : the Belgian Linguistic case (1968), the case of Kjelsen, Busk Madsen and Pedersen (1976) and the case of Campbell and Cosans (1982). The Strasbourg organs have used these cases to define the meaning and scope of the right to education. The case law on Article 2 offers an interpretation of the right to education which is evidence of the dynamic development of this right in the Member States of the Council of Europe. In particular, the social changes that have taken place in these states since the sixties are reflected in this case law. This is especially demonstrated in the positive way in which the Commission and the Court have interpreted the obligations of states pursuant to Article 2 and in their broad interpretation of the term "religious and philosophical convictions".

Another method of international supervision is the reporting system. This system is founded on various conventions in which the right to education is laid down. According to this system, states report periodically to an international organ of experts on the progress made in realizing the right to education and the difficulties encountered in achieving such. This chapter treats the international implementation procedures pursuant to the ICESCR and the UNESCO Convention against Discrimination in Education. The main focus is on 24 state reports on the implementation of Article 13 ICESCR. These reports have shown a varying degree of quality, which has not always presented a clear picture of the real situation as far as education is concerned. What did become clear was that Third World countries, in particular, owing to financial-economic problems, are not able to comply with the 
international norms as formulated in Article 13 ICESCR, on many points. As a matter of fact, industrialized states are increasingly confronted as well with problems of this nature. The discussion of the state reports pursuant to the ICESCR takes place in the form of a dialogue between the supervisory organ and the representatives of the state in question. The activities of the Sessional Working Group of Governmental Experts (from 1979-1986), operating as the initial supervisory organ of the ICESCR, were characterized by superficiality and a not very critical attitude vis-a-vis the information presented in the state reports. Its successor, the Committee on Economic, Social and Cultural Rights has a more serious approach, shows more thoroughness and looks into the actual situation with respect to the realization of the right to education and the obstacles encountered.

In Chapter 5, the analysis of state obligations pursuant to Article 2, paragraph 1 ICESCR is further developed. The question put forward here concerns the obligations that may arise from Article 13 in conjunction with Article 2, paragraph 1 ICESCR. A dynamic interpretation of Article 13 aimed at an effective protection of the right to education is advocated. The interpretation is worked out in the question about the meaning of the terms "to recognize' and 'to respect', which designate the character and scope of the obligation in Article 13. On these grounds, it can be stated that the realization of the social aspect of Article 13 is progressive in nature, whereas the aspect of freedom is for immediate application. In addition, Article 13 may be defined in terms of 'obligations of conduct" and 'obligations of result'. This distinction in terms of state responsibility, is useful, because it provides an insight into the meaning and scope of the state obligations in realizing the right to education. The distinction can also be helpful in answering the question as to whether the states in effect meet their obligations. The obligations of states related to the right of education may also be worked out on the basis of the typology of obligations proposed in the second chapter. The measures to be taken by a state in order to realize the right to education can be defined in terms of the obligations 'to respect', 'to protect' and 'to fulfil'.

Narrowly related to the definition of economic, social and cultural rights, in terms of obligations of states, is the question of when an actual violation of such a right occurs. It can be stated, in general, that this problem, for which no clear criteria exist, has been underexposed up to now. Pursuing the Limburg Principles on the Implementation of the International Covenant on Economic, Social and Cultural Rights, the present study proposes that violation of a social right be said to exist, if the state intentionally acts in contravention of the international norm, or if it fails to take those measures as required by the international norm. In both cases, the state must be in a position to comply with the international norm, that is to say, not be faced with a situation which is beyond its control and for which it cannot be hell responsible (force majeure). When applied to the right to education, this criterion must then be interpreted as follows : violation exists if the state does not comply with the minimum core content of that right. The term 
'minimum core content of the right to education' implies that the state must respect the free choice of education (especially with respect to religion and conviction). And secondly, that no one shall be denied the right to education and that primary education must be compulsory and free of charge. The issue of violation of the right to education is, for instance, illustrated by the educational situation in the Israeli-occupied Arab territories and in South Africa.

The value of the ICESCR norms in times of economic recession, as discussed in chapter 2, is again taken up. Against this background, the realization of the right to education and in particular the question of the compatibility of the Netherlands Tuition and Course Fees Act with Article 13 in conjunction with Article 2, paragraph 1 ICESCR, is discussed. In 1987, as a result of a reduction in the financial resources available in the national budget, the Dutch Government introduced 'school fees', the parental financial contribution towards the education of 16- and 17-year olds. This study concludes that the Act is in contravention to the letter and the spirit of the ICESCR.

Another important question discussed in chapter 5 , is the question of the universal character of the right to education. This question may be approached from different angles. One approach deals with the question of whether the value of education and each individual's claim to education are endorsed by the various political, social and cultural communities. A tentative survey shows that both the value of education and the right to education are universally accepted, but that freedom of education is not recognized and guaranteed in certain political and cultural systems. The author concludes that the right to education has the features of an operational right, that is to say, an instrument with which other rights may be realized. Such characterization strengthens its universal claim.

Chapter 6 treats the possibilities for improvement of international supervision on compliance with the education provisions of the ICESCR and discusses a number of recommendations. In this procedure, the discussion of the periodic state reports by the Committee on Economic, Social and Cultural Rights plays a central role. The reports are drafted according to guidelines established by the Committee. These guidelines serve as an aid for governments and are designed to trace the actual situation with regard to the realization of economic, social and cultural rights. Other actors may also play a role in the discussion of state reports. UNESCO, a specialized agency with expertise in the field of education, should participate actively when state reports are discussed by the Committee. UNESCO can provide up-to-date information on the educational situation in the countries of the reports under discussion. Non-governmental organizations may also be a source from which the Committee may draw information for the benefit of the discussion. The Committee might consult NGOs with consultative status at ECOSOC. Their information could be of important additional value, complementing the information provided by governments in their reports. The 
Committee itself should also make a contribution towards improving the international implementation of the right to education. On the basis of a comparison between the state of education in countries whose reports have been discussed by the Committee, and the experience gained through this, the Committee is able to further interpret Article 13 ICESCR and work out its applicability to concrete situations. This could take place in the form of a 'general comment' intended as a policy-making guideline for the States Parties. In addition to this, the Committee, in assessing the reports, should make use of quantitative indicators. These are mostly statistical data that allow an insight into the socioeconomic development of a particular country at a certain point in time or during a particular period. The purpose of indicators is to enable the Committee to measure the progress achieved and the obstacles encountered in the realization of economic, social and cultural rights in a particular state. This implies that international human rights norms need to be coupled to practical and reliable indicators. For the evaluation of the degree of realization of particular elements of the right to education in separate states, this study proposes the following indicators: the percentage of illiterates under or over the age of 15 years, classified according to sex, urban and rural populations, linguistic and ethnic origin; the percentage of pupils of a certain age group enroled in primary education; per capita government expenditure on education.

Lastly, the international implementation of the right to education should be strengthened by adding an optional protocol to the ICESCR, entitling individuals to lodge a complaint in case of an alleged violation of the right to education. Such alleged violation must be directly attributable to the state in question. Providing the complaint is considered admissible, the Committee on Economic, Social and Cultural Rights should examine the merits of the complaint and subsequently make its views public. 


\section{Curriculum vitae}

Fons Coomans werd op 3 februari 1956 geboren te 's-Gravenhage. In 1976 behaalde hij het VWO-diploma aan het Stedelijk Lyceum in Maastricht. Vervolgens studeerde hij politieke wetenschappen aan de Universiteit van Amsterdam. In 1983 studeerde hij af met als specialisatie internationale betrekkingen en volkenrecht. Daarna vervulde hij de militaire dienstplicht. Sinds 1985 is hij werkzaam aan de Rijksuniversiteit Limburg.

Tot september 1990 was hij wetenschappelijk assistent bij de vakgroep Internationaal Recht. Sedertdien is hij als universitair docent Staats- en Bestuursrecht verbonden aan de vakgroep Publiekrecht. 